\title{
Supplement to the Annual Energy Outlook 1995
}

February 1995

Energy Information Administration 
This publication and other Energy Information Administration (EIA) publications may be purchased from the Superintendent of Documents, U.S. Government Printing Office.

Telephone orders may be directed to:

Superintendent of Documents

U.S. Government Printing Office

Main Order Desk

(202) 512-1800

FAX: (202) 512-2250

8 a.m. to $4: 30$ p.m., eastern time, M-F

All mail orders should be directed to:

U.S. Government Printing Office

P.O. Box 371954

Pittsburgh, PA 15250-7954

Complimentary subscriptions and single issues are available to certain groups of subscribers, such as public and academic libraries, Federal, State, local and foreign governments, EIA survey respondents, and the media. For further information and for answers to questions on energy statistics, please contact EIA's National Energy Information Center. Address, telephone numbers, and hours are as follows:

National Energy Information Center, EI-231

Energy Information Administration

Forrestal Building, Room 1F-048

Washington, DC 20585

(202)586-8800

Internet E-Mail: INFOCTR@EIA.DOE.GOV

TTY: For people who are deaf or hard

of hearing: (202)586-1181

9 a.m. to 5 p.m., eastern time, M-F

Released for Printing: February 9, 1995

GPO Stock No.: 061-003-00900-0 


\section{DISCLAIMER}

This report was prepared as an account of work sponsored by an agency of the United States Government. Neither the United States Government nor any agency thereof, nor any of their employees, make any warranty, express or implied, or assumes any legal liability or responsibility for the accuracy, completeness, or usefulness of any information, apparatus, product, or process disclosed, or represents that its use would not infringe privately owned rights. Reference herein to any specific commercial product, process, or service by trade name, trademark, manufacturer, or otherwise does not necessarily constitute or imply its endorsement, recommendation, or favoring by the United States Government or any agency thereof. The views and opinions of authors expressed herein do not necessarily state or reflect those of the United States Government or any agency thereof. 


\section{DISCLAIMER}

Portions of this document may be illegible in electronic image products. Images are produced from the best available original document. 


\title{
Supplement to the Annual Energy Outlook 1995
}

\author{
February 1995
}

Energy Information Administration

Office of Integrated Analysis and Forecasting

U.S. Department of Energy

Washington, DC 20585

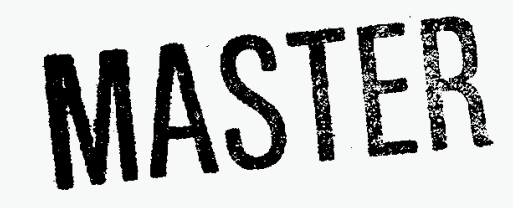

PSTRIBUTION OF THIS DOCUMENT 18 UNLMATED

D)C

This report was prepared by the Energy Information Administration, the independent statistical and analytical agency within the Department of Energy. The information contained herein should not be construed as advocating or reflecting any policy position of the Department of Energy or of any other organization. 


\title{
Preface
}

The Supplement to the Annual Energy Outlook 1995 (Supplement) is a companion document to the Annual Energy Outlook 1995 (AEO95), (DOE/ELA-0383(95)), released in January 1995. The AEO95 presents national forecasts of energy production, demand, and prices through 2010 for five cases, including a reference case and four additional cases that assume higher and lower economic growth and higher and lower world oil prices. These forecasts are used by Federal, State, and local governments, trade associations, and other planners and decisionmakers in the public and private sectors.

Part I of the Supplement presents the key quantitative assumptions underlying the AEO95 projections, responding to requests by energy analysts for additional information on the forecasts. In Part II, the Supplement provides regional projections and other underlying details of the reference case projections in the $A E O 95$.

The AEO95 and the Supplement were prepared by the Energy Information Administration (EIA), Office of Integrated Analysis and Forecasting, under the direction of Mary J. Hutzler (202/586-2222), Director of the Office of Integrated Analysis and Forecasting, Arthur T. Andersen (202/586-1441), Director of the Energy Demand and Integration Division, and Scott Sitzer (202/586-2308), Director of the Energy Supply and Conversion Division. Detailed questions concerning the forecasts and the related model components may be addressed to the following analysts:

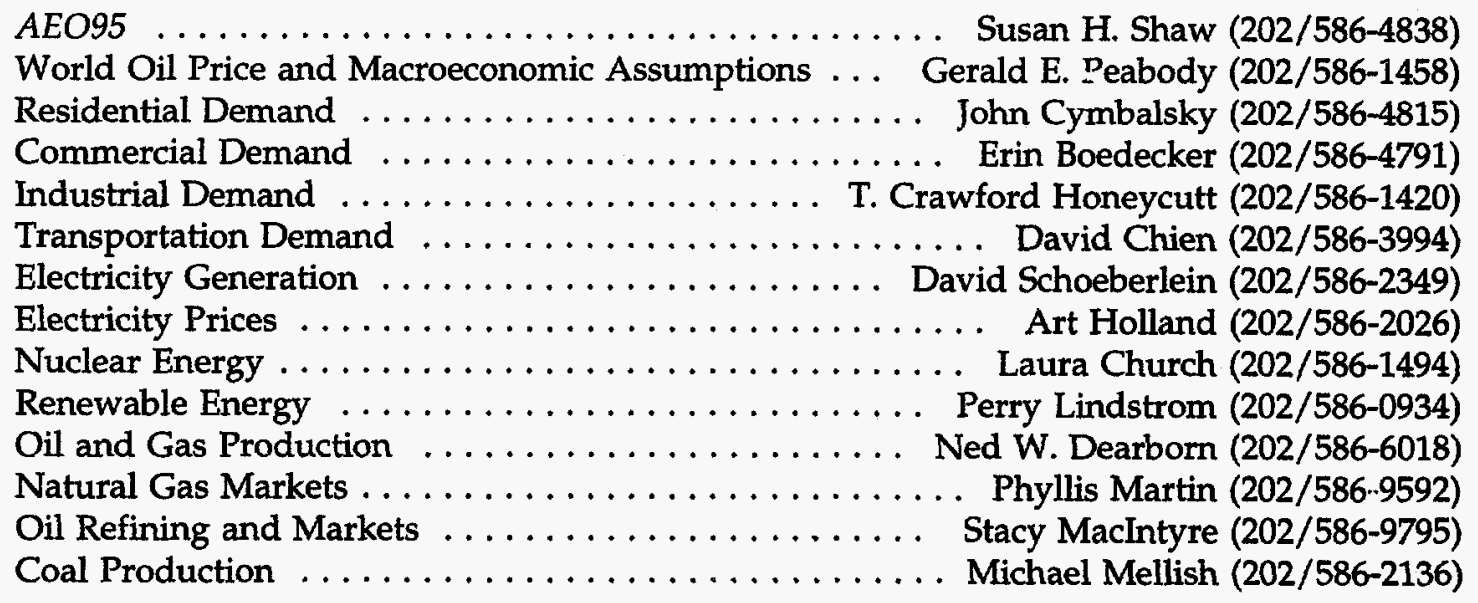

Forecast tables for the five cases presented in the AEO95 are available via modem on EIA's Electronic Publishing System (202/586-2557). The tables presented in the AEO95 and this Supplement will be available on diskette from the Office of Integrated Analysis and Forecasting in March 1995. Copies of the AEO95, the Supplement, and model documentation reports for the National Energy Modeling System are available by contacting:

\author{
National Energy Information Center, EI-231 \\ Energy Information Administration \\ Forrestal Building, Room 1F-048 \\ Washington, DC 20585 \\ 202/586-8800 \\ TTY: For people who are deaf \\ or hard of hearing: (202)586-1181 \\ 9 a.m. to 5 p.m., eastern time, M-F \\ Internet: INFOCTR@EIA.DOE.GOV
}




\section{Contents}

\section{Part I. Assumptions for the Annual Energy Outlook 1995}

Page

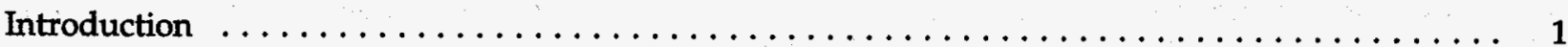

Macroeconomic Activity Module $\ldots \ldots \ldots \ldots \ldots \ldots \ldots \ldots \ldots \ldots \ldots \ldots, \quad 9$

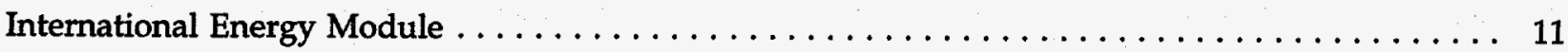

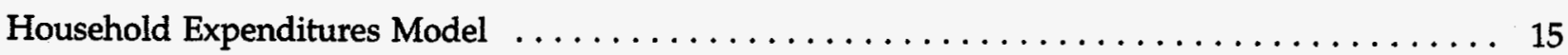

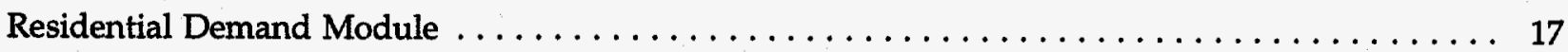

Commercial Demand Module $\ldots \ldots \ldots \ldots \ldots \ldots \ldots \ldots \ldots \ldots \ldots \ldots \ldots . \ldots \ldots$

Industrial Demand Module $\ldots \ldots \ldots \ldots \ldots \ldots \ldots \ldots \ldots \ldots \ldots \ldots \ldots \ldots \ldots, 31$

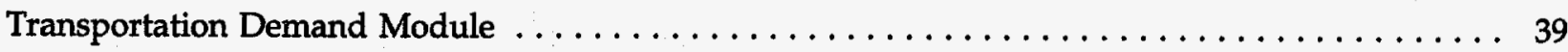

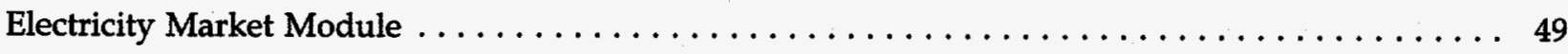

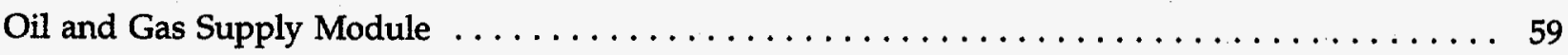

Natural Gas Transmission and Distribution Module $\ldots \ldots \ldots \ldots \ldots \ldots \ldots \ldots \ldots \ldots$

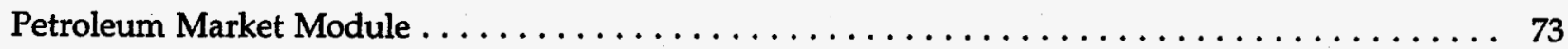

Coal Market Module $\ldots \ldots \ldots \ldots \ldots \ldots \ldots \ldots \ldots \ldots \ldots \ldots \ldots \ldots \ldots \ldots \ldots \ldots \ldots$

Renewable Fuels Module $\ldots \ldots \ldots \ldots \ldots \ldots \ldots \ldots \ldots \ldots \ldots \ldots \ldots \ldots \ldots, 91$

\section{Tables}

1. Emission Factors $\ldots \ldots \ldots \ldots \ldots \ldots \ldots \ldots \ldots \ldots \ldots \ldots \ldots \ldots \ldots \ldots \ldots \ldots \ldots, \quad 7$

2. Growth in Gross Domestic Product, Labor Force, and

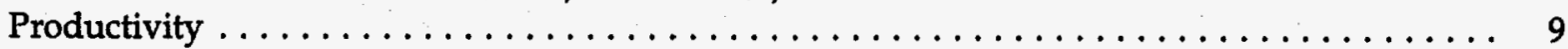

3. Average Annual Regional Gross Domestic Product Growth Rates, $1990-2010 \ldots \ldots \ldots \ldots \ldots .13$

4. Average Annual Regional Growth Rates for Oil Demand, 1990-2010 . . . . . . . . . . . . 13

5. 1990 Households . . . . . . . . . . . . . . . . . . . . . . . . . . . . . . . . . . 17

6. Capital Cost and Efficiency Ratings of Selected Equipment in $1998 \ldots \ldots \ldots \ldots \ldots \ldots \ldots 18$

7. Minimum and Maximum Life Expectancies of Equipment $\ldots \ldots \ldots \ldots \ldots \ldots \ldots \ldots \ldots$

8. 1989 Total Floorspace from Commercial Buildings Energy Consumption Survey ......... 24

9. Behavior Rules for Choosing Space Heating Equipment in Large Office Buildings ........ 26

10. Distribution of Time Preference Premiums $\ldots \ldots \ldots \ldots \ldots \ldots \ldots \ldots \ldots \ldots \ldots \ldots, 27$

11. Technology Characteristics for Space Heating in New England $\ldots \ldots \ldots \ldots \ldots \ldots \ldots \ldots 28$

12. Equipment Efficiencies Before and After Standards $\ldots \ldots \ldots \ldots \ldots \ldots \ldots \ldots \ldots \ldots, 29$

13. Industry Categories $\ldots \ldots \ldots \ldots \ldots \ldots \ldots \ldots \ldots \ldots \ldots \ldots \ldots \ldots, 32$

14. Building Component Unit Energy Consumption $\ldots \ldots \ldots \ldots \ldots \ldots \ldots \ldots \ldots \ldots \ldots \ldots \ldots, 34$ 


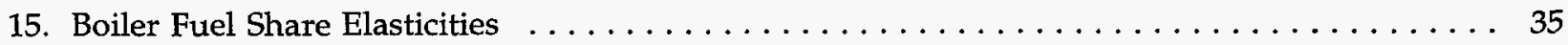

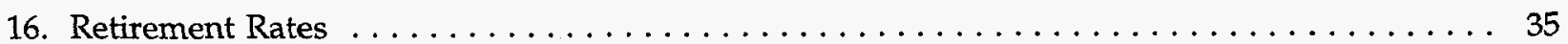

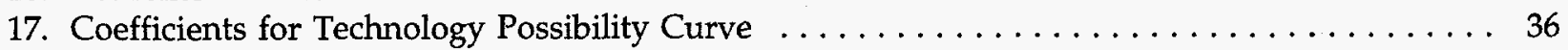

18. Macroeconomic Inputs to the Transportation Module $\ldots \ldots \ldots \ldots \ldots \ldots \ldots \ldots \ldots \ldots \ldots$

19. Car and Light Truck Degradation Factors $\ldots \ldots \ldots \ldots \ldots \ldots \ldots \ldots \ldots \ldots \ldots \ldots \ldots 40$

20. The Average Length of Time Vehicles Are Kept Before Sold to Others . . . . . . . . . 40

21. Commercial Fleet Size Class Shares by Fleet and Vehicle Type . . . . . . . . . . 41

22. Alternative-Fuel Vehicle Attribute Inputs For Three Stage Logit Model . . . . . . . . . 42

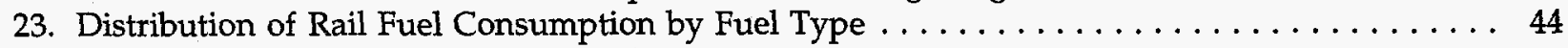

24. Constant Available Seat-Miles Assumptions by Aircraft Type $\ldots \ldots \ldots \ldots \ldots \ldots \ldots \ldots \ldots$

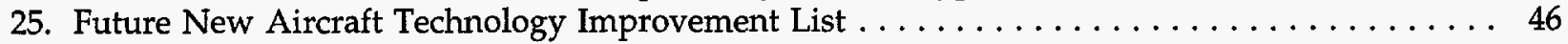

26. EPACT Alternative-Fuel Vehicle Fleet Sale Estimates . . . . . . . . . . . . . . . 46

27. California Low Emission Vehicle Program Legislatively Mandated Alternative-Fuel

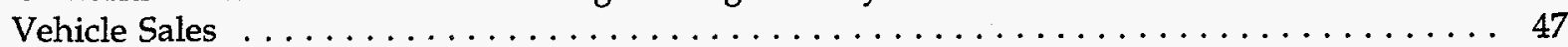

28. Capacity Types Represented in the Electricity Market Module . . . . . . . . . . . . . 49

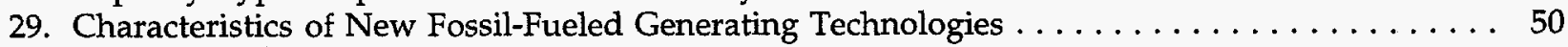

30. Regional Multipliers for New Construction $\ldots \ldots \ldots \ldots \ldots \ldots \ldots \ldots \ldots \ldots \ldots \ldots \ldots$

31. Load Segments for the Electricity Market Module $\ldots \ldots \ldots \ldots \ldots \ldots \ldots \ldots \ldots \ldots \ldots \ldots$

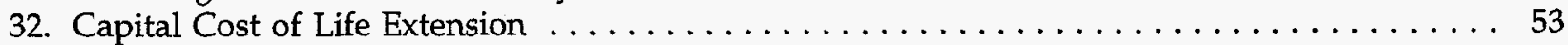

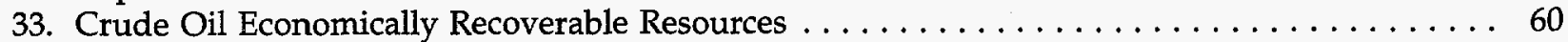

34. Natural Gas Economically Recoverable Resources $\ldots \ldots \ldots \ldots \ldots \ldots \ldots \ldots \ldots \ldots \ldots . \ldots 2$

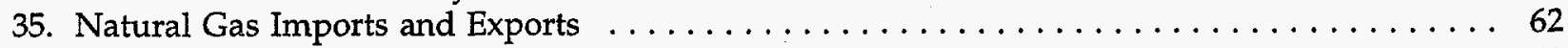

36. Number and Production of Mines Reached by CCAP Plan $35 \ldots \ldots \ldots \ldots \ldots \ldots \ldots \ldots$

37. Electric Utility Natural Gas Demand Classification . . . . . . . . . . . . . . . 65

38. Base Year Average Annual Distributor Markup for Local Transportation Service $\ldots \ldots \ldots 67$

39. Vehicle Natural Gas (VNG) Pricing $\ldots \ldots \ldots \ldots \ldots \ldots \ldots \ldots \ldots \ldots \ldots \ldots \ldots$

40. Incremental Storage Expansion Factors (Over Existing Levels) $\ldots \ldots \ldots \ldots \ldots \ldots \ldots \ldots \ldots$

41. FERC Order 636 Transition Costs by Pipeline Company $\ldots \ldots \ldots \ldots \ldots \ldots \ldots \ldots \ldots$

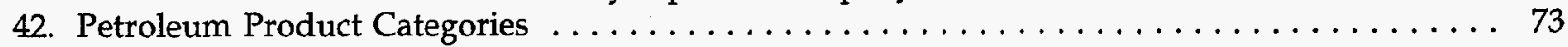

43. Gasoline Specifications by PAD District $\ldots \ldots \ldots \ldots \ldots \ldots \ldots \ldots \ldots \ldots \ldots \ldots \ldots \ldots \ldots \ldots$

44. Percent Market Share for Gasoline Types by Census Division $\ldots \ldots \ldots \ldots \ldots \ldots \ldots \ldots \ldots$

45. Summary of Fixed Costs by Petroleum Administration for Defense Districts . . . . . . . . 77

46. Petroleum Product End-Use Markups by Sector and Census Division . . . . . . . . . . 78

47. State-Level Taxes on Petroleum Transportation Fuels by Census Division . . . . . . . . . . 79

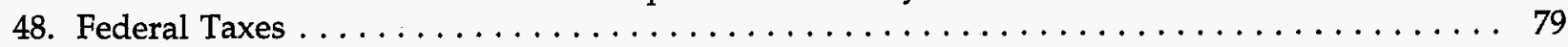

49. Crude Oil Specifications $\ldots \ldots \ldots \ldots \ldots \ldots \ldots \ldots \ldots \ldots \ldots \ldots \ldots \ldots \ldots \ldots \ldots$

50. Retirement of Existing Underground Mine Production Capacity in the Coal Production Submodule, $1995-2010 \ldots \ldots \ldots \ldots \ldots \ldots \ldots \ldots \ldots \ldots \ldots \ldots \ldots \ldots$

51. Retirement of Existing Surface Mine Production Capacity in the Coal Production

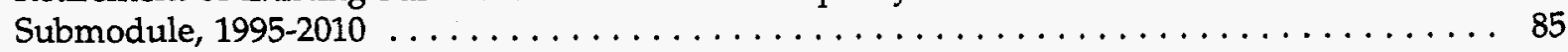

52. Transportation Rate Escalators, $1992-2010 \ldots \ldots \ldots \ldots \ldots \ldots \ldots \ldots \ldots \ldots \ldots \ldots$

53. World Steam Coal Import Demand by Import Region, $1995-2010$. . . . . . . . . . . . . 87

54. World Metallurgical Coal Import Demand by Import Region, $1995-2010$. . . . . . . . . . . 88

55. Renewable Fuels Cost and Performance Data for $2005 \ldots \ldots \ldots \ldots \ldots \ldots \ldots \ldots \ldots \ldots$

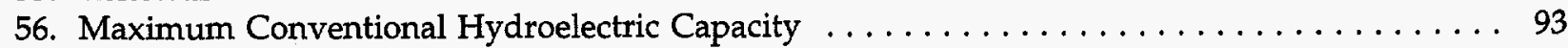

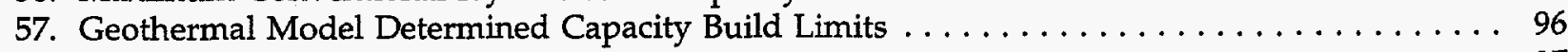

58. Biomass - Regional Model Determined Build Patterns . . . . . . . . . . . . . . . . 97

\section{Figures}

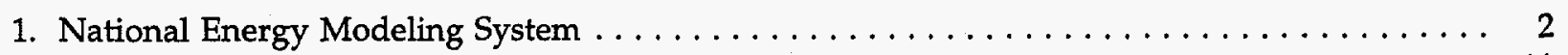

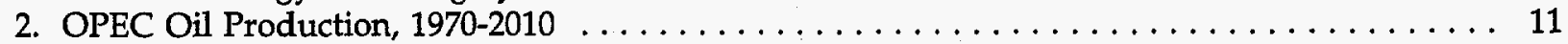

3. Non-OPEC Oil Production, $1970-2010 \ldots \ldots \ldots \ldots \ldots \ldots \ldots \ldots \ldots \ldots \ldots \ldots \ldots$ 


\section{Part II. Detailed Tables}

1. Energy Consumption by End-Use Sector and Source, New England Census Division . . . . 102

2. Energy Consumption by End-Use Sector and Source, Middle Atlantic Census Division . . . . 104

3. Energy Consumption by End-Use Sector and Source, East North Central Census Division . . 106

4. Energy Consumption by End-Use Sector and Source, West North Central Census Division . . 108

5. Energy Consumption by End-Use Sector and Source, South Atlantic Census Division . . . . . 110

6. Energy Consumption by End-Use Sector and Source, East South Central Census Division . . 112

7. Energy Consumption by End-Use Sector and Source, West South Central Census Division . . 114

8. Energy Consumption by End-Use Sector and Source, Mountain Census Division . . . . . 116

9. Energy Consumption by End-Use Sector and Source, Pacific Census Division . . . . . . . 118

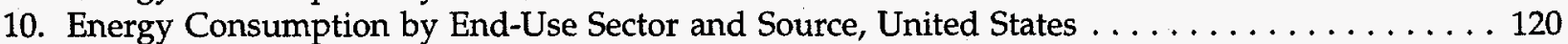

11. Energy Prices by End-Use Sector and Source, New England Census Division . . . . . . . . 122

12. Energy Prices by End-Use Sector and Source, Middle Atlantic Census Division . . . . . . . . 124

13. Energy Prices by End-Use Sector and Source, East North Central Census Division . . . . . 126

14. Energy Prices by End-Use Sector and Source, West North Central Census Division . . . . . . 128

15. Energy Prices by End-Use Sector and Source, South Atlantic Census Division . . . . . . . . 130

16. Energy Prices by End-Use Sector and Source, East South Central Census Division . . . . . 132

17. Energy Prices by End-Use Sector and Source, West South Central Census Division . . . . . . . 134

18. Energy Prices by End-Use Sector and Source, Mountain Census Division . . . . . . . . 136

19. Energy Prices by End-Use Sector and Source, Pacific Census Division . . . . . . . . . . 138

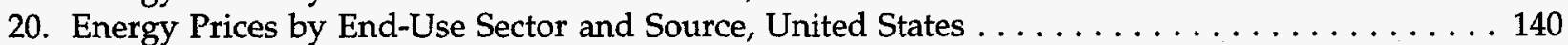

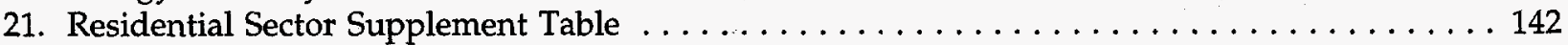

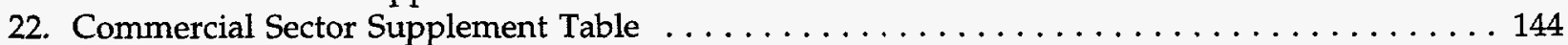

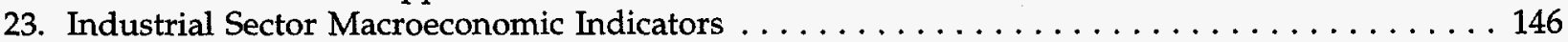

24. Energy Consumption for Heat and Power by Refineries $\ldots \ldots \ldots \ldots \ldots \ldots \ldots \ldots \ldots \ldots$

25. Energy Consumption for Heat and Power by the Food Industry $\ldots \ldots \ldots \ldots \ldots \ldots \ldots \ldots 148$

26. Energy Consumption for Heat and Power by the Paper Industry . . . . . . . . . . . . . 149

27. Energy Consumption for Heat and Power by the Chemical Industry . . . . . . . . . . . 150

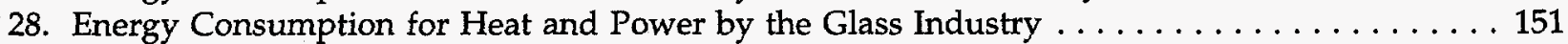

29. Energy Consumption for Heat and Power by the Cement Industry . . . . . . . . . 152

30. Energy Consumption for Heat and Power by the Iron and Steel Industry $\ldots \ldots \ldots \ldots \ldots 153$

31. Energy Consumption for Heat and Power by the Aluminum Industry $\ldots \ldots \ldots \ldots \ldots \ldots$

32. Transportation Sector Energy Use by Mode and Type $\ldots \ldots \ldots \ldots \ldots \ldots \ldots \ldots \ldots \ldots$

33. Transportation Sector Energy Use by Fuel Type Within a Mode $\ldots \ldots \ldots \ldots \ldots \ldots \ldots \ldots 157$

34. Light-Duty Vehicle Energy Consumption by Technology Type and Fuel Type . . . . . . . . 159

35. Light-Duty Vehicle Sales by Technology Type New England Census Division . . . . . . . . 160

36. Light-Duty Vehicle Sales by Technology Type Middle Atlantic Census Division . . . . . . . 162

37. Light-Duty Vehicle Sales by Technology Type East North Central Census Division . . . . . . . 164

38. Light-Duty Vehicle Sales by Technology Type West North Central Census Division . . . . . . 166

39. Light-Duty Vehicle Sales by Technology Type South Atlantic Census Division . . . . . . . 168

40. Light-Duty Vehicle Sales by Technology Type East South Central Census Division . . . . . 170

41. Light-Duty Vehicle Sales by Technology Type West South Central Census Division . . . . . 172

42. Light-Duty Vehicle Sales by Technology Type Mountain Census Division . . . . . . . . . 174

43. Light-Duty Vehicle Sales by Technology Type Pacific Census Division $\ldots \ldots \ldots \ldots \ldots \ldots 176$

44. Light-Duty Vehicle Sales by Technology Type United States $\ldots \ldots \ldots \ldots \ldots \ldots \ldots \ldots \ldots 178$

45. Light-Duty Vehicle Stock by Technology Type $\ldots \ldots \ldots \ldots \ldots \ldots \ldots \ldots \ldots \ldots \ldots \ldots$

46. Light-Duty Vehicle MPG by Technology Type $\ldots \ldots \ldots \ldots \ldots \ldots \ldots \ldots \ldots \ldots \ldots \ldots \ldots 2$

47. Light-Duty Vehicle VMT by Technology Type . . . . . . . . . . . . . . . . . . 184

48. Transportation Fleet Car and Truck Fuel Consumption by Type and Technology . . . . . 185

49. Transportation Fleet $C a x$ and Truck Fuel Sales by Type and Technology $\ldots \ldots \ldots \ldots \ldots \ldots$

50. Transportation Fleet Car and Truck Fuel Stock by Type and Technology . . . . . . . . 187

51. Transportation Fleet Car and Truck VMT by Type and Technology $\ldots \ldots \ldots \ldots \ldots \ldots \ldots 188$

52. Air Travel Energy Use . . . . . . . . . . . . . . . . . . . . . . . . . . . 189 
53. Freight Transportation Energy Use $\ldots \ldots \ldots \ldots \ldots \ldots \ldots \ldots \ldots \ldots \ldots \ldots \ldots$

54. Electric Power Data Projections for the EMM Region East Central Area Reliability

Coordination Agreement (ECAR) . . . . . . . . . . . . . . . . . . . . . . . . . . 192

55. Electric Power Data Projections for the EMM Region Electric Reliability Council of Texas

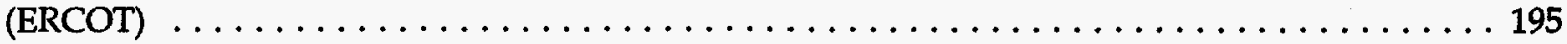

56. Electric Power Data Projections for the EMM Region Mid-Atlantic Area Council (MAAC) . . 198

57. Electric Power Data Projections for the EMM Region Mid-America Interconnected Network

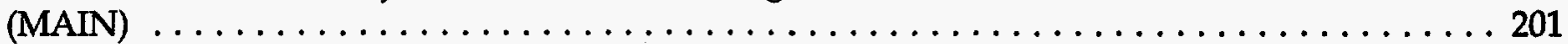

58. Electric Power Data Projections for the EMM Region Mid-Continent Area Power Pool

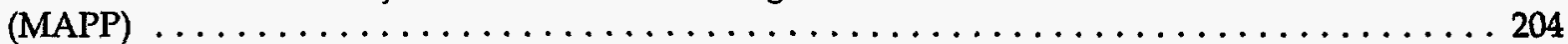

59. Electric Power Data Projections for the EMM Region Northeast Power Coordinat

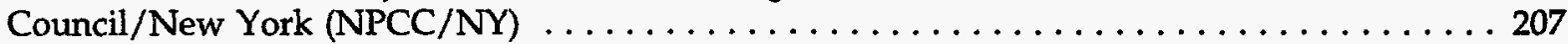

60. Electric Power Data Projections for the EMM Region Northeast Power Coordinating

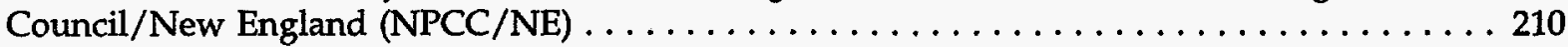

61. Electric Power Data Projections for the EMM Region Southeastern Electric Reliability

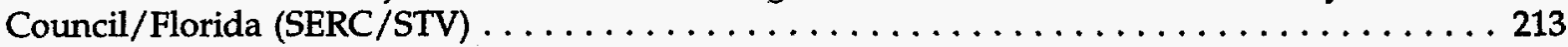

62. Electric Power Data Projections for the EMM Region Southeastern Electric Reliability

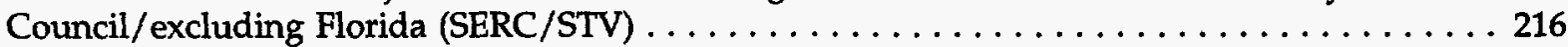

63. Electric Power Data and Projections for the EMM Region Southwest Power Pool (SPP) . . . . . 219

64. Electric Power Data and Projections for the EMM Region Western Systems Coordinating Council/Northwest Power Pool Area (WSCC/NWP) . . . . . . . . . . . . . . 222

65. Electric Power Data and Projections for the EMM Region Western Systems Coordinating Council/Rocky Mountain Power Area and Arizona (WSCC/RA) . . . . . . . . . 225

66. Electric Power Data and Projections for the EMM Region Western Systems Coordinating

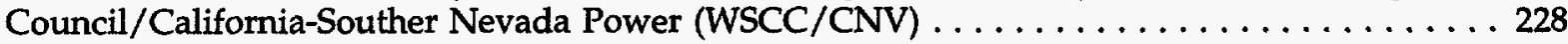

67. Electric Power and Projections for the United States $\ldots \ldots \ldots \ldots \ldots \ldots \ldots \ldots \ldots \ldots \ldots \ldots$

68. Electric Generation by Electricity Market Module Region and Source . . . . . . . . . 234

69. Electricity Generating Capacity by Electricity Market Module Region and Source . . . . . . . 237

70. Domestic Refinery Distillation Base Capacity, Expansion, and Utilization . . . . . . . . 240

71. Lower 48 Crude Oil Production and Wellhead Prices by Supply Region . . . . . . . . 241

72. Lower 48 Natural Gas Production and Wellhead Prices by Supply Region . . . . . . . . 242

73. Oil and Gas Reserves ................................... 243

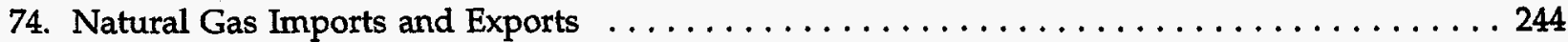

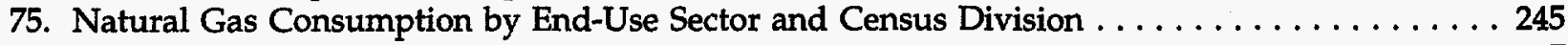

76. Natural Gas Delivered Prices by End-Use Sector and Census Division $\ldots \ldots \ldots \ldots \ldots \ldots 247$

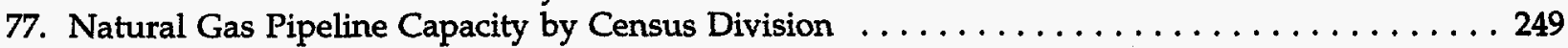

78. Natural Gas Pipeline Capacity Utilization by Census Division . . . . . . . . . . . . 250

79. Domestic Coal Supply, Disposition, and Prices New England Census Division . . . . . . 251

80. Domestic Coal Supply, Disposition, and Prices Middle Atlantic Census Division . . . . . . 252

81. Domestic Coal Supply, Disposition, and Prices East North Central Census Division . . . . . . 253

82. Domestic Coal Supply, Disposition, and Prices West North Central Census Division . . . . . . 254

83. Domestic Coal Supply, Disposition, and Prices South Atlantic Census Division . . . . . . . 255

84. Domestic Coal Supply, Disposition, and Prices East South Central Census Division . . . . . . 256

85. Domestic Coal Supply, Disposition, and Prices West South Central Census Division . . . . . 257

86. Domestic Coal Supply, Disposition, and Prices Mountain Census Division . . . . . . . 258

87. Domestic Coal Supply, Disposition, and Prices Pacific Census Division . . . . . . . . . 259

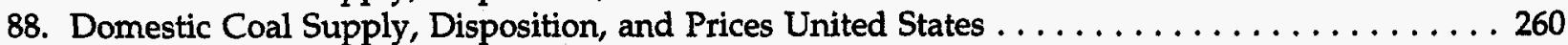

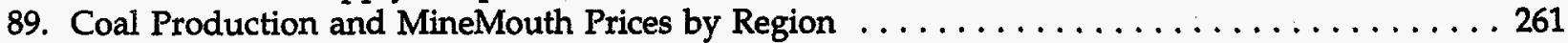

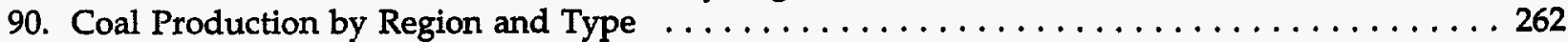

91. World Steam Coal Flows By Importing Regions and Exporting Countries . . . . . . . . . 263

92. World Metallurgical Coal Flows By Importing Regions and Exporting Countries Regions . . 264

93. World Total Coal Flows By Importing Regions and Exporting Countries . . . . . . . . 265

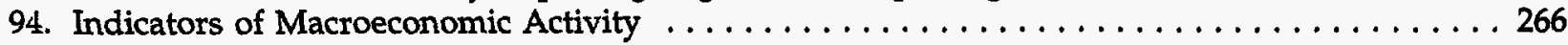

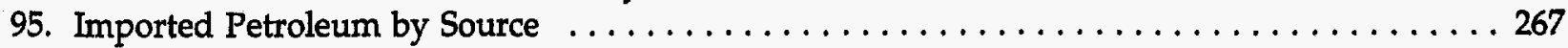


Appendices

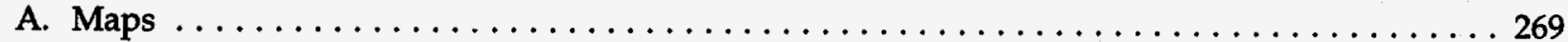

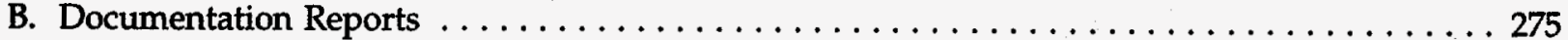

C. Results from Side Cases $\ldots \ldots \ldots \ldots \ldots \ldots \ldots \ldots \ldots \ldots \ldots \ldots \ldots \ldots \ldots \ldots \ldots \ldots \ldots$ 


\section{Part I}

\section{Assumptions \\ for the \\ Annual Energy Outlook 1995}




\section{Introduction}

This section of the Supplement to the Annual Energy Outlook 1995 (Supplement) presents the major assumptions of the modeling system used to generate the projections in the Annual Energy Outlook 1995 (AEO95). In this context, assumptions include general features of the model structure, assumptions concerning energy markets, and the key input data and parameters that are most significant in formulating the model results. Detailed documentation of the modeling system is available in a series of documentation reports listed in Appendix B. ${ }^{1}$ A synopsis of the National Energy Modeling System, the model components, and the interrelationships of the modules is presented in The National Energy Modeling System: An Overview.

\section{The National Energy Modeling System}

The projections in the AEO95 and the Supplement were produced with the National Energy Modeling System (NEMS). NEMS is developed and maintained by the Office of Integrated Analysis and Forecasting of the Energy Information Administration (EIA) to provide projections of domestic energy-economy markets in the midterm time period and perform policy analyses requested by decisionmakers and analysts in the U.S. Congress, the Department of Energy's Office of Policy, other DOE offices, other government agencies, and the private sector.

The time horizon of NEMS is 20 years, the midterm period in which the structure of the economy and the nature of energy markets are sufficiently understood that it is possible to represent considerable structural and regional detail. Because of the diverse nature of energy supply, demand, and conversion in the United States, NEMS supports regional modeling and analysis in order to represent the regional differences in energy markets, to provide policy impacts at the regional level, and to portray transportation flows. The level of regional detail for the end-use demand modules is the nine Census divisions. Other regional structures include production and consumption regions specific to oil, gas, and coal supply and distribution, the North American Electric Reliability Council regions and subregions for electricity, and the Petroleum Administration for Defense districts for refineries (Appendix A). Only national results are presented in the AEO95, with the regional and other detailed results in this Supplement.

For each fuel and consuming sector, NEMS balances the energy supply and demand, accounting for the economic competition between the various energy fuels and sources. NEMS is organized and implemented as a modular system (Figure 1). The modules represent each of the fuel supply markets, conversion sectors, and end-use consumption sectors of the energy system. NEMS also includes macroeconomic and international modules. The primary flows of information among each of these modules are the delivered prices of energy to the end user and the quantities consumed by product, region, and sector. The delivered prices of fuel encompass all the activities necessary to produce, import, and transport fuels to the end user. The information flows also include other data such as economic activity, domestic production activity, and international petroleum supply availability.

The integrating module of NEMS controls the execution of each of the component modules. To facilitate modularity, the components do not pass information to each other directly but communicate through a central data storage location. This modular design provides the capability to execute modules

${ }^{1}$ NEMS documentation reports are available from the National Energy Information Center (202/586-8800). 
Figure 1. National Energy Modeling System

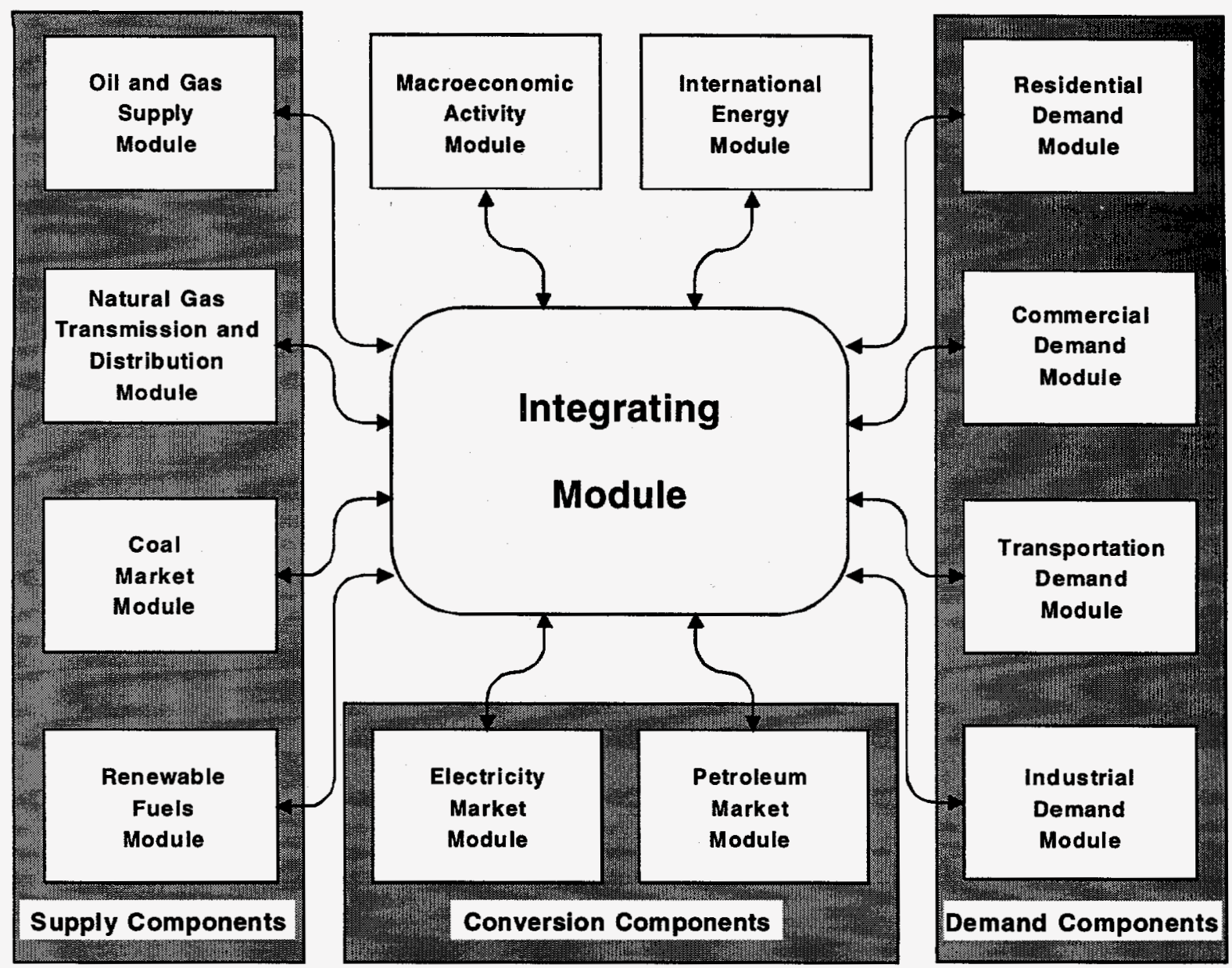

individually, thus allowing decentralized development of the system and independent analysis and testing of individual modules. This modularity allows use of the methodology and level of detail most appropriate for each energy sector. NEMS solves by calling each supply, conversion, and end-use demand module in sequence until the delivered prices of energy and the quantities demanded have converged within tolerance, thus achieving an economic equilibrium of supply and demand in the consuming sectors. Solution is reached annually through the midterm horizon. Other variables are also evaluated for convergence such as petroleum product imports, crude oil imports, and several macroeconomic indicators.

Each NEMS component also represents the impact and cost of legislation and environmental regulations that affect that sector and reports key emissions. NEMS reflects all current legislation and environmental regulations, such as the Clean Air Act Amendments of 1990, and the costs of compliance with other regulations. The calculation and reporting of carbon emissions is centralized in the integrating model. For the AEO95, NEMS includes an analysis of the impacts of the provisions of the Climate Change Action Plan, which are separately described under each module.

\section{Component Modules}

The component modules of NEMS represent the individual supply, demand, and conversion sectors of domestic energy markets and also include international and macroeconomic modules. In general, the modules interact through values representing the prices of energy delivered to the consuming sectors and 
the quantities of end-use energy consumption. This section provides brief summaries of each of the modules.

\section{Macroeconomic Activity Module}

The Macroeconomic Activity Module provides a set of essential macroeconomic drivers to the energy modules, a macroeconomic feedback mechanism within NEMS, and a mechanism to evaluate detailed macroeconomic and interindustry impacts associated with energy events. Key macroeconomic variables include gross domestic product (GDP), interest rates, disposable income, and employment. Industrial drivers are calculated for 35 industrial sectors. This module is a response surface representation of the Data Resources, Inc., Quarterly Model of the U.S. Economy.

\section{International Energy Module}

The International Module represents the world oil markets, calculating the average world oil price and computing supply curves for five categories of imported crude oil for the Petroleum Market Module of NEMS, in response to changes in U.S. import requirements. International petroleum product supply curves, including curves for oxygenates, are also calculated.

\section{Household Expenditures Module}

The Household Expenditures Module provides estimates of average household direct expenditures for energy used in the home and in private motor vehicle transportation. The forecasts of expenditures reflect the projections from NEMS for the residential and transportation sectors. The projected household energy expenditures incorporate the changes in residential energy prices and motor gasoline price determined in NEMS, as well as the changes in the efficiency of energy use for residential end-uses and in light-duty vehicle fuel efficiency. Average expenditures estimates are provided for households by income group, race, Census division, and other characteristics.

\section{Residential and Commercial Demand Modules}

The Residential Demand Module forecasts consumption of residential sector energy by housing type and end use, subject to delivered energy prices, availability of renewable sources of energy, and macroeconomic variables representing population, disposable personal income, interest rates, and housing starts. The Commercial Demand Module forecasts consumption of commercial sector energy by building types and nonbuilding uses of energy and by category of end use, subject to delivered prices of energy, availability of renewable sources of energy, and macroeconomic variables representing GDP, employment, interest rates, and floorspace construction. Both modules estimate the equipment stock for the major enduse services, incorporating assessments of advanced technologies, including representations of renewable energy technologies, and analyses of both building shell and appliance standards.

\section{Industrial Demand Module}

The Industrial Demand Module forecasts the consumption of energy for heat and power and for feedstocks and raw materials in each of 35 industries, subject to the delivered prices of energy and macroeconomic variables representing GDP, interest rates, employment and labor cost, and the value of output for each industry. The industries are classified into three groups-energy intensive, nonenergy intensive, and nonmanufacturing. Of the eight energy-intensive industries, seven are modeled in the Industrial Demand Module with components for boiler/steam/cogeneration, buildings, and process/assembly use of energy. A representation of cogeneration and a recycling component are also included. The use of energy for petroleum refining is modeled in the Petroleum Market Module, and the projected consumption is included in the industrial totals. 


\section{Transportation Demand Module}

The Transportation Demand Module forecasts consumption of transportation sector fuels, including petroleum products, electricity, methanol, ethanol, and compressed natural gas by transportation mode, vehicle vintage, and size class, subject to delivered prices of energy fuels and macroeconomic variables representing disposable personal income, GDP, population, interest rates, and the value of output for industries in the freight sector. Fleet vehicles are represented separately to allow analysis of the Clean Air Act Amendments and other legislative proposals, and the module includes a component to explicitly assess the penetration of alternative-fuel vehicles.

\section{Electricity Market Module}

The Electricity Market Module represents generation, transmission, and pricing of electricity, subject to delivered prices for coal, petroleum products, and natural gas, costs of generation by centralized renewables, macroeconomic variables for costs of capital and domestic investment, and electricity load shapes and demand. There are four primary submodules-capacity planning, fuel dispatching, finance and pricing, and load and demand-side management. Nonutility generation and transmission and trade are represented in the planning and dispatching submodules. The levelized fuel cost of uranium fuel for nuclear generation is directly incorporated into the Electricity Market Module. All Clean Air Act compliance options are explicitly represented in the capacity expansion and dispatch decisions. Both new generating technologies and renewable technologies compete directly in these decisions. The competition between utility and nonutility generation and several options for wholesale pricing are included.

\section{Oil and Gas Supply Module}

The Oil and Gas Supply Module represents domestic crude oil, natural gas liquids, and natural gas production within an integrated framework that captures the interrelationships among the various sources of supply-onshore, offshore, and Alaska-using both conventional and nonconventional techniques, including enhanced oil recovery and unconventional gas recovery from tight gas formations, Devonian shale, and coalbeds. This framework analyzes cash flow and profitability to compute investment and drilling in each of the supply sources, subject to the prices for crude oil and natural gas, the domestic recoverable resource base, and technology. Oil and gas production functions are computed at a level of 12 supply regions, including 3 offshore and 3 Alaskan regions. This module also represents foreign sources of natural gas, including pipeline imports and exports with Canada and Mexico, and liquefied natural gas imports. The crude oil and natural gas liquids supply curves are input to the Petroleum Market Module in NEMS for conversion and blending into refined petroleum products. The supply curves for natural gas are input to the Natural Gas Transmission and Distribution Module.

\section{Natural Gas Transmission and Distribution Module}

The Natural Gas Transmission and Distribution Module represents the transmission, distribution, and pricing of natural gas, subject to end-use demand for natural gas, the supply of domestic natural gas, and the availability of natural gas traded on the international market. The module tracks the flow of natural gas in an aggregate, domestic pipeline network, connecting the domestic and foreign supply sources with 12 demand regions. This capability allows the analysis of impacts of interregional constraints in the interstate natural gas pipeline network and the identification of pipeline capacity expansion requirements. There is an explicit representation of core and noncore markets for natural gas transmission and distribution, and the key components of pipeline and distributor tariffs are included in the pricing algorithms.

\section{Petroleum Market Module}

The Petroleum Market Module forecasts prices of petroleum products, crude oil and product import activity, and domestic refinery operations, including fuel consumption, subject to the demand for 
petroleum products, availability and price of imported petroleum, and domestic production of crude oil, natural gas liquids, and alcohol fuels. The module represents refining activities for the five Petroleum Administration for Defense districts, using the same crude oil types as the International Module. It explicitly models the requirements of the Clean Air Act Amendments of 1990 and the costs of new automotive fuels, such as oxygenated and reformulated gasoline, and includes oxygenated production and blending for reformulated gasoline. Costs include capacity expansion for refinery processing units. Enduse prices are based on the marginal costs of production, plus markups representing product distribution costs, State and Federal taxes, and environmental costs.

\section{Coal Market Module}

The Coal Market Module represents mining, transportation, and pricing of coal, subject to the end-use demand for coal differentiated by physical characteristics, such as the heat and sulfur content. The coal supply curves include a response to capacity utilization and fuel costs, as well as reserve depletion, labor productivity, and factor input costs. Thirty-two potential coal types are represented, differentiated by thermal grade, sulfur content, and mining process. Production and distribution are computed for 16 supply and 23 demand regions, by transportation mode. Transportation rates are constructed using imputed coal transportation costs and trends in factor input costs. The Coal Market Module also forecasts the requirements for U.S. coal exports and imports. The international coal market is represented by a linear program which computes trade in 4 types of coal for 20 import and 16 export regions.

\section{Renewable Fuels Module}

The Renewable Fuels Module includes submodules representing wood, municipal solid waste, wind energy, solar energy, hydroelectric power, geothermal energy, and biofuels (ethanol) supply. (The Electricity Market Module represents market penetration of renewable technologies used for centralized electricity generation, and the end-use demand modules incorporate dispersed renewables.) The Renewable Fuels Module provides costs and performance criteria to the Electricity Market Module and also interacts with the Petroleum Market Module to represent the production and pricing of alcohol fuels.

\section{Cases for the Annual Energy Outlook 1995}

The AEO95 presents five cases which differ from each other due to fundamental assumptions concerning the domestic economy and world oil market conditions. Three alternative assumptions are specified for each of these two factors, with the Reference Case using the midlevel assumption for each.

- Economic Growth. In the Reference Case, productivity grows at an average annual rate of 1.1 percent from 1993 through 2010 and the labor force at 1.2 percent per year, yielding a growth in real GDP of 2.2 percent per year. In the High Economic Growth Case, productivity and the labor force grow at 1.3 and 1.4 percent per year, respectively, resulting in GDP growth of 2.7 percent annually. The average annual growth in productivity, the labor force, and GDP are 0.9, 0.9, and 1.8 percent, respectively, in the Low Economic Growth Case.

- World Oil Markets. In the Reference Case, the average world oil price remains below $\$ 20$ per barrel (in real 1993 dollars) through 2001 and then gradually increases to slightly over $\$ 24$ per barrel in 2010. Reflecting uncertainty in world markets, the price in 2010 remains below $\$ 15$ per barrel in the Low Oil Price Case and reaches $\$ 29$ per barrel in the High Oil Price Case. The key factor underlying the differences in the oil prices is the assumption concerning production in the Organization of Petroleum Exporting Countries (OPEC). Additional factors are oil production in non-OPEC countries, net oil exports by the formerly centrally planned economies, and the worldwide demand for oil. 
In addition, the $A E O 95$ contains analyses of 16 side cases that were performed by using portions of NEMS. For each of the residential, commercial, industrial, transportation, and oil and gas supply sectors, two cases examine the impacts of higher and lower technology penetration relative to that assumed in the Reference Case. Other cases analyze assumptions of higher electricity demand, earlier and later retirement of nuclear generation units, higher investment in natural gas pipeline refurbishment, and higher and lower labor productivity in coal production. Most of these cases were executed by operating only one module in the stand-alone mode, i.e., the Residential Demand, Commercial Demand, Industrial Demand, Transportation Demand, Oil and Gas Supply, Natural Gas Transmission and Distribution, and Coal Market Modules. The higher electricity demand and earlier and later nuclear retirement cases were executed with the Electricity Market, Oil and Gas Supply, Natural Gas Transmission and Distribution, Coal Market, and Renewable Fuels Modules. Key results from the side cases are presented in Appendix C.

These side cases were designed to examine the impacts of varying key assumptions for individual modules, and thus the full market consequences, such as the consumption or price impacts, are not captured. In a fully integrated run, the impacts would tend to narrow the range of the differences from the Reference Case. For example, in the residential demand high technology side case, it is assumed that all equipment purchases from 1995 onward are those with the highest efficiency available as of 1993 . In a fully integrated NEMS run, the lower resulting fuel consumption would have the effect of lowering slightly the market prices of those fuels with the concomitant impact of increasing economic growth, thus stimulating some additional consumption. As another example, the higher electricity demand side case results in higher electricity prices. If the end-use demand modules were executed in a full run, the demand for electricity would be reduced slightly as a result of the higher prices and resulting lower economic growth, thus moderating somewhat the input assumptions. The results of these cases should be considered the maximum range of the impacts that could occur with the assumptions defined for the case.

All projections are prepared assuming Federal, State, and local laws and regulations in effect on August 15, 1994. These include the additional fuels taxes in the Omnibus Budget Reconciliation Act of 1993, the Clean Air Act Amendments of 1990, and the Energy Policy Act of 1992. Pending legislation and sections of existing legislation for which funds have not been appropriated are not reflected in these forecasts.

The projections include analysis of the provisions of the Climate Change Action Plan (CCAP), 44 actions to achieve carbon stabilization in the United States by 2000, relative to 1990 . Thirteen of the actions are not related to the combustion of energy fuels and are not incorporated in the analysis. Since funding for many of the CCAP programs have been curtailed in budget negotiations, their full impact is not reflected in these projections.

\section{Emissions}

Total carbon emitted by the combustion of energy is a function of both the carbon content of each fuel and the use of that fuel. Fuel consumption is calculated by aggregating the fuel requirements of the four end-use demand sectors and the electricity conversion sector. Total fuel consumption by type is multiplied by an emissions coefficient to calculate the carbon emitted to the atmosphere.

It is assumed that combustion is 99 percent complete for non-gaseous fuels and 99.5 percent complete for gaseous fuels. In addition, a portion of certain fossil fuels is used for non-fuel processes, such as feedstocks for chemical production. In this case a significant proportion of the carbon is sequestered in the product and not released to the atmosphere. These fuels are subtracted from the total fuel demands in the emissions calculations. Table 1 displays the emission factors and sequestration rates used in the AEO95. 


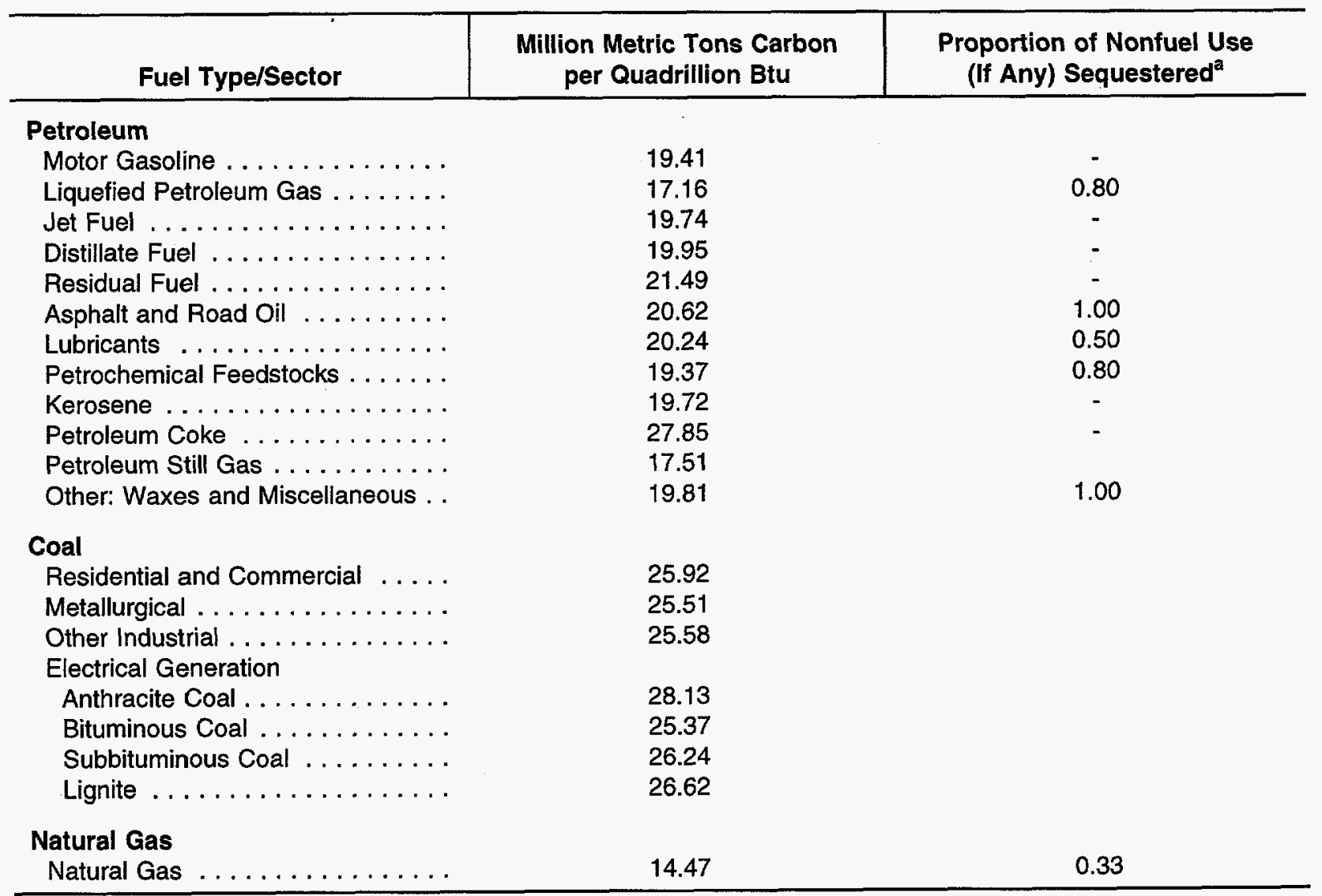

${ }^{a}$ The sequestered portion of nonfuel use does not emit carbon because it is permanently contained in the end product.

Source: Energy Information Administration, Emissions of Greenhouse Gases in the United States, 1987-1992, DOE/EIA-0573, (Washington, DC, October 1994). 



\section{Macroeconomic Activity Module}

The Macroeconomic Activity Module represents the interaction between the U.S. economy as a whole and energy markets. The rate of growth of the economy, measured by the growth in gross domestic product (GDP) is a key determinant of the growth in demand for energy. Associated economic factors, such as interest rates and disposable income, strongly influence various elements of the supply and demand for energy. At the same time, reactions to energy markets by the aggregate economy, such as a slowdown in economic growth resulting from increasing energy prices, are also reflected in this module.

\section{Key Assumptions}

The output of the Nation's economy, measured by GDP, is expected to increase by 2.2 percent between 1993 and 2010 in the Reference Case. The growth in GDP can be decomposed into two key factors: the growth rate of the labor force and rate of productivity change associated with the labor force. As Table 2 indicates, the rate of growth of GDP is slower in the latter half of the forecast period due to a slowdown in the expansion of the labor force. The growth of the labor force depends upon the forecasted population growth and the labor force participation rate. The Census Bureau's middle series population projection is used as a basis for the AEO95. Total population is expected to grow by 0.9 percent between 1993 and 2010, showing slower rates of growth post-2000. Over the forecast period, the labor force participation rate is expected to peak in 2005 and then decline as "baby boom" cohorts begin to retire. Combining population projections with labor force participation rates gives an increase in labor force earlier in the forecast horizon and then post-2000, the economy experiences slower growth as demographic trends affect future economic growth.

Table 2. Growth in Gross Domestic Product, Labor Force, and Productivity (Percent per Year)

\begin{tabular}{|c|c|c|c|c|c|}
\hline Assumptions & 1990-1995 & $1995-2000$ & 2000-2005 & 2005-2010 & $1993-2010$ \\
\hline \multicolumn{6}{|l|}{ GDP } \\
\hline High Growth & 2.4 & 2.8 & 2.6 & 2.2 & 2.7 \\
\hline Reference $\ldots \ldots \ldots$ & 2.1 & 2.5 & 2.3 & 1.8 & 2.2 \\
\hline Low Growth ........ & 1.8 & 2.1 & 1.9 & 1.3 & 1.8 \\
\hline \multicolumn{6}{|l|}{ Labor Force } \\
\hline High Growth . . . . . . . & 1.5 & 1.6 & 1.4 & 1.0 & 1.5 \\
\hline Reference $\ldots \ldots \ldots$ & 1.4 & 1.3 & 1.2 & 0.8 & 1.3 \\
\hline Low Growth ......... & 1.3 & 1.1 & 1.0 & 0.6 & 1.0 \\
\hline \multicolumn{6}{|l|}{ Productlvity } \\
\hline High Growth . . . . . . . & 0.8 & 1.2 & 1.2 & 1.2 & 1.1 \\
\hline $\begin{array}{l}\text { Reference } \\
\text { Low Growth } \ldots \ldots \ldots \ldots\end{array}$ & 0.7 & $\begin{array}{l}1.1 \\
1.0\end{array}$ & $\begin{array}{l}1.1 \\
0.9\end{array}$ & $\begin{array}{l}1.0 \\
0.7\end{array}$ & $\begin{array}{l}1.0 \\
0.8\end{array}$ \\
\hline
\end{tabular}

Source: Energy Information Administration, AEO 1995 National Energy Modeling System runs: AEO95B.D1103942; LMAC95.D1103941; and HMAC95.D1103941. 
The productivity of labor is the second major determinate of economic growth and combines the positive effects of a growing capital stock of the economy as well as technological change occurring over time. A key to achieving the Reference Case's long-run 2.2 percent growth is an anticipated recovery in productivity growth. Productivity growth slowed in the 1970's, compared to the growth experienced postWorld War II. There is no consensus about why productivity growth declined so much after 1973. However, between 1980 and 1990, business investment's share of GDP declined at the same time that both the Federal budget deficit and the trade deficit increased. Since 1991, the economic recovery has been led by strong gains in business investment as a result of lower interest rates. Productivity has shown recent strong gains as economic output has increased more rapidly than employment gains.

In the Reference Case, productivity growth remains relatively constant throughout the forecast period. The Federal deficit is expected to diminish over time, helping lead a recovery in private investment and spending on research and development. Business fixed investment rises as a share of GDP. The resulting growth in the capital stock and the technology base of that capital stock helps to sustain productivity growth in the range of 1 percent. This growth in productivity offsets some of the decline in the labor force growth, but the economy continues to slow down over time.

To reflect the uncertainty in forecasts of economic growth, the AEO95 forecasts use High and Low Economic Growth Cases along with the Reference Case to project the possible energy markets. All three economic growth cases are based on forecasts prepared by Data Resources, Inc. (DRI). ${ }^{2}$ The DRI forecasts used in AEO95 are the Trend Growth scenario and the Optimistic and Pessimistic growth projections. EIA has used DRI's forecasts directly, apart from an adjustment to incorporate EIA's world oil price assumptions. The three economic growth cases have been modified by EIA to incorporate the world oil price assumptions for the $A E O 95$ Reference Case. With this change, the DRI projections are used as the starting point for the macroeconomic forecasts within the NEMS simulations for the AEO95. The macroeconomic activity module incorporates energy price feedback impacts on the aggregate economy.

The High Economic Growth Case incorporates higher population, labor force and productivity growth rates than the Reference Case. Due to the higher productivity gains, inflation and interest rates are lower compared to the Reference Case. Investment, disposable income, and industrial production are increased. Economic output is projected to increase by 2.7 percent between 1993 and 2010. The Low Economic Growth Case assumes lower population, labor force, and productivity gains, with resulting higher prices and interest rates and lower industrial output growth. In the Low Growth Case, economic output is expected to increase by 1.8 percent over the forecast horizon.

The regional disaggregation of the economic variables uses regional shares coming from a regional model solution. These shares change over time, but do not change as energy prices change from the projected reference price path. The regional disaggregation of disposable income and nonagricultural employment is presented in Table 94 in Part II.

\footnotetext{
${ }^{2}$ The underlying macroeconomic growth cases use DRI/McGraw-Hill's February 1994 Trend, Optimistic and Pessimistic Growth Cases. See DRI/McGraw-Hill, Review of the U.S. Economy: Long-Range Focus, Winter 1993-94 (Lexington, MA, 1994).
} 


\section{International Energy Module}

The International Energy Module determines changes in the world oil price and the supply prices of petroleum products for import to the United States in response to changes in U.S. import requirements. A market clearing method is used to determine the price at which worldwide demand for oil is equal to the worldwide supply. The module determines new values for oil production and demand for regions outside the United States, along with a new world oil price that balances supply and demand in the international oil market.

\section{Key Assumptions}

The level of oil production by countries in the Organization of Petroleum Exporting Countries (OPEC) is a key factor influencing the world oil price projections incorporated into AEO95. Non-OPEC production, worldwide regional economic growth rates and the associated regional demand for oil, and the level of net oil exports from Eurasia (the former Soviet Union, China, and Eastern Europe) are additional factors affecting the world oil price.

OPEC oil production is assumed to increase throughout the forecast, making OPEC the source for the worldwide increase in oil consumption expected over the forecast period (Figure 2). OPEC is assumed to be the source of additional production because its member nations hold a major portion of the world's total reserves-in the neighborhood of 750 billion barrels, over 75 percent of the world's total, at the end of $1993 .^{3}$ For the AEO95 forecasts, three different OPEC production paths are the principal assumptions leading to the three world oil price path cases examined: the Low Oil Price Case, Reference Case, and High Oil Price Case. The values assumed for OPEC production for the three world oil price cases are given in Figure 2.

Figure 2. OPEC Oil Production, 1970-2010 (Million Barrels per Day)

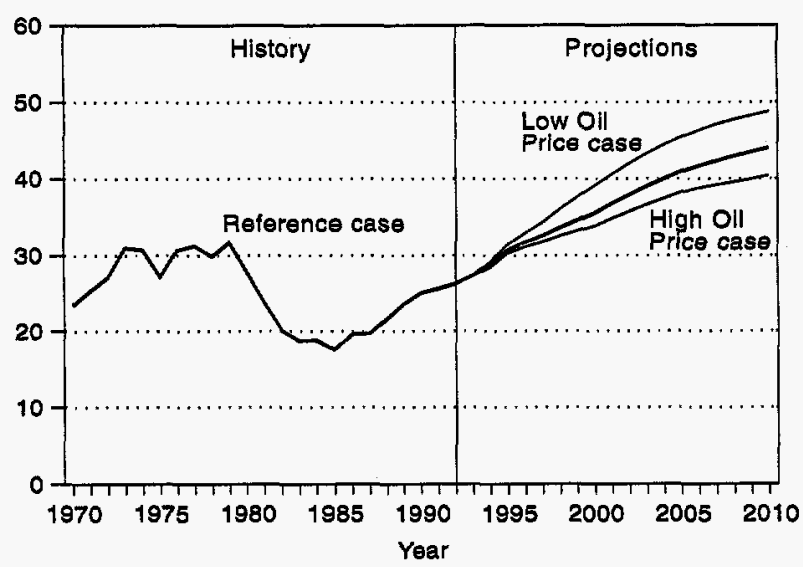

OPEC = Organization of Petroleum Exporting Countries.

Source: Energy information Administration, AEO 1995 National Energy Modeling System runs: LWOP95.D1103941; AEO95B.D1103942; and HWOP95.D1103942.

${ }^{3}$ Energy Information Administration, International Energy Outlook 1994, DOE/EIA-0484(93) (Washington DC, June 1994). 
Non-OPEC oil production is expected to follow a fairly flat path-with a slight rise through the year 2000 and a modest decline thereafter-as production declines in some parts of the world are offset by increases in other regions (Figure 3). One fixed path for non-OPEC oil production is initially input for all three world oil price case projections. Non-OPEC production depends upon the values of world oil prices, so the final forecast solutions of the levels of non-OPEC production for the three oil prices cases diverge from the initial assumptions. Production is higher in the High Oil Price Case since more marginal wells are profitable at the higher prices. Likewise, lower world oil prices are associated with lower production levels. The final non-OPEC production paths for the three oil price cases are shown in Figure 3.

Figure 3. Non-OPEC Oil Production, 1970-2010

(Million Barrels per Day)

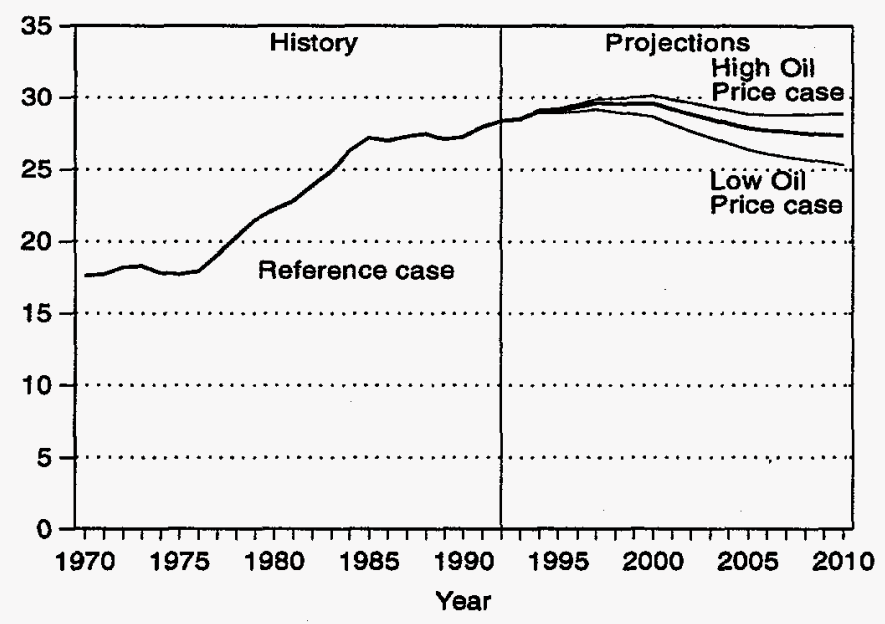

OPEC = Organization of Petroleum Exporting Countries

Source: Energy Information Administration, AEO 1995 National Energy Modeling System runs: LWOP95.D1103941; AEO95B.D1103942; and HWOP95.D1103942.

The assumed growth rates for gross domestic product (GDP) for various regions in the world are shown in Table 3. This set of growth rates for GDP was assumed for all three price cases. The GDP growth rate assumptions are from selected issues of The WEFA Group, World Economic Outlook. The WEFA GDP growth rates have been used for all regions of the world except for the developing countries, for which the GDP growth rates have been assumed to be about 1 percentage point per year lower than the WEFA values.

The WEFA GDP forecasts are made with limited consideration of prospective energy market conditions. ELA's analysis indicates that economic growth by the developing countries at the rates suggested by WEFA would put upward pressures on energy production and prices (particularly for oil) that could not be sustained by the market. These high economic growth rates would lead to oil prices high enough to retard economic growth. The 1-percentage-point reduction in economic growth rates for developing countries provides a better balance between sustainable economic growth rates and growth in energy production.

The values for growth in oil demand calculated in the International Energy Module, which depend upon the oil price levels as well as the GDP growth rates, are shown in Table 4 for the three oil price cases by regions of the world. The different rates of growth for oil consumption in the three price cases reflect the different levels in consumption calculated for the different oil prices. 
Table 3. Average Annual Regional Gross Domestic Product Growth Rates, 1990-2010 (Percent per Year)

\begin{tabular}{|c|c|}
\hline Region & Gross Domestic Product \\
\hline Organization for Economic Cooperation and Development . . . . . . . & 2.4 \\
\hline Organization of Petroleum Exporting Countries $\ldots \ldots \ldots \ldots \ldots$ & 4.2 \\
\hline Other Developing Countries . . . . . . . . . . . . . . . . . & 4.2 \\
\hline Eurasia $\ldots \ldots \ldots \ldots \ldots \ldots \ldots \ldots \ldots \ldots \ldots \ldots \ldots \ldots$ & 2.3 \\
\hline China $\ldots \ldots \ldots \ldots \ldots \ldots \ldots \ldots \ldots \ldots \ldots \ldots \ldots \ldots$ & 7.0 \\
\hline Former Soviet Union $\ldots \ldots \ldots \ldots \ldots \ldots \ldots \ldots \ldots$ & 0.5 \\
\hline Eastern Europe $\ldots \ldots \ldots \ldots \ldots \ldots \ldots \ldots \ldots \ldots \ldots \ldots$ & 1.1 \\
\hline Total World $\ldots \ldots \ldots \ldots \ldots \ldots \ldots \ldots \ldots \ldots \ldots$ & 2.7 \\
\hline
\end{tabular}

Source: The WEFA Group, World Economic Service and World Economic Service Historical Data (June 1993) and World Economic Outlook (February and July 1994).

Table 4. Average Annual Regional Growth Rates for Oil Demand, 1990-2010 (Percent per Year)

\begin{tabular}{|c|c|c|c|}
\hline Region & Low Price & Reference & High Price \\
\hline Organization for Economic Cooperation and Development . . . . . . . & 2.3 & 1.4 & 1.1 \\
\hline Organization of Petroleum Exporting Countries . . . . . . . . . . & 2.1 & 2.1 & 2.1 \\
\hline Other Developing Countries . . . . . . . . . . . . . . . . & 3.1 & 2.3 & 2.1 \\
\hline 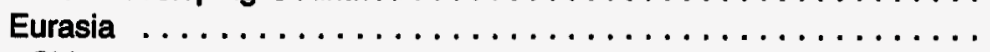 & 1.8 & 1.1 & 0.7 \\
\hline China $\ldots \ldots \ldots \ldots \ldots \ldots \ldots \ldots \ldots \ldots \ldots \ldots$ & 2.4 & 2.8 & 3.2 \\
\hline Former Soviet Union $\ldots \ldots \ldots \ldots \ldots \ldots \ldots \ldots \ldots$ & -0.8 & -0.6 & -0.2 \\
\hline Eastern Europe $\ldots \ldots \ldots \ldots \ldots \ldots \ldots \ldots \ldots \ldots \ldots$ & -0.3 & 0.3 & 0.6 \\
\hline Total World $\ldots \ldots \ldots \ldots \ldots \ldots \ldots \ldots \ldots \ldots \ldots$ & 2.6 & 1.6 & 1.3 \\
\hline
\end{tabular}

Source: Energy Information Administration, AEO 1995 National Energy Modeling System runs: LWOP95.D1103941; AEO95B.D1009941; and HWOP95.D1103942.

Economic growth and oil consumption in Eurasia (the former Soviet Union, China, and Eastern Europe) are projected to decline through 1995, with virtually all of the decline occurring in the former Soviet Union (FSU). Oil production in the FSU is assumed to decline through 1995 but to remain well above domestic FSU oil consumption. After 1995, oil production in the FSU recovers along with oil consumption, and the FSU remains a net exporter through 2010. In contrast, China is expected to become a net importer of oil before 1995 and remain so through 2010. Currently, Eastern Europe depends on imports for most of its oil and will continue to do so. However, as a group, Eurasia is assumed to remain a net exporter of oil to the rest of the world over the entire projection period. Eurasian net oil exports approach zero by 2010 in the High Oil Price Case (-1.0 for China, 2.7 for Russia, and -1.7 for Eastern Europe), 1.6 million barrels per day in the Reference Case (-0.5 for China, 3.6 for Russia, and -1.6 for Eastern Europe), and 3.2 million barrels per day in the Low Oil Price Case ( 0 for China, 4.5 for Russia, and -1.3 for Eastern Europe). 


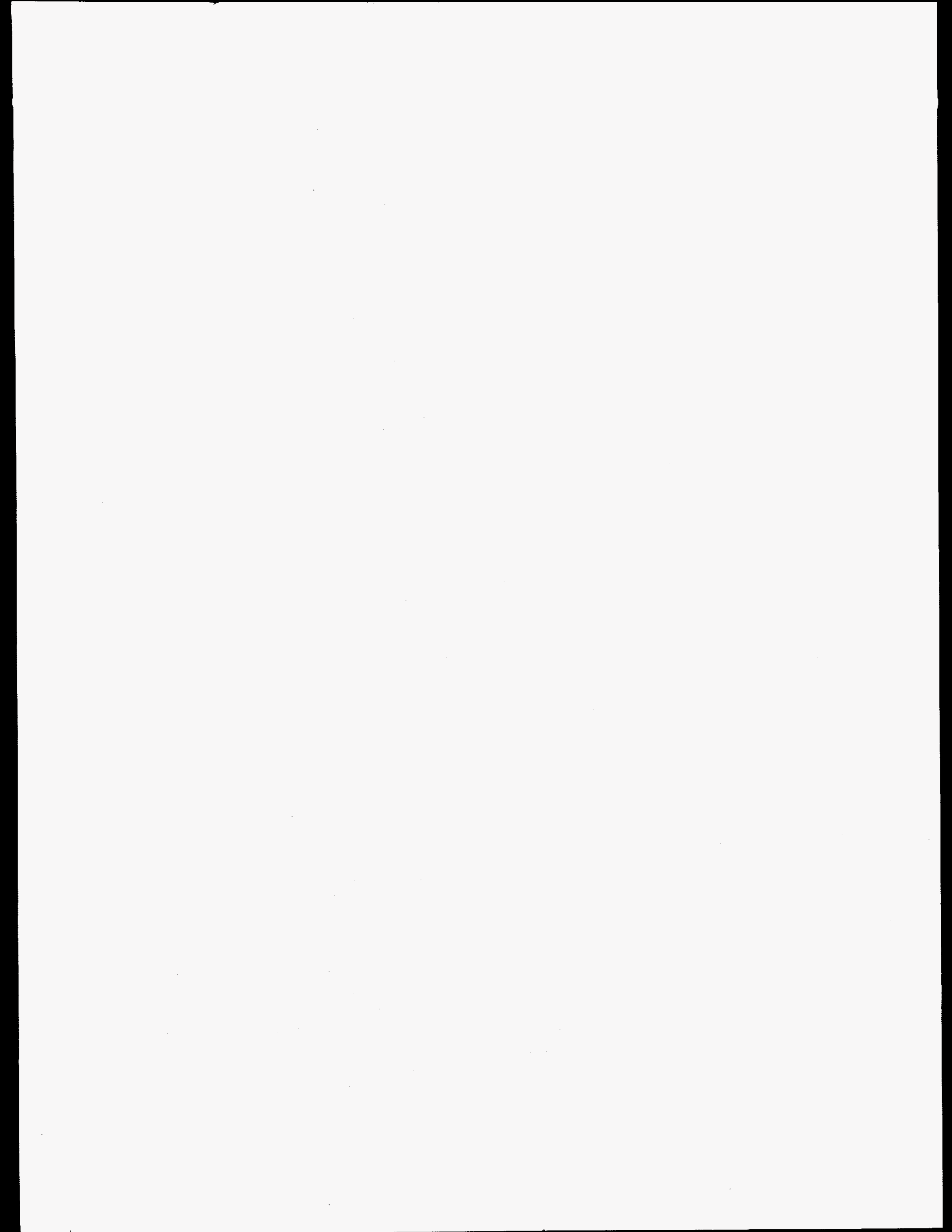




\section{Household Expenditures Module}

The Household Expenditures Module (HEM) constructs household energy expenditure profiles using historical survey data on household income, population and demographic characteristics, and consumption and expenditures for fuels for various end-uses. These data are combined with NEMS forecasts of household disposable income, fuel consumption, and fuel expenditures by end-use and household type. The HEM disaggregation algorithm uses these combined results to forecast household fuel consumption and expenditures by income quintile, ethnicity, and Census division.

\section{Key Assumptions}

The historical input data used to develop the HEM version for the AEO95 consists of recent household survey responses, aggregated to the desired level of detail. Two surveys performed by the Energy Information Administration are included in the AEO95 HEM database, and together these input data are used to develop a set of baseline household consumption profiles for the direct fuel expenditure analysis. These surveys are the 1990 Residential Energy Consumption Survey (RECS) and the 1991 Residential Transportation Energy Consumption Survey (RTECS).

HEM uses the consumption forecast by NEMS for the residential and transportation sectors as inputs to the disaggregation algorithm that results in the direct fuel expenditure analysis. Household end-use and personal transportation service consumption are obtained by HEM from the NEMS Residential Demand Module and the Transportation Demand Module. Household disposable income is adjusted with forecasts of total disposable income from the NEMS Macroeconomic Activity Module.

The fundamental assumptions underlying HEM's processing of the historical and NEMS forecast data to obtain its results are:

- Individual households are assumed not to migrate between income quintiles throughout the analysis period.

- All households within a household segment are assumed to consume the average quantity of fuel for that segment. Distributions about, or deviations from, the average are not explicitly modeled.

- The change in average household consumption between forecast year y and survey base year $y_{0}$ is captured from the NEMS run at the finest available level of detail, and the same proportional change is assumed to occur in each HEM subsegment of the analysis.

Application of the HEM algorithm produces a direct household fuel expenditure forecast at the finest level of disaggregation; namely, by fuel, end-use service, housing type and vintage, ethnicity, disposable income quintile, Census division, and year. Results obtained are summed across end-uses to yield total direct fuel expenditures as a function of disposable income for each household segment. The consolidation of these high-resolution results into national average household expenditure results requires a weighted averaging in order to obtain the desired aggregations. The weighting scheme used requires the proportions of households of each type and vintage headed by householders of each ethnicity and income quintile. The survey data provides these historical subsegment proportions, and for the AEO95 they are assumed to remain constant throughout the forecast period. 



\section{Residential Demand Module}

The National Energy Modeling System (NEMS) Residential Demand Module estimates future residential sector energy requirements based on estimates of the number of households and the stock and efficiency of energy-consuming equipment contained in these houses. The primary inputs for the module are housing starts by type (single-family, multifamily, and mobile homes) and Census division and prices by fuel type and Census division. The end-use services for which equipment is tracked include space conditioning (heating and cooling), water heating, refrigeration, freezers, cooking, and clothes dryers. In addition to these major end-use services, the average unit energy consumption (UEC) is tracked for secondary heating, lighting, and other electric and nonelectric appliances. The geographic coverage is the nine Census divisions. The module's output includes number of households, equipment stock, average equipment efficiencies, and energy consumed by service, fuel, and geographic location. The fuels represented are distillate fuel oil, liquefied petroleum gas, natural gas, kerosene, electricity, wood, geothermal, coal, and solar (active) energy.

\section{Key Assumptions}

\section{Housing Stock Submodule}

The key driver in the residential sector is the number of occupied households. The number of households for the base year (1990) is derived from the Energy Information Administration's (EIA) Residential Energy Consumption Survey (RECS) (Table 5). The forecast for occupied households is based on the combination of the previous year's surviving stock and housing starts provided by the NEMS' Macroeconomic Activity Module. The Housing Stock Submodule assumes a constant survival rate for each type of household unit: .995 for single-family units, .99 for multifamily units, and .981 for mobile home units.

Table 5. 1990 Households

(Thousands)

\begin{tabular}{|c|c|c|c|c|}
\hline Region & $\begin{array}{l}\text { SIngle-family } \\
\text { Units }\end{array}$ & $\begin{array}{l}\text { Multifamily } \\
\text { Units }\end{array}$ & $\begin{array}{l}\text { Mobile Home } \\
\text { Units }\end{array}$ & $\begin{array}{l}\text { Total } \\
\text { Units }\end{array}$ \\
\hline New England & 2,532 & 1,860 & 152 & 4,544 \\
\hline Mid Atlantic $\ldots \ldots \ldots$ & 9,334 & 4,968 & 376 & 14,679 \\
\hline East North Central .... & 11,250 & 4,137 & 1,224 & 16,611 \\
\hline West North Central .... & 4,765 & 1,307 & 385 & 6,458 \\
\hline South Atlantic . . . . . . . & 11,703 & 3,787 & 1,068 & 16,558 \\
\hline East South Central .... & 4,666 & 1,278 & 487 & 6,431 \\
\hline West South Central .... & 7,342 & 1,640 & 325 & 9,307 \\
\hline Mountain $\ldots \ldots \ldots$ & 3,469 & 887 & 489 & 4,844 \\
\hline Pacific $\ldots \ldots \ldots \ldots$ & 9,302 & 4,551 & 706 & 14,559 \\
\hline United States . . . . . & 64,364 & 24,415 & 5,212 & 93,991 \\
\hline
\end{tabular}

Source: Energy Information Administration, Housing Characteristics 1990, DOE/EIA-0314(90) (Washington, DC, May 1992).

${ }^{4}$ Energy consumed by a technology or service measured in million Btu per household per year. 
Fuel consumption is dependent not only on the number of houses, but also on the type and geographic distribution of the houses. For example, distillate oil is the most common heating fuel in New England, while natural gas dominates in the Midwest. Liquefied petroleum gas is a prevalent heating fuel in mobile homes.

\section{Technology Choice Submodule}

The key inputs in the Technology Choice Submodule are fuel prices and equipment characteristics (capital cost, efficiency, etc.) by Census division. Fuel prices are exogenous variables passed to the submodule from the various supply modules through the NEMS integration system. Equipment characteristics are exogenous variables which can be modified to reflect Federal standards and anticipated changes in the market place. Table 6 lists capital cost and efficiency for selected residential appliances for the year 1998.

Table 6. Capital Cost and Efficiency Ratings of Selected Equipment in 1998

\begin{tabular}{|c|c|c|c|}
\hline Equipment & & $\begin{array}{l}\text { Capital Cost } \\
\text { (1990 dollars) }\end{array}$ & Efficiency Rating \\
\hline \multirow[t]{2}{*}{ Electric Heat Pump } & base & 3,563 & 10.00 \\
\hline & best ...... & 4,722 & 13.30 \\
\hline \multirow{2}{*}{ Natural Gas Furnace } & base $\ldots . .$. & 1,639 & .78 \\
\hline & best $\ldots \ldots \ldots$ & 2,719 & .95 \\
\hline \multirow[t]{2}{*}{ Room Air Conditioner } & base $\ldots \ldots$ & 523 & 10.61 \\
\hline & best $\ldots \ldots$. & 616 & 12.28 \\
\hline \multirow[t]{2}{*}{ Refrigerator (18 cubic feet) } & base ..... & 674 & 595 \\
\hline & best ...... & 890 & 300 \\
\hline \multirow[t]{2}{*}{ Electric Water Heater } & base $\ldots . .$. & 307 & .93 \\
\hline & best $\ldots \ldots$ & 395 & .96 \\
\hline
\end{tabular}

Notes: Base refers to the lowest efficiency equipment available to consumers in 1998. Best refers to the highest efficiency equipment available in 1998. Efficiency measurements vary by equipment type. Electric heat pumps are based on seasonal energy efficiency ratio; natural gas furnaces are based on annual fuel utilization efficiency; room air conditioners are based on energy efficiency ratio; refrigerators are based on kilowatthours per year; and water heaters are based on energy factor (delivered Btu divided by input Btu). See Table 21 in Part II of this report for a complete description of these efficiency ratings.

Sources: Lawrence Berkeley Laboratory, "U.S. Residential Appliance Energy Efficiency: Present Status and Future Directions," 1991. Lawrence Berkeley Laboratory, "Baseline Data for the Residential Sector and Development of a Residential Forecasting Database," May 1994. United States Environmental Protection Agency, Space Conditioning: The Next Frontier (Washington, DC, April 1993).

Logit functions calculate new home heating fuel choice as well as each service equipment's relative weight in a given market (service, housing type, and division). These relative weights are then normalized to determine the market share for each competing technology within a service. The logit functions determine the market share for each competing technology on the basis of life-cycle cost, first cost, and operating cost. The relative importance of each of these factors varies by service type. The installed efficiency for a given year is calculated by weighting all competing efficiencies by their respective market share.

\section{Appliance Stock Submodule}

The Appliance Stock Submodule computes the quantity and mix of equipment installed in new construction (based on the market shares mentioned above), tracks surviving equipment installed in previous years, and calculates the number of replacement units needed in the current year. 
A "saturation/penetration" approach is used to determine equipment purchases in a given year; therefore, the number of appliance purchases is a function of the number of households. The number of newly constructed houses determines the number of appliances to be installed, and the market shares (developed in the Technology Choice Submodule) determine the mix of the equipment. For existing structures (any house constructed prior to the current forecast year), the difference between the number of surviving houses and the number of surviving pieces of equipment determines the number of replacement equipment installations needed for a given year. Fuel switching at the time of replacement is based on the American Gas Association's Residential Natural Gas Market Survey, 1992 as well as changes in the relative prices of each fuel. Most equipment is replaced with like equipment; i.e., gas furnaces are replaced with gas furnaces that have characteristics (improved efficiency) typical of those purchased in that year.

The Appliance Stock Submodule works in conjunction with the Housing Stock Submodule to track the number of items of each type of equipment. Several assumptions are made in tracking the equipment stock. First, it is assumed that an appliance survives a minimum number of years after installation. Second, appliances do not survive beyond the maximum life expectancy. Between the minimum and maximum life expectancy, all appliances retire based on a linear decay function. It is further assumed that, when a house is retired from the stock, all of the equipment contained in that house retires as well; i.e., there is no secondhand market for this equipment (Table 7).

Table 7. Minimum and Maximum Life Expectancies of Equipment

\begin{tabular}{|c|c|c|}
\hline Equipment & Minimum Life & Maximum Life \\
\hline Heat Pumps $\ldots \ldots \ldots \ldots \ldots \ldots \ldots \ldots$ & 8 & 16 \\
\hline Central Forced-Air Furnaces $\ldots \ldots \ldots \ldots \ldots$ & 18 & 29 \\
\hline Hydronic Space Heaters $\ldots . \ldots \ldots$. . . . . & 20 & 25 \\
\hline Room Air Conditioners $\ldots \ldots \ldots \ldots \ldots$ & 12 & 18 \\
\hline Central Air Conditioners $\ldots \ldots \ldots \ldots \ldots$ & 8 & 16 \\
\hline Water Heaters $\ldots \ldots \ldots \ldots \ldots \ldots$ & 5 & 30 \\
\hline Cooking Stoves $\ldots \ldots \ldots \ldots \ldots \ldots \ldots$ & 16 & 21 \\
\hline Clothes Dryers $\ldots \ldots \ldots \ldots \ldots \ldots \ldots$ & 6 & 30 \\
\hline Refrigerators . . . . . . . . . . . . . . & 7 & 29 \\
\hline Freezers $\ldots \ldots \ldots \ldots \ldots \ldots \ldots$ & 11 & 31 \\
\hline
\end{tabular}

Source: Lawrence Berkeley Laboratory, "Baseline Data for the Residential Sector and Development of a Residential Forecasting Database," May 1994.

\section{Fuel Consumption Submodule}

Energy consumption is calculated by multiplying equipment stock of different vintages by their respective UEC's. The various levels of aggregated consumption (consumption by fuel, by service, etc.) are derived from these basic calculations. Included within these calculations are assumptions with regard to price elasticities, heating and cooling degree-days, shell efficiency, and the Energy Policy Act of 1992.

\section{Short Term Price Effect}

It is assumed that prices have a direct effect on energy consumption; i.e., the annual change in the price of a fuel has an inverse effect on fuel consumption. The services affected by this assumption are space heating and cooling. The current value for this price elasticity is $-0.15 .^{5}$

\footnotetext{
5Carol Dahl, "A Survey of Energy Demand Elasticities in Support of the Development of NEMS," an unpublished report prepared for the Energy Information Administration, (Washington, DC, October 1993) p. 84.
} 


\section{Shell Efficiency}

The shell integrity of the building envelope is an important determinant of the heating and cooling load for each type of household. In the NEMS Residential Demand Module, the shell integrity is represented by an index that changes over time to reflect improvements in the building shell. The shell integrity index takes into account vintage of house, fuel type, service (heating and cooling), and Census division.

Age, location, and type of heating fuel are important factors in determining the level of shell integrity. The ages of homes are classified as new (post-1990) and existing (pre-1991). Existing homes are characterized by the RECS 1990 survey and are assigned a shell index value of 1.0 for the base year (1990). The improvement over time in the shell integrity of these homes is a function of fuel prices. As fuel prices increase relative to their 1990 levels, it is assumed that the shell integrity of these homes improves. New homes are more efficient than old homes in terms of their building envelope. Based on RECS data, newer homes are roughly 10 percent more efficient than the existing stock, depending upon the heating fuel used and Census division where the homes are located. Over time, the shell integrity of new homes is assumed to improve as tighter building codes become more widespread. The shell integrity index directly affects the assumptions about space heating and cooling loads: as the shell integrity improves, fuel consumed for these services decreases.

\section{Legislation}

\section{Energy Policy Act of 1992}

The Energy Policy Act of 1992 (EPACT) contains several policies that are designed to improve residential sector energy efficiency. The EPACT policies analyzed in the NEMS Residential Demand Module include the sections relating to window-labeling programs, low-flow showerheads, and building codes. The impact of building codes is captured in the shell efficiency index for new buildings listed above. Other EPACT provisions, such as home energy-efficiency ratings and energy-efficient mortgages are voluntary, and their effects on residential energy consumption have not been estimated.

The window-labeling program is designed to help consumers determine which windows are most energy efficient. These labels already exist for all major residential appliances. Based on analysis of RECS data, it is assumed that the window labeling program will decrease heating loads by 8 percent and cooling loads by 3 percent. Approximately 20 percent of the housing stock will be affected by this policy by 2010 .

The low-flow showerhead program is designed to cut domestic hot water use for showers. It is assumed that these showerheads cut hot water use for showers by 50 percent. Since showers account for approximately 30 percent of domestic hot water use, total hot water use decreases by 15 percent. It is further assumed that these showerheads are installed exclusively in new construction.

\section{National Appliance Energy Conservation Act of 1987}

The Technology Choice Submodule incorporates equipment standards established by the National Appliance Energy Conservation Act of 1987 (NAECA). Some of the NAECA standards implemented in the model include: a seasonal energy efficiency rating of 10.0 for heat pumps; an annual fuel utilization efficiency (energy output over energy input) of .78 for oil and gas furnaces; an efficiency factor of .88 for electric water heaters; electric dryer standards that set consumption limits at 3.01 pounds per kilowatthour; and refrigerator standards that set consumption limits to 976 kilowatthours per year in 1990 and 691 kilowatthours per year in 1993. 


\section{Climate Change Action Plan}

The Climate Change Action Plan (CCAP) contains many policies which are designed to reduce carbon emissions in the United States to 1990 levels by the year 2000. The CCAP strategies analyzed in the NEMS Residential Demand Module for AEO95 include Action Items 6, 7, 8, and 10. Specifically, these sections relate to Federal Efficiency Standards for several household appliances, stricter building codes, and the expansion of "Golden Carrot" demand-pull type programs. Action Items 9 and 11 were not included in the module since funding was not secured in Fiscal Year 1995. Analyses relating to CCAP programs are on an ongoing basis, as funding changes over time.

AEO95 assumes that the 1998 Federal Efficiency Standards will impact three product classes directly, namely, room air conditioners, water heaters, and kitchen ranges and stoves. The efficiency levels assumed are: 10.61 energy efficiency ratio for room air conditioners, .93 energy factor for electric water heaters, .57 energy factor for gas water heaters, 561 kilowatthours per year for electric ranges, and 3.10 million Btu per year for gas ranges. The energy savings from these standards is approximately 40 trillion Btu by 2000 .

CCAP Action Items 8 and 10 are policies designed to reduce energy consumption by strengthening building shell efficiency. In AEO95, the shell integrity (efficiency) of new construction is assumed to increase relative to 1993 levels as stricter building codes, energy-efficient mortgages, and home energy rating systems become more widespread. Energy-efficient mortgages allow home buyers to qualify for higher loan amounts if the home is energy-efficient. The combined energy savings due to these measures is approximately 30 trillion Btu by 2000 .

\section{Efficiency Side Cases}

In addition to the AEO95 Reference Case, two side cases were developed to examine the effect of equipment and building standards on residential energy use. The 1993 technology case assumes that all future equipment purchases are made at the efficiency level consistent with 1993 shipments. There is one exception for standards already in place, the efficiencies of clothes dryers are adjusted for 1994 minimum efficiencies. The best technology case assumes that all equipment purchases from 1995 forward are characterized by those with the highest efficiency available as of 1993. The best technology assumption disregards the economic costs of such a decision, and is merely designed to show how much energy could be saved if currently available, high-efficiency equipment were chosen. Fuel shares of each technology remain fixed at the reference case level, only efficiencies change. Both cases were run with only the Residential Demand Module rather than as a fully integrated NEMS run. Consequently, no potential fuel price or macroeconomic feedback on residential demand was captured. Key results from the side cases are presented in Appendix $C$. 



\section{Commercial Demand Module}

The National Energy Modeling System (NEMS) Commercial Demand Module (CDM) generates midterm forecasts of commercial sector energy demand. The definition of the commercial sector is, with only minor exceptions, consistent with EIA's State Energy Data System (SEDS). ${ }^{6}$ That is, the commercial sector includes business establishments that are not engaged in transportation or in manufacturing or other types of industrial activity (e.g., agriculture, mining, or construction). The bulk of commercial sector energy is consumed within buildings; however, street lights, pumps, bridges, and public services are also included if the establishment operating them is considered commercial. Since most of commercial energy consumption occurs in buildings, CDM relies on the data from the EIA Commercial Buildings Energy Consumption Survey (CBECS) for characterizing the commercial sector activity mix as well as the equipment stock and fuels consumed to provide end use services.

The CDM forecasts consumption by fuel ${ }^{8}$ at the Census division level using prices from the NEMS energy supply modules, macroeconomic variables from the NEMS Macroeconomic Activity Module, as well as external data sources (technology characterizations, for example). Energy demands are forecast for 10 enduse services ${ }^{9}$ for 11 building categories $^{10}$ in each of the 9 Census divisions. The model begins by developing forecasts of floorspace for the 99 building category and Census division combinations. Next, the end-use service demands required for the projected floorspace are developed. Technologies are then chosen to meet the projected service demands for the seven major end uses. ${ }^{11}$ Once technologies are chosen, the energy consumed by the equipment stock (both previously existing and purchased equipment) chosen to meet the projected end-use service demands is developed. ${ }^{12}$

\section{Key Assumptions}

The key assumptions made by the CDM are presented in terms of the flow of the calculations described above. Each section below will summarize the assumptions in each of the CDM submodules: floorspace, service demand, technology choice, and end-use consumption. The four submodules are executed sequentially in the order presented, and the outputs of each submodule become the inputs to subsequently executed submodules. As a result, key forecast drivers for the floorspace submodule are also key drivers for the service demand submodule, and so on.

\footnotetext{
6Some minor electricity transfers have been made out of the SEDS definition of the commercial sector and into transportation to account for public agencies providing transportation services. Also, very small amounts of natural gas have been transferred out of the commercial sector to account for nonutility generation of electricity in the electric generator sector.

${ }^{7}$ See Energy Information Administration, Commercial Buildings Characteristics 1989, DOE/EIA-0246(89) (Washington, DC, June 1991); Commercial Buildings Energy Consumption and Expenditures 1989, DOE/EIA-0318(89) (Washington, DC, April 1992); and Energy End-Use Intensities in Commercial Buildings, DOE/EIA-0555(94)/2 (Washington, DC, September 1994).

${ }^{8}$ The fuels accounted for by the CSDM are electricity, natural gas, distillate fuel oil, residual fuel oil, liquefied petroleum gas (LPG), coal, motor gasoline, and kerosene. In addition to these fuels, the use of solar energy is projected based on an exogenous forecast.

${ }^{9}$ The end-use services in CSDM are heating, cooling, water heating, ventilation, cooking, lighting, refrigeration, personal computer (PC) and non-PC office equipment, and an other category to account for all other minor end uses.

${ }^{10}$ The 11 building categories are assembly, education, food sales, food services, health care, lodging, large offices, small offices, mercantile/service, warehouse, and other.

${ }^{11}$ Minor end uses are modeled based on penetration rates and efficiency trends.

${ }^{12}$ The detailed documentation of CSDM contains additional details concerning model structure and operation. Refer to Energy Information Administration, Model Documentation Report: Commercial Sector Demand Module of the National Energy Modeling System, DOE/EIA-M066R (Washington, DC, August 1994).
} 


\section{Floorspace Submodule}

Floorspace is forecast by starting with the previous year's stock of floorspace and eliminating a certain portion to represent the removal of buildings. Total floorspace is the sum of the surviving floorspace plus new additions to the stock derived from the Macroeconomic Activity Module's (MAM) floorspace projection. ${ }^{13}$

\section{Existing Floorspace Attrition}

Existing floorspace is based on the floorspace estimate from the Commercial Buildings Energy Consumption Survey 1989 (Table 8). Over time, the 1989 stock is projected to decline as buildings are removed from service (floorspace attrition). Floorspace attrition is estimated by a logistic decay function, the shape of which is dependent upon the values of two parameters: average building lifetime and gamma. Gamma controls the acceleration of the rate of retirement around the average building lifetime. The current values for the average building lifetime and gamma are 59 years and 5.4, respectively. ${ }^{14}$

Table 8. 1989 Total Floorspace from Commercial Buildings Energy Consumption Survey (Million Square Feet)

\begin{tabular}{|c|c|c|c|c|c|c|c|c|c|c|c|c|}
\hline Region & Assembly & Education & $\begin{array}{l}\text { Food } \\
\text { Sales }\end{array}$ & $\begin{array}{l}\text { Food } \\
\text { Servlce }\end{array}$ & $\begin{array}{c}\text { Health } \\
\text { Care }\end{array}$ & Lodging & $\begin{array}{l}\text { Large } \\
\text { Office }\end{array}$ & $\begin{array}{l}\text { Small } \\
\text { Offlce }\end{array}$ & $\begin{array}{l}\text { Mercantil } \\
\text { a/ Service }\end{array}$ & $\begin{array}{l}\text { Ware- } \\
\text { house }\end{array}$ & Other & Total \\
\hline New England .... & 431 & 294 & 80 & 90 & 118 & 188 & 461 & 231 & 608 & 310 & 363 & 3,174 \\
\hline Mid-Atlantic $\ldots$. & 1,077 & 1,594 & 171 & 195 & 258 & 361 & 1,367 & 643 & 2,039 & 1,500 & 1,190 & 10,395 \\
\hline East North Central & 837 & 1,604 & 79 & 236 & 476 & 482 & 1,054 & 561 & 1,853 & 2,045 & 1,453 & 10,680 \\
\hline West North Central & 571 & 617 & 49 & 101 & 438 & 499 & 273 & 393 & 1,207 & 594 & 531 & 5,273 \\
\hline South Allantic . . . & 1,063 & 971 & 113 & 145 & 232 & 548 & 1,008 & 759 & 2,049 & 1,865 & 1,338 & 10,091 \\
\hline East South Central & 477 & 514 & 29 & 113 & 104 & 165 & 538 & 439 & 899 & 570 & 448 & 4,296 \\
\hline West South Central & 1,281 & 848 & 134 & 113 & 135 & 520 & 413 & 659 & 1,830 & 989 & 746 & 7,668 \\
\hline Mountain $\ldots \ldots$. & 504 & 962 & 35 & 68 & 101 & 236 & 305 & 401 & 798 & 534 & 444 & 4,388 \\
\hline Pacilic ........ & 670 & 674 & 101 & 105 & 190 & 479 & 1,421 & 873 & 1,085 & 846 & 775 & 7,219 \\
\hline United States ... . & 6,911 & 8,078 & 791 & 1,166 & 2,052 & 3,478 & 6,840 & 4,959 & 12,368 & 9,253 & 7,288 & 63,184 \\
\hline
\end{tabular}

Source: Energy Information Administration, Commercial Buildings Characteristics 1989, DOE/EIA-0246(89) (Washington, DC, June 1991).

\section{New Construction Additions to Floorspace}

The CDM develops estimates of projected commercial floorspace additions that are embodied in the Data Resources, Inc., (DRI) total floorspace forecast. New construction is calculated by applying DRI's assumed regional building retirement rates to the DRI building types, by Census division. ${ }^{15}$ The DRI surviving floorspace from the previous year is subtracted from the DRI floorspace forecast for the current year from

\footnotetext{
${ }^{13}$ The floorspace from the MAM is based on the Data Resources, Inc., (DRI) floorspace estimates which are approximately 10 percent lower than the estimate obtained from the CBECS used for the CSDM. The DRI forecast is developed using the F.W. Dodge data on commercial floorspace. See F.W. Dodge, Building Stock Database Methodology and 1991 Results (New York, NY: McGraw-Hill, 1992). Due to the higher floorspace estimates from CBECS, the additions implicit in the MAM forecast are derived from the forecast and added to the surviving CBECS stock.

${ }^{14}$ The CSDM performs attrition for 5 vintages of floorspace developed from the CBECS 1989 stock estimate and historical floorspace additions data from F.W. Dodge data.

${ }^{15}$ The DRI building retirement rates by Census region are: Northeast - 1.30 percent, Midwest - 1.33 percent, South - 1.29 percent, and West - 1.30 percent.
} 
MAM to yield new floorspace additions. ${ }^{16} \mathrm{New}$ additions are then mapped from the DRI definitions to the NEMS Commercial Demand Module's building types based on the CBECS building types shares.

\section{Service Demand Submodule}

Once the building stock is projected, the CDM develops a forecast of demand for energy-consuming services required for the projected floorspace. The module projects service demands for the following explicit end-use services: space heating, space cooling, ventilation, water heating, lighting, cooking, refrigeration, personal computer office equipment, and other office equipment. ${ }^{17}$ The service demand intensity (SDI) is measured in thousand Btu of end-use service demand per square foot and differs across service, Census division, and building type. The SDIs are based on a hybrid engineering and statistical approach to CBECS consumption data. ${ }^{18}$ Projected service demand is the product of square feet and SDI for all end uses across the 11 building categories with 2 adjustments. One adjustment accounts for changes in the usage intensity of a service in response to changes in real energy prices. The effects of price changes are modeled by adjusting the service demand forecasts through applying a short-term price elasticity of demand of -0.15 . The other adjustment is for improvements in building shell efficiency, which affect service demand for space heating and cooling. The current assumptions are for a 2-percent increase in existing shell efficiency by 2010 (relative to 1990) and for improvements in the shells of new buildings up to 30 percent above 1990 levels for existing buildings.

\section{Technology Choice Submodule}

The technology choice submodule develops projections of the results of the capital purchase decisions for equipment fueled by the three major fuels (electricity, natural gas, and distillate fuel). Capital purchase decisions are driven by assumptions concerning behavioral rule proportions and time preferences as well as projected fuel prices, average utilization of equipment (the "capacity factors"), relative technology capital costs, and operating and maintenance (O\&M) costs.

\section{Decision Types}

In each forecast year, equipment is potentially purchased based on three "decision types." Equipment must be purchased for newly added floorspace and to replace proportion of equipment in existing floorspace projected to wear out. ${ }^{19}$ Equipment is also potentially purchased for retrofitting equipment that has become economically obsolete. The purchase of retrofit equipment occurs only if the annual operating costs of a current technology exceed the annualized capital and operating costs of a technology available as a retrofit candidate.

\section{Behavioral Rules}

The CDM allows the use of three alternate assumptions about equipment choice behavior. These assumptions constrain the equipment choice among three choice sets, which are progressively more restrictive. The choice sets vary by decision type and building type:

1. Unrestricted Choice Behavior. This rule assumes that commercial consumers consider all types of equipment that provide a given service, across all fuels, when faced with a capital purchase decision.

\footnotetext{
${ }^{16}$ In the event that the computation of additions produces a negative value for a specific building type, the result is assumed to be zero.

17 "Other office equipment" includes communications equipment, security equipment, some appliances, tools, cash registers, elevators, water fountains, and clocks.

${ }^{18}$ D.B. Belzer, L.E. Wrench, and T.E. Marsh, End-Use Energy Consumption Estimates for U.S. Commercial Buildings, 1989, Pacific Northwest Laboratories, PNL-8946, prepared for the U.S. Department of Energy under Contract DE-AC06-76RLO-1830 (Richland, WA, November 1993).

${ }^{19}$ The proportion of equipment retiring is inversely related to the equipment life.
} 
2. Same Fuel Behavior. This rule restricts the capitol purchase decision to the set of technologies that consume the same fuel that currently meets the decisionmaker's service demand.

3. Same Technology Behavior. Under this rule, commercial consumers consider only the available models of the same technology and fuel that currently meets service demand, when facing a capital stock decision.

Under any of the above three behavior rules, equipment that meets the service at the lowest annualized lifecycle cost is chosen. Table 9 below illustrates the proportions of floorspace subject to the different behavior rules for space heating technology choices in large office buildings.

Table 9. Behavior Rules for Choosing Space Heating Equipment in Large Office Buildings (Percent)

\begin{tabular}{l|c|c|c|c}
\hline Technology Choice & Unrestricted & Same Fuel & Same Technology & Total \\
\hline New Equipment Decision . . . . . . . & 18 & 33 & 49 & 100 \\
Replacement Equipment Decision . . & 9 & 35 & 56 & 100 \\
Retrofit Equipment Decision ....... & 1 & 4 & 95 & 100 \\
\hline
\end{tabular}

Source: Energy Information Administration, Office of Integrated Analysis and Forecasting.

\section{Time Preferences}

The time preferences of owners of commercial buildings are assumed to be distributed among six alternate time preference premiums. Adding the time preference premiums to the 10 -year Treasury bill rate results in discount rates applicable to the assumed proportions of commercial floorspace. The effect of the use of this distribution of discount rates is to prevent a single technology from dominating purchase decisions in the lifecycle cost comparisons. The distribution used for AEO95 assigns some floorspace a very high discount rate to simulate floorspace that will never retrofit existing equipment and that will only purchase equipment with the lowest capital cost. Discount rates for the remaining five segments of the distribution become progressively lower, simulating increased sensitivity to the fuel costs of the equipment that is purchased.

The discount rate distribution for all end uses other than lighting is given in Table 10 below. For lighting, the block of commercial floorspace with a premium of 55.4 percent has been "promoted" to a premium of 6 percent. This is to simulate additional retrofitting behavior resulting from the Environmental Protection Agency's Green Lights Program. ${ }^{20}$

\section{Technology Characterization Database}

The technology characterization database organizes all relevant technology data by end use, fuel, and Census division. Equipment is identified in the database by a technology index as well as a vintage index, the index of the fuel it consumes, the index of the service it provides, its initial market share, the Census division index for which the entry under consideration applies, its efficiency (or coefficient of performance; efficacy in the case of lighting equipment), installed capital cost per unit of service demand satisfied, operating and maintenance cost per unit of service demand satisfied, average service life, year of initial availability, and last year available for purchase. Equipment may only be selected to satisfy service demand if the year in which the decision is made falls within the window of availability. Equipment

${ }^{20} \mathrm{Green}$ Lights will also be discussed in the section relating to the Administration's Climate Change Action Plan below. 
Table 10. Distribution of Time Preference Premiums

(Percentage)

\begin{tabular}{c|c}
\hline Proportion of Consumers & Time Preference Premiums \\
\hline 12.4 & $1,000.0$ \\
14.4 & 152.9 \\
16.4 & 55.4 \\
19.2 & 30.9 \\
19.6 & 19.9 \\
18.0 & 13.6 \\
\hline
\end{tabular}

Source: Energy Information Administration, Office of Integrated Analysis and Forecasting.

acquired prior to the lapse of its availability continues to be treated as part of the existing stock and is subject to replacement or retrofitting. This flexibility in limiting equipment availability allows the direct modeling of equipment efficiency standards. Table 11 provides a sample of the technology data for space heating in the New England Census Division.

\section{End-Use Consumption Submodule}

The end-use consumption submodule calculates the consumption of each of the three major fuels for the 10 end-use services plus fuel consumption for cogeneration and district services. For the 10 end-use services, energy consumption is calculated as the end-use service demand met by a particular type of equipment divided its efficiency and summed over all existing equipment types. This calculation includes dimensions for Census division, building type and fuel. Consumption of the five minor fuels is forecast based on historical trends.

\section{Cogeneration}

Nonutility power production applications within the commercial sector are concentrated in education, health care, office, and warehouse buildings. Historical data from Form EIA-867, "Annual Nonutility Power Producer Report," are used to derive electricity cogeneration for the years 1990 and 1991 by Census division, building type, and fuel. After 1991, a forecast of electricity cogeneration, as disaggregated above, is developed as follows: first, relative prices of energy sources for generation are compared with the price of electricity; second, if the price of electricity increases relative to generation fuels, then cogeneration increases based on a sensitivity parameter. ${ }^{21}$ If the price of electricity falls relative to the prices of other fuels, then cogeneration decreases based on the same sensitivity parameter. For each year of the forecast period, all cogenerated electricity is assumed to be sold to the grid and, subsequently, a portion is bought back to meet part of the consumption necessary to satisfy service demands.

\section{Legislation}

\section{Energy Policy Act of 1992}

A key assumption incorporated in the technology selection process is that the equipment efficiency standards described in the Energy Policy Act of 1992 (EPACT) and projected standards for 1998 will constrain minimum equipment efficiencies which are part of the Administration's Climate Change Action Plan. The effects of standards are modeled by modifying the technology database to eliminate equipment

\footnotetext{
${ }^{21}$ The sensitivity parameter assumes that a 10-percent change in relative prices results in a 1-percent change in cogeneration activity.
} 
Table 11. Technology Characteristics for Space Heating in New England

\begin{tabular}{|c|c|c|c|c|c|}
\hline Technology Class & Vintage & Efficiency & $\begin{array}{l}\text { Service } \\
\text { Life } \\
\text { (years) }\end{array}$ & $\begin{array}{c}\text { Capital Cost } \\
\text { (1987\$ per } \\
\text { MBtu/hour) }\end{array}$ & $\begin{array}{c}\text { O\&M Cost } \\
\text { (1987\$ per } \\
\text { MBtu/hour } \\
\text { per year) }\end{array}$ \\
\hline Electric Boilers $\ldots \ldots \ldots$ & 1989 & 0.99 & 25 & 6.89 & 0.45 \\
\hline Electric Baseboard . . . . . & 1989 & 0.80 & 18 & 18.63 & 3.29 \\
\hline $\begin{array}{l}\text { Electric Air Source Heat } \\
\text { Pump } \ldots \ldots \ldots \ldots \ldots\end{array}$ & $\begin{array}{l}1989 \text { - average } \\
1989 \text { - high efficiency } \\
1995 \\
2000\end{array}$ & $\begin{array}{l}1.56 \\
1.64 \\
2.53 \\
2.67\end{array}$ & $\begin{array}{l}10 \\
10 \\
10 \\
10\end{array}$ & $\begin{array}{l}53.88 \\
60.53 \\
67.72 \\
75.15\end{array}$ & $\begin{array}{l}3.78 \\
4.25 \\
5.08 \\
5.64\end{array}$ \\
\hline $\begin{array}{l}\text { Electric Water Source Heat } \\
\text { Pump } \ldots \ldots \ldots \ldots \ldots \ldots\end{array}$ & 1989 & 3.50 & 10 & 75.08 & 5.09 \\
\hline Gas Furnace & $\begin{array}{l}1989 \text { - average } \\
1989 \text { - high efficiency } \\
1992 \\
2000 \\
2005\end{array}$ & $\begin{array}{l}0.70 \\
0.78 \\
0.80 \\
0.83 \\
0.86\end{array}$ & $\begin{array}{l}25 \\
25 \\
25 \\
21 \\
21\end{array}$ & $\begin{array}{l}5.66 \\
6.10 \\
6.42 \\
6.50 \\
6.72\end{array}$ & $\begin{array}{l}0.24 \\
0.24 \\
0.25 \\
0.26 \\
0.27\end{array}$ \\
\hline Gas Boilers & $\begin{array}{l}1989 \text { - average } \\
1989 \text { - high efficiency } \\
1992 \\
2000\end{array}$ & $\begin{array}{l}0.70 \\
0.77 \\
0.80 \\
0.84\end{array}$ & $\begin{array}{l}35 \\
35 \\
35 \\
25\end{array}$ & $\begin{array}{l}7.96 \\
8.58 \\
9.02 \\
9.13\end{array}$ & $\begin{array}{l}0.39 \\
0.39 \\
0.41 \\
0.41\end{array}$ \\
\hline Gas Air Source Heat Pump & $\begin{array}{l}1994 \\
2000\end{array}$ & $\begin{array}{l}1.37 \\
1.40\end{array}$ & $\begin{array}{l}10 \\
10\end{array}$ & $\begin{array}{l}119.44 \\
122.25\end{array}$ & $\begin{array}{l}5.97 \\
6.11\end{array}$ \\
\hline Oil Furnace $\ldots \ldots \ldots \ldots$ & $\begin{array}{l}1989 \text { - average } \\
1989 \text { - high efficiency } \\
1998 \\
2000\end{array}$ & $\begin{array}{l}0.72 \\
0.81 \\
0.83 \\
0.86\end{array}$ & $\begin{array}{l}15 \\
15 \\
15 \\
15\end{array}$ & $\begin{array}{l}13.86 \\
14.95 \\
16.06 \\
16.26\end{array}$ & $\begin{array}{l}0.23 \\
0.23 \\
0.25 \\
0.26\end{array}$ \\
\hline Oil Boiler $\ldots \ldots \ldots \ldots \ldots$ & $\begin{array}{l}1989 \text { - average } \\
1989 \text { - high efficiency } \\
1992 \\
2000\end{array}$ & $\begin{array}{l}0.72 \\
0.80 \\
0.85 \\
0.86\end{array}$ & $\begin{array}{l}35 \\
35 \\
35 \\
23\end{array}$ & $\begin{array}{l}18.47 \\
19.91 \\
20.87 \\
21.13\end{array}$ & $\begin{array}{l}0.39 \\
0.39 \\
0.40 \\
0.40\end{array}$ \\
\hline
\end{tabular}

O\&M = Operation and maintenance, exclusive of fuel costs.

Note: Efficiency measurements vary by equipment type. Heat pumps (gas and electric) are based on the coefficient of performance (COP). Boilers and furnaces are based upon the ratio of Btu output to Btu input.

Source: Energy Information Administration, Model Documentation Report: Commercial Sector Demand Module of the National Energy Modeling System, DOE/EIA-M066R (Washington, DC, August 1994), Appendix A, and NEMS input file cn6005.com.ktech.base.d1003941.

that no longer meets minimum efficiency requirements. The efficiency standards for all choices made after 1993 and 1998 are shown in Table 12 below. For standards effective January 1, 1994, affected equipment includes electric heat pumps, furnaces and boilers, electric air conditioning units, water heaters, and fluorescent and incandescent lighting. Projected 1998 standards are assumed to affect only heat pumps and air conditioning units.

\section{Climate Change Action Plan}

The Administration's Climate Change Action Plan (CCAP) contains five action items which affect the commercial sector. Action Items 1, 4, and 5 are designed to stimulate investment in more efficient building shells and equipment for heating, cooling, and other uses. Action Item 2 targets the retrofitting of lighting equipment. Action Item 3 was unfunded and not included in CDM. Equipment standards for 
Table 12. Equipment Efficiencies Before and After Standards

\begin{tabular}{|c|c|c|c|}
\hline Equipment Type & 1990 & 1994 Standards & 1998 Standards \\
\hline Heat Pump ${ }^{a} \ldots \ldots \ldots \ldots \ldots \ldots \ldots$ & 1.56 & 1.64 & 2.53 \\
\hline Gas/Oil Boiler/Furnace $^{b} \ldots \ldots \ldots \ldots \ldots$ & 0.7 & 0.8 & $N / A$ \\
\hline Air Conditioner $^{\mathrm{a}} \ldots$ & 2.34 & 3.07 & 3.34 \\
\hline Electric Water Heater ${ }^{c}$. & 0.76 & 0.85 & N/A \\
\hline Gas/Oil Water Heater ${ }^{c} \ldots \ldots \ldots \ldots \ldots$ & 0.67 & 0.78 & $N / A$ \\
\hline Incandescent Light $^{d} \quad \ldots \ldots \ldots \ldots \ldots \ldots \ldots$ & 13 & 16.9 & N/A \\
\hline Fluorescent Light $(4 \mathrm{ft})^{d} \ldots \ldots \ldots \ldots$ & 65 & 75 & N/A \\
\hline
\end{tabular}

aMeasured as the coefficient of performance (COP).

bMeasured as the annual fuel utilization factor (AFUE).

'Measured as the energy factor (EF).

'Measured as lumens per watt (efficacy).

N/A = Not applicable.

space heating and cooling in 1998 are also considered part of CCAP. The CDM includes several features that allow projected efficiency to increase in response to voluntary programs (e.g., the distribution of time preference premiums and shell efficiency parameters). The standards component of CCAP is modeled directly in the technology characterization database as described above. For Action Item 2, the distribution of discount rate premiums for lighting has been adjusted to include a lower premium based on the retrofitting agreements made by participants in the Environmental Protection Agency's Green Lights Program (and its planned expansion which is part of CCAP). For Action Items 1,4, and 5, retrofits of equipment for space heating and air conditioning are incorporated in the distribution of premiums given in Table 10 above. Also, for Items 1, 4, and 5, the shell efficiency of existing buildings is assumed to increase at a uniform annual rate to a level that is 2 percent more efficient by 2010 than in 1990 .

\section{Efficiency Side Cases}

In addition to the Reference Case, two side cases were also developed to examine the effect of technologies and building standards on commercial energy use. The 1993 technology case assumes that all future equipment choices are made from the menu of equipment available in 1993. However, the choice of specific equipment type and efficiency is still made endogenously. For example, if the price of a particular fuel rises relative to other fuels, shifts to competing technologies using different fuels could occur, or more efficient 1993 models of the same technology might be chosen. The best technology case assumes that all future equipment choices are made from a menu of technologies which includes only the most efficient models available in a particular year. The best technology case disregards the economic costs of such a decision, and is merely designed to show how much energy could be saved if high-efficiency equipment were chosen. Fuel shares are allowed to change for an end use as the best technologies from each technology type compete to serve certain segments of the commercial floorspace market. For example, in the best technology case, the most efficient gas furnace technology competes with the most efficient electric heat pump technology. Building shells are also assumed to become 6 percent more efficient by 2010 in the best technology case. Both cases were run with only the Commercial Demand Module rather than as a fully integrated NEMS run. Consequently, no potential fuel price or macroeconomic feedback on commercial demand was captured. Key results from the side cases are presented in Appendix C. 



\section{Industrial Demand Module}

The National Energy Modeling System (NEMS) Industrial Demand Module estimates energy consumption by energy source (fuels and feedstocks) for 25 manufacturing and 6 nonmanufacturing industries. The manufacturing industries are further subdivided into the energy-intensive manufacturing industries and nonenergy-intensive manufacturing industries. The distinction between the two sets of manufacturing industries pertains to the level of modeling. The energy-intensive industries are modeled through the use of a detailed process flow accounting procedure, whereas the nonenergy-intensive and the nonmanufacturing industries are modeled through econometrically based equations (Table 13). The Industrial Demand Module forecasts energy consumption at the four Census region levels; energy consumption at the Census division level is allocated by using the State Energy Data System (SEDS) ${ }^{22}$ data, and the shares remain constant over time.

The energy-intensive industries (food and kindred products, paper and allied products, bulk chemicals, glass and glass products, hydraulic cement, blast furnace and basic steel products, and primary aluminum) are modeled in considerable detail with aggregate process flows. Each industry is modeled as three separate but interrelated components consisting of the Process/Assembly Component, the Buildings Component, and the Boiler/Steam/Cogeneration Component. The BSC Component satisfies the steam demand from the PA and BLD Components. In some industries, the PA Component produces byproducts that are consumed in the BSC Component. For the energy-intensive industries, the PA Component is broken down into the major production processes or end uses. Petroleum refining (Standard Industrial Classification 2911) is modeled in detail in a separate module of NEMS, and the projected energy consumption is included in the manufacturing total. Forecasts of refining use of oil and gas lease and plant fuel and fuels consumed in cogeneration (Standard Industrial Classification 1311) are exogenous to the Industrial Demand Module, but endogenous to the NEMS modeling system.

\section{Key Assumptions}

The NEMS Industrial Demand Module combines the use of a bottom-up process modeling approach with a top-down econometric approach. An energy accounting framework was developed to trace energy flows from fuels to the industry's output. An important assumption in the development of this system is the use of 1988 baseline Unit Energy Consumption (UEC) estimates based on analysis of the Manufacturing Energy Consumption Survey $1988^{23}$ and Standard and Poor's Major Industrial Plant Database. ${ }^{24}$ The UEC represents the energy required to produce one unit of the industry's output. The output may be defined in terms of physical units (e.g., tons of steel) or in terms of the dollar value of output.

The module depicts the seven most energy-intensive manufacturing industries (apart from petroleum refining, which is modeled in the Petroleum Market Module of NEMS) with a detailed process flow approach. The dominant process technologies are characterized by a combination of estimates and "technology possibility curves." The technology possibility curves indicate the energy intensity of new and existing stock relative to the 1988 stock over time. Rates of energy efficiency improvements assumed for new and existing plants vary by industry and process. These assumed rates were developed using

\footnotetext{
${ }^{22}$ Energy Information Administration, State Energy Data Report 1992, DOE/EIA-0214(92) (Washington, DC, May 1994).

${ }^{23}$ Energy Information Administration, Manufacturing Energy Consumption Survey: Consumption of Energy 1988, DOE/EIA0512(88) (Washington, DC, May 1991).

${ }^{24}$ Standard and Poor's, Inc., Major Industrial Plant Database (New York, NY, 1989).
} 
Table 13. Industry Categories

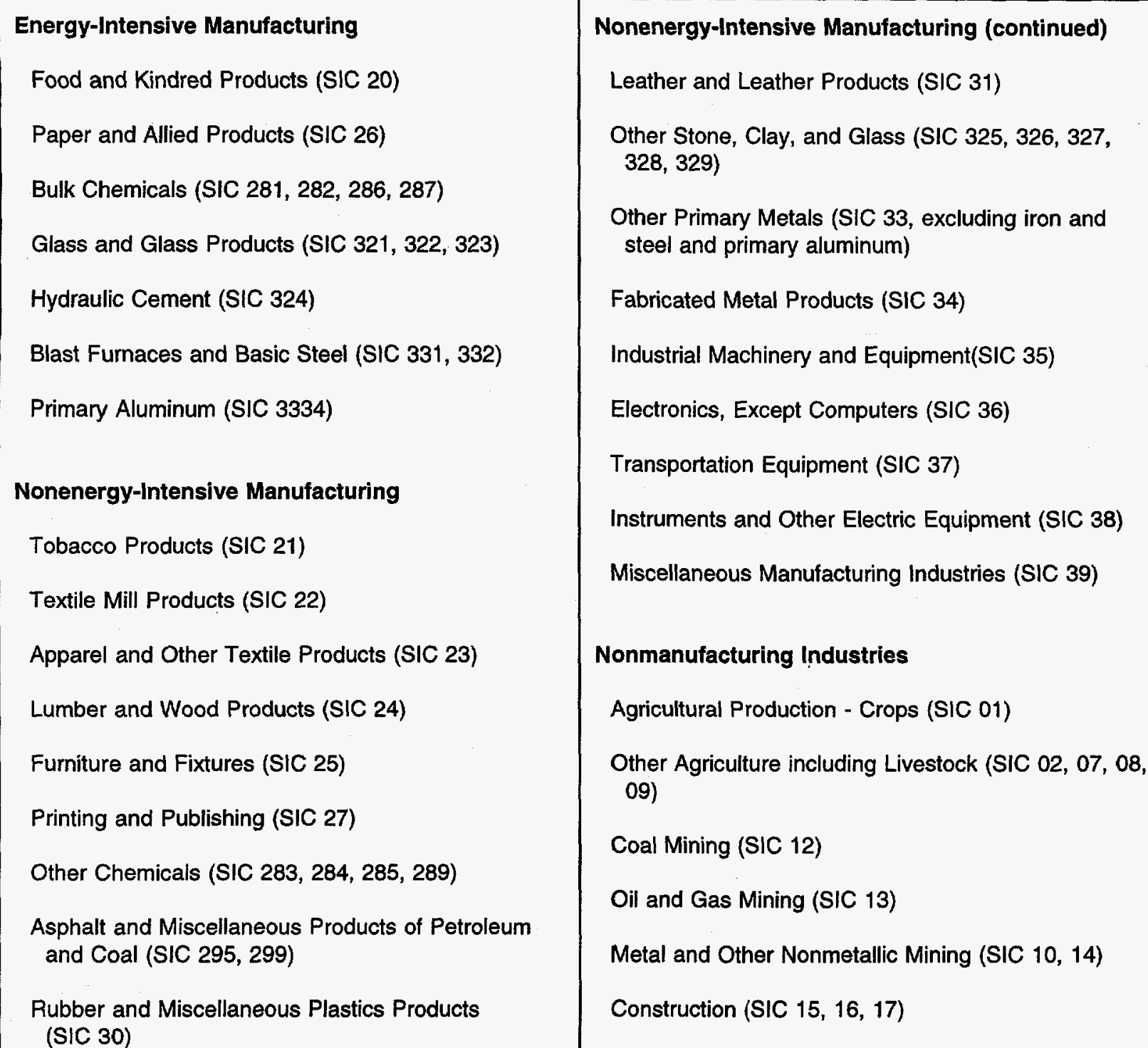

SIC = Standard Industrial Classification

Source: Energy Information Administration, Model Documentation Report: Industrial Sector Demand Module of the National Energy Modeling System, DOE/EIA-M064 (Washington, DC, January 1994).

professional engineering judgments regarding the energy characteristics, year of availability, and rate of market adoption of new process technologies.

\section{Process/Assembly Component}

The Process/Assembly Component models each major manufacturing production step for the energyintensive industries. The throughput production for each process step is computed as well as the energy required to produce it.

Within this component, the UEC is adjusted based on the technology possibility curves for each step. (For example, additions to waste fiber pulping capacity are assumed to require only 93 percent as much energy 
as does the average existing plant. $)^{25}$ The technology possibility curve is a means of embodying assumptions regarding new technology adoption in the manufacturing industry and the associated increased energy efficiency of capital without characterizing individual technologies. It is unlikely that new technology is employed in all new capacity additions. Many facilities will only partially incorporate the technology or will need time to debug the operating aspects of the newly installed capacity. To some extent, all industries will increase the energy efficiency of their process and assembly steps. The reasons for the increased efficiency are not likely to be directly attributable to changing energy prices but due to other exogenous factors. Since the exact nature of the technology improvement is too uncertain to model in detail, the module employs a technology possibility curve. In addition, byproducts produced in the Process/Assembly Component serve as fuels for the Boiler/Steam/Cogeneration Component. In the industrial module, byproducts are assumed to be consumed before purchased fuel.

\section{Buildings Component}

The total buildings energy demand by industry for each region is the product of the building UEC and regional industrial employment. Building were derived by first estimating energy requirements for building lighting, air conditioning, and space heating, where space heating was further divided to estimate the amount provided by direct combustion of fossil fuels and that provided by steam (Table 14). Energy consumption in the Building Component for an industry is assumed to grow at the same rate as regional employment for that industry.

\section{Boiler/Steam/Cogeneration Component}

The steam demand and byproducts from the Process/Assembly and Buildings Components are passed to the Boiler/Steam/Cogeneration Component, which applies a heat rate and fuel share elasticities (Table 15) to the boiler share to compute the required energy consumption. The byproduct fuels are consumed before the quantity of purchased fuels is estimated. The heat rate is estimated from the Industrial Sector Technology Use Model, and the boiler fuel shares are assumed to be those estimated using the Major Industrial Plant Database. ${ }^{26}$

\section{Nonenergy-Intensive Industries}

The UECs for the Process/Assembly Component of the nonenergy-intensive industries are econometrically estimated with autonomous and price-induced technical change. The autonomous trend is represented by cumulative output from existing technology. The short-term response to fuel price changes occurs by applying the estimated own- and cross-price elasticities ${ }^{27}$ to the Process/Assembly UECs to reflect the response. The cumulative output variable captures any autonomous trend over time within the industry that may affect the energy intensity of the production process.

\section{Technology}

The amount of energy consumption reported by the industrial module is also a function of vintage of the capital stock that produces the output. It is assumed that new vintage stock will consist of state-of-the-art technologies that are more energy efficient than the average efficiency of the existing capital stock. Consequently, the amount of energy required to produce a unit of output using new capital stock is less than that required by the existing capital stock. Capital stock is grouped into three vintages: old, middle, and new. The old vintage consists of capital in production prior to 1991 and is assumed to retire at a

\footnotetext{
${ }^{25}$ Energy Information Administration, Model Documentation Report: Industrial Sector Demand Module of the National Energy Modeling System, DOE/EIA-MO64 (Washington, DC, January 1994).

${ }^{26}$ Energy and Environmental Analysis, Inc., "Overview: the Industrial Sector Technology Use Model: ISTUM-2," March 1986.

${ }^{27}$ The various elasticities are documented in Energy Information Administration, Model Documentation Report: Industrial Sector Demand Module of the National Energy Modeling System, DOE/EIA-MO64 (Washington, DC, January 1994).
} 
Table 14. Building Component Unit Energy Consumption

(Trillion Btu/ Thousand People Employed)

\begin{tabular}{|c|c|c|c|c|c|}
\hline \multirow[b]{3}{*}{ sic } & \multirow[b]{3}{*}{ Industry } & \multicolumn{4}{|c|}{ Building Use and Energy Source } \\
\hline & & \multirow{2}{*}{$\begin{array}{c}\text { Lighting } \\
\text { Electric } \\
\text { UEC }\end{array}$} & \multicolumn{3}{|c|}{ HVAC } \\
\hline & & & $\begin{array}{c}\text { Electric } \\
\text { UEC }\end{array}$ & $\begin{array}{c}\text { Natural Gas } \\
\text { UEC }\end{array}$ & $\begin{array}{l}\text { Steam } \\
\text { UEC }\end{array}$ \\
\hline $20 \ldots \ldots$ & $\begin{array}{l}\text { Food \& Kindred } \\
\text { Products }\end{array}$ & 0.009 & 0.006 & 0.013 & 0.062 \\
\hline 21 & Tobacco Products & 0.007 & 0.005 & a & 0.071 \\
\hline 22 & $\begin{array}{l}\text { Textiles Mill } \\
\text { Products }\end{array}$ & 0.017 & 0.014 & 0.005 & 0.033 \\
\hline $23 \ldots$ & Apparel & 0.001 & 0.002 & 0.005 & 0.009 \\
\hline $24 \ldots \ldots$ & Lumber & 0.002 & 0.006 & a & 0.031 \\
\hline 25 & Furniture & 0.001 & 0.002 & 0.002 & 0.030 \\
\hline $26 \ldots$ & $\begin{array}{l}\text { Paper \& Allied } \\
\text { Products }\end{array}$ & 0.054 & 0.008 & 0.002 & 0.096 \\
\hline $27 \ldots \ldots$ & $\begin{array}{l}\text { Printing \& } \\
\text { Publishing }\end{array}$ & 0.001 & 0.008 & 0.002 & 0.016 \\
\hline $281,282,286,287$ & Bulk Chemicals & 0.037 & 0.018 & 0.002 & 0.118 \\
\hline $283,284,285,289 \ldots \ldots$ & Other Chemicals & 0.002 & 0.001 & 0.002 & 0.002 \\
\hline $2911 \ldots \ldots$ & $\begin{array}{l}\text { Petroleum } \\
\text { Refining }\end{array}$ & 0.156 & 0.074 & 0.036 & 0.123 \\
\hline 295,299 & $\begin{array}{l}\text { Asphalt \& Misc. } \\
\text { Petroleum } \\
\text { and Coal Products }\end{array}$ & 0.002 & 0.001 & 0.001 & 0.001 \\
\hline $30 \ldots \ldots \ldots \ldots$ & Rubber & 0.005 & 0.015 & 0.002 & 0.013 \\
\hline $31 \ldots \ldots \ldots \ldots \ldots$ & Leather & 0.003 & 0.003 & a & 0.035 \\
\hline $321,322,323$ & $\begin{array}{l}\text { Glass and Glass } \\
\text { Products }\end{array}$ & 0.148 & 0.084 & 0.030 & 0.000 \\
\hline $324 \ldots \ldots \ldots \ldots$ & Hydraulic Cement & 0.010 & 0.006 & a & 0.000 \\
\hline $325,326,327,328,329$ & $\begin{array}{l}\text { Other Stone, Clay } \\
\text { and, Glass }\end{array}$ & 0.005 & 0.003 & 0.002 & 0.000 \\
\hline 331,332 , etc. $\ldots \ldots \ldots$ & $\begin{array}{l}\text { Blast Furnaces \& } \\
\text { Basic Steel }\end{array}$ & 0.788 & 0.374 & 0.957 & 1.231 \\
\hline 3334,3341, etc. $\ldots \ldots$ & Primary Aluminum & 0.053 & 0.025 & a & 0.007 \\
\hline 333-336, 339 & $\begin{array}{l}\text { Other Primary } \\
\text { Metals }\end{array}$ & 0.003 & 0.001 & a & 0.004 \\
\hline $34 \ldots \ldots \ldots \ldots \ldots$ & Fabricated Metals & 0.006 & 0.005 & 0.012 & 0.030 \\
\hline 35 & $\begin{array}{l}\text { Industrial } \\
\text { Machinery }\end{array}$ & 0.006 & 0.012 & a & 0.014 \\
\hline 36 & $\begin{array}{l}\text { Electronic } \\
\text { Equipment }\end{array}$ & 0.006 & 0.017 & 0.001 & 0.011 \\
\hline $37 \ldots$ & $\begin{array}{l}\text { Transportation } \\
\text { Equipment }\end{array}$ & 0.010 & 0.007 & 0.003 & 0.037 \\
\hline $38 \ldots \ldots \ldots \ldots$ & Instruments & 0.004 & 0.014 & 0.001 & 0.027 \\
\hline 39 & $\begin{array}{l}\text { Miscellaneous } \\
\text { Manufacturing }\end{array}$ & 0.003 & 0.003 & 0.007 & 0.011 \\
\hline
\end{tabular}

This value is less than 0.0005 .

SIC $=$ Standard Industrial Classification.

UEC = Unit Energy Consumption.

HVAC = Heating, Ventilation, Air Conditioning.

Source: Energy Information Administration, Model Documentation Report: Industrial Sector Demand Module of the National Energy Modeling System, DOE/EIA-MO64 (Washington, DC, January 1994). 
Table 15. Boiler Fuel Share Elasticities

\begin{tabular}{l|c|c|c}
\hline & Petroleum & Natural Gas & Steam Coal \\
\hline Petroleum . . . . . . . & -0.78 & 0.50 & 0.17 \\
Natural Gas $\ldots \ldots \ldots \ldots$ & 0.40 & -0.83 & 0.00 \\
Steam Coal $\ldots \ldots \ldots \ldots$ & 0.63 & 0.00 & -1.01 \\
\hline
\end{tabular}

Source: Energy Information Administration; Office of Integrated Analysis and Forecasting.

fixed rate each year (Table 16). Middle vintage capital is that which is added after 1990 but not including the year of the forecast. New production capacity is built in the forecast years when the capacity of the existing stock of capital in the industrial model cannot produce the output forecasted by the NEMS Regional Macroeconomic Model. Capital additions during the forecast horizon are retired in subsequent years at the same rate as the pre-1991 capital stock.

The energy intensity of the new capital stock relative to 1990 capital stock is reflected in the parameter of the Technology Possibility Curve estimated for each of the energy-intensive industries. These curves are based on engineering judgment of the likely future path of energy intensity changes (Table 17). The energy intensity of the existing capital stock also is assumed to decrease over time, but not as rapidly as new capital stock. The net effect is that over time the amount of energy required to produce a unit of output declines. Although total energy consumption in the industrial sector is projected to increase, overall energy intensity is projected to decrease.

Table 16. Retirement Rates

\begin{tabular}{|c|c|c|c|}
\hline Industry & $\begin{array}{c}\text { Retirement Rate } \\
\text { (percent) }\end{array}$ & Industry & $\begin{array}{c}\text { Retirement Rate } \\
\text { (percent) }\end{array}$ \\
\hline $\begin{array}{l}\text { Food and Kindred } \\
\text { Products } \ldots \ldots \ldots \ldots\end{array}$ & 1.7 & $\begin{array}{l}\text { Blast Furnace and Basic } \\
\text { Steel Products (Blast } \\
\text { Furnace/Open Hearth) }\end{array}$ & 50.0 \\
\hline Tobacco Products ...... & 4.3 & $\begin{array}{l}\text { Blast Furnace and Basic } \\
\text { Steel Products (Blast } \\
\text { Furnace/Basic Oxygen } \\
\text { Furnace) }\end{array}$ & 0.0 \\
\hline Textile Mill Products . . . . & 4.6 & $\begin{array}{l}\text { Blast Furnace and Basic } \\
\text { Steel Products (Electric } \\
\text { Arc Furnace) }\end{array}$ & 1.5 \\
\hline $\begin{array}{l}\text { Apparel and Other Textile } \\
\text { Products . . . . . . . . . }\end{array}$ & 1.9 & Primary Aluminum & 2.1 \\
\hline $\begin{array}{l}\text { Lumber and Wood } \\
\text { Products ........... }\end{array}$ & 0.7 & Other Primary Metals & 1.2 \\
\hline Furniture and Fixtures ... & 1.0 & Fabricated Metals & 2.1 \\
\hline Paper and Allied Products & 2.3 & Industrial Machinery & 2.7 \\
\hline Printing and Publishing ... & 5.4 & Electronic Equipment & 4.5 \\
\hline Bulk Chemicals . . . . . . . & 1.9 & Transportation Equipment & 1.6 \\
\hline Other Chemicals . . . . . . & 3.6 & Instruments & 1.5 \\
\hline $\begin{array}{l}\text { Asphalt and Miscellaneous } \\
\text { Coal Products } \ldots \ldots \ldots \ldots\end{array}$ & 2.2 & $\begin{array}{l}\text { Miscellaneous } \\
\text { Manufacturing }\end{array}$ & 2.3 \\
\hline
\end{tabular}

Source: Energy Information Administration, Model Documentation Report: Industrial Sector Demand Module of the National Energy Modeling System, DOE/EIA-MO64 (Washington, DC, January 1994). 
Table 17. Coefficients for Technology Possibility Curve

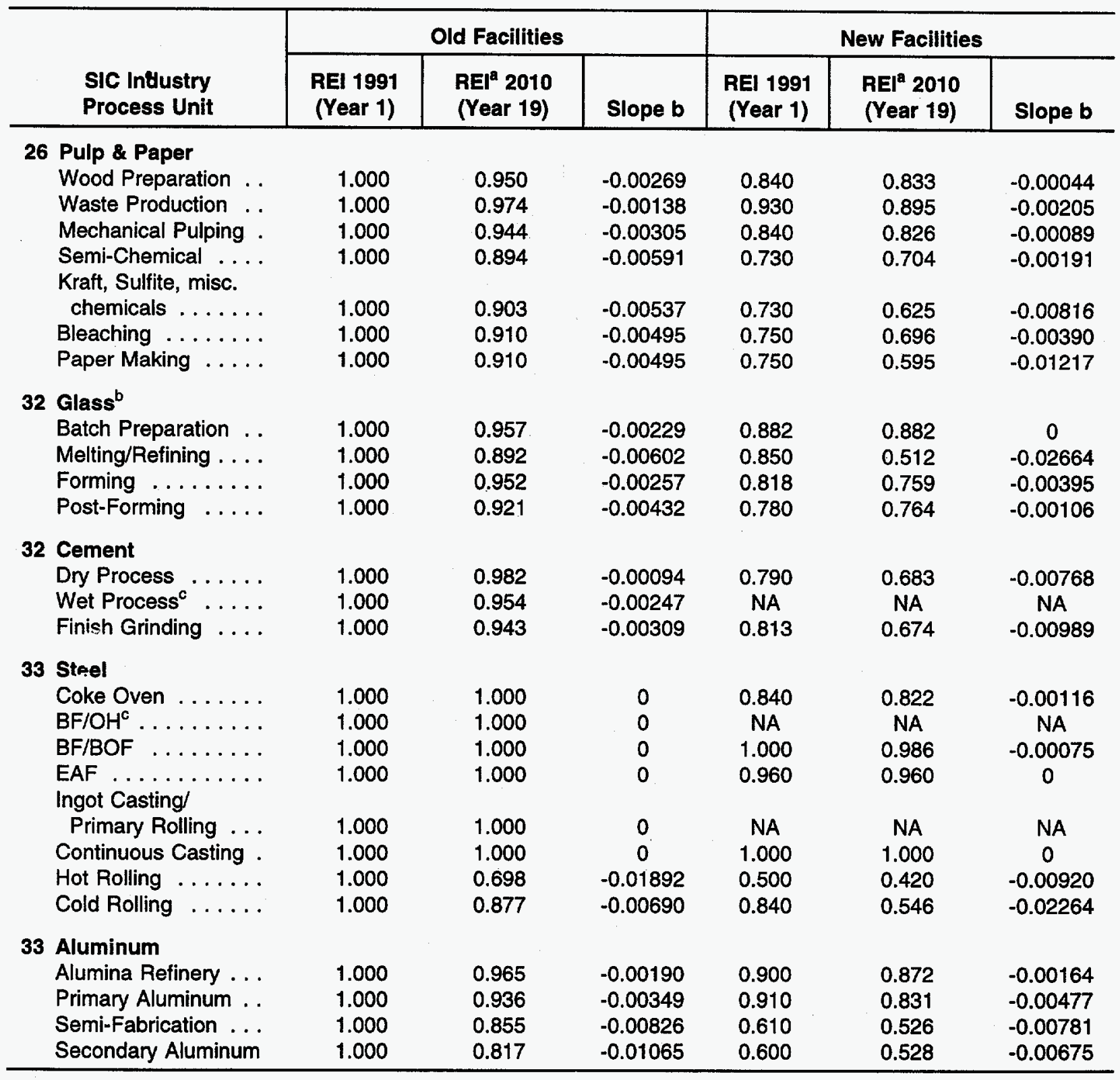

${ }^{a}$ Calculated from slope value $b$ and exponential equation (see text).

${ }^{b}$ REIs and slope apply to virgin and recycled materials.

${ }^{\mathrm{C}}$ No new plants are likely to be built with these technologies.

SIC = Standard Industrial Classification.

$\mathrm{REI}=$ Relative Energy Intensity.

NA $=$ Not applicable.

BF = Blast furnace.

$\mathrm{OH}=$ Open hearth.

BOF = Basic oxygen furnace.

EAF = Electric arc furnace.

Source: Arthur D. Little Inc., "NEMS Industrial Model: Update on Selected Process Flows and Energy Use." Unpublished report prepared for Energy Information Administration (Vienna, VA, April 28, 1994). 


\section{Cogeneration}

Cogeneration (the generation of electricity and steam) has been a standard practice in the industrial sector for many years. The cogeneration estimates in the module are based on the assumption that the historical relationship between industrial steam demand and cogeneration will continue in the future. The data source is Form EIA-867, "Annual Nonutility Power Producer Report," consisting of data from approximately 400 cogenerators for 1989, 1990, and 1992.

\section{Legislation}

The Energy Policy Act of 1992 (EPACT) and the Clean Air Act Amendments of 1990 contain several implications for the industrial module. These implications fall into three categories: coke oven standards; efficiency standards for boilers, furnaces, and electric motors; and industrial process technologies. The industrial module assumes the leakage standards for coke oven doors do not reduce the efficiency of producing coke or increase unit energy consumption. The industrial module uses heat rates of 1.25 (80 percent efficiency) and 1.22 ( 82 percent efficiency) for gas and oil burners respectively. These efficiencies meet the EPACT standards. The standards for electric motors call for a 10-percent efficiency increase. The industrial module incorporates a 10-percent savings for state-of-the-art motors increasing to 20-percent savings in 2015. Given the time lag in the legislation and the expected lifetime of electric motors, no further adjustments are necessary to meet the EPACT standards for electric motors. The industrial module incorporates the necessary reductions in unit energy consumption for the energy-intensive industries. Both cases were run with only the Industrial Demand Module rather than as a fully integrated NEMS run. Consequently, no potential fuel price or macroeconomic feedback on industrial demand was captured.

\section{Climate Change Action Plan}

Several programs included in the CCAP target the industrial sector. The intent of these programs is to reduce greenhouse gas emissions by lowering industrial energy consumption. It was estimated that full implementation of these programs would reduce industrial electricity consumption by 55 billion kilowatthours and nonelectric consumption by 370 trillion Btu by 2000 . However, the programs were not fully funded. The energy savings were revised in proportion to the funding received. Consequently, electricity consumption is reduced by 6 billion kilowatthours, and nonelectric energy consumption is reduced by 43 trillion Btu. The nonelectric energy is assumed to be steam coal.

\section{High Efficiency and 1993 Technology Side Cases}

Over the 1970-1990 period, industrial energy intensity fell by 1.9 percent annually. This was due to energy conservation and the changing composition of industrial output. The high efficiency case replicates the 1.9percent annual decline from 1995 through 2010. This is twice the rate of decline anticipated in the Reference Case ( 0.9 percent). For this exercise, the composition of industrial output remained the same as in the Reference Case.

The 1993 technology case holds the energy efficiency of new plant and equipment constant over the forecast. New Equipment and processes, however, typically are more energy efficient than those used in existing plants. As a result, the average energy intensity declines as old equipment is retired and new production capacity is added.

A standalone model run examined these side cases. Consequently, no potential fuel price or macroeconomic feedback effects are considered. Key results are presented in Appendix C. 



\section{Transportation Demand Module}

The National Energy Modeling System (NEMS) Transportation Demand Module estimates energy consumption across the 9 Census divisions and over 10 fuel types. Each fuel type is modeled according to fuel-specific technology attributes applicable by transportation mode. Total transportation energy consumption is the sum of energy use in seven transport modes: light-duty vehicles (cars, light trucks, and vans), freight trucks, freight and passenger airplanes, freight rail, freight shipping, mass transit, and miscellaneous transport. Light-duty vehicle fuel consumption is further subdivided into personal usage and commercial fleet consumption.

\section{Key Assumptions}

\section{Macroeconomic Sector Inputs}

Macroeconomic sector inputs used in the NEMS Transportation Demand Module (Table 18) consist of the following: gross domestic product, industrial output by Standard Industrial Classification code, personal disposable income, new car and light truck sales, total population, driving age population, total value of imports and exports, and the military budget.

Table 18. Macroeconomic Inputs to the Transportation Module (Millions)

\begin{tabular}{|c|c|c|c|c|c|}
\hline Macroeconomic input & 1990 & 1995 & 2000 & 2005 & 2010 \\
\hline New Car Sales & 9.5 & 9.0 & 9.6 & 9.9 & 10.2 \\
\hline New Light Truck Sales & 4.4 & 5.9 & 6.4 & 7.2 & 7.1 \\
\hline Driving Age Population & 192.7 & 202.1 & 212.8 & 223.8 & 235.4 \\
\hline Total Population & 250.3 & 263.6 & 275.6 & 287.1 & 298.9 \\
\hline
\end{tabular}

Source: Energy Information Administration, AEO95 Forecasting System run AEO95B.D1103942.

\section{Light-Duty Vehicle Assumptions}

The vehicle sales share module holds vehicle sales shares by import and domestic manufacturers constant within a vehicle size class benchmarked to 1992 Oak Ridge National Laboratory data. ${ }^{28}$

The fuel economy module utilizes 52 new technologies for each size class and origin of manufacturer (domestic or foreign) based on the cost-effectiveness of each technology and an initial availability year. The discounted stream of fuel savings is compared to the marginal cost of each technology. The fuel economy module assumes the following:

- All fuel saving technologies have a 4-year payback period.

- The real discount rate remains steady at 10 percent.

- Corporate Average Fuel Efficiency standards remain constant at 1993 levels.

\footnotetext{
${ }^{28}$ Oak Ridge National Laboratory, Transportation Energy Data Book: Edition 14 (Oak Ridge, TN, May 1994).
} 
- Expected future fuel prices are calculated based on an extrapolation of the growth rate between fuel prices 3 years and 5 years prior to the present year. This assumption is founded upon an assumed lead time of 3 to 5 years to significantly modify the vehicles offered by a manufacturer.

- Degradation factors (Table 19) used to convert Environmental Protection Agency-rated fuel economy to actual "on the road" fuel economy are based on application of a logistic curve to the projections of three factors: increases in city/highway driving, increasing congestion levels, and rising highway speeds. ${ }^{29,30,31}$ Automobile and light truck degradation factors are assumed to be the same over time.

Table 19. Car and Light Truck Degradation Factors

\begin{tabular}{c|c|c|c}
\hline 1990 & 2000 & 2005 & 2010 \\
\hline .847 & .831 & .824 & .817 \\
\hline
\end{tabular}

Source: Decision Analysis Corporation of Virginia, "Fuel Degradation Factor," unpublished final report prepared for Energy Information Administration (Vienna, VA, August 3, 1992).

The vehicle miles traveled (VMT) module forecasts VMT as a function of the cost of driving per mile, income per capita, ratio of female to male VMT, and age distribution of the driving population. The ratio of female to male VMT is assumed to asymptotically approach 72 percent by 2010 . Total VMT is calibrated to Federal Highway Administration VMT data. ${ }^{32}$

\section{Commercial Fleet Assumptions}

With the current focus of transportation legislation on commercial fleets and their composition, the Transportation Demand Module has been designed to divide commercial fieets into three types of fleets: business, government, and utility. Based on this classification, commercial fleet vehicles vary in survival rates and duration in the fleet, before being combined with the personal vehicle stock (Table 20).

Table 20. The Average Length of Time Vehicles Are Kept Before Sold to Others (Months)

\begin{tabular}{l|c|c|c}
\hline Vehicle Type & Business & Utility & Government \\
\hline Cars $\ldots \ldots \ldots \ldots \ldots$ & 35 & 68 & 81 \\
Light Trucks $\ldots \ldots \ldots \ldots$ & 56 & 60 & 82 \\
Medium Trucks ...... & 83 & 86 & 96 \\
Heavy Trucks ...... & 103 & 132 & 117 \\
\hline
\end{tabular}

Source: Oak Ridge National Laboratory, "Fleet Vehicles in the United States: Composition, Operating Characteristics, and Fueling Practices," prepared for the Department of Energy, Office of Transportation Technologies and Office of Policy, Planning, and Analysis (Oak Ridge, TN, May 1992).

\footnotetext{
${ }^{29}$ Maples, John D., "The Light-Duty Vehicle MPG Gap: Its Size Today and Potential Impacts in the Future," University of Tennessee Transportation Center, Knoxville, TN, May 28, 1993, Draft.

${ }^{30}$ Decision Analysis Corporation of Virginia, "Fuel Efficiency Degradation Factor," unpublished final report prepared for Energy Information Administration, (Vienna, VA, August 3, 1992).

${ }^{31}$ U.S. Department of Transportation, Federal Highway Administration, New Perspectives in Commuting (Washington, DC, July 1992).

${ }^{32}$ U.S. Department of Transportation, Federal Highway Administration, Highway Statistics 1992, FHWA-PL-93-023 (Washington, DC, 1992).
} 
Sales shares of fleet vehicles by fleet type remain constant over the forecast period. Automobile fleets are divided into the following shares: business ( 85.59 percent), government $(7.09$ percent), and utilities $(7.27$ percent). Both car (23.17 percent) and light truck (13.95 percent) fleet sales are assumed to be a constant fraction of total vehicle sales. ${ }^{33}$

Alternative-fuel shares of fleet sales by fleet type are initially set according to historical shares, then compared to a minimum constraint level of sales based on legislative initiatives, such as the Energy Policy Act and the Low Emission Vehicle Program. ${ }^{34,35}$ Size class sales of alternative-fuel and conventional vehicles are held constant at historical levels (Table 21) ${ }^{36}$ Individual sales shares of alternative-fuel fleet vehicles by technology type are assumed to remain at historical levels for utility and government fleets, but vary for business fleets in accordance with the technology shares applied in the personal vehicle stocks.

Table 21. Commercial Fleet Size Class Shares by Fleet and Vehicle Type (Percentage)

\begin{tabular}{|c|c|c|}
\hline Fleet Type by Size Class & Automobiles & Light Trucks \\
\hline 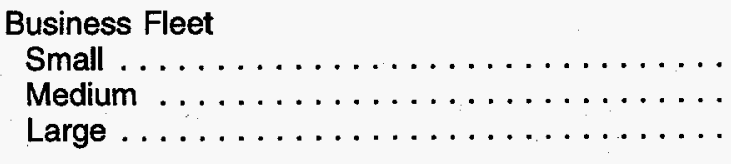 & $\begin{array}{r}4.55 \\
71.59 \\
23.86\end{array}$ & $\begin{array}{l}37.34 \\
37.90 \\
24.76\end{array}$ \\
\hline 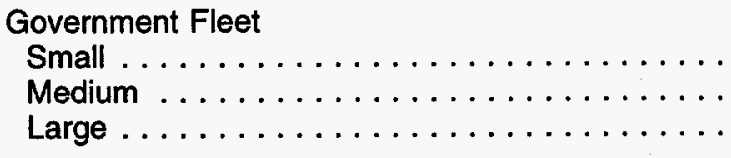 & $\begin{array}{r}4.35 \\
56.52 \\
39.13\end{array}$ & $\begin{array}{l}21.34 \\
44.39 \\
34.27\end{array}$ \\
\hline 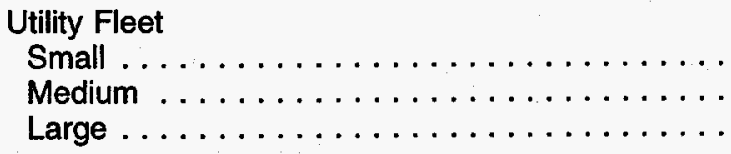 & $\begin{array}{l}16.67 \\
70.00 \\
13.33\end{array}$ & $\begin{array}{l}30.03 \\
38.51 \\
31.46\end{array}$ \\
\hline
\end{tabular}

Source: Oak Ridge National Laboratory, "Fleet Vehicles in the United States: Composition, Operating Characteristics, and Fueling Practices," unpublished final report prepared for the Department of Energy, Office of Transportation Technologies and Office of Policy, Planning, and Analysis (Oak Ridge, TN, May 1992).

Annual VMT per vehicle by fleet type stays constant over the forecast period based on the Oak Ridge National Laboratory fleet data.

Fleet fuel economy for both conventional and alternative-fuel vehicles is assumed to be the same as the personal vehicle new vehicle fuel economy and is subdivided into three size classes.

\section{Alternative-Fuel Vehicle Technology Choice Assumptions}

The alternative-fuel vehicle technology choice module utilizes a discrete choice specification, which uses vehicle attributes as inputs and forecasts vehicle sales shares among the following 16 light-duty

\footnotetext{
${ }^{33}$ Oak Ridge National Laboratory, "Fleet Vehicles in the United States: Composition, Operating Characteristics, and Fueling Practices," prepared for the Department of Energy, Office of Transportation Technologies and Office of Policy, Planning, and Analysis (Oak Ridge, TN, May 1992).

${ }^{34}$ U.S. Department of Energy, Office of Domestic and International Energy Policy, Assessment of Costs and Benefits of Flexible and Alternative Fuel Use in the U.S. Transportation Sector, Technical Report Ten: Analysis of Alternative-Fuel Fleet Requirements (Washington, DC, May 1992).

${ }^{35}$ California Air Resources Board, "Proposed Regulations for Low-Emission Vehicles and Clean Fuels, Staff Report," August 13, 1990.

${ }^{36}$ Oak Ridge National Laboratory, "Fleet Vehicles in the United States: Composition, Operating Characteristics, and Fueling Practices," prepared for the Department of Energy, Office of Transportation Technologies and Office of Policy, Planning, and Analysis (Oak Ridge, TN, May 1992).
} 
technologies: gasoline internal combustion engine (ICE), diesel ICE, ethanol flex, ethanol neat, methanol flex, methanol neat, electric dedicated (uses only electricity), electric hybrid with large ICE, electric hybrid with small ICE, electric hybrid with gas turbine, compressed natural gas (CNG), liquefied petroleum gas, gas turbine gasoline, gas turbine CNG, fuel cell methanol, and fuel cell liquid hydrogen.

Listed in Table 22 are a few examples of the input variables that correspond to the vehicle attributes used in the analysis. With the exception of vehicle fuel economy, all other attributes are exogenously set, based on offline analysis. ${ }^{37,38,39,40,41,42}$

Table 22. Alternative-Fuel Vehicle Attribute Inputs For Three Stage Logit Model

\begin{tabular}{|c|c|c|c|c|c|c|c|}
\hline $\begin{array}{l}\text { Small Vehicle } \\
\text { Size Class }\end{array}$ & Year & Gasoline & $\begin{array}{l}\text { Ethanol } \\
\text { Flex }\end{array}$ & $\begin{array}{l}\text { Methanol } \\
\text { Flex }\end{array}$ & CNG & $\begin{array}{l}\text { Electric } \\
\text { Vehicle } \\
\text { Hybrid }\end{array}$ & $\begin{array}{c}\text { Dedicated } \\
\text { Electric } \\
\text { Vehicle }\end{array}$ \\
\hline \multirow{2}{*}{$\begin{array}{l}\text { Vehicle Price (thousand } \\
1990 \text { dollars) } \ldots \ldots \ldots\end{array}$} & 1990 & 8.20 & 12.70 & 12.90 & 10.95 & $58.20^{a}$ & $53.20^{a}$ \\
\hline & 2010 & 12.18 & 12.85 & 13.05 & 13.23 & $22.81^{a}$ & $22.34^{a}$ \\
\hline \multirow{2}{*}{$\begin{array}{l}\text { Vehicle MPG Relative to } \\
\text { Gasoline . . . . . . . }\end{array}$} & 1990 & 1.00 & 1.00 & 1.01 & 0.95 & 1.40 & 1.50 \\
\hline & 2010 & 1.00 & 1.00 & 1.01 & 0.95 & 1.40 & 1.50 \\
\hline \multirow{2}{*}{$\begin{array}{l}\text { Vehicle Range } \\
\text { (100 miles) } \ldots\end{array}$} & 1990 & 3.50 & 2.60 & 2.20 & 2.25 & 2.50 & 1.20 \\
\hline & 2010 & 4.27 & 3.17 & 2.68 & 2.75 & 3.05 & 1.46 \\
\hline \multirow{2}{*}{$\begin{array}{l}\text { Fuel Availability Relative } \\
\text { to Gasoline } \ldots \ldots \ldots \ldots\end{array}$} & 1990 & 1.00 & 0.02 & 0.05 & 0.02 & 0.05 & 0.05 \\
\hline & 2010 & 1.00 & 0.12 & 0.31 & 0.12 & 1.00 & 1.00 \\
\hline \multirow{2}{*}{$\begin{array}{l}\text { Emission Levels } \\
\text { Indexed to Gasoline }\end{array}$} & 1990 & 1.00 & 1.00 & 1.00 & 1.00 & 0.80 & 0.60 \\
\hline & 2010 & 1.00 & 1.00 & 1.00 & 1.00 & 0.80 & 0.60 \\
\hline \multirow{2}{*}{$\begin{array}{l}\text { Commercial Availability } \\
\text { Indexed to Gasoline .. }\end{array}$} & 1990 & 1.00 & 0.018 & 0.018 & 0.001 & 0.000 & 0.007 \\
\hline & 2010 & 1.00 & 0.998 & 0.998 & 0.924 & 0.818 & 0.993 \\
\hline
\end{tabular}

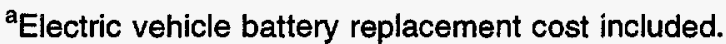

CNG = Compressed natural gas.

MPG = Miles per gallon .

Source: Science Applications International Corporation, "Alternative-Fuel Vehicle Module Database," draft report prepared for Energy Information Administration (Washington, DC, September 15, 1992).

Vehicle attributes vary by three size classes, and fuel availability varies by Census division. However, all vehicle attributes correspond to prototype vehicles. It is assumed that once the logit model estimates future sales shares, these shares are applicable to both cars and light trucks. Vehicle prices are assumed to represent mass production prices. All alternative-fuel vehicle fuel efficiencies are calculated relative

\footnotetext{
${ }^{37}$ Science Applications International Corporation, "Alternative-Fuel Vehicle Module Database," draft report prepared for Energy Information Administration (Washington, DC, September 15, 1992).

${ }^{38}$ Decision Analysis Corporation of Virginia, "Alternative Fuel Model Database Updates," draft report prepared for Energy Information Administration (Vienna, VA, September 15, 1992).

${ }^{39}$ EA Engineering, Science, and Technology, Inc., "AFV Differential Costs and Performance Attributes," report prepared for Oak Ridge National Laboratory (Washington, DC, November 1993).

${ }^{40}$ Fulton, Lew, "AFV and EPACT: A Case Study in Technology Policy," Dissertation Draft, June 1994.

${ }^{41}$ Department of Energy, Office of Transportation Technologies and Energy Efficiency and Renewable Energy, Federal Alternative Fuel Program Light Duty Vehicle Operations: Second Annual Report to Congress for Fiscal Year 1992, July 1993

${ }^{42}$ Department of Energy, Office of Transportation Technologies and Energy Efficiency and Renewable Energy, AlternativeFuel Vehicle Model, 1994.
} 
to conventional gasoline miles per gallon. It is assumed that fuel efficiency improvements to conventional vehicles will be transferred to alternative-fuel vehicles. ${ }^{43}$ Specific individual alternative-fuel technological improvements are handled separately by varying the fuel efficiency index over time. Commercial availability estimates are assumed values according to a logistic curve based on the initial technology introduction date and were constructed in cooperation with the DOE Office of Energy Efficiency and Renewable Energy. Coefficients summarizing consumer valuation of vehicle attributes were derived from a stated preference survey conducted in California ${ }^{44}$ and are assumed to be representative of the United States.

\section{Freight Truck Assumptions}

The freight truck module converts industrial output in dollar terms to an equivalent measure of volume by using a freight adjustment coefficient. These freight truck adjustment coefficients vary by NEMS Standard Industrial Classification (SIC) code, remaining constant over time, and are estimated from historical freight data. ${ }^{45,46}$ Freight truck load factors (ton-miles per truck) by SIC code are constants formulated from historical load factors. ${ }^{47}$ Growth of VMT in the retail sector is assumed to be proportional to growth in total industrial output. Growth of VMT in the construction sector is assumed to be proportional to the growth in total disposable income. All freight trucks are subdivided into light, medium, and heavy-duty trucks. Freight truck fuel efficiency growth rates relative to fuel prices are tied to historical growth rates by size class. ${ }^{48}$ VMT freight estimates by size class and technology are based on historical growth rates. Fuel consumption by freight trucks is regionalized according to the State Energy Data Report 1991 distillate regional shares. ${ }^{49}$

\section{Freight and Transit Rail Assumptions}

The freight rail module receives industrial output by SIC code measured in real 1987 dollars and converts these dollars into an adjusted volume equivalent. Freight rail adjustment coefficients, which are used to convert dollars into volume equivalents, remain constant and are based on historical data. ${ }^{50,51}$. Initial freight rail efficiencies are based on the freight model from Argonne National Laboratory. ${ }^{52}$ The distribution of rail fuel consumption by fuel type remains constant and is based on historical data (Table 23). ${ }^{53}$ Regional freight rail consumption estimates are distributed according to the State Energy Data Report $1991 .^{54}$

\footnotetext{
${ }^{43}$ Energy and Environmental Analysis, K.G. Duleep, initial coefficients for alternative-fuel vehicles relative to conventional vehicles were used from the Department of Energy, Office of Policy Analysis IDEAS Model.

${ }^{44}$ Bunch, David S., Mark Bradley, Thomas F. Golob, Ryuichi Kitamura, Gareth P. Occhiuzzo, "Demand for Clean-Fuel Personal Vehicles in California: A Discrete-Choice Stated Preference Survey," paper presented at the Conference on Transportation and Global Climate Change: Long Run Options (Asilomar Conference Center, Pacific Grove, CA, August 26, 1991).

${ }^{45}$ Decision Analysis Corporation of Virginia, Freight Transportation Requirements Analysis For The NEMS Transportation Sector Model, report prepared for Energy Information Administration (August 3, 1992).

${ }^{46}$ Reebie Associates, TRANSEARCH Freight Commodity Flow Database (Greenwich, CT, 1992).

${ }^{47}$ Oak Ridge National Laboratory, Transportation Energy Data Book: Edition 14 (Oak Ridge, TN, May 1994).

${ }^{48}$ Oak Ridge National Laboratory, Transportation Energy Data Book: Edition 14 (Oak Ridge, TN, May 1994).

${ }^{49}$ Energy Information Administration, State Energy Data Report 1992, DOE/EIA-0214(92) (Washington, DC, May 1994).

${ }^{50}$ Decision Analysis Corporation of Virginia, Freight Transportation Requirements Analysis For The NEMS Transportation Sector Model, report prepared for Energy Information Administration (August 3, 1992).

${ }^{51}$ U.S. Department of Transportation, Federal Railroad Administration, 1989 Carload Waybill Statistics; Territorial Distribution, Traffic and Revenue by Commodity Classes, September 1991 and prior issues.

${ }^{52}$ Argonne National Laboratory, Transportation Energy Demand Through 2010 (Argonne, IL, 1992).

${ }^{53}$ Oak Ridge National Laboratory, Transportation Energy Data Book: Edition 14, May 1994.

${ }^{54}$ Energy Information Administration, State Energy Data Report 1992, DOE/EIA-0214(92) (Washington, DC, May 1994).
} 
Table 23. Distribution of Rail Fuel Consumption by Fuel Type (Percent)

\begin{tabular}{|c|c|c|}
\hline Rail Transit Type & Diesel Fuel & Electricity \\
\hline Freight & 100 & 0 \\
\hline \multicolumn{3}{|l|}{ Passenger } \\
\hline Transit . . & 0 & 100 \\
\hline Commuter...$\ldots \ldots$ & 34 & 66 \\
\hline Intercity $\ldots \ldots \ldots \ldots \ldots \ldots \ldots \ldots \ldots$ & 73 & 27 \\
\hline
\end{tabular}

Source: Oak Ridge National Laboratory, Transportation Energy Data Book: Edition 14 (Oak Ridge, TN, May 1994).

\section{Freight Domestic and International Shipping Assumptions}

The freight domestic shipping module also converts industrial output by SIC code measured in dollars, to a volumetric equivalent by SIC code. ${ }^{55}$ These freight adjustment coefficients are based on analysis of historical data ${ }^{56}$ and remain constant throughout the forecast period. Domestic shipping efficiencies are based on the freight model by Argonne National Laboratory. ${ }^{57}$ The energy consumption in the freight international shipping module is a function of the total level of imports and exports. The distribution of domestic and international shipping fuel consumption by fuel type remains constant throughout the analysis and is based on historical data. ${ }^{58}$ Regional domestic and international shipping consumption estimates are distributed according to the State Energy Data Report 1991 residual oil regional shares..$^{59}$

\section{Air Travel Demand Assumptions}

The air travel demand module calculates the ticket price for travel as a function of fuel cost and other operating costs. Nonfuel operating costs are assumed to remain constant across the forecast horizon. ${ }^{60}$ A demographic index based on the propensity to fly was introduced into the air travel demand equation. ${ }^{61}$ The propensity to fly was made a function of the age and sex group distribution over the forecast period. ${ }^{62,63}$ The air travel demand module assumes that these relationships between the groups and their propensity to fly remain constant over time. International revenue passenger miles are calculated as a percentage of domestic revenue passenger miles based on an extrapolation of historical data, which asymptotically approaches 50 percent by $2010 .{ }^{64}$ Load factors, represented as the average number of passengers per airplane, are assumed to remain constant over the forecast period.

\footnotetext{
${ }^{55}$ Decision Analysis Corporation of Virginia, Freight Transportation Requirements Analysis For The NEMS Transportation Sector Model, report prepared for Energy Information Administration (August 3, 1992).

${ }^{56}$ Army Corps of Engineers, Waterborne Commerce of the United States (Waterborne Statistics Center: New Orleans, LA, 1991).

${ }^{57}$ Argonne National Laboratory, Transportation Energy Demand Through 2010 (Argonne, IL, 1992).

${ }^{58}$ Oak Ridge National Laboratory, Transportation Energy Data Book: Edition 14, May 1994.

${ }^{59}$ Energy Information Administration, State Energy Data Report 1992, DOE/EIA-0214(92) (Washington, DC, May 1994).

${ }^{60}$ U.S. Department of Transportation, Research and Special Programs Administration, Air Carrier Financial Statistics Quarterly and Monthly, December 1990/1989, and prior issues.

${ }^{61}$ Transportation Research Board, Forecasting Civil Aviation Activity: Methods and Approaches, Appendix A, Transportation Research Circular Number 372, June 1991.

${ }^{62}$ Decision Analysis Corporation of Virginia, Proposed Methodology For Projecting Air Transportation Demand, final report prepared for the Energy Information Administration, (Vienna, VA, July 8, 1992).

${ }^{63}$ Air Transport Association of America, Air Travel Survey (Washington DC, 1990).

${ }^{64}$ U.S. Department of Transportation, U.S. International Air Travel Statistics, Transportation Systems Center, Cambridge, MA, annual issues.
} 


\section{Aircraft Stock/Efficiency Assumptions}

The aircraft stock and efficiency module consists of a stock model of both wide and narrow body planes by vintage. The shifting of passenger load between narrow and wide body aircraft occurs at a constant historical annual 1-percent rate. ${ }^{65}$ The available seat-miles per plane, which measure the carrying capacity of the airplanes by aircraft type, remain constant and are based on holding the following constant within an aircraft type: airborne hours per aircraft per year, average flight speed, and the number of seats per aircraft (Table 24). The difference between the seat-miles demanded and the available seat-miles represents newly purchased aircraft. Aircraft purchases in a given year cannot exceed historical annual growth rates, a constraint that sets an upper limit on the application of new aircraft to meet the gap between seat-miles demanded and available seat-miles. With a constraint on new aircraft purchases, it is assumed that when the gap exceeds historical aircraft sales levels, planes that have been temporarily stored or retired will be brought back into service. Technological availability, economic viability, and efficiency characteristics of new aircraft are based on the technologies listed in the Oak Ridge National Laboratory Air Transport Energy Use Model. ${ }^{66,67}$ Fuel efficiency of new aircraft acquisitions represents, at a minimum, a 5-percent improvement over the stock efficiency of surviving airplanes. ${ }^{68}$ Maximum growth rates of fuel efficiency for new aircraft are based on a future technology improvement list consisting of an estimate of the introduction year, jet fuel price, and an estimate of the proposed marginal fuel efficiency improvement (Table 25). Regional shares of all types of aircraft fuel are assumed to be constant and are consistent with the State Energy Data Report 1991 estimate of regional jet fuel shares. ${ }^{69}$

Table 24. Constant Avallable Seat-Miles Assumptions by Aircraft Type

\begin{tabular}{|c|c|c|}
\hline Seat-Mile Variable & Narrow Body Aircraft & Wide Body Aircraft \\
\hline Airborne Hours/Aircraft per Year & 2,409 & 3,344 \\
\hline Average Flight Speed (MPH) . . . . . . . . . . . & 398 & 485 \\
\hline Number of Seats/Aircraft . . . . . . . . . . . . . . & 125 & 296 \\
\hline
\end{tabular}

$\mathrm{MPH}=$ Miles per hour.

Source: Federal Aviation Administration, FAA Aviation Forecasts Fiscal Years 1991-2002, FAA-APO 90-1, and previous editions.

\section{Legislation}

\section{Energy Policy Act of 1992}

Fleet alternative-fuel vehicle sales necessary to meet the Energy Policy Act of 1992 (EPACT) regulations come from the DOE Office of Domestic and International Energy Policy (Table 26). ${ }^{70}$ Total projected alternative-fuel vehicle sales are divided into fleets by government, utility, business, and fuel providers. The business fleets represent one-half of the DOE Office of Policy Analysis estimate, because it is assumed that only half of the business fleets are capable of being centrally fueled (refueled at the same location).

\footnotetext{
${ }^{65}$ U.S. Department of Transportation, Federal Aviation Administration, FAA Aviation Forecasts Fiscal Years 1993-2004 (Washington, DC, February 1993).

${ }^{66}$ Oak Ridge National Laboratory, Energy Efficiency Improvement of Potential Commercial Aircraft to 2010, ORNL-6622 (Oak Ridge, TN, June 1990).

${ }^{67}$ Oak Ridge National Laboratory, "Air Transport Energy Use Model," draft report (Oak Ridge, TN, April 1991).

${ }^{68}$ U.S. Department of Transportation, Federal Aviation Administration, FAA Aviation Forecasts Fiscal Years 1993-2004 (Washington, DC, February 1993).

${ }^{69}$ Energy Information Administration, State Energy Data Report 1992, DOE/EIA-0214(92) (Washington, DC, May 1994).

${ }^{70}$ U.S. Department of Energy, Office of Domestic and International Energy Policy, Assessment of Costs and Benefits of Flexible and Alternative Fuel Use in the U.S. Transportation Sector, Technical Report Ten: Analysis of Alternative-Fuel Fleet Requirements, May 1992.
} 
Although inclusion of the business fleet is dependent upon a rulemaking by the Secretary of Energy, the assumption is that fuel displacement goals set in EPACT can only be reached by inclusion of the business fleet.

Table 25. Future New Aircraft Technology Improvement List

\begin{tabular}{|c|c|c|c|c|}
\hline \multirow[b]{2}{*}{ Proposed Technology } & \multirow{2}{*}{$\begin{array}{c}\text { Introduction } \\
\text { Year }\end{array}$} & \multirow{2}{*}{$\begin{array}{c}\text { Jet Fuel Price } \\
\text { Necessary For } \\
\text { Cost- } \\
\text { Effectiveness } \\
\text { (1987 dollars } \\
\text { per gallon) }\end{array}$} & \multicolumn{2}{|c|}{$\begin{array}{l}\text { Seat-Miles per Gallon Gain } \\
\text { Over } 1990 \\
\text { (percent) }\end{array}$} \\
\hline & & & Narrow Body & Wide Body \\
\hline \multicolumn{5}{|l|}{ Engines } \\
\hline Ultra-high Bypass & 1995 & 0.69 & 10 & 10 \\
\hline Proptan $\ldots \ldots \ldots \ldots \ldots$ & 2000 & 1.36 & 23 & 0 \\
\hline \multicolumn{5}{|l|}{ Aerodynamics } \\
\hline Hybrid Laminar Flow . . . . . . . & 2020 & 1.53 & 15 & 15 \\
\hline Advanced Aerodynamics & 2000 & 1.70 & 18 & 18 \\
\hline \multicolumn{5}{|l|}{ Other } \\
\hline Weight Reducing Materials .. & 2000 & - & 15 & 15 \\
\hline Thermodynamics $\ldots \ldots \ldots$ & 2010 & 1.22 & 20 & 20 \\
\hline
\end{tabular}

Source: Greene, D.L., Energy Efficiency Improvement Potential of Commercial Aircraft to 2010, ORNL-6622, 6/1990., and from data tables in the Air Transportation Energy Use Model (ATEM), Oak Ridge National Laboratory.

Table 26. EPACT Alternative-Fuel Vehicle Fleet Sale Estimates

\begin{tabular}{|c|c|c|c|c|c|c|}
\hline Vehicle Type & Fleet Type & 1990 & 1995 & 2000 & 2005 & 2010 \\
\hline \multirow{4}{*}{ Automobiles } & $\begin{array}{l}\text { State and } \\
\text { Local } \\
\text { Government }\end{array}$ & 0 & 0 & 0 & 85,538 & 92,149 \\
\hline & $\begin{array}{l}\text { Federal } \\
\text { Government }\end{array}$ & 0 & 5,000 & 10,692 & 13,365 & 13,365 \\
\hline & Business & 0 & 64,637 & 69,633 & 405,826 & 437,189 \\
\hline & Fuel Provider & 0 & 129,274 & 139,265 & 150,028 & 161,623 \\
\hline \multirow{4}{*}{ Light Trucks } & $\begin{array}{l}\text { State and } \\
\text { Local } \\
\text { Government }\end{array}$ & 0 & 0 & 0 & 19,612 & 21,128 \\
\hline & $\begin{array}{l}\text { Federal } \\
\text { Government }\end{array}$ & 0 & 5,000 & 10,692 & 13,365 & 13,365 \\
\hline & Business & 0 & 32,319 & 34,816 & 94,612 & 101,924 \\
\hline & Fuel Provider & 0 & 64,637 & 69,632 & 75,014 & 80,811 \\
\hline
\end{tabular}

EPACT = Energy Policy Act of 1992.

Source: U.S. Department of Energy, Office of Domestic and International Energy Policy, Assessment of Costs and Benefits of Flexible and Altemative Fuel Use in the U.S. Transportation Sector, Technical Report Ten: Analysis of Alternative-Fuel Fleet Requirements (Washington, DC, May 1992). 


\section{Low Emission Vehicle Program}

The Low Emission Vehicle Program, which began in California, has now been instituted in New York and Massachusetts. The following Zero Emission Vehicle (ZEV) and Ultra-Low Emission Vehicle (ULEV) sales numbers (Table 27) come from the California Air Resources Board. ${ }^{71}$ In the Low Oil Price Case and the Reference Case, only the ZEV sales shares are used. With the High Oil Price Case, the ZEV and one-half of the ULEV sales shares are included. Only half of the ULEV sales were included, because there is uncertainty with respect to meeting the ULEV air standards with reformulated gasoline and a heated catalytic converter.

The alternative-fuel vehicle sales module compares these legislatively mandated sales to the results from the alternative-fuel vehicle logit market-driven sales shares. The legislatively mandated sales serve as a minimum constraint to alternative-fuel vehicle sales.

Table 27. California Low Emission Vehicle Program Legislatively Mandated Alternative-Fuel Vehicle Sales

(Percentage)

\begin{tabular}{c|c|c|c|c|c|c|c}
\hline Vehicle & 1997 & 1998 & 1999 & 2000 & 2001 & 2002 & 2003 \\
\hline Ultra-Low Emission Vehicles . . . . . . . . . . & 2 & 2 & 2 & 2 & 5 & 10 & 15 \\
Zero Emission Vehicles ............... & $\ldots$ & 2 & 2 & 2 & 5 & 5 & 10 \\
\hline
\end{tabular}

Source: California Air Resources Board, "Proposed Regulations for Low Emission Vehicles and Clean Fuels, Staff Report," August 13, 1990.

\section{Climate Change Action Plan}

There were four programs implemented from the CCAP transportation policies-reform Federal subsidy for employer-provided parking, adopt a transportation system efficiency strategy, promote telecommuting, and develop fuel economy labels for tires. The combined effect of the Federal subsidy, system efficiency, and telecommuting policies was a reduction in VMT of 1.3 percent, representing a decline in consumption of approximately 190 trillion Btu. The fuel economy tire labeling program improved new fuel efficiency by 4 percent among vehicles that switched to low rolling resistance tires, and resulted in a reduction in fuel consumption of 40 trillion Btu.

\section{High Efficiency and 1993 Technology Cases}

Over the 1970-1990 period, transportation energy efficiency rose by 1.9 percent annually for light-duty vehicles, 1.5 percent for freight trucks, 1.6 percent for rail locomotives and marine vessels, and 2.1 percent for aircraft. In the high efficiency case, fuel efficiency improvements from new technology more than offset the increasing travel in each transportation mode. As a result, the total energy consumption in the transportation sector was 9.5 percent lower (26.2 quadrillion Btu) than in the Reference Case.

The 1993 technology case assumed that new fuel efficiencies were held constant at 1993 levels over the forecast. As a result, the energy use in the transportation sector was 5.2 percent higher ( 30.4 quadrillion Btu) than in the Reference Case.

\footnotetext{
${ }^{71}$ California Air Resources Board, "Proposed Regulations for Low Emission Vehicles and Clean Fuels, Staff Report," August 13, 1990.
} 
Both cases were run with only the transportation demand module rather than as a fully integrated NEMS run. Consequently, no potential macroeconomic feedback on travel demand was captured. Key results from these cases are presented in Appendix C. 


\section{Electricity Market Module}

The Electricity Market Module (EMM) of the National Energy Modeling System (NEMS) represents the planning, operations, and pricing of electricity in the United States. It is composed of four primary submodules-electricity capacity planning, electricity fuel dispatching, load and demand-side management, and electricity finance and pricing. In addition, nonutility generation and supply and electricity transmission and trade are represented in the planning and dispatching submodules.

Based on fuel prices and electricity demands provided by the other modules of the NEMS, the EMM determines the most economical way to supply electricity, within environmental and operational constraints. There are assumptions about the operations of the electricity sector and the costs of various options in each of the EMM submodules. The major assumptions are summarized below.

\section{Key Assumptions}

\section{Capacity Types}

Twenty-four capacity types are presented in the EMM (Table 28).

Table 28. Capacity Types Represented in the Electricity Market Module

\section{Capacity Type}

Existing Unscrubbed Coal, sulfur dioxide standard $\leq 1.20$ pounds per million Btu Existing Unscrubbed Coal, sulfur dioxide standard $\leq 2.50$ pounds per million Btu Existing Unscrubbed Coal, sulfur dioxide standard $\leq 3.34$ pounds per million Btu Existing Unscrubbed Coal, sulfur dioxide standard $>3.34$ pounds per million Btu Existing Scrubbed Coal to 2.5 pounds sulfur dioxide per million Btu

Existing Scrubbed Coal to 1.2 pounds sulfur dloxide per million Btu Existing Scrubbed Coal to 0.6 pounds sulfur dloxide per million Btu Existing Scrubbed Coal, 90 percent sulfur dioxide removal New High Sulfur Pulverized Coal with Wet Flue Gas Desulfurization New Advanced Coal - Integrated Coal Gasification Combined Cycle Oll/Gas Steam - Oil/Gas Steam Turbine

Combined Cycle - Conventional Gas/Oil Combined Cycle Combustion Turbine New Advanced Combined Cycle - Advanced Gas/Oil Combined Cycle Combustion Turbine Combustion Turbine - Conventional Combustion Turbine

Advanced Combustion Turbine - Steam injected Gas Turbine

Nuclear - Evolutionary Advanced Boiling Water Reactor

Advanced Nuclear - Mid-Size Advanced Pressurized Water Reactor

Conventional Hydropower - Hydraulic Turbine

Plpeline Hydropower - Hydraulic Turbine

Pumped Storage - Hydraullc Turbine Reversible

Geothermal - Steam Turbine

Municipal Solld Waste

Biomass

Solar

Wind

Source: Energy Information Administration, Office of Integrated Analysis and Forecasting. 


\section{New Fossil-Fueled Generating Plant Characteristics}

The operational characteristics of new generating technologies are the most important inputs to the electricity capacity planning submodule. The key characteristics for fossil-fueled technologies are summarized in Table 29. These characteristics are used, in combination with fuel price foresight from the NEMS Integrating Module, to compare resource options when new capacity is needed. The assumptions for nuclear technologies are described later in this section, while the costs and supplies of renewable generating technologies are described in the Renewable Fuels Module section.

Table 29. Characteristics of New Fossil-Fueled Generating Technologies

\begin{tabular}{|c|c|c|c|c|c|}
\hline Technology & Year Available & $\begin{array}{l}\text { Overnight } \\
\text { Costs } \\
\text { (1987 dollars } \\
\text { per kilowatt) }\end{array}$ & $\begin{array}{l}\text { Heat Rate } \\
\text { (Btu per } \\
\text { kilowatthour) }\end{array}$ & $\begin{array}{l}\text { Fixed O\&M } \\
\text { (1987 dollars } \\
\text { per kilowatt) }\end{array}$ & $\begin{array}{l}\text { Variable O\&M } \\
\text { (1987 dollars } \\
\text { per thousand } \\
\text { kilowatthours) }\end{array}$ \\
\hline Pulverized Coal & 1990 & 1,213 & 9,649 & 17.6 & 4.3 \\
\hline Advanced Coal & 2000 & 1,345 & 8,809 & 33.3 & 2.5 \\
\hline Oil/Gas Steam & 1990 & 785 & 9,477 & 5.3 & 5.2 \\
\hline Combined-Cycle & 1990 & 486 & 7,707 & 3.7 & 3.7 \\
\hline Advanced Combined-Cycle & 2005 & 476 & 7,369 & 6.7 & 2.6 \\
\hline Combustion Turbine . ....... & 1990 & 352 & 11,456 & 0.6 & 6.2 \\
\hline Advanced Combustion Turbine & 1990 & 566 & 9,149 & 10.0 & 5.0 \\
\hline
\end{tabular}

$O \& M=$ Operation and maintenance.

Source: Argonne National Laboratory, "Cost and Performance Database for Electric Power Generating Technologies."

The overnight costs listed for each technology in Table 29 are the base costs estimated to build a plant in "Middletown, U.S.A." Differences in plant costs due to regional distinctions are calculated by applying regional multipliers (Table 30) to the cost of labor, factory equipment, and site material for each new generating technology.

Table 30. Regional Multipliers for New Construction

\begin{tabular}{|c|c|c|c|c|c|}
\hline EMM Region & NE, NY & MAAC & STV & $\begin{array}{l}\text { MAPP, } \\
\text { ECAR MAIN }\end{array}$ & SPP \\
\hline Factory Equipment $\ldots \ldots$ & 1.09 & 1.01 & 0.95 & 1.01 & 1.03 \\
\hline Site Labor $\ldots . .$. & 1.33 & 0.97 & 0.69 & 1.03 & 0.98 \\
\hline Site Material . . . . . . . . . & 1.08 & 0.97 & 0.93 & 1.00 & 1.00 \\
\hline EMM Region & RA & NWP & FL & CNV & ERCOT \\
\hline Factory Equipment & 1.05 & 0.99 & 0.90 & 1.01 & 1.02 \\
\hline Site Labor $\ldots \ldots \ldots$ & 1.02 & 1.20 & 0.70 & 1.45 & 0.89 \\
\hline Site Material $\ldots \ldots \ldots \ldots$ & 1.03 & 1.00 & 0.80 & 1.01 & 0.98 \\
\hline
\end{tabular}

Note: See Part II, Detailed Tables, Tables 54 through 66 for regional descriptions.

Source: Argonne National Laboratory, "Cost and Performance Database for Electric Power Generating Technologies."

\section{Representation of Electricity Demand}

The annual electricity demand projections from the NEMS demand modules are converted into load duration curves for each of the EMM regions (based on North American Electric Reliability Council 
regions and subregions) using historical hourly load data. However, unlike traditional load duration curves where the demands for an entire period would be ordered from highest to lowest, losing their chronological order, the load duration curves in the EMM are segmented into nine different time slices (Table 31). The time periods shown were mainly chosen to accommodate intermittent generating technologies (i.e., solar and wind facilities) and demand-side management programs.

Table 31. Load Segments for the Electricity Market Module

\begin{tabular}{|c|c|c|c|}
\hline Season & Months & Period & Hours \\
\hline Summer ........... & June-September & $\begin{array}{l}\text { Daytime } \\
\text { Morning/Evening } \\
\text { Night }\end{array}$ & $\begin{array}{l}0700-1800 \\
0500-0700,1800-2400 \\
0000-0500\end{array}$ \\
\hline Winter & December-March & $\begin{array}{l}\text { Daytime } \\
\text { Morning/Evening } \\
\text { Night }\end{array}$ & $\begin{array}{l}0800-1600 \\
0500-0800,1600-2400 \\
0000-0500\end{array}$ \\
\hline \multirow[t]{2}{*}{ Offpeak } & April-May & Daytime & $0700-1700$ \\
\hline & October-November & $\begin{array}{l}\text { Morning/Evening } \\
\text { Night }\end{array}$ & $\begin{array}{l}0500-0700,1700-2400 \\
0000-0500\end{array}$ \\
\hline
\end{tabular}

Note: Both the summer and winter periods are represented by 2 vertical slices each (a peak slice and an off-peak slice). The remaining 7 periods are represented by 1 vertical slice each, resulting in a total of 11 vertical slices.

Source: Energy Information Administration, Office of Integrated Analysis and Forecasting.

\section{Fossil Fuel-Fired Steam Plant Life Extension/Retirement}

A large number of the fossil fuel-fired steam plants operating today are approaching the end of their normal lives, typically after 40 to 45 years. However, utilities have not reported plans to retire these units and appear to be planning to utilize these plants for the foreseeable future. Fossil fuel-fired steam plants with nameplate ratings greater than or equal to 100 megawatts and with no reported retirement dates are considered eligible for life extension at capital costs (Table 32) typically lower than those of new construction. Gas and oil-fired steam plants are eligible for life extension only in the New England and West South Central Census divisions and the states of New York, New Jersey, Florida and California where these plants account for more than 10 percent of total generation. Regions that do not rely heavily on oil or gas generation are assumed to use other resource options more economically attractive. After 25 years of service, life extended plants are refurbished over 5 years during planned outages. In the EMM it is assumed that most of the fossil fuel-fired steam plants reaching 25 years of age (248 gigawatts of coalfired, and 93 gigawatts of oil- and gas-fired plants) will be maintained throughout the forecast period.

Table 32. Capital Cost of Life Extension (1987 Dollars per Kilowatt)

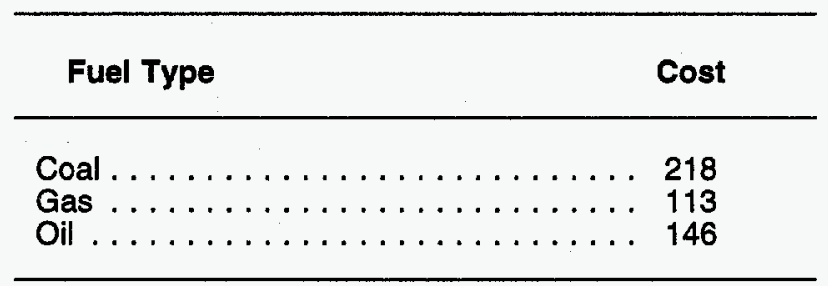

Source: Energy Information Administration, Estimating the Capital Cost of Life Extension for Fossil-Fuel Steam Plants, DOE/EIA-0509 (Washington, DC, July 1988). 
Units with nameplate capacities less than 100 megawatts are assumed to retire after 45 years of service. Approximately 50 gigawatts are retired from 1994 through 2010 . These include 9.3 gigawatts of retirements in 1994 to 2010 reported by utilities, as well as 28 gigawatts of small fossil steam units (less than 100 megawatts capacity) retired at 45 years of age and retirements of 17 nuclear units totaling 12.7 gigawatts. Of the 12.7 gigawatts of nuclear capacity retired, 1.9 gigawatts have been reported to EIA by utilities. The remaining 10.8 gigawatts are assumed to retire at the end of their licensing period (see New Nuclear Power Plant Orders below). No retirement of nonutility or cogenerator units is assumed.

\section{Nonutility Generation and Supply}

Nonutility generators (excluding cogenerators that are represented in the NEMS' refinery, oil and gas supply, and demand modules) compete with traditional electric utility supply options when new resources are needed. While the technology characteristics for nonutility units are assumed to be the same as those for utilities, however, the financial structure of nonutilities is represented differently. The break-even cost for each project is calculated based on single project financing. Based on previous analysis, the financial structure of nonutilities is assumed to be 80 percent debt and 20 percent equity. ${ }^{73}$ The cost of equity for nonutilities is assumed to be 1.5 percentage points higher than that for utilities, while the cost of debt to nonutilities is 0.75 percentage points higher.

The break-even costs of nonutility projects are compared with the levelized generation costs of utility projects in the capacity planning submodule and the most economical option is chosen. However, nonutility development is limited to reflect the debt obligation imposed on the purchasing utility. Debt rating agencies are including obligations to purchase power from nonutilities when calculating utilities' credit ratings. This inclusion of the off-balance sheet debt obligations has contributed to the downgrading of some utilities' debt. Currently, the adjusted national interest coverage ratio is approximately 2.96 , and in the module it is allowed to fall to a low of 2.15 between 1990 and 2010 .

\section{Electricity Trade}

Both firm and economy electricity transactions among utilities in different regions are represented within the EMM. In general, firm power transactions involve the trading of capacity and energy to help another region satisfy its reserve margin requirement, while economy transactions involve energy transactions motivated by the marginal generation costs of different regions. The flow of power from region to region is constrained by the existing and planned capacity limits as reported on the April 1994 "Coordinated Bulk Power Supply Program Report" (DOE Form OE-411). Known firm power contracts are locked in for the term of the contract. In addition, in certain regions where data show an established commitment to build plants to serve another region, new plants are permitted to be built to serve the other region's needs. This option is available to compete with other resource options.

Economy transactions are determined in the dispatching submodule by comparing the marginal generating costs of adjacent regions in each time slice. If one region has less expensive generating resources available in a given time period (adjusting for transmission losses and transmission capacity limits) than another region, the regions are allowed to exchange power. The price for the economy transactions is assumed to be set by splitting the difference between the exporting and importing region's marginal generation costs.

\section{International Electricity Trade}

Two components of international firm power trade are represented in the EMM-existing and planned transactions, and unplanned transactions. Existing and planned transactions are obtained from the North American Electric Reliability Council regional publications of the "Coordinated Bulk Power Supply

\footnotetext{
${ }^{73}$ Washington Consulting Group, "Establishing Constraints on Purchased Nonutility Generation," prepared for the Energy Information Administration, Washington, DC, January 1993.
} 
Program Report" (DOE Form OE-411). Unplanned firm power trade is represented by competing Canadian supply with U.S. domestic supply options. Canadian supply is represented via supply curves using cost data from the Department of Energy report Northern Lights: The Economic and Practical Potential of Imported Power from Canada (DOE/PE-0079).

International economy trade is determined exogenously based on historic trade relationships between the United States and Canada and Mexico and domestic demand growth expectations for each nation.

\section{Electricity Finance and Pricing}

The provisions of the Energy Policy Act of 1992 create a new class of electricity suppliers referred to as exempt wholesale generators. These exempt wholesale generators are included among nonutility producers and are assumed to have a highly leveraged capital structure compared to that of investorowned regulated utilities.

Prices for electricity are assumed to be regulated at the State level. Prices for the residential, commercial, industrial, and transportation sectors are developed by classifying costs into four categories: fuel, fixed operation and maintenance, variable operation and maintenance, and capital. These costs are allocated to each of the four customer classes using the proportion of sales to the class and each class's contribution to system peak load requirements. These allocated costs are divided by the sales to each sector to obtain electricity prices to the sector.

\section{Nuclear Power Plant Orders}

It is assumed that two nuclear generating units currently under construction will be operational by 2010: Watts Bar 1 in 1995 and Watts Bar 2 in 1997. Bellefonte 1 and 2 are assumed not to be completed. These four units are owned by the Tennessee Valley Authority (TVA). TVA is in the process of developing an Integrated Resource Plan, to be completed by late 1995, to determine long-term energy needs in the region, and the most economical way to meet them. In recent months, the chairman of TVA has made several statements that make the completion of these nuclear units highly uncertain. In particular, he stated that completion of the unfinished units may not be economically feasible, and said that he has had cost estimates developed for the conversion of the Bellefonte units to coal or natural gas facilities. In addition, TVA has, for the first time, issued requests for proposals totaling 4 gigawatts of power, suggesting that purchased power is a preferable option to the completion of the nuclear units.

The licensing status as of year end 1993 defines unit operating life. This information includes the recoupment of construction time for those plants whose licenses have been redefined by the Nuclear Regulatory Commission. Operating plants to term assumes that there are no aging effects. This implies that the cost of operating nuclear power plants is cost-competitive with other technologies. On average, the reference forecast assumes no license renewal and no retirements prior to term. This assumption is based on an economic analysis of the operating lives of nuclear power plants in the United States. ${ }^{74}$

It is assumed that no newly ordered nuclear power plants will be operational through 2010 for the following reasons:

- Concerns about the disposal of radioactive waste

- Public concerns about safety

- Concern about economic and financial risks

- Uncertainty about power plant performance

- Uncertainty in the licensing and regulatory processes.

\footnotetext{
${ }^{74}$ James G. Hewlett, "The Operating Costs and Longevity of Nuclear Power Plants: Evidence from the USA," Energy Policy, Volume 20, Number 7, July 1992.
} 
With regard to the waste disposal issue, either a high-level waste repository, or, temporarily, a monitored retrievable storage facility is required; however, a permanent repository is not scheduled to be operational until at least 2010. According to the Nuclear Waste Policy Act of 1982, DOE is to take title to nuclear waste beginning in 1998, but this provision will be adjudicated in the courts since a storage facility will not be available. In June 1994, two separate lawsuits were filed against DOE, one by a group of 14 utilities, the other by a group of 20 States and public utility commissions. They are asking the court to declare that the law requires DOE to accept spent fuel and high-level waste from utilities unconditionally, by the 1998 deadline, and that DOE must develop a program to enable it to meet this deadline without placing further financial burden on the utilities and the ratepayers. This issue is becoming critical, as many units are reaching the limits of their spent-fuel storage space. Furthermore, with a number of nuclear units scheduled for retirement beginning around 2005, the lack of a high-level waste repository becomes critical for decommissioning purposes as well. According to the Nuclear Waste Policy Amendments Act of 1987, construction of a monitored retrievable storage (MRS) facility cannot begin until the Nuclear Regulatory Commission issues a construction permit for the high-level waste repository. Under the current schedule, construction of an MRS could begin in 2004 at the earliest, and the facility would open in 2007, assuming a site is found and licensed to operate by the Nuclear Regulatory Commission. Given the history of schedule slippages in the waste repository program and the first-of-a-kind nature of the project, it is assumed that utilities, investors, and State regulatory commissions would not commit to a new order until an MRS was completed and available to receive waste. Assuming this occurs in 2007 and, given the 4- to 5 -year construction lead time for a new plant, an order placed in 2007 would result in an operational plant after 2010.

Public concerns about nuclear power plant operational safety and waste disposal must also be addressed. The safety concerns stem from the public's association of the technology with its weapons origin and the well-publicized accidents at operating plants, particularly at Three Mile Island and Chernobyl.

Utilities currently have an aversion to capital-intensive technologies with long lead times. With the increased competition in electricity generation markets, especially from short leadtime, low capital cost options, this aversion is likely to increase in the future. In addition, there are substantial uncertainties associated with the costs and risks of nuclear power. Research has shown that there is a 3.5- to 4.0percentage point risk premium associated with the common stock of utilities with nuclear power plants. ${ }^{75}$ More importantly, this risk premium is not construction and licensing issues, but rather to concerns about safety, operational factors, and decommissioning. There is growing investor concern about the escalation in decommissioning cost, early retirements, and the "stranded plant" problem. ${ }^{76}$

Additionally, even though vendors estimate competitive economics and 4- to 5-year construction lead times, these estimates are targets or best-case estimates. No nuclear plant to date has been built at initial estimated cost and/or schedule. ${ }^{77}$ Also, major parts of new midsize plants will be prefabricated and constructed modularly. This new construction approach, while likely to decrease lead times in follow-on units, is less flexible than the conventional approach if design changes are required and, therefore, adds uncertainty when building a first-of-a-kind unit. Also, a new plant incorporates a large percentage of untested new technology, thereby greatly increasing the uncertainty associated with plant performance.

Given the history of ex post facto nuclear prudence reviews and cost disallowances, coupled with the high capital intensity of nuclear investments and historically long construction lead times, investments in nuclear technology would likely require some form of financial protection.

\footnotetext{
${ }^{75}$ R. Fuller, G. Hinman, and T. Lowinger, "The Impact of Nuclear Power on the Systematic Risk and Market Value of Electric Utility Common Stock," The Energy Journal, Volume 11, Issue 2.

${ }^{76}$ The stranded plant problem refers to capital-intensive plants that cannot recover all their capital costs because of the competitive pressure from lower cost plants.

"Energy Information Administration, An Analysis of Nuclear Power Plant Construction Costs, DOE/EIA-0485 (Washington, DC, March 1986).
} 


\section{Demand-Side Management}

Improvements in energy efficiency induced by growing energy prices, new appliance standards, and utility demand-side management programs are represented in the end-use demand models. Appliance choice decisions are a function of the relative costs and performance characteristics of a menu of technology options. Utilities have reported plans to increase their expenditures on demand-side management programs to more than $\$ 4$ billion per year by $1997 .^{78}$

\section{Fuel Price Expectations}

Capacity planning decisions for the electric power industry are based on a lifecycle cost analysis over a 30-year period. This requires foresight assumptions for fuel prices. Expected prices for coal, natural gas, and oil are derived using adaptive expectations, in which future prices are extrapolated from recent historical trends. ${ }^{79}$ Coal prices are estimated using a regression analysis based on the coal and world oil price from the previous year. For each oil product, future prices are estimated by applying a constant markup to an external forecast of world oil prices. The markups are calculated by taking the differences between the regional product prices and the world oil price for the previous forecast year. For natural gas, expected wellhead prices are based on a nonlinear function that relates the expected price to the cumulative domestic gas production. Delivered prices are developed by applying a constant markup, which represents the difference between the delivered and wellhead prices from the prior forecast year. The approach was developed to have the following properties:

1. The natural gas wellhead price should be upward sloping as a function of cumulative gas production.

2. The rate of change in wellhead prices should increase as fewer economical reserves remain to be discovered and produced.

The approach assumes that at some point in the future a given target price, PF, results when cumulative gas production reaches a given level, QF. The target values for PF and QF were assumed to be $\$ 6.00$ per thousand cubic feet (1987 dollars) and 875 trillion cubic feet, respectively. The future annual production is assumed to be constant at the prior year's level.

The wellhead gas price equation is of the following form:

$$
P_{k}=A^{*} Q_{k}^{1.5}+B
$$

where $P$ is the wellhead price for year $k, Q$ is the cumulative production from 1991 to year $k$, and $A$ and $B$ are determined each year such that the price equation will intersect the future target point (PF, $Q F)$.

\section{Externality Costs}

Externality costs of $40.8,27.73,17.72,15.45,11.69$, and 9.83 mills per kilowatthour (1987 dollars) for pulverized coal, advanced coal, gas combined-cycle, advanced gas combined-cycle, gas combustion turbine and steam-injected combustion turbine, respectively, were assumed for the California/Nevada (CNV) region. Externality costs for these respective technologies for the New York (NY) region are assumed to 8.28, 5.41, 3.62, 3.13, 2.13 and 1.79 mills per kilowatthour (1987 dollars). Although other States have applied or are considering externality costs (e.g. Massachusetts, Minnesota, Nevada, Oregon, and Wisconsin) in developing generating capacity options, they are located in regions in the EMM that include States or parts of States with no externality costs. As a result, no externality costs were assumed for these

\footnotetext{
${ }^{78}$ Form EIA-861, “Annual Electric Utility Report," 1992.

${ }^{79}$ Energy Information Administration, NEMS Integrating Module Documentation Report, DOE/EIA-M057 (Washington, DC, December 1993).
} 
multistate regions. The costs used for $\mathrm{NY}$ and $\mathrm{CNV}$ are based on values extracted from a bulletin board (EPRINET) originating from the Electric Power Research Institute.

\section{Technological Optimism and Learning Factors}

Overnight cost are calculated for each new generating technology by applying the regional cost multipliers from Table 30, to the base overnight costs in Table 29. These costs are assumed to be n-th-of-a-kind costs. For advanced technologies (e.g., advanced coal, advanced combined-cycle, advanced combustion turbine, advanced nuclear, solar, geothermal, and wind), technological optimism factors of 1.19, 1.12, 1.12, 1.52, $1.19,1.12$, and 1.19 , respectively, are applied to the first-of-a-kind unit. ${ }^{80}$ These factors decrease linearly until 4 units are constructed after which time a 10-percent decrease in cost due to learning effects are assumed for each doubling of total capacity until 40 units have been built. After 40 units have been built, it is assumed all the learning has been realized.

\section{Legislation}

\section{Clean Air Act Amendments of 1990}

It is assumed that electricity producers comply with the Clean Air Act Amendments of 1990, which mandate a limit of 8.95 million short tons of sulfur dioxide emissions by 2000 . Utilities are assumed to comply with the limits on sulfur emissions by retrofitting units with flue gas desulfurization (FGD) equipment, transferring or purchasing sulfur emission allowances, operating high-sulfur coal units at a lower capacity utilization rate, or switching to low-sulfur fuels. The costs for FGD equipment average approximately $\$ 144$ per kilowatt, in 1987 dollars, although the costs vary widely across the regions. It is also assumed that the market for trading emission allowances is allowed to operate without regulation and that the States do not further regulate the selection of coal to be used.

Utilities are assumed to comply with the mandates set forth in the Clean Air Act Amendments of 1990 (CAAA90) by reducing emissions of $\mathrm{NO}_{\mathrm{x}}$ by 2 million tons from 1980 levels. Similarly, it is assumed that utilities will comply with CAAA90 and reduce their emissions of sulfur dioxide $\left(\mathrm{SO}_{2}\right)$ by 10 million tons over the forecast period. Consequently, the forecast assumes that the cost associated with purchasing an $\mathrm{SO}_{2}$ allowance (dollars per ton of $\mathrm{SO}_{2}$ ) is equivalent to the marginal cost of compliance (dollars per ton of $\mathrm{SO}_{2}$ removed).

\section{Energy Policy Act of 1992}

The provisions of the Energy Policy Act of 1992 (EPACT) include revised licensing procedures for nuclear plants and the creation of exempt wholesale generators (EWGs).

EPACT allows the issuance of a combined construction and operating license for nuclear plants; however, it also allows for a post-construction hearing and judicial review. The uncertainty associated with waste, regulatory, and financial issues is sufficiently large to require their resolution or some manner of financial protection for investors before investments in nuclear power would take place. Unresolved, these conditions would lead to investments in alternative capacity additions or a delay in capital investment. Therefore, no newly ordered nuclear plants are assumed to become operational by 2010 .

EPACT reformed the Public Utility Holding Company Act of 1935 (PUHCA). Prior to the passage of EPACT, PUHCA required that utility holding companies register with the Securities and Exchange

\footnotetext{
${ }^{80}$ Energy Information Administration, Risk Analysis of Three Emerging Power Generation Technologies, Independent Project Analysis, Inc., December 1993 and Rahul Varma, Jack B. Hartung, Jr., and Dean Findley, An Analysis of the Potential for Cost Improvement in Emerging Power Generation Technologies, prepared for the Energy Information Administration, June 1993.
} 
Commission (SEC) and restricted their business activities and corporate structures. ${ }^{81}$ Entities that wished to develop facilities in several States were regulated under PUHCA. To avoid the stringent SEC regulation, nonutilities had to limit their development to a single State or limit their ownership share of projects to less than 10 percent. EPACT changed this by creating a class of generators that, under certain conditions, are exempt from PUHCA restrictions. These EWGs can be affiliated with an existing utility (affiliated power producers) or independently owned (independent power producers). In general, subject to State commission approval, these facilities are free to sell their generation to any electric utility, but they cannot sell to a retail consumer. These EWGs are represented in NEMS.

\section{Climate Change Action Plan}

The energy supply actions specified in the Climate Change Action Plan were reviewed and incorporated in the model where appropriate. However, if funds were not allocated to the action, no changes were made. As a result, of the eight actions specifically impacting electricity supply, Actions 24 through 31 , only Action 26 was incorporated within the model. This action, Form Renewable Energy Market Mobilization Collaborative with Technology Demonstrations, involves funding for demonstration projects for certain renewable generating technologies. For a discussion of how this action was represented, see the renewable energy assumptions later in this section.

\section{High Electricity Demand Side Case}

The High Electricity Demand Case assumes that the demand for electricity grows at the same rate as the economy in the Reference Case through 2000. After 2000, the ratio of electricity demand growth to economic growth is assumed to fall in a linear fashion from 1.00 in 2000 to 0.55 in 2010 . The 0.55 ratio was chosen because it is approximately the ratio of electricity sales growth to economic growth over the 1993 to 2010 timeframe in the Reference Case. No attempt was made to determine the changes necessary in the end-use sectors needed to result in the stronger demand growth. The High Electricity Demand Case is a partially integrated run, i.e., the Macroeconomic Activity, Petroleum Marketing, International Energy, and end-use demand modules use the Reference Case values and are not affected by the higher electricity demand growth. Conversely, the Oil and Gas, Coal Market, and Renewable Fuels Modules are allowed to interact with the Electricity Market Module in the High Electricity Demand Case. Key results are presented in Appendix $C$.

\section{Low and High Nuclear Side Cases}

The low and high nuclear cases assume different retirement schedules. The low nuclear case assumes each unit retires 5 years before its license expires, while the high nuclear case assumes 5 additional years of operation after the current expiration date. These alternate scenarios model situations where either the majority of the plants retires early, or a substantial number of units renews their licenses. The cases do not attempt to pick which units will or will not perform well in the future, but only to look at the aggregate effects on the electricity industry if nuclear units, on the average, have a longer or shorter lifetime than projected using their license expiration dates. The high and low nuclear cases are partiallyintegrated model runs, i.e., the Macroeconomic Sectoral Demand, Refinery and International modules are benchmarked to the Reference case inputs and outputs and are not affected by changes in nuclear capacity. Conversely, the Oil and Gas, Coal, and Renewables modules are allowed to interact with the Electricity Market Module in the high and low nuclear cases. Key results are presented in Appendix C.

\footnotetext{
${ }^{81}$ A registered utility holding company is defined as any company that owns or controls 10 percent of the voting securities of a public utility company. PUHCA defines a public utility company as any company that owns or operates generation, transmission, or distribution facilities for the sale of electricity to the public.
} 


\section{Oil and Gas Supply Module}

The Oil and Gas Supply Module (OGSM) constitutes a comprehensive framework with which to analyze oil and gas supply. The OGSM provides crude oil and natural gas short-term supply parameters to both the Natural Gas Transmission and Distribution Module and the Petroleum Market Module. The OGSM simulates the activity of numerous firms that produce oil and natural gas from domestic fields throughout the United States, acquire natural gas from foreign producers for resale in the United States, or sell U.S. gas to foreign consumers.

OGSM encompasses domestic crude oil and natural gas supply by both conventional and nonconventional recovery techniques. Nonconventional recovery includes enhanced oil recovery and unconventional gas recovery from tight gas formations, Devonian shale, and coalbeds. Foreign gas transactions may occur via either pipeline (Canada or Mexico) or transport ships as liquefied natural gas.

Primary inputs for the module are varied. One set of key assumptions concerns domestic economically recoverable oil and gas resources and the assumed expansion of the resource target due to the development and penetration of new technology. Another set of key assumptions concerns the response of drilling activities to changes in oil and gas prices. Other major factors affecting the projection include the start date and threshold price for the Alaskan Natural Gas Transportation System (ANGTS), projections for enhanced oil recovery production, supplemental gas supplies over time, and natural gas import and export capacities.

\section{Key Assumptions}

\section{Domestic Oil and Gas Economically Recoverable Resources and Technology}

Domestic oil and gas economically recoverable resources ${ }^{82}$ consist of proved reserves, $^{83}$ inferred reserves, ${ }^{84}$ and undiscovered economically recoverable resources. ${ }^{85}$ OGSM employs regional estimates that are derived by EIA staff using analysis from the United States Geological Survey and the Minerals Management Service of the Department of the Interior, the National Petroleum Council, the Office of Fossil Energy of the Department of Energy, and the Potential Gas Committee. ${ }^{86}$ Published estimates were adjusted to remove intervening reserve additions resulting in estimates consistent with end-of-year 1990.

\footnotetext{
${ }^{82}$ Economically recoverable resources are those volumes considered to be of sufficient size and quality for their production to be commercially profitable by current conventional or nonconventional technologies, under specified economic conditions.

${ }^{8}$ Proved reserves are the estimated quantities that analysis of geological and engineering data demonstrate with reasonable certainty to be recoverable in future years from known reservoirs under existing economic and operating conditions.

${ }^{84}$ Inferred reserves are that part of expected ultimate recovery from known fields in excess of cumulative production plus current reserves.

${ }^{83}$ Undiscovered resources are located outside oil and gas fields in which the presence of resources has been confirmed by exploratory drilling; they include resources from undiscovered pools within confirmed fields when they occur as unrelated accumulations controlled by distinctly separate structural features or stratigraphic conditions.

${ }^{86}$ Richard F. Mast and others, United States Department of the Interior, U.S. Geological Survey and Minerals Management Service, Estimates of Undiscovered Conventional Oil and Gas Resources in the United States-A Part of the Nation's Energy Endowment (Washington, DC, 1989); Larry W. Cooke, United States Department of the Interior, Minerals Management Service, Estimates of Undiscovered, Economically Recoverable Oil and Gas Resources for the Outer Continental Shelf, Revised as of January 1990 , OCS Report MMS 91-0051, July 1991; National Petroleum Council, Committee on Natural Gas, The Potential for Natural Gas in the United States, Volume II, Source and Supply (Washington, DC, December 1992); William L. Fisher and others, Oil Resources Panel convened by the U.S. Department of Energy, An Assessment of the Oil Resource Base of the United States (Washington, DC, October 1992); Potential Gas Committee, Potential Supply of Natural Gas in the United States (December 31, 1992), Potential Gas Agency, (Golden, CO: Colorado School of Mines, May 1993).
} 
Expected recoverable resource estimates (Tables 33 and 34) reflect static technology and economic conditions. Within the 1990-2010 projection period of the model, the state of technology development and penetration proceeds, thus expanding the volume of economically recoverable resources. The initial recoverable resource estimates reflect the 1990 level of technological development and penetration. The 2010 estimates are based on the assumed rate of technological progress drawn from a review of the literature.

Table 33. Crude Oil Economically Recoverable Resources (Billion Barrels)

\begin{tabular}{|c|c|c|c|c|c|c|c|}
\hline \multirow[b]{2}{*}{$\begin{array}{c}\text { Crude Oil } \\
\text { Resource Category }\end{array}$} & \multirow[b]{2}{*}{1990 Level } & \multicolumn{2}{|c|}{ Reference } & \multicolumn{2}{|c|}{ Low Technology } & \multicolumn{2}{|c|}{ High Technology } \\
\hline & & 2010 Level & $\begin{array}{l}\text { Technology } \\
\text { Improvement } \\
\text { Rate }\end{array}$ & 2010 Level & $\begin{array}{c}\text { Technology } \\
\text { Improvement } \\
\text { Rate }\end{array}$ & 2010 Level & $\begin{array}{c}\text { Technology } \\
\text { Improvement } \\
\text { Rate }\end{array}$ \\
\hline Undiscovered & 43.21 & 67.31 & - & 53.95 & -- & 83.90 & -- \\
\hline Onshore .. & 33.53 & 49.82 & 2.0 & 40.91 & 1.0 & 60.56 & 3.0 \\
\hline Offshore ....... & 9.68 & 17.48 & 3.0 & 13.04 & 1.5 & 23.35 & 4.5 \\
\hline Inferred Reserves ... & 32.00 & 42.59 & - & 36.75 & - & 49.76 & -- \\
\hline EOR .......... & 11.83 & 11.83 & - & 11.83 & -- & 11.83 & -- \\
\hline Other Onshore & 17.70 & 26.30 & 2.0 & 21.60 & 1.0 & 31.97 & 3.0 \\
\hline Offshore $\ldots \ldots \ldots$ & 2.47 & 4.46 & 3.0 & 3.33 & 1.5 & 5.96 & 4.5 \\
\hline $\begin{array}{l}\text { Total Lower } 48 \text { States } \\
\text { Unproved . . . . . . }\end{array}$ & 75.21 & 109.90 & -- & 90.70 & -- & 133.66 & - \\
\hline Alaska .......... & 10.53 & 19.02 & 3.0 & 14.18 & 1.5 & 25.40 & 4.5 \\
\hline Total U.S. Unproved & 85.74 & 128.92 & -- & 104.89 & -- & 159.05 & -- \\
\hline Proved Reserves .. & 26.25 & 26.25 & - & 26.25 & -- & 26.25 & -- \\
\hline Total Crude Oil .... & 111.99 & 155.17 & - & 131.14 & - & 185.30 & -- \\
\hline
\end{tabular}

"The improved analytic method for enhanced oil recovery (EOR) used in AEO95 does not readily yield 1990 resource estimates based on 1990 technology. Hence, the AEO95 1990 resource estimates for EOR that are based on 1990 technology include additional resource recovery due to more advanced technology assumptions.

Source: Energy Information Administration, Office of Integrated Analysis and Forecasting. 


\section{Alaskan Natural Gas}

The outlook for natural gas production from the North Slope of Alaska is affected strongly by the unique circumstances regarding its transport to market. Unlike virtually all other identified deposits of natural gas in the United States, North Slope gas lacks a means of economic transport to major commercial markets. The lack of viable marketing potential at present has led to the use of Prudhoe Bay gas to maximize crude oil recovery in that field. This use is expected to delay extraction of gas for market until the post-2000 period.

Table 34. Natural Gas Economically Recoverable Resources (Trillion Cubic Feet)

\begin{tabular}{|c|c|c|c|c|c|c|c|}
\hline \multirow[b]{2}{*}{$\begin{array}{c}\text { Natural Gas } \\
\text { Resource Category }\end{array}$} & \multirow[b]{2}{*}{1990 Level } & \multicolumn{2}{|c|}{ Reference } & \multicolumn{2}{|c|}{ Low Technology } & \multicolumn{2}{|c|}{ High Technology } \\
\hline & & 2010 Level & $\begin{array}{c}\text { Technology } \\
\text { Improvement } \\
\text { Rate }\end{array}$ & 2010 Level & $\begin{array}{c}\text { Technology } \\
\text { Improvement } \\
\text { Rate }\end{array}$ & 2010 Level & $\begin{array}{c}\text { Technology } \\
\text { Improvement } \\
\text { Rate }\end{array}$ \\
\hline Undiscovered $\ldots \ldots \ldots \ldots$ & 356.63 & 591.37 & -- & 459.46 & -- & 760.32 & -- \\
\hline Onshore & 234.53 & 370.84 & $-\cdot$ & 259.01 & -- & 465.85 & -- \\
\hline Deep (>15,000 feet) $\ldots \ldots$ & 69.79 & 126.05 & 3.0 & 94.00 & 1.5 & 168.31 & 4.5 \\
\hline Shallow $(0-15,000$ feet $) \ldots$ & 164.74 & 244.79 & 2.0 & 201.01 & 1.0 & 297.54 & 3.0 \\
\hline Offshore $\ldots \ldots \ldots \ldots$ & 122.10 & 220.53 & 3.0 & 164.45 & 1.5 & 294.47 & 4.5 \\
\hline Inferred Reserves $\ldots \ldots \ldots$ & 145.31 & 225.81 & -- & 181.22 & - & 281.15 & - \\
\hline Other Onshore $\ldots \ldots \ldots$ & 114.42 & 170.02 & 2.0 & 139.61 & 1.0 & 206.66 & 3.0 \\
\hline Offshore $\ldots . . . \ldots$ & 30.89 & 55.79 & 3.0 & 41.60 & 1.5 & 74.50 & 4.5 \\
\hline $\begin{array}{l}\text { Unconventional Gas } \\
\text { Recovery .............. }\end{array}$ & 316.63 & 671.87 & -- & 426.45 & -- & 763.62 & -- \\
\hline Tight Gas ........... & 232.40 & 419.74 & 3.0 & 313.01 & 1.5 & 560.48 & 4.5 \\
\hline Devonian & 21.23 & 38.34 & 3.0 & 28.59 & 1.5 & 51.20 & 4.5 \\
\hline Coalbed & 63.00 & 113.79 & 3.0 & 84.85 & 1.5 & 151.94 & 4.5 \\
\hline $\begin{array}{l}\text { Total Lower } \mathbf{4 8} \text { States } \\
\text { Unproved } \ldots \ldots \ldots \ldots\end{array}$ & 818.57 & 1389.05 & -- & 1067.14 & -- & 1805.10 & - \\
\hline Alaska $\ldots \ldots \ldots \ldots \ldots$ & 33.31 & 60.16 & 3.0 & 44.86 & 1.5 & 80.33 & 4.5 \\
\hline Total U.S. Unproved . . . . & 851.88 & 1449.21 & -- & 1112.00 & -- & 1885.43 & -- \\
\hline Proved Reserves . . . . . . . & 169.35 & 169.35 & -- & 169.35 & - & 169.35 & - \\
\hline Total Natural Gas & 1021.23 & 1618.56 & -. & 1281.35 & -- & 2054.78 & -- \\
\hline
\end{tabular}

Source: Energy Information Administration, Offlce of Integrated Analysis and Forecasting.

The estimates for gas from the North Slope that will be transported to lower 48 States markets through ANGTS are dependent on the capacity of this system. ANGTS is projected to flow gas to market in two phases, and it is assumed that production will be available to fully utilize the capacity in both phases, if constructed. Operational capacity for the first phase is 767 billion cubic feet per year delivered to the U.S./Canadian border. Annual capacity increases to 1,150 billion cubic feet upon the completion of the second phase. Operation for each phase is assumed to begin at mid-year; thus only half capacity is available for the first year of operation, with full capacity available in each year thereafter. It is assumed that ANGTS will not begin operations until 2005 at the earliest, to support oil recovery in the Prudhoe Bay field. Each phase of ANGTS is brought on line in OGSM when the appropriate border-crossing price 
is reached for gas delivered to the lower 48 States. The price for phase one is $\$ 3.65$, in 1993 dollars per thousand cubic feet. When this price is reached, ANGTS is brought on line in the following year, with a total flow of 383 billion cubic feet, reaching the full capacity of 767 billion cubic feet in subsequent years. If a higher threshold price of $\$ 4.89$, in 1993 dollars per thousand cubic feet is reached, then phase two will begin the following year. The flow will increase by 192 billion cubic feet, to 959 billion cubic feet, and in each subsequent year the flow will be 1,150 billion cubic feet. This methodology is applied in all the scenarios.

\section{Supplemental Gas Supplies}

The projection for supplemental gas supply is identified for three separate categories: synthetic natural gas (SNG) from liquids, SNG from coal, and other supplemental supplies.

Projected SNG production from liquids is based on an econometrically derived equation, with the independent variable being the regional average market price for natural gas. SNG from the currently operating Great Plains Coal Gasification Plant is assumed to continue throughout the projection period, at 50 billion cubic feet per year. In all cases, it is assumed that in mid-year 2009 the Great Plains facility will close. Other supplemental supplies are held at a constant level of 58.06 billion cubic feet per year throughout the forecast.

\section{Natural Gas Imports and Exports}

U.S. natural gas trade with Mexico and liquefied natural gas (LNG) imports and exports are determined exogenously to NEMS. Natural gas exports from the United States to Canada are also exogenously determined. U.S. import flows from Canada are determined endogenously within the model but are constrained by assumed pipeline capacities. Exogenously specified projections of pipeline import and export values from Canada and Mexico are shown below (Table 35).

Table 35. Natural Gas Imports and Exports (Billion Cubic Feet per Year)

\begin{tabular}{c|c|c|c|c}
\hline \multirow{2}{*}{ Year } & \multicolumn{2}{|c|}{ Canada } & \multicolumn{2}{c}{ Mexico } \\
\cline { 2 - 5 } & Imports $^{\mathbf{a}}$ & Exports & Imports & Exports \\
\hline $1993 \ldots \ldots \ldots \ldots$ & 3,495 & 50 & 0 & 38 \\
$1995 \ldots \ldots \ldots \ldots$ & 3,543 & 62 & 0 & 38 \\
2000 & $\ldots, 904$ & 144 & 0 & 10 \\
2005 & $\ldots \ldots \ldots$ & 204 & 10 & 10 \\
$2010 \ldots \ldots$ & 4,028 & 238 & 183 & 10 \\
\hline
\end{tabular}

aCanadian 'import' figures represent design capacity, not actual flow projections, because flows are not an assumption. Canadian import flows are determined endogenously within the model.

Notes: Imports are imports to the United States. Exports are exports from the United States.

Source: 1993 import and export volumes: Department of Energy, Office of Fuels Programs, Office of Fossil Energy, Natural Gas Imports and Exports, Fourth Quarter Report 1993, DOE/FE-0298. Projections: Energy Information Administration, Office of Integrated Analysis and Forecasting.

Mexican import and export volumes for natural gas were drawn heavily from the analysis work supporting the recent National Petroleum Council study, The Potential for Natural Gas in the United States (Washington, DC, 1993).

Canadian production and exports to the United States are determined endogenously within the model. Assumed Canadian gas consumption levels (with an associated price) also affect the wellhead price by limiting the gas supply available for export to the United States. The consumption of gas in Canada was assumed to grow at 1.2 percent per year throughout the projection and in each scenario from its historical 
level of 2.47 trillion cubic feet in 1990 (taken from the International Energy Annual, DOE/EIA-0219(90)). Natural gas exports to Canada from the United States are expected to grow annually by 14 billion cubic feet from the 1993 level of approximately 50.0 billion cubic feet, reaching 238 billion cubic feet by 2010 . The Canadian economically recoverable resource base estimate used in the model for the beginning of year 1990 is 304 trillion cubic feet for gas, derived from figures published by the National Energy Board. This quantity was assumed to increase at a rate of 2 percent each projection year to reflect improvements in and penetration of technology.

Annual U.S. exports of LNG were assumed to be a constant 56 billion cubic feet in each projection year. LNG imports are determined endogenously within the model. The outlook for LNG imports was based on a combination of influences, including available gasification capacity, announced plans by each company, tanker availability, expected utilization rates, projected gas prices and liquefaction capacity, and long-term contracts with a responsible purchaser. LNG flow capacity was 0.3 trillion cubic feet in 1993 and it is projected to be 0.9 trillion cubic feet by 2010. The outlook for LNG imports also includes an implicit assumption that no major operational or institutional difficulties arise that are not resolved expeditiously. In general, tankers were considered to be a constraining factor in the near term, but the necessary additional capacity is expected in time to support the projected flow volumes.

Currently, only two LNG import terminals are in operation: the Distrigas facility in Everett, Massachusetts, and the Trunkline facility in Lake Charles, Louisiana. The announced plans for the other two existing import terminals, at Cove Point, Maryland, and at Elba Island, Georgia, were the primary determinants of the time for reopening these facilities. Once in operation, continued maintenance is expected to be sufficient to keep all plants operable at the stated rates throughout the projection.

\section{Climate Change Action Plan}

The natural gas production forecasts incorporate the expected results of the Climate Change Action Plan (CCAP)-Action Item 35, entitled "Launch Coalbed Methane Outreach Program." Under Action Item 35, DOE and EPA will create a program to raise the awareness among key coal companies and State agencies of the potential for cost-effective methane emissions reduction. As a result of the program, a total of 10 "gassy" (high methane content) coal mines that would, otherwise, not have been capturing their methane effluent are assumed to be doing so by 2000 .

The cumulative number of mines effectively reached by CCAP Action Item 35 and the production from these mines are presented in Table 36. No further mines are assumed to be successfully targeted after 2000.

Table 36. Number and Production of Mines Reached by CCAP Action Item 35

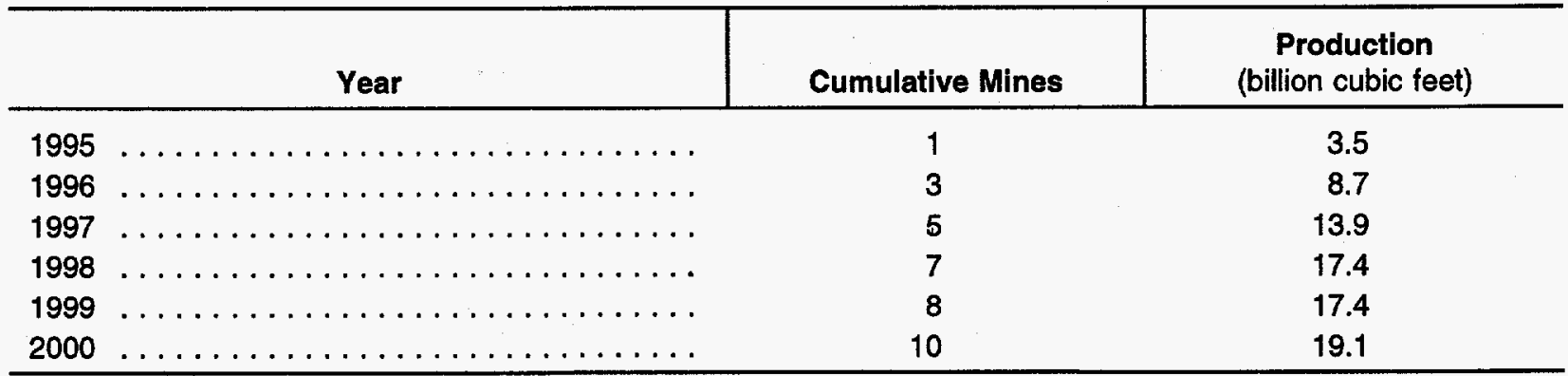

The annual production increases resulting form CCAP Action Item 35 are added to baseline forecasts of coalbed methane production from the Oil and Gas Supply Module (OGSM). The additional production 
is allocated regionally based on sharing factors derived from analysis in the EPA report, "Opportunities to Reduce Anthropogenic Methane Emissions in the United States." ${ }^{17}$

\section{High and Low Technology Side Cases}

An additional analysis was performed to assess the sensitivity of the projections to the technology assumptions. Two special technology cases were created by adjusting all oil and gas technological progress rates upward and downward by a given proportion-overall, approximately 50 percent. This change affects both the size of reserve additions per new well and the number of new well completions. Key results from these cases are presented in Appendix $C$.

The analysis used the oil and gas prices of the reference case to examine the impact on oil and gas production of varying just the oil and gas technological assumptions, without demand-related feedback effects. The specific variations in economically recoverable resources used in the analysis are shown in Table 33 and Table 34.

One limitation of the analysis is that EOR was not subject to the technology adjustment. Appropriately varying EOR in the analysis would be unlikely to affect the basic conclusion that gas production is more sensitive than oil production to the rate of technological change.

\footnotetext{
${ }^{87}$ United States Environmental Protection Agency, Opportunities to Reduce Anthropogenic Emissions in the United States: Report to Congress, EPA430-R-93-012 (Washington, DC, October 1993).
} 


\section{Natural Gas Transmission and Distribution Module}

The Natural Gas Transmission and Distribution Model (NGTDM) derives natural gas production, prices (end-use, wellhead, and border) and flows of natural gas through the regional interstate network. These are derived by obtaining a least-cost market equilibrium across the three main components of the natural gas market: the supply component, the demand component, and the transmission and distribution network that links them. The major assumptions used within the NGTDM are divided into five general categories. They relate to (1) the classification of demand into core and noncore transportation service classes, (2) the pricing of transmission and distribution services, (3) the implementation of recent regulatory reform, (4) emissions associated with the transmission and distribution of natural gas, and (5) pipeline and storage capacity expansion and utilization. A complete discussion of NGTDM assumptions is presented in Chapter 9 and Appendix F of Model Documentation Report: Natural Gas Transmission and Distribution Model of the National Energy Modeling System, forthcoming.

\section{Key Assumptions}

\section{Demand Classification}

Customers demanding natural gas are classified as either core or noncore customers, with core customers transporting their gas under firm (or near firm) transportation agreements and noncore customers transporting their gas under interruptible or short-term capacity release transportation agreements. All residential, commercial, and transportation (vehicles using compressed natural gas) end-use customers are assumed to be core customers. Industrial customers fall into both categories, with industrial boilers and refineries assumed to be noncore and all other industrial users assumed to be core.

Likewise, customers in the electric generator sector are assumed to be both core and noncore. ${ }^{88}$ The noncore category is subdivided into services that are priced to be competitive with distillate fuel oil and services that are priced to be competitive with residual fuel oil. The classification is based on the type of utility boiler (Table 37).

Table 37. Electric Utility Natural Gas Demand Classification

\begin{tabular}{|c|c|}
\hline Service Category & Plant Type \\
\hline Core $\ldots \ldots \ldots \ldots \ldots \ldots \ldots \ldots$ & $\begin{array}{l}\text { Gas Steam Units } \\
\text { Gas Combined-Cycle Units }\end{array}$ \\
\hline \multicolumn{2}{|l|}{ Noncore } \\
\hline Competitive With Distillate Fuel Oil . . . . . . & $\begin{array}{l}\text { Gas Turbine Units } \\
\text { Dual-Fired Turbine Units }\end{array}$ \\
\hline Competitive With Residual Fuel Oil . . . . . . . & Dual-Fired Steam Units \\
\hline
\end{tabular}

\footnotetext{
${ }^{88}$ The electric generator end-use category includes gas consumption by any facilities whose sole purpose is electricity generation (including independent power producers). Natural gas consumption by cogenerators (producers of electricity as a by-product of another process) is included in industrial end-use consumption.
} 
End-use sector load patterns do not change over the forecast. (No representation of DSM or change in load patterns from new technologies like natural gas cooling.) Pipeline loads do not change over the forecast as the composition of end-use changes and as more pipeline and storage capacity becomes available.

\section{Pricing of Services}

Firm transportation rates for interstate pipeline services (both between NGTDM regions and within a region) are calculated assuming that the costs of new pipeline capacity will be rolled into the existing rate base (the test for determining whether or not to build new capacity is done based on incremental rates, however). Core market transmission and distribution services remain subject to cost of service, rate of return regulation. Noncore transmission services are competitively priced with the price floor equal to the variable cost of delivering natural gas (generally compressor station fuel plus a few cents). End-use prices for residential, commercial, and core industrial customers are derived by adding a markup to the regional hub price of natural gas associated with core service. These markups include the cost of service provided by intraregional interstate pipelines, intrastate pipelines, and local distributors. The intrastate tariffs are accounted for endogenously through historical model benchmarking. The distribution tariffs are based on historical data (Table 38). Nonutility core market distribution markups are assumed to decline at a rate of 1 percent per year throughout the forecast. This compares to an average 1.2 percent per year decline observed in the commercial sector distributor markup since 1984 (the first year EIA collected such data). Between 1986 and 1993, the residential and commercial distributor margins have declined at an average annual rate of 1.9 and 2.9 percent, respectively.

Similarly, prices for natural gas service to the core segment of the electric generator sector are derived by adding a markup to the regional hub price of core market natural gas supplies. The markups for electric generators are endogenously derived based on historical end-use prices and are modified over the forecast period as a function of user-specified parameters. The base electric generators' markup (excluding the intraregional interstate markup) is the average of the 1992 and 1993 markup to gas steam and gas combined-cycle units. This markup is derived as the difference between the NGTDM regional hub price for core natural gas supplies (minus the intraregional interstate tariff) and an historically based regional electric generators' price for gas steam units and gas combined-cycle units. During the forecast period, the base markup is linearly reduced so that, by 1999, the markup is 50 percent of the average of the base value and a minimum markup. (The minimum markup from the regional hub to the power plant is $\$ 0.04$ (1993 dollars per thousand cubic feet)). The reduction is to capture the threat of bypass, which creates a downward trend in the markups. Beyond 1999, the markup is held constant.

End-use prices for industrial noncore customers are established by adding a markup to the natural gas supply price for the noncore segment at the regional market hub. These markups are endogenously derived as the difference between estimated historical 1993 end-use prices ${ }^{89}$ and the NGTDM regional noncore hub price, and held constant throughout the forecast.

In the electric generator sector, the derivation of the competitive natural gas price employs a discount from the price of competing fuels (residual or distillate fuel oil). The discount factor is endogenously derived as a function of natural gas and fuel oil consumption levels in the electric generator sector. The end-use price is bounded by a minimum price equal to the sum of the interruptible regional hub price and a $\$ 0.14$ (1993 dollars per thousand cubic feet) markup for delivery of the supplies from the hub to the power plant.

\footnotetext{
${ }^{89} \mathrm{Historical}$ noncore industrial prices were based on data from the 3/31/94 draft version of Manufacturing Consumption of Energy 1991.
} 
Table 38. Base Year Average Annual Distributor Markup for Local Transportation Service (1993 Dollars per Thousand Cubic Feet)

\begin{tabular}{|c|c|c|c|}
\hline Region & Residential & Commercial & Core Industrial \\
\hline New England . & 4.62 & 2.77 & 0.19 \\
\hline Mid Atlantic $\ldots \ldots \ldots$ & 4.06 & 2.62 & 0.47 \\
\hline East North Central .... & 2.10 & 1.54 & 0.00 \\
\hline West North Central .... & 2.12 & 1.24 & 0.11 \\
\hline South Atlantic . . . . . . . & 3.56 & 2.19 & 0.00 \\
\hline East South Central .... & 2.71 & 1.97 & 0.00 \\
\hline West South Central .... & 2.79 & 1.45 & 0.21 \\
\hline Mountain $\ldots \ldots \ldots$ & 2.04 & 1.33 & 0.51 \\
\hline Pacific $\ldots \ldots \ldots \ldots$ & 3.47 & 2.36 & 0.41 \\
\hline$\ldots \ldots \ldots \ldots$ & 7.02 & 2.43 & 0.00 \\
\hline Arizona/New Mexico . . . & 3.74 & 2.02 & 0.51 \\
\hline California & 3.34 & 2.50 & 0.41 \\
\hline
\end{tabular}

Note: Starting in 1994, the markups are decreased by 1 percent per year.

Source: Energy Information Administration, Office of Integrated Analysis and Forecasting. Derived from Form EIA-176, "Annual Report of Natural and Supplemental Gas Supply and Disposition" for residential and commercial and from the March 31, 1994, draft "Manufacturing Energy Consumption Survey Consumption of Energy 1991" (Form ElA846) for core industrial. Residential and commercial are based on 1992 data and core industrial is based on the average of 1990, 1991, and 1992 data.

Prices for compressed natural gas used as a vehicle fuel (VNG) undergo a transition during the forecast period. The pricing change is intended to capture the evolution in the market from government/industry sponsored demonstration programs to large scale commercial use. Initially, the VNG price reflects markups based on EIA's Natural Gas Annual..$^{90}$ The historical transportation prices do not include all Federal and State taxes or the full cost of dispensing the fuel. The VNG markup in 2005 is assumed to reflect fully all components of the retail price. The linear phase-in begins in 1994 and continues through 2005, after which the price is assumed to be the core market industrial price plus a markup to cover the cost of dispensing the fuel ( $\$ 3.73$ per thousand cubic feet $[\mathrm{Mcf}]$ plus taxes). The phase-in period represents the transition from a market where users must obtain and dispense their own supplies (as in the case of fleet vehicles) to a market in which retail outlets are readily available to all customers. Federal taxes of $\$ 0.49$ (1993 dollars) per Mcf plus corresponding State taxes (Table 39) are levied starting in 1994.

\section{Capacity Expansion and Utilization}

The model methodology assumes that pipeline and storage capacity is available 2 years from the decision to add new capacity. Average capital costs for pipeline expansion (1993 dollars per Mcf-mile per day) are assumed to be $\$ 1.55$ for compression, $\$ 1.74$ for looping, and $\$ 2.24$ for new pipe. The average costs are regionalized by applying regional cost factors reflecting differences in terrain and labor costs.

It is assumed that pipelines and local distribution companies build and subscribe to a portfolio of pipeline and storage capacity to serve a region-specific colder-than-normal winter demand level (percentages vary from 5 to 15 percent, with lower percentages in areas with greater load diversity). Annual maximum pipeline capacity utilization is assumed to be limited to 99 percent of the design capacity (with the exceptions of capacity into Florida and California, which is assumed to be 100 percent of design capacity). The overall level and profile of consumption as well as the availability and price of supplies generally

\footnotetext{
90Energy Information Administration, Natural Gas Annual 1992, DOE/EIA-0131(92) (Washington, DC, November, 1993).
} 
cause realized pipeline utilization levels to be lower than the maximum. Within the Capacity Expansion Module, consumption is represented for peak and offpeak periods based on historically based sectoral splits, held constant throughout the forecast period.

Table 39. Vehicle Natural Gas (VNG) Pricing

\begin{tabular}{|c|c|}
\hline Modified Census Divisions & $\begin{array}{c}\text { Total Federal and } \\
\text { State VNG Tax } \\
\text { (1993 dollars per thousand cubic feet) }\end{array}$ \\
\hline 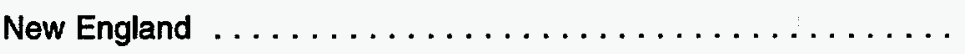 & 1.69 \\
\hline Middle Atlantic $\ldots \ldots \ldots \ldots \ldots \ldots \ldots \ldots \ldots \ldots$ & 0.91 \\
\hline East North Central $\ldots \ldots \ldots \ldots \ldots \ldots \ldots$ & 0.85 \\
\hline West North Central $\ldots \ldots \ldots \ldots \ldots \ldots \ldots \ldots$ & 1.45 \\
\hline South Atlantic (excludes Florida) . . . . . & 1.35 \\
\hline East South Central $\ldots \ldots \ldots \ldots \ldots \ldots \ldots \ldots$ & 1.26 \\
\hline West South Central $\ldots \ldots \ldots \ldots \ldots \ldots \ldots \ldots$ & 1.14 \\
\hline Mountain (excludes Arizona and New Mexico) $\ldots \ldots \ldots \ldots$ & 1.23 \\
\hline Pacific (excludes California) $\ldots \ldots \ldots \ldots \ldots \ldots \ldots \ldots$ & 1.63 \\
\hline Florida $\ldots \ldots \ldots \ldots \ldots \ldots \ldots \ldots \ldots \ldots \ldots$ & 1.31 \\
\hline Arizona and New Mexico $\ldots \ldots \ldots \ldots \ldots \ldots \ldots$ & 1.64 \\
\hline California $\ldots \ldots \ldots \ldots \ldots \ldots \ldots \ldots \ldots$ & 1.31 \\
\hline
\end{tabular}

assuming a $\$ 0.49$ (1993 dollars per thousand cubic feet) Federal Tax.

Source: Energy Information Administration, Office of Integrated Analysis and Forecasting, based on State taxes published in the Information Resources, Inc., publication Octane Week, August 9, 1993.

Additions to underground storage capacity are constrained to capture limitations of geology in each of the market regions. The constraints limit total storage additions to be less than an expansion factor times the 1990 storage capacity (Table 40 ).

The model methodology assumes that storage utilization plans are developed annually and that all natural gas is injected into storage in the off-peak period and is withdrawn during the peak period. Annual net storage withdrawals equal zero in all years of the forecast.

\section{Legislation and Regulation}

All interstate pipeline companies are assumed to have completed the switch from modified fixed variable to straight fixed variable rate design by January 1994 to comply with Federal Energy Regulatory Commission (FERC) Order 636 rate design changes. Approved transition costs are assumed to be consistent with FERC's revised cost estimate as published by the General Accounting Office in Natural Gas: Costs, Benefits, and Concerns Related to FERC Order 636, Final Report, November 1993 (Table 41). It is assumed that the gas supply realignment costs will be recovered over a 5-year period beginning in 1994. Furthermore, it is assumed that 90 percent of these costs will be assigned to core markets and 10 percent will be assigned to noncore markets as stipulated in Order 636. Purchased Gas Adjustment Account Balance (Account 191) costs are assumed to be collected over a 2-year period, also beginning in 1994. These costs will be paid only by core customers. 
Table 40. Incremental Storage Expansion Factors (Over Existing 1993 Levels)

\begin{tabular}{|c|c|}
\hline Region & Expansion Factor \\
\hline 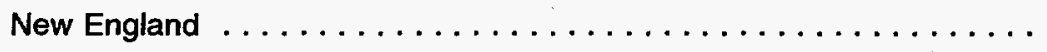 & 0 \\
\hline 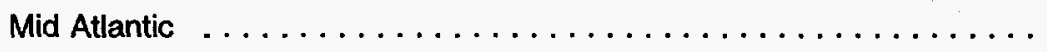 & 2.33 \\
\hline East North Central $\ldots \ldots \ldots \ldots \ldots \ldots \ldots \ldots \ldots \ldots \ldots \ldots \ldots \ldots \ldots$ & 3.00 \\
\hline West North Central $\ldots \ldots \ldots \ldots \ldots \ldots \ldots \ldots \ldots \ldots$ & 1.00 \\
\hline 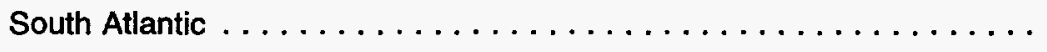 & 0.50 \\
\hline East South Central $\ldots \ldots \ldots \ldots \ldots \ldots \ldots \ldots \ldots \ldots \ldots \ldots$ & 7.00 \\
\hline West South Central $\ldots \ldots \ldots \ldots \ldots \ldots \ldots \ldots \ldots$ & 3.00 \\
\hline 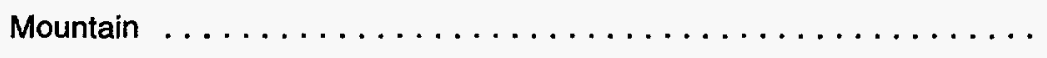 & 1.00 \\
\hline 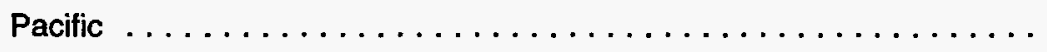 & 1.00 \\
\hline 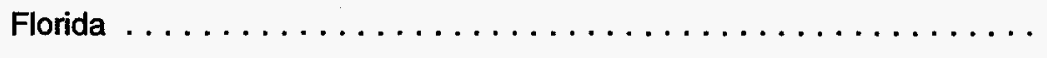 & 0 \\
\hline Arizona/New Mexico $\ldots \ldots \ldots \ldots \ldots \ldots \ldots \ldots \ldots \ldots$ & 0.33 \\
\hline California $\ldots \ldots \ldots \ldots \ldots \ldots \ldots \ldots \ldots \ldots \ldots \ldots \ldots \ldots$ & 0.25 \\
\hline
\end{tabular}

Source: Energy Information Administration, Office of Integrated Analysis and Forecasting.

The AEO95 methodology employed in solving for the natural gas supply and demand equilibrium assumes that core market transmission and distribution services remain subject to cost of service, rate of return regulation. Noncore transmission services are competitively priced with the price floor equal to the variable cost of delivering natural gas (generally compressor station fuel plus a few cents).

\section{Climate Change Action Plan}

Provisions of the Climate Change Action Plan relating to natural gas transmission and distribution are assumed to have no impact on the forecasts. Although regulatory changes that are recommended in the plan may be considered by FERC in the near future, they go beyond the current FERC regulatory policy and thus are not considered in the reference case. The Natural Gas Star program is generally targeting reductions in fugitive methane emissions. This program is not considered in the Reference Case because the National Energy Modeling System generates a forecast for combustion emissions and specifically excludes fugitive emissions such as methane leaks in the transmission and distribution network.

\section{Refurbishment Side Case}

The refurbishment case was conducted as a standalone side case to explore the impact higher costs may have on the interstate natural gas pipeline industry's revenue requirement and the average transmission and distribution markup. The higher level of costs were assumed to be related to extending the life of aging plant, to refurbish and replace pipe as it approaches the end of its useful life, or to address new pipeline safety initiatives. The refurbishment case does not assume that these specific actions will be undertaken; it merely shows the impact that this level of incremental investment and operations and maintenance costs may have on the industry's revenue requirement and the corresponding increase in the average markup to the end user. Key results are presented in Appendix C.

Industry estimates for pipeline safety and refurbishment costs were reviewed to develop a cost estimate that was appropriate for the EIA refurbishment case. The refurbishment case assumes that in addition to the costs represented in the reference case (capacity expansion costs and base-level operations and maintenance expenses), that the industry will incur an additional $\$ 1.7$ billion dollars per year in capital 
expenditures and an additional $\$ 116.2$ million dollars per year in operation and maintenance expenses. The incremental costs are assigned to pipeline companies represented in the model in proportion to each individual pipeline's contribution to the industry's total gas plant in service. Incremental capital costs are distributed among all pipelines that were in service in 1990 while incremental operations and maintenance expenses are distributed among all the pipelines in service in the particular year of the forecast. 
Table 41. FERC Order 636 Transition Costs by Pipeline Company (1992 Dollars)

\begin{tabular}{|c|c|c|c|}
\hline Interstate Pipeline Company & $\begin{array}{c}\text { Purchased Gas } \\
\text { Adjustment Account } \\
\text { Balance }\end{array}$ & $\begin{array}{l}\text { Gas Supply } \\
\text { Realignment }\end{array}$ & Total \\
\hline Algonquin Gas Transmission Co. . . & 0 & 0 & 0 \\
\hline ANR Pipeline Co. ........ & 0 & $229,862,348$ & $229,862,348$ \\
\hline Arkla, Inc. . . . . . . . . . . . & 97,814 & $29,344,130$ & $29,441,943$ \\
\hline Colorado Interstate Gas Co. . . . . . . & 0 & $5,868,826$ & $5,868,826$ \\
\hline CNG Transmission Corp. . . . . . . . & $78,251,012$ & $33,256,680$ & $111,507,692$ \\
\hline Columbia Gas Transmission Corp. . . . & $171,174,089$ & 0 & $171,174,089$ \\
\hline Columbia Gulf Transmission Corp. . . . & 0 & 0 & $\mathbf{0}$ \\
\hline East Tennessee Natural Gas Co. ... & 0 & 0 & 0 \\
\hline El Paso Natural Gas Co. . . . . . . . . . & 0 & 0 & 0 \\
\hline Florida Gas Transmission Co. . . . . . & 0 & $52,819,433$ & $52,819,433$ \\
\hline Great Lakes Gas Transmission Co. . . & 0 & 0 & 0 \\
\hline Kern River Gas Transmission Co. . . . & 0 & 0 & 0 \\
\hline K-N Energy, Inc. . . . . . . . . . & 0 & $244,534,413$ & $244,534,413$ \\
\hline Midwestern Gas Transmission Co. . . . & 0 & 0 & 0 \\
\hline Mississippi River Transmission Corp. . & 0 & $24,453,441$ & $24,453,441$ \\
\hline National Fuel Gas Supply Corp. . . . . & 0 & 0 & 0 \\
\hline Natural Gas Pipeline Co. of America . & 0 & $537,975,709$ & $537,975,709$ \\
\hline Northern Border Pipeline Co. ....... & 0 & 0 & 0 \\
\hline Northern Natural Gas Co. . . . . . . . . & 0 & 0 & 0 \\
\hline Northwest Pipeline Corp. . . . . . . . & 48,907 & 19,500 & 68,407 \\
\hline Pacific Gas Transmission Co. . . . . . & 0 & 0 & 0 \\
\hline Panhandle Eastern Pipeline Co. . . . . & $19,562,753$ & $48,906,883$ & $68,469,636$ \\
\hline Questar Pipeline Co. . . . . . . . . . . & 0 & 0 & 0 \\
\hline Southern Natural Gas Co. . . . . . . . . & 0 & $465,593,522$ & $465,593,522$ \\
\hline Tennessee Gas Pipeline Co. . . . . . . & $120,897,814$ & $432,336,842$ & $553,234,656$ \\
\hline TETCO $\ldots \ldots \ldots \ldots \ldots \ldots \ldots$ & $83,028,212$ & $546,778,947$ & $629,807,159$ \\
\hline Texas Gas Transmission Corp. ..... . & 0 & $171,174,089$ & $171,174,089$ \\
\hline Trailblazer Pipeline Co. . . . . . . . . . . & 0 & 0 & 0 \\
\hline Transcontinental Gas PL Corp. . ..... & 0 & 0 & 0 \\
\hline Transwestern Pipeline Co. . . . . . . . & $14,085,182$ & $16,139,271$ & $30,224,453$ \\
\hline Trunkline Gas Co. ............. & $14,672,065$ & $9,781,377$ & $24,453,441$ \\
\hline United Gas Pipeline Co. & $6,749,150$ & $20,540,891$ & $27,290,040$ \\
\hline Williams Natural Gas Co. . . . . . . . & $17,606,478$ & $29,344,130$ & $46,950,607$ \\
\hline Williston Basin Interstate Gas Co. ... & 0 & $19,562,753$ & $19,562,753$ \\
\hline Wyoming Interstate Natural Gas Co. . & 0 & 0 & 0 \\
\hline Other Pipeline Companies ........ & $5,022,597$ & $225,402,041$ & $230,424,637$ \\
\hline Total Industry Costs . . . . . . . . . & $531,196,072$ & $3,143,695,225$ & $3,674,891,297$ \\
\hline
\end{tabular}

Source: Memorandum from Elizabeth Moler (FERC) to Chairman John Dingell, Response to Chairman Dingell's Questions Regarding Various Aspects of Order 636, March 16, 1993. 



\section{Petroleum Market Module}

The Petroleum Market Module (PMM) forecasts petroleum product prices and sources of supply for meeting petroleum product demand. The sources of supply include crude oil (both domestic and imported), petroleum product imports, other refinery inputs including alcohols and ethers, natural gas plant liquids production, and refinery processing gain. In addition, the PMM estimates capacity expansion and fuel consumption of domestic refineries.

The PMM contains a linear programming representation of refining activities in five U.S. regions. This representation provides the marginal costs of production for a number of traditional and new petroleum products. The linear programming results are used to determine end-use product prices for each Census division using the assumptions and methods described below.

\section{Key Assumptions}

\section{Product Types and Specifications}

The PMM models refinery production of the products shown in Table 42.

Table 42. Petroleum Product Categories

\begin{tabular}{|c|c|}
\hline Product Category & Specific Products \\
\hline Motor Gasoline & $\begin{array}{l}\text { Traditional Unleaded, Oxygenated, Reformulated/High } \\
\text { Oxygen }\end{array}$ \\
\hline Jet Fuel $\ldots \ldots \ldots \ldots \ldots \ldots \ldots \ldots \ldots$ & Kerosene-type \\
\hline Distillates $\ldots \ldots \ldots \ldots \ldots \ldots \ldots \ldots \ldots$ & Kerosene, Heating Oil, Highway Diesel \\
\hline Residual Fuels & Low Sulfur, High Sulfur \\
\hline Liquefied Petroleum Gases $\ldots . \ldots \ldots \ldots \ldots$ & Propane, Liquified Petroleum Gases Mixed \\
\hline Petrochemical Feedstocks $\ldots \ldots \ldots \ldots \ldots \ldots \ldots$ & $\begin{array}{l}\text { Petrochemical Naptha, Petrochemical Gas Oil, } \\
\text { Propylene, Aromatics }\end{array}$ \\
\hline Others $\ldots \ldots \ldots \ldots \ldots \ldots \ldots \ldots \ldots$ & $\begin{array}{l}\text { Lubricating products and Waxes, Asphalt/Road Oil, } \\
\text { Still Gas, Petroleum Coke, Special Naphthas }\end{array}$ \\
\hline
\end{tabular}

Source: Energy Information Administration, Office of Integrated Analysis and Forecasting.

The costs of producing new formulations of gasoline and diesel fuel that will be phased in as a result of the Clean Air Act Amendments of 1990 (CAAA90) are determined within the linear programming representation by incorporating specifications and demands for these fuels. The PMM assumes that the specifications for these new fuels will remain the same as specified in current legislation.

\section{Motor Gasoline Specifications and Market Shares}

The PMM models the production and distribution of four different types of gasoline: traditional, oxygenated, reformulated, and reformulated/high-oxygen. The following specifications are included in 
PMM to differentiate between traditional and reformulated gasoline blends (Table 43): octane, oxygen content, Reid vapor pressure (Rvp), benzene content, aromatic content, sulfur content, and olefin content.

Beginning in 1995, traditional gasoline must comply with antidumping requirements aimed at preventing the quality of traditional gasoline from eroding as the reformulated gasoline program is implemented. The 1994-1997 specifications in PMM assume Simple Model compliance standards which restrict benzene, sulfur, and olefin specifications from exceeding 125 percent of the Environmental Protection Agency's (EPA) "1990 baseline. ${ }^{\prime \prime 11}$ Starting in 1998, traditional gasoline must meet the Complex Model compliance standards which cannot exceed average 1990 levels of toxic and nitrogen oxide emissions. ${ }^{92}$ Traditional gasoline during the 1998-2010 time period is assumed to have "1990 baseline" specifications.

Oxygenated gasoline, which has been required during winter in many U.S. cities since October of 1992, requires a oxygen content of 2.7 percent by weight. Some areas that require oxygenated gasoline will also require reformulated gasoline. In those overlapping areas, reformulated-high oxygen gasoline containing 2.7 percent oxygen will be required. Oxygenated gasoline is assumed to have specifications identical to traditional gasoline with the exception of a higher oxygen requirement. Similarly, the oxygen requirement is assumed to be the only difference between reformulated/high oxygen and reformulated gasoline blends.

Beginning in 1995, many areas of the country will require reformulated gasoline. Between 1995 and 1997 the Environmental Protection Agency (EPA) will certify reformulated gasoline according to either the "simple" or "complex" models. The PMM assumes that reformulated gasoline during this time period will meet the EPA's "simple model" definition, which allows no lead content, limits benzene content to 1.0 percent and aromatics content to 25 percent by volume, requires an oxygen content of 2.0 percent by weight, and caps nitrogen oxide emissions at a baseline level (Table 43). Beginning in 1998, the EPA will only certify reformulated gasoline using the "complex model," which allows refiners to specify reformulated gasoline-based emissions reductions from their companies 1990 baseline or the EPA's 1990 baseline. The PMM uses a set of specifications that meet the "complex model" requirements, but it does not attempt to determine the optimal specifications that meet the "complex model." Specifications such as Rvp, aromatics, sulfur, and olefin content change in the year 2000 reflecting further emissions reductions required by CAAA 90 .

The CAAA90 provided for special treatment of California that would allow different specifications for oxygenated and reformulated gasoline in that State. In 1992, California requested a waiver from the winter oxygen requirements of 2.7 percent to reduce the requirement to a range of 1.8 to 2.2 percent. The PMM assumes that PAD District V refiners must meet the California specifications. Therefore, for 19931994, the specifications for oxygenated gasoline in PAD District V meet a 2.0-percent standard. Starting in 1996, the specifications for reformulated gasoline in PAD District V are the same as California standards.

Rvp limitations are effective during summer months, which are defined differently in different regions. In addition, different Rvp specifications apply within each refining region, or Petroleum Administration for Defense (PAD) district. The PMM assumes that these variations in Rvp are captured in the annual average specifications, which are based on summertime Rvp limits, wintertime estimates, and seasonal weights.

\footnotetext{
${ }^{91}$ Federal Register, Environmental Protection Agency, 40 CFR Part 80, "Regulation of Fuels and Fuel Additives: Standards for Reformulated and Conventional Gasoline," Rules and Regulations, p. 7800 (Washington, DC, February 1994)

${ }^{92}$ Tbid.
} 
Table 43. Year Round Gasoline Specifications by PAD District

\begin{tabular}{|c|c|c|c|c|c|c|c|}
\hline \multirow[b]{2}{*}{ PAD District } & \multirow{2}{*}{$\begin{array}{l}\text { Reid Vapor } \\
\text { Pressure } \\
\text { (Max) }\end{array}$} & \multicolumn{2}{|c|}{$\begin{array}{c}\text { Oxygen } \\
\text { Weight Percent }\end{array}$} & \multirow{2}{*}{$\begin{array}{l}\text { Aromatics } \\
\text { Volume } \\
\text { Percent } \\
\text { (Max) }\end{array}$} & \multirow{2}{*}{$\begin{array}{c}\text { Benzene } \\
\text { Volume } \\
\text { Percent } \\
\text { (Max) }\end{array}$} & \multirow{2}{*}{$\begin{array}{l}\text { Sulfur } \\
\text { PPM } \\
\text { (Max) }\end{array}$} & \multirow{2}{*}{$\begin{array}{c}\text { Olefin } \\
\text { Volume } \\
\text { Percent } \\
\text { (Max) }\end{array}$} \\
\hline & & (Min) & (Max) & & & & \\
\hline \multicolumn{8}{|l|}{ Traditional } \\
\hline \multicolumn{8}{|l|}{$1993-1997$} \\
\hline PAD District I-IV & 10.2 & -- & -- & 39.0 & 1.9 & 423.0 & 13.54 \\
\hline PAD District V & 9.2 & -- & -- & 39.0 & 1.9 & 423.0 & 13.54 \\
\hline \multicolumn{8}{|l|}{$1998-2010$} \\
\hline PAD District I-IV & 10.2 & - & -- & 28.62 & 1.6 & 338.4 & 10.83 \\
\hline PAD District V & 9.2 & -- & -- & 28.62 & 1.6 & 338.4 & 10.83 \\
\hline \multicolumn{8}{|l|}{ Reformulated } \\
\hline \multicolumn{8}{|l|}{$1995-1997$} \\
\hline PAD District I-IV & 9.7 & 2.0 & 2.7 & 25.0 & 1.0 & 349.0 & 9.7 \\
\hline PAD District V & 8.7 & 1.8 & 2.2 & 25.0 & 1.0 & 349.0 & 9.7 \\
\hline \multicolumn{8}{|l|}{$1998-1999$} \\
\hline PAD District I-IV & 9.5 & 2.1 & 2.7 & 25.6 & 0.95 & 339.0 & 10.6 \\
\hline PAD District V & 8.7 & 1.8 & 2.2 & 25.0 & 1.0 & 40.0 & 6.0 \\
\hline \multicolumn{8}{|l|}{$2000-2010$} \\
\hline PAD District I-IV & 9.1 & 2.1 & 2.7 & 25.0 & 0.95 & 140.0 & 12.0 \\
\hline PAD District V & 8.7 & 1.8 & 2.2 & 25.0 & 1.0 & 40.0 & 6.0 \\
\hline
\end{tabular}

Max $=$ Maximum .

Min $=$ Minimum.

$P A D=$ Petroleum Administration for Defense.

PPM $=$ Parts per million by weight.

Source: Energy Information Administration, Office of Integrated Analysis and Forecasting.

\section{Motor Gasoline Market Shares}

Within the PMM, total gasoline demand is disaggregated into demand for traditional, oxygenated, reformulated, and reformulated/high-oxygen gasolines by applying assumptions about the annual market shares for each type. The shares change over time based on assumptions about the market penetration of new fuels. Annual assumptions for each region account for the seasonal and city-by-city nature of the regulations. (See Table 44 for AEO95 market share assumptions.) The market shares reflect the mandated use of reformulated blends in nonattainment areas as well as assumptions about opt-in and spillover demand from outside these areas. AEO95 assumes a 3-percent spillover of oxygenated and reformulated gasoline into attainment areas. 
Table 44. Percent Market Share for Gasoline Types by Census Division (Percentage)

\begin{tabular}{|c|c|c|c|c|c|c|c|c|c|}
\hline \multirow[b]{2}{*}{ Gasoline Type/Year } & \multicolumn{9}{|c|}{ Census Division } \\
\hline & 1 & 2 & 3 & 4 & 5 & 6 & 7 & 8 & 9 \\
\hline \multicolumn{10}{|l|}{ Traditional Gasoline } \\
\hline 1990-1991 . . . & 100 & 100 & 100 & 100 & 100 & 100 & 100 & 100 & 100 \\
\hline $1992 \ldots \ldots \ldots$ & 97 & 90 & 100 & 100 & 99 & 100 & 100 & 96 & 86 \\
\hline 1993 & 91 & 68 & 100 & 99 & 98 & 99 & 100 & 89 & 58 \\
\hline $1994 \ldots \ldots \ldots$ & 91 & 68 & 100 & 99 & 98 & 99 & 100 & 89 & 58 \\
\hline $1995 \ldots \ldots \ldots$ & 11 & 9 & 76 & 84 & 79 & 92 & 71 & 89 & 33 \\
\hline $1996 \ldots \ldots \ldots$ & 11 & 9 & 76 & 84 & 73 & 92 & 71 & 89 & 17 \\
\hline 1997 forward & 11 & 9 & 76 & 74 & 73 & 92 & 71 & 89 & 17 \\
\hline \multicolumn{10}{|c|}{ Oxygenated Gasoline (2.7\% oxygen) } \\
\hline $1990-1991 \ldots \ldots$ & 0 & 0 & 0 & 0 & 0 & 0 & 0 & 0 & 0 \\
\hline $1992 \ldots \ldots \ldots$ & 3 & 10 & 0 & 0 & 1 & 0 & 0 & 4 & 14 \\
\hline $1993 \ldots \ldots$ & 9 & 32 & 0 & 1 & 2 & 1 & 1 & 11 & 42 \\
\hline $1994 \ldots \ldots \ldots$ & 9 & 32 & 0 & 1 & 2 & 1 & 1 & 11 & 42 \\
\hline $1995 \ldots \ldots$ & 0 & 0 & 0 & 16 & 1 & 1 & 1 & 11 & 22 \\
\hline 1996 & 0 & 0 & 0 & 16 & 1 & 1 & 1 & 11 & 7 \\
\hline 1997 fonward . . . & 0 & 0 & 0 & 26 & 1 & 1 & 1 & 11 & 7 \\
\hline \multicolumn{10}{|c|}{ Reformulated Gasoline (2.0\% oxygen) } \\
\hline $1990-1994$ & 0 & 0 & 0 & 0 & 0 & 0 & 0 & 0 & 0 \\
\hline $1995 \ldots \ldots \ldots$ & 81 & 60 & 24 & 0 & 18 & 7 & 28 & 0 & 45 \\
\hline 1996 forward $\ldots$ & 81 & 60 & 24 & 0 & 25 & 7 & 28 & 0 & 76 \\
\hline \multicolumn{10}{|c|}{ Reformulated/High Oxygen ( $2.7 \%$ oxygen) } \\
\hline 1990-1994. & 0 & 0 & 0 & 0 & 0 & 0 & 0 & 0 & 0 \\
\hline 1995 forward & 9 & 32 & 0 & 0 & 2 & 0 & 0 & 0 & 0 \\
\hline
\end{tabular}

Source: Energy Information Administration, Office of Integrated Analysis and Forecasting.

The oxygenated gasoline shares throughout the forecast assume wintertime participation of 39 carbon monoxide nonattainment areas. Year-round consumption of oxygenated gasoline in Minnesota is assumed beginning in 1997 in accordance with State legislation. AEO95 also assumes that, starting in 1995, reformulated gasoline will be consumed in the nine required areas plus areas that had petitioned the EPA to opt in as of January $1994 .{ }^{93}$ The assumed opt-in areas include areas of New York, Pennsylvania, and Maine which opted-out of the program in December 1994 or January 1995. Nonattainment areas in Wisconsin and Atlanta, Georgia, are assumed to opt into the program starting in $1996 .{ }^{94}$

\footnotetext{
${ }^{93}$ Required areas: Baltimore, Chicago, Hartford, Houston, Los Angeles, Milwaukee, New York City, Philadelphia, and San Diego. 1995 Opt-ins: Texas, District of Columbia, New Jersey, Maryland, Delaware, New York, Connecticut, Virginia, New Hampshire, Massachusetts, Pennsylvania, Maine, and Rhode Island.

${ }^{94}$ The Governor of Wisconsin actually notified the EPA in May 1994 that Wisconsin would opt into the program. Areas in Wisconsin will join the program in June 1995. Contrary to model assumptions, Georgia officials who had been considering an opt-in for Atlanta recently decided to impose further Rvp limits on gasoline instead.
} 


\section{Diesel Fuel Specifications and Market Shares}

In order to account for diesel desulfurization regulations, low-sulfur diesel is differentiated from other distillates. Diesel fuel in Census Divisions 1 through 9 is assumed to meet Federal requirements.

The PMM contains a sharing methodology to allocate distillate demands between low and high sulfur. Market shares for low-sulfur diesel and distillate fuel are estimated based on data from EIA's annual Fuel Oil and Kerosene Sales 1992 (DOE/EIA-0535(92) (Washington, DC, October 1993). Since about 20 percent of current demand in the transportation sector is off highway, 80 percent of transportation demand for distillate fuel is assumed to be low sulfur. Consumption of low-sulfur distillate outside of the transportation sector is assumed to be zero.

\section{End-Use Product Prices}

End-use petroleum product prices are based on marginal costs of production plus production-related fixed costs plus distribution costs and taxes. The marginal costs of production are determined by the model and represent variable costs of production including additional costs for meeting reformulated fuels provisions of the CAAA90. Fixed refinery costs include fixed operating costs, ${ }^{95}$ a 4-percent return on assets, and environmental costs associated with controlling pollution at refineries ${ }^{96}$ (Table 45). Assuming that refinery-related fixed costs are recovered in the prices of light products, fixed costs are allocated among the prices of liquefied petroleum gases, gasoline, distillate, kerosene, and jet fuel. These costs are based on average annual estimates and are assumed to remain constant over the forecast period.

Table 45. Summary of Fixed Costs by Petroleum Administration for Defense Districts (1993 Dollars per Barrel)

\begin{tabular}{c|c|c|c|c|c}
\hline Cost Category & $\begin{array}{c}\text { PAD } \\
\text { District I }\end{array}$ & $\begin{array}{c}\text { PAD } \\
\text { District II }\end{array}$ & $\begin{array}{c}\text { PAD } \\
\text { District III }\end{array}$ & $\begin{array}{c}\text { PAD } \\
\text { District IV }\end{array}$ & $\begin{array}{c}\text { PAD } \\
\text { District V }\end{array}$ \\
\hline Fixed Operating Costs . . . . . & 3.28 & 2.11 & 2.50 & 2.06 & 3.14 \\
Return on Assets at 4 Percent . & 0.30 & 0.17 & 0.26 & 0.22 & 0.29 \\
Environmental Costs . . . . . & 1.44 & 1.45 & 1.14 & 2.10 & 1.59 \\
Total ................... & 5.02 & 3.74 & 3.90 & 4.38 & 5.02 \\
\hline
\end{tabular}

$P A D=$ Petroleum Administration for Defense.

Source: Energy Information Administration, Office of Integrated Analysis and Forecasting.

The costs of distributing and marketing petroleum products are represented by adding fixed distribution costs to the marginal and refinery fixed costs of products. The distribution costs are applied at the Census division level (Table 46) and are assumed to be constant throughout the forecast and across scenarios. Distribution costs for each product, sector, and Census division represent average historical differences between end-use and wholesale prices. The costs for kerosene are the average difference between end-use prices of kerosene and wholesale distillate prices.

State and Federal taxes are also added to transportation fuels to determine final end-use prices (Tables 47 and 48). Recent tax trend analysis indicated that State taxes increase at the rate of inflation, while Federal taxes do not. In AEO95, therefore, State taxes are held constant in real terms throughout the forecast while Federal taxes are deflated as follows:

$$
\text { Federal Tax } \text { product, year }=1993 \text { Federal Tax }_{\text {product }} / \text { GDP Deflator year }
$$

\footnotetext{
${ }^{95}$ Fixed operating costs include payroll, maintenance, labor and materials, depreciation, and other expenses.

${ }^{96}$ Environmental cost estimates are based on National Petroleum Council, U.S. Petroleum Refining - Meeting Requirements for Cleaner Fuels and Refineries, Volume I (Washington, DC, August 1993).
} 
Table 46. Petroleum Product End-Use Markups by Sector and Census Division (1993 Dollars per Million Btu)

\begin{tabular}{|c|c|c|c|c|c|c|c|c|c|}
\hline \multirow[b]{2}{*}{ Sector/Product } & \multicolumn{9}{|c|}{ Census Division } \\
\hline & 1 & 2 & 3 & 4 & 5 & 6 & 7 & 8 & 9 \\
\hline \multicolumn{10}{|l|}{ Residential Sector } \\
\hline Distillate Fuel Oil & 2.59 & 2.93 & 2.05 & 1.89 & 2.88 & 2.00 & 1.29 & 1.81 & 2.57 \\
\hline$\ldots \ldots \ldots \ldots \ldots$ & 0.00 & 0.00 & 0.00 & 0.00 & 0.00 & 0.00 & 0.00 & 0.00 & 0.00 \\
\hline Kerosene .......... & 3.70 & 4.06 & 3.30 & 2.80 & 3.68 & 2.37 & 3.18 & 4.57 & 6.02 \\
\hline Liquefied Petroleum Gases . . . . . & 9.59 & 9.82 & 5.84 & 3.62 & 8.08 & 6.70 & 5.97 & 5.82 & 8.79 \\
\hline \multicolumn{10}{|l|}{ Commercial Sector } \\
\hline Distillate Fuel Oil & 0.92 & 0.77 & 0.23 & 0.11 & 0.35 & 0.22 & 0.28 & 0.14 & 0.36 \\
\hline Gasoline $\ldots \ldots \ldots \ldots \ldots$ & 1.10 & 1.03 & 0.93 & 1.19 & 1.00 & 1.17 & 1.30 & 1.10 & 0.92 \\
\hline Kerosene ............... & 1.90 & 1.36 & 1.36 & 0.75 & 1.42 & 1.54 & 1.10 & 0.79 & 1.60 \\
\hline Liquefied Petroleum Gases . . . . . & 7.76 & 7.09 & 4.86 & 4.21 & 6.76 & 4.10 & 1.80 & 4.10 & 6.19 \\
\hline Low-Sulfur Residual Fuel Oil . . . & 0.07 & 0.28 & 0.31 & 0.18 & 0.25 & 0.27 & -0.15 & 0.04 & 0.61 \\
\hline \multicolumn{10}{|l|}{ Utility Sector } \\
\hline Distillate Fuel Oil $\ldots \ldots \ldots \ldots$ & -0.08 & 0.20 & 0.18 & 0.12 & -0.02 & 0.52 & 0.27 & 0.27 & 0.49 \\
\hline High-Sulfur Residual Fuel Oil ... & -0.13 & 0.17 & 0.84 & 0.27 & 0.04 & -0.10 & 0.43 & 0.04 & 0.42 \\
\hline Low-Sulfur Residual Fuel Oil . . . & -0.03 & 0.13 & 1.27 & 0.86 & 0.10 & 1.79 & 0.72 & 0.57 & 1.27 \\
\hline \multicolumn{10}{|l|}{ Transportation Sector } \\
\hline Distillate Fuel Oil & 1.70 & 1.34 & 0.89 & 0.96 & 1.03 & 0.89 & 1.05 & 1.04 & 1.39 \\
\hline Ethanol $\ldots$ & 1.79 & 1.79 & 1.79 & 1.79 & 1.79 & 1.79 & 1.79 & 1.79 & 1.79 \\
\hline Gasoline $\ldots \ldots \ldots \ldots$ & 1.08 & 0.94 & 0.92 & 1.16 & 0.97 & 1.18 & 1.29 & 1.06 & 0.84 \\
\hline High-Sulfur Residual Fuel Oil & -0.24 & 0.16 & 0.78 & 0.00 & -0.05 & -0.35 & 0.52 & 0.95 & 0.56 \\
\hline Jet Fuel $\ldots \ldots \ldots \ldots \ldots \ldots$ & 0.01 & 0.02 & -0.15 & -0.20 & -0.42 & 0.08 & 0.04 & -0.27 & 0.12 \\
\hline Liquefied Petroleum Gases . . . . & 9.10 & 7.69 & 5.52 & 3.91 & 6.87 & 4.54 & 1.40 & 4.24 & 6.17 \\
\hline Methanol $\ldots \ldots \ldots \ldots \ldots$ & 1.88 & 1.88 & 1.88 & 1.88 & 1.88 & 1.88 & 1.88 & 1.88 & 1.88 \\
\hline \multicolumn{10}{|l|}{ Industrial Sector } \\
\hline Asphalt and Road Oil ........ & 1.31 & 1.03 & 1.63 & 2.01 & 1.18 & 1.28 & 1.53 & 1.88 & 1.87 \\
\hline Distillate Fuel Oil $\ldots \ldots \ldots \ldots$ & 0.77 & 0.63 & 0.60 & 0.54 & 0.67 & 0.53 & 0.57 & 0.46 & 0.68 \\
\hline Gasoline & 1.10 & 0.93 & 0.92 & 1.27 & 0.95 & 1.20 & 1.28 & 1.16 & 0.92 \\
\hline Kerosene .............. & 1.92 & 1.35 & 1.40 & 0.66 & 1.27 & 1.46 & 1.05 & 0.84 & 1.37 \\
\hline Liquefied Petroleum Gases . . . . . & 8.09 & 7.01 & 5.46 & 3.15 & 6.55 & 3.58 & 0.52 & 3.42 & 6.19 \\
\hline Low-Sulfur Residual Fuel Oil . . . . & 0.04 & 0.18 & 0.37 & 0.18 & 0.17 & 0.41 & -0.14 & 0.28 & 0.35 \\
\hline
\end{tabular}

Note: Use conversion factors listed in Table 11 of the Annual Energy Outlook 1995 to convert values to physical units.

Sources: Markups based on data from Energy Information Administration (EIA), Form ElA-782A, "Refiners'/Gas Plant Operators' Monthly Petroleum Product Sales Repo't'; EIA, Form EIA-782B, "Resellers'/Retailers' Monthly Petroleum Report Product Sales Report'; EIA, Form FERC-423, "Monthly Report of Cost and Quality of Fuels for Electric Plants"; EIA, Form EIA-759 "Monthly Power Plant Report"; EIA, State Energy Data Report 1992, DOE/EIA-0214(92) (Washington, DC, May 1994); ElA, State Energy Price and Expenditures Report 1991, DOE/EIA-0376(91) (Washington, DC, September 1993); and EIA, Petroleum Marketing Monthly March 1994, DOE/EIA-0380(94/03) (Washington, DC, March 1994). 
Table 47. State-Level Taxes on Petroleum Transportation Fuels by Census Division (1993 Dollars per Million Btu)

\begin{tabular}{|c|c|c|c|c|c|c|c|c|c|}
\hline \multirow[b]{2}{*}{ Year/Product } & \multicolumn{9}{|c|}{ Census Division } \\
\hline & 1 & 2 & 3 & 4 & 5 & 6 & 7 & 8 & 9 \\
\hline \multicolumn{10}{|l|}{1994} \\
\hline Gasoline $^{a}$ & 1.96 & 1.65 & 1.70 & 1.49 & 1.27 & 1.47 & 1.53 & 1.71 & 1.88 \\
\hline Diesel & 1.52 & 1.55 & 1.53 & 1.35 & 1.21 & 1.18 & 1.34 & 1.20 & 1.65 \\
\hline Liquefied Petroleum Gases & 1.53 & 1.64 & 1.78 & 1.41 & 1.35 & 1.73 & 0.00 & 1.27 & 0.55 \\
\hline Methanol & 2.57 & 1.96 & 2.40 & 2.33 & 1.99 & 2.39 & 2.49 & 2.56 & 1.08 \\
\hline Ethanol & 2.19 & 2.08 & 2.05 & 1.94 & 1.70 & 2.05 & 2.13 & 2.17 & 0.98 \\
\hline Jet Fuel & 0.26 & 0.18 & 0.06 & 0.22 & 0.32 & 0.18 & 0.00 & 0.22 & 0.18 \\
\hline
\end{tabular}

${ }^{\text {a }}$ Tax also applies to gasoline consumed in the commercial and industrial sectors.

Note: Use conversion factors listed in Table 11 of the Annual Energy Outlook 1995 to convert values to physical units.

Source: Aggregated from Energy Information Administration, Petroleum Marketing Monthly, DOE/EIA-0380(94/07) (Washington, DC, July 1994).

Table 48. Federal Taxes

(1993 Dollars per Million Btu)

\begin{tabular}{|c|c|}
\hline Product & $\operatorname{Tax}$ \\
\hline Gasoline & 1.47 \\
\hline$\ldots \ldots \ldots \ldots$ & 1.76 \\
\hline Jet Fuel ${ }^{\mathrm{a}} \ldots \ldots \ldots \ldots$ & 0.32 \\
\hline Liquefied Petroleum Gases & 2.01 \\
\hline Methanol $\ldots \ldots \ldots \ldots \ldots \ldots \ldots \ldots \ldots \ldots \ldots \ldots \ldots$ & 1.83 \\
\hline 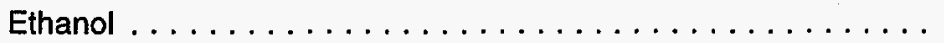 & 1.56 \\
\hline
\end{tabular}

${ }^{\text {a }}$ Tax begins in 1996.

Note: Use conversion factors listed in Table 11 of the Annual Energy Outlook 1995 to convert values to physical units.

Sources: Energy Information Administration, Petroleum Marketing Monthly, DOE/EIA-0380(94/07) (Washington, DC, July 1994); Omnibus Budget Reconciliation Act of 1993 (H.R. 2264); and Information Resources, Inc., Octane Week (Washington, DC, August 9, 1993).

\section{Crude Oil Quality}

In the PMM, the quality of crude oil is characterized by average gravity and sulfur levels. Both domestic and imported crude oil are divided into five categories as defined by the ranges of gravity and sulfur shown in Table 49.

A "composite" crude oil with the appropriate yields and qualities is developed for each category by averaging the characteristics of specific crude oil streams that fall into each category. While the domestic and foreign categories are the same, the composite crudes for each category may differ because different crude streams make up the composites. For domestic crude oil, an estimate of total production is made first, then shared out to each of the five categories based on historical data. For imported crude oil, a separate supply curve is provided for each of the five categories. 


\begin{tabular}{|c|c|c|}
\hline Crude Oil Categories & $\begin{array}{c}\text { Sulfur } \\
\text { (percent) }\end{array}$ & $\begin{array}{c}\text { Gravity } \\
\text { (degrees API) }\end{array}$ \\
\hline 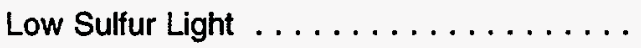 & $0-0.5$ & $>24$ \\
\hline Medium Sulfur Heavy $\ldots \ldots \ldots \ldots$ & $0.35-1.1$ & $>24$ \\
\hline High Sulfur Light $\ldots \ldots \ldots \ldots \ldots \ldots$ & $>1.1$ & $>32$ \\
\hline High Sulfur Heavy . . . . . . . . . . . . & $>1.1$ & $24-33$ \\
\hline High Sulfur Very Heavy . . . . . . . . . . . . . & $>0$ & $0-23$ \\
\hline
\end{tabular}

Source: Energy Information Administration, Office of Integrated Analysis and Forecasting.

\section{Regional Assumptions}

PMM refining regions are the five Petroleum Administration for Defense (PAD) districts. Individual refineries are aggregated into one linear programming representation for each PAD district region. In order to interact with other NEMS modules with different regional representations, certain PMM inputs and outputs are converted from a PAD district to a non-PAD district regional structure and vice versa.

\section{Capacity Expansion Assumptions}

PMM allows for capacity expansion of all processing units including distillation capacity, vacuum distillation, hydrotreating, coking, fluid catalytic cracking, hydrocracking, alkylation, and methyl tertiary butyl ether manufacture. Capacity expansion occurs by processing unit, starting from base year capacities established by PAD district using historical data. Expansion of distillation capacity is limited to 600 thousand barrels per day in each PAD district, reflecting an assumption that capacity additions will be limited to existing sites.

Expansion is determined when the value received from the additional product sales exceeds the investment and operating costs of the new unit. The investment costs assume a 15-percent rate of return over a 15-year plant life. Expansion through 1994 is determined by adding to the existing capacities of units planned and under construction that are expected to begin operating during this time. Capacity expansion plans are done every three years. For example, after the model has reached a solution for forecast year 1994, the PMM looks ahead and determines the optimal capacities given the demands and prices existing in the 1997 forecast year. The PMM then allows 50 percent of that capacity to be built in forecast year 1995, 25 percent in 1996, and 25 percent in 1997. At the end of 1997, the cycle begins anew, looking ahead to 2000 .

\section{Strategic Petroleum Reserve Fill Rate}

AEO95 assumes no additions for the Strategic Petroleum Reserve during the forecast period. Additions to the Strategic Petroleum Reserve have not been included in recent budgets.

\section{Legislation}

The PMM reflects recent national and regional legislative and regulatory changes that will affect future petroleum supply and product prices. It incorporates taxes imposed by the 1993 Budget Reconciliation Act as well as costs resulting from environmental legislation.

The Budget Reconciliation Act imposes a tax increase of 4.3 cents per gallon on transportation fuels including gasoline, diesel, liquefied petroleum gases, and jet fuel. Except for jet fuel, the tax began on 
October 1, 1993, and takes effect in the PMM in forecast year 1994. Jet fuel has been granted a 2-year delay.

With a goal of reducing tailpipe emissions in areas failing to meet Federal air quality standards (nonattainment areas), Title II of the CAAA90 established regulations for gasoline formulation. Starting in November 1992, gasoline sold during the winter in 39 carbon monoxide nonattainment areas was required to be oxygenated. ${ }^{97}$ Starting in 1995, gasoline sold in nine major U.S. cities that are considered the most severe ozone nonattainment areas must be reformulated to reduce volatile organic compounds (which contribute to ozone formation) and toxic air pollutants, as well as meet a number of other new specifications. Additional areas with less severe ozone problems may choose to "opt in" to the reformulated gasoline requirement. In a few metropolitan areas with both ozone and carbon monoxide problems, the requirements for oxygenated and reformulated gasoline will overlap. In other words, during the winter months a reformulated/high oxygen gasoline will be required. ${ }^{98}$

The AEO95 reformulated gasoline projections assume that the Renewable Oxygenate Standard (ROS) promulgated by EPA in 1994 will be implemented. In 1995, ROS requires renewable oxygenates such as ethanol and ethyl tertiary butyl ether to be used in 15 percent of reformulated gasoline. The renewable oxygenate requirement will then be increased to 30 percent of reformulated gasoline in 1996 . The implementation of ROS is uncertain because the U.S. Court of Appeals has ordered a stay on the ROS pending further legal review. At a minimum, the stay will delay the implementation of ROS.

Title II of the CAAA90 also established regulations on the sulfur and aromatics content of diesel fuel, which took effect October 1, 1993. All diesel fuel sold for use on highways now contains less sulfur and meets new aromatics or cetane level standards.

A number of pieces of legislation are aimed at controlling air, water, and waste emissions from refineries themselves. The PMM incorporates related environmental investments as refinery fixed costs. The estimated expenditures are based on results of the 1993 National Petroleum Council Study. ${ }^{99}$ These investments reflect compliance with Titles I, III, and V of CAAA90, the Clean Water Act, the Resource Conservation and Recovery Act, and anticipated regulations including the phaseout of hydrofluoric acid and a broad-based requirement for corrective action. No costs for remediation beyond the refinery site are included.

\footnotetext{
${ }^{97}$ Oxygenated gasoline must contain an oxygen content of 2.7 percent by weight.

${ }^{98}$ The gasoline must meet the requirements of reformulated gasoline and must have an oxygen content of 2.7 percent by weight.

${ }^{99}$ National Petroleum Council, U.S. Petroleum Refining - Meeting Requirements for Cleaner Fuels and Refineries, Volume I (Washington, DC, August 1993).
} 



\section{Coal Market Module}

The Coal Market Module (CMM) provides forecasts of U.S. coal production, consumption, exports, distribution, and prices. The CMM comprises three submodules: the Coal Production Submodule, the Coal Distribution Submodule, and the Coal Export Submodule.

\section{Key Assumptions}

\section{Coal Production Submodule}

The Coal Production Submodule (CPS) generates a different set of supply curves for the CMM for each year of the forecast. Separate supply curves are developed for each of 16 supply regions, 16 coal types, and 2 mine types (surface or underground). The supply curves generated reflect the relationship between capacity utilization and minemouth prices in the short-run. In addition, annual adjustments to the CPS supply curves are made to reflect the effects of reserve depletion and changes in labor productivity and factor input costs (labor and diesel fuel).

To estimate annual production capacity for each supply curve, the CPS makes use of projections of coal demand from other NEMS modules and the Coal Export Submodule and coal distribution projections from the Coal Distribution Submodule. Projections for labor costs are provided by the Macroeconomic Activity Module, and diesel fuel costs are obtained from the Petroleum Market Module.

The key assumptions underlying the CPS are:

- Estimates of recoverable coal reserves are based on the EIA Demonstrated Reserve Base (DRB) of in-ground coal resources of the United States, plus some additional resource estimates of coal contained within the inferred coal resource category, which have a higher degree of uncertainty than DRB estimates. Resource estimates are correlated with data on coal quality and geological characteristics from other sources to create a Coal Reserves Data Base. Estimates are developed on a regionally disaggregated basis. Recoverable DRB coal reserves in the United States are estimated at 265 billion short tons. Low-sulfur recoverable coal reserves in the DRB are estimated to total 100 billion short tons, with 87 percent concentrated in the West.

- Coal producers face lead-time constraints for bringing new production capacity on line to meet increased demand. In the CPS, it is assumed that coal producers add new mine capacity in response to projected changes in coal demand and that lowest-cost reserves will be mined first. The CPS uses projections of coal demand from the Electricity Market Module, End-Use Demand Modules and the Coal Export Submodule, and coal distribution projections from the Coal Distribution Submodule.

- In the short term, mining costs are assumed to vary with changes in capacity utilization of mines, labor productivity, and factor input costs. In the CPS, factor input costs are represented by projections of diesel fuel prices from the Petroleum Market Module and labor costs from the Macroeconomic Activity Module.

- Between 1978 and 1993, U.S. coal mining productivity (measured in short tons of coal produced per miner per hour) increased at an average rate of 6.7 percent per year. The major factors underlying these gains were interfuel price competition, structural change in the industry, and 
technological improvements in coal mining. ${ }^{100}$ Based on the expectation that further penetration of certain more productive mining technologies, such as longwall methods and large capacity surface mining equipment, will gradually level off, productivity improvements are assumed to continue, but to decline in magnitude. Different rates of improvement are assumed by region and by mine type, surface and underground. The following general pattern applies to the rate of improvement: from 1993 to 2000, declining from 8 to 5 percent per year; and from 2000 to 2010, declining from 5 to 2 percent. These estimates are based on recent historical data reported on Form EIA-7A, Coal Production Report, and expectations regarding the penetration and impact of new coal mining technologies. ${ }^{101}$

- The CPS accounts for the retirement of existing mines over the forecast by annually decrementing the segment of coal supply curves represented by existing mines. The decrements used for this year's forecast, by coal supply region, mining method, and year, are shown in Tables 50 and 51 .

Table 50. Retirement of Existing Underground Mine Production Capacity ${ }^{a}$ in the Coal Production Submodule, 1995-2010

(Fractions)

\begin{tabular}{|c|c|c|c|c|}
\hline Coal Production Regions & 1995 & 2000 & 2005 & 2010 \\
\hline Pennsylvania, Ohio, Maryland & 0.05 & 0.16 & 0.29 & 0.52 \\
\hline West Virginia, North $\ldots \ldots \ldots \ldots \ldots \ldots \ldots$ & 0.11 & 0.28 & 0.41 & 0.61 \\
\hline West Virginia, South . . . . . . . . . . . . . & 0.25 & 0.58 & 0.73 & 0.84 \\
\hline Kentucky, East $\ldots \ldots \ldots \ldots \ldots \ldots \ldots \ldots \ldots$ & 0.34 & 0.73 & 0.88 & 0.93 \\
\hline Virginia, Tennessee $\ldots \ldots \ldots \ldots \ldots \ldots \ldots$ & 0.26 & 0.53 & 0.73 & 0.88 \\
\hline Alabama $\ldots \ldots \ldots \ldots \ldots \ldots$ & 0.01 & 0.06 & 0.22 & 0.32 \\
\hline Kentucky, West ............ & 0.17 & 0.35 & 0.53 & 0.68 \\
\hline Illinois, Indiana $\ldots \ldots \ldots \ldots \ldots \ldots \ldots \ldots$ & 0.03 & 0.19 & 0.45 & 0.62 \\
\hline Arkansas, lowa, Kansas, Missouri, Oklahoma . . . . . . . . & 0.25 & 0.58 & 0.73 & 0.84 \\
\hline Texas, Louisiana . . . . . . . . . . . . . . . . . . . . & -- & -- & - & - \\
\hline North Dakota, South Dakota, Montana . . . . . . . . . . . & - & -- & -- & -- \\
\hline Wyorning, East . . . . . . . . . . . . . . & -- & -- & -- & - \\
\hline Wyorming, West $\ldots \ldots \ldots \ldots \ldots \ldots \ldots$ & 0.04 & 0.07 & 0.07 & 0.63 \\
\hline Arizona, New Mexico, Colorado, Utah . . . . . . . . . . & 0.10 & 0.21 & 0.28 & 0.37 \\
\hline Washington, Oregon, California . . . . . . . . . . & -- & -- & -- & -- \\
\hline Alaska $\ldots \ldots \ldots \ldots \ldots \ldots \ldots$ & -- & -- & -. & -- \\
\hline
\end{tabular}

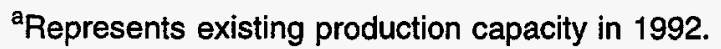

$--=$ No existing underground production capacity in these regions.

Note: A value of 1.00 represents full (i.e., 100 percent) retirement of existing production capacity.

Source: Energy Information Administration, Office of Integrated Analysis and Forecasting.

\section{Coal Distribution Submodule}

The Coal Distribution Submodule (CDS) determines the least-cost (minemouth price plus transportation cost) supplies of coal by supply region for a given set of coal demands in each demand sector in each demand region using a heuristic algorithm which compares alternative sources. Production and distribution are computed for 16 supply and 23 demand regions for 23 demand subsectors.

\footnotetext{
${ }^{100}$ Energy Information Administration, The U.S. Coal Industry, 1970-1990: Two Decades of Change, DOE/EIA-0559 (Washington, DC, November 1992).

${ }^{101}$ Stanley C. Suboleski, et al., Central Appalachia: Coal Mine Productivity and Expansion, Electric Power Research Institute, EPRI IE-7117, September 1991.
} 


\section{Table 51. Retirement of Existing Surface Mine Production Capacity in the Coal Production}

Submodule, 1995-2010

(Fractions)

\begin{tabular}{|c|c|c|c|c|}
\hline Supply Regions & 1995 & 2000 & 2005 & 2010 \\
\hline Pennsylvania, Ohio, Maryland & 0.30 & 0.59 & 0.74 & 0.82 \\
\hline West Virginia, North . . . . . & 0.40 & 0.66 & 0.86 & 1.00 \\
\hline West Virginia, South & 0.29 & 0.67 & 0.91 & 0.98 \\
\hline Kentucky, East .... & 0.42 & 0.86 & 0.94 & 0.98 \\
\hline Virginia, Tennessee & 0.53 & 0.91 & 0.96 & 0.97 \\
\hline Alabama $\ldots . . .$. & 0.25 & 0.42 & 0.54 & 0.75 \\
\hline Kentucky, West & 0.38 & 0.71 & 0.89 & 0.98 \\
\hline Ullinois, Indiana $\ldots \ldots \ldots \ldots \ldots \ldots \ldots \ldots \ldots \ldots$ & ' 0.29 & 0.60 & 0.75 & 0.87 \\
\hline Arkansas, lowa, Kansas, Missouri, Oklahoma . . . . & 0.20 & 0.34 & 0.38 & 0.40 \\
\hline Texas, Louisiana $\ldots \ldots \ldots \ldots \ldots \ldots \ldots$ & 0.00 & 0.00 & 0.00 & 0.00 \\
\hline North Dakota, South Dakota, Montana & 0.04 & 0.07 & 0.13 & 0.20 \\
\hline Wyoming, East $\ldots \ldots \ldots \ldots \ldots \ldots \ldots \ldots \ldots \ldots$ & 0.00 & 0.03 & 0.12 & 0.34 \\
\hline$\ldots \ldots \ldots \ldots \ldots \ldots \ldots \ldots \ldots$ & 0.00 & 0.04 & 0.12 & 0.29 \\
\hline Arizona, New Mexico, Colorado, Utah $\ldots \ldots \ldots \ldots \ldots$ & 0.09 & 0.15 & 0.21 & 0.36 \\
\hline Washington, Oregon, California . . . . . & 0.00 & 0.00 & 0.00 & 0.35 \\
\hline Alaska $\ldots \ldots \ldots \ldots \ldots \ldots \ldots \ldots \ldots$ & 0.00 & 0.00 & 0.00 & 0.00 \\
\hline
\end{tabular}

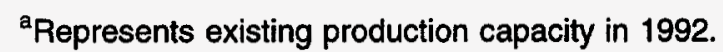

Note: A value of 1.0 represents full (i.e., 100 percent) retirement of existing production capacity.

Source: Energy Information Administration, Office of Integrated Analysis and Forecasting.

The projected levels of industrial, coking, and residential/commercial coal demand are provided by the Industrial, Commercial, and Residential Demand Modules; electricity coal demands are provided by the Electricity Market Module, and coal export demands are provided by the Coal Export Submodule. Coal supply curves are provided by the CPS.

The key assumptions underlying the CDS are:

- In the CDS, base-year transportation costs are estimates of average transportation costs for each origin-destination pair. These costs are computed as the difference between the average delivered price for a demand region (by sector and for export) and the average minemouth price for a supply region. Delivered price data are from Form EIA-3, "Quarterly Coal Consumption ReportManufacturing Plants," Form EIA-5, "Coke Plant Report-Quarterly," Federal Energy Regulatory Commission (FERC) Form 423, "Monthly Report of Cost and Quality of Fuels for Electric Plants," and the U.S. Bureau of the Census' Monthly Report EM-522. Minemouth price data are from Form EIA-7A, "Coal Production Report."

- Coal transportation costs are assumed to change uniformly over time across all regions and demand sectors. Transportation rates are escalated over time in response to projected variations in Reference Case fuel costs (No. 2 diesel fuel), labor costs (railroad-related wage plus wage supplements), and other rail-industry-related operating costs (material and supplies, equipment rent, purchased services, depreciation, interest, and taxes). The transportation rate escalators used for all five AEO95 scenarios are shown in Table 52.

- Electric utility demand received by the CDS is subdivided into "coal groups" representing demands for four different sulfur and four thermal heat content categories. This process allows the Electricity Market Module to determine the economically optimal blend of different coals to minimize delivered cost, while meeting the sulfur emissions requirements of the Clean Air Act 
Amendments of 1990 . Similarly, nonutility demands are subdivided into subsectors with their own coal groups to ensure that, for example, lignite is not used to meet a coking coal demand.

\section{Coal Export Submodule}

The Coal Export Submodule (CES) is a linear program which provides annual forecasts of U.S. steam and metallurgical coal exports, in the context of world coal trade, for input to the CMM. The linear program determines the pattern of world coal trade flows that minimize the production and transportation costs of meeting a prespecified set of regional coal import demands. It does this subject to constraints on export capacity, trade flows, and sulfur emissions.

Table 52. Transportation Rate Escalators, 1992-2010 $(1992=1.0000)$

\begin{tabular}{|c|c|c|c|c|c|c|}
\hline & Year & $\begin{array}{c}\text { Reference } \\
\text { Case }\end{array}$ & $\begin{array}{l}\text { Low } \\
\text { Economic } \\
\text { Growth }\end{array}$ & $\begin{array}{l}\text { High } \\
\text { Economic } \\
\text { Growth }\end{array}$ & $\begin{array}{l}\text { Low } \\
\text { Oil } \\
\text { Price }\end{array}$ & $\begin{array}{l}\text { High } \\
\text { Oil } \\
\text { Price }\end{array}$ \\
\hline 1992 & $\cdots \ldots \ldots \ldots \ldots \ldots$ & 1.0000 & 1.0000 & 1.0000 & 1.0000 & 1.0000 \\
\hline 1993 & $\ldots \ldots \ldots \ldots \ldots$ & 0.9825 & 0.9825 & 0.9825 & 0.9825 & 0.9825 \\
\hline 1994 & $\ldots \ldots \ldots \ldots \ldots$ & 0.9761 & 0.9772 & 0.9754 & 0.9761 & 0.9761 \\
\hline 1995 & $\ldots \ldots \ldots \ldots \ldots$ & 0.9832 & 0.9864 & 0.9833 & 0.9753 & 0.9871 \\
\hline 1996 & $\ldots \ldots \ldots \ldots \ldots$ & 0.9849 & 0.9889 & 0.9849 & 0.9727 & 0.9918 \\
\hline 1997 & $\ldots \ldots \ldots \ldots \ldots$ & 0.9889 & 0.9927 & 0.9891 & 0.9757 & 0.9977 \\
\hline 1998 & $\ldots \ldots \ldots \ldots \ldots$ & 0.9926 & 0.9965 & 0.9925 & 0.9783 & 1.0016 \\
\hline 1999 & $\ldots \ldots \ldots \ldots \ldots$ & 0.9961 & 0.9995 & 0.9964 & 0.9804 & 1.0052 \\
\hline 2000 & $\ldots \ldots \ldots \ldots \ldots$ & 0.9986 & 1.0029 & 0.9996 & 0.9820 & 1.0085 \\
\hline 2001 & $\ldots \ldots \ldots \ldots$ & 1.0022 & 1.0053 & 1.0038 & 0.9841 & 1.0127 \\
\hline 2002 & $\ldots \ldots \ldots \ldots \ldots$ & 1.0053 & 1.0085 & 1.0075 & 0.9864 & 1.0161 \\
\hline 2003 & $\ldots \ldots \ldots \ldots \ldots$ & 1.0087 & 1.0111 & 1.0115 & 0.9886 & 1.0202 \\
\hline 2004 & $\ldots \ldots \ldots \ldots \ldots$ & 1.0121 & 1.0143 & 1.0157 & 0.9907 & 1.0242 \\
\hline 2005 & $\ldots \ldots \ldots \ldots \ldots$ & 1.0157 & 1.0173 & 1.0196 & 0.9932 & 1.0284 \\
\hline 2006 & $\ldots \ldots \ldots \ldots \ldots$ & 1.0188 & 1.0200 & 1.0236 & 0.9956 & 1.0321 \\
\hline 2007 & & 1.0223 & 1.0226 & 1.0275 & 0.9979 & 1.0363 \\
\hline 2008 & $\ldots \ldots \ldots \ldots \ldots$ & 1.0256 & 1.0254 & 1.0319 & 0.9998 & 1.0401 \\
\hline 2009 & & 1.0288 & 1.0277 & 1.0358 & 1.0023 & 1.0440 \\
\hline 2010 & $\ldots \ldots \ldots \ldots$ & 1.0323 & 1.0301 & 1.0398 & 1.0045 & 1.0481 \\
\hline
\end{tabular}

Source: Energy Information Administration, Office of Integrated Analysis and Forecasting.

The CES projects steam and metallurgical coal trade flows from 16 coal-exporting regions of the world to 20 import regions for 4 coal types (coking, low-sulfur steam, high-sulfur steam, and subbituminous). The CES includes five U.S. export regions and four U.S. import regions.

The key assumptions underlying the CES are:

- The coal market is competitive. In other words, no large suppliers or groups of producers are able to influence the price through adjusting their output. This means suppliers gain no producer surplus. Producers' decisions on how much and who they supply are driven by their costs, rather than prices being set by perceptions of what the market can bear. In this situation, the buyer gains the full consumer surplus.

- Coal buyers (importing regions) tend to spread their purchases among several suppliers in order to reduce the impact of supply disruption, even though this adds to their purchase costs. Similarly, producers choose not to rely on any one buyer and diversify their sales. 
- While subbituminous coal is included, use of this coal is constrained by the capacity of subbituminous coal-fired plants in an import region and the extent that it can be substituted/blended.

- Coking coal is treated as homogeneous. The model does not address quality parameters that define coking coals. The values of these quality parameters are defined within small ranges and affect world coking flows very little.

Data inputs to the CES:

- In the CES, U.S. coal exports are determined, in part, by the projected level of world coal import demand. World steam and metallurgical coal import demands for the AEO95 forecast scenarios are shown in Tables 53 and 54.

Table 53. World Steam Coal Import Demand by Import Region, 1995-2010 (Million Metric Tons of Coal Equivalent)

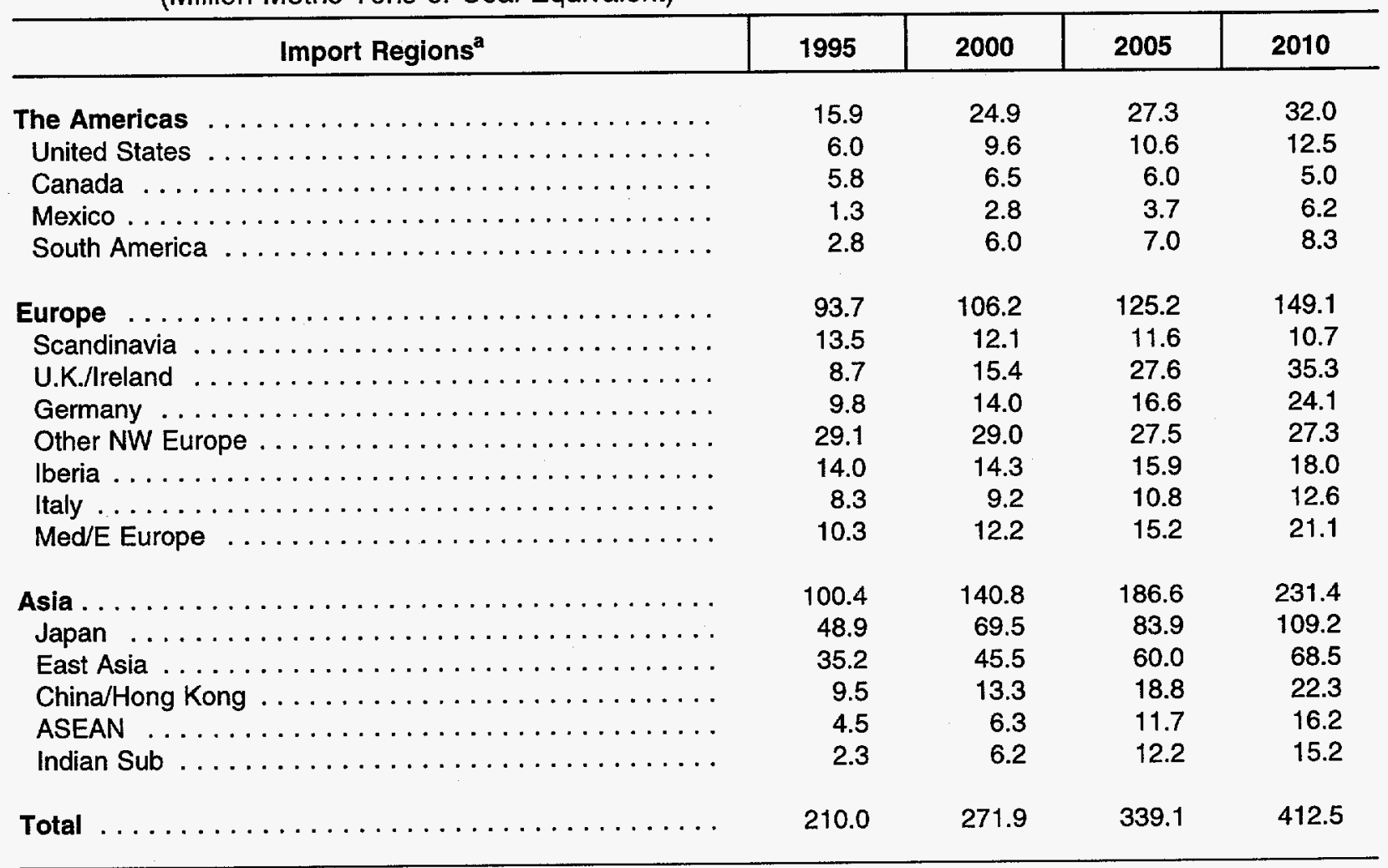

Import Regions: United States: United States; Canada: Canada; Scandinavia: Denmark, Finland, Norway, Sweden; U.K.Ireland: Ireland, United Kingdom; Germany: Austria, Germany; Other NW Europe: Belgium, France, Luxembourg, Netherlands; Iberia: Portugal, Spain; Italy: Italy; Med/E Europe: Algeria, Bulgaria, Croatia, Egypt, Greece, Israel, Malta, Morocco, Romania, Tunisia, Turkey; Mexico: Mexico; South America: Argentina, Brazil, Chile; Japan: Japan; East Asia: North Korea, South Korea, Taiwan; China/Hong Kong: China, Hong Kong; ASEAN: Malaysia, Philippines, Thailand; Indian Sub: Bangladesh, India, Iran, Pakistan, Sri Lanka.

Notes: One "metric ton of coal equivalent" contains 27.78 million Btu. Totals may not equal sum of components due to independent rounding.

Source: Energy Information Administration, Office of Integrated Analysis and Forecasting. 
Table 54. World Metallurgical Coal Import Demand by Import Region, 1995-2010 (Million Metric Tons of Coal Equivalent)

\begin{tabular}{|c|c|c|c|c|}
\hline Import Regions $^{a}$ & 1995 & 2000 & 2005 & 2010 \\
\hline 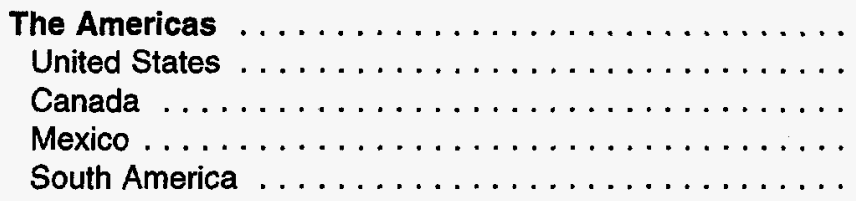 & $\begin{array}{r}17.8 \\
0.0 \\
4.0 \\
1.6 \\
12.2\end{array}$ & $\begin{array}{r}18.0 \\
0.0 \\
4.0 \\
1.5 \\
12.5\end{array}$ & $\begin{array}{r}17.6 \\
0.0 \\
3.5 \\
1.7 \\
12.4\end{array}$ & $\begin{array}{r}16.7 \\
0.0 \\
3.0 \\
1.4 \\
12.3\end{array}$ \\
\hline 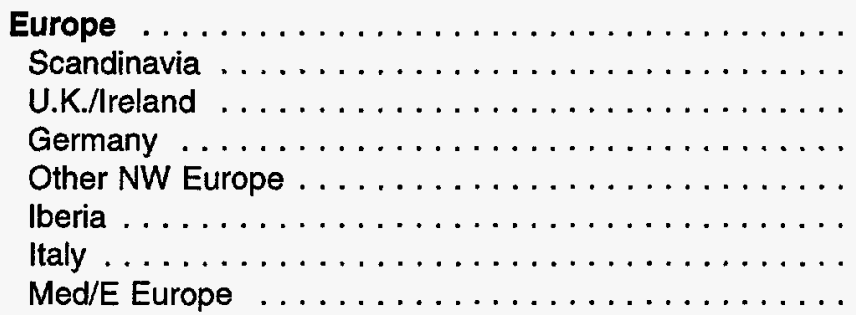 & $\begin{array}{r}45.8 \\
2.4 \\
8.1 \\
3.8 \\
12.5 \\
4.5 \\
7.0 \\
7.5\end{array}$ & $\begin{array}{r}45.2 \\
2.0 \\
7.4 \\
3.9 \\
10.1 \\
4.0 \\
7.2 \\
10.6\end{array}$ & $\begin{array}{r}47.8 \\
1.8 \\
7.1 \\
6.0 \\
10.0 \\
3.5 \\
7.2 \\
12.2\end{array}$ & $\begin{array}{r}50.1 \\
1.7 \\
6.7 \\
7.5 \\
9.3 \\
3.0 \\
7.3 \\
14.6\end{array}$ \\
\hline 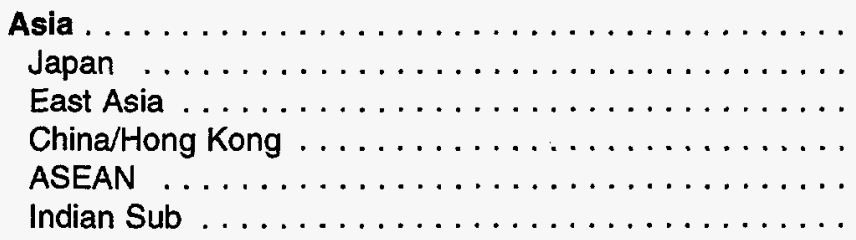 & $\begin{array}{r}85.9 \\
59.1 \\
17.1 \\
2.2 \\
0.0 \\
7.5\end{array}$ & $\begin{array}{r}90.1 \\
59.7 \\
19.2 \\
2.2 \\
0.0 \\
9.0\end{array}$ & $\begin{array}{r}90.0 \\
58.1 \\
19.1 \\
2.7 \\
0.0 \\
10.1\end{array}$ & $\begin{array}{r}87.1 \\
55.5 \\
18.2 \\
3.2 \\
0.0 \\
10.2\end{array}$ \\
\hline Total $\ldots \ldots \ldots \ldots \ldots \ldots \ldots \ldots \ldots \ldots$ & 149.5 & 153.3 & 155.4 & 153.9 \\
\hline
\end{tabular}

Import Regions: United States: United States; Canada: Canada; Scandinavia: Denmark, Finland, Norway, Sweden; U.K./Ireland: Ireland, United Kingdom; Germany: Austria, Germany; Other NW Europe: Belgium, France, Luxembourg, Netherlands; Iberia: Portugal, Spain; Italy: Italy; Med/E Europe: Algeria, Bulgaria, Croatia, Egypt, Greece, Israel, Malta, Morocco, Romania, Tunisia, Turkey; Mexico: Mexico; South America: Argentina, Brazil, Chile; Japan: Japan; East Asia: North Korea, South Korea, Taiwan; China/Hong Kong: China, Hong Kong; ASEAN: Malaysia, Philippines, Thailand; Indian Sub: Bangladesh, India, Iran, Pakistan, Sri Lanka.

Notes: One "metric ton of coal equivalent" contains 27.78 million Btu. Totals may not equal sum of components due to independent rounding.

Source: Energy Information Administration, Office of Integrated Analysis and Forecasting.

\section{Legislation}

It is assumed that provisions of the Energy Policy Act of 1992 that relate to the future funding of the Health and Benefits Fund of the United Mine Workers of America will have no significant effect on estimated production costs, although liabilities of company's contributions will be redistributed. The electric utility demand for coal, which represented almost 88 percent of domestic coal demand in 1993, incorporates the provisions of the Clean Air Act Amendments of 1990. It is assumed that utilities will be granted the full flexibility to meet the specified reductions in sulfur dioxide emissions.

\section{Climate Change Action Plan}

Provisions of the Climate Change Action Plan that concern coalbed methane recovery are incorporated in the Oil and Gas Supply Module. 


\section{Labor Productivity Side Cases}

In the reference case, labor productivity is assumed to increase at an average rate of 3.9 percent a year through 2010. Two alternative cases were modeled in the NEMS Coal Market Module, assuming labor productivity growth of 5.4 percent a year (high productivity case) and 2.4 percent a year (low productivity case). In the two alternative cases that were run to examine the impacts of different labor productivity assumptions, the annual growth rates were increased and decreased by 50 percent in each year after 1995. For example, a 4-percent productivity rate specific to a given year, mine type, and region in the reference case was set to 6 percent in the high productivity case and to 2 percent in the low productivity case. Both cases were run using only the Coal Market Module, rather than as a fully integrated NEMS run. Consequently, no demand feedback on coal markets was captured. In an integrated run, the demand response would tend to moderate the magnitude of the equilibrium price response. Key results are displayed in Appendix C. 



\section{Renewable Fuels Module}

The Renewable Fuels Module (RFM) consists of seven highly distinct submodules that represent the major renewable energy technologies. Some, such as ethanol and other biomass products, are fuels in the conventional sense of the word, while others, such as wind and solar radiation, are energy sources that do not require the production of a fuel. A common feature that extends across all renewable energy forms is that consumption of the energy form today does not lessen the supply of that form in the future. The technologies cover the gamut of commercial market penetration, from hydroelectric power, which was the original source of electricity generation and is a mature and possibly declining source, to new power systems using wind, solar, biomass, and geothermal energy, which in some cases require technological innovation to become cost effective or have inherent characteristics, such as intermittency, which make their penetration into the electricity grid dependent upon new methods for utility system planning or upon low-cost energy storage.

Because of the high degree of diversity of the energy forms within the RFM, the submodules of the RFM have interaction only with modules and submodules outside of the RFM rather than links with other RFM submodules. These interactions occur through common elements of the model with the Electricity Market Module (EMM) and the Petroleum Market Module for ethanol. Because of the high level of integration with these other National Energy Modeling System (NEMS) modules, the final outputs (levels of consumption and market penetration over time) for renewable energy forms are largely dependent upon assumptions in those other modules. The RFM includes the investment tax and energy production credits called for in the Energy Policy Act of 1992 for the appropriate energy types.

For $A E O 95$, the EMM represents learning effects for new technologies, which are implemented as a decrease in capital costs as a function of the level of market penetration. The RFM provides to the EMM the overnight capital cost for each technology that corresponds to the point where learning effects are estimated to end. In addition, unit size is provided to the EMM for renewable technologies so that the level of market penetration can be determined. As a rule of thumb, a doubling of market penetration produces a 10-percent decline in capital costs (the exception to this rule is wind, as discussed below). For an indepth discussion of the learning curves see the EMM section.

\section{Key Assumptions}

\section{Nonelectric Renewable Energy Uses}

In addition to projections for renewable energy used in electricity generation, the AEO95 contains projections for nonelectric renewable energy uses for industrial and residential wood consumption, solar residential and commercial hot water heating, and residential and commercial geothermal (groundsource) heat pumps. Additional renewable energy applications, such as direct solar thermal industrial applications or direct lighting, off-grid electricity generation and geothermal water use (e.g., district heating and greenhouses), are not included in the projections because their expected penetration is limited to niche markets.

\section{Electric Power Generation}

The RFM specifically and NEMS in general consider only grid-connected, central-power generation. This means that distributed sources such as some types of photovoltaic, Stirling engine solar, and wind generation that is not from a central power station are not included in the energy balances for the AEO95. 
The renewable submodules that interact with the EMM are the hydroelectric power, solar, wind, geothermal, wood, and MSW submodules. Each provides specific data that characterize that resource in a representative manner. In addition, a set of cost and performance data is provided directly to the EMM. These data are central to the build and dispatch decisions of the EMM. The data are presented in Table 55.

Table 55. Renewable Fuels Cost and Performance Data for 2005

\begin{tabular}{|c|c|c|c|c|c|c|}
\hline Parameters & $\begin{array}{l}\text { Hydro- } \\
\text { electric }\end{array}$ & $\begin{array}{c}\text { Solar } \\
\text { Thermal }^{a}\end{array}$ & Wind & $\begin{array}{c}\text { Geo- } \\
\text { thermal }^{b}\end{array}$ & MSW & Wood \\
\hline \multicolumn{7}{|l|}{ Capacity Factor } \\
\hline Maximum & 0.78 & 0.40 & 0.33 & 0.80 & 0.85 & 0.80 \\
\hline Minimum & 0.27 & 0.24 & $0.22^{c}$ & 0.80 & 0.85 & 0.80 \\
\hline Capital Cost with Contingency (dollars per kilowatt) ${ }^{d}$. & 1,818 & 1,840 & 740 & 1,924 & 4,828 & 1,181 \\
\hline Fixed Operating Costs (dollars per kilowatt) ${ }^{d}$. & 0.00 & 27.86 & 20.86 & 75.94 & 12.80 & 84.69 \\
\hline Variable Operating Costs (mills per kilowatthour) ${ }^{d}$ & 3.15 & 0.00 & 0.00 & 0.00 & $-16.42^{\ominus}$ & $64.03^{\prime}$ \\
\hline Date of Commercial Availability & 1990 & 2005 & 1990 & 1997 & 1990 & 2000 \\
\hline Construction Lead Time (years) & N/A & 3.00 & 3.00 & 3.00 & 3.00 & 3.00 \\
\hline
\end{tabular}

${ }^{2}$ Solar thermal only operates in Electricity Market Module regions 2, 5, and 10-13 because of its requirement for significant direct, normal insolation.

${ }^{b}$ Costs are representative of California sites.

${ }^{c}$ Factor varies according to time slice and region.

dValues are in 1987 dollars.

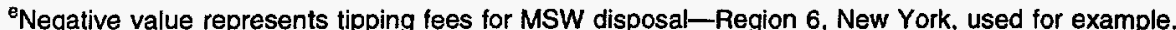

'Value represents the sum of variable operating and maintenance and fuel costs-Region 6 , New York, used for example.

MSW = Municipal solid waste.

Notes: All technologies and costs only consider grid-connected electricity generation.

Sources: Hydroelectric: Forms EIA-860 and EIA-867. Solar Thermal: California Energy Commission, "1992 Energy Technology Status Report," December 1992. Wind: Electric Power Research Institute (EPRI), Technical Assessment Guide (TAG) 1993. Geothermal: EPRI-TAG, 1993. MSW: EPRI-TAG, 1993. Biomass: K.R. Craig, M.K. Mann, "Cost and Performance of Integrated Gasification Combined Cycle (IGCC) Power Systems Incorporating a Directly Heated Biomass Gasifier," NREL (TP 430-6086) 1994.

\section{Conventional Hydroelectric Power Submodule}

\section{Background}

The Hydroelectric Power Submodule represents planned new conventional hydroelectric power capacity connected to the transmission grid and reported on Form EIA-860, "Annual Electric Generator Report," and Form EIA-867, "Annual Nonutility Power Producer Report." The submodule does not estimate additional unplanned capacity. Moreover, the submodule does not estimate any hydroelectric capacity not connected to the grid or hydropower uses other than for electric power (such as for direct drives). Finally, the submodule also excludes pumped storage hydroelectric power, which is considered a storage medium for coal and nuclear power and is not a renewable energy use. Hydroelectric power is not competed against any other electricity generation technologies for capacity expansion, and all the hydropower generated (from power marketing administrations, etc.) is consumed. The submodule provides for conventional hydropower, the available capacity, capacity factors, costs (capital and fixed and variable operating and maintenance) to the EMM by region. The fossil-fuel heat rate equivalents for hydropower, like all other submodules, are provided to the report writer for consumption calculation purposes only. An important factor determining the future growth in hydropower capacity and generation potential is the licensing/relicensing decisions of the Federal Energy Regulatory Commission (FERC). 


\section{Assumptions}

- Because of hydroelectric power's position in the merit order of generation, it is assumed that all available installed hydroelectric capacity will be used within the constraints of available water supply and general operating requirements.

- Capacity expansion is determined exogenously based on industry data as reported on Forms EIA-860 and EIA-867. Unplanned capacity changes (expansion or decrements) could be a variable for future sensitivity analysis, yet are assumed to be zero for the Reference Case and alternative cases as little unplanned growth is currently anticipated.

Data for hydroelectric capacity (Table 56) are derived from capacity changes reported on Forms EIA-860 and EIA-867 and are outputs from the Hydroelectric Power Submodule.

Table 56. Maximum Conventional Hydroelectric Capacity

(Megawatts)

\begin{tabular}{|c|c|c|c|}
\hline Year & Maximum Capacity & Year & Maximum Capacity \\
\hline 1992 & 76,550 & 2001 & 79,380 \\
\hline 1993 & 76,740 & 2002 & 79,430 \\
\hline 1994 & 77,070 & 2003 & 79,540 \\
\hline 1995 & 77,310 & 2004 & 79,590 \\
\hline 1996 & 77,560 & 2005 & 79,650 \\
\hline 1997 & 77,740 & 2006 & 79,700 \\
\hline 1998 & 77,870 & 2007 & 79,750 \\
\hline 1999 & 79,270 & 2008 & 79,810 \\
\hline \multirow[t]{2}{*}{2000} & 79,270 & 2009 & 79,810 \\
\hline & & 2010 & 79,810 \\
\hline
\end{tabular}

Source: Energy Information Administration, Office of Integrated Analysis and Forecasting.

\section{Solar Electric Submodule}

\section{Background}

The Solar Electric Submodule (SOLES) currently models two solar technologies, crystalline silicon photovoltaic collectors (PV) and central receiver solar thermal electric systems (ST). PV is assumed to be available in all 15 EMM regions while ST is available in only 6 regions, primarily in the Southwestern United States, where the necessary kind of solar conditions prevail. The technological performance, costs, and other data used in NEMS are derived for PV from the Technological Characterization efforts of the Department of Energy, Office of Energy Efficiency and Renewable Energy, and for ST from the Pacific Gas and Electric Co. report entitled Solar Central Receiver Technology Advancement for Electric Utility Application dated September 1988. SOLES provides to the EMM: capital investment cost, fixed operation and maintenance costs, variable operating costs, construction lead times, and the profile of construction costs as the percent of the total cost spent each year. For reporting purposes, solar output is aggregated into one number, which is primarily ST with a small portion of it PV.

\section{Assumptions}

- Because solar technologies are more expensive than other utility grid-connected technologies, early penetration will be driven by broad economic decisions such as the desire to become familiar with a new technology and environmental considerations. 
- Solar resources are well in excess of conceivable demand, so that supply curves are considered to be flat within regions. Accordingly, there is no reason to track installed solar capacity in NEMS. However, other issues such as proximity to transmission lines and land use and environmental restrictions could limit solar from major penetration within the forecast horizon. In the nine regions where ST technology is not modeled, the level of direct, normal insolation (the kind needed for that technology) is insufficient to make that technology commercially viable in the near to intermediate term.

- NEMS models the 10-percent investment tax credit for solar electric power generation by taxpaying entities. However, it does not include the 1.5-cent-per-kilowatthour subsidy to solar energy production for State and nonprofit electric cooperatives, since it does not keep track of these distinctions within the model.

\section{Wind-Electric Power Submodule}

\section{Background}

The specific wind technology modeled in NEMS is the horizontal-axis wind turbine. Unlike the solar resource, wind is considered a finite resource so the submodule calculates a maximum available capacity by North American Electric Reliability Council (NERC) region. The minimum economically viable wind speed is about $13 \mathrm{mph}$, and wind speeds are categorized into three wind classes according to annual average wind speed. The RFM keeps track of wind capacity within a region and moves to the next best wind class when one category is exhausted. Wind resource data on the amount and quality of wind per NERC region come from Pacific Northwest Laboratories studies and publications. ${ }^{102}$ The technological performance, cost, and other data used in NEMS are derived from the Electric Power Research Institute's Technology Assessment Guide. ${ }^{103}$

Maximum wind capacity, capacity factors, capital costs, fixed and variable operating and maintenance costs, and incentives are provided to the EMM for capacity planning and dispatch decisions. The fossilfuel heat rate equivalents for wind are provided to the report writer for energy consumption calculation purposes only. These form the basis on which the EMM decides how much power generation capacity is available from wind energy.

\section{Assumptions}

- Only grid-connected (utility and nonutility) generation is included. The forecasts do not include dispersed electric generation.

- Availability of wind power is based on the Pacific Northwest laboratories' Environmental and Moderate Land-Use Exclusions Scenario, in which some of the windy land area is not available for siting of wind turbines. The percent of total windy land unavailable under this scenario consists of all environmentally protected lands (such as parks and wilderness areas), all urban lands, all wetlands, 50 percent of forest lands, 30 percent of agricultural lands, and 10 percent of range and barren lands.

- Depending on the NERC region, the cost of competing fuels and other factors, wind plants can be built to meet system capacity requirements or as "fuel savers" to displace generation from existing capacity. For wind to penetrate as a fuel saver, the total fixed (capital and fixed

\footnotetext{
${ }^{102}$ D.L. Elliott, L.L. Wendell, and G.L. Gower, "An Assessment of the Available Windy Land Area and Wind Energy Potential in the Contiguous United States" (Richland, WA: Pacific Northwest Laboratory, August 1991).

${ }^{103}$ In collaboration with EPRI, capital costs declining as a function of time were converted to costs declining as a function of market penetration for use in the learning functions detailed elsewhere in this report.
} 
operations and maintenance) costs plus operating (variable operations and maintenance minus applicable subsidies from the Energy Policy Act of 1992) costs for new wind units must be less than the operating costs for existing capacity.

- Because of downwind turbulence and other aerodynamic effects, the model assumes an average spacing between turbine rows of 5 rotor diameters and a lateral spacing between turbines of 10 rotor diameters. This spacing requirement determines the amount of power that can be generated from windy land area and is factored into requests for generating capacity by the EMM.

- It is expected that wind turbine technology will improve in performance and that blade lengths will increase, as the cubic relationship between the area swept by the rotor and power generation provides a large incentive for increasing blade length. Capacity factors are assumed to increase to a national average of about 31 percent. However, as better wind resources are depleted, capacity factors go down.

- Because of increased market activity in windpower and the introduction of improved technologies, the capital cost for wind energy at the time learning is assumed to be fully achieved is $\$ 690$ in 1987 dollars (excluding contingencies). This so-called "nth-of-a-kind" cost represents a 20-percent decrease in capital costs for a doubling of capacity. This corresponds to 3,300 megawatts (MW) of capacity or 66 wind farms with a capacity of 50 megawatts each.

\section{Geothermal-Electric Power Submodule}

\section{Background}

In developing geothermal capacity growth projections, hydrothermal resources are considered, but hot dry rock is not included in the analysis. This is because the technology probably will not be available during the projection period, and reliable cost and resource data are not yet available. While the Geothermal-Electric Power Submodule (GES) is not interactively linked to NEMS, site data from the GES database is used to develop geothermal supply curves. The GES utilizes a process of resource accounting based on Sandia National Laboratory's 1991 geothermal resource assessment. ${ }^{104}$ Site-specific costs, including those for drilling, steam collection, and electricity transmission to the grid, as well as site characteristics, are used in identifying available resources and capacities by EMM region. The values passed to EMM for $A E O 95$ were based on an offline analysis using the personal computer version of the GES where data for geothermal costs and resource amounts were developed using an average cost of $\$ 0.05$ per kilowatthour as the criteria for the resources that were made available to the EMM for capacity expansion.

\section{Assumptions}

- Existing and planned capacity data are accessed directly by the EMM. The data are obtained from Forms EIA-860 and EIA-867. The build limits in Table 57 are independent of this capacity.

- Limits on new capacity (Table 57) are determined by site data in each region and are based on conservative estimates of the total resource.

- Supply and demand are assumed to be homogeneous within a region (i.e. supply is not linked to specific electricity transmission grids).

\footnotetext{
${ }^{104}$ Sandia National Laboratories, "Supply of Geothermal Power from Hydrothermal Sources: A Study of the Cost of Power in 20 and 40 Years" (Albuquerque, NM, June 1991).
} 
- Plant retirements are not considered within the GES. Insufficient information is available on retirement plans for capacity that was installed prior to the simulation period. New plants installed during the midterm forecast are assumed not to retire during the period.

- Capital and operating costs vary by sites and years; values shown in Table 55 are indicative of those used by EMM for geothermal build and dispatch decisions.

Table 57. Geothermal Model Determined Capacity Build Limits (Megawatts Electric)

\begin{tabular}{|c|c|c|c|}
\hline \multirow[b]{2}{*}{ Year } & \multicolumn{3}{|c|}{ Electricity Market Module Region } \\
\hline & 11 & 12 & 13 \\
\hline 2000 & 980 & 60 & 729 \\
\hline$\ldots \ldots \ldots \ldots \ldots \ldots \ldots \ldots$ & 1,588 & 60 & 926 \\
\hline $2010 \ldots \ldots \ldots \ldots \ldots \ldots \ldots \ldots$ & 1,778 & 140 & 345 \\
\hline
\end{tabular}

Source: Energy Information Administration, AEO95 Forecasting System run AEO95B.D1103942.

\section{Biomass (Wood)-Electric Power Submodule}

\section{Background}

In the electricity sector, capital and operating costs, fuel costs, and capacity factors, as shown in Table 55, are provided to the EMM to allow wood-fired units to compete with other fuels. Fuel costs are developed on a regional basis and combined with variable operating costs. Lower capital costs are used than are indicated in the Technology Assessment Guide from the Electric Power Research Institute as there is disagreement on the appropriate value within the industry. ${ }^{105}$ Because of the uncertainty surrounding this technology, unplanned builds were restricted to one per NERC region during the last 10 years of the forecast period. This is meant to emulate the conservative nature of the electricity generation industry especially in light of reduced fuel costs. The specific build patterns are presented in Table 58.

\section{Assumptions}

- Existing and planned capacity data are accessed directly by the EMM. The data are obtained from Forms EIA-860 and EIA-867.

- The conversion technology represented, upon which the costs in Table 55 are based, is an advanced gasifier-combined cycle plant. Co-firing with coal is a distinct possibility, but it would not add capacity.

- The submodule deals with noncaptive wood consumption only. Consumption by the wood products and paper industries is modeled in the industrial demand model.

\footnotetext{
${ }^{105}$ Gasification technology cost and performance data were obtained from NREL. These data were used because the technology characterized by NREL has been judged by EIA staff to be more consistent with future capacity additions. The principal difference is that EPRI cost estimates are based on a technology that could be built today using a more expensive exhaust gas quench system. NREL costs assume a less expensive hot gas cleanup system can be developed over the next 5 years.
} 
Table 58. Biomass - Regional Model Determined Build Patterns

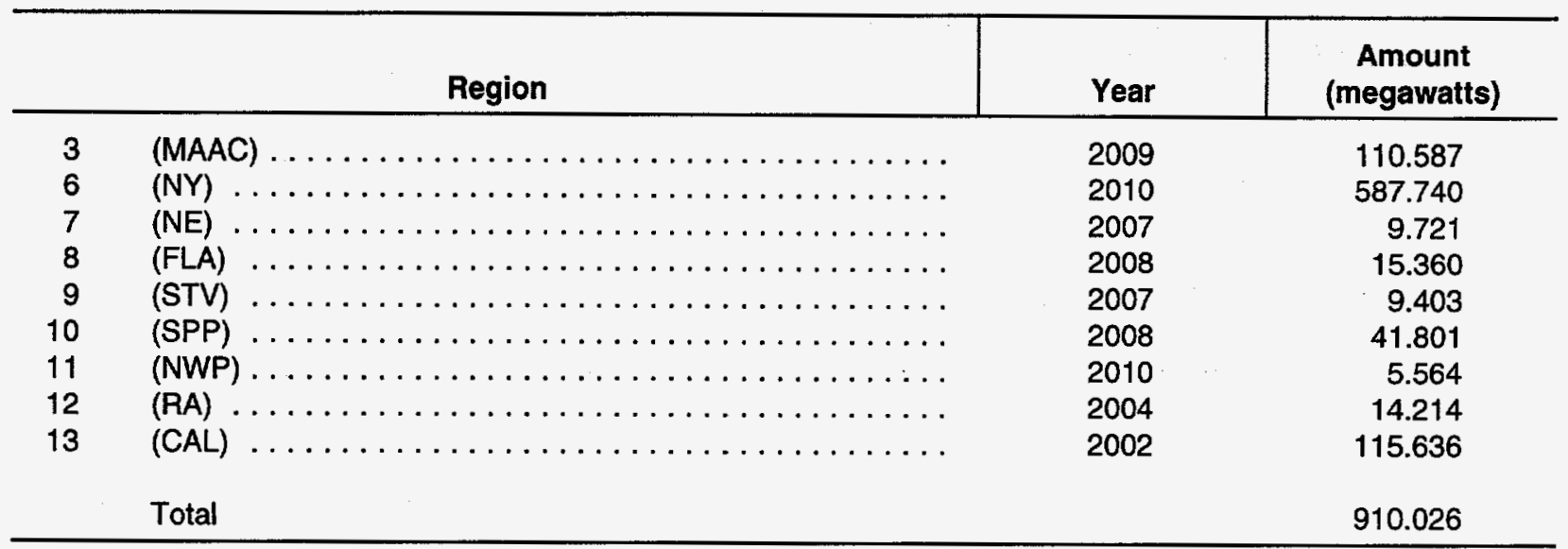

Source: Energy Information Administration, AEO95 Forecasting System run AEO95B.D1103942.

\section{Biomass (Municipal Solid Waste)-Electric Power Submodule}

\section{Background}

Municipal solid waste (MSW) combustion is treated within NEMS as a separate technology whose electricity production is exogenous to the EMM. The cost of producing electricity is passed to the EMM only as an input to the calculation that derives the average cost of producing electricity. Energy from. MSW is a byproduct of waste disposal activity and, therefore, not competed against other technologies in model decisions regarding new capacity additions. ${ }^{106}$

\section{Assumptions}

- MSW is assumed to displace other energy forms lower in the merit order.

- Build decisions are based on a stepwise process involving waste disposal parameters.

- Gross domestic product is used as the principal driver in establishing the supply of MSW.

- The heat content of the MSW is assumed to increase from 5,114 Btu per pound in 1990 to $5,569 \mathrm{Btu}$ per pound in 2000 and remain at that level for the remainder of the projection.

- The percentage of waste combusted is estimated to trend upward from 15 percent in 1990 to 30 percent by 2010 . This latter value is developed from an analysis of current regional percentages and assumed limits and growth rates for each region.

- The total energy from MSW projected for the United States is disaggregated into regions, sectors, and energy types (electricity and steam). This breakdown is performed by maintaining the projected 1996 distribution of these factors as represented in the Government Advisory Associates database of MSW plants.

- Capacities are computed from total energy by applying an assumed heat rate of 16,284 Btu per kilowatthour and capacity factor of 0.85 for all regions and years.

\footnotetext{
${ }^{106}$ For more details on the methodology outlined below, see the Model Documentation Report: Model Documentation Renewable Fuels Module of the National Energy Modeling System, DOE/EIA-M069.
} 


\section{Biofuels (Ethanol) Supply Submodule}

\section{Background}

The Biofuels (Ethanol) Supply Submodule employs supply functions on an annual basis through 2010 for ethanol produced from corn to produce transportation fuel.

\section{Assumptions}

- Corn feedstock production is provided exogenously to NEMS. Only ethanol production from corn is currently modeled. ${ }^{107}$

- Most production is projected to come from Petroleum Administration for Defense District II, where most of the corn is grown. This is not an assumption of the model, but rather a result of the exogenous projections of feedstock costs and quantities. However, it is assumed that the mathematical decision will approximate reality to the point that it captures most of the production.

- The tax subsidy to ethanol of $\$ 0.54$ per gallon of ethanol (5.4 cents per gallon subsidy to gasohol at a 10-percent volumetric blending portion) is applied within the PMM.

- Interregional transportation costs are not calculated within the Biofuels Supply submodule.

\section{Legislation}

The RFM includes the investment tax and energy production credits called for in the Energy Policy Act of 1992 (EPACT) for the appropriate energy types. EPACT provides a renewable electricity production credit of 1.5 cents per kilowatthour for electricity produced by wind, applied to plants that become operational between January 1, 1994, and June 30,1999. The credit extends for 10 years after the date of initial operation. EPACT also includes provisions that allow an investment tax credit of 10 percent for solar and geothermal technologies that generate electric power. This credit is represented as a 10-percent reduction in the capital costs in the RFM.

\section{Mandated Capacity Additions}

In addition to reported generating capacity plans and capacity projected through use of the RFM, the AEO95 also includes EIA estimates of mandated new capacity (net summer capability) powered by renewable resources, as follows:

- Wind:

- Geothermal:

- Wood

Total:
1,313 megawatts
159 megawatts
119 megawatts

1,591 megawatts

Mandated capacity additions reflect responses to state laws, public utility commission orders, and the Climate Change Action Plan (see below).

\footnotetext{
${ }^{107}$ About 95 percent of the U.S. proảuction of fuel ethanol is derived from corn. Source: U.S. Department of Energy, Energy Information Administration, Estimates of U.S. Biomass Energy Consumption 1992 (Washington, DC, May 1994) p.25
} 


\section{Climate Change Action Plan}

Action Item 26, "Form Renewable Energy Market Mobilization Collaborative with Technology Demonstration," of the Climate Change Action Plan (CCAP), ${ }^{108}$ is designed to spur field validation of selected renewable energy technologies by supporting specified electric utility tests. The demonstrations, along with information dissemination, intend to address market barriers by increasing utility and investor confidence in the technologies. Technologies included in Action Item 26 include assistance to "ice breaker" geothermal plants, site testing advanced wind turbines, and assistance and collaboration in launching test biomass-fueled and photovoltaic electricity generating technologies.

The electricity generating capacity effects on AEO95 of Action Item 26 are incorporated in EIA's projections for renewable technologies in two ways. First, the mandated capacity additions (above) include additions that will be cost-shared by DOE and industry; second, for wind-powered technologies, CCAP results in capital cost declines that are more rapid than for other technologies. While the stated goal of this action item is "increased utility and investor experience and confidence" in renewable technologies in general, no additional cost declines beyond those discussed above are assumed.

\footnotetext{
${ }^{108}$ U.S. Department of Energy, The Climate Change Action Plan: Technical Supplement, DOE/PO-0011 (Washington, DC, March
} 1994) p. 57. 

Part II

\section{Detailed Tables}


Table 1. Energy Consumption by End-Use Sector and Source New England Census Division

(Quadrillion Btu per Year)

\begin{tabular}{|c|c|c|c|c|c|}
\hline \multirow{2}{*}{ Sector and Source } & \multicolumn{4}{|c|}{ Reference Case } & \multirow{2}{*}{$\begin{array}{l}\text { Annual } \\
\text { Growth } \\
\text { 1993-2010 } \\
\text { (percent) }\end{array}$} \\
\hline & 1993 & 2000 & 2005 & 2010 & \\
\hline \multicolumn{6}{|l|}{ Residential } \\
\hline Distillate Fuel $\ldots \ldots \ldots \ldots \ldots \ldots \ldots \ldots$ & 0.276 & 0.256 & 0.249 & 0.249 & $-0.6 \%$ \\
\hline Kerosene $\ldots \ldots \ldots \ldots \ldots \ldots \ldots \ldots \ldots$ & 0.008 & 0.007 & 0.006 & 0.005 & $-2.8 \%$ \\
\hline Liquefied Petroleum Gas . . . . . . . . . . . . & 0.023 & 0.021 & 0.020 & 0.019 & $-1.0 \%$ \\
\hline Natural Gas $\ldots \ldots \ldots \ldots \ldots \ldots \ldots \ldots$ & 0.210 & 0.219 & 0.224 & 0.233 & $0.6 \%$ \\
\hline Coal $\ldots \ldots \ldots \ldots \ldots \ldots \ldots \ldots \ldots$ & 0.001 & 0.002 & 0.002 & 0.002 & $2.6 \%$ \\
\hline Renewable Energy ${ }^{t} \ldots \ldots \ldots \ldots \ldots \ldots$ & 0.042 & 0.042 & 0.043 & 0.044 & $0.2 \%$ \\
\hline Electricity $\ldots \ldots \ldots \ldots \ldots \ldots \ldots \ldots \ldots$ & 0.136 & 0.145 & 0.153 & 0.162 & $1.0 \%$ \\
\hline Total $\ldots \ldots \ldots \ldots \ldots \ldots \ldots \ldots \ldots$ & 0.697 & 0.692 & 0.697 & 0.713 & $0.1 \%$ \\
\hline \multicolumn{6}{|l|}{ Commercial } \\
\hline Distillate Fuel $\ldots \ldots \ldots \ldots \ldots \ldots \ldots \ldots$ & 0.073 & 0.063 & 0.056 & 0.049 & $-2.2 \%$ \\
\hline Kerosene $\ldots \ldots \ldots \ldots \ldots \ldots \ldots \ldots \ldots$ & 0.001 & 0.001 & 0.001 & 0.001 & $-0.1 \%$ \\
\hline Motor Gasoline ${ }^{2} \ldots \ldots \ldots \ldots \ldots \ldots$ & 0.009 & 0.014 & 0.020 & 0.030 & $7.3 \%$ \\
\hline Residual Fuel $\ldots \ldots \ldots \ldots \ldots \ldots \ldots \ldots \ldots$ & 0.038 & 0.037 & 0.037 & 0.037 & $-0.1 \%$ \\
\hline Natural Gas $\ldots \ldots \ldots \ldots \ldots \ldots \ldots \ldots \ldots$ & 0.118 & 0.113 & 0.115 & 0.117 & $-0.1 \%$ \\
\hline Other $^{3} \ldots \ldots \ldots \ldots \ldots \ldots \ldots \ldots \ldots$ & 0.004 & 0.005 & 0.005 & 0.005 & $2.5 \%$ \\
\hline Renewable Energy ${ }^{4} \ldots \ldots \ldots \ldots \ldots \ldots \ldots$ & 0.000 & 0.000 & 0.000 & 0.000 & $5.5 \%$ \\
\hline Electricity $\ldots \ldots \ldots \ldots \ldots \ldots \ldots \ldots \ldots$ & 0.138 & 0.141 & 0.140 & 0.138 & $0.0 \%$ \\
\hline Total $\ldots \ldots \ldots \ldots \ldots \ldots \ldots \ldots \ldots$ & 0.381 & 0.375 & 0.375 & 0.378 & $-0.1 \%$ \\
\hline \multicolumn{6}{|l|}{ Industrial ${ }^{5}$} \\
\hline Distillate Fuel $\ldots \ldots \ldots \ldots \ldots \ldots \ldots \ldots$ & 0.028 & 0.032 & 0.036 & 0.037 & $1.8 \%$ \\
\hline Liquefied Petroleum Gas . . . . . . . . . . . . & 0.006 & 0.007 & 0.007 & 0.007 & $1.1 \%$ \\
\hline Motor Gasoline $^{2} \ldots \ldots \ldots \ldots \ldots \ldots \ldots$ & 0.004 & 0.006 & 0.006 & 0.007 & $2.5 \%$ \\
\hline Petrochemical Feedstocks $\ldots \ldots \ldots \ldots \ldots \ldots$ & 0.014 & 0.014 & 0.014 & 0.014 & $0.2 \%$ \\
\hline Residual Fuel $\ldots \ldots \ldots \ldots \ldots \ldots \ldots \ldots \ldots$ & 0.068 & 0.080 & 0.086 & 0.091 & $1.7 \%$ \\
\hline Other Petroleum ${ }^{6} \ldots \ldots \ldots \ldots \ldots \ldots \ldots$ & 0.060 & 0.069 & 0.074 & 0.076 & $1.4 \%$ \\
\hline Natural Gas ${ }^{7} \ldots \ldots \ldots \ldots \ldots \ldots \ldots$ & 0.126 & 0.142 & 0.154 & 0.166 & $1.6 \%$ \\
\hline Metallurgical Coal $\ldots \ldots \ldots \ldots \ldots \ldots \ldots$ & 0.000 & 0.000 & 0.000 & 0.000 & $N / A$ \\
\hline Steam Coal $\ldots \ldots \ldots \ldots \ldots \ldots \ldots \ldots \ldots \ldots$ & 0.016 & 0.028 & 0.029 & 0.030 & $3.8 \%$ \\
\hline Net Coal Coke Imports $\ldots \ldots \ldots \ldots \ldots \ldots \ldots$ & 0.000 & 0.000 & 0.000 & 0.000 & N/A \\
\hline Renewable Energy $\ldots \ldots \ldots \ldots \ldots \ldots \ldots$ & 0.145 & 0.161 & 0.175 & 0.185 & $1.4 \%$ \\
\hline Electricity $\ldots \ldots \ldots \ldots \ldots \ldots \ldots \ldots \ldots$ & 0.091 & 0.099 & 0.107 & 0.110 & $1.1 \%$ \\
\hline Total $\ldots \ldots \ldots \ldots \ldots \ldots \ldots \ldots \ldots \ldots$ & 0.559 & 0.637 & 0.688 & 0.723 & $1.5 \%$ \\
\hline \multicolumn{6}{|l|}{ Transportation } \\
\hline Distillate Fuel $\ldots \ldots \ldots \ldots \ldots \ldots \ldots \ldots$ & 0.114 & 0.133 & 0.145 & 0.153 & $1.8 \%$ \\
\hline Jet Fuel ${ }^{8} \ldots \ldots \ldots \ldots \ldots \ldots \ldots \ldots$ & 0.075 & 0.090 & 0.100 & 0.106 & $2.1 \%$ \\
\hline Motor Gasoline $^{2} \ldots \ldots \ldots \ldots \ldots \ldots \ldots$ & 0.677 & 0.739 & 0.770 & 0.763 & $0.7 \%$ \\
\hline Residual Fuel $\ldots \ldots \ldots \ldots \ldots \ldots \ldots \ldots$ & 0.005 & 0.006 & 0.007 & 0.007 & $1.9 \%$ \\
\hline Liquefied Petroleum Gas . . . . . . . . . . . . . . & 0.001 & 0.004 & 0.009 & 0.013 & $20.9 \%$ \\
\hline Other Petroleum ${ }^{9} \ldots \ldots \ldots \ldots \ldots \ldots \ldots$ & 0.007 & 0.008 & 0.008 & 0.008 & $1.2 \%$ \\
\hline Pipeline Fuel Natural Gas $\ldots \ldots \ldots \ldots \ldots \ldots$ & 0.003 & 0.002 & 0.002 & 0.003 & $-1.0 \%$ \\
\hline Compressed Natural Gas . . . . . . . . . . . . . . & 0.000 & 0.009 & 0.017 & 0.024 & $26.5 \%$ \\
\hline Renewables (ethanol) ${ }^{10} \ldots \ldots \ldots \ldots \ldots$ & 0.000 & 0.001 & 0.002 & 0.004 & $35.4 \%$ \\
\hline Liquid Hydrogen $\ldots \ldots \ldots \ldots \ldots \ldots \ldots$ & 0.000 & 0.000 & 0.000 & 0.000 & N/A \\
\hline Meihanol $^{11} \ldots \ldots \ldots \ldots \ldots \ldots \ldots \ldots$ & 0.000 & 0.001 & 0.002 & 0.003 & $31.0 \%$ \\
\hline Electricity $\ldots \ldots \ldots \ldots \ldots \ldots \ldots \ldots \ldots$ & 0.003 & 0.005 & 0.007 & 0.010 & $6.8 \%$ \\
\hline Total $\ldots \ldots \ldots \ldots \ldots \ldots \ldots \ldots \ldots$ & 0.884 & 0.997 & 1.069 & 1.093 & $1.3 \%$ \\
\hline \multicolumn{6}{|l|}{ Electric Generators ${ }^{12}$} \\
\hline Distillate Fuel $\ldots \ldots \ldots \ldots \ldots \ldots \ldots \ldots$ & 0.000 & 0.000 & 0.000 & 0.000 & $\mathbf{N} / \mathbf{A}$ \\
\hline Residual Fuel $\ldots \ldots \ldots \ldots \ldots \ldots \ldots \ldots \ldots$ & 0.186 & 0.175 & 0.277 & 0.245 & $1.6 \%$ \\
\hline Natural Gas $\ldots \ldots \ldots \ldots \ldots \ldots \ldots \ldots$ & 0.082 & 0.098 & 0.108 & 0.155 & $3.8 \%$ \\
\hline Steam Coal $\ldots \ldots \ldots \ldots \ldots \ldots \ldots \ldots \ldots$ & 0.150 & 0.159 & 0.152 & 0.160 & $0.4 \%$ \\
\hline Nuclear Power $\ldots \ldots \ldots \ldots \ldots \ldots \ldots \ldots$ & 0.418 & 0.436 & 0.436 & 0.327 & $-1.4 \%$ \\
\hline Renewable Energy/Other ${ }^{13} \ldots \ldots \ldots \ldots \ldots \ldots$ & 0.186 & 0.262 & 0.201 & 0.257 & $1.9 \%$ \\
\hline Total $\ldots \ldots \ldots \ldots \ldots \ldots \ldots \ldots$ & 1.023 & 1.130 & 1.173 & 1.143 & $0.7 \%$ \\
\hline
\end{tabular}


Table 1. Energy Consumption by End-Use Sector and Source New England Census Division (Continued) (Quadrillion Btu per Year)

\begin{tabular}{|c|c|c|c|c|c|}
\hline \multirow{2}{*}{ Sector and Source } & \multicolumn{4}{|c|}{ Reference Case } & \multirow{2}{*}{$\begin{array}{c}\text { Annual } \\
\text { Growth } \\
1993-2010 \\
\text { (percent) }\end{array}$} \\
\hline & 1993 & 2000 & 2005 & 2010 & \\
\hline \multicolumn{6}{|l|}{ Primary Energy Consumption } \\
\hline Distillate Fuel $\ldots \ldots \ldots \ldots$ & 0.490 & 0.483 & 0.486 & 0.488 & $0.0 \%$ \\
\hline Kerosene $\ldots \ldots \ldots \ldots \ldots \ldots \ldots \ldots$ & 0.010 & 0.009 & 0.008 & 0.007 & $-2.2 \%$ \\
\hline Jet Fuel ${ }^{8} \ldots \ldots \ldots \ldots \ldots \ldots \ldots \ldots \ldots$ & 0.075 & 0.090 & 0.100 & 0.106 & $2.1 \%$ \\
\hline Liquefied Petroleum Gas $\ldots \ldots \ldots \ldots \ldots \ldots$. . & 0.033 & 0.036 & 0.039 & 0.043 & $1.6 \%$ \\
\hline Motor Gasoline ${ }^{2} \ldots \ldots \ldots \ldots \ldots \ldots \ldots$ & 0.690 & 0.758 & 0.797 & 0.799 & $0.9 \%$ \\
\hline Petrochemical Feedstocks .... & 0.014 & 0.014 & 0.014 & 0.014 & $0.2 \%$ \\
\hline Residual Fuel $\ldots \ldots \ldots$. & 0.298 & 0.298 & 0.407 & 0.381 & $1.4 \%$ \\
\hline Other Petroleum ${ }^{14}$ & 0.066 & 0.075 & 0.081 & 0.084 & $1.4 \%$ \\
\hline Natural Gas .... & 0.540 & 0.583 & 0.620 & 0.697 & $1.5 \%$ \\
\hline Metallurgical Coal & 0.000 & 0.000 & 0.000 & 0.000 & NA \\
\hline Steam Coal $\ldots \ldots \ldots \ldots \ldots \ldots \ldots \ldots$ & 0.169 & 0.190 & 0.184 & 0.193 & $0.8 \%$ \\
\hline Net Coal Coke Imports $\ldots \ldots \ldots \ldots \ldots \ldots$ & 0.000 & 0.000 & 0.000 & 0.000 & N/A \\
\hline Nuclear Power...$\ldots \ldots$. & 0.418 & 0.436 & 0.436 & 0.327 & $-1.4 \%$ \\
\hline Renewable Energy/Other ${ }^{15} \ldots \ldots \ldots \ldots \ldots \ldots$ & 0.373 & 0.467 & 0.423 & 0.492 & $1.6 \%$ \\
\hline Total $\ldots \ldots \ldots \ldots \ldots \ldots \ldots \ldots \ldots \ldots \ldots \ldots$ & 3.176 & 3.440 & 3.595 & 3.631 & $0.8 \%$ \\
\hline Electricity Consumption (all sectors) $\ldots \ldots \ldots$. & 0.368 & 0.390 & 0.406 & 0.420 & $0.8 \%$ \\
\hline
\end{tabular}

'Includes electricity generated by the sector for self-use from hydroelectric, geothermal, wood and wood waste, municipal solid waste, other biomass, wind, photovoltaic and solar thermal sources, and non-electric energy from renewable sources, such as solar thermal water heaters, ground-water heat pumps, and wood.

${ }^{2}$ Includes ethanol (blends of 10 percent or less) and ethers blended into gasoline.

Includes liquefied petroleum gas and coal.

"Includes commercial sector electricity cogenerated using wood and wood waste, municipal solid waste, and other biomass; non-electric energy from renewable sources, such as active solar and passive solar systems, geothermal heat pumps, and solar water heating systems.

${ }^{5}$ Fuel consumption includes consumption for cogeneration.

Includes petroleum coke, asphalt, road oil, lubricants, still gas, and miscellaneous petroleum products.

IIncludes lease and plant fuel.

Includes naphtha and kerosene type.

Includes aviation gas and lubricants.

${ }^{10}$ Only E85 (85 percent ethanol).

${ }^{11}$ Only M85 (85 percent methanol).

${ }^{12}$ Includes consumption of energy by all electric power generators except cogenerators, and generators with standard industrial classification other than 49 , both of which produce electricity as a by-product of other processes.

${ }^{13}$ Includes hydroelectric, geothermal, wood and wood waste, municipal solid waste, other biomass, wind, photovoltaic and solar thermal sources, plus net electricity imports.

${ }^{14}$ Includes unfinished oils, natural gasoline, motor gasoline blending compounds, aviation gasoline, lubricants, still gas, asphalt, road oil, and miscellaneous petroleum products.

${ }^{15}$ Includes electricity generated for sale to electric utilities and for self use from renewable sources, non-electric energy from renewable sources, net electricity imports, liquid hydrogen, and methanol.

Btu $=$ British thermal unit.

N/A = Not applicable.

Note: Totals may not equal sum of components due to independent rounding. Figures for 1993 may differ from published data due to internal conversion factors in the AEO95 National Energy Modeling System.

Sources: 1993 natural gas lease, plant, and pipeline fuel values: Energy Information Administration (EIA), Natural Gas Monthly, DOE/EIA0130(94/6) (Washington, D.C., June 1994). 1993 transportation sector compressed natural gas consumption: ElA, AEO95 National Energy Modeling System run AEO95B.D1103942. 1993 coal consumption is estimated from EIA, State Energy Data Report 1992, DOE/EIA-0214(92) (Washington, D.C., May 1994). 1993 metallurgical consumption is estimated from this source using unpublished data. 1993 residential and commercial coal consumption tonnages are from EIA, Quarterly Coal Report, October-December 1993, DOE/EIA-0121(93/4Q) (Washington, D.C., May 1994) and have been converted to quadrillion Btu using State Energy Data Report 1992 thermal conversion factors. Other 1993 values: ElA, Short-Term Energy Outlook, DOE/EIA-0202(94/3Q) (Washington, D.C., August 1994) with adjustments to end-use consumption levels for consumption of natural gas by electric wholesale generators based on EIA, AEO95 National Energy Modeling System run AEO95B.D1103942. Projections: EIA, AEO95 National Energy Modeling System run AEO95B.D1103942. 
Table 2. Energy Consumption by End-Use Sector and Source Middle Atlantic Census Division (Quadrillion Btu per Year)

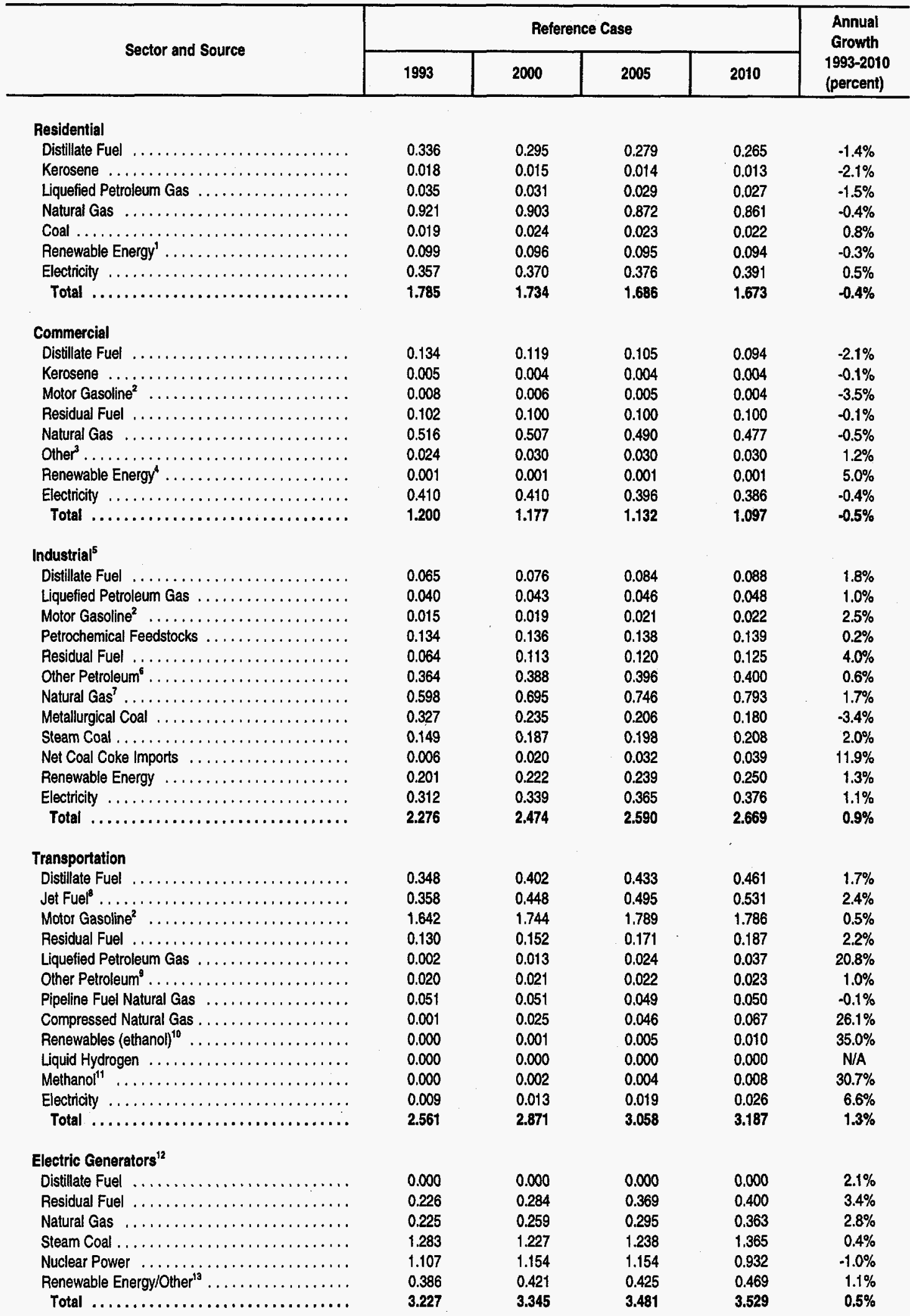




\section{Table 2. Energy Consumption by End-Use Sector and Source Middle Atlantic Census Division (Continued) (Quadrillion Btu per Year)}

\begin{tabular}{|c|c|c|c|c|c|}
\hline \multirow{2}{*}{ Sector and Source } & \multicolumn{4}{|c|}{ Reference Case } & \multirow{2}{*}{$\begin{array}{l}\text { Annual } \\
\text { Growth } \\
\text { 1993-2010 } \\
\text { (percent) }\end{array}$} \\
\hline & 1993 & 2000 & 2005 & 2010 & \\
\hline \multicolumn{6}{|l|}{ Primary Energy Consumption } \\
\hline Kerosene $\ldots \ldots \ldots \ldots \ldots \ldots \ldots \ldots$ & 0.025 & 0.022 & 0.021 & 0.020 & $-1.4 \%$ \\
\hline Jet Fuel ${ }^{8} \ldots \ldots \ldots \ldots \ldots \ldots \ldots \ldots$ & 0.358 & 0.448 & 0.495 & 0.531 & $2.4 \%$ \\
\hline Liquefied Petroleum Gas . . . . . . . . . . . . . . & 0.082 & 0.092 & 0.104 & 0.117 & $2.1 \%$ \\
\hline Molor Gasoline ${ }^{2} \ldots \ldots \ldots \ldots \ldots \ldots$ & 1.665 & 1.770 & 1.815 & 1.812 & $0.5 \%$ \\
\hline Petrochemical Feedstocks $\ldots \ldots \ldots \ldots \ldots \ldots$. & 0.134 & 0.136 & 0.138 & 0.139 & $0.2 \%$ \\
\hline Residual Fuel $\ldots \ldots \ldots \ldots \ldots \ldots \ldots \ldots$ & 0.522 & 0.649 & 0.760 & 0.812 & $2.6 \%$ \\
\hline Steam Coal $\ldots \ldots \ldots \ldots \ldots \ldots \ldots \ldots \ldots$ & 1.469 & 1.462 & 1.483 & 1.619 & $0.6 \%$ \\
\hline Net Coal Coke Imports $\ldots \ldots \ldots \ldots \ldots \ldots$ & 0.006 & 0.020 & 0.032 & 0.039 & $11.9 \%$ \\
\hline Nuclear Power $\ldots \ldots \ldots \ldots \ldots \ldots \ldots \ldots$ & 1.107 & 1.154 & 1.154 & 0.932 & $-1.0 \%$ \\
\hline Renewable Energy/Other ${ }^{15} \ldots \ldots \ldots \ldots \ldots$ & 0.687 & 0.744 & 0.770 & 0.831 & $1.1 \%$ \\
\hline Total $\ldots \ldots \ldots \ldots \ldots \ldots \ldots \ldots$ & 9.961 & 10.470 & 10.792 & 10.974 & $0.6 \%$ \\
\hline Electricity Consumption (all sectors) $\ldots \ldots \ldots$ & 1.088 & 1.131 & 1.155 & 1.180 & $0.5 \%$ \\
\hline
\end{tabular}

'Includes electricity generated by the sector for self-use from hydroelectric, geothermal, wood and wood waste, municipal solid waste, other biomass, wind, photovoltaic and solar thermal sources, and non-electric energy from renewable sources, such as solar thermal water heaters, ground-water heat pumps, and wood.

${ }^{2}$ Includes ethanol (blends of 10 percent or less) and ethers blended into gasoline.

Includes liquefied petroleum gas and coal.

"Includes commercial sector electricity cogenerated using wood and wood waste, municipal solid waste, and other biomass; non-electric energy from renewable sources, such as active solar and passive solar systems, geothermal heat pumps, and solar water heating systems.

${ }^{5}$ Fuel consumption includes consumption for cogeneration.

Includes petroleum coke, asphalt, road oil, lubricants, still gas, and miscellaneous petroleum products.

'Includes lease and plant fuel.

Includes naphtha and kerosene type.

Includes aviation gas and lubricants.

"Only E85 (85 percent ethanol).

"Only M85 (85 percent methanol).

${ }^{12}$ includes consumption of energy by all electric power generators except cogenerators, and generators with standard industrial classification other than 49 , both of which produce electricity as a by-product of other processes.

${ }^{13}$ Includes hydroelectric, geothermal, wood and wood waste, municipal solid waste, other biomass, wind, photovoltaic and solar thermal sources, plus net electricity imports.

"Includes unfinished oils, natural gasoline, motor gasoline blending compounds, aviation gasoline, lubricants, still gas, asphalt, road oil, and miscellaneous petroleum products.

${ }^{15}$ Includes electricity generated for sale to electric utilities and for self use from renewable sources, non-electric energy from renewable sources, net electriclity imports, liquid hydrogen, and methanol.

Btu $=$ British thermal unit.

N/A $=$ Not applicable.

Note: Tolals may not equal sum of components due to independent rounding. Figures for 1993 may differ from published data due to internal conversion factors in the AEO95 National Energy Modeling System.

Sources: 1993 natural gas lease, plant, and pipeline fuel values: Energy Information Administration (EIA), Natural Gas Monthly, DOE/EIA0130(94/6) (Washington, D.C., June 1994). 1993 transportation sector compressed natural gas consumption: ElA, AEO95 National Energy Modeling System run AEO95B.D1103942. 1993 coal consumption is estimated from ElA, State Energy Data Report 1992, DOE/EIA-0214(92) (Washington, D.C., May 1994). 1993 metallurgical consumption is estimated from this source using unpublished data. 1993 residential and commercial coal consumption tonnages are from ElA, Quarterly Coal Report, October-December 1993, DOE/EIA-0121(93/4Q) (Washington, D.C., May 1994) and have been converted to quadrillion Btu using State Energy Data Report 1992 thermal conversion factors. Other 1993 values: ElA, Short-Term Energy Outlook, DOEJEIA-0202(94/3Q) (Washington, D.C., August 1994) with adjustments to end-use consumption levels for consumption of natural gas by electric wholesale generators based on EIA, AEO95 National Energy Modeling System run AEO95B.D1103942. Projections: EIA, AEO95 National Energy Modeling System run AEO95B.D1103942. 
Table 3. Energy Consumption by End-Use Sector and Source East North Central Census Division (Quadrillion Btu per Year)

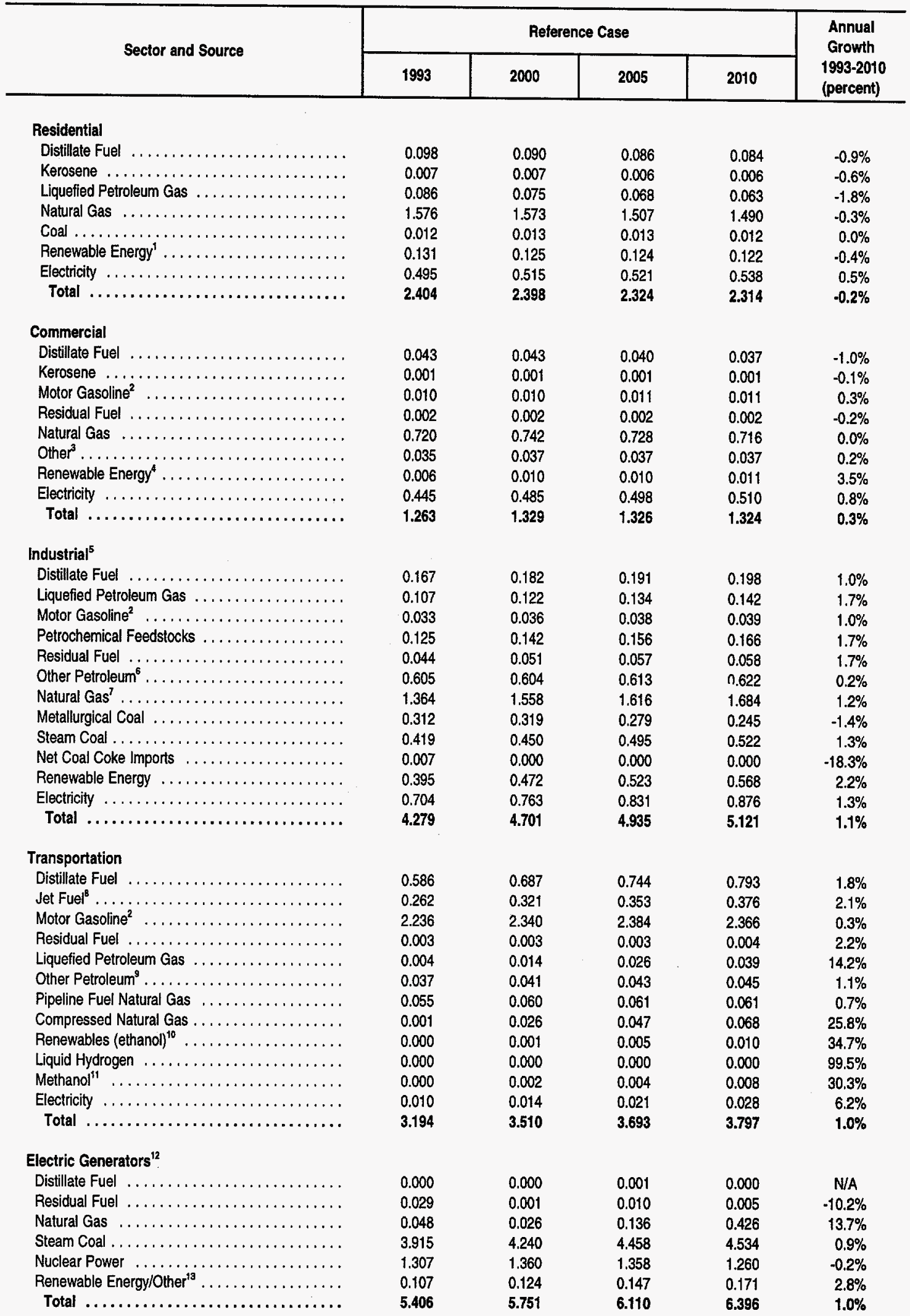


Table 3. Energy Consumption by End-Use Sector and Source

East North Central Census Division (Continued)

(Quadrillion Btu per Year)

\begin{tabular}{|c|c|c|c|c|c|}
\hline \multirow{2}{*}{ Sector and Source } & \multicolumn{4}{|c|}{ Reference Case } & \multirow{2}{*}{$\begin{array}{c}\text { Annual } \\
\text { Growth } \\
\text { 1993-2010 } \\
\text { (percent) }\end{array}$} \\
\hline & 1993 & 2000 & 2005 & 2010 & \\
\hline \multicolumn{6}{|l|}{ Primary Energy Consumption } \\
\hline Distillate Fuel ............ & 0.894 & 1.001 & 1.062 & 1.111 & $1.3 \%$ \\
\hline Kerosene $\ldots \ldots \ldots \ldots \ldots \ldots \ldots \ldots \ldots$ & 0.009 & 0.009 & 0.009 & 0.009 & $-0.4 \%$ \\
\hline Jet Fuel ${ }^{8} \ldots \ldots \ldots \ldots$ & 0.262 & 0.321 & 0.353 & 0.376 & $2.1 \%$ \\
\hline Liquefied Petroleum Gas & 0.210 & 0.224 & 0.241 & 0.256 & $1.2 \%$ \\
\hline Motor Gasoline ${ }^{2} \ldots \ldots \ldots \ldots \ldots \ldots \ldots$ & 2.279 & 2.387 & 2.433 & 2.416 & $0.3 \%$ \\
\hline Petrochemical Feedstocks ................ & 0.125 & 0.142 & 0.156 & 0.166 & $1.7 \%$ \\
\hline Residual Fuel $\ldots \ldots \ldots \ldots \ldots \ldots \ldots$ & 0.077 & 0.057 & 0.072 & 0.069 & $-0.7 \%$ \\
\hline Other Petroleum ${ }^{14}$ & 0.640 & 0.644 & 0.655 & 0.665 & $0.2 \%$ \\
\hline Natural Gas .... & 3.764 & 3.986 & 4.096 & 4.445 & $1.0 \%$ \\
\hline Metallurgical Coal & 0.312 & 0.319 & 0.279 & 0.245 & $-1.4 \%$ \\
\hline Steam Coal $\ldots \ldots \ldots \ldots \ldots \ldots \ldots \ldots \ldots$ & 4.368 & 4.727 & 4.990 & 5.091 & $0.9 \%$ \\
\hline Net Coal Coke Imports $\ldots \ldots \ldots \ldots \ldots \ldots$ & 0.007 & 0.000 & 0.000 & 0.000 & $-18.3 \%$ \\
\hline Nuclear Power $\ldots \ldots \ldots \ldots \ldots \ldots \ldots \ldots$ & 1.307 & 1.360 & 1.358 & 1.260 & $-0.2 \%$ \\
\hline Renewable Energy/Other ${ }^{15} \ldots \ldots \ldots \ldots \ldots$ & 0.639 & 0.734 & 0.814 & 0.890 & $2.0 \%$ \\
\hline 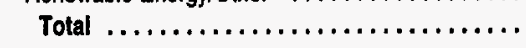 & 14.894 & 15.911 & 16.517 & 17.000 & $0.8 \%$ \\
\hline Electricity Consumption (all sectors) $\ldots \ldots \ldots$. & 1.653 & 1.777 & 1.870 & 1.952 & $1.0 \%$ \\
\hline
\end{tabular}

'Includes electricity generated by the sector for self-use from hydroelectric, geothermal, wood and wood waste, municipal solid waste, other biomass, wind, photovoltaic and solar thermal sources, and non-electric energy from renewable sources, such as solar thermal water heaters, ground-water heat pumps, and wood.

${ }^{2}$ Includes ethanol (blends of 10 percent or less) and ethers blended into gasoline.

includes liquefied petroleum gas and coal.

Includes commercial sector electricity cogenerated using wood and wood waste, municipal solid waste, and other biomass; non-electric energy from renewable sources, such as active solar and passive solar systems, geothermal heat pumps, and solar water heating systems.

F Fuel consumption includes consumption for cogeneration.

"Includes petroleum coke, asphalt, road oil, lubricants, still gas, and miscellaneous petroleum products.

'Includes lease and plant fuel.

Includes naphtha and kerosene type.

Includes aviation gas and lubricants.

${ }^{10}$ Only E85 (85 percent ethanol).

"Only M85 (85 percent methanol).

${ }^{12}$ Includes consumption of energy by all electric power generators except cogenerators, and generators with standard industrial classification other than 49 , both of which produce electricity as a by-product of other processes.

${ }^{13}$ Includes hydroelectric, geothermal, wood and wood waste, municipal solid waste, other biomass, wind, photovoltaic and solar thermal sources, plus net electricity imports.

${ }^{14}$ Includes unfinished oils, natural gasoline, motor gasoline blending compounds, aviation gasoline, lubricants, still gas, asphalt, road oil, and miscellaneous petroleum products.

${ }^{15}$ Includes electricity generated for sale to electric utilities and for self use from renewable sources, non-electric energy from renewable sources, net electricity imports, liquid hydrogen, and methanol.

Btu = British thermal unit.

N/A = Not applicable.

Note: Totals may not equal sum of components due to independent rounding. Figures for 1993 may differ from published data due to internal conversion factors in the AEO95 National Energy Modeling System.

Sources: 1993 natural gas lease, plant, and pipeline fuel values: Energy Information Administration (EIA), Natural Gas Monthly, DOE/EIA0130(94/6) (Washington, D.C., June 1994). 1993 transportation sector compressed natural gas consumption: EIA, AEO95 National Energy Modeling System run AEO95B.D1 103942. 1993 coal consumption is estimated from EIA, State Energy Data Report 1992, DOE/EIA-0214(92) (Washington, D.C. May 1994). 1993 metallurgical consumption is estimated from this source using unpublished data. 1993 residential and commercial coal consumption tonnages are from EIA, Quarterly Coal Report, October-December 1993, DOE/EIA-0121(93/4Q) (Washington, D.C., May 1994) and have been converted to quadrillion Btu using State Energy Data Report 1992 thermal conversion factors. Other 1993 values: ElA, Short-Term Energy Outlook, DOE/EIA-0202(94/3Q) (Washington, D.C., August 1994) with adjustments to end-use consumption levels for consumption of natural gas by electric wholesale generators based on EIA, AEO95 National Energy Modeling System run AEO95B.D1103942. Projections: EIA, AEO95 National Energy Modeling System run AEO95B.D1103942. 
Table 4. Energy Consumption by End-Use Sector and Source West North Central Census Division (Quadrillion Btu per Year)

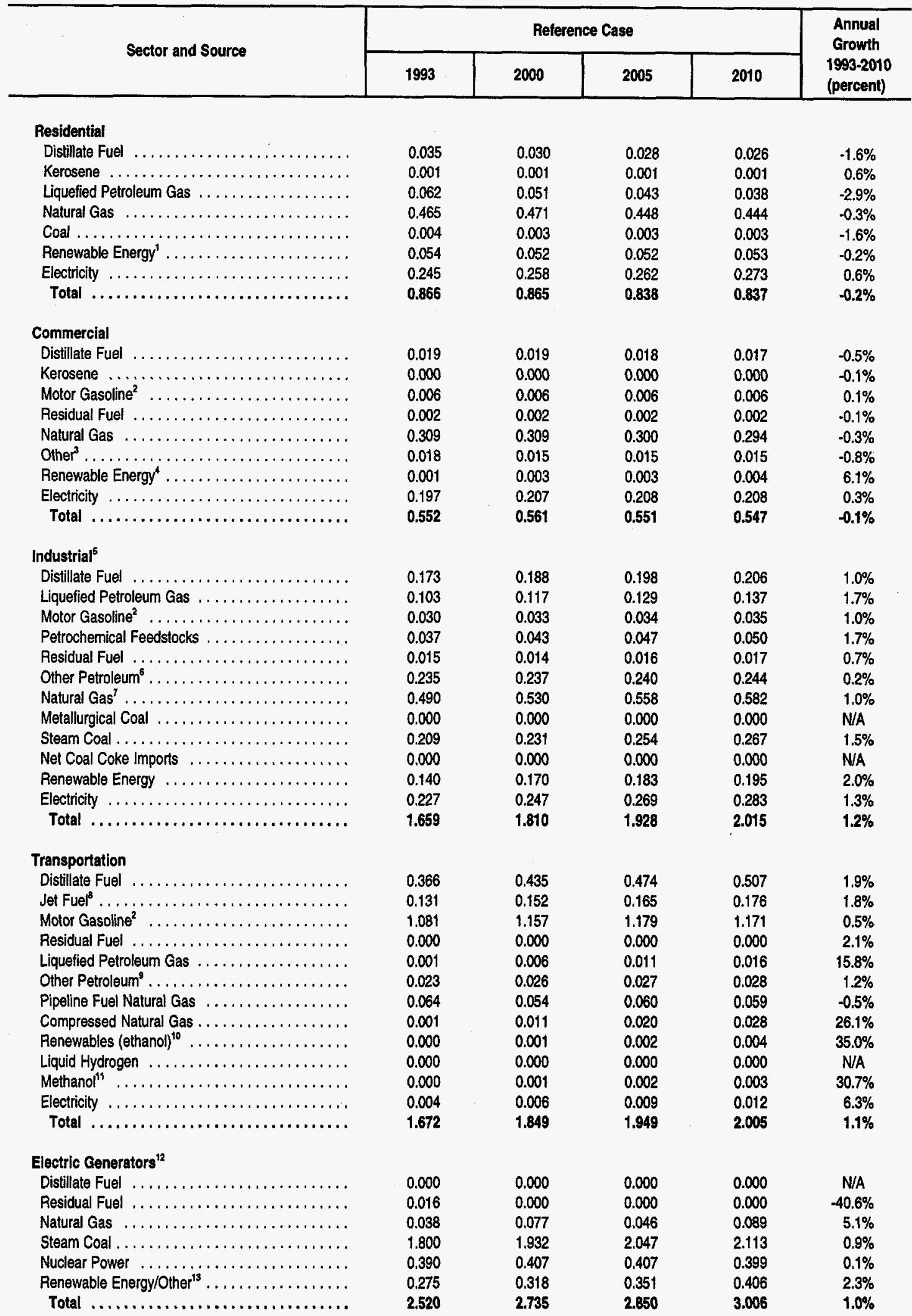


Table 4. Energy Consumption by End-Use Sector and Source West North Central Census Division (Continued) (Quadrillion Btu per Year)

\begin{tabular}{|c|c|c|c|c|c|}
\hline \multirow{2}{*}{ Sector and Source } & \multicolumn{4}{|c|}{ Reterence Case } & \multirow{2}{*}{$\begin{array}{c}\text { Annual } \\
\text { Growth } \\
\text { 1993-2010 } \\
\text { (percent) }\end{array}$} \\
\hline & 1993 & 2000 & 2005 & 2010 & \\
\hline \multicolumn{6}{|l|}{ Primary Energy Consumption } \\
\hline Distillate Fuel $\ldots \ldots \ldots \ldots$ & 0.593 & 0.672 & 0.717 & 0.757 & $1.4 \%$ \\
\hline Kerosene $\ldots \ldots \ldots \ldots \ldots$ & 0.001 & 0.001 & 0.001 & 0.001 & $0.4 \%$ \\
\hline Jet Fuel ${ }^{\natural} \ldots \ldots \ldots \ldots$ & 0.131 & 0.152 & 0.165 & 0.176 & $1.8 \%$ \\
\hline Liquefied Petroleum Gas ... & 0.176 & 0.184 & 0.192 & 0.200 & $0.8 \%$ \\
\hline Motor Gasoline ${ }^{2} \ldots \ldots$ & 1.116 & 1.195 & 1.219 & 1.212 & $0.5 \%$ \\
\hline Petrochemical Feedstocks & 0.037 & 0.043 & 0.047 & 0.050 & $1.7 \%$ \\
\hline Residual Fuel ......... & 0.033 & 0.017 & 0.018 & 0.019 & $-3.3 \%$ \\
\hline Other Petroleum ${ }^{14}$ & 0.259 & 0.263 & 0.267 & 0.272 & $0.3 \%$ \\
\hline Natural Gas .... & 1.368 & 1.451 & 1.431 & 1.496 & $0.5 \%$ \\
\hline Metallurgical Coal ...... & 0.000 & 0.000 & 0.000 & 0.000 & N/A \\
\hline Steam Coal .......... & 2.021 & 2.173 & 2.310 & 2.389 & $1.0 \%$ \\
\hline Net Coal Coke Imporis & 0.000 & 0.000 & 0.000 & 0.000 & N/A \\
\hline Nuclear Power ........ & 0.390 & 0.407 & 0.407 & 0.399 & $0.1 \%$ \\
\hline Renewable Energy/Other ${ }^{15} \ldots \ldots \ldots \ldots \ldots \ldots$ & 0.470 & 0.544 & 0.594 & 0.665 & $2.1 \%$ \\
\hline 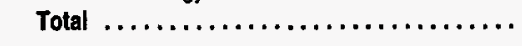 & 6.595 & 7.102 & 7.369 & 7.635 & $0.9 \%$ \\
\hline Electricity Consumption (all sectors) $\ldots \ldots \ldots$. & 0.674 & 0.718 & 0.747 & 0.776 & $0.8 \%$ \\
\hline
\end{tabular}

'Includes electricity generated by the sector for self-use from hydroelectric, geothermal, wood and wood waste, municipal solid waste, other biomass, wind, photovoltaic and solar thermal sources, and non-electric energy from renewable sources, such as solar thermal water heaters, ground-water heat pumps, and wood.

${ }^{2}$ Includes ethanol (blends of 10 percent or less) and ethers blended into gasoline.

Includes liquefied petroleum gas and coal.

${ }^{4}$ Includes commercial sector electricity cogenerated using wood and wood waste, municipal solid waste, and other biomass; non-electric energy from renewable sources, such as active solar and passive solar systems, geothermal heat pumps, and solar water heating systems.

5Fuel consumption includes consumption for cogeneration.

"Includes petroleum coke, asphalt, road oil, lubricants, still gas, and miscellaneous petroleum products.

'Includes lease and plant fuel.

Bncludes naphtha and kerosene type.

Includes aviation gas and lubricants.

${ }^{10}$ Only E85 (85 percent ethanol).

"Only M85 (85 percent methanol).

${ }^{12}$ Includes consumption of energy by all electric power generators except cogenerators, and generators with standard industrial classification other than 49 , both of which produce electricity as a by-product of other processes.

${ }^{23}$ Includes hydroelectric, geothermal, wood and wood waste, municipal solid waste, other biomass, wind, photovoltaic and solar thermal sources, plus net electricity imports.

${ }^{14}$ Includes unfinished oils, natural gasoline, motor gasoline blending compounds, aviation gasoline, lubricants, still gas, asphalt, road ail, and miscellaneous petroleum products.

${ }^{15}$ Includes electricity generated for sale to electric utilities and for self use from renewable sources, non-electric energy from renewable sources, net electricity imports, liquid hydrogen, and methanol.

Btu $=$ British thermal unit.

N/A $=$ Not applicable.

Note: Totals may not equal sum of components due to independent rounding. Figures for 1993 may differ from published data due to internal conversion factors in the AEO95 National Energy Modeling System.

Sources: 1993 natural gas lease, plant, and pipeline fuel values: Energy Intormation Administration (EIA), Natural Gas Monthly, DOE/EIA0130(94/6) (Washington, D.C., June 1994). 1993 transportation sector compressed natural gas consumption: EIA, AEO95 National Energy Modeling System run AEO95B.D1103942. 1993 coal consumption is estimated from ElA, State Energy Data Report 1992, DOE/EIA-0214(92) (Washington, D.C.; May 1994). 1993 metallurgical consumption is estimated from this source using unpublished data. 1993 residential and commercial coal consumption tonnages are from EIA, Quarterly Coal Report, October-December 1993, DOE/EIA-0121(93/4Q) (Washington, D.C., May 1994) and have been converted to quadrillion Btu using State Energy Data Report 1992 thermal conversion factors. Other 1993 values: ElA, Short-Term Energy Outlook, DOE/EIA-0202(94/3Q) (Washington, D.C., August 1994) with adjustments to end-use consumption leveis for consumption of natural gas by electric wholesale generators based on EIA, AEO95 National Energy Modeling System run AEO95B.D1103942. Projections: EIA, AEO95 National Energy Modeling System run AEO95B.D1103942. 
Table 5. Energy Consumption by End-Use Sector and Source South Atlantic Census Division

(Quadrillion Btu per Year)

\begin{tabular}{|c|c|c|c|c|c|}
\hline \multirow{2}{*}{ Sector and Source } & \multicolumn{4}{|c|}{ Reference Case } & \multirow{2}{*}{$\begin{array}{c}\text { Annual } \\
\text { Growth } \\
\text { 1993-2010 } \\
\text { (percent) }\end{array}$} \\
\hline & 1993 & 2000 & 2005 & 2010 & \\
\hline \multicolumn{6}{|l|}{ Residential } \\
\hline Distillate Fuel $\ldots \ldots \ldots \ldots \ldots \ldots \ldots \ldots$ & 0.092 & 0.082 & 0.077 & 0.073 & $-1.4 \%$ \\
\hline Kerosene $\ldots \ldots \ldots \ldots \ldots \ldots \ldots \ldots \ldots$ & 0.027 & 0.026 & 0.025 & 0.025 & $-0.4 \%$ \\
\hline Liquefied Petroleum Gas . . . . . . . . . . . . & 0.079 & 0.069 & 0.063 & 0.058 & $-1.8 \%$ \\
\hline Natural Gas $\ldots \ldots \ldots \ldots \ldots \ldots \ldots \ldots$ & 0.422 & 0.453 & 0.463 & 0.476 & $0.7 \%$ \\
\hline Coal $\ldots \ldots \ldots \ldots \ldots \ldots \ldots \ldots \ldots$ & 0.008 & 0.006 & 0.006 & 0.005 & $-2.2 \%$ \\
\hline Renewable Energy ${ }^{1} \ldots \ldots \ldots \ldots \ldots \ldots \ldots$ & 0.108 & 0.114 & 0.117 & 0.121 & $0.6 \%$ \\
\hline Electricity $\ldots \ldots \ldots \ldots \ldots \ldots \ldots \ldots$ & 0.795 & 0.873 & 0.925 & 0.997 & $1.3 \%$ \\
\hline Total $\ldots \ldots \ldots \ldots \ldots \ldots \ldots \ldots \ldots$ & 1.531 & 1.622 & 1.676 & 1.755 & $0.8 \%$ \\
\hline \multicolumn{6}{|l|}{ Commercial } \\
\hline Distillate Fuel $\ldots \ldots \ldots \ldots \ldots \ldots \ldots \ldots$ & 0.063 & 0.063 & 0.063 & 0.064 & $0.0 \%$ \\
\hline Kerosene $\ldots \ldots \ldots \ldots \ldots \ldots \ldots \ldots \ldots$ & 0.002 & 0.002 & 0.002 & 0.002 & $-0.1 \%$ \\
\hline Motor Gasoline ${ }^{2} \ldots \ldots \ldots \ldots \ldots \ldots \ldots$ & 0.011 & 0.011 & 0.010 & 0.009 & $-1.2 \%$ \\
\hline Residual Fuel $\ldots \ldots \ldots \ldots \ldots \ldots \ldots \ldots$ & 0.017 & 0.017 & 0.017 & 0.017 & $-0.1 \%$ \\
\hline Natural Gas $\ldots \ldots \ldots \ldots \ldots \ldots \ldots$ & 0.311 & 0.334 & 0.355 & 0.379 & $1.2 \%$ \\
\hline Other ${ }^{3} \ldots \ldots \ldots \ldots \ldots \ldots \ldots \ldots \ldots$ & 0.027 & 0.023 & 0.023 & 0.023 & $-1.1 \%$ \\
\hline Renewable Energy ${ }^{4} \ldots \ldots \ldots \ldots \ldots \ldots \ldots$ & 0.000 & 0.001 & 0.001 & 0.001 & $5.4 \%$ \\
\hline Electricity $\ldots \ldots \ldots \ldots \ldots \ldots \ldots \ldots$ & 0.614 & 0.697 & 0.751 & 0.818 & $1.7 \%$ \\
\hline Total $\ldots \ldots \ldots \ldots \ldots \ldots \ldots \ldots \ldots$ & 1.047 & 1.147 & 1.221 & 1.312 & $1.3 \%$ \\
\hline \multicolumn{6}{|l|}{ Industrial $^{5}$} \\
\hline Distillate Fuel $\ldots \ldots \ldots \ldots \ldots \ldots \ldots \ldots$ & 0.102 & 0.112 & 0.120 & 0.127 & $1.3 \%$ \\
\hline Liquefied Petroleum Gas . . . . . . . . . . . . . . & 0.049 & 0.055 & 0.060 & 0.065 & $1.7 \%$ \\
\hline Motor Gasoline $^{2} \ldots \ldots \ldots \ldots \ldots \ldots \ldots$ & 0.026 & 0.029 & 0.031 & 0.033 & $1.3 \%$ \\
\hline Petrochemical Feedstocks $\ldots \ldots \ldots \ldots \ldots \ldots$ & 0.161 & 0.183 & 0.200 & 0.215 & $1.7 \%$ \\
\hline Residual Fuel $\ldots \ldots \ldots \ldots \ldots \ldots \ldots \ldots$ & 0.135 & 0.136 & 0.152 & 0.155 & $0.8 \%$ \\
\hline Other Petroleum ${ }^{6} \ldots \ldots \ldots \ldots \ldots \ldots \ldots$ & 0.342 & 0.361 & 0.382 & 0.392 & $0.8 \%$ \\
\hline Natural Gas $^{7} \ldots \ldots \ldots \ldots \ldots \ldots \ldots \ldots$ & 0.666 & 0.671 & 0.707 & 0.747 & $0.7 \%$ \\
\hline Metallurgical Coal $\ldots \ldots \ldots \ldots \ldots \ldots \ldots$ & 0.071 & 0.068 & 0.060 & 0.052 & $-1.8 \%$ \\
\hline Steam Coal $\ldots \ldots \ldots \ldots \ldots \ldots \ldots \ldots \ldots$ & 0.351 & 0.434 & 0.461 & 0.486 & $1.9 \%$ \\
\hline Net Coal Coke Imports $\ldots \ldots \ldots \ldots \ldots \ldots$ & 0.001 & 0.000 & 0.000 & 0.001 & $-5.2 \%$ \\
\hline Renewable Energy $\ldots \ldots \ldots \ldots \ldots \ldots \ldots \ldots$ & 0.388 & 0.461 & 0.509 & 0.550 & $2.1 \%$ \\
\hline Electricity $\ldots \ldots \ldots \ldots \ldots \ldots \ldots \ldots \ldots$ & 0.540 & 0.601 & 0.660 & 0.704 & $1.6 \%$ \\
\hline Total $\ldots \ldots \ldots \ldots \ldots \ldots \ldots \ldots \ldots$ & 2.831 & 3.110 & 3.341 & 3.527 & $1.3 \%$ \\
\hline \multicolumn{6}{|l|}{ Transportation } \\
\hline Distillate Fuel $\ldots \ldots \ldots \ldots \ldots \ldots \ldots \ldots$ & 0.658 & 0.805 & 0.902 & 1.001 & $2.5 \%$ \\
\hline Jet Fuel ${ }^{\natural} \ldots \ldots \ldots \ldots \ldots \ldots \ldots \ldots \ldots \ldots$ & 0.344 & 0.414 & 0.463 & 0.508 & $2.3 \%$ \\
\hline Molor Gasoline ${ }^{2} \quad \ldots \ldots \ldots \ldots \ldots \ldots \ldots$ & 2.622 & 2.865 & 3.002 & 3.075 & $0.9 \%$ \\
\hline Residual Fuel $\ldots \ldots \ldots \ldots \ldots \ldots \ldots \ldots$ & 0.131 & 0.159 & 0.185 & 0.210 & $2.8 \%$ \\
\hline Liquefied Petroleum Gas . . . . . . . . . . . . . & 0.003 & 0.015 & 0.030 & 0.046 & $18.1 \%$ \\
\hline Other Petroleum ${ }^{9} \ldots \ldots \ldots \ldots \ldots \ldots \ldots$ & 0.027 & 0.032 & 0.034 & 0.037 & $1.8 \%$ \\
\hline Pipeline Fuel Natural Gas $\ldots \ldots \ldots \ldots \ldots$ & 0.050 & 0.040 & 0.045 & 0.050 & $0.0 \%$ \\
\hline Compressed Natural Gas . . . . . . . . . . . . & 0.001 & 0.029 & 0.054 & 0.081 & $26.5 \%$ \\
\hline Renewables (ethanol) ${ }^{10} \ldots \ldots \ldots \ldots \ldots \ldots$ & 0.000 & 0.002 & 0.006 & 0.012 & $35.5 \%$ \\
\hline Liquid Hydrogen $\ldots \ldots \ldots \ldots \ldots \ldots \ldots \ldots$ & 0.000 & 0.000 & 0.000 & 0.000 & N/A \\
\hline Methanol $^{11} \quad \ldots \ldots \ldots \ldots \ldots \ldots \ldots \ldots$ & 0.000 & 0.002 & 0.005 & 0.009 & $31.1 \%$ \\
\hline Electricity $\ldots \ldots \ldots \ldots \ldots \ldots \ldots \ldots \ldots$ & 0.011 & 0.016 & 0.024 & 0.033 & $6.9 \%$ \\
\hline Total $\ldots \ldots \ldots \ldots \ldots \ldots \ldots \ldots \ldots$ & 3.847 & 4.378 & 4.751 & 5.061 & $1.6 \%$ \\
\hline \multicolumn{6}{|l|}{ Electric Generators ${ }^{12}$} \\
\hline Distillate Fuel $\ldots \ldots \ldots \ldots \ldots \ldots \ldots \ldots$ & 0.001 & 0.000 & 0.009 & 0.045 & $29.4 \%$ \\
\hline Residual Fuel $\ldots \ldots \ldots \ldots \ldots \ldots \ldots \ldots$ & 0.447 & 0.327 & 0.439 & 0.512 & $0.8 \%$ \\
\hline Natural Gas $\ldots \ldots \ldots \ldots \ldots \ldots \ldots \ldots$ & 0.248 & 0.526 & 0.814 & 1.272 & $10.1 \%$ \\
\hline Steam Coal $\ldots \ldots \ldots \ldots \ldots \ldots \ldots \ldots$ & 3.313 & 3.723 & 3.845 & 3.961 & $1.1 \%$ \\
\hline Nuclear Power $\ldots \ldots \ldots \ldots \ldots \ldots \ldots \ldots$ & 1.562 & 1.639 & 1.644 & 1.557 & $0.0 \%$ \\
\hline Renewable Energy/Other ${ }^{13} \ldots \ldots \ldots \ldots \ldots \ldots$ & 0.170 & 0.187 & 0.189 & 0.189 & $0.6 \%$ \\
\hline Total $\ldots \ldots \ldots \ldots \ldots \ldots \ldots \ldots \ldots$ & 5.742 & 6.403 & 6.939 & 7.537 & $1.6 \%$ \\
\hline
\end{tabular}


Table 5. Energy Consumption by End-Use Sector and Source South Atlantic Census Division (Continued)

(Quadrillion Btu per Year)

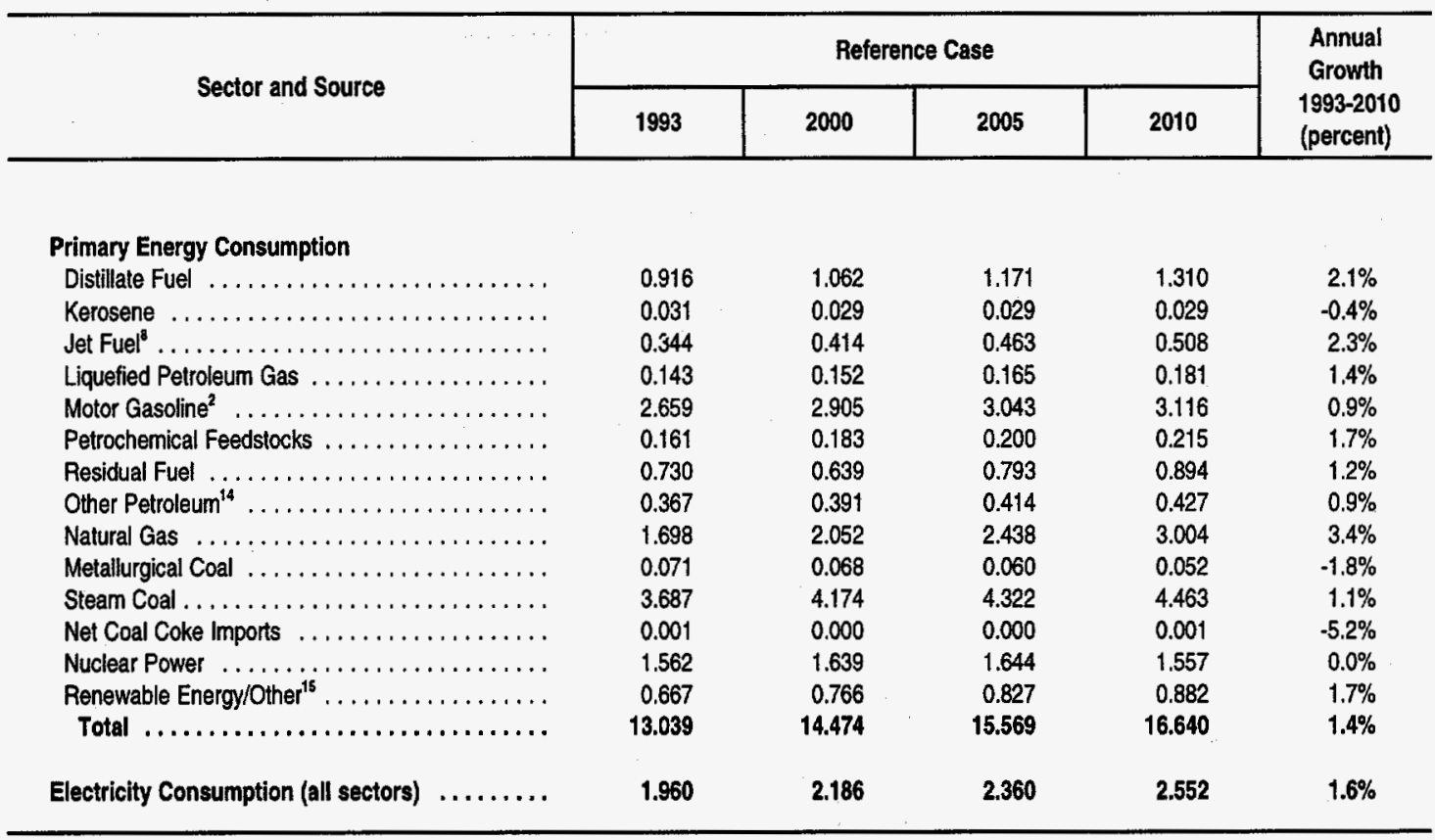

${ }^{1}$ Includes electricity generated by the sector for self-use from hydroelectric, geothermal, wood and wood waste, municipal solid waste, other biomass, wind, photovoltaic and solar thermal sources, and non-electric energy from renewable sources, such as solar thermal water heaters, ground-water heat pumps, and wood.

Includes ethanol (blends of 10 percent or less) and ethers blended into gasoline.

Includes liquefied petroleum gas and coal.

"Includes commercial sector electricity cogenerated using wood and wood waste, municipal solid waste, and other biomass; non-electric energy from renewable sources, such as active solar and passive solar systems, geothermal heat pumps, and solar water heating systems.

sFuel consumption includes consumption for cogeneration.

includes petroleum coke, asphalt, road oil, lubricants, still gas, and miscellaneous petroleum products.

'Includes lease and plant fuel.

Includes naphtha and kerosene type.

Includes aviation gas and lubricants.

${ }^{10}$ Only E85 (85 percent ethanol).

${ }^{11}$ Only M85 (85 percent methanol)

${ }^{12}$ Includes consumption of energy by all electric power generators except cogenerators, and generalors with standard industrial classification other than 49 , both of which produce electricity as a by-product of other processes.

${ }^{13}$ Includes hydroelectric, geothermal, wood and wood waste, municipal solid waste, other biomass, wind, photovoltaic and solar thermal sources, plus net electricity imports.

14 Includes unfinished oils, natural gasoline, motor gasoline blending compounds, aviation gasoline, lubricants, still gas, asphalt, road oil, and miscellaneous petroleum products.

${ }^{13}$ Includes electricity generated for sale to electric utilities and for self use from renewable sources, non-electric energy from renewable sources, net electricity imports, liquid hydrogen, and methanol.

Btu $=$ British thermal unit.

N/A $=$ Not applicable.

Note: Totals may not equal sum of components due to independent rounding. Figures for 1993 may differ from published data due to internal conversion factors in the AEO95 National Energy Modeling System.

Sources: 1993 natural gas lease, plant, and pipeline fuel values: Energy Information Administration (EIA), Natural Gas Monthly, DOE/EIA0130(94/6) (Washington, D.C., June 1994). 1993 transportation sector compressed natural gas consumption: EIA, AEO95 National Energy Modeling System run AEO95B.D1103942. 1993 coal consumption is estimated from EIA, State Energy Data Report 1992, DOE/EIA-0214(92) (Washington, D.C., May 1994). 1993 metallurgical consumption is estimated from this source using unpublished data. 1993 residential and commercial coal consumption tonnages are from EIA, Quarteriy Coal Report, October-December 1993, DOE/EIA-0121(93/4Q) (Washington, D.C., May 1994) and have been converted to quadrillion Btu using State Energy Data Report 1992 thermal conversion factors. Other 1993 values: ElA, Short-Tem Energy Outlook, DOE/EIA-0202(94/3Q) (Washington, D.C., August 1994) with adjustments to end-use consumption levels for consumption of natural gas by electric wholesale generators based on EIA, AEO95 National Energy Modeling System run AEO95B.D1103942. Projections: EIA, AEO95 National Energy Modeling System run AEO95B.D1103942. 
Table 6. Energy Consumption by End-Use Sector and Source East South Central Census Division (Quadrillion Btu per Year)

\begin{tabular}{|c|c|c|c|c|c|}
\hline \multirow{2}{*}{ Sector and Source } & \multicolumn{4}{|c|}{ Reference Case } & \multirow{2}{*}{$\begin{array}{c}\text { Annual } \\
\text { Growth } \\
1993-2010 \\
\text { (percent) }\end{array}$} \\
\hline & 1993 & 2000 & 2005 & 2010 & \\
\hline \multicolumn{6}{|l|}{ Residential } \\
\hline Distillate Fuel $\ldots \ldots \ldots \ldots \ldots \ldots \ldots \ldots \ldots$ & 0.006 & 0.005 & 0.005 & 0.005 & $-1.5 \%$ \\
\hline Kerosene $\ldots \ldots \ldots \ldots \ldots \ldots \ldots \ldots$ & 0.004 & 0.004 & 0.004 & 0.004 & $-1.1 \%$ \\
\hline Liquefied Petroleum Gas . . . . . . . . . . . . & 0.030 & 0.026 & 0.024 & 0.022 & $-1.7 \%$ \\
\hline Natural Gas $\ldots \ldots \ldots \ldots \ldots \ldots \ldots \ldots$ & 0.210 & 0.217 & 0.215 & 0.216 & $0.2 \%$ \\
\hline Coal $\ldots \ldots \ldots \ldots \ldots \ldots \ldots \ldots \ldots \ldots$ & 0.004 & 0.004 & 0.004 & 0.004 & $-0.3 \%$ \\
\hline Renewable Energy ${ }^{1} \ldots \ldots \ldots \ldots \ldots \ldots$ & 0.079 & 0.075 & 0.075 & 0.074 & $-0.4 \%$ \\
\hline Electricity $\ldots \ldots \ldots \ldots \ldots \ldots \ldots \ldots$ & 0.293 & 0.309 & 0.318 & 0.333 & $0.8 \%$ \\
\hline Total $\ldots \ldots \ldots \ldots \ldots \ldots \ldots \ldots \ldots$ & 0.626 & 0.641 & 0.645 & 0.657 & $0.3 \%$ \\
\hline \multicolumn{6}{|l|}{ Commercial } \\
\hline Distillate Fuel $\ldots \ldots \ldots \ldots \ldots \ldots \ldots \ldots$ & 0.018 & 0.018 & 0.017 & 0.017 & $-0.4 \%$ \\
\hline Kerosene $\ldots \ldots \ldots \ldots \ldots \ldots \ldots \ldots \ldots$ & 0.001 & 0.001 & 0.001 & 0.001 & $-0.1 \%$ \\
\hline Motor Gasoline $^{2} \ldots \ldots \ldots \ldots \ldots \ldots$ & 0.004 & 0.004 & 0.004 & 0.004 & $-0.7 \%$ \\
\hline Residual Fuel $\ldots \ldots \ldots \ldots \ldots \ldots \ldots \ldots$ & 0.000 & 0.000 & 0.000 & 0.000 & $-0.1 \%$ \\
\hline Natural Gas $\ldots \ldots \ldots \ldots \ldots \ldots \ldots \ldots$ & 0.135 & 0.134 & 0.135 & 0.140 & $0.2 \%$ \\
\hline Other $^{3} \ldots \ldots \ldots \ldots \ldots \ldots \ldots \ldots \ldots \ldots$ & 0.012 & 0.012 & 0.012 & 0.012 & $0.2 \%$ \\
\hline Renewable Energy ${ }^{4} \ldots \ldots \ldots \ldots \ldots \ldots \ldots$ & 0.000 & 0.000 & 0.000 & 0.000 & $6.0 \%$ \\
\hline Electricity $\ldots \ldots \ldots \ldots \ldots \ldots \ldots \ldots$ & 0.132 & 0.143 & 0.147 & 0.154 & $0.9 \%$ \\
\hline Total $\ldots \ldots \ldots \ldots \ldots \ldots \ldots \ldots$ & 0.303 & 0.313 & 0.318 & 0.328 & $0.5 \%$ \\
\hline \multicolumn{6}{|l|}{ Industrial $^{5}$} \\
\hline Distillate Fuel $\ldots \ldots \ldots \ldots \ldots \ldots \ldots \ldots$ & 0.110 & 0.120 & 0.129 & 0.136 & $1.3 \%$ \\
\hline Liquelied Petroleum Gas . . . . . . . . . . . . . & 0.041 & 0.046 & 0.051 & 0.055 & $1.7 \%$ \\
\hline Motor Gasoline $^{2} \ldots \ldots \ldots \ldots \ldots \ldots \ldots$ & 0.013 & 0.014 & 0.015 & 0.016 & $1.3 \%$ \\
\hline Petrochemical Feedstocks $\ldots \ldots \ldots \ldots \ldots \ldots$ & 0.062 & 0.070 & 0.077 & 0.083 & $1.7 \%$ \\
\hline Residual Fuel $\ldots \ldots \ldots \ldots \ldots \ldots \ldots \ldots$ & 0.008 & 0.015 & 0.017 & 0.017 & $4.6 \%$ \\
\hline Other Petroleum ${ }^{6} \ldots \ldots \ldots \ldots \ldots \ldots \ldots$ & 0.258 & 0.268 & 0.275 & 0.282 & $0.5 \%$ \\
\hline Natural Gas $^{7} \ldots \ldots \ldots \ldots \ldots \ldots \ldots$ & 0.529 & 0.552 & 0.620 & 0.736 & $2.0 \%$ \\
\hline Metallurgical Coal $\ldots \ldots \ldots \ldots \ldots \ldots \ldots$ & 0.117 & 0.117 & 0.102 & 0.089 & $-1.6 \%$ \\
\hline Steam Coal $\ldots \ldots \ldots \ldots \ldots \ldots \ldots \ldots$ & 0.230 & 0.247 & 0.269 & 0.286 & $1.3 \%$ \\
\hline Nel Coal Coke Imports $\ldots \ldots \ldots \ldots \ldots \ldots$ & 0.002 & 0.000 & 0.000 & 0.001 & $-5.2 \%$ \\
\hline Renewable Energy $\ldots \ldots \ldots \ldots \ldots \ldots \ldots$ & 0.208 & 0.235 & 0.256 & 0.269 & $1.5 \%$ \\
\hline Electricity $\ldots \ldots \ldots \ldots \ldots \ldots \ldots \ldots$ & 0.420 & 0.467 & 0.512 & 0.546 & $1.6 \%$ \\
\hline Total $\ldots \ldots \ldots \ldots \ldots \ldots \ldots \ldots$ & 1.997 & 2.151 & 2.322 & 2.515 & $1.4 \%$ \\
\hline \multicolumn{6}{|l|}{ Transportation } \\
\hline Distillate Fuel $\ldots \ldots \ldots \ldots \ldots \ldots \ldots \ldots$ & 0.384 & 0.455 & 0.494 & 0.526 & $1.9 \%$ \\
\hline Jet Fuel ${ }^{8} \ldots \ldots \ldots \ldots \ldots \ldots \ldots \ldots$ & 0.140 & 0.169 & 0.184 & 0.196 & $2.0 \%$ \\
\hline Motor Gasoline ${ }^{2} \quad \ldots \ldots \ldots \ldots \ldots \ldots \ldots$ & 0.962 & 1.037 & 1.059 & 1.050 & $0.5 \%$ \\
\hline Residual Fuel $\ldots \ldots \ldots \ldots \ldots \ldots \ldots \ldots$ & 0.039 & 0.046 & 0.052 & 0.057 & $2.1 \%$ \\
\hline Liquefied Petroleum Gas . . . . . . . . . . . . . . . & 0.001 & 0.005 & 0.009 & 0.014 & $14.9 \%$ \\
\hline Other Petroleum ${ }^{\prime} \ldots \ldots \ldots \ldots \ldots \ldots \ldots$ & 0.015 & 0.016 & 0.017 & 0.017 & $1.1 \%$ \\
\hline Pipeline Fuel Natural Gas $\ldots \ldots \ldots \ldots \ldots \ldots$ & 0.090 & 0.114 & 0.114 & 0.116 & $1.6 \%$ \\
\hline Compressed Natural Gas . . . . . . . . . . . . . & 0.000 & 0.009 & 0.016 & 0.023 & $26.2 \%$ \\
\hline Renewables (ethanol) ${ }^{10}, \ldots \ldots \ldots \ldots \ldots \ldots$ & 0.000 & 0.001 & 0.002 & 0.003 & $35.1 \%$ \\
\hline Liquid Hydrogen $\ldots \ldots \ldots \ldots \ldots \ldots \ldots$ & 0.000 & 0.000 & 0.000 & 0.000 & $N / A$ \\
\hline Methanol $^{1 t} \ldots \ldots \ldots \ldots \ldots \ldots \ldots$ & 0.000 & 0.001 & 0.002 & 0.003 & $30.7 \%$ \\
\hline Electricity $\ldots \ldots \ldots \ldots \ldots \ldots \ldots \ldots \ldots$ & 0.004 & 0.005 & 0.007 & 0.010 & $6.0 \%$ \\
\hline Total $\ldots \ldots \ldots \ldots \ldots \ldots \ldots \ldots \ldots$ & 1.635 & 1.858 & 1.957 & 2.015 & $1.2 \%$ \\
\hline \multicolumn{6}{|l|}{ Electric Generators ${ }^{12}$} \\
\hline Distillale Fuel $\ldots \ldots \ldots \ldots \ldots \ldots \ldots \ldots \ldots$ & 0.000 & 0.000 & 0.000 & 0.000 & NA \\
\hline Residual Fuel $\ldots \ldots \ldots \ldots \ldots \ldots \ldots \ldots$ & 0.040 & 0.002 & 0.008 & 0.011 & $-7.1 \%$ \\
\hline Natural Gas $\ldots \ldots \ldots \ldots \ldots \ldots \ldots \ldots$ & 0.048 & 0.085 & 0.086 & 0.121 & $5.6 \%$ \\
\hline Steam Coal $\ldots \ldots \ldots \ldots \ldots \ldots \ldots \ldots \ldots$ & 2.167 & 1.893 & 1.880 & 1.868 & $-0.9 \%$ \\
\hline Nuclear Power $\ldots \ldots \ldots \ldots \ldots \ldots \ldots \ldots$ & 0.536 & 0.724 & 0.727 & 0.729 & $1.8 \%$ \\
\hline Renewable Energy/Other ${ }^{t 3} \ldots \ldots \ldots \ldots \ldots$ & 0.227 & 0.250 & 0.252 & 0.252 & $0.6 \%$ \\
\hline Total $\ldots \ldots \ldots \ldots \ldots \ldots \ldots \ldots \ldots \ldots$ & 3.018 & 2.954 & 2.953 & 2.981 & $-0.1 \%$ \\
\hline
\end{tabular}


Table 6. Energy Consumption by End-Use Sector and Source East South Central Census Division (Continued) (Quadrillion Btu per Year)

\begin{tabular}{|c|c|c|c|c|c|}
\hline \multirow{2}{*}{ Sector and Source } & \multicolumn{4}{|c|}{ Reference Case } & \multirow{2}{*}{$\begin{array}{c}\text { Annual } \\
\text { Growth } \\
\text { 1993-2010 } \\
\text { (percent) }\end{array}$} \\
\hline & 1993 & 2000 & 2005 & 2010 & \\
\hline \multicolumn{6}{|l|}{ Primary Energy Consumption } \\
\hline Distillate Fuel $\ldots \ldots \ldots \ldots \ldots \ldots \ldots \ldots$ & 0.518 & 0.598 & 0.646 & 0.684 & $1.6 \%$ \\
\hline Kerosene $\ldots \ldots \ldots \ldots \ldots \ldots \ldots \ldots \ldots$ & 0.006 & 0.006 & 0.005 & 0.005 & $-0.8 \%$ \\
\hline Jet Fuel ${ }^{8} \ldots \ldots \ldots \ldots$ & 0.140 & 0.169 & 0.184 & 0.196 & $2.0 \%$ \\
\hline Liquefied Petroleum Gas ................. & 0.077 & 0.083 & 0.089 & 0.095 & $1.3 \%$ \\
\hline Motor Gasoline ${ }^{2} \ldots \ldots \ldots \ldots \ldots \ldots$ & 0.979 & 1.056 & 1.079 & 1.070 & $0.5 \%$ \\
\hline Petrochemical Feedstocks ... & 0.062 & 0.070 & 0.077 & 0.083 & $1.7 \%$ \\
\hline Residual Fuel $\ldots \ldots \ldots$. & 0.087 & 0.064 & 0.077 & 0.085 & $-0.1 \%$ \\
\hline Other Petroleum ${ }^{14} \ldots$ & 0.272 & 0.283 & 0.291 & 0.299 & $0.6 \%$ \\
\hline Natural Gas .... & 1.013 & 1.110 & 1.187 & 1.352 & $1.7 \%$ \\
\hline Metallurgical Coal ..... & 0.117 & 0.117 & 0.102 & 0.089 & $-1.6 \%$ \\
\hline Steam Coal $\ldots \ldots \ldots \ldots \ldots \ldots \ldots \ldots$ & 2.407 & 2.151 & 2.160 & 2.165 & $-0.6 \%$ \\
\hline Net Coal Coke Imports & 0.002 & 0.000 & 0.000 & 0.001 & $-5.2 \%$ \\
\hline Nuclear Power ......... & 0.536 & 0.724 & 0.727 & 0.729 & $1.8 \%$ \\
\hline Renewable Energy/Other ${ }^{15}$. & 0.514 & 0.562 & 0.586 & 0.602 & $0.9 \%$ \\
\hline Total $\ldots \ldots \ldots \ldots \ldots \ldots \ldots \ldots \ldots \ldots \ldots$ & 6.731 & 6.992 & 7.210 & 7.454 & $0.6 \%$ \\
\hline Electricity Consumption (all sectors) $\ldots \ldots \ldots \ldots$ & 0.848 & 0.925 & 0.984 & 1.042 & $1.2 \%$ \\
\hline
\end{tabular}

'Includes electricity generated by the sector for self-use from hydroelectric, geothermal, wood and wood waste, municipal solid waste, other biomass, wind, photovoltaic and solar thermal sources, and non-electric energy from renewable sources, such as solar thermal water heaters, ground-water heat pumps, and wood.

'Includes ethanol (blends of 10 percent or less) and ethers blended into gasoline.

Includes liquetied petroleum gas and coal.

"Includes commercial sector electricity cogenerated using wood and wood waste, municipal solid waste, and other biomass; non-electric energy from renewable sources, such as active solar and passive solar systems, geothermal heat pumps, and solar water heating systems.

${ }^{5} \mathrm{Fuel}$ consumption includes consumption for cogeneration.

Includes petroleum coke, asphalt, road oil, lubricants, still gas, and miscellaneous petroleum products.

'Includes lease and plant fuel.

Includes naphtha and kerosene type.

Includes aviation gas and lubricants.

${ }^{10}$ Only E85 (85 percent ethanol).

${ }^{11}$ Only M85 (85 percent methanol).

${ }^{12}$ Includes consumption of energy by all electric power generators except cogenerators, and generators with standard industrial classification other than 49 , both of which produce electricity as a by-product of other processes.

${ }^{13}$ Includes hydroelectric, geothermal, wood and wood waste, municipal solid waste, other biomass, wind, photovoltaic and solar thermal sources, plus net electricity imports.

${ }^{14}$ Includes unfinished oils, natural gasoline, motor gasoline blending compounds, aviation gasoline, lubricants, still gas, asphalt, road oil, and miscellaneous petroleum products.

${ }^{15}$ Includes electricity generated for sale to electric utilities and for self use from renewable sources, non-electric energy from renewable sources, net electricity imports, liquid hydrogen, and methanol.

Btu = British thermal unit.

N/A = Not applicable.

Note: Totals may not equal sum of components due to independent rounding. Figures for 1993 may differ from published data due to internal conversion factors in the AEO95 National Energy Modeling System.

Sources: 1993 natural gas lease, plant, and pipeline fuel values: Energy Information Administration (EIA), Natural Gas Monthly, DOE/EIA0130(94/6) (Washington, D.C., June 1994). 1993 transportation sector compressed natural gas consumption: EIA, AEO95 National Energy Modeling System run AEO95B.D1103942. 1993 coal consumption is estimated from ElA, State Energy Data Report 1992, DOE/ElA-0214(92) (Washington, D.C., May 1994). 1993 metallurgical consumption is estimated from this source using unpublished data, 1993 residential and commercial coal consumption tonnages are from EIA, Quarterly Coal Report, October-December 1993, DOE/EIA-0121 (93/4Q) (Washington, D.C., May 1994) and have been converted to quadrillion Btu using State Energy Data Report 1992 thermal conversion factors. Other 1993 values: ElA, Short-Term Energy Outlook, DOE/EIA-0202(94/3Q) (Washington, D.C.. August 1994) with adjustments to end-use consumption levels for consumption of natural gas by electric wholesale generators based on EIA, AEO95 National Energy Modeling System run AEO95B.D1 103942. Projections: EIA, AEO95 National Energy Modeling System run AEO95B.D1103942. 
Table 7. Energy Consumption by End-Use Sector and Source West South Central Census Division (Quadrillion Btu per Year)

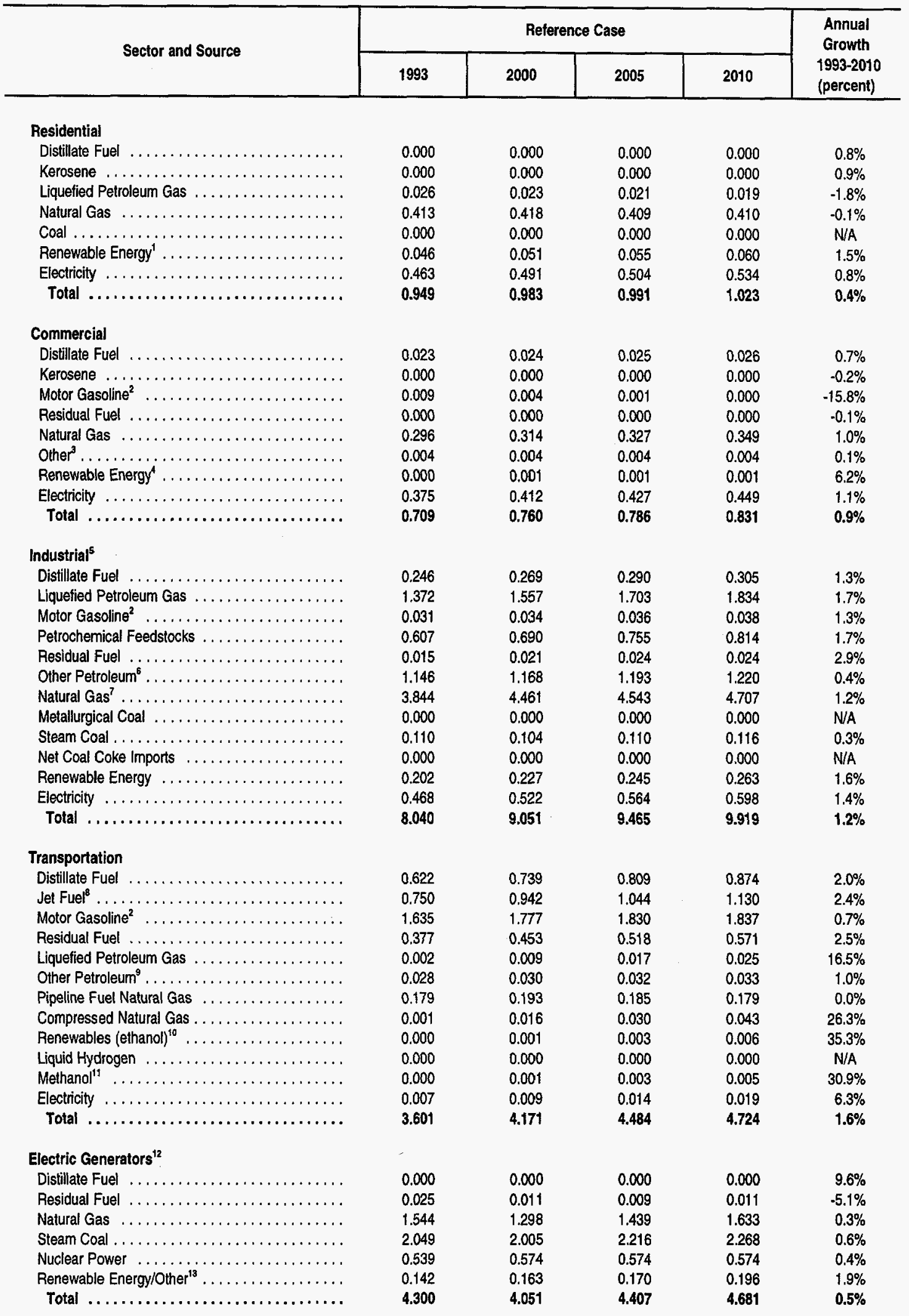


Table 7. Energy Consumption by End-Use Sector and Source

West South Central Census Division (Continued)

(Quadrillion Btu per Year)

\begin{tabular}{|c|c|c|c|c|c|}
\hline \multirow{2}{*}{ Sector and Source } & \multicolumn{4}{|c|}{ Reference Case } & \multirow{2}{*}{$\begin{array}{c}\text { Annual } \\
\text { Growth } \\
1993-2010 \\
\text { (percent) }\end{array}$} \\
\hline & 1993 & 2000 & 2005 & 2010 & \\
\hline \multicolumn{6}{|l|}{ Primary Energy Consumption } \\
\hline Distillate Fuel $\ldots \ldots \ldots \ldots$. & 0.891 & 1.033 & 1.124 & 1.206 & $1.8 \%$ \\
\hline Kerosene $\ldots \ldots$ & 0.001 & 0.002 & 0.002 & 0.002 & $0.2 \%$ \\
\hline Jet Fuel ${ }^{8}$. & 0.750 & 0.942 & 1.044 & 1.130 & $2.4 \%$ \\
\hline Liquefied Petroleum Gas & 1.404 & 1.593 & 1.745 & 1.883 & $1.7 \%$ \\
\hline Motor Gasoline ${ }^{2} \ldots \ldots$ & 1.675 & 1.814 & 1.867 & 1.876 & $0.7 \%$ \\
\hline Petrochemical Feedsfocks $\ldots . . \ldots$. & 0.607 & 0.690 & 0.755 & 0.814 & $1.7 \%$ \\
\hline Residual Fuel $\ldots \ldots \ldots$. & 0.417 & 0.485 & 0.551 & 0.606 & $2.2 \%$ \\
\hline Other Petroleum ${ }^{14}$ & 1.173 & 1.197 & 1.224 & 1.252 & $0.4 \%$ \\
\hline Natural Gas $\ldots \ldots \ldots \ldots \ldots \ldots \ldots \ldots$ & 6.279 & 6.699 & 6.933 & 7.322 & $0.9 \%$ \\
\hline Metallurgical Coal $\ldots \ldots \ldots \ldots \ldots \ldots \ldots \ldots$ & 0.000 & 0.000 & 0.000 & 0.000 & N/A \\
\hline Steam Coal $\ldots \ldots \ldots \ldots \ldots \ldots \ldots \ldots \ldots$ & 2.159 & 2.109 & 2.326 & 2.384 & $0.6 \%$ \\
\hline Net Coal Coke Imports $\ldots \ldots \ldots \ldots \ldots \ldots$ & 0.000 & 0.000 & 0.000 & 0.000 & N/A \\
\hline Nuclear Power $\ldots \ldots \ldots \ldots \ldots \ldots \ldots \ldots$ & 0.539 & 0.574 & 0.574 & 0.574 & $0.4 \%$ \\
\hline Renewable Energy/Other 15 ............... & 0.390 & 0.444 & 0.477 & 0.530 & $1.8 \%$ \\
\hline Total $\ldots \ldots \ldots \ldots \ldots \ldots \ldots \ldots \ldots \ldots \ldots \ldots$ & 16.287 & 17.581 & 18.623 & 19.578 & $1.1 \%$ \\
\hline Electricity Consumption (all sectors) $\ldots \ldots \ldots$. & 1.312 & 1.434 & 1.509 & 1.599 & $1.2 \%$ \\
\hline
\end{tabular}

'Includes electricity generated by the sector for self-use from hydroelectric, geothermal, wood and wood waste, municipal solid waste, other biomass, wind, photovoltaic and solar thermal sources, and non-electric energy from renewable sources, such as solar thermal water heaters, ground-water heat pumps, and wood.

${ }^{2}$ Includes ethanol (blends of 10 percent or less) and ethers blended into gasoline.

${ }^{3}$ Includes liquefied petroleum gas and coal.

${ }^{4}$ Includes commercial sector electricity cogenerated using wood and wood waste, municipal solid waste, and other biomass; non-electric energy from renewable sources, such as active solar and passive solar systems, geothermal heat pumps, and solar water heating systems.

${ }^{5}$ Fuel consumption includes consumption for cogeneration.

Includes petroleum coke, asphalt, road oil, lubricants, still gas, and miscellaneous petroleum products.

${ }^{7}$ Includes lease and plant fuel.

Includes naphtha and kerosene type.

Includes aviation gas and lubricants.

${ }^{10}$ Only E85 (85 percent ethanof).

${ }^{11}$ Only M85 (85 percent methanol).

${ }^{12}$ Includes consumption of energy by all electric power generators except cogenerators, and generators with standard industrial classification other than 49 , both of which produce electricity as a by-product of other processes.

${ }^{13}$ Includes hydroelectric, geothermal, wood and wood waste, municipal solid waste, other biomass, wind, photovoltaic and solar thermal sources, plus net electricity imports.

${ }^{14}$ Includes unfinished oils, natural gasoline, motor gasoline blending compounds, aviation gasoline, lubricants, still gas, asphalt, road oil, and miscellaneous petroleum products.

${ }^{15}$ Includes electricity generated for sale to electric utilities and for self use from renewable sources, non-electric energy from renewable sources, net electricity imports, liquid hydrogen, and methanol.

Btu = British thermal unit.

N/A $=$ Not applicable.

Note: Totals may not equal sum of components due to independent rounding. Figures for 1993 may differ from published data due to internal conversion factors in the AEO95 National Energy Modeling System.

Sources: 1993 natural gas lease, plant, and pipeline fuel values: Energy Information Administration (EIA), Natural Gas Monthly, DOE/EIA0130(94/6) (Washington, D.C., June 1994). 1993 transportation sector compressed natural gas consumption: ElA, AEO95 National Energy Modeling System run AEO95B.D1103942. 1993 coal consumption is estimated from EIA, State Energy Data Report 1992, DOE/EIA-0214(92) (Washington, D.C. May 1994). 1993 metallurgical consumption is estimated from this source using unpublished data. 1993 residential and commercial coal consumption tonnages are from EIA, Quarterly Coal Report, October-December 1993, DOE/EIA-0121(93/4Q) (Washington, D.C., May 1994) and have been converted to quadrillion Btu using State Energy Data Report 1992 thermal conversion factors. Other 1993 values: EIA, Short-Term Energy Outlook, DOEJEIA-0202(94/3Q) (Washington, D.C., August 1994) with adjustments to end-use consumption levels for consumption of natural gas by electric wholesale generators based on EIA, AEO95 National Energy Modeling System run AEO958.D1103942. Projections: EIA, AEO95 National Energy Modeling System run AEO95B.D1103942. 
Table 8. Energy Consumption by End-Use Sector and Source Mountain Census Division (Quadrillion Btu per Year)

\begin{tabular}{|c|c|c|c|c|c|}
\hline \multirow{2}{*}{ Sector and Source } & \multicolumn{4}{|c|}{ Reference Case } & \multirow{2}{*}{$\begin{array}{c}\text { Annual } \\
\text { Growth } \\
\text { 1993-2010 } \\
\text { (percent) }\end{array}$} \\
\hline & 1993 & 2000 & 2005 & 2010 & \\
\hline \multicolumn{6}{|l|}{ Residential } \\
\hline Distillate Fuel $\ldots \ldots \ldots \ldots \ldots \ldots \ldots$ & 0.007 & 0.007 & 0.006 & 0.006 & $-1.0 \%$ \\
\hline Kerosene $\ldots \ldots \ldots \ldots \ldots \ldots \ldots \ldots \ldots$ & 0.000 & 0.000 & 0.000 & 0.000 & $1.2 \%$ \\
\hline Liquefied Petroleum Gas . . . . . . . . . . . . . . . & 0.022 & 0.020 & 0.019 & 0.018 & $-1.4 \%$ \\
\hline Natural Gas $\ldots \ldots \ldots \ldots \ldots \ldots \ldots \ldots$ & 0.280 & 0.290 & 0.284 & 0.286 & $0.1 \%$ \\
\hline Coal $\ldots \ldots \ldots \ldots \ldots \ldots \ldots \ldots \ldots$ & 0.003 & 0.004 & 0.004 & 0.003 & $0.8 \%$ \\
\hline Renewable Energy' . . . . . . . . . . . . . . . . & 0.044 & 0.047 & 0.049 & 0.051 & $0.9 \%$ \\
\hline Electricity $\ldots \ldots \ldots \ldots \ldots \ldots \ldots \ldots \ldots$ & 0.187 & 0.208 & 0.220 & 0.238 & $1.4 \%$ \\
\hline Total $\ldots \ldots \ldots \ldots \ldots \ldots \ldots \ldots \ldots$ & 0.544 & 0.576 & 0.582 & 0.603 & $0.6 \%$ \\
\hline \multicolumn{6}{|l|}{ Commercial } \\
\hline Distillate Fuel,$\ldots \ldots \ldots \ldots \ldots \ldots \ldots \ldots$ & 0.015 & 0.015 & 0.015 & 0.015 & $-0.2 \%$ \\
\hline Kerosene $\ldots \ldots \ldots \ldots \ldots \ldots \ldots \ldots \ldots$ & 0.000 & 0.000 & 0.000 & 0.000 & $-0.2 \%$ \\
\hline Motor Gasoline ${ }^{2} \ldots \ldots \ldots \ldots \ldots \ldots$ & 0.005 & 0.006 & 0.006 & 0.006 & $0.8 \%$ \\
\hline Residual Fuel $\ldots \ldots \ldots \ldots \ldots \ldots \ldots \ldots$ & 0.000 & 0.000 & 0.000 & 0.000 & $-0.2 \%$ \\
\hline Natural Gas $\ldots \ldots \ldots \ldots \ldots \ldots \ldots \ldots \ldots$ & 0.197 & 0.201 & 0.193 & 0.187 & $-0.3 \%$ \\
\hline Other $^{3} \ldots \ldots \ldots \ldots \ldots \ldots \ldots \ldots \ldots$ & 0.010 & 0.010 & 0.010 & 0.010 & $0.4 \%$ \\
\hline Renewable Energy ${ }^{4} \ldots \ldots \ldots \ldots \ldots \ldots$ & 0.002 & 0.004 & 0.005 & 0.005 & $6.2 \%$ \\
\hline Electricity $\ldots \ldots \ldots \ldots \ldots \ldots \ldots \ldots$ & 0.207 & 0.227 & 0.231 & 0.236 & $0.8 \%$ \\
\hline Total $\ldots \ldots \ldots \ldots \ldots \ldots \ldots \ldots$ & 0.436 & 0.464 & 0.461 & 0.460 & $0.3 \%$ \\
\hline \multicolumn{6}{|l|}{ Industrial| $\left.\right|^{5}$} \\
\hline$\ldots \ldots \ldots \ldots \ldots \ldots \ldots \ldots \ldots$ & 0.122 & 0.137 & 0.148 & 0.156 & $1.5 \%$ \\
\hline Liquetied Petroleum Gas . . . . . . . . . . . . . & 0.045 & 0.049 & 0.053 & 0.057 & $1.4 \%$ \\
\hline Motor Gasoline $^{2} \ldots \ldots \ldots \ldots \ldots \ldots$ & 0.015 & 0.018 & 0.019 & 0.020 & $1.6 \%$ \\
\hline Petrochemical Feedstocks $\ldots \ldots \ldots \ldots \ldots \ldots \ldots$ & 0.001 & 0.001 & 0.001 & 0.001 & $1.3 \%$ \\
\hline Residual Fuel $\ldots \ldots \ldots \ldots \ldots \ldots \ldots \ldots \ldots$ & 0.004 & 0.005 & 0.007 & 0.008 & $4.6 \%$ \\
\hline Other Petroleum ${ }^{6} \ldots \ldots \ldots \ldots \ldots \ldots \ldots \ldots$ & 0.185 & 0.187 & 0.198 & 0.202 & $0.5 \%$ \\
\hline Natural Gas $^{7} \ldots \ldots \ldots \ldots \ldots \ldots \ldots \ldots \ldots$ & 0.397 & 0.467 & 0.497 & 0.518 & $1.6 \%$ \\
\hline Metallurgical Coal $\ldots \ldots \ldots \ldots \ldots \ldots \ldots \ldots$ & 0.031 & 0.029 & 0.026 & 0.023 & $-1.7 \%$ \\
\hline Steam Coal $\ldots \ldots \ldots \ldots \ldots \ldots \ldots \ldots \ldots$ & 0.105 & 0.109 & 0.115 & 0.118 & $0.7 \%$ \\
\hline Net Coal Coke Imports $\ldots \ldots \ldots \ldots \ldots \ldots$ & 0.000 & 0.000 & 0.000 & 0.000 & N/A \\
\hline Renewable Energy $\ldots \ldots \ldots \ldots \ldots \ldots \ldots$ & 0.061 & 0.070 & 0.075 & 0.079 & $1.5 \%$ \\
\hline Electricity $\ldots \ldots \ldots \ldots \ldots \ldots \ldots \ldots \ldots$ & 0.196 & 0.213 & 0.231 & 0.246 & $1.3 \%$ \\
\hline Total $\ldots \ldots \ldots \ldots \ldots \ldots \ldots \ldots \ldots$ & 1.162 & 1.286 & 1.369 & 1.429 & $1.2 \%$ \\
\hline \multicolumn{6}{|l|}{ Transportation } \\
\hline$\ldots \ldots \ldots \ldots \ldots \ldots \ldots \ldots$ & 0.279 & 0.345 & 0.382 & 0.419 & $2.4 \%$ \\
\hline Jet Fuel ${ }^{8} \ldots \ldots \ldots \ldots \ldots \ldots \ldots \ldots \ldots \ldots$ & 0.183 & 0.214 & 0.234 & 0.253 & $1.9 \%$ \\
\hline Motor Gasoline ${ }^{2} \ldots \ldots \ldots \ldots \ldots \ldots$ & 0.834 & 0.937 & 0.978 & 0.993 & $1.0 \%$ \\
\hline Residual Fuel $\ldots \ldots \ldots \ldots \ldots \ldots \ldots \ldots$ & 0.000 & 0.000 & 0.000 & 0.000 & NA \\
\hline Liquefied Pelroleum Gas . . . . . . . . . . . . . . & 0.001 & 0.005 & 0.009 & 0.014 & $14.2 \%$ \\
\hline Other Petroleum ${ }^{9} \ldots \ldots \ldots \ldots \ldots \ldots \ldots \ldots$ & 0.014 & 0.015 & 0.017 & 0.017 & $1.5 \%$ \\
\hline Pipeline Fuel Natural Gas $\ldots \ldots \ldots \ldots \ldots \ldots$ & 0.104 & 0.115 & 0.111 & 0.105 & $0.0 \%$ \\
\hline Compressed Natural Gas . . . . . . . . . . . . . . & 0.000 & 0.009 & 0.016 & 0.024 & $27.0 \%$ \\
\hline Renewables (ethanol) ${ }^{10} \ldots \ldots \ldots \ldots \ldots$ & 0.000 & 0.000 & 0.002 & 0.003 & $35.9 \%$ \\
\hline Liquid Hydrogen $\ldots \ldots \ldots \ldots \ldots \ldots \ldots \ldots \ldots$ & 0.000 & 0.000 & 0.000 & 0.000 & N/A \\
\hline Methanol $^{11} \ldots \ldots \ldots \ldots \ldots \ldots \ldots \ldots$ & 0.000 & 0.001 & 0.001 & 0.003 & $31.5 \%$ \\
\hline Electricity $\ldots \ldots \ldots \ldots \ldots \ldots \ldots \ldots \ldots$ & 0.003 & 0.005 & 0.007 & 0.010 & $6.5 \%$ \\
\hline Total $\ldots \ldots \ldots \ldots \ldots \ldots \ldots \ldots$ & 1.419 & 1.646 & 1.757 & 1.840 & $1.5 \%$ \\
\hline \multicolumn{6}{|l|}{ Electric Generators ${ }^{12}$} \\
\hline Distillate Fuel $\ldots \ldots \ldots \ldots \ldots \ldots \ldots \ldots \ldots$ & 0.003 & 0.000 & 0.000 & 0.000 & N/A \\
\hline Residual Fuel $\ldots \ldots \ldots \ldots \ldots \ldots \ldots \ldots \ldots$ & 0.002 & 0.004 & 0.011 & 0.005 & $4.5 \%$ \\
\hline Natural Gas $\ldots \ldots \ldots \ldots \ldots \ldots \ldots \ldots$ & 0.084 & 0.432 & 0.414 & 0.315 & $8.1 \%$ \\
\hline Steam Coal $\ldots \ldots \ldots \ldots \ldots \ldots \ldots \ldots$ & 2.030 & 2.037 & 2.207 & 2.713 & $1.7 \%$ \\
\hline Nuclear Power $\ldots \ldots \ldots \ldots \ldots \ldots \ldots \ldots \ldots$ & 0.266 & 0.277 & 0.277 & 0.277 & $0.2 \%$ \\
\hline Renewable Energy/Other ${ }^{13} \ldots \ldots \ldots \ldots \ldots \ldots$ & 0.367 & 0.409 & 0.421 & 0.431 & $1.0 \%$ \\
\hline Total $\ldots \ldots \ldots \ldots \ldots \ldots \ldots \ldots \ldots$ & 2.752 & 3.160 & 3.330 & 3.741 & $1.8 \%$ \\
\hline
\end{tabular}


Table 8. Energy Consumption by End-Use Sector and Source Mountain Census Division (Continued) (Quadrillion Btu per Year)

\begin{tabular}{|c|c|c|c|c|c|}
\hline \multirow{2}{*}{ Sector and Source } & \multicolumn{4}{|c|}{ Reference Case } & \multirow{2}{*}{$\begin{array}{l}\text { Annual } \\
\text { Growth } \\
\text { t993-2010 } \\
\text { (percent) }\end{array}$} \\
\hline & 1993 & 2000 & 2005 & 2010 & \\
\hline \multicolumn{6}{|l|}{ Primary Energy Consumption } \\
\hline Kerosene $\ldots \ldots \ldots \ldots \ldots \ldots \ldots \ldots$ & 0.001 & 0.001 & 0.001 & 0.001 & $0.7 \%$ \\
\hline Jet Fuel ${ }^{a} \ldots \ldots \ldots \ldots \ldots \ldots \ldots \ldots \ldots$ & 0.183 & 0.214 & 0.234 & 0.253 & $1.9 \%$ \\
\hline Liquefied Petroleum Gas . . . . . . . . . . . . . . & 0.073 & 0.078 & 0.084 & 0.092 & $1.4 \%$ \\
\hline Motor Gasoline $^{2} \ldots \ldots \ldots \ldots \ldots \ldots \ldots$ & 0.855 & 0.961 & 1.003 & 1.019 & $1.0 \%$ \\
\hline Petrochemical Feedstocks . . . . . . . . . . . . . & 0.001 & 0.001 & 0.001 & 0.001 & $1.3 \%$ \\
\hline Residual Fuel $\ldots \ldots \ldots \ldots \ldots \ldots \ldots \ldots$ & 0.007 & 0.010 & 0.018 & 0.014 & $4.4 \%$ \\
\hline Steam Coal $\ldots \ldots \ldots \ldots \ldots \ldots \ldots \ldots$ & 2.144 & 2.157 & 2.332 & 2.842 & $1.7 \%$ \\
\hline Net Coal Coke Imports $\ldots \ldots \ldots \ldots \ldots \ldots$ & 0.000 & 0.000 & 0.000 & 0.000 & N/A \\
\hline Nuclear Power $\ldots \ldots \ldots \ldots \ldots \ldots \ldots$ & 0.266 & 0.277 & 0.277 & 0.277 & $0.2 \%$ \\
\hline Renewable Energy/Other ${ }^{15} \ldots \ldots \ldots \ldots \ldots$ & 0.474 & 0.532 & 0.553 & 0.573 & $1.1 \%$ \\
\hline Total $\ldots \ldots \ldots \ldots \ldots \ldots \ldots \ldots \ldots \ldots$ & 5.720 & 6.478 & 6.810 & 7.344 & $1.5 \%$ \\
\hline Electricity Consumption (all seclors) $\ldots \ldots \ldots$ & 0.594 & 0.653 & 0.689 & 0.730 & $1.2 \%$ \\
\hline
\end{tabular}

'Includes electricity generated by the sector for self-use from hydroelectric, geothermal, wood and wood waste, municipal solid waste, other biomass, wind, photovoltaic and solar thermal sources, and non-electric energy from renewable sources, such as solar thermal water heaters, ground-water heat pumps, and wood.

Includes ethanol (blends of 10 percent or less) and ethers blended into gasoline.

Includes liquefied petroleum gas and coal.

Includes commercial sector electricity cogenerated using wood and wood waste, municipal solid waste, and other biomass; non-electric energy from renewable sources, such as active solar and passive solar systems, geothermal heat pumps, and solar water heating systerns.

${ }^{5}$ Fuel consumption includes consumption for cogeneration.

Includes petroleum coke, asphalt, road oil, lubricants, still gas, and miscellaneous petroleum products.

'Includes lease and plant fuel.

Includes naphtha and kerosene type.

Includes aviation gas and lubricants.

${ }^{10}$ Only E85 (85 percent ethanol).

${ }^{11}$ Only M85 (85 percent methanol).

${ }^{12}$ Includes consumption of energy by all electric power generators except cogenerators, and generators with standard industrial classification other than 49 , both of which produce electricity as a by-product of other processes.

${ }^{13}$ Includes hydroelectric, geothermal, wood and wood waste, municipal solid waste, other biomass, wind, photovoltaic and solar thermal sources, plus net electricity imports.

${ }^{14}$ Includes unfinished oils, natural gasoline, motor gasoline blending compounds, aviation gasoline, lubricants, still gas, asphalt, road oil, and miscellaneous petroleum products.

${ }^{15}$ Includes electricity generated for sale to electric utilities and for self use from renewable sources, non-electric energy from renewable sources, net electricity imports, liquid hydrogen, and methanol.

Btu = British thermal unit.

N/A = Not applicable.

Note: Totals may not equal sum of components due to independent rounding. Figures for 1993 may differ from published data due to internal conversion factors in the AEO95 National Energy Modeling System.

Sources: 1993 natural gas lease, plant, and pipeline fuel values: Energy Information Administration (EIA), Natural Gas Monthly, DOE/EIA0130(94/6) (Washington, D.C., June 1994). 1993 transportation sector compressed natural gas consumption: ElA, AEO95 National Energy Modeling System run AEO95B.D1103942. 1993 coal consumption is estimated from EIA, State Energy Data Report 1992, DOE/EIA-0214(92) (Washington, D.C. May 1994). 1993 metallurgical consumption is estimated from this source using unpublished data. 1993 residential and commercial coal consumption tonnages are from EIA, Quarterly Coal Report, October-December 1993, DOE/EIA-0121(93/4Q) (Washington, D.C., May 1994) and have been converted to quadrillion Btu using State Energy Data Report 1992 themal conversion factors. Other 1993 values: ElA, Short-Term Energy Outlook, DOE/EIA-0202(94/3Q) (Washington, D.C.. August 1994) with adjustments to end-use consumption levels for consumption of natural gas by electric wholesale generators based on EIA, AEO95 National Energy Modeling System run AEO95B.D1103942. Projections: EIA, AEO95 National Energy Modeling System run AEO95B.D1103942. 
Table 9. Energy Consumption by End-Use Sector and Source

Pacific Census Division

(Quadrillion Btu per Year)

\begin{tabular}{|c|c|c|c|c|c|}
\hline \multirow{2}{*}{ Sector and Source } & \multicolumn{4}{|c|}{ Reference Case } & \multirow{2}{*}{$\begin{array}{c}\text { Annual } \\
\text { Growth } \\
1993-2010 \\
\text { (percent) }\end{array}$} \\
\hline & 1993 & 2000 & 2005 & 2010 & \\
\hline \multicolumn{6}{|l|}{ Residential } \\
\hline Distillate Fuel & 0.028 & 0.025 & 0.023 & 0.023 & $-1.2 \%$ \\
\hline Kerosene $\ldots \ldots \ldots \ldots \ldots \ldots \ldots \ldots \ldots \ldots$ & 0.000 & 0.000 & 0.000 & 0.000 & $-0.9 \%$ \\
\hline Liquefied Petroleum Gas . .............. & 0.025 & 0.024 & 0.024 & 0.025 & $-0.1 \%$ \\
\hline Natural Gas $\ldots \ldots \ldots \ldots \ldots \ldots \ldots \ldots$ & 0.611 & 0.626 & 0.616 & 0.625 & $0.1 \%$ \\
\hline Coal $\ldots \ldots \ldots, \ldots, \ldots, \ldots, \ldots, \ldots, \ldots$ & 0.005 & 0.004 & 0.004 & 0.003 & $-2.1 \%$ \\
\hline Renewable Energy ${ }^{1} \ldots \ldots \ldots \ldots \ldots \ldots$ & 0.117 & 0.123 & 0.123 & 0.124 & $0.3 \%$ \\
\hline Electricity $\ldots \ldots \ldots \ldots \ldots \ldots \ldots \ldots \ldots$ & 0.420 & 0.443 & 0.455 & 0.478 & $0.8 \%$ \\
\hline Total $\ldots \ldots \ldots \ldots \ldots \ldots \ldots \ldots \ldots \ldots \ldots \ldots \ldots$ & 1.205 & 1.244 & 1.247 & 1.278 & $0.3 \%$ \\
\hline \multicolumn{6}{|l|}{ Commercial } \\
\hline Distillate Fuel & 0.028 & 0.029 & 0.029 & 0.030 & $0.3 \%$ \\
\hline Kerosene $\ldots .$. & 0.000 & 0.000 & 0.000 & 0.000 & $-0.1 \%$ \\
\hline Motor Gasoline ${ }^{2}$ & 0.009 & 0.009 & 0.008 & 0.008 & $-0.8 \%$ \\
\hline Residual Fuel $\ldots \ldots \ldots \ldots \ldots \ldots \ldots \ldots$ & 0.008 & 0.008 & 0.008 & 0.008 & $-0.1 \%$ \\
\hline Natural Gas .. & 0.377 & 0.386 & 0.392 & 0.405 & $0.4 \%$ \\
\hline Other ${ }^{3} \ldots \ldots \ldots \ldots \ldots \ldots \ldots$ & 0.013 & 0.009 & 0.009 & 0.009 & $-2.2 \%$ \\
\hline Renewable Energy ${ }^{4} \ldots \ldots \ldots \ldots \ldots \ldots \ldots$ & 0.003 & 0.007 & 0.008 & 0.009 & $6.1 \%$ \\
\hline Electricity $\ldots \ldots \ldots \ldots \ldots \ldots \ldots \ldots \ldots$ & 0.443 & 0.502 & 0.543 & 0.601 & $1.8 \%$ \\
\hline Total $\ldots \ldots \ldots \ldots \ldots \ldots \ldots \ldots \ldots \ldots \ldots \ldots$ & 0.881 & 0.950 & 0.998 & 1.069 & $1.1 \%$ \\
\hline \multicolumn{6}{|l|}{ Industrial $\left.\right|^{5}$} \\
\hline Distillate Fuel $\ldots \ldots \ldots \ldots$ & 0.110 & 0.124 & 0.134 & 0.142 & $1.5 \%$ \\
\hline Liquefied Petroleum Gas $\ldots \ldots \ldots \ldots \ldots \ldots$ & 0.060 & 0.047 & 0.055 & 0.055 & $.0 .6 \%$ \\
\hline Motor Gasoline ${ }^{2} \ldots \ldots \ldots \ldots \ldots \ldots \ldots$ & 0.024 & 0.027 & 0.029 & 0.031 & $1.6 \%$ \\
\hline Petrochemical Feedstocks $\ldots \ldots \ldots \ldots \ldots \ldots$ & 0.028 & 0.030 & 0.032 & 0.035 & $1.3 \%$ \\
\hline Residual Fuel $\ldots \ldots \ldots \ldots \ldots \ldots \ldots$ & 0.031 & 0.053 & 0.058 & 0.060 & $3.9 \%$ \\
\hline Other Petroleum ${ }^{6} \ldots \ldots \ldots \ldots$ & 0.589 & 0.574 & 0.606 & 0.626 & $0.4 \%$ \\
\hline Natural Gas? $\ldots$. . & 1.072 & 1.243 & 1.270 & 1.351 & $1.4 \%$ \\
\hline Metallurgical Coal $\ldots \ldots \ldots \ldots \ldots \ldots \ldots$ & 0.000 & 0.000 & 0.000 & 0.000 & $N / A$ \\
\hline Steam Coal $\ldots \ldots \ldots \ldots \ldots \ldots \ldots \ldots$ & 0.061 & 0.075 & 0.078 & 0.081 & $1.7 \%$ \\
\hline Net Coal Coke Imports $\ldots \ldots \ldots \ldots \ldots \ldots$ & 0.000 & 0.000 & 0.000 & 0.000 & N/A \\
\hline Renewable Energy $\ldots \ldots \ldots \ldots \ldots \ldots \ldots$ & 0.384 & 0.430 & 0.459 & 0.482 & $1.3 \%$ \\
\hline Electricity $\ldots \ldots \ldots \ldots \ldots \ldots \ldots \ldots \ldots$ & 0.396 & 0.432 & 0.468 & 0.498 & $1.4 \%$ \\
\hline Total $\ldots \ldots \ldots \ldots \ldots \ldots \ldots \ldots \ldots \ldots \ldots$ & 2.756 & 3.036 & 3.189 & 3.360 & $1.2 \%$ \\
\hline \multicolumn{6}{|l|}{ Transportation } \\
\hline Distillate Fuel & 0.501 & 0.587 & 0.641 & 0.693 & $1.9 \%$ \\
\hline Jet Fuel ${ }^{8} \ldots \ldots$ & 0.798 & 0.986 & 1.091 & 1.180 & $2.3 \%$ \\
\hline Motor Gasoline ${ }^{2}$ & 2.188 & 2.368 & 2.452 & 2.469 & $0.7 \%$ \\
\hline Residual Fuel $\ldots \ldots \ldots$. & 0.411 & 0.498 & 0.571 & 0.631 & $2.5 \%$ \\
\hline Liquefied Petroleum Gas . . & 0.004 & 0.014 & 0.026 & 0.040 & $14.8 \%$ \\
\hline Other Petroleum ${ }^{9} \ldots \ldots \ldots \ldots$ & 0.034 & 0.038 & 0.040 & 0.041 & $1.1 \%$ \\
\hline Pipeline Fuel Natural Gas $\ldots \ldots \ldots \ldots \ldots \ldots$ & 0.029 & 0.043 & 0.046 & 0.044 & $2.4 \%$ \\
\hline Compressed Natural Gas . ............... & 0.001 & 0.026 & 0.048 & 0.070 & $26.4 \%$ \\
\hline Renewables (ethanol) ${ }^{10} \ldots \ldots \ldots \ldots \ldots \ldots$ & 0.000 & 0.001 & 0.006 & 0.010 & $35.3 \%$ \\
\hline Liquid Hydrogen ..................... & 0.000 & 0.000 & 0.000 & 0.000 & N/A \\
\hline Methanol $^{11} \quad \ldots \ldots \ldots \ldots \ldots \ldots \ldots \ldots$ & 0.000 & 0.002 & 0.004 & 0.008 & $30.9 \%$ \\
\hline Electricity $\ldots \ldots \ldots \ldots \ldots \ldots \ldots \ldots \ldots$ & 0.010 & 0.014 & 0.021 & 0.029 & $6.7 \%$ \\
\hline Total $\ldots \ldots \ldots \ldots \ldots \ldots \ldots \ldots \ldots \ldots \ldots \ldots \ldots$ & 3.976 & 4.577 & 4.945 & 5.215 & $1.6 \%$ \\
\hline \multicolumn{6}{|l|}{ Electric Generators ${ }^{12}$} \\
\hline Distillate Fuel ..... & 0.006 & 0.004 & 0.005 & 0.005 & $-1.1 \%$ \\
\hline Residual Fuel $\ldots \ldots \ldots \ldots \ldots \ldots \ldots \ldots$ & 0.096 & 0.127 & 0.133 & 0.120 & $1.3 \%$ \\
\hline Natural Gas $\ldots \ldots \ldots \ldots \ldots \ldots \ldots \ldots$ & 0.685 & 0.616 & 0.671 & 0.450 & $-2.4 \%$ \\
\hline Steam Coal $\ldots \ldots \ldots \ldots \ldots \ldots \ldots \ldots$ & 0.131 & 0.142 & 0.146 & 0.147 & $0.7 \%$ \\
\hline Nuclear Power $\ldots \ldots \ldots \ldots \ldots \ldots \ldots \ldots$ & 0.389 & 0.392 & 0.392 & 0.309 & $-1.3 \%$ \\
\hline Renewable Energy/Other ${ }^{13} \ldots \ldots \ldots \ldots \ldots \ldots$ & 2.061 & 2.460 & 2.645 & 3.275 & $2.8 \%$ \\
\hline Total $\ldots \ldots \ldots \ldots \ldots \ldots \ldots \ldots \ldots \ldots \ldots \ldots \ldots$ & 3.367 & 3.742 & 3.992 & 4.305 & $1.5 \%$ \\
\hline
\end{tabular}




\section{Table 9. Energy Consumption by End-Use Sector and Source Pacific Census Division (Continued) (Quadrillion Btu per Year)}

\begin{tabular}{|c|c|c|c|c|c|}
\hline \multirow{2}{*}{ Sector and Source } & \multicolumn{4}{|c|}{ Reference Case } & \multirow{2}{*}{$\begin{array}{c}\text { Annual } \\
\text { Growth } \\
1993-2010 \\
\text { (percent) }\end{array}$} \\
\hline & 1993 & 2000 & 2005 & 2010 & \\
\hline \multicolumn{6}{|l|}{ Primary Energy Consumption } \\
\hline Distillate Fuel,$\ldots \ldots \ldots \ldots \ldots$ & 0.674 & 0.770 & 0.833 & 0.892 & $1.7 \%$ \\
\hline Kerosene $\ldots \ldots \ldots \ldots \ldots \ldots \ldots \ldots$ & 0.001 & 0.001 & 0.001 & $0.00 t$ & $-0.4 \%$ \\
\hline Jet Fuel ${ }^{8} \ldots \ldots \ldots \ldots \ldots \ldots \ldots \ldots \ldots$ & 0.798 & 0.986 & 1.091 & 1.180 & $2.3 \%$ \\
\hline Liquefied Petroleum Gas $\ldots \ldots \ldots \ldots \ldots \ldots \ldots$ & 0.093 & 0.089 & 0.110 & 0.123 & $1.6 \%$ \\
\hline Motor Gasoline ${ }^{2} \ldots \ldots \ldots \ldots$ & 2.220 & 2.404 & 2.489 & 2.507 & $0.7 \%$ \\
\hline Petrochemical Feedstocks & 0.028 & 0.030 & 0.032 & 0.035 & $1.3 \%$ \\
\hline Residual Fuel $\ldots \ldots \ldots \ldots, \ldots \ldots \ldots \ldots \ldots$ & 0.547 & 0.685 & 0.769 & 0.819 & $2.4 \%$ \\
\hline Other Petroleum ${ }^{14}$. & 0.623 & 0.612 & 0.645 & 0.667 & $0.4 \%$ \\
\hline Natural Gas $\ldots \ldots \ldots \ldots \ldots \ldots \ldots \ldots$ & 2.774 & 2.941 & 3.043 & 2.944 & $0.4 \%$ \\
\hline Metallurgical Coal . . . . . . . . . . . . . . . & 0.000 & 0.000 & 0.000 & 0.000 & N/A \\
\hline Steam Coal ......... & 0.206 & 0.227 & 0.233 & 0.236 & $0.8 \%$ \\
\hline Net Coal Coke imports .. & 0.000 & 0.000 & 0.000 & 0.000 & N/A \\
\hline Nuclear Power...... . & 0.389 & 0.392 & 0.392 & 0.309 & $-1.3 \%$ \\
\hline Renewable Energy/Other ${ }^{15} \ldots \ldots \ldots \ldots \ldots$ & 2.565 & 3.023 & 3.245 & 3.908 & $2.5 \%$ \\
\hline Total...$\ldots \ldots \ldots \ldots \ldots \ldots \ldots \ldots \ldots \ldots \ldots \ldots$ & 10.918 & 12.158 & 12.882 & 13.621 & $1.3 \%$ \\
\hline Electricity Consumption (all sectors) $\ldots \ldots \ldots$ & 1.268 & 1.391 & 1.488 & 1.607 & $1.4 \%$ \\
\hline
\end{tabular}

1 Includes electricity generated by the sector for self-use from hydroelectric, geothermal, wood and wood waste, municipal solid waste, other biomass, wind, photovoltaic and solar thermal sources, and non-electric energy from renewable sources, such as solar thermal water heaters, ground-water heat pumps, and wood.

${ }^{2}$ Includes ethanol (blends of 10 percent or less) and ethers blended into gasoline.

${ }^{3}$ Includes liquefied petroleum gas and coal.

"Includes commercial sector electricity cogenerated using wood and wood waste, municipal solid waste, and other biomass; non-electric energy from renewable sources, such as active solar and passive solar systems, geothermal heat pumps, and solar water heating systems.

${ }^{5}$ Fuel consumption includes consumption for cogeneration.

'Includes petroleum coke, asphalt, road oil, lubricants, still gas, and miscellaneous petroleum products.

'Includes lease and plant fuel.

Includes naphtha and kerosene type.

Includes aviation gas and lubricants.

${ }^{10}$ Only E85 (85 percent ethanol).

"Only M85 (85 percent methanol).

${ }^{12}$ Includes consumption of energy by all electric power generators except cogenerators, and generators with standard industrial classification other than 49 , both of which produce electricity as a by-product of other processes.

${ }^{13}$ Includes hydroelectric, geothermal, wood and wood waste, municipal solid waste, other biomass, wind, photovoltaic and solar thermal sources, plus net electricity imports.

${ }^{14}$ Includes untinished oils, natural gasoline, motor gasoline blending compounds, aviation gasoline, lubricants, still gas, asphalt, road oil, and miscellaneous petroleum products.

${ }^{15}$ Includes electricity generated for sale to electric utilities and for self use from renewable sources, non-electric energy from renewable sources, net electricity imports, liquid hydrogen, and methanol.

Btu = British thermal unit.

N/A = Not applicable.

Note: Totals may not equal sum of components due to independent rounding. Figures for 1993 may differ from published data due to internal conversion factors in the AEO95 National Energy Modeling System.

Sources: 1993 natural gas lease, plant, and pipeline fuel values: Energy Information Administration (EIA), Natural Gas Monthly, DOE/EIA0130(94/6) (Washington, D.C., June 1994). 1993 transportation sector compressed natural gas consumption: EIA, AEO95 National Energy Modeling System run AEO95B.D1103942. 1993 coal consumption is estimated from EIA, State Energy Data Report 1992, DOE/EIA-0214(92) (Washington, D.C., May 1994). 1993 melallurgical consumption is estimated from this source using unpublished data. 1993 residential and commercial coal consumption tonnages are from E|A, Quarterly Coal Report, October-December 1993, DOE/EIA-0121(93/4Q) (Washington, D.C., May 1994) and have been converted to quadrillion Btu using State Energy Data Report 1992 thermal conversion factors. Other 1993 values: ElA, Short-Term Energy Outlook, DOE/EIA-0202(94/3Q) (Washington, D.C., August 1994) with adjustments to end-use consumption levels for consumption of natural gas by electric wholesale generators based on EIA, AEO95 National Energy Modeling System run AEO95B.D1103942. Projections: EIA, AEO95 National Energy Modeling System run AEO95B.D1103942. 
Table 10. Energy Consumption by End-Use Sector and Source United States

(Quadrillion Btu per Year)

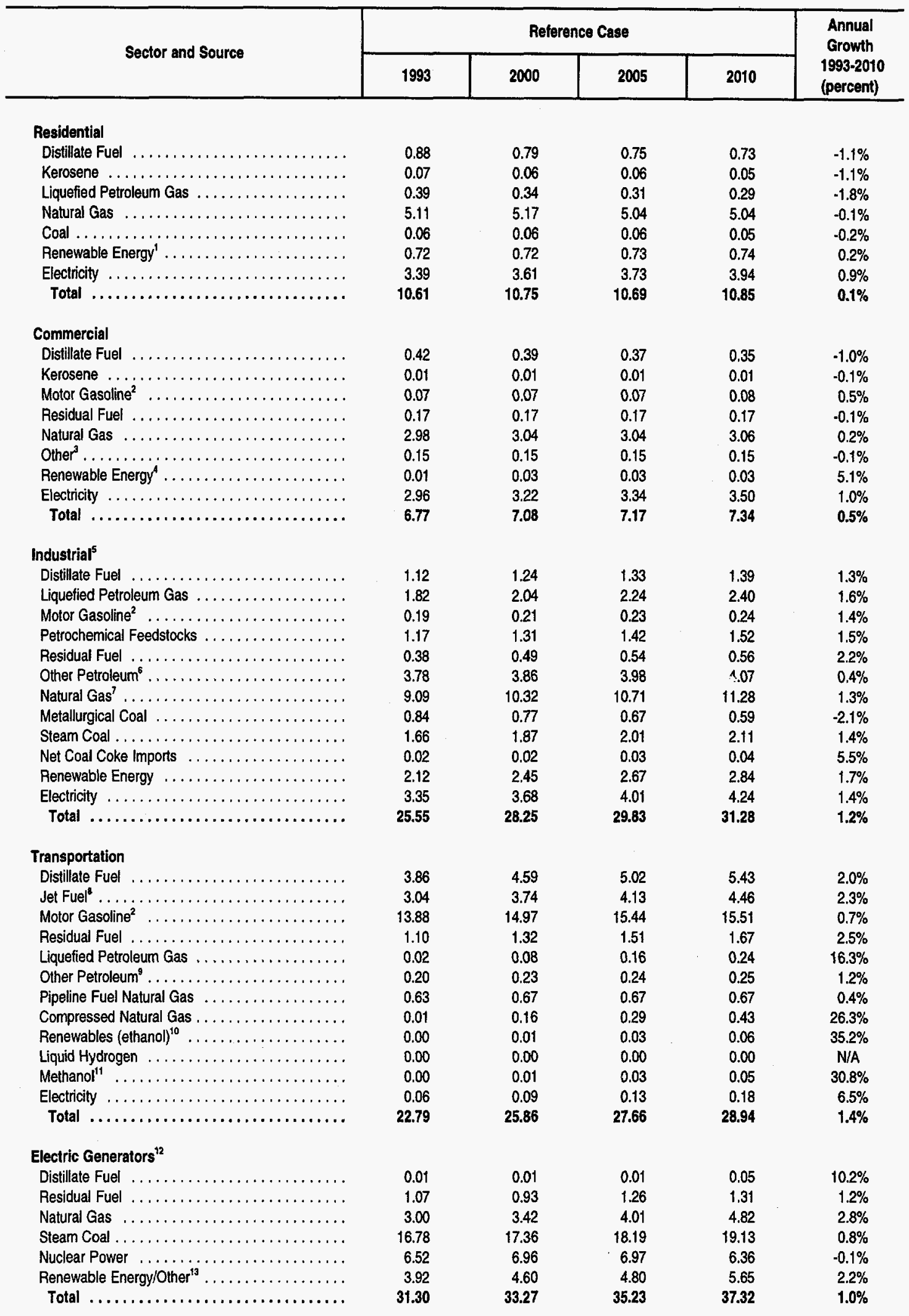


Table 10. Energy Consumption by End-Use Sector and Source United States (Continued)

(Quadrillion Btu per Year)

\begin{tabular}{|c|c|c|c|c|c|}
\hline \multirow{2}{*}{ Sector and Source } & \multicolumn{4}{|c|}{ Reference Case } & \multirow{2}{*}{$\begin{array}{l}\text { Annual } \\
\text { Growth } \\
1993-2010 \\
\text { (percent) }\end{array}$} \\
\hline & 1993 & 2000 & 2005 & 2010 & \\
\hline \multicolumn{6}{|l|}{ Primary Energy Consumption } \\
\hline Distillate Fuel $\ldots \ldots \ldots \ldots$. & 6.29 & 7.02 & 7.49 & 7.95 & $1.4 \%$ \\
\hline Kerosene $\ldots \ldots \ldots \ldots \ldots \ldots$ & 0.09 & 0.08 & 0.08 & 0.07 & $-0.9 \%$ \\
\hline Jet Fuel ${ }^{s} \ldots \ldots \ldots \ldots$ & 3.04 & 3.74 & 4.13 & 4.46 & $2.3 \%$ \\
\hline Liquefied Petroleum Gas . & 2.29 & 2.53 & 2.77 & 2.99 & $1.6 \%$ \\
\hline Motor Gasoline ${ }^{2} \ldots \ldots$ & 14.14 & 15.25 & 15.75 & 15.83 & $0.7 \%$ \\
\hline Petrochemical Feedstocks. & 1.17 & 1.31 & 1.42 & 1.52 & $1.5 \%$ \\
\hline Residual Fuel $\ldots \ldots \ldots$. & 2.72 & 2.90 & 3.47 & 3.70 & $1.8 \%$ \\
\hline Other Petroleum ${ }^{14} \ldots \ldots \ldots \ldots$ & 3.98 & 4.07 & 4.21 & 4.31 & $0.5 \%$ \\
\hline Natural Gas $\ldots \ldots \ldots \ldots \ldots \ldots$ & 20.81 & 22.78 & 23.76 & 25.30 & $1.2 \%$ \\
\hline Metallurgical Coal $\ldots \ldots \ldots \ldots \ldots \ldots \ldots \ldots$ & 0.84 & 0.77 & 0.67 & 0.59 & $-2.1 \%$ \\
\hline Steam coal $\ldots \ldots \ldots \ldots \ldots \ldots \ldots \ldots \ldots$ & 18.59 & 19.37 & 20.34 & 21.38 & $0.8 \%$ \\
\hline Net Coal Coke Imports $\ldots \ldots \ldots \ldots \ldots \ldots \ldots$ & 0.02 & 0.02 & 0.03 & 0.04 & $5.5 \%$ \\
\hline Nuclear Power $\ldots \ldots \ldots \ldots \ldots$. & 6.52 & 6.96 & 6.97 & 6.36 & $-0.1 \%$ \\
\hline Renewable Energy/Other ${ }^{15}$ & 6.78 & 7.81 & 8.29 & 9.37 & $1.9 \%$ \\
\hline Total $\ldots \ldots \ldots \ldots \ldots \ldots \ldots \ldots \ldots \ldots \ldots \ldots \ldots$ & 87.26 & 94.61 & 99.37 & 103.88 & $1.0 \%$ \\
\hline Electricity Consumption (all sectors) $\ldots \ldots \ldots$ & 9.77 & 10.60 & 11.21 & 11.86 & $1.1 \%$ \\
\hline
\end{tabular}

IIncludes electricity generated by the sector for self-use from hydroelectric, geothermal, wood and wood waste, municipal solid waste, other biomass, wind, photovoltaic and solar thermal sources, and non-electric energy from renewable sources, such as solar thermal water heaters, ground-water heat pumps, and wood.

includes ethanol (blends of 10 percent or less) and ethers blended into gasoline.

${ }^{3}$ Includes liquefied petroleum gas and coal.

Includes commercial sector electricity cogenerated using wood and wood waste, municipal solid waste, and other biomass; non-electric energy from renewable sources, such as active solar and passive solar systems, geothermal heal pumps, and solar water heating systems.

${ }^{5}$ Fuel consumption includes consumption for cogeneration.

includes petroleum coke, asphalt, road oil, lubricants, still gas, and miscellaneous petroleum products.

'Includes lease and plant fuel.

Includes naphtha and kerosene type.

Includes aviation gas and lubricants.

${ }^{10}$ Only E85 (85 percent ethanol).

"Only M85 (85 percent methanol).

${ }^{12}$ Includes consumption of energy by all electric power generators except cogenerators, and generators with standard industrial classification other than 49 , both of which produce electricity as a by-product of other processes.

${ }^{13}$ Includes hydroelectric, geothermal, wood and wood waste, municipal solid waste, other biomass, wind, photovoltaic and solar thermal sources, plus net electricity imports.

${ }^{14}$ Includes unfinished oils, natural gasoline, motor gasoline blending compounds, aviation gasoline, lubricants, still gas, asphalt, road oil, and miscellaneous petroleum products.

${ }^{15}$ Includes electricity generated for sale to electric utilities and for self use from renewable sources, non-electric energy from renewable sources, net electricity imports, liquid hydrogen, and methanol.

Btu $=$ British thermal unit.

N/A $=$ Not applicable.

Note: Totals may not equal sum of components due to independent rounding. Figures for 1993 may differ from published data due to internal conversion factors in the AEO95 National Energy Modeling System.

Sources: 1993 natural gas lease, plant, and pipeline fuel values: Energy Information Administration (EIA), Natura/ Gas Monthly, DOE/EIA0130(94/6) (Washington, D.C., June 1994). 1993 transportation sector compressed natural gas consumption: EIA, AEO95 National Energy Modeling System run AEO95B.D1103942. 1993 coal consumption is estimated from EIA, State Energy Data Report 1992, DOE/EIA-0214(92) (Washington, D.C., May 1994). 1993 metallurgical consumption is estimated from this source using unpublished data. 1993 residential and commercial coal consumption tonnages are from EIA, Quarterly Coal Report, October-December 1993, DOE/EIA-0121(93/4Q) (Washington, D.C., May 1994) and have been converted to quadrillion Btu using State Energy Data Report 1992 thermal conversion factors. Other 1993 values: ElA, Short-Term Energy Outlook, DOE/EIA-0202(94/3Q) (Washington, D.C., August 1994) with adjustments to end-use consumption levels for consumption of natural gas by electric wholesale generators based on EIA, AEO95 National Energy Modeling System run AEO95B.D1103942. Projections: EIA, AEO95 National Energy Modeling System run AEO95B.D1103942. 
Table 11. Energy Prices by End-Use Sector and Source New England Census Division

(1993 Dollars per Million Btu)

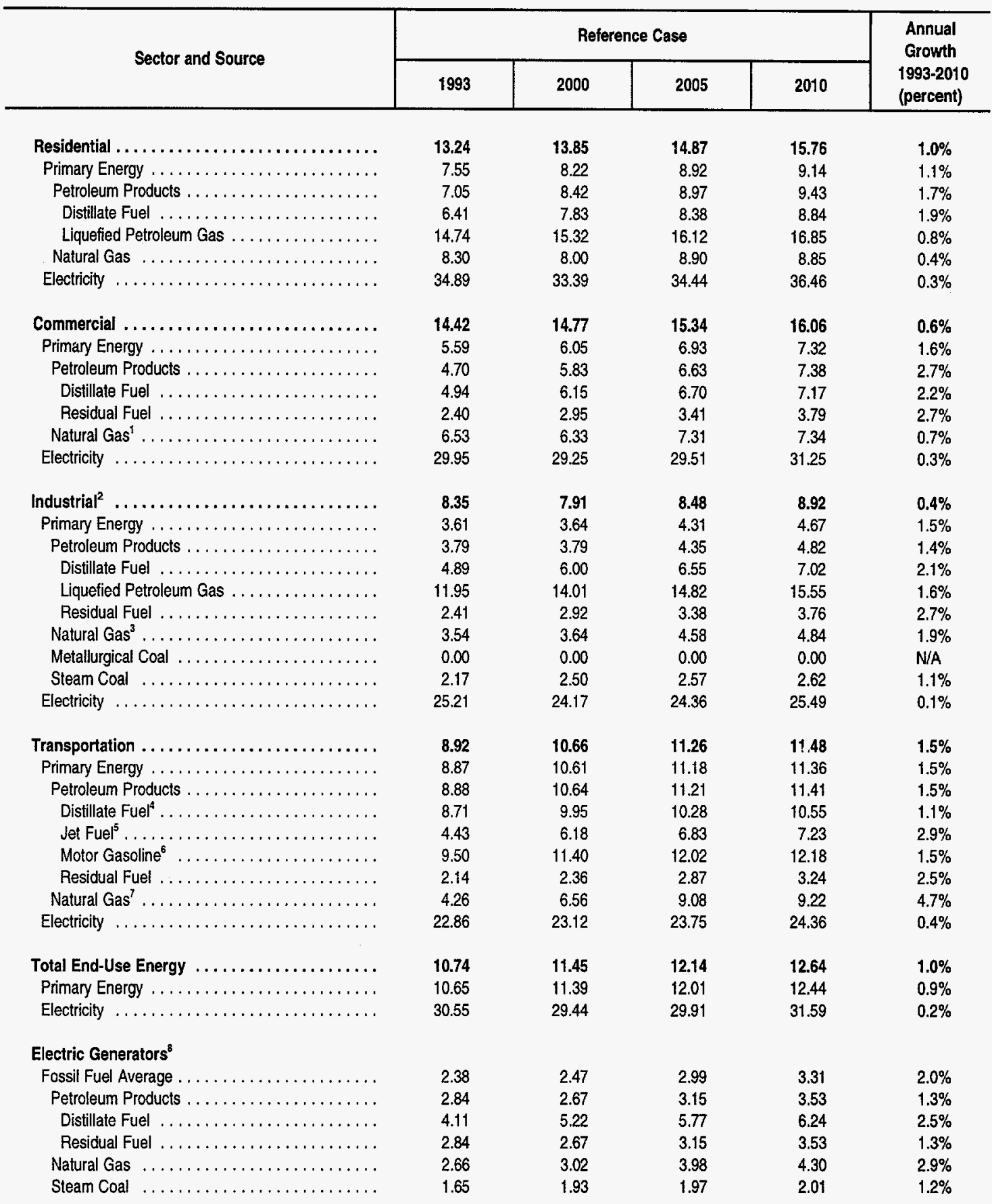


Table 11. Energy Prices by End-Use Sector and Source

New England Census Division (Continued)

(1993 Dollars per Million Btu)

\begin{tabular}{|c|c|c|c|c|c|}
\hline \multirow{2}{*}{ Sector and Source } & \multicolumn{4}{|c|}{ Reference Case } & \multirow{2}{*}{$\begin{array}{c}\text { Annual } \\
\text { Growth } \\
\text { 1993-2010 } \\
\text { (percent) }\end{array}$} \\
\hline & 1993 & 2000 & 2005 & 2010 & \\
\hline \multicolumn{6}{|l|}{ Average Price to All Users ${ }^{\mathrm{g}}$} \\
\hline Petroleum Products . . . . . . . . . . . . . . . & 7.01 & 8.37 & 8.67 & 9.07 & $1.5 \%$ \\
\hline Jet Fuel $\ldots \ldots \ldots \ldots \ldots \ldots \ldots \ldots \ldots$ & 4.43 & 6.18 & 6.83 & 7.23 & $2.9 \%$ \\
\hline Liquefied Petroleum Gas . . . . . . . . . . . . & 13.88 & 15.28 & 16.35 & 17.26 & $1.3 \%$ \\
\hline Motor Gasoline $e^{6} \ldots \ldots \ldots \ldots \ldots \ldots \ldots$ & 9.50 & 11.37 & 11.98 & 12.14 & $1.4 \%$ \\
\hline Residual Fuel $\ldots \ldots \ldots \ldots \ldots \ldots \ldots \ldots$ & 2.67 & 2.76 & 3.22 & 3.61 & $1.8 \%$ \\
\hline Natural Gas $\ldots \ldots \ldots \ldots \ldots \ldots \ldots$ & 5.92 & 5.75 & 6.68 & 6.64 & $0.7 \%$ \\
\hline Coal $\ldots \ldots \ldots \ldots \ldots \ldots \ldots \ldots \ldots$ & 1.73 & 2.02 & 2.08 & 2.12 & $1.2 \%$ \\
\hline
\end{tabular}

'Excludes independent power producers.

Includes cogenerators.

${ }^{3}$ Excludes uses for lease and plant fuel.

Includes Federal and State taxes on diesel fuel and excludes county and local taxes.

SKerosene-type jet fuel.

Average price for all grades. Includes Federal and State taxes and excludes county and local taxes.

${ }^{7}$ Compressed natural gas used as a vehicle fuel.

${ }^{8}$ Includes all electric power generators except cogenerators, which produce electricity as a by-product of other processes.

'Weighted averages of end-use fuel prices are derived from the prices shown in each sector and the corresponding sectoral consumption.

Btu = British thermal unit.

Note: 1993 figures may differ from published data due to internal rounding in the AEO95 National Energy Modeling System.

Sources: 1993 prices for gasoline, distillate, and jet fuel are based on prices in various 1993 issues of Energy Information Administration (ElA), Petroleum Marketing Monthly, DOE/EIA-0380(93/1-12) (Washington, D.C., 1993). 1993 prices for all other petroleum praducts are derived from the EIA, State Energy Price and Expenditure Report 1991, DOE/EIA-0376(91) (Washington, D.C., September 1993). 1993 residential natural gas delivered prices: EIA, Natural Gas Monthly, DOE/EIA-0130(94/6) (Washington, D.C., June 1994). Other 1993 natural gas delivered prices: EIA, AEO95 National Energy Modeling System run AEO95B.D1103942. Values for 1993 coal prices have been estimated from EIA, State Energy Price and Expenditure Report 1992, DOE/EIA-0376(92) (Washington, D.C., December 1994) using consumption quantities aggregated from ElA, State Energy Data Report 1992, DOE/EIA-0214(92) (Washington, D.C., May 1994). 1993 electricity prices for commercial, industrial, and transportation: EIA, AEO95 National Energy Modeling System run AEO95B.D1103942. Projections: EIA, AEO95 National Energy Modeling System run AEO95B.D1103942. 
Table 12. Energy Prices by End-Use Sector and Source Middle Atlantic Census Division

(1993 Dollars per Million Btu)

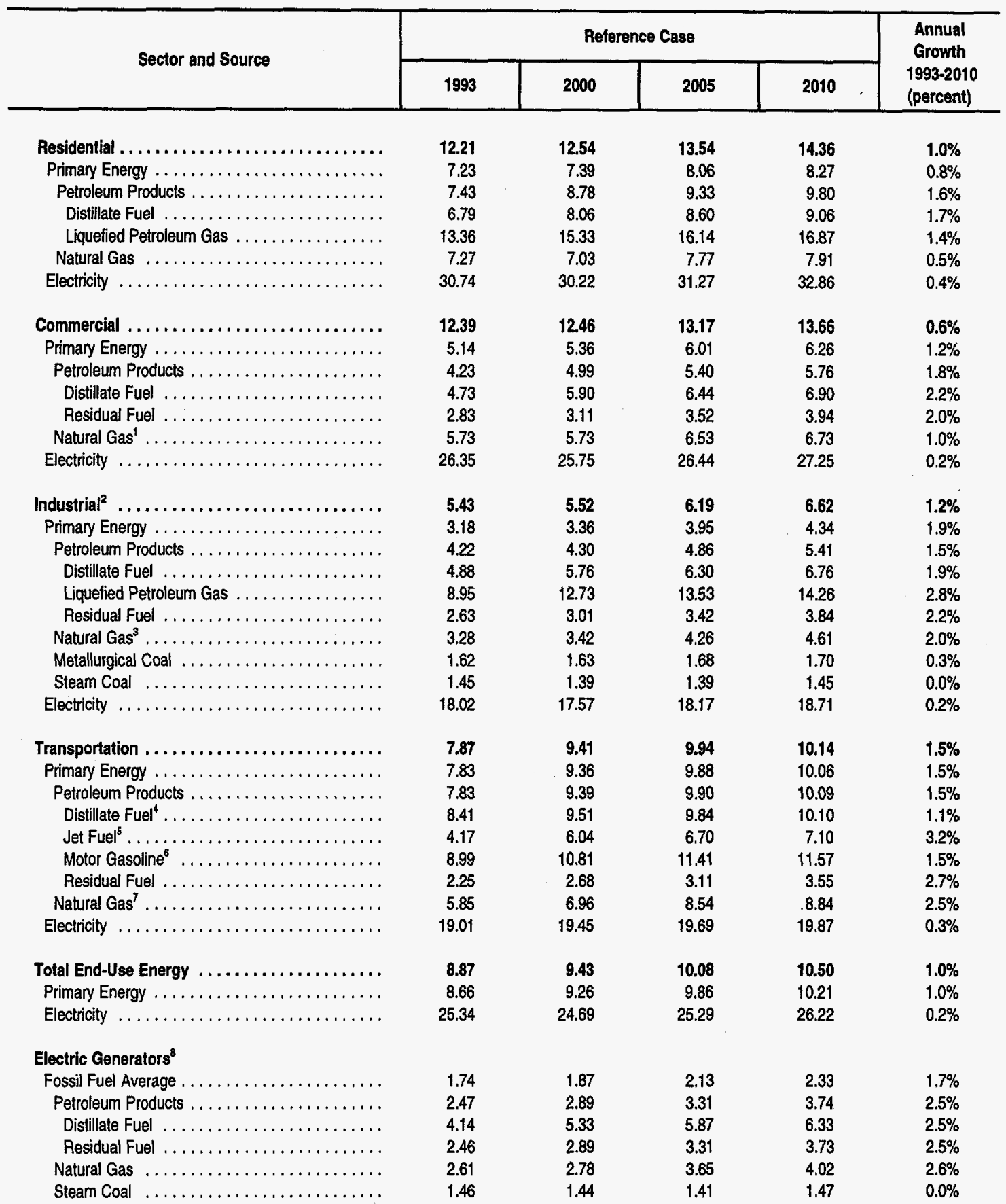


Table 12. Energy Prices by End-Use Sector and Source

Middle Atlantic Census Division (Continued)

(1993 Dollars per Million Btu)

\begin{tabular}{|c|c|c|c|c|c|}
\hline \multirow{2}{*}{ Sector and Source } & \multicolumn{4}{|c|}{ Reference Case } & \multirow{2}{*}{$\begin{array}{c}\text { Annual } \\
\text { Growth } \\
1993-2010 \\
\text { (percent) }\end{array}$} \\
\hline & 1993 & 2000 & 2005 & 2010 & \\
\hline \multicolumn{6}{|l|}{ Average Price to All Users' } \\
\hline Jet Fuel $\ldots \ldots \ldots \ldots \ldots \ldots \ldots \ldots \ldots$ & 4.17 & 6.04 & 6.70 & 7.10 & $3.2 \%$ \\
\hline Liquefied Pelroleum Gas . . . . . . . . . . . . & 10.91 & 14.15 & 15.13 & 15.99 & $2.3 \%$ \\
\hline Molor Gasoline ${ }^{\mathrm{G}} \ldots \ldots \ldots \ldots \ldots \ldots \ldots$ & 8.99 & 10.80 & 11.40 & 11.55 & $1.5 \%$ \\
\hline Residual Fuel . . . . . . . . & 2.50 & 2.90 & 3.31 & 3.73 & $2.4 \%$ \\
\hline Natural Gas $\ldots \ldots \ldots \ldots \ldots \ldots \ldots \ldots$ & 5.40 & 5.24 & 5.98 & 6.14 & $0.8 \%$ \\
\hline
\end{tabular}

'Excludes independent power producers.

includes cogenerators.

${ }^{3}$ Excludes uses for lease and plant fuel.

includes Federal and State taxes on diesel fuel and excludes county and local taxes.

${ }^{5}$ Kerosene-type jet fuel.

Average price for all grades. Includes Federal and State taxes and excludes county and local taxes.

'Compressed natural gas used as a vehicle fuel.

Includes all electric power generators except cogenerators, which produce electricity as a by-product of other processes.

'Weighted averages of end-use fuel prices are derived from the prices shown in each sector and the corresponding sectoral consumption.

Btu $=$ British thermal unit.

Note: 1993 figures may differ from published data due to internal rounding in the AEO95 National Energy Modeling System.

Sources: 1993 prices for gasoline, distillate, and jet fuel are based on prices in various 1993 issues of Energy Information Administration (ElA), Petroleum Marketing Monthly, DOE/EIA-0380(93/1-12) (Washington, D.C., 1993). 1993 prices for all other petroleum products are derived from the EIA, State Energy Price and Expenditure Report 1991, DOE/EIA-0376(91) (Washington, D.C., September 1993). 1993 residential natural gas delivered prices: EIA, Natural Gas Monthly, DOE/EIA-0130(94/6) (Washington, D.C., June 1994). Other 1993 natural gas delivered prices: ElA, AEO95 National Energy Modeling System run AEO95B.D1103942. Values for 1993 coal prices have been estimated from EIA, State Energy Price and Expenditure Report 1992, DOE/EIA-0376(92) (Washington, D.C., December 1994) using consumption quantities aggregated from ElA, State Energy Data Report 1992, DOE/EIA-0214(92) (Washington, D.C., May 1994). 1993 electricity prices for commercial, industrial, and transportation: EIA, AEO95 National Energy Modeling System run AEO958.D1103942. Projections: EIA, AEO95 National Energy Modeling System run AEO95B.D1103942. 
Table 13. Energy Prices by End-Use Sector and Source East North Central Census Division (1993 Dollars per Million Btu)

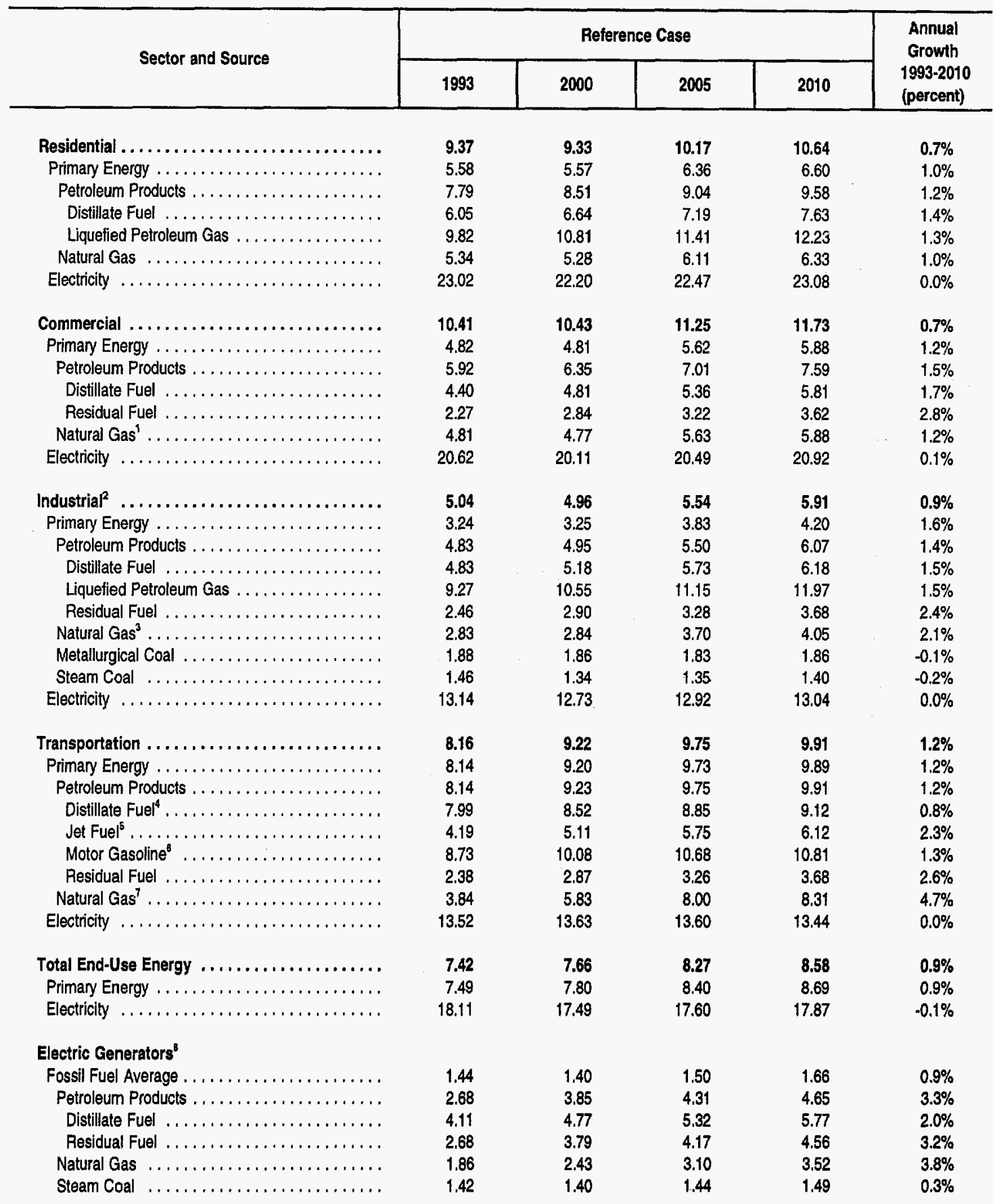


Table 13. Energy Prices by End-Use Sector and Source

East North Central Census Division (Continued)

(1993 Dollars per Million Btu)

\begin{tabular}{|c|c|c|c|c|c|}
\hline \multirow{2}{*}{ Sector and Source } & \multicolumn{4}{|c|}{ Reference Case } & \multirow{2}{*}{$\begin{array}{c}\text { Annual } \\
\text { Growth } \\
\text { 1993-2010 } \\
\text { (percent) }\end{array}$} \\
\hline & 1993 & 2000 & 2005 & 2010 & \\
\hline \multicolumn{6}{|l|}{ Average Price to All Users ${ }^{9}$} \\
\hline Petroleum Products ...... & 7,33 & 8.22 & 8.73 & 9.01 & $1.2 \%$ \\
\hline Distillate Fuel $\left.\right|^{4} \ldots$ & 7.01 & 7.59 & 8.02 & 8.37 & $1.0 \%$ \\
\hline Jet Fuel $\ldots \ldots \ldots \ldots \ldots \ldots \ldots \ldots \ldots$ & 4.19 & 5.11 & 5.75 & 6.12 & $2.3 \%$ \\
\hline Liquefied Petroleum Gas ................. & 9.49 & 10.81 & 11.54 & 12.46 & $1.6 \%$ \\
\hline Motor Gasoline ${ }^{6} \ldots . .$. & 8.73 & 10.05 & 10.66 & 10.79 & $1.3 \%$ \\
\hline Residual Fuel . ........... & 2.54 & 2.91 & 3.40 & 3.74 & $2.3 \%$ \\
\hline Natural Gas $\ldots \ldots \ldots \ldots \ldots \ldots \ldots \ldots$ & 4.27 & 4.20 & 4.98 & 5.14 & $1.1 \%$ \\
\hline 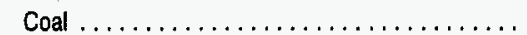 & 1.46 & 1.39 & 1.43 & 1.48 & $0.1 \%$ \\
\hline Electricity $\ldots \ldots \ldots \ldots \ldots \ldots \ldots \ldots \ldots$ & 18.11 & 17.49 & 17.60 & 17.87 & $-0.1 \%$ \\
\hline
\end{tabular}

'Excludes independent power producers.

${ }^{2}$ Includes cogenerators.

${ }^{3}$ Excludes uses for lease and plant fuel.

Includes Federal and State taxes on diesel fuel and excludes county and local taxes.

SKerosene-type jet fuel.

Average price for all grades. Includes Federal and State taxes and excludes county and local taxes.

${ }^{7}$ Compressed natural gas used as a vehicle fuel.

Includes all electric power generators except cogenerators, which produce electricity as a by-product of other processes.

Weighted averages of end-use fuel prices are derived from the prices shown in each sector and the corresponding sectoral consumption.

Btu $=$ British thermal unit.

Note: 1993 figures may differ from published data due to internal rounding in the AEO95 National Energy Modeling System.

Sources: 1993 prices for gasoline, distillate, and jet fuel are based on prices in various 1993 issues of Energy information Administration (EIA), Petroleum Marketing Monthly, DOE/EIA-0380(93/1-12) (Washington, D.C., 1993). 1993 prices for all other petroleum products are derived from the EIA, State Energy Price and Expenditure Report 1991, DOE/EIA-0376(91) (Washington, D.C., September 1993). 1993 residential natural gas delivered prices: EIA, Natural Gas Monthly, DOE/EIA-0130(94/6) (Washington, D.C., June 1994). Other 1993 natural gas delivered prices: EIA, AEO95 National Energy Modeling System run AEO95B.D1103942. Values for 1993 coal prices have been estimated from EIA, State Energy Price and Expenditure Report 1992, DOE/EIA-0376(92) (Washington, D.C., December 1994) using consumption quantities aggregated from EIA, State Energy Data Report 1992, DOE/EIA-0214(92) (Washington, D.C., May 1994). 1993 electricity prices for commercial, industrial, and transportation: EIA, AEO95 National Energy Modeling System run AEO95B.D1103942. Projections: EIA, AEO95 National Energy Modeling System run AEO95B.D1103942. 
Table 14. Energy Prices by End-Use Sector and Source West North Central Census Division (1993 Dollars per Million Btu)

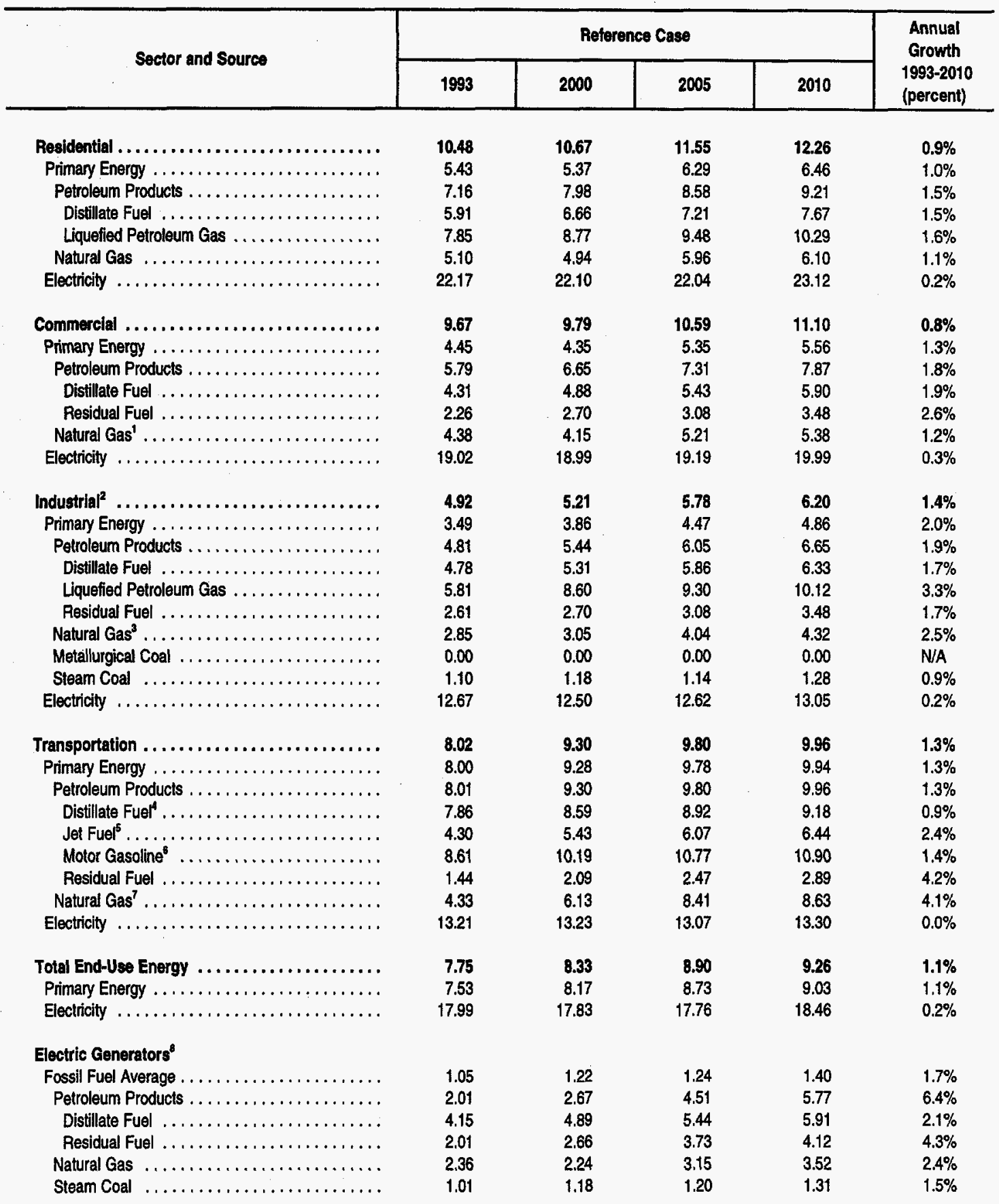


Table 14. Energy Prices by End-Use Sector and Source West North Central Census Division (Continued) (1993 Dollars per Million Btu)

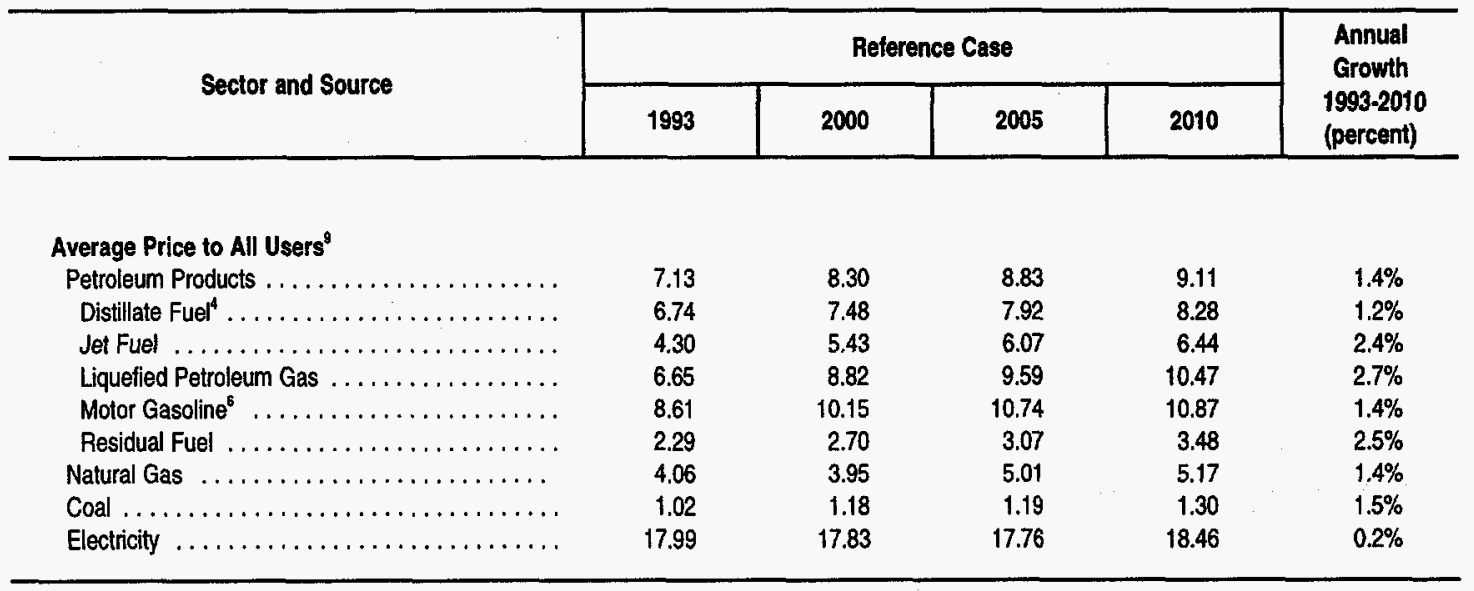

'Excludes independent power producers.

${ }^{2}$ Includes cogenerators.

${ }^{3}$ Excludes uses for lease and plant fuel.

"Includes Federal and State taxes on diesel fuel and excludes county and local taxes.

5Kerosene-type jet fuel.

'Average price for all grades. Includes Federal and State taxes and excludes county and local taxes.

'Compressed natural gas used as a vehicle fuel.

${ }^{9}$ Includes all electric power generators except cogenerators, which produce electricity as a by-product of other processes.

'Weighted averages of end-use fuel prices are derived from the prices shown in each sector and the corresponding sectoral consumption. Btu $=$ British thermal unit.

Note: 1993 figures may differ from published data due to internal rounding in the AEO95 National Energy Modeling System.

Sources: 1993 prices for gasoline, distillate, and jet fuel are based on prices in various 1993 issues of Energy Information Administration (ElA), Petroleum Marketing Monthly, DOE/EIA-0380(93/1-12) (Washington, D.C., 1993). 1993 prices for all other petroleum products are derived from the EIA, State Energy Price and Expenditure Report 1991, DOE/EIA-0376(91) (Washington, D.C., September 1993). 1993 residential natural gas delivered prices: EIA, Natural Gas Monthly, DOE/EIA-0130(94/6) (Washington, D.C., June 1994). Other 1993 natural gas delivered prices: EIA, AEO95 National Energy Modeling System run AEO95B.D1 103942. Values for 1993 coal prices have been estimated from ElA, State Energy Price and Expenditure Report 1992, DOE/EIA-0376(92) (Washington, D.C., December 1994) using consumption quantities aggregated from ElA, State Energy Data Report 1992, DOE/EIA-0214(92) (Washington, D.C., May 1994). 1993 electricity prices for commercial, industrial, and transportation: EIA, AEO95 National Energy Modeling System run AEO95B.D1103942. Projections: EIA, AEO95 National Energy Modeling System run AEO95B.D1103942. 
Table 15. Energy Prices by End-Use Sector and Source South Atlantic Census Division (1993 Dollars per Million Btu)

\begin{tabular}{|c|c|c|c|c|c|}
\hline \multirow{2}{*}{ Sector and Source } & \multicolumn{4}{|c|}{ Reference Case } & \multirow{2}{*}{$\begin{array}{c}\text { Annual } \\
\text { Growth } \\
1993-2010 \\
\text { (percent) }\end{array}$} \\
\hline & 1993 & 2000 & 2005 & 2010 & \\
\hline 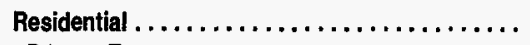 & 16.11 & 16.32 & 17.05 & 18.04 & $0.7 \%$ \\
\hline Primary Energy $\ldots \ldots \ldots \ldots \ldots \ldots \ldots \ldots$ & 7.41 & 7.59 & 8.13 & 8.41 & $0.7 \%$ \\
\hline Liquefied Petroleum Gas . . . . . . . . . . . . . . & 10.74 & 13.49 & 14.09 & 14.91 & $1.9 \%$ \\
\hline Natural Gas $\ldots \ldots \ldots \ldots \ldots \ldots \ldots \ldots$ & 7.01 & 6.68 & 7.30 & 7.58 & $0.5 \%$ \\
\hline Electricity,$\ldots \ldots \ldots \ldots \ldots \ldots \ldots$ & 22.99 & 22.68 & 23.17 & 24.19 & $0.3 \%$ \\
\hline Commercial...$\ldots \ldots \ldots \ldots \ldots \ldots \ldots \ldots$ & 13.66 & 13.97 & 14.58 & 15.27 & $0.7 \%$ \\
\hline Residual Fuel $\ldots \ldots \ldots \ldots \ldots \ldots \ldots \ldots$ & 2.40 & 2.99 & 3.39 & 3.82 & $2.8 \%$ \\
\hline Natural Gas ${ }^{3} \ldots \ldots \ldots \ldots \ldots \ldots \ldots$ & 5.56 & 5.33 & 6.01 & 6.36 & $0.8 \%$ \\
\hline Electricity $\ldots \ldots \ldots \ldots \ldots \ldots \ldots \ldots$ & 19.53 & 19.50 & 19.91 & 20.61 & $0.3 \%$ \\
\hline Industrial $^{2} \ldots \ldots \ldots \ldots \ldots \ldots \ldots \ldots$ & 5.69 & 5.89 & 6.41 & 6.88 & $1.1 \%$ \\
\hline Primary Energy $\ldots \ldots \ldots \ldots \ldots \ldots \ldots \ldots$ & 3.06 & 3.22 & 3.73 & 4.13 & $1.8 \%$ \\
\hline Petroleum Products $\ldots \ldots \ldots \ldots \ldots \ldots \ldots$ & 4.00 & 4.41 & 4.91 & 5.48 & $1.9 \%$ \\
\hline Distillate Fuel $\ldots \ldots \ldots \ldots \ldots \ldots \ldots \ldots$ & 4.62 & 5.53 & 6.08 & 6.55 & $2.1 \%$ \\
\hline Liquefied Petroleum Gas . . . . . . . . . . . . . & 9.10 & 12.02 & 12.63 & 13.44 & $2.3 \%$ \\
\hline Residual Fuel $\ldots \ldots \ldots \ldots \ldots \ldots \ldots \ldots$ & 2.20 & 2.91 & 3.32 & 3.74 & $3.2 \%$ \\
\hline Natural Gas ${ }^{3} \ldots \ldots \ldots \ldots \ldots \ldots \ldots$ & 2.79 & 2.90 & 3.69 & 4.11 & $2.3 \%$ \\
\hline Metallurgical Coal $\ldots \ldots \ldots \ldots \ldots \ldots \ldots \ldots$ & 8.26 & 1.36 & 1.43 & 1.44 & $-9.8 \%$ \\
\hline Steam Coal $\ldots \ldots \ldots \ldots \ldots \ldots \ldots \ldots$ & 0.32 & 1.62 & 1.68 & 1.71 & $10.3 \%$ \\
\hline Electricity $\ldots \ldots \ldots \ldots \ldots \ldots \ldots \ldots$ & 14.88 & 14.95 & 15.21 & 15.70 & $0.3 \%$ \\
\hline Transportation ....................... & 7.67 & 8.98 & 9.49 & 9.67 & $1.4 \%$ \\
\hline Primary Energy $\ldots \ldots \ldots \ldots \ldots \ldots \ldots \ldots$ & 7.66 & 8.96 & 9.47 & 9.64 & $1.4 \%$ \\
\hline Petroleum Products $\ldots \ldots \ldots \ldots \ldots \ldots \ldots \ldots$ & 7.66 & 8.98 & 9.49 & 9.66 & $1.4 \%$ \\
\hline Distillate Fuel ${ }^{4} \ldots \ldots \ldots \ldots \ldots \ldots \ldots \ldots$ & 7.51 & 8.61 & 8.93 & 9.20 & $1.2 \%$ \\
\hline Jet Fuel ${ }^{5}, \ldots \ldots \ldots \ldots \ldots \ldots \ldots \ldots$ & 4.19 & 5.41 & 6.05 & 6.45 & $2.6 \%$ \\
\hline Motor Gasoline ${ }^{8} \ldots \ldots \ldots \ldots \ldots \ldots$ & 8.48 & 9.99 & 10.60 & 10.74 & $1.4 \%$ \\
\hline Residual Fuel $\ldots \ldots \ldots \ldots \ldots \ldots \ldots \ldots$ & 1.90 & 2.36 & 2.78 & 3.22 & $3.2 \%$ \\
\hline Natural Gas ${ }^{7} \ldots \ldots \ldots \ldots \ldots \ldots \ldots \ldots$ & 4.87 & 6.43 & 8.13 & 8.57 & $3.4 \%$ \\
\hline Electricity $\ldots \ldots \ldots \ldots \ldots \ldots \ldots \ldots$ & 12.91 & 13,70 & 13.62 & 13.55 & $0.3 \%$ \\
\hline Total End-Use Energy . .................. & 9.52 & 10.16 & 10.69 & 11.17 & $0.9 \%$ \\
\hline Primary Energy $\ldots \ldots \ldots \ldots \ldots \ldots \ldots \ldots$ & 8.29 & 9.06 & 9.56 & 9.88 & $1.0 \%$ \\
\hline Electricity,$\ldots \ldots \ldots \ldots \ldots \ldots \ldots \ldots$ & 19.62 & 19.48 & 19.81 & 20.56 & $0.3 \%$ \\
\hline \multicolumn{6}{|l|}{ Electric Generators ${ }^{8}$} \\
\hline Fossil Fuel Average $\ldots \ldots \ldots \ldots \ldots \ldots \ldots \ldots$ & 1.75 & 1.81 & 2.11 & 2.38 & $1,8 \%$ \\
\hline Petroleum Products $\ldots \ldots \ldots \ldots \ldots \ldots \ldots \ldots$ & 2.18 & 2.59 & 3.08 & 3.67 & $3.1 \%$ \\
\hline Distillate Fuel $\ldots \ldots \ldots \ldots \ldots \ldots \ldots$ & 4.01 & 4.83 & 5.38 & 5.85 & $2.2 \%$ \\
\hline Residual Fuel $\ldots \ldots \ldots \ldots \ldots \ldots \ldots \ldots$ & 2.18 & 2.59 & 3.04 & 3.48 & $2.8 \%$ \\
\hline Natural Gas $\ldots \ldots \ldots \ldots \ldots \ldots \ldots \ldots$ & 2.44 & 2.69 & 3.46 & 3.86 & $2.8 \%$ \\
\hline Steam Coal $\ldots \ldots \ldots \ldots \ldots \ldots \ldots \ldots$ & 1.64 & 1.61 & 1.71 & 1.72 & $0.3 \%$ \\
\hline
\end{tabular}


Table 15. Energy Prices by End-Use Sector and Source

South Atlantic Census Division (Continued)

(1993 Dollars per Million Btu)

\begin{tabular}{|c|c|c|c|c|c|}
\hline \multirow{2}{*}{ Sector and Source } & \multicolumn{4}{|c|}{ Reference Case } & \multirow{2}{*}{$\begin{array}{c}\text { Annual } \\
\text { Growth } \\
1993-2010 \\
\text { (percent) }\end{array}$} \\
\hline & 1993 & 2000 & 2005 & 2010 & \\
\hline \multicolumn{6}{|l|}{ Average Price to All Users ${ }^{9}$} \\
\hline Petroleum Products ...... & 6.63 & 7.92 & 8.33 & 8.55 & $1.5 \%$ \\
\hline Distillate Fuel ${ }^{4} \ldots \ldots \ldots \ldots \ldots \ldots \ldots$ & 6.90 & 8.01 & 8.40 & 8.66 & $1.3 \%$ \\
\hline Jet Fuel $\ldots \ldots \ldots \ldots \ldots \ldots \ldots \ldots \ldots$ & 4.19 & 5.41 & 6.05 & 6.45 & $2.6 \%$ \\
\hline Liquefied Petroleum Gas ................ & 10.06 & 13.05 & 13.77 & 14.66 & $2.2 \%$ \\
\hline Motor Gasoline ${ }^{6} \ldots . .$. & 8.48 & 9.98 & 10.58 & 10.73 & $1.4 \%$ \\
\hline Residual Fuel $\ldots \ldots \ldots \ldots \ldots \ldots \ldots \ldots$ & 2.14 & 2.61 & 3.04 & 3.47 & $2.9 \%$ \\
\hline Natural Gas $\ldots \ldots \ldots \ldots \ldots \ldots \ldots \ldots$ & 4.36 & 4.15 & 4.76 & 4.98 & $0.8 \%$ \\
\hline 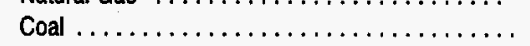 & 1.64 & 1.61 & 1.71 & 1.72 & $0.3 \%$ \\
\hline Electricity $\ldots \ldots \ldots \ldots \ldots \ldots \ldots \ldots \ldots$ & 19.62 & 19.48 & 19.81 & 20.56 & $0.3 \%$ \\
\hline
\end{tabular}

'Excludes independent power producers.

2Includes cogenerators.

${ }^{3}$ Excludes uses for lease and plant fuel.

Includes Federal and State taxes on diesel fuel and excludes county and local taxes.

5erosene-type jet fuel.

Average price for all grades. Includes Federal and State taxes and excludes county and local taxes.

'Compressed natural gas used as a vehicle fuel.

Includes all electric power generalors except cogenerators, which produce electricity as a by-product of other processes.

Weighted averages of end-use fuel prices are derived from the prices shown in each sector and the corresponding sectoral consumption.

Btu = British thermal unit.

Note: 1993 figures may differ from published data due to internal rounding in the AEO95 National Energy Modeling System.

Sources: 1993 prices for gasoline, distillate, and jet fuel are based on prices in various 1993 issues of Energy information Administration (ElA), Petroleum Marketing Monthly, DOE/ElA-0380(93/1-12) (Washington, D.C., 1993). 1993 prices for all other petroleum products are derived from the EIA, State Energy Price and Expenditure Report 1991, DOE/EIA-0376(91) (Washington, D.C., September 1993). 1993 residential natural gas delivered prices: EIA, Natural Gas Monthly, DOE/EIA-0130(94/6) (Washington, D.C., June 1994). Other 1993 natural gas delivered prices: EIA, AEO95 National Energy Modeling System run AEO95B.D1103942. Values for 1993 coal prices have been estimated from EIA, State Energy Price and Expenditure Report 1992, DOE/EIA-0376(92) (Washington, D.C., December 1994) using consumption quantities aggregated from EIA, State Energy Data Report 1992, DOE/EIA-0214(92) (Washington, D.C., May 1994). 1993 electricity prices for commercial; industrial, and transportation: EIA, AEO95 National Energy Modeling System run AEO95B.D1103942. Projections: EIA, AEO95 National Energy Modeling System run AEO95B.D1103942. 
Table 16. Energy Prices by End-Use Sector and Source East South Central Census Division (1993 Dollars per Million Btu)

\begin{tabular}{|c|c|c|c|c|c|}
\hline \multirow{2}{*}{ Sector and Source } & \multicolumn{4}{|c|}{ Reference Case } & \multirow{2}{*}{$\begin{array}{c}\text { Annual } \\
\text { Growth } \\
1993-2010 \\
\text { (percent) }\end{array}$} \\
\hline & 1993 & 2000 & 2005 & 2010 & \\
\hline Residential . . . . . . . . . . . . . . . . . . . . . & 14.54 & 14.32 & 14.88 & 15.57 & $0.4 \%$ \\
\hline Primary Energy $\ldots \ldots \ldots \ldots \ldots \ldots \ldots \ldots \ldots$ & 6.15 & 6.35 & 6.93 & 7.23 & $1.0 \%$ \\
\hline Distillate Fuel $\ldots \ldots \ldots \ldots \ldots \ldots \ldots \ldots$ & 5.81 & 6.85 & 7.40 & 7.85 & $1.8 \%$ \\
\hline Liquefied Petroleum Gas . .............. & 10.38 & 11.78 & 12.51 & 13.30 & $1.5 \%$ \\
\hline Natural Gas $\ldots \ldots \ldots \ldots \ldots \ldots \ldots \ldots$ & 5.65 & 5.75 & 6.37 & 6.66 & $1.0 \%$ \\
\hline Electricity $\ldots \ldots \ldots \ldots \ldots \ldots \ldots \ldots \ldots$ & 21.83 & 20.93 & 21.19 & 21.85 & $0.0 \%$ \\
\hline 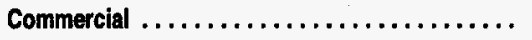 & 11.16 & 11.40 & 11.85 & 12.25 & $0.6 \%$ \\
\hline Petroleum Products . . . . . . . . . . . . . & 5.70 & 6.41 & 7.03 & 7.51 & $1.6 \%$ \\
\hline Distillate Fuel $\ldots \ldots \ldots \ldots \ldots \ldots \ldots \ldots$ & 4.11 & 5.06 & 5.61 & 6.06 & $2.3 \%$ \\
\hline Residual Fuel $\ldots \ldots \ldots \ldots \ldots \ldots \ldots$ & 3.18 & 2.84 & 3.21 & 3.63 & $0.8 \%$ \\
\hline Natural Gas $^{1} \ldots \ldots \ldots \ldots \ldots \ldots \ldots$ & 4.97 & 5.09 & 5.74 & 6.06 & $1.2 \%$ \\
\hline Electricity $\ldots \ldots \ldots \ldots \ldots \ldots \ldots \ldots$ & 19.17 & 18.78 & 18.89 & 19.21 & $0.0 \%$ \\
\hline Industrial $^{2} \ldots \ldots \ldots \ldots \ldots \ldots \ldots \ldots \ldots$ & 5.43 & 5.61 & 6.08 & 6.45 & $1.0 \%$ \\
\hline Primary Energy $\ldots \ldots \ldots \ldots \ldots \ldots \ldots$ & 3.15 & 3.31 & 3.83 & 4.22 & $1.7 \%$ \\
\hline Petroleum Products $\ldots \ldots \ldots \ldots \ldots \ldots \ldots \ldots$ & 4.68 & 4.79 & 5.33 & 5.91 & $1.4 \%$ \\
\hline Distillate Fuel $\ldots \ldots \ldots \ldots \ldots \ldots \ldots$ & 4.50 & 5.39 & 5.94 & 6.38 & $2.1 \%$ \\
\hline Liquefied Petroleum Gas . . . . . . . . . . . . & 9.31 & 9.04 & 9.77 & 10.56 & $0.7 \%$ \\
\hline Residual Fuel $\ldots \ldots \ldots \ldots \ldots \ldots \ldots \ldots$ & 2.62 & 2.97 & 3.35 & 3.76 & $2.2 \%$ \\
\hline Natural Gas $^{3} \ldots \ldots \ldots \ldots \ldots \ldots \ldots$ & 2.79 & 3.02 & 3.77 & 4.18 & $2.4 \%$ \\
\hline Metallurgical Coal $\ldots \ldots \ldots \ldots \ldots \ldots \ldots$ & 1.73 & 1.62 & 1.68 & 1.70 & $-0.1 \%$ \\
\hline Steam Coal $\ldots \ldots \ldots \ldots \ldots \ldots \ldots$ & 1.40 & 1.52 & 1.58 & 1.60 & $0.8 \%$ \\
\hline Electricity $\ldots \ldots \ldots \ldots \ldots \ldots \ldots \ldots$ & 12.75 & 12.43 & 12.42 & 12.54 & $-0.1 \%$ \\
\hline Transportation ...................... & 7.76 & 9.09 & 9.57 & 9.73 & $1.3 \%$ \\
\hline Primary Energy $\ldots \ldots \ldots \ldots \ldots \ldots \ldots$ & 7.75 & 9.08 & 9.56 & 9.72 & $1.3 \%$ \\
\hline Petroleum Products $\ldots \ldots \ldots \ldots \ldots \ldots \ldots \ldots$ & 7.75 & 9.09 & 9.57 & 9.73 & $1.3 \%$ \\
\hline Distillate Fuel ${ }^{4} \ldots \ldots \ldots \ldots \ldots \ldots \ldots \ldots$ & 7.59 & 8.44 & 8.77 & 9.03 & $1.0 \%$ \\
\hline Jet Fuel ${ }^{s} \ldots \ldots \ldots \ldots \ldots \ldots \ldots \ldots \ldots$ & 4.19 & 5.73 & 6.38 & 6.74 & $2.8 \%$ \\
\hline Motor Gasoline ${ }^{6} \ldots \ldots \ldots \ldots \ldots \ldots$ & 8.66 & 10.31 & 10.91 & 11.05 & $1.4 \%$ \\
\hline Residual Fuel $\ldots \ldots \ldots \ldots \ldots \ldots \ldots \ldots$ & 1.54 & 1.80 & 2.20 & 2.62 & $3.2 \%$ \\
\hline Natural $\operatorname{Gas}^{7} \ldots \ldots \ldots \ldots \ldots \ldots \ldots \ldots$ & 5.75 & 6.84 & 8.17 & 8.58 & $2.4 \%$ \\
\hline Electricity $\ldots \ldots \ldots \ldots \ldots \ldots \ldots \ldots \ldots$ & 12.31 & 12.80 & 12.61 & 12.48 & $0.1 \%$ \\
\hline Total End-Use Energy . . . . . . . . . . . . . . . & 8.16 & 8.68 & 9.12 & 9.45 & $0.9 \%$ \\
\hline Primary Energy $\ldots \ldots \ldots \ldots \ldots \ldots \ldots \ldots$ & 7.51 & 8.22 & 8.68 & 8.94 & $1.0 \%$ \\
\hline Electricity $\ldots \ldots \ldots \ldots \ldots \ldots \ldots \ldots$ & 16.89 & 16.26 & 16.22 & 16.50 & $-0.1 \%$ \\
\hline \multicolumn{6}{|l|}{ Electric Generators ${ }^{8}$} \\
\hline Fossil Fuel Average . . . . . . . . . . . . . & 1.42 & 1.32 & 1.39 & 1.49 & $0.3 \%$ \\
\hline Petroleum Products $\ldots \ldots \ldots \ldots \ldots \ldots \ldots$ & 1.80 & 2.72 & 3.16 & 3.56 & $4.1 \%$ \\
\hline Distillate Fuel $\ldots \ldots \ldots \ldots \ldots \ldots \ldots \ldots$ & 4.32 & 5.37 & 5.92 & 6.37 & $2.3 \%$ \\
\hline Residual Fuel $\ldots \ldots \ldots \ldots \ldots \ldots \ldots$ & 1.80 & 2.72 & 3.16 & 3.56 & $4.1 \%$ \\
\hline Natural Gas $\ldots \ldots \ldots \ldots \ldots \ldots \ldots$ & 2.42 & 2.36 & 3.30 & 3.76 & $2.6 \%$ \\
\hline Steam Coal $\ldots \ldots \ldots \ldots \ldots \ldots \ldots \ldots$ & 1.39 & 1.28 & 1.29 & 1.33 & $-0.2 \%$ \\
\hline
\end{tabular}


Table 16. Energy Prices by End-Use Sector and Source East South Central Census Division (Continued) (1993 Dollars per Million Btu)

\begin{tabular}{|c|c|c|c|c|c|}
\hline \multirow{2}{*}{ Sector and Source } & \multicolumn{4}{|c|}{ Reference Case } & \multirow{2}{*}{$\begin{array}{l}\text { Annual } \\
\text { Growth } \\
1993-2010 \\
\text { (percent) }\end{array}$} \\
\hline & 1993 & 2000 & 2005 & 2010 & \\
\hline \multicolumn{6}{|l|}{ Average Price to All Users" } \\
\hline Distillate Fuel ${ }^{4} \ldots \ldots \ldots \ldots \ldots \ldots \ldots \ldots$ & 6.79 & 7.71 & 8.10 & 8.42 & $1.3 \%$ \\
\hline Jet Fuel $\ldots \ldots \ldots \ldots \ldots \ldots \ldots \ldots \ldots$ & 4.19 & 5.73 & 6.38 & 6.74 & $2.8 \%$ \\
\hline Liquefied Petroleum Gas . . . . . . . . . . . . . & 9.74 & 10.20 & 10.96 & 11.77 & $1.1 \%$ \\
\hline Motor Gasoline $^{6} \ldots \ldots \ldots \ldots \ldots \ldots \ldots$ & 8.66 & 10.29 & 10.89 & 11.03 & $1.4 \%$ \\
\hline Residual Fuel $\ldots \ldots \ldots \ldots \ldots \ldots \ldots \ldots$ & 1.76 & 2.11 & 2.55 & 2.98 & $3.1 \%$ \\
\hline Natural Gas $\ldots \ldots \ldots \ldots \ldots \ldots \ldots \ldots$ & 3.77 & 3.93 & 4.67 & 5.01 & $1.7 \%$ \\
\hline
\end{tabular}

'Excludes independent power producers.

IIncludes cogenerators.

${ }^{3}$ Excludes uses for lease and plant fuel.

"Includes Federal and State taxes on diesel fuel and excludes county and local taxes.

${ }^{5}$ Kerosene-type jet fuel.

${ }^{B}$ Average price for all grades. Includes Federal and State taxes and excludes county and local taxes.

${ }^{7}$ Compressed natural gas used as a vehicle fuel.

Bincludes all electric power generators except cogenerators, which produce electricity as a by-product of other processes.

Weighted averages of end-use fuel prices are derived from the prices shown in each sector and the corresponding sectoral consumption.

Btu $=$ British thermal unit.

Note: 1993 figures may differ from published data due to internal rounding in the AEO95 National Energy Modeling System.

Sources: 1993 prices for gasoline, distillate, and jet fuel are based on prices in various 1993 issues of Energy Information Administration (EIA), Petroleum Marketing Monthly, DOE/EIA-0380(93/1-12) (Washington, D.C., 1993). 1993 prices for all other pelroleum products are derived from the EIA, State Energy Price and Expenditure Report 1991, DOE/EIA-0376(91) (Washington, D.C., September 1993). 1993 residential natural gas delivered prices: EIA, Natural Gas Monthly, DOE/EIA-0130(94/6) (Washington, D.C., June 1994). Other 1993 natural gas delivered prices: EIA, AEO95 National Energy Modeling System run AEO95B.D1 103942. Values for 1993 coal prices have been estimated from ElA, State Energy Price and Expenditure Report 1992, DOEJEIA-0376(92) (Washington, D.C., December 1994) using consumption quantities aggregated from EIA, State Energy Data Report 1992, DOE/EIA-0214(92) (Washington, D.C., May 1994). 1993 electricity prices for commercial, industrial, and transportation: EIA, AEO95 National Energy Modeling System run AEO95B.D1103942. Projections: EIA, AEO95 National Energy Modeling System run AEO95B.D1103942. 
Table 17. Energy Prices by End-Use Sector and Source West South Central Census Division (1993 Dollars per Million Btu)

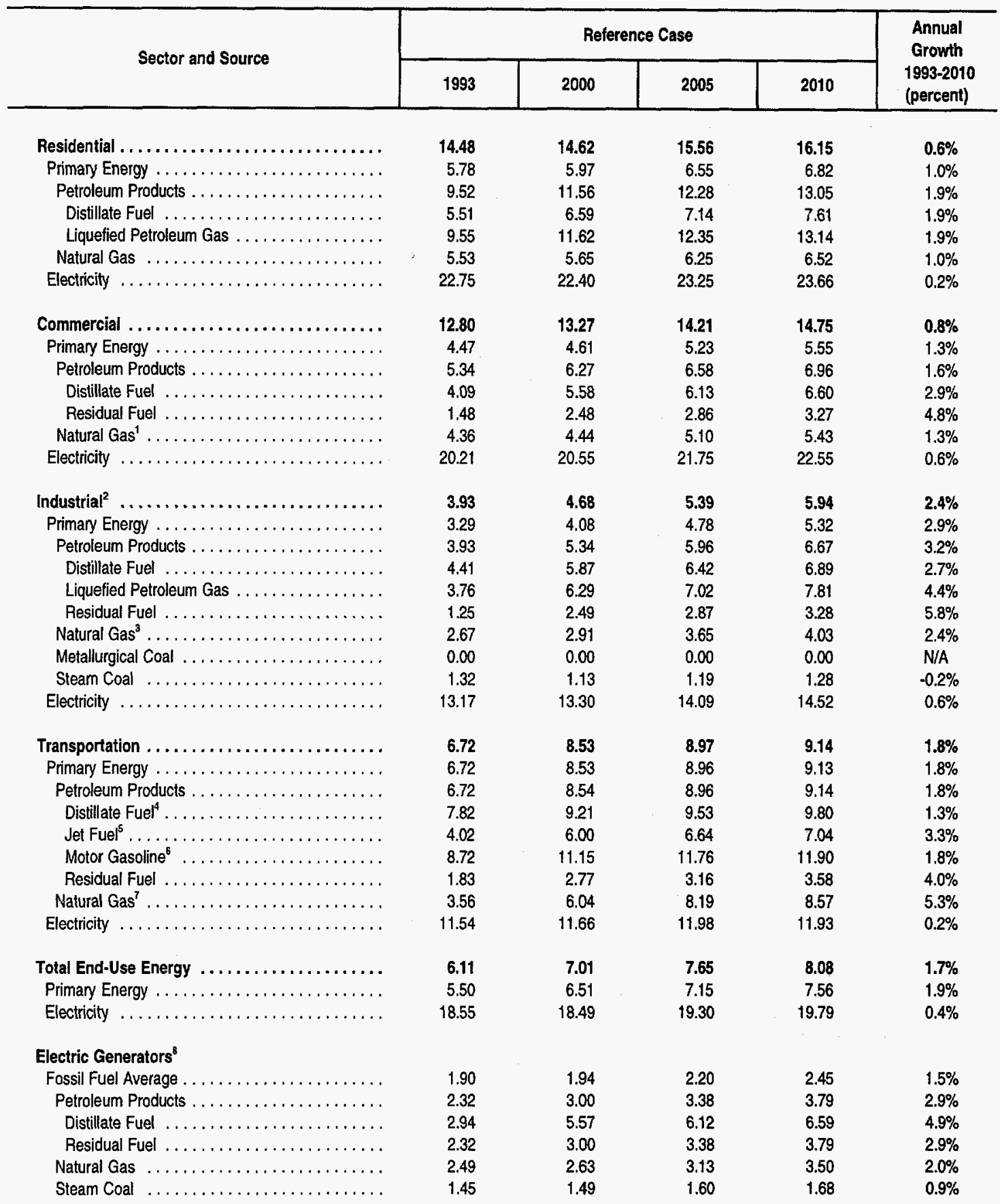


Table 17. Energy Prices by End-Use Sector and Source West South Central Census Division (Continued) (1993 Dollars per Million Btu)

\begin{tabular}{|c|c|c|c|c|c|}
\hline \multirow{2}{*}{ Sector and Source } & \multicolumn{4}{|c|}{ Reference Case } & \multirow{2}{*}{$\begin{array}{c}\text { Annual } \\
\text { Growth } \\
\text { 1993-2010 } \\
\text { (percent) }\end{array}$} \\
\hline & 1993 & 2000 & 2005 & 2010 & \\
\hline
\end{tabular}

Average Price to All Users ${ }^{9}$

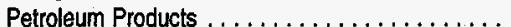

Distillate Fuel ${ }^{4} \ldots \ldots \ldots \ldots \ldots \ldots \ldots \ldots$

Jet Fuel $\ldots \ldots \ldots \ldots \ldots \ldots \ldots \ldots \ldots$

Liquefied Petroleum Gas . . . . . . . . . . . . .

Motor Gasoline ${ }^{6} \ldots \ldots \ldots \ldots \ldots \ldots \ldots \ldots$

Residual Fuel $\ldots \ldots \ldots \ldots \ldots \ldots \ldots \ldots$

Natural Gas . . . . . . . . . . . . . . . . .

Coal $\ldots \ldots \ldots \ldots \ldots \ldots \ldots \ldots \ldots \ldots$

Electricity $\ldots \ldots \ldots \ldots \ldots \ldots \ldots \ldots \ldots$

$\begin{array}{rr}5.49 & 7.15 \\ 6.78 & 8.25 \\ 4.02 & 6.00 \\ 3.88 & 6.39 \\ 8.72 & 11.13 \\ 1.83 & 2.76 \\ 2.93 & 3.14 \\ 1.44 & 1.47 \\ 18.55 & 18.49\end{array}$

7.66
8.65
6.64
7.11
11.74
3.15
3.80
1.58
19.30

$$
\begin{array}{rrr}
7.15 & 7.66 & 8.08 \\
8.25 & 8.65 & 8.99 \\
6.00 & 6.64 & 7.04 \\
6.39 & 7.11 & 7.90 \\
11.13 & 11.74 & 11.89 \\
2.76 & 3.15 & 3.57 \\
3.14 & 3.80 & 4.16 \\
1.47 & 1.58 & 1.66 \\
18.49 & 19.30 & 19.79
\end{array}
$$

'Excludes independent power producers.

${ }^{2}$ Includes cogenerators.

${ }^{3}$ Excludes uses for lease and plant fuel.

"Includes Federal and State taxes on diesel fuel and excludes county and local taxes.

5Kerosene-type jet fuel.

Average price for all grades. Includes Federal and State taxes and excludes county and local taxes.

${ }^{7}$ Compressed natural gas used as a vehicle fuel.

Includes all electric power generators except cogenerators, which produce electricity as a by-product of other processes.

Weighted averages of end-use fuel prices are derived from the prices shown in each sector and the corresponding sectoral consumption. Btu $=$ British thermal unit.

Note: 1993 figures may differ from published data due to internal rounding in the AEO95 National Energy Modeling System.

Sources: 1993 prices for gasoline, distillate, and jet fuel are based on prices in various 1993 issues of Energy Information Administration (ElA), Petroleum Marketing Monthly, DOEJEIA-0380(93/1-12) (Washington, D.C., 1993). 1993 prices for all other petroleum products are derived from the EIA, State Energy Price and Expenditure Report 1991, DOE/EIA-0376(91) (Washington, D.C., September 1993). 1993 residential natural gas delivered prices: EIA, Natural Gas Monthly, DOEJEIA-0130(94/6) (Washington, D.C., June 1994). Other 1993 natural gas delivered prices: EIA, AEO95 National Energy Modeling System run AEO95B.D1103942. Values for 1993 coal prices have been estimated from ElA, State Energy Price and Expenditure Report 1992, DOE/EIA-0376(92) (Washington, D.C., December 1994) using consumption quantities aggregated from ElA, State Energy Data Report 1992, DOE/EIA-0214(92) (Washington, D.C., May 1994). 1993 electricity prices for commercial, industrial, and transportation: EIA, AEO95 National Energy Modeling System run AEO95B.D1103942. Projections: EIA, AEO95 National Energy Modeling System run AEO95B.D1103942. 
Table 18. Energy Prices by End-Use Sector and Source Mountain Census Division (1993 Dollars per Million Btu)

\begin{tabular}{|c|c|c|c|c|c|}
\hline \multirow{2}{*}{ Sector and Source } & \multicolumn{4}{|c|}{ Reference Case } & \multirow{2}{*}{$\begin{array}{l}\text { Annual } \\
\text { Growth } \\
1993-2010 \\
\text { (percent) }\end{array}$} \\
\hline & 1993 & 2000 & 2005 & 2010 & \\
\hline Residential . . . . . . . . . . . . . . . . . . . & 11.79 & 11.97 & 13.54 & 14.17 & $1.1 \%$ \\
\hline Primary Energy $\ldots \ldots \ldots \ldots \ldots \ldots \ldots \ldots$ & 5.34 & 5.25 & 6.25 & 6.52 & $1.2 \%$ \\
\hline Distillate Fuel $\ldots \ldots \ldots \ldots \ldots \ldots \ldots \ldots \ldots$ & 6.41 & 6.79 & 7.26 & 7.69 & $1.1 \%$ \\
\hline Liquefied Petroleum Gas . . . . . . . . . . . . & 9.70 & 9.56 & 10.41 & 11.37 & $0.9 \%$ \\
\hline Natural Gas $\ldots \ldots \ldots \ldots \ldots \ldots \ldots \ldots \ldots$ & 4.99 & 4.96 & 6.00 & 6.24 & $1.3 \%$ \\
\hline Electricity $\ldots \ldots \ldots \ldots \ldots \ldots \ldots \ldots$ & 22.60 & 22.34 & 23.94 & 24.26 & $0.4 \%$ \\
\hline Commercial $\ldots \ldots \ldots \ldots \ldots \ldots \ldots \ldots \ldots \ldots$ & 11.44 & 11.53 & 12.94 & 13.53 & $1.0 \%$ \\
\hline Primary Energy $\ldots \ldots \ldots \ldots \ldots \ldots \ldots \ldots$ & 4.32 & 4.27 & 5.27 & 5.57 & $1.5 \%$ \\
\hline Petroleum Products $\ldots \ldots \ldots \ldots \ldots \ldots \ldots \ldots$ & 6.26 & 6.55 & 7.13 & 7.63 & $1.2 \%$ \\
\hline Distillate Fuel $\ldots \ldots \ldots \ldots \ldots \ldots \ldots \ldots \ldots$ & 4.78 & 5.11 & 5.58 & 6.02 & $1.4 \%$ \\
\hline Residual Fuel $\ldots \ldots \ldots \ldots \ldots \ldots \ldots \ldots$ & 3.91 & 2.55 & 2.93 & 3.33 & $-0.9 \%$ \\
\hline Natural Gas $^{1} \ldots \ldots \ldots \ldots \ldots \ldots \ldots \ldots$ & 4.17 & 4.08 & 5.16 & 5.44 & $1.6 \%$ \\
\hline Electricity $\ldots \ldots \ldots \ldots \ldots \ldots \ldots \ldots$ & 19.23 & 18.98 & 20.41 & 20.91 & $0.5 \%$ \\
\hline Industrial| $^{2} \ldots \ldots \ldots \ldots \ldots \ldots \ldots \ldots$ & 5.83 & 5.86 & 6.64 & 7.04 & $1.1 \%$ \\
\hline Primary Energy $\ldots \ldots \ldots \ldots \ldots \ldots \ldots \ldots$ & 3.78 & 3.85 & 4.53 & 4.96 & $1.6 \%$ \\
\hline Petroleum Products $\ldots \ldots \ldots \ldots \ldots \ldots \ldots \ldots$ & 4.81 & 5.06 & 5.62 & 6.19 & $1.5 \%$ \\
\hline Distillate Fuel $\ldots \ldots \ldots \ldots \ldots \ldots \ldots \ldots$ & 5.18 & 5.44 & 5.91 & 6.34 & $1.2 \%$ \\
\hline Liquefied Petroleum Gas . . . . . . . . . . . . . & 5.37 & 7.18 & 8.03 & 8.99 & $3.1 \%$ \\
\hline Residual Fuel $\ldots \ldots \ldots \ldots \ldots \ldots \ldots \ldots$ & 3.79 & 2.79 & 3.17 & 3.57 & $-0.4 \%$ \\
\hline Natural $\mathrm{Gas}^{3} \ldots \ldots \ldots \ldots \ldots \ldots \ldots$ & 2.91 & 3.22 & 4.35 & 4.67 & $2.8 \%$ \\
\hline Metallurgical Coal $\ldots \ldots \ldots \ldots \ldots \ldots \ldots \ldots$ & 6.84 & 2.08 & 2.14 & 2.18 & $-6.5 \%$ \\
\hline Steam coal $\ldots \ldots \ldots \ldots \ldots \ldots \ldots \ldots \ldots$ & 1.38 & 1.38 & 1.44 & 1.52 & $0.6 \%$ \\
\hline Electricity $\ldots \ldots \ldots \ldots \ldots \ldots \ldots \ldots \ldots$ & 13.85 & 13.36 & 14.25 & 14.44 & $0.2 \%$ \\
\hline Transportation $\ldots \ldots \ldots \ldots \ldots \ldots \ldots \ldots$ & 8.53 & 9.45 & 9.79 & 9.93 & $0.9 \%$ \\
\hline Primary Energy $\ldots \ldots \ldots \ldots \ldots \ldots \ldots \ldots$ & 8.51 & 9.43 & 9.76 & 9.89 & $0.9 \%$ \\
\hline Petroleum Products $\ldots \ldots \ldots \ldots \ldots \ldots \ldots \ldots$ & 8.51 & 9.45 & 9.77 & 9.90 & $0.9 \%$ \\
\hline Distillate Fuel ${ }^{4} \ldots \ldots \ldots \ldots \ldots \ldots$ & 8.43 & 8.66 & 8.98 & 9.21 & $0.5 \%$ \\
\hline Jet Fuel ${ }^{5} \ldots \ldots \ldots \ldots \ldots \ldots \ldots \ldots \ldots$ & 4.61 & 5.50 & 5.92 & 6.31 & $1.9 \%$ \\
\hline Motor Gasoline ${ }^{6} \ldots \ldots \ldots \ldots \ldots \ldots$ & 9.50 & 10.74 & 11.10 & 11.19 & $1.0 \%$ \\
\hline Residual Fuel $\ldots \ldots \ldots \ldots \ldots \ldots \ldots \ldots \ldots$ & 2.07 & 3.43 & 3.92 & 4.55 & $4.7 \%$ \\
\hline Natural $\operatorname{Gas}^{7} \ldots \ldots \ldots \ldots \ldots \ldots \ldots$ & 4.31 & 6.19 & 8.58 & 8.90 & $4.4 \%$ \\
\hline Electricity $\ldots \ldots \ldots \ldots \ldots \ldots \ldots \ldots$ & 15.87 & 16.21 & 16.46 & $\{6.57$ & $0.3 \%$ \\
\hline Total End-Use Energy . . . . . . . . . . . . . . . . . & 8.67 & 9.13 & 9.88 & 10.20 & $1.0 \%$ \\
\hline Primary Energy $\ldots \ldots \ldots \ldots \ldots \ldots \ldots \ldots \ldots$ & 8.38 & 8.91 & 9.54 & 9.80 & $0.9 \%$ \\
\hline Electricity $\ldots \ldots \ldots \ldots \ldots \ldots \ldots \ldots$ & 18.49 & 18.19 & 19.43 & 19.76 & $0.4 \%$ \\
\hline \multicolumn{6}{|l|}{ Electric Generators ${ }^{8}$} \\
\hline Fossil Fuel Average $\ldots \ldots \ldots \ldots \ldots \ldots \ldots$ & 1.19 & 1.33 & 1.58 & 1.58 & $1.7 \%$ \\
\hline Petroleum Products $\ldots \ldots \ldots \ldots \ldots \ldots \ldots \ldots$ & 4.33 & 3.04 & 3.36 & 3.87 & $-0.7 \%$ \\
\hline Distillate Fuel $\ldots \ldots \ldots \ldots \ldots \ldots \ldots \ldots \ldots$ & 4.99 & 5.25 & 5.72 & 6.15 & $1.2 \%$ \\
\hline Residual Fuel $\ldots \ldots \ldots \ldots \ldots \ldots \ldots \ldots$ & 3.52 & 3.04 & 3.36 & 3.87 & $0.6 \%$ \\
\hline Natural Gas $\ldots \ldots \ldots \ldots \ldots \ldots \ldots \ldots$ & 2.42 & 2.20 & 3.51 & 3.92 & $2.9 \%$ \\
\hline Steam Coal $\ldots \ldots \ldots \ldots \ldots \ldots \ldots$ & 1.13 & 1.14 & 1.21 & 1.31 & $0.8 \%$ \\
\hline
\end{tabular}


Table 18. Energy Prices by End-Use Sector and Source

Mountain Census Division (Continued)

(1993 Dollars per Million Btu)

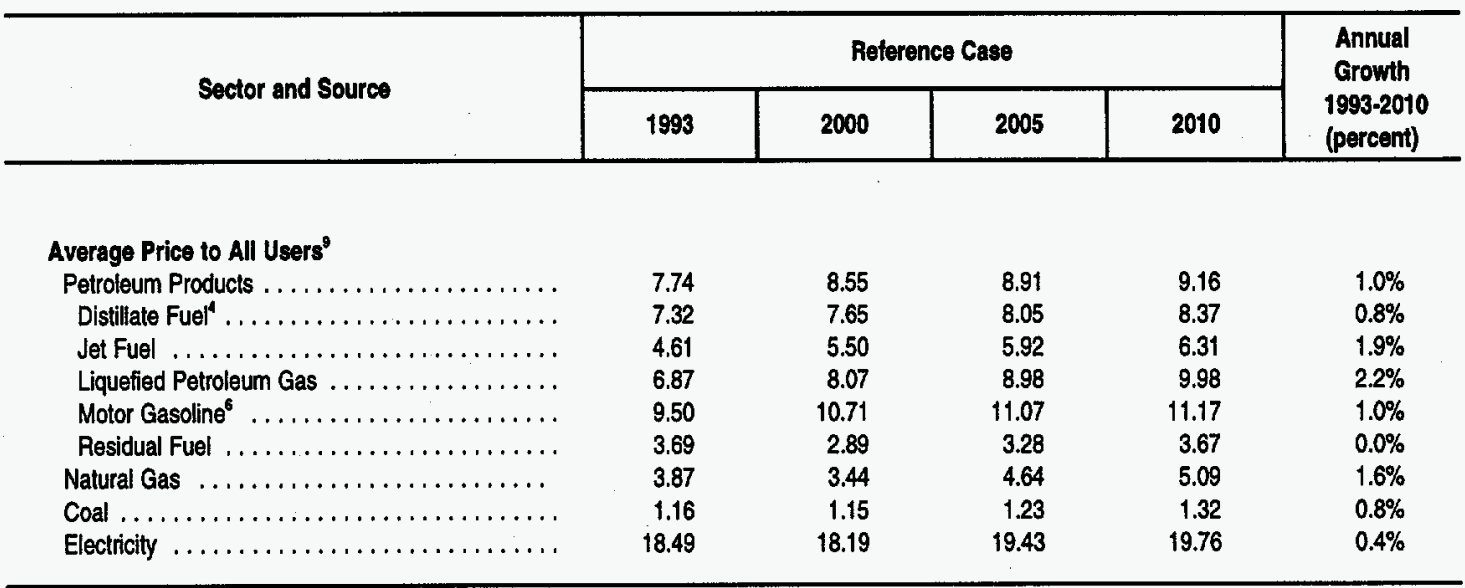

'Excludes independent power producers.

${ }^{2}$ Includes cogenerators.

${ }^{3}$ Excludes uses for lease and plant fuel.

"Includes Federal and State taxes on diesel fuel and excludes county and local taxes.

${ }^{5}$ Kerosene-type jet fuel.

"Average price for all grades. Includes Federal and State taxes and excludes county and local taxes.

${ }^{7}$ Compressed natural gas used as a vehicle fuel.

"Includes all electric power generators except cogenerators, which produce electricity as a by-product of other processes.

Weighted averages of end-use fuel prices are derived from the prices shown in each sector and the corresponding sectoral consumption.

Btu = British thermal unit.

Note: 1993 figures may differ from published data due to internal rounding in the AEO95 National Energy Modeling System.

Sources: 1993 prices for gasoline, distillate, and jet fuel are based on prices in various 1993 issues of Energy Information Administration (ElA), Petroleum Marketing Monthly, DOE/EIA-0380(93/1-12) (Washington, D.C., 1993). 1993 prices for all other petroleum products are derived from the EIA, State Energy Price and Expenditure Report 1991, DOE/EIA-0376(91) (Washington, D.C., Seplember 1993). 1993 residential natural gas delivered prices: EIA, Natural Gas Monthly, DOE/EIA-0130(94/6) (Washington, D.C., June 1994). Other 1993 natural gas delivered prices: EIA, AEO95 National Energy Modeling System run AEO95B.D1103942. Values for 1993 coal prices have been estimated from EIA, State Energy Price and Expenditure Report 1992, DOEJEIA-0376(92) (Washington, D.C., December 1994) using consumption quantities aggregated from EIA, State Energy Data Report 1992, DOE/EIA-0214(92) (Washington, D.C., May 1994). 1993 electricity prices for commercial, industrial, and transportation: EIA, AEO95 National Energy Modeling System run AEO95B.D1103942. Projections: EIA, AEO95 National Energy Modeling System run AEO95B.D1103942. 
Table 19. Energy Prices by End-Use Sector and Source

Pacific Census Division

(1993 Dollars per Million Btu)

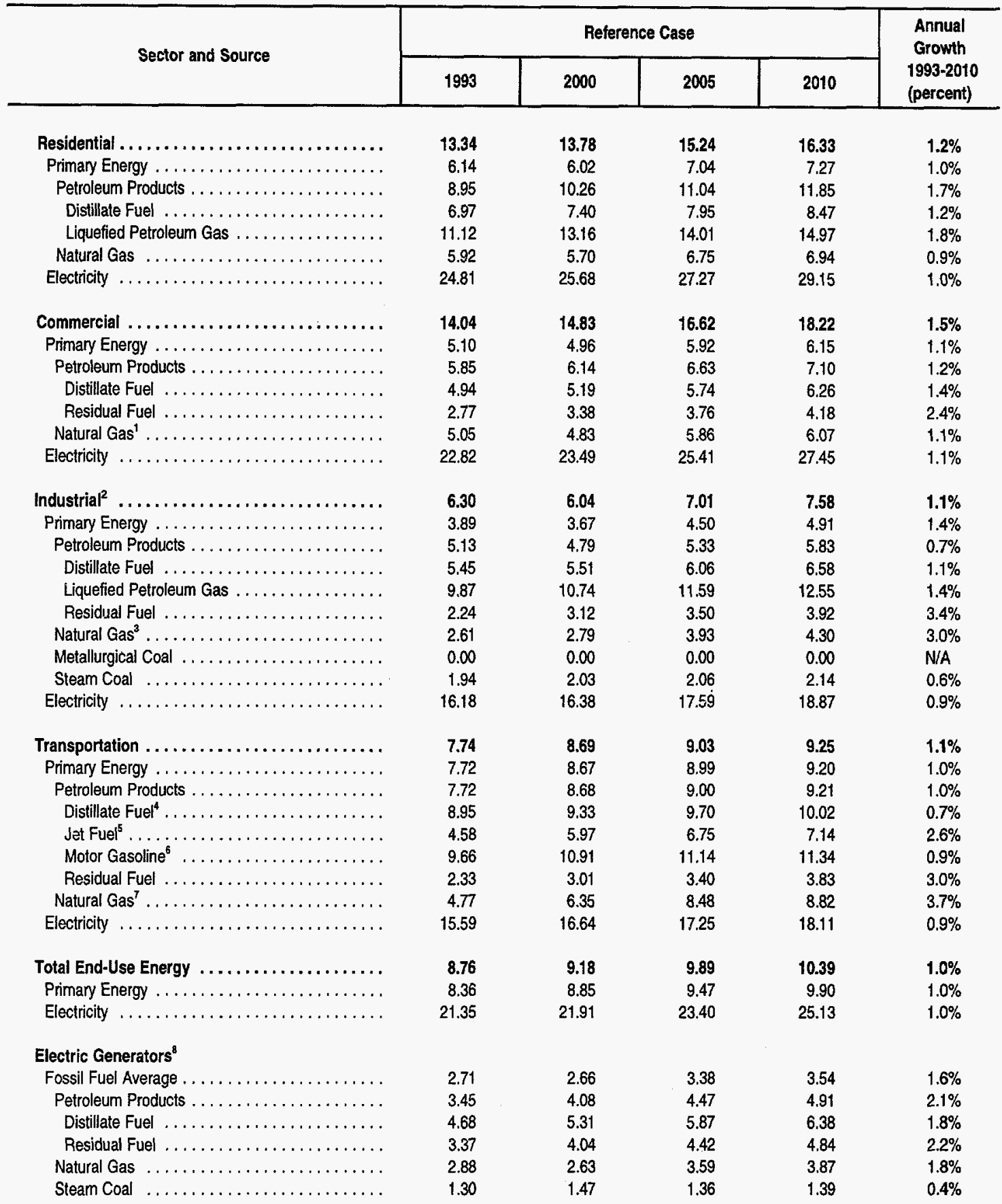


Table 19. Energy Prices by End-Use Sector and Source

Pacific Census Division (Continued)

(1993 Dollars per Million Btu)

\begin{tabular}{|c|c|c|c|c|c|}
\hline \multirow{2}{*}{ Sector and Source } & \multicolumn{4}{|c|}{ Reference Case } & \multirow{2}{*}{$\begin{array}{c}\text { Annual } \\
\text { Growth } \\
1993-2010 \\
\text { (percent) }\end{array}$} \\
\hline & 1993 & 2000 & 2005 & 2010 & \\
\hline
\end{tabular}

Average Price to All Users ${ }^{9}$

Petroleum Products . . . . . . . . . . . . . . . . . . . . . 7.29

Distillate Fuel ${ }^{4} \ldots \ldots \ldots \ldots \ldots \ldots \ldots \ldots \ldots \ldots \ldots, \quad 8.09$

Jet Fuel ....................... 4.58

Liquefied Petroleum Gas . . . . . . . . . . . . . $\quad 10.20$

Motor Gasoline $^{6} \ldots \ldots \ldots \ldots \ldots \ldots \ldots$

Residual Fuel $\ldots \ldots \ldots \ldots \ldots \ldots \ldots \ldots \ldots \ldots, \quad 2.52$

Natural Gas .......................... 3.91

Coal $\ldots \ldots \ldots \ldots \ldots \ldots \ldots \ldots \ldots \ldots \ldots \ldots \ldots, \quad 1.50$

Electricity $\ldots \ldots \ldots \ldots \ldots \ldots \ldots \ldots \ldots \ldots \ldots, 21.35$

$\begin{array}{rr}8.07 & 8.43 \\ 8.47 & 8.90 \\ 5.97 & 6.75 \\ 11.73 & 12.59 \\ 10.89 & 11.13 \\ 3.21 & 3.59 \\ 3.79 & 4.84 \\ 1.72 & 1.66 \\ 21.91 & 23.40\end{array}$

8.71
9.29
7.14
13.59
11.33
3.99
5.25
1.71
25.13

$1.1 \%$

$\begin{array}{lll}8.90 & 9.29 & 0.8 \%\end{array}$

$\begin{array}{lll}6.75 & 7.14 & 2.6 \%\end{array}$

$\begin{array}{lll}6.59 & 13.59 & 1.7 \%\end{array}$

$\begin{array}{lll}13.33 & 11.33 & 0.9 \%\end{array}$

$\begin{array}{lll}3.59 & 3.99 & 2.7 \%\end{array}$

3.25
4.84 $\quad 1.7 \%$

$\begin{array}{lll}1.66 & 1.71 & 0.8 \%\end{array}$

'Excludes independent power producers.

${ }^{2}$ Includes cogenerators.

${ }^{3}$ Excludes uses for lease and plant fuel.

${ }^{4}$ Includes Federal and State taxes on diesel fuel and excludes county and local taxes.

5Kerosene-type jet fuel.

${ }^{6}$ Average price for all grades. Includes Federal and State taxes and excludes county and local taxes.

${ }^{7}$ Compressed natural gas used as a vehicle fuel.

Includes all electric power generators except cogenerators, which produce electricity as a by-product of other processes.

Weighted averages of end-use fuel prices are derived from the prices shown in each sector and the corresponding sectoral consumption.

Btu $=$ British thermal unit.

Note: 1993 figures may differ from published data due to internal rounding in the AEO95 National Energy Modeling System.

Sources: 1993 prices for gasoline, distillate, and jet fuel are based on prices in various 1993 issues of Energy Information Administration (EIA), Petroleum Marketing Monthly, DOE/EIA-0380(93/1-12) (Washington, D.C., 1993). 1993 prices for all other petroleum products are derived from the EIA, State Energy Price and Expenditure Report 1991, DOE/EIA-0376(91) (Washington, D.C., September 1993). 1993 residential natural gas delivered prices: EIA, Natural Gas Monthly, DOE/EIA-0130(94/6) (Washington, D.C., June 1994). Other 1993 natural gas delivered prices: EIA, AEO95 National Energy Modeling System run AEO95B.D1103942. Values for 1993 coal prices have been estimated fram EIA, State Energy Price and Expenditure Report 1992, DOE/EIA-0376(92) (Washington, D.C., December 1994) using consumption quantities aggregated from EIA, State Energy Data Report 1992, DOE/EIA-0214(92) (Washington, D.C., May 1994). 1993 electricity prices for commercial, industrial, and transportation: EIA, AEO95 National Energy Modeling System run AEO95B.D1103942. Projections: EIA, AEO95 National Energy Modeling System run AEO95B.D1103942. 
Table 20. Energy Prices by End-Use Sector and Source

United States

(1993 Dollars per Million Btu)

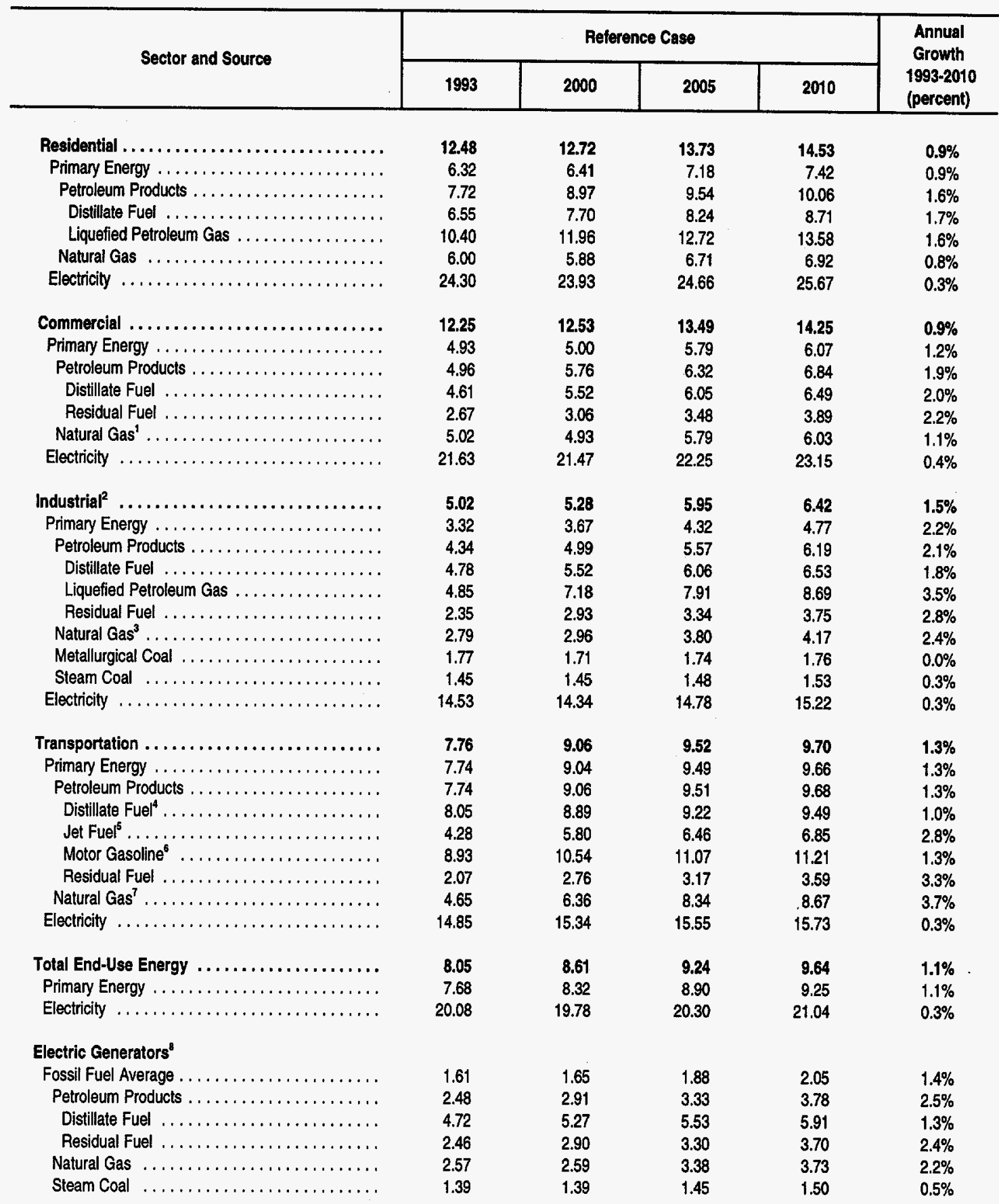


Table 20. Energy Prices by End-Use Sector and Source

United States (Continued)

(1993 Dollars per Million Btu)

\begin{tabular}{|c|c|c|c|c|c|}
\hline \multirow{2}{*}{ Sector and Source } & \multicolumn{4}{|c|}{ Reference Case } & \multirow{2}{*}{$\begin{array}{c}\text { Annual } \\
\text { Growth } \\
1993-2010 \\
\text { (percent) }\end{array}$} \\
\hline & 1993 & 2000 & 2005 & 2010 & \\
\hline \multicolumn{6}{|l|}{ Average Price to All Users ${ }^{9}$} \\
\hline Distillate Fuel ${ }^{4} \ldots \ldots \ldots \ldots \ldots \ldots \ldots$ & 7.02 & 7.97 & 8.39 & 8.74 & $1.3 \%$ \\
\hline Jet Fuel $\ldots \ldots \ldots \ldots \ldots \ldots \ldots \ldots \ldots$ & 4.28 & 5.80 & 6.46 & 6.85 & $2.8 \%$ \\
\hline Liquefied Petroleum Gas . . . . . . . . . . . . . . . & 5.94 & 8.13 & 8.90 & 9.74 & $3.0 \%$ \\
\hline Motor Gasoline $e^{8} \ldots \ldots \ldots \ldots \ldots \ldots \ldots$ & 8.93 & 10.52 & 11.05 & 11.20 & $1.3 \%$ \\
\hline Residual Fuel $\ldots \ldots \ldots \ldots \ldots \ldots \ldots \ldots \ldots$ & 2.30 & 2.85 & 3.26 & 3.67 & $2.8 \%$ \\
\hline Natural Gas $\ldots \ldots \ldots \ldots \ldots \ldots \ldots \ldots$ & 3.97 & 3.94 & 4.74 & 5.01 & $1.4 \%$ \\
\hline
\end{tabular}

${ }^{1}$ Excludes independent power producers.

Includes cogenerators.

${ }^{3}$ Excludes uses for lease and plant fuel.

Includes Federal and State taxes on diesel fuel and excludes county and local taxes.

sKerosene-type jet fuel.

'Average price for all grades. Includes Federal and State taxes and excludes county and local taxes.

'Compressed natural gas used as a vehicle fuel.

includes all electric power generators except cogenerators, which produce electricity as a by-product of other processes.

Weighted averages of end-use fuel prices are derived from the prices shown in each sector and the corresponding sectoral consumption.

Biu = British thermal unit.

Note: 1993 figures may differ from published data due to internal rounding in the AEO95 National Energy Modeling System.

Sources: 1993 prices for gasoline, distillate, and jet fuel are based on prices in various 1993 issues of Energy Intormation Administration (EIA), Petroleum Marketing Monthly, DOE/EIA-0380(93/1-12) (Washington, D.C., 1993). 1993 prices for all other petroleum products are derived from the EIA, State Energy Price and Expenditure Report 1991, DOE/EIA-0376(91) (Washington, D.C., September 1993). 1993 residential natural gas delivered prices: ElA, Natural Gas Monthly, DOE/EIA-0130(94/6) (Washington, D.C., June 1994). Other 1993 natural gas delivered prices: ElA, AEO95 National Energy Modeling System run AEO95B.D1 103942. Values for 1993 coal prices have been estimated from EIA, State Energy Price and Expenditure Report 1992, DOE/EIA-0376(92) (Washington, D.C., December 1994) using consumption quantities aggregated from EIA, State Energy Data Report 1992, DOE/EIA-0214(92) (Washington, D.C., May 1994). 1993 electricity prices for commercial, industrial, and transportation: EIA, AEO95 National Energy Modeling System run AEO95B.D1103942. Projections: EIA, AEO95 National Energy Modeling System run AEO95B.D1103942. 
Table 21. Residential Sector Supplement Table

\begin{tabular}{c|c|c|c|c|c|c|}
\hline \multirow{2}{*}{ Equipment Stock Data } & \multicolumn{4}{|c|}{ Reterence Case } & $\begin{array}{c}\text { Annual } \\
\text { Growth } \\
1993-2010 \\
\text { (percent) }\end{array}$ \\
\cline { 2 - 6 } & 1993 & 2000 & 2005 & $2010 \quad$ \\
\hline
\end{tabular}

Equipment Stock (million units)

Main Space Healers

Electric Heat Pumps $\ldots . \ldots \ldots \ldots \ldots \ldots \ldots \ldots \ldots$

Natural Gas Heat Pumps . . . . . . . . . . . . . . . . $\quad 0.04$

Natural Gas Other . . . . . . . . . . . . . . . . . $\quad 53.70$

Distillate ..........................., $\quad 10.18$

Liquid Petroleum Gas . .................. 4.09

Kerosene $\ldots \ldots \ldots \ldots \ldots \ldots \ldots \ldots \ldots, \quad 1.03$

Wood Stoves ....................... $\quad 3.77$

Geothermal Heat Pumps ................. $\quad 0.20$

Total ........................... 95.04

8.64
15.63
0.15
58.21
9.95
3.60
0.91
3.68
0.36
101.14

9.81

16.18

0.22

61.06

9.94

3.34

0.84

3.64

0.49

105.52

Space Cooling (million units)

Natural Gas Heat Pumps . . . . . . . . . . . . . .

Geothermal Heat Pumps ................... $\quad 0.20$

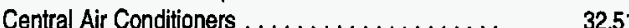

Room Air Conditioners . . . . . . . . . . . . . $\quad 40.13$

Total $\ldots \ldots \ldots \ldots \ldots \ldots \ldots \ldots \ldots \ldots, \quad 79.89$

$\begin{array}{ll}40.13 & 40.31 \\ 79.89 & 87.16\end{array}$

Water Heaters (million units)

Electric ........................... 35.79

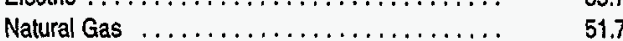

Distillate ......................... 5.12

Liquid Petroleum Gas ....................

Solar Thermal .......................... $\quad 0.57$

Total $\ldots \ldots \ldots \ldots \ldots \ldots \ldots \ldots \ldots \ldots \ldots, \quad 96.39$

$\begin{array}{rr}0.39 & 02.51\end{array}$

\subsection{4}

0.15

0.36

37.70

9.81

0.22

0.49

41.30

40.41

92.22

$\begin{array}{rr}11.03 & 2.7 \% \\ 16.76 & 0.7 \% \\ 0.29 & 11.8 \% \\ 63.84 & 1.0 \% \\ 9.90 & -0.2 \% \\ 3.17 & -1.5 \% \\ 0.78 & -1.6 \% \\ 3.61 & -0.3 \% \\ 0.61 & 6.8 \% \\ 109.98 & 0.9 \%\end{array}$

Cooking Equipment (million units)'

Electric ......................... 56.13

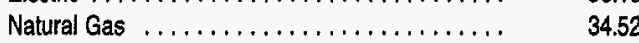

Liquid Petroleum Gas .................., $\quad 5.17$

Total ......................... 95.82

$\begin{array}{rrrr}37.76 & 39.27 & 40.90 & 0.8 \% \\ 55.96 & 58.82 & 61.62 & 1.0 \% \\ 5.16 & 5.22 & 5.28 & 0.2 \% \\ 3.00 & 2.93 & 2.88 & -0.5 \% \\ 0.63 & 0.66 & 0.69 & 1.1 \% \\ 102.51 & 106.90 & 111.38 & 0.9 \%\end{array}$

Clothes Dryers (million units)

Electric ........................... $\quad 50.89$

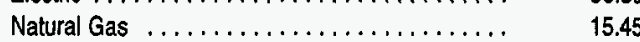

Total $\ldots \ldots \ldots \ldots \ldots \ldots \ldots \ldots \ldots \ldots \ldots \ldots \ldots, \quad 66.34$

$\begin{array}{rrrr}60.23 & 63.18 & 66.17 & 1.0 \% \\ 36.86 & 38.48 & 40.09 & 0.9 \% \\ 4.80 & 4.59 & 4.42 & -0.9 \% \\ 101.89 & 106.24 & 110.68 & 0.9 \%\end{array}$

Other Appliances (million units)

Refrigerators. ...................... $\quad 103.83$

Freezers. .......................... $\quad 31.97$

$\quad 110.37$

54.67

16.13

57.13

16.55

59.54

16.97

76.51

$0.9 \%$

$0.6 \%$

$0.8 \%$

Stock Average Equipment Efficiency

Main Space Heaters

Electric Heat Pumps (HSPF) . . . . . . . . . . . . $\quad 7.14$

Natural Gas

Natural Gas Furnace (AFUE) $\ldots \ldots \ldots \ldots \ldots \ldots$

Distillate Fumace (AFUE) $\ldots \ldots \ldots \ldots \ldots \ldots$

\section{Space Cooiling Systems}

Electric Heat Pumps (SEER) . . . . . . . . . . . . . $\quad 9.20$

Natural Gas Heal Pumps (COP) . . . . . . . . . . . .

Geothermal Heat Pumps (EER) . . . . . . . . . . . . $\quad 10.88$

Central Air Conditioners (SEER) . . . . . . . . . . . . $\quad 9.01$

Room Air Conditioners (EER) . . . . . . . . . . . . $\quad 7.77$

$\begin{array}{llll}7.86 & 8.11 & 8.18 & 0.8 \% \\ 1.25 & 1.25 & 1.25 & \text { N/A } \\ 2.93 & 2.95 & 2.96 & 0.3 \% \\ 0.76 & 0.79 & 0.82 & 0.9 \% \\ 0.78 & 0.81 & 0.83 & 0.7 \%\end{array}$

Water Heaters

Electric (EF). ....................... $\quad 0.84$

Natural Gas (EF) $\ldots \ldots \ldots \ldots \ldots \ldots \ldots \ldots \ldots, \quad 0.52$

Distillate (EF) . . . . . . . . . . . . . . . . . . . . . . $\quad 0.49$

Liquid Petroleum Gas (EF)

.............

$\begin{array}{rrrl}10.42 & 10.82 & 10.91 & 1.0 \% \\ 0.93 & 0.93 & 0.93 & \text { N A } \\ 12.40 & 12.79 & 12.97 & 1.0 \% \\ 10.08 & 10.48 & 10.52 & 0.9 \% \\ 8.76 & 9.82 & 10.28 & 1.7 \%\end{array}$

$\begin{array}{llll}0.87 & 0.89 & 0.91 & 0.5 \% \\ 0.54 & 0.55 & 0.56 & 0.5 \% \\ 0.53 & 0.55 & 0.56 & 0.8 \% \\ 0.53 & 0.54 & 0.56 & 0.5 \%\end{array}$


Table 21. Residential Sector Supplement Table (Continued)

\begin{tabular}{|c|c|c|c|c|c|}
\hline Equipment Slock Data & 1993 & 2000 & 2005 & 2010 & $\begin{array}{c}\text { Annual } \\
\text { Growth } \\
\text { 1993-2010 } \\
\text { (percent) }\end{array}$ \\
\hline Freezers. $\ldots \ldots \ldots \ldots \ldots \ldots \ldots \ldots \ldots$ & 870.40 & 690.77 & 560.98 & 441.44 & $-3.9 \%$ \\
\hline \multicolumn{6}{|l|}{$\begin{array}{l}\text { Building Shell Efficiency Index }(1990=1.0) \\
\text { Space Heating }\end{array}$} \\
\hline Pre-1991 Homes . . . . . . . . . . . . . . . . . . . . & 1.00 & 0.99 & 0.98 & 0.97 & $-0.2 \%$ \\
\hline New Construction $\ldots \ldots \ldots \ldots \ldots \ldots \ldots \ldots$ & 0.92 & 0.85 & 0.81 & 0.80 & $-0.8 \%$ \\
\hline All Homes $\ldots \ldots \ldots \ldots \ldots \ldots \ldots \ldots \ldots$ & 1.00 & 0.98 & 0.96 & 0.94 & $-0.4 \%$ \\
\hline \multicolumn{6}{|l|}{ Space Cooling } \\
\hline Pre-1991 Homes . . . . . . . . . . . . . . . . . . . . & 1.00 & 1.00 & 0.99 & 0.98 & $-0.1 \%$ \\
\hline New Construction $\ldots \ldots \ldots \ldots \ldots \ldots \ldots \ldots$ & 0.92 & 0.85 & 0.81 & 0.80 & $-0.8 \%$ \\
\hline All Homes $\ldots \ldots \ldots \ldots \ldots \ldots \ldots \ldots \ldots$ & 1.00 & 0.98 & 0.96 & 0.94 & $-0.4 \%$ \\
\hline
\end{tabular}

'Does not include microwave ovens or outdoor grills.

HSPF = Heating Seasonal Performance Factor: The total heating output of a heat pump during its normal annual usage period for heating divided by total electric input in watt-hours during the same period.

COP = Coefficient of Performance: Energy efficiency rating measure determined, under specific testing conditions, by dividing the energy output by the energy input.

AFUE = Annual Fuel Utilization Efficiency: Efficiency rating based on average usage, including on and off cycling, as set out in the standardized Department of Energy test procedures.

SEER = Seasonal Energy Efficiency Ratio: The total cooling of a central unitary air conditioner or a unitary heat pump in Btu during its normal annual usage period for cooling divided by the total electric energy input in watt-hours during the same period.

$\mathrm{EER}$ = Energy Efficiency Ration: A ratio calculated by dividing the cooling capacity in Btu per hour by the power input in watts at any given set of rating conditions, expressed in Btu per hour per watt.

EF = Efficiency Factor: Efficiency (measured in Btu out / Btu in) of water heaters under certain test conditions specified by the Department of Energy.

Btu = British thermal unit.

N/A $=$ Not applicable.

Note: Totals may not equal sum of components due to independent rounding.

Source: 1993: Energy Information Administration (EIA), Short-Term Energy Outlook, DOE/E1A-0202(94/3Q) (Washington, D.C., August 1994).

Projections: EIA, AEO95 National Energy Modeling System run AEO95B.D1103942. 
Table 22. Commercial Sector Supplement Table

\begin{tabular}{|c|c|c|c|c|c|}
\hline \multirow{2}{*}{ Indicators } & \multicolumn{4}{|c|}{ Reference Case } & \multirow{2}{*}{$\begin{array}{c}\text { Annual } \\
\text { Growth } \\
1993-2010 \\
\text { (percent) }\end{array}$} \\
\hline & 1993 & 2000 & 2005 & 2010 & \\
\hline \multicolumn{6}{|l|}{$\begin{array}{l}\text { Building Energy Consumption' } \\
\text { (quadrillion Btu) }\end{array}$} \\
\hline Assembly $\ldots \ldots \ldots \ldots \ldots \ldots \ldots \ldots$ & 0.47 & 0.46 & 0.44 & 0.42 & $-0.7 \%$ \\
\hline Education $\ldots \ldots \ldots \ldots \ldots \ldots \ldots \ldots \ldots$ & 0.80 & 0.76 & 0.71 & 0.66 & $-1.1 \%$ \\
\hline Food Sales $\ldots \ldots \ldots \ldots \ldots \ldots \ldots \ldots \ldots$ & 0.15 & 0.16 & 0.17 & 0.18 & $1.1 \%$ \\
\hline Food Service $\ldots \ldots \ldots \ldots \ldots \ldots \ldots \ldots \ldots$ & 0.28 & 0.30 & 0.31 & 0.33 & $1.0 \%$ \\
\hline Health Care $\ldots \ldots \ldots \ldots \ldots \ldots \ldots \ldots$ & 0.51 & 0.56 & 0.57 & 0.60 & $1.0 \%$ \\
\hline Lodging ......................... & 0.44 & 0.46 & 0.45 & 0.45 & $0.1 \%$ \\
\hline Office $-\operatorname{Large} \ldots \ldots \ldots \ldots \ldots \ldots \ldots \ldots$ & 0.80 & 0.87 & 0.91 & 0.95 & $1.0 \%$ \\
\hline Otfice - Small $\ldots \ldots \ldots \ldots \ldots \ldots \ldots \ldots$ & 0.60 & 0.65 & 0.68 & 0.71 & $1.0 \%$ \\
\hline Mercantile/Service $\ldots \ldots \ldots \ldots \ldots \ldots \ldots$ & 1.14 & 1.27 & 1.37 & 1.50 & $1.6 \%$ \\
\hline Warehouse $\ldots \ldots \ldots \ldots \ldots \ldots \ldots \ldots$ & 0.56 & 0.59 & 0.60 & 0.62 & $0.5 \%$ \\
\hline Other $\ldots \ldots \ldots \ldots \ldots \ldots \ldots \ldots \ldots \ldots$ & 0.60 & 0.56 & 0.53 & 0.50 & $-1.1 \%$ \\
\hline Total $\ldots \ldots \ldots \ldots \ldots \ldots \ldots \ldots$ & 6.35 & 6.64 & 6.73 & 6.91 & $0.5 \%$ \\
\hline \multicolumn{6}{|l|}{$\begin{array}{l}\text { Commercial Building Floor Space } \\
\text { (billion square feet) }\end{array}$} \\
\hline Assembly $\ldots \ldots \ldots \ldots \ldots \ldots \ldots \ldots$ & 7.03 & 7.07 & 6.99 & 6.88 & $-0.1 \%$ \\
\hline Education $\ldots \ldots \ldots \ldots \ldots \ldots \ldots \ldots$ & 8.45 & 8.38 & 8.09 & 7.77 & $-0.5 \%$ \\
\hline Food Sales $\ldots \ldots \ldots \ldots \ldots \ldots \ldots \ldots \ldots$ & 0.85 & 0.96 & 1.05 & $\$ .14$ & $1.7 \%$ \\
\hline Food Service $\ldots \ldots \ldots \ldots \ldots \ldots \ldots \ldots \ldots$ & 1.25 & 1.40 & 1.51 & 1.64 & $1.6 \%$ \\
\hline Health Care $\ldots \ldots \ldots \ldots \ldots \ldots \ldots \ldots \ldots$ & 2.37 & 2.79 & 2.98 & 3.24 & $1.9 \%$ \\
\hline Lodging $\ldots \ldots \ldots \ldots \ldots \ldots \ldots \ldots \ldots$ & 3.70 & 4.07 & 4.21 & 4.34 & $1.0 \%$ \\
\hline Office-Large $\ldots \ldots \ldots \ldots \ldots \ldots \ldots \ldots$ & 7.34 & 8.22 & 8.75 & 9.25 & $1.4 \%$ \\
\hline Office - Small $\ldots \ldots \ldots \ldots \ldots \ldots \ldots \ldots \ldots$ & 5.31 & 5.95 & 6.31 & 6.65 & $1.3 \%$ \\
\hline Mercantile/Service $\ldots \ldots \ldots \ldots \ldots \ldots \ldots \ldots$ & 13.47 & 15.65 & 17.39 & 19.42 & $2.2 \%$ \\
\hline Warehouse $\ldots \ldots \ldots \ldots \ldots \ldots \ldots \ldots \ldots$ & 9.96 & 10.94 & 11.52 & 11.93 & $1.1 \%$ \\
\hline Other $\ldots \ldots \ldots \ldots \ldots \ldots \ldots \ldots \ldots \ldots$ & 7.29 & 6.91 & 6.55 & 6.14 & $-1.0 \%$ \\
\hline Total $\ldots \ldots \ldots \ldots \ldots \ldots \ldots \ldots \ldots$ & 67.01 & 72.36 & 75.34 & 78.41 & $0.9 \%$ \\
\hline \multicolumn{6}{|l|}{ Efficiency Indicators ${ }^{2}$} \\
\hline \multicolumn{6}{|l|}{ Space Heating } \\
\hline Electricity $\ldots \ldots \ldots \ldots \ldots \ldots \ldots \ldots$ & 1.10 & 1.19 & 1.23 & 1.25 & $0.8 \%$ \\
\hline Natural Gas $\ldots \ldots \ldots \ldots \ldots \ldots \ldots \ldots$ & 0.75 & 0.77 & 0.79 & 0.80 & $0.4 \%$ \\
\hline Distillate $\ldots \ldots \ldots \ldots \ldots \ldots \ldots \ldots \ldots$ & 0.76 & 0.78 & 0.80 & 0.81 & $0.3 \%$ \\
\hline \multicolumn{6}{|l|}{ Space Cooling } \\
\hline Electricity $\ldots \ldots \ldots \ldots \ldots \ldots \ldots \ldots \ldots$ & 3.01 & 3.33 & 3.54 & 3.73 & $1.3 \%$ \\
\hline Natural Gas $\ldots \ldots \ldots \ldots \ldots \ldots \ldots \ldots$ & 1.27 & 1.32 & 1.34 & 1.35 & $0.4 \%$ \\
\hline \multicolumn{6}{|l|}{ Water Heating } \\
\hline Electricity $\ldots \ldots \ldots \ldots \ldots \ldots \ldots \ldots$ & 0.81 & 0.84 & 0.85 & 0.86 & $0.3 \%$ \\
\hline Natural Gas $\ldots \ldots \ldots \ldots \ldots \ldots \ldots \ldots$ & 0.68 & 0.72 & 0.74 & 0.76 & $0.6 \%$ \\
\hline Distillate $\ldots \ldots \ldots \ldots \ldots \ldots \ldots \ldots \ldots$ & 0.69 & 0.73 & 0.74 & 0.75 & $0.5 \%$ \\
\hline \multicolumn{6}{|l|}{ Ventilation $^{3}$} \\
\hline Electricity $\ldots \ldots \ldots \ldots \ldots \ldots \ldots \ldots$ & 1.06 & 1.12 & 1.15 & 1.17 & $0.6 \%$ \\
\hline \multicolumn{6}{|l|}{ Cooking } \\
\hline Electricity $\ldots \ldots \ldots \ldots \ldots \ldots \ldots \ldots \ldots$ & 0.51 & 0.56 & 0.59 & 0.60 & $1.0 \%$ \\
\hline Natural Gas $\ldots \ldots \ldots \ldots \ldots \ldots \ldots \ldots \ldots$ & 0.52 & 0.52 & 0.53 & 0.54 & $0.3 \%$ \\
\hline \multicolumn{6}{|l|}{$\begin{array}{l}\text { Lighting Efficacy } \\
\text { (lumens per watt) }\end{array}$} \\
\hline Electricity $\ldots \ldots \ldots \ldots \ldots \ldots \ldots \ldots \ldots$ & 42.55 & 47.52 & 49.94 & 51.65 & $1.1 \%$ \\
\hline \multicolumn{6}{|l|}{ Refrigeration } \\
\hline Electricity $\ldots \ldots \ldots \ldots \ldots \ldots \ldots \ldots \ldots$ & 1.76 & 1.92 & 2.01 & 2.07 & $0.9 \%$ \\
\hline
\end{tabular}


Table 22. Commercial Sector Supplement Table (Continued)

\begin{tabular}{|c|c|c|c|c|c|}
\hline \multirow{2}{*}{ Indicators } & \multicolumn{4}{|c|}{ Reference Case } & \multirow{2}{*}{$\begin{array}{c}\text { Annual } \\
\text { Growth } \\
\text { 1993-2010 } \\
\text { (percent) }\end{array}$} \\
\hline & 1993 & 2000 & 2005 & 2040 & \\
\hline \multicolumn{6}{|l|}{ Office Equipment (PC) } \\
\hline Electricity $\ldots \ldots \ldots \ldots \ldots \ldots \ldots \ldots \ldots \ldots$ & 1.09 & 1.28 & 1.42 & 1.59 & $2.2 \%$ \\
\hline \multicolumn{6}{|l|}{ Office Equipment (non-PC) } \\
\hline Electricity $\ldots \ldots \ldots \ldots \ldots \ldots \ldots \ldots \ldots$ & 1.02 & 1.05 & 1.07 & 1.10 & $0.4 \%$ \\
\hline
\end{tabular}

${ }^{1}$ Excludes commercial sector energy consumption (from uses such as street lights) that is not attributable to buildings.

${ }^{2}$ Unless noted otherwise, the efficiency measures are in the terms of coefficient of performance (COP). The COP is measured as Btu of energy output divided by Btu of purchased energy input.

Index of efficiency relative to $1989(1989=1.0)$. Index values greater than 1.00 represent proportionate increases relative to 1989 .

${ }^{4} \mathrm{~A}$ measurement of the ratio of light produced by a light source to the electrical power used to produce that quality of light, expressed in lumens per watt.

Błu $=$ British thermal unit.

$\mathrm{PC}=$ Personal computer.

Note: Totals may not equal sum of components due to independent rounding.

Source: Energy Information Administration, AEO95 National Energy Modeling System run AEO95B.01103942. 
Table 23. Industrial Sector Macroeconomic Indicators

\begin{tabular}{|c|c|c|c|c|c|}
\hline \multirow{2}{*}{ Indicators } & \multicolumn{4}{|c|}{ Reference Case } & \multirow{2}{*}{$\begin{array}{c}\text { Annual } \\
\text { Growth } \\
1993-2010 \\
\text { (percent) }\end{array}$} \\
\hline & 1993 & 2000 & 2005 & 2010 & \\
\hline GDP (billion 1987 dollars) $\ldots \ldots \ldots \ldots \ldots \ldots \ldots$ & 5135.6 & 6126.2 & 6851.6 & 7485.3 & $2.2 \%$ \\
\hline Non-Agricultural Employment (millions) ........ & 107.9 & 120.4 & 128.9 & 133.5 & $1.3 \%$ \\
\hline \multicolumn{6}{|l|}{$\begin{array}{l}\text { Value of Gross Output } \\
\text { (billion } 1987 \text { dollars) }\end{array}$} \\
\hline \multicolumn{6}{|l|}{ Nonmanufacturing Sector } \\
\hline Agriculitural $\ldots \ldots \ldots \ldots \ldots \ldots \ldots \ldots \ldots$ & 177.1 & 207.1 & 220.1 & 229.1 & $1.5 \%$ \\
\hline Mining $\ldots \ldots \ldots \ldots \ldots \ldots \ldots \ldots \ldots \ldots$ & 128.1 & 131.2 & 137.0 & 144.3 & $0.7 \%$ \\
\hline Construction $\ldots \ldots \ldots \ldots \ldots \ldots \ldots \ldots \ldots$ & 583.4 & 707.6 & 775.3 & 824.9 & $2.1 \%$ \\
\hline \multicolumn{6}{|l|}{ Manufacturing Sector } \\
\hline Food and Kindred Products $\ldots \ldots \ldots \ldots \ldots \ldots$ & 363.8 & 411.1 & 439.2 & 462.2 & $1.4 \%$ \\
\hline Tobacco Products ...................... & 27.7 & 26.4 & 26.5 & 25.4 & $-0.5 \%$ \\
\hline $\begin{array}{l}\text { Textile Mill Products } \ldots \ldots \ldots \ldots \ldots \ldots \ldots \ldots \\
\text { Apparel and Other Textile }\end{array}$ & 52.5 & 59.6 & 64.9 & 69.1 & $1.6 \%$ \\
\hline Products $\ldots \ldots \ldots \ldots \ldots \ldots \ldots \ldots \ldots$ & 76.6 & 83.4 & 88.0 & 89.6 & $0.9 \%$ \\
\hline Lumber and Wood Products ................ & 65.7 & 75.8 & 81.9 & 85.9 & $1.6 \%$ \\
\hline Furniture and Fixtures $\ldots \ldots \ldots \ldots \ldots \ldots \ldots$ & 36.6 & 40.9 & 43.3 & 45.3 & $1.3 \%$ \\
\hline Paper and Allied Products,$\ldots \ldots \ldots \ldots \ldots$ & 113.6 & 134.2 & 148.2 & 159.9 & $2.0 \%$ \\
\hline Printing and Publishing $\ldots \ldots \ldots \ldots \ldots \ldots$ & 87.8 & 105.5 & 117.5 & 126.8 & $2.2 \%$ \\
\hline Chemical and Allied Products .............. & 254.8 & 316.2 & 355.0 & 390.3 & $2.5 \%$ \\
\hline $\begin{array}{l}\text { Bulk Chemicals } \ldots \ldots \ldots \ldots \ldots \ldots \ldots \ldots \\
\text { Other Chemicals and }\end{array}$ & 144.7 & 170.9 & 190.7 & 208.3 & $2.2 \%$ \\
\hline Allied Products...$\ldots \ldots \ldots \ldots \ldots \ldots$ & 110.0 & 145.3 & 164.2 & 182.0 & $3.0 \%$ \\
\hline Petroleum and Coal Products ................ & 132.1 & 145.5 & 149.8 & 153.3 & $0.9 \%$ \\
\hline $\begin{array}{l}\text { Petroleum Refining } \ldots \ldots \ldots \ldots \ldots \ldots \ldots \\
\text { Other Petroleum and }\end{array}$ & 116.4 & 127.2 & 129.7 & 132.0 & $0.7 \%$ \\
\hline $\begin{array}{l}\text { Coal Products } \ldots \ldots \ldots \ldots \ldots \ldots \ldots \ldots \\
\text { Rubber and Miscellaneous }\end{array}$ & 15.7 & 18.4 & 20.1 & 21.4 & $1.8 \%$ \\
\hline 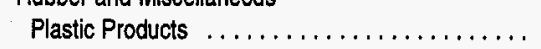 & 94.6 & 122.0 & 144.8 & 164.1 & $3.3 \%$ \\
\hline Leather and Leather Products ................ & 7.7 & 6.9 & 6.8 & 6.2 & $-1.3 \%$ \\
\hline Stone, Clay, and Glass Products .............. & 60.5 & 71.3 & 77.8 & 82.2 & $1.8 \%$ \\
\hline Glass and Glass Products $\ldots \ldots \ldots \ldots \ldots \ldots$ & 16.8 & 20.4 & 23.0 & 24.9 & $2.3 \%$ \\
\hline $\begin{array}{l}\text { Cement, Hydraulic ............................ } \\
\text { Other Stone, Clay, and }\end{array}$ & 3.9 & 4.6 & 4.8 & 4.9 & $1.4 \%$ \\
\hline Glass Products $\ldots \ldots \ldots \ldots \ldots \ldots \ldots \ldots$ & 39.8 & 46.4 & 50.1 & 52.4 & $1.6 \%$ \\
\hline $\begin{array}{l}\text { Primary Metals Industry .................... } \\
\text { Blast Furnace and Basic }\end{array}$ & 115.1 & 121.6 & 133.6 & 141.6 & $1.2 \%$ \\
\hline Steel Products $\ldots \ldots \ldots \ldots \ldots \ldots \ldots \ldots$ & 50.8 & 47.6 & 50.6 & 52.2 & $0.2 \%$ \\
\hline Aluminum $\ldots \ldots \ldots \ldots \ldots \ldots \ldots \ldots$ & 8.5 & 7.8 & 8.8 & 9.3 & $0.5 \%$ \\
\hline Other Primary Metal Products $\ldots \ldots \ldots \ldots \ldots$ & 55.8 & 66.2 & 74.3 & 80.1 & $2.2 \%$ \\
\hline $\begin{array}{l}\text { Fabricated Metal Products } \ldots \ldots \ldots \ldots \ldots \ldots \ldots \\
\text { Industrial Machinery and }\end{array}$ & 143.5 & 163.6 & 177.2 & 185.8 & $1.5 \%$ \\
\hline $\begin{array}{l}\text { Equipment } \ldots \ldots \ldots \ldots \ldots \ldots \ldots \ldots \ldots \\
\text { Electronic and Other Electric }\end{array}$ & 221.4 & 289.7 & 347.3 & 400.5 & $3.5 \%$ \\
\hline Equipment $\ldots \ldots \ldots \ldots \ldots \ldots \ldots \ldots$ & 252.6 & 321.1 & 394.4 & 459.7 & $3.6 \%$ \\
\hline Transportation Equipment $\ldots \ldots \ldots \ldots \ldots \ldots$ & 356.7 & 436.5 & 499.4 & 535.4 & $2.4 \%$ \\
\hline $\begin{array}{l}\text { Instruments and Related Products } \ldots \ldots \ldots \ldots \ldots \\
\text { Miscellaneous Manufacturing }\end{array}$ & 63.7 & 78.1 & 89.0 & 98.0 & $2.6 \%$ \\
\hline Industries.$\ldots \ldots \ldots \ldots \ldots \ldots \ldots \ldots \ldots \ldots$ & 32.7 & 38.4 & 42.8 & 46.2 & $2.1 \%$ \\
\hline Total Industrial Gross Output $\ldots \ldots \ldots \ldots \ldots$. & 3448.0 & 4093.9 & 4559.7 & 4926.0 & $2.1 \%$ \\
\hline
\end{tabular}

GDP = Gross domestic product.

Note: Totals may not equal sum of components due to independent rounding.

Source: 1993: Data Resources Incorporated (DRI), DRI OIUOS/0294/ SERIES, DRI TREND0294. Projections: Energy Information Administration, AE095 National Energy Modeling System run AEO95B.D1103942. 
Table 24. Energy Consumption for Heat and Power by Refineries

\begin{tabular}{|c|c|c|c|c|c|}
\hline \multirow{2}{*}{ Industry Output and Consumption ${ }^{1}$} & \multicolumn{4}{|c|}{ Reference Case } & \multirow{2}{*}{$\begin{array}{c}\text { Annual } \\
\text { Growth } \\
\text { 1993-2010 } \\
\text { (percent) }\end{array}$} \\
\hline & 1993 & 2000 & 2005 & 2010 & \\
\hline Industry Output (billion dollars) . . . . . . . . . . . & 116.42 & 127.19 & 129.72 & 131.97 & $0.7 \%$ \\
\hline \multicolumn{6}{|l|}{ Energy Consumption (trillion Btu) } \\
\hline Purchased Electricity . . . . . . . . . . . . . & 119.1 & 127.0 & 122.2 & 120.5 & $0.1 \%$ \\
\hline Natural Gas $^{2} \ldots \ldots \ldots \ldots \ldots \ldots \ldots$ & 760.2 & 933.4 & 838.0 & 854.2 & $0.7 \%$ \\
\hline Steam Coal $\ldots \ldots \ldots \ldots \ldots \ldots \ldots \ldots \ldots$ & 3.2 & 0.0 & 0.0 & 0.0 & N/A \\
\hline Residual Oil $\ldots \ldots \ldots \ldots \ldots \ldots \ldots \ldots$ & 65.8 & 34.5 & 37.9 & 38.7 & $-3.1 \%$ \\
\hline Distillate Oil ........................ & 3.0 & 0.0 & 0.0 & 0.0 & N/A \\
\hline Liquefied Petroleum Gas . . . . . . . . . . . . . . & 32.7 & 0.0 & 9.5 & 0.0 & N/A \\
\hline Other Petroleum ${ }^{3} \ldots \ldots \ldots \ldots \ldots \ldots \ldots$ & 1922.6 & 2246.9 & 2270.5 & 2306.2 & $1.1 \%$ \\
\hline Subtotal $\ldots \ldots \ldots \ldots \ldots \ldots \ldots \ldots \ldots$ & 2906.5 & 3341.8 & 3278.0 & 3319.6 & $0.8 \%$ \\
\hline Renewables $\ldots \ldots \ldots \ldots \ldots \ldots \ldots \ldots$ & 0.0 & 0.0 & 0.0 & 0.0 & N/A \\
\hline Total $\ldots \ldots \ldots \ldots \ldots \ldots \ldots \ldots \ldots \ldots$ & 2906.5 & 3341.8 & 3278.0 & 3319.6 & $0.8 \%$ \\
\hline \multicolumn{6}{|l|}{$\begin{array}{l}\text { Energy Consumption per Unit of Output } \\
\text { (thousand dollars per } 1987 \text { dollar) }\end{array}$} \\
\hline Purchased Electricity $\ldots \ldots \ldots \ldots \ldots \ldots \ldots$ & 0.33 & 0.31 & 0.28 & 0.26 & $-1.3 \%$ \\
\hline Natural $\mathrm{Gas}^{2} \ldots \ldots \ldots \ldots \ldots \ldots \ldots$ & 2.09 & 2.27 & 1.91 & 1.85 & $-0.7 \%$ \\
\hline Steam Coal $\ldots \ldots \ldots \ldots \ldots \ldots \ldots \ldots$ & 0.01 & 0.00 & 0.00 & 0.00 & N/A \\
\hline Residual Oil $\ldots \ldots \ldots \ldots \ldots \ldots \ldots \ldots$ & 0.18 & 0.08 & 0.09 & 0.08 & $-4.4 \%$ \\
\hline Distillate Oil $\ldots \ldots \ldots \ldots \ldots \ldots \ldots \ldots \ldots$ & 0.01 & 0.00 & 0.00 & 0.00 & N/A \\
\hline Liquefied Petroleum Gas . . . . . . . . . . . . . & 0.09 & 0.00 & 0.02 & 0.00 & N/A \\
\hline Other Petroleum ${ }^{3} \ldots \ldots \ldots \ldots \ldots \ldots \ldots$ & 5.29 & 5.47 & 5.17 & 4.99 & $-0.3 \%$ \\
\hline Subtotal $\ldots \ldots \ldots \ldots \ldots \ldots \ldots \ldots \ldots$ & 7.99 & 8.13 & 7.46 & 7.18 & $-0.6 \%$ \\
\hline Renewables $\ldots \ldots \ldots \ldots \ldots \ldots \ldots \ldots \ldots$ & 0.00 & 0.00 & 0.00 & 0.00 & N/A \\
\hline Total $\ldots \ldots \ldots \ldots \ldots \ldots \ldots \ldots \ldots$ & 7.99 & 8.13 & 7.46 & 7.18 & $-0.6 \%$ \\
\hline
\end{tabular}

'Fuel consumption includes consumption for cogeneration.

${ }^{2}$ Does not include lease and plant fuel.

${ }^{3}$ Includes petroleum coke, lubricants, still gas, and miscellaneous petroleum products.

Btu $=$ British thermal unit.

N/A $=$ Not applicable.

Note: Totals may not equal sum of components due to independent rounding

Source: Energy Information Administration, AEO95 National Energy Modeling System run AEO95B.D1103942. 
Table 25. Energy Consumption for Heat and Power by the Food Industry

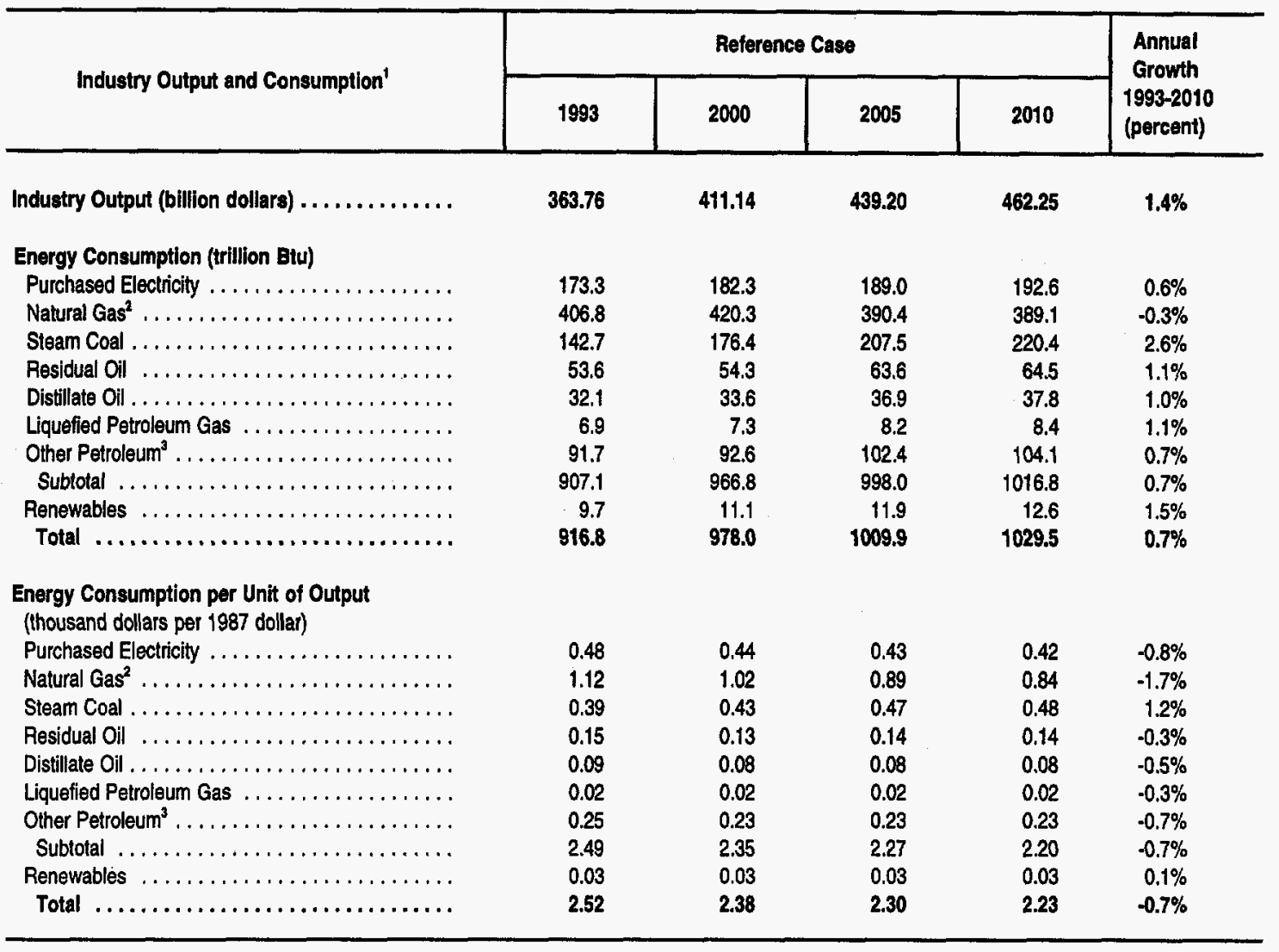

'Fuel consumption includes consumption for cogeneration.

${ }^{2}$ Does not include lease and plant fuel.

${ }^{3}$ Includes petroleum coke, lubricants, still gas, and miscellaneous petroleum products.

Btu = British thermal unit.

N/A = Not applicable.

Note: Totals may not equal sum of components due to independent rounding.

Source: Energy Information Administration, AEO95 National Energy Modeling System run AEO95B.01103942. 
Table 26. Energy Consumption for Heat and Power by the Paper Industry

\begin{tabular}{|c|c|c|c|c|c|}
\hline \multirow{2}{*}{ Industry Output and Consumption' } & \multicolumn{4}{|c|}{ Reference Case } & \multirow{2}{*}{$\begin{array}{l}\text { Annual } \\
\text { Growth } \\
1993-2010 \\
\text { (percent) }\end{array}$} \\
\hline & 1993 & 2000 & 2005 & 2010 & \\
\hline Industry Output (billion dollars) . . . . . . . . . . . & 113.63 & 134.21 & 148.16 & 159.88 & $2.0 \%$ \\
\hline \multicolumn{6}{|l|}{ Energy Consumption (trillion Btu) } \\
\hline Purchased Electricity $\ldots \ldots \ldots \ldots \ldots \ldots \ldots$ & 198.0 & 217.5 & 230.8 & 238.4 & $1.1 \%$ \\
\hline Natural Gas ${ }^{2} \ldots \ldots \ldots \ldots \ldots \ldots \ldots \ldots$ & 293.4 & 253.7 & 220.5 & 205.4 & $-2.1 \%$ \\
\hline Steam Coal $\ldots \ldots \ldots \ldots \ldots \ldots \ldots \ldots \ldots$ & 220.8 & 221.1 & 215.9 & 196.1 & $-0.7 \%$ \\
\hline Residual Oil $\ldots \ldots \ldots \ldots \ldots \ldots \ldots \ldots \ldots$ & 161.1 & 130.8 & 122.8 & 106.1 & $-2.4 \%$ \\
\hline Distillate Oil $\ldots \ldots \ldots \ldots \ldots \ldots \ldots \ldots \ldots \ldots$ & 10.2 & 8.6 & 7.9 & 7.0 & $-2.2 \%$ \\
\hline Liquefied Petroleum Gas $\ldots \ldots \ldots \ldots \ldots \ldots \ldots$ & 2.7 & 2.9 & 3.0 & 3.1 & $0.7 \%$ \\
\hline Other Petroleum ${ }^{3}, \ldots \ldots \ldots \ldots \ldots \ldots \ldots$ & 28.3 & 20.9 & 18.0 & 14.4 & $-3.9 \%$ \\
\hline Subtotal $\ldots \ldots \ldots \ldots \ldots \ldots \ldots \ldots \ldots \ldots$ & 914.4 & 855.4 & 818.9 & 770.5 & $-1.0 \%$ \\
\hline Renewables $\ldots \ldots \ldots \ldots \ldots$. & 1474.5 & 1705.7 & 1865.6 & 1999.3 & $1.8 \%$ \\
\hline Total $\ldots \ldots \ldots \ldots \ldots \ldots \ldots \ldots \ldots \ldots \ldots \ldots \ldots$ & 2388.9 & 2561.1 & 2684.5 & 2769.8 & $0.9 \%$ \\
\hline \multicolumn{6}{|l|}{$\begin{array}{l}\text { Energy Consumption per Unit of Output } \\
\text { (thousand dollars per } 1987 \text { dollar) }\end{array}$} \\
\hline Purchased Electricity $, \ldots, \ldots, \ldots, \ldots, \ldots, \ldots$ & 1.74 & 1.62 & 1.56 & 1.49 & $-0.9 \%$ \\
\hline Natural $\operatorname{Gas}^{2} \ldots \ldots \ldots \ldots \ldots \ldots \ldots \ldots \ldots$ & 2.58 & 1.89 & 1.49 & 1.28 & $-4.0 \%$ \\
\hline Steam Coal $\ldots \ldots \ldots \ldots \ldots \ldots \ldots \ldots \ldots \ldots$ & 1.94 & 1.65 & 1.46 & 1.23 & $-2.7 \%$ \\
\hline Residual Oil $\ldots \ldots \ldots \ldots \ldots \ldots \ldots \ldots$ & 1.42 & 0.97 & 0.83 & 0.66 & $-4.4 \%$ \\
\hline Distillale Oil $\ldots \ldots \ldots \ldots \ldots \ldots \ldots \ldots \ldots \ldots$ & 0.09 & 0.06 & 0.05 & 0.04 & $-4.1 \%$ \\
\hline Liquefied Petroleum Gas $\ldots \ldots \ldots \ldots \ldots \ldots$ & 0.02 & 0.02 & 0.02 & 0.02 & $-1.3 \%$ \\
\hline Other Petroleum ${ }^{3} \ldots \ldots \ldots \ldots \ldots$ & 0.25 & 0.16 & 0.12 & 0.09 & $-5.8 \%$ \\
\hline Subtotal $\ldots \ldots \ldots \ldots \ldots \ldots \ldots \ldots \ldots$ & 8.05 & 6.37 & 5.53 & 4.82 & $-3.0 \%$ \\
\hline Renewables $\ldots \ldots \ldots \ldots \ldots \ldots \ldots \ldots \ldots$ & 12.98 & 12.71 & 12.59 & 12.51 & $-0.2 \%$ \\
\hline Total $\ldots \ldots \ldots, \ldots, \ldots, \ldots, \ldots, \ldots, \ldots, \ldots$ & 21.02 & 19.08 & 18.12 & 17.32 & $-1.1 \%$ \\
\hline
\end{tabular}

'Fuel consumption includes consumption for cogeneration.

${ }^{2}$ Does not include lease and plant fuel.

${ }^{3}$ Includes petroleum coke, lubricants, still gas, and miscellaneous petroleum products.

Btu $=$ British thermal unit.

N/A $=$ Not applicable.

Note: Totals may not equal sum of components due to independent rounding.

Source: Energy Information Administration, AEO95 National Energy Modeling System run AEO958.D1103942. 
Table 27. Energy Consumption for Heat and Power by the Chemical Industry

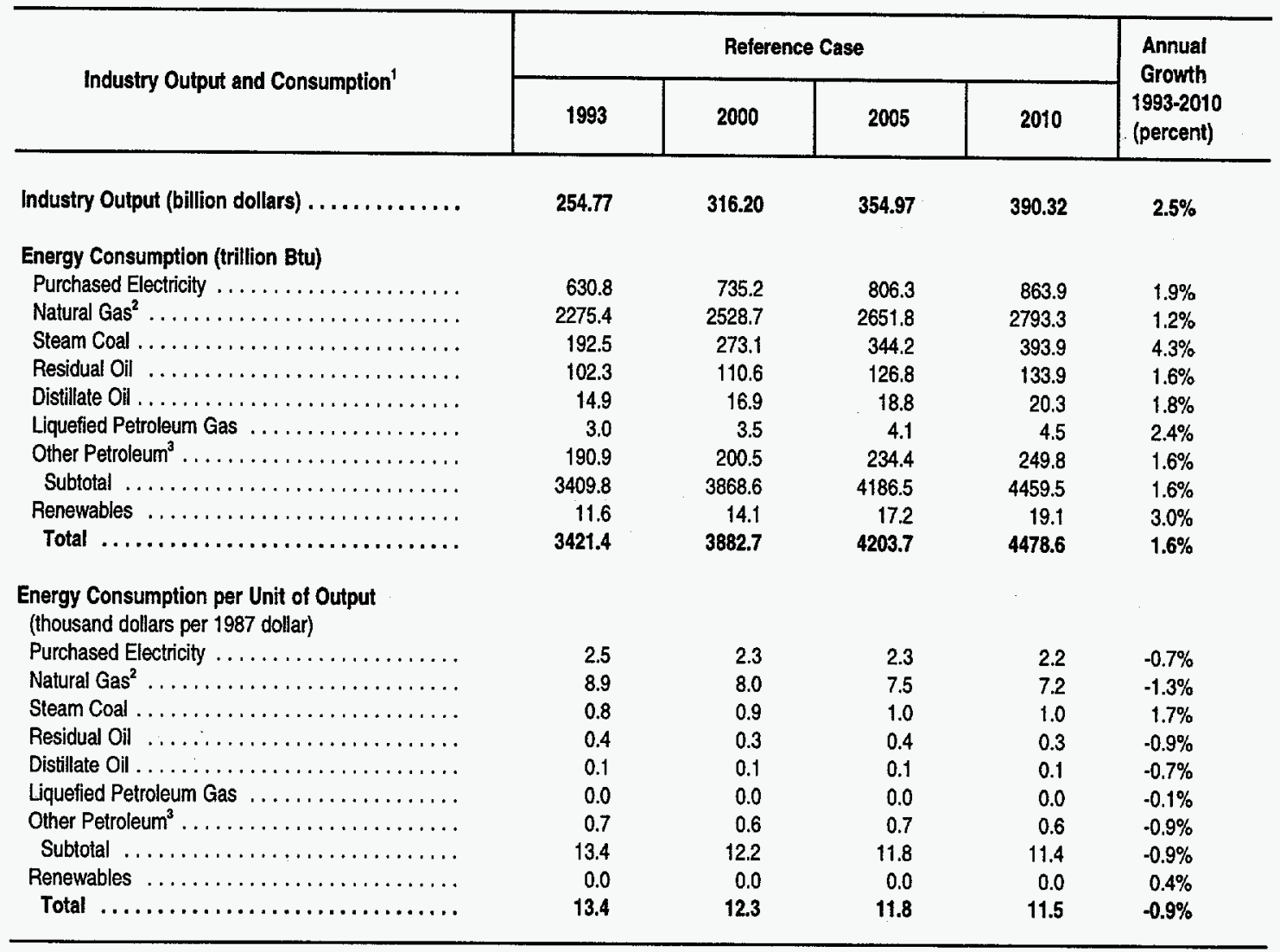

'Fuel consumption includes consumption for cogeneration.

${ }^{2}$ Does not include lease and plant fuel.

${ }^{3}$ Includes petroleum coke, lubricants, still gas, and miscellaneous petroleum products.

Btu = British thermal unit.

N/A = Not applicable.

Note: Totals may not equal sum of components due to independent rounding.

Source: Energy Information Administration, AEO95 National Energy Modeling System run AEO95B.D1103942. 
Table 28. Energy Consumption for Heat and Power by the Glass Industry

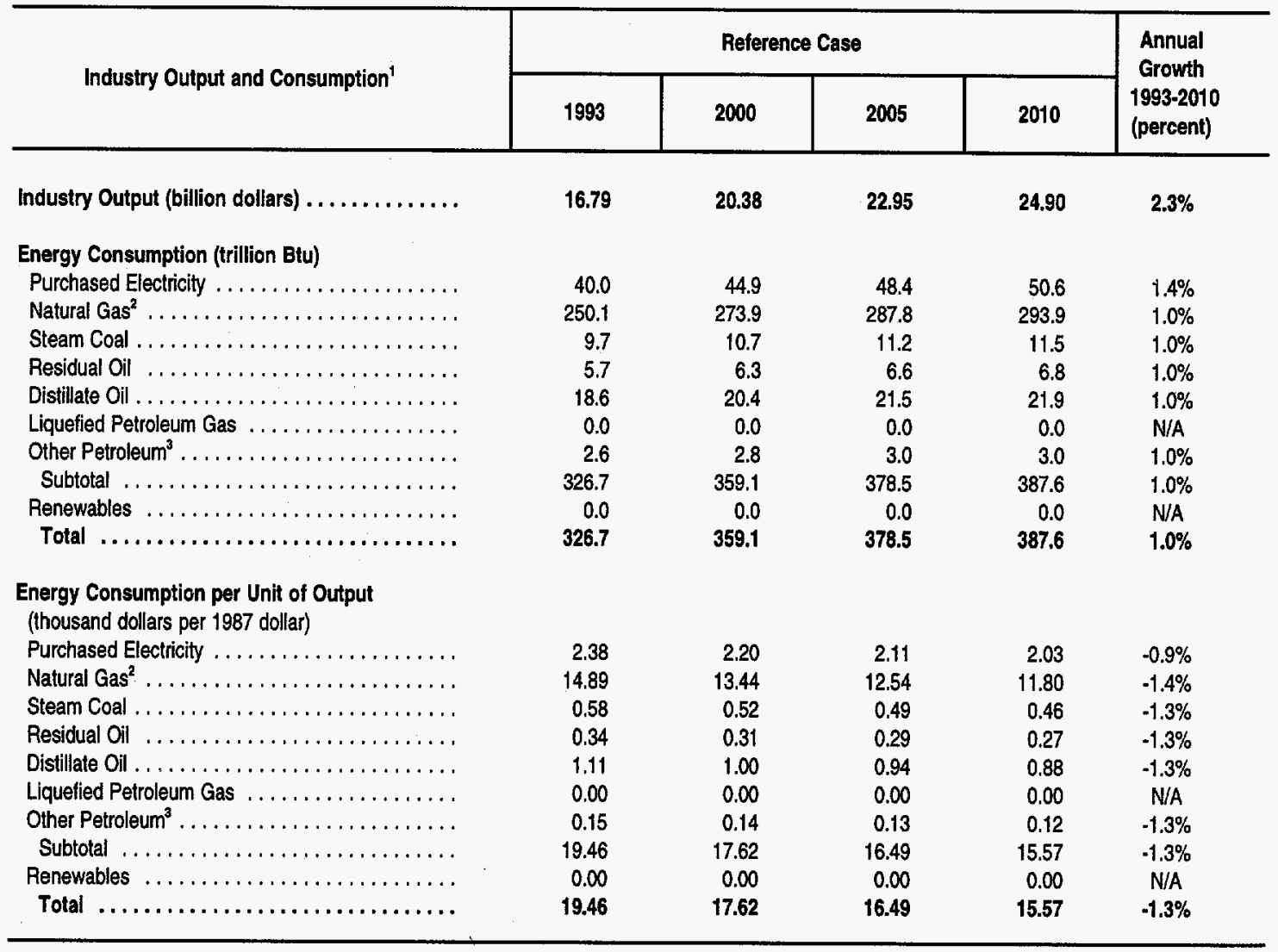

${ }^{1} F u e l$ consumption includes consumption for cogeneration.

${ }^{2}$ Does not include lease and plant fuel.

${ }^{3}$ Includes petroleum coke, lubricants, still gas, and miscellaneous petroleum products.

Btu = British thermal unit.

$\mathrm{N} / \mathrm{A}=$ Not applicable.

Note: Totals may not equal sum of components due to independent rounding.

Source: Energy Information Administration, AEO95 National Energy Modeling System run AEO95B.D1103942. 
Table 29. Energy Consumption for Heat and Power by the Cement Industry

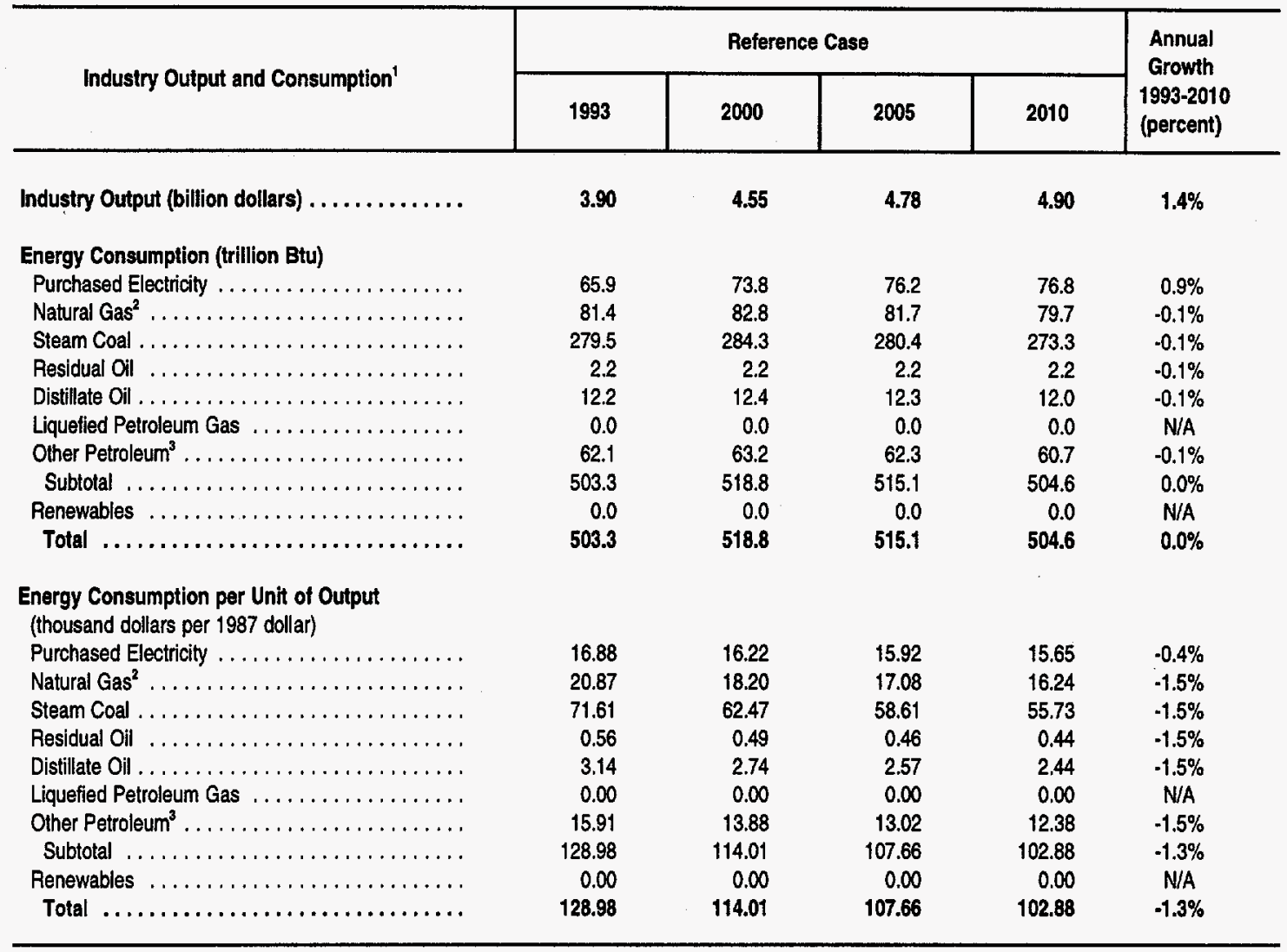

${ }^{1}$ Fuel consumption includes consumption for cogeneration.

${ }^{2}$ Does not include lease and plant fuel.

${ }^{3}$ Includes petroleum coke, lubricants, still gas, and miscellaneous petroleum products.

$B t u=$ British thermal unit.

N/A = Not applicable.

Note: Totals may not equal sum of components due to independent rounding.

Source: Energy Information Administration, AEO95 National Energy Modeling System run AEO95B.D1103942. 
Table 30. Energy Consumption for Heat and Power by the Iron and Steel Industries

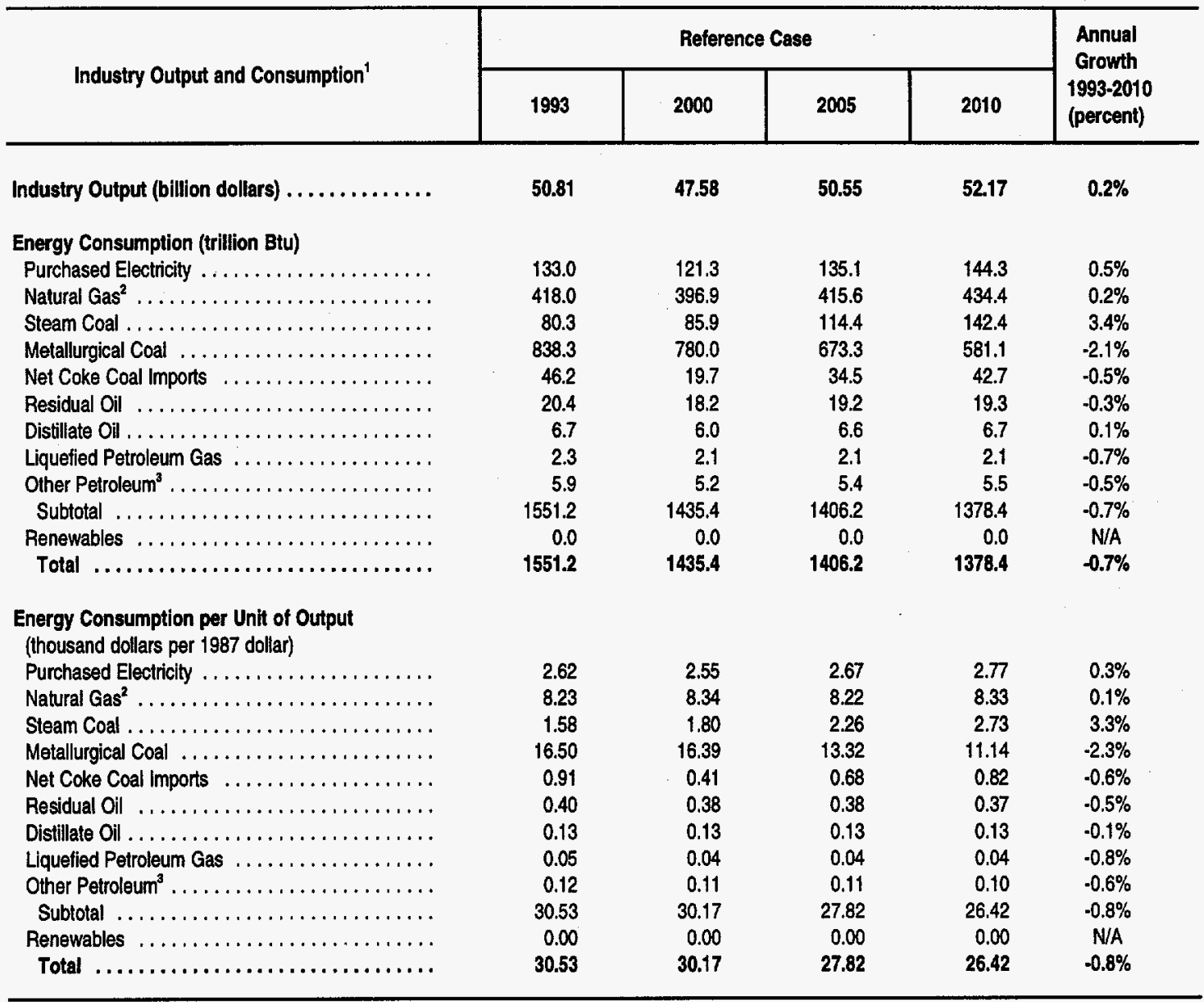

'Fuel consumption includes consumption for cogeneration.

${ }^{2}$ Does not include lease and plant fuel.

Includes petroleum coke, lubricants, still gas, and miscellaneous pelroleum products.

Btu = British thermal unit.

$\mathrm{N} / \mathrm{A}=$ Not applicable.

Note: Totals may not equal sum of components due to independent rounding.

Source: Energy Information Administration, AEO95 National Energy Modeling System run AEO95B.D1103942. 
Table 31. Energy Consumption for Heat and Power by the Aluminum Industry

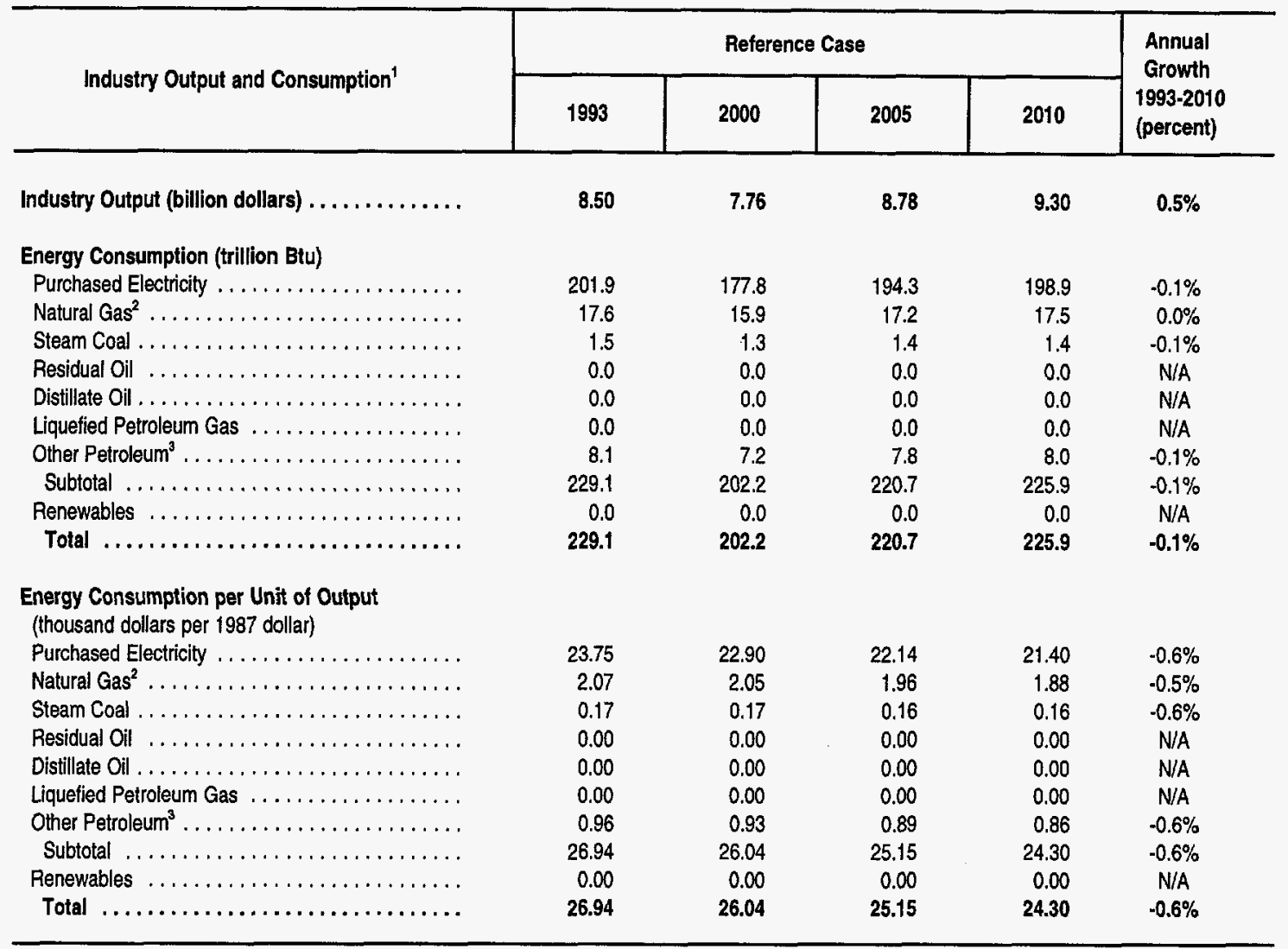

'Fuel consumption includes consumption for cogeneration.

${ }^{2}$ Does not include lease and plant fuel.

${ }^{3}$ Includes petroleum coke, lubricants, still gas, and miscellaneous petroleum products.

Btu = British thermal unit.

$\mathrm{N} / \mathrm{A}=$ Not applicable.

Note: Totals may not equal sum of components due to independent rounding.

Source: Energy Information Administration, AEO95 National Energy Modeling System run AEO95B.D1103942. 
Table 32. Transportation Sector Energy Use by Mode and Type (Trillion Btu per Year)

\begin{tabular}{|c|c|c|c|c|c|}
\hline \multirow{2}{*}{ Mode and Type } & \multicolumn{4}{|c|}{ Reference Case } & \multirow{2}{*}{$\begin{array}{l}\text { Annual } \\
\text { Growth } \\
\text { 1993-2010 } \\
\text { (percent) }\end{array}$} \\
\hline & 1993 & 2000 & 2005 & 2010 & \\
\hline \multicolumn{6}{|l|}{$\begin{array}{l}\text { Energy Use by Mode } \\
\text { Highway }\end{array}$} \\
\hline Light-Duty Vehicles & 13088.4 & 14305.1 & 15085.2 & 15499.2 & $1.0 \%$ \\
\hline Automobiles ...... & 9305.7 & 9097.0 & 9250.1 & 9368.2 & $0.0 \%$ \\
\hline Light Trucks' ......... & 3756.1 & 5182.1 & 5808.7 & 6104.3 & $2.9 \%$ \\
\hline Motorcycles & 26.6 & 26.0 & 26.4 & 26.7 & $0.0 \%$ \\
\hline Buses $[\ldots, \ldots, \ldots, \ldots, \ldots, \ldots, \ldots, \ldots$ & 152.0 & 160.1 & 166.3 & 170.8 & $0.7 \%$ \\
\hline Transit $\ldots \ldots \ldots \ldots \ldots \ldots \ldots \ldots \ldots \ldots$ & 72.2 & 75.7 & 78.6 & 80.7 & $0.7 \%$ \\
\hline Intercity $\ldots \ldots \ldots \ldots \ldots \ldots \ldots \ldots \ldots \ldots \ldots$ & 21.6 & 22.6 & 23.5 & 24.1 & $0.7 \%$ \\
\hline$\ldots \ldots \ldots \ldots \ldots \ldots \ldots \ldots \ldots$ & 58.2 & 61.8 & 64.2 & 65.9 & $0.7 \%$ \\
\hline Freight Trucks ${ }^{2} \ldots \ldots \ldots \ldots \ldots \ldots \ldots$ & 4782.3 & 5887.9 & 6331.7 & 6697.9 & $2.0 \%$ \\
\hline Small $(<10,000$ pounds) $\ldots \ldots \ldots \ldots \ldots \ldots$ & 1453.5 & 1771.0 & 1869.4 & 1940.4 & $1.7 \%$ \\
\hline Medium $(10,000-19,500$ pounds $) \ldots \ldots \ldots \ldots$ & 940.0 & 1176.5 & 1274.0 & 1357.2 & $2.2 \%$ \\
\hline Large $(>19,500$ pounds) $\ldots \ldots \ldots \ldots \ldots \ldots$ & 2388.8 & 2940.4 & 3188.3 & 3400.3 & $2.1 \%$ \\
\hline \multicolumn{6}{|l|}{ Non-Highway } \\
\hline 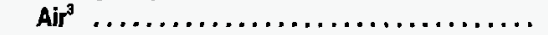 & 2416.4 & 3215.4 & 3612.7 & 3937.5 & $2.9 \%$ \\
\hline General Aviation $\ldots \ldots \ldots \ldots \ldots \ldots \ldots$ & 156.6 & 197.2 & 215.8 & 231.2 & $2.3 \%$ \\
\hline 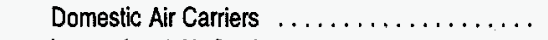 & 1635.6 & 2082.8 & 2264.4 & 2413.6 & $2.3 \%$ \\
\hline Intemational Air Carriers $\ldots \ldots \ldots \ldots \ldots \ldots$ & 287.1 & 431.5 & 482.0 & 527.7 & $3.6 \%$ \\
\hline Freight Carriers . . . . . . . . . . . . . . . . & 337.1 & 503.8 & 650.5 & 765.0 & $4.9 \%$ \\
\hline Water $^{4} \ldots \ldots \ldots \ldots \ldots \ldots \ldots \ldots \ldots \ldots \ldots \ldots \ldots$ & 1631.1 & 1899.7 & 2128.4 & 2321.1 & $2.1 \%$ \\
\hline Freight $\ldots \ldots \ldots \ldots \ldots \ldots \ldots \ldots \ldots$ & 1383.2 & 1637.8 & 1859.2 & 2045.3 & $2.3 \%$ \\
\hline Domestic Shipping $\ldots \ldots \ldots \ldots \ldots \ldots \ldots$ & 317.5 & 335.4 & 356.5 & 376.5 & $1.0 \%$ \\
\hline International Shipping $\ldots \ldots \ldots \ldots \ldots \ldots \ldots$ & 1065.7 & 1302.4 & 1502.7 & 1668.8 & $2.7 \%$ \\
\hline Recreational Boats $\ldots \ldots \ldots \ldots \ldots \ldots \ldots$ & 247.9 & 261.9 & 269.2 & 275.8 & $0.6 \%$ \\
\hline Rail $\ldots \ldots \ldots \ldots \ldots \ldots \ldots \ldots \ldots \ldots \ldots \ldots \ldots \ldots$ & 612.1 & 634.6 & 670.7 & 699.3 & $0.8 \%$ \\
\hline Freight $\ldots \ldots \ldots \ldots \ldots \ldots \ldots \ldots \ldots$ & 534.2 & 556.9 & 591.7 & 619.6 & $0.9 \%$ \\
\hline Passenger $\ldots \ldots \ldots \ldots \ldots \ldots \ldots \ldots \ldots$ & 77.9 & 77.7 & 79.0 & 79.6 & $0.1 \%$ \\
\hline Transit $\ldots \ldots \ldots \ldots \ldots \ldots \ldots \ldots \ldots$ & 15.5 & 15.2 & 15.5 & 15.6 & $0.1 \%$ \\
\hline Commuter $\ldots, \ldots \ldots \ldots \ldots \ldots \ldots \ldots$ & 40.9 & 41.0 & 41.7 & 42.0 & $0.2 \%$ \\
\hline Intercity $\ldots \ldots \ldots \ldots \ldots \ldots \ldots \ldots \ldots$ & 21.6 & 21.5 & 21.8 & 22.0 & $0.1 \%$ \\
\hline Lubricants $\ldots \ldots \ldots \ldots \ldots \ldots \ldots \ldots \ldots \ldots$ & 157.0 & 181.2 & 194.8 & 206.2 & $1.6 \%$ \\
\hline Pipeline Fuel Natural Gas..$\ldots \ldots \ldots \ldots \ldots$ & 625.2 & 671.8 & 672.8 & 666.5 & $0.4 \%$ \\
\hline Military Use $\ldots \ldots \ldots \ldots \ldots \ldots \ldots \ldots \ldots \ldots$ & 858.1 & 646.0 & 641.7 & 650.6 & $-1.6 \%$ \\
\hline Aviation $^{5} \ldots \ldots \ldots \ldots \ldots \ldots \ldots \ldots \ldots$ & 743.6 & 559.3 & 555.5 & 563.3 & $-1.6 \%$ \\
\hline Residual Fuel Use $\ldots \ldots \ldots \ldots \ldots \ldots \ldots$ & 16.6 & 12.6 & 12.6 & 12.7 & $-1.5 \%$ \\
\hline Distillate Fuel Use $\ldots \ldots \ldots \ldots \ldots \ldots \ldots \ldots$ & 98.0 & 74.1 & 73.6 & 74.6 & $-1.6 \%$ \\
\hline $\operatorname{Total}^{8} \ldots \ldots \ldots$ & 22789.5 & 25830.7 & 27634.9 & 28908.9 & $1.4 \%$ \\
\hline \multicolumn{6}{|l|}{ Energy Use by Type } \\
\hline 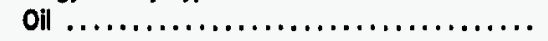 & 22095.0 & 24893.6 & 26477.0 & 27525.5 & $1.3 \%$ \\
\hline Motor Gasoline $\ldots \ldots \ldots \ldots \ldots \ldots \ldots \ldots$ & 13876.3 & 14951.3 & 15424.8 & 15482.9 & $0.6 \%$ \\
\hline Distillate (diesel) $\ldots \ldots \ldots \ldots \ldots \ldots \ldots$ & 3859.6 & 4583.5 & 5017.4 & 5420.6 & $2.0 \%$ \\
\hline Jet Fuel (kerosene \& naphtha) $\ldots \ldots \ldots \ldots \ldots$ & 3040.2 & 3728.3 & 4122.2 & 4454.9 & $2.3 \%$ \\
\hline Residual Oil $\ldots \ldots \ldots \ldots \ldots \ldots \ldots \ldots \ldots$ & 1096.0 & 1318.4 & 1510.5 & 1670.8 & $2.5 \%$ \\
\hline Aviation Gasoline $\ldots \ldots \ldots \ldots \ldots \ldots \ldots$ & 47.2 & 46.3 & 46.0 & 45.9 & $-0.2 \%$ \\
\hline Liquid Petroleum Gas. . ................ & 18.6 & 84.6 & 161.3 & 244.2 & $16.3 \%$ \\
\hline Lubricants...$\ldots \ldots \ldots \ldots \ldots \ldots \ldots \ldots$ & 157.0 & 181.2 & 194.8 & 206.2 & $1.6 \%$ \\
\hline
\end{tabular}


Table 32. Transportation Sector Energy Use by Mode and Type (Continued) (Trillion Btu per Year)

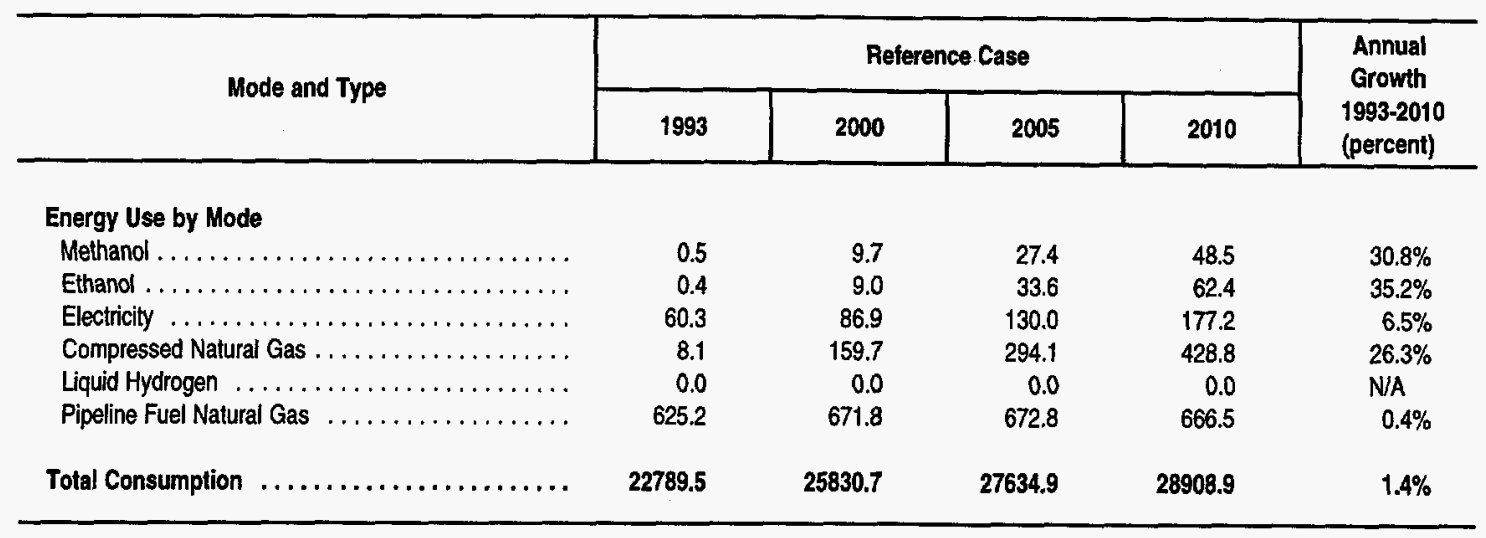

'Includes personal vehicles, fleet vehicles, and treight light trucks.

2Does not include commercial bus and military use.

${ }^{3}$ Does not include military jet fuel use.

${ }^{4}$ Does not include military residual oil.

sincludes jet fuel and naphtha use.

'Total not sum of components due to double counting of freight light truck consumption.

Btu = British thermal unit.

Note: Totals may not equal sum of components due to independent rounding.

Sources: 1993 compressed natural gas volumes: Energy information Administration (EIA), AEO95 National Energy Modeling System run AEO95B.D1103942. Other 1993 values derived using: EIA, Short-Term Energy Outlook, DOE/EIA-0202(94/3Q) (Washington, D.C., August 1994); EIA, Fuel Oil and Kerosene Sales 1992, DOE/EIA-0535(92) (Washington, D.C., October 1993); Oak Ridge National Laboratory, Transportation Energy Book: 12, 13, and 14, (May 1994); Department of Defense, Defense Fuel Supply Center; and EIA, AEO95 National Energy Modeling System run AEO95B.D1103942. Projections: EIA, AEO95 National Energy Modeling System run AEO95B.D1103942. 
Table 33. Transportation Sector Energy Use by Fuel Type Within a Mode (Trillion Btu per Year)

\begin{tabular}{|c|c|c|c|c|c|}
\hline \multirow{2}{*}{ Mode and Type } & \multicolumn{4}{|c|}{ Reference Case } & \multirow{2}{*}{$\begin{array}{c}\text { Annual } \\
\text { Growth } \\
\text { 1993-2010 } \\
\text { (percent) }\end{array}$} \\
\hline & 1993 & 2000 & 2005 & 2010 & \\
\hline \multicolumn{6}{|l|}{ Light-Duty Vehicles' } \\
\hline Motor Gasoline $\ldots \ldots \ldots \ldots \ldots \ldots \ldots$ & 12896.76 & 13888.42 & 14369.62 & 14450.54 & $0.7 \%$ \\
\hline Methanol $\ldots \ldots \ldots \ldots \ldots \ldots \ldots \ldots \ldots$ & 0.50 & 9.65 & 27.40 & 48.51 & $30.8 \%$ \\
\hline Ethanol $\ldots \ldots \ldots \ldots \ldots \ldots \ldots \ldots \ldots \ldots$ & 0.37 & 9.01 & 33.64 & 62.40 & $35.2 \%$ \\
\hline Compressed Natural Gas . . . . . . . . . . . . & 8.12 & 159.65 & 294.12 & 428.76 & $26.3 \%$ \\
\hline Liquid Petroleum Gas $\ldots \ldots \ldots \ldots \ldots \ldots$ & 18.62 & 75.64 & 151.53 & 233.77 & $16.0 \%$ \\
\hline Electricity $\ldots \ldots \ldots \ldots \ldots \ldots \ldots \ldots$ & 0.62 & 27.02 & 69.13 & 115.82 & $36.0 \%$ \\
\hline Liquid Hydrogen $\ldots \ldots \ldots \ldots \ldots \ldots \ldots$ & 0.00 & 0.00 & 0.00 & 0.00 & $N / A$ \\
\hline Distillate (diesel) $\ldots \ldots \ldots \ldots \ldots \ldots \ldots$ & 163.44 & 135.67 & 139.81 & 159.44 & $-0.1 \%$ \\
\hline Total $\ldots \ldots \ldots \ldots \ldots \ldots \ldots \ldots \ldots \ldots$ & 13088.42 & 14305.07 & 15085.24 & 15499.23 & $1.0 \%$ \\
\hline \multicolumn{6}{|l|}{ Freight Trucks ${ }^{2}$} \\
\hline Motor Gasoline $\ldots \ldots \ldots \ldots \ldots \ldots \ldots$ & 2117.91 & 2473.40 & 2529.18 & 2536.00 & $1.1 \%$ \\
\hline Distillate (diesel) $\ldots \ldots \ldots \ldots \ldots \ldots \ldots \ldots$ & 2656.49 & 3404.58 & 3791.75 & 4150.43 & $2.7 \%$ \\
\hline Methanol . . . . . . . . . . . . . . . . . & 0.00 & 0.00 & 0.00 & 0.00 & N/A \\
\hline Compressed Natural Gas . . . . . . . . . . . . . & 0.00 & 0.00 & 0.00 & 0.00 & N/A \\
\hline Liquid Petroleum Gas $\ldots \ldots \ldots \ldots \ldots \ldots$ & 7.92 & 9.96 & 10.77 & 11.46 & $2.2 \%$ \\
\hline Total $\ldots \ldots \ldots \ldots \ldots \ldots \ldots \ldots \ldots \ldots$ & 4782.32 & 5887.93 & 6331.70 & 6697.88 & $2.0 \%$ \\
\hline \multicolumn{6}{|l|}{ Freight Rail } \\
\hline Distillate (diesel) $\ldots \ldots \ldots \ldots \ldots \ldots \ldots \ldots$ & 534.16 & 556.93 & 591.71 & 619.64 & $0.9 \%$ \\
\hline Total $\ldots \ldots \ldots \ldots \ldots \ldots \ldots \ldots \ldots \ldots \ldots$ & 534.16 & 556.93 & 591.71 & 619.64 & $0.9 \%$ \\
\hline \multicolumn{6}{|l|}{ Domestic Shipping } \\
\hline Distillate (diesel) . ................... & 228.32 & 240.55 & 255.68 & 270.03 & $1.0 \%$ \\
\hline Residual Oil $\ldots \ldots \ldots \ldots \ldots \ldots \ldots \ldots$ & 89.22 & 94.82 & 100.78 & 106.44 & $1.0 \%$ \\
\hline Motor Gasoline . . . . . . . . . . . . . . & 0.00 & 0.00 & 0.00 & 0.00 & N/A \\
\hline Total $\ldots \ldots \ldots \ldots \ldots \ldots \ldots \ldots \ldots \ldots \ldots$ & 317.54 & 335.37 & 356.45 & 376.47 & $1.0 \%$ \\
\hline \multicolumn{6}{|l|}{ International Shipping } \\
\hline Distillate (diesel) $\ldots \ldots \ldots \ldots \ldots \ldots \ldots \ldots$ & 75.46 & 91.49 & 105.57 & 117.23 & $2.6 \%$ \\
\hline Residual Oil $\ldots \ldots \ldots \ldots \ldots \ldots \ldots \ldots$ & 990.23 & 1210.92 & 1397.18 & 1551.60 & $2.7 \%$ \\
\hline Total $\ldots \ldots \ldots \ldots \ldots \ldots \ldots \ldots \ldots \ldots \ldots$ & 1065.69 & 1302.41 & 1502.74 & 1668.84 & $2.7 \%$ \\
\hline \multicolumn{6}{|l|}{ Air Transportation } \\
\hline Jet Fuel $\ldots \ldots \ldots \ldots \ldots \ldots \ldots \ldots \ldots \ldots$ & 2296.68 & 3169.02 & 3566.69 & 3891.66 & $3.2 \%$ \\
\hline Aviation Gasoline $\ldots \ldots \ldots \ldots \ldots \ldots \ldots \ldots$ & 47.23 & 46.33 & 46.00 & 45.88 & $-0.2 \%$ \\
\hline Total $\ldots \ldots \ldots \ldots \ldots \ldots \ldots \ldots \ldots \ldots$ & 2343.91 & 3215.35 & 3612.69 & 3937.53 & $3.1 \%$ \\
\hline \multicolumn{6}{|l|}{$\begin{array}{l}\text { Miscellaneous Transportation } \\
\text { Mllitary Use }\end{array}$} \\
\hline Jet Fuel (kerosene) . . . . . . . . . . . . . . & 435.80 & 327.80 & 325.61 & 330.13 & $-1.6 \%$ \\
\hline Jet Fuel (naphtha) . . . . . . . . . . . . . . . & 307.75 & 231.48 & 229.93 & 233.13 & $-1.6 \%$ \\
\hline Residual Fuel $\ldots \ldots \ldots \ldots \ldots \ldots \ldots \ldots$ & 16.59 & 12.65 & 12.56 & 12.74 & $-1.5 \%$ \\
\hline Distillate $\ldots \ldots \ldots \ldots \ldots \ldots \ldots \ldots \ldots$ & 98.01 & 74.08 & 73.59 & 74.61 & $-1.6 \%$ \\
\hline Total $\ldots \ldots \ldots \ldots \ldots \ldots \ldots \ldots \ldots \ldots$ & 858.15 & 646.02 & 641.69 & 650.61 & $-1.6 \%$ \\
\hline
\end{tabular}


Table 33. Transportation Sector Energy Use by Fuel Type Within a Mode (Continued)

(Trillion Btu per Year)

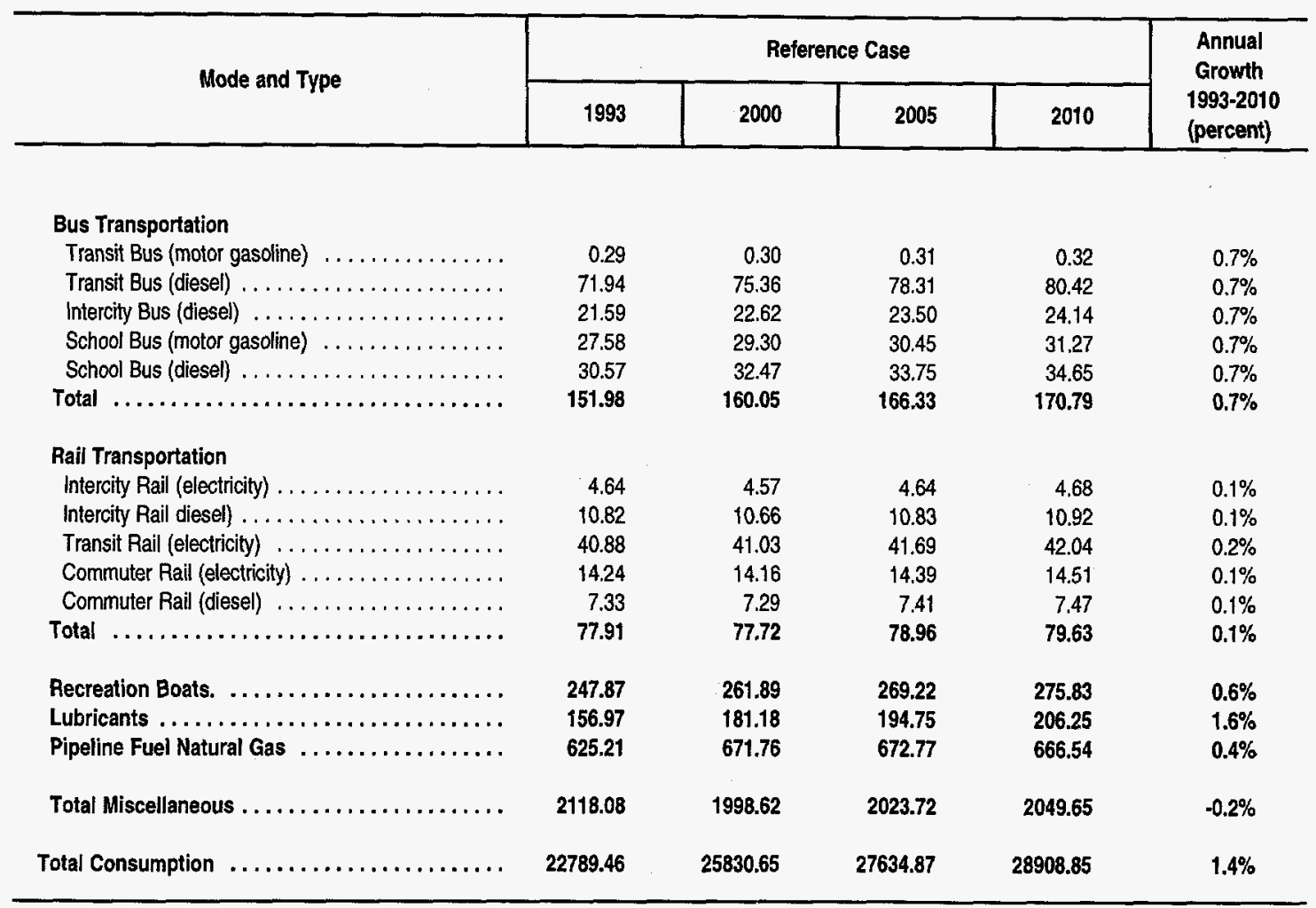

'Includes personal vehicles, fleet vehicles, and freight light trucks.

${ }^{2}$ Freight light trucks are included in both light duty vehicles and freight trucks. Does not include military distillate. Does not include commercial buses.

${ }^{3}$ Does not include passenger rail.

$\mathrm{Btu}=$ British thermal unit.

N/A $=$ Not applicable.

Note: Totals may not equal sum of components due to independent rounding.

Sources: 1993 compressed natural gas volumes: Energy information Administration (EIA), AEO95 National Energy Modeling System run AEO95B.D1103942. Other 1993 values derived using: EIA, Short-Term Energy Outlook, DOE/EIA-0202(94/3Q) (Washington, D.C., August 1994); EIA, Fuel OIl and Kerosene Sales 1992, DOE/EIA-0535(92) (Washington, D.C., October 1993); Oak Ridge National Laboratory, Transportation Energy Book: 12, 13, and 14, (May 1994); Department of Defense, Defense Fuel Supply Center; and EIA, AEO95 National Energy Modeling System run AEO95B.D1103942. Projections: EIA, AEO95 National Energy Modeling System run AEO95B.D1103942. 
Table 34. Light-Duty Vehicle Energy Consumption by Technology Type and Fuel Type (Trillion Btu per Year)

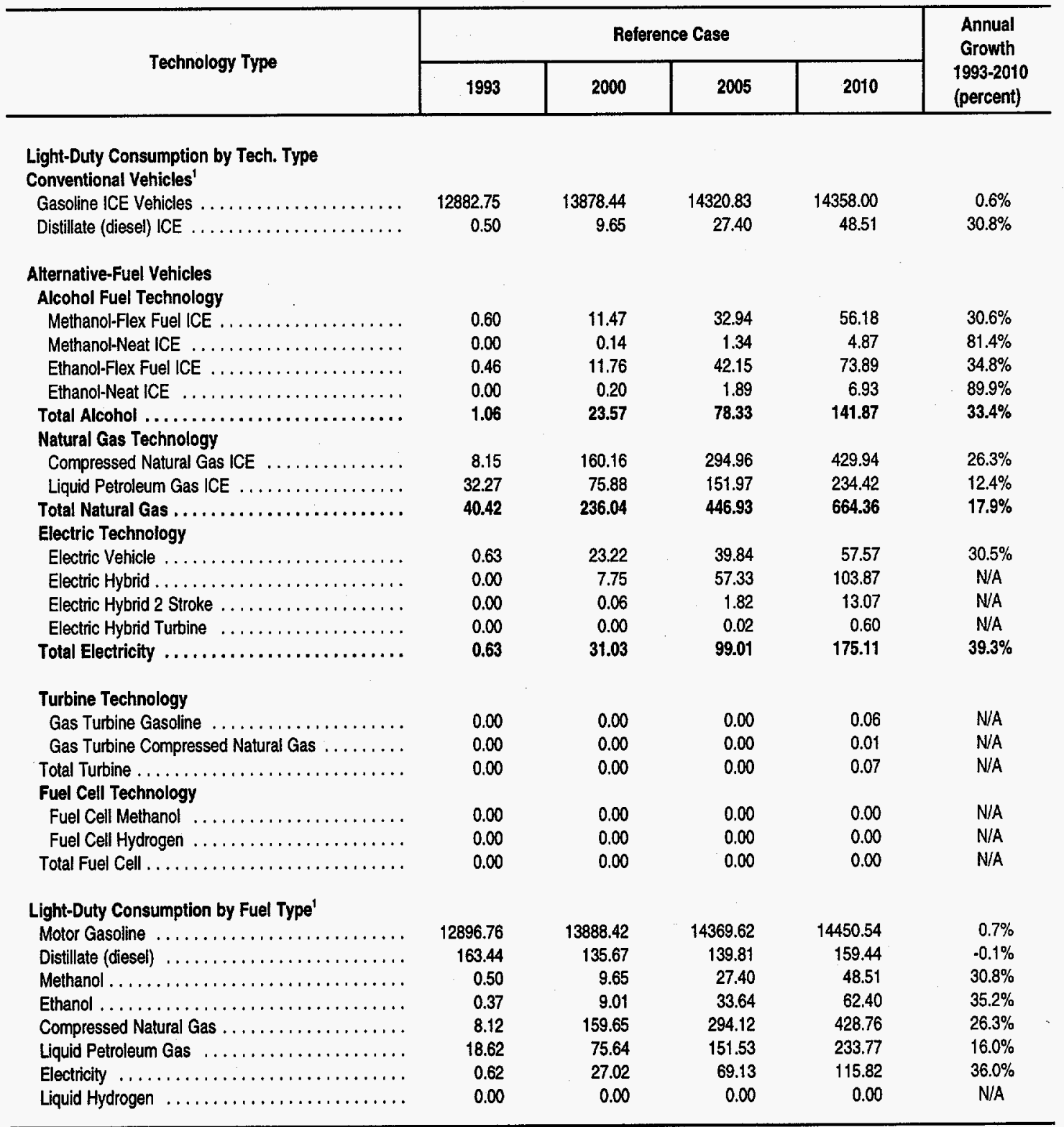

'Includes personal vehicles, fleet vehicles, and freight line trucks. Includes both cars and trucks. Btu = British thermal unit.

ICE = Internal combustion engine.

NA $=$ Not applicable.

Source: Energy Information Administration, AEO95 National Energy Modeling System run AEO95B.D1103942. 
Table 35. Light-Duty Vehicle Sales by Technology Type New England Census Division

(Thousands)

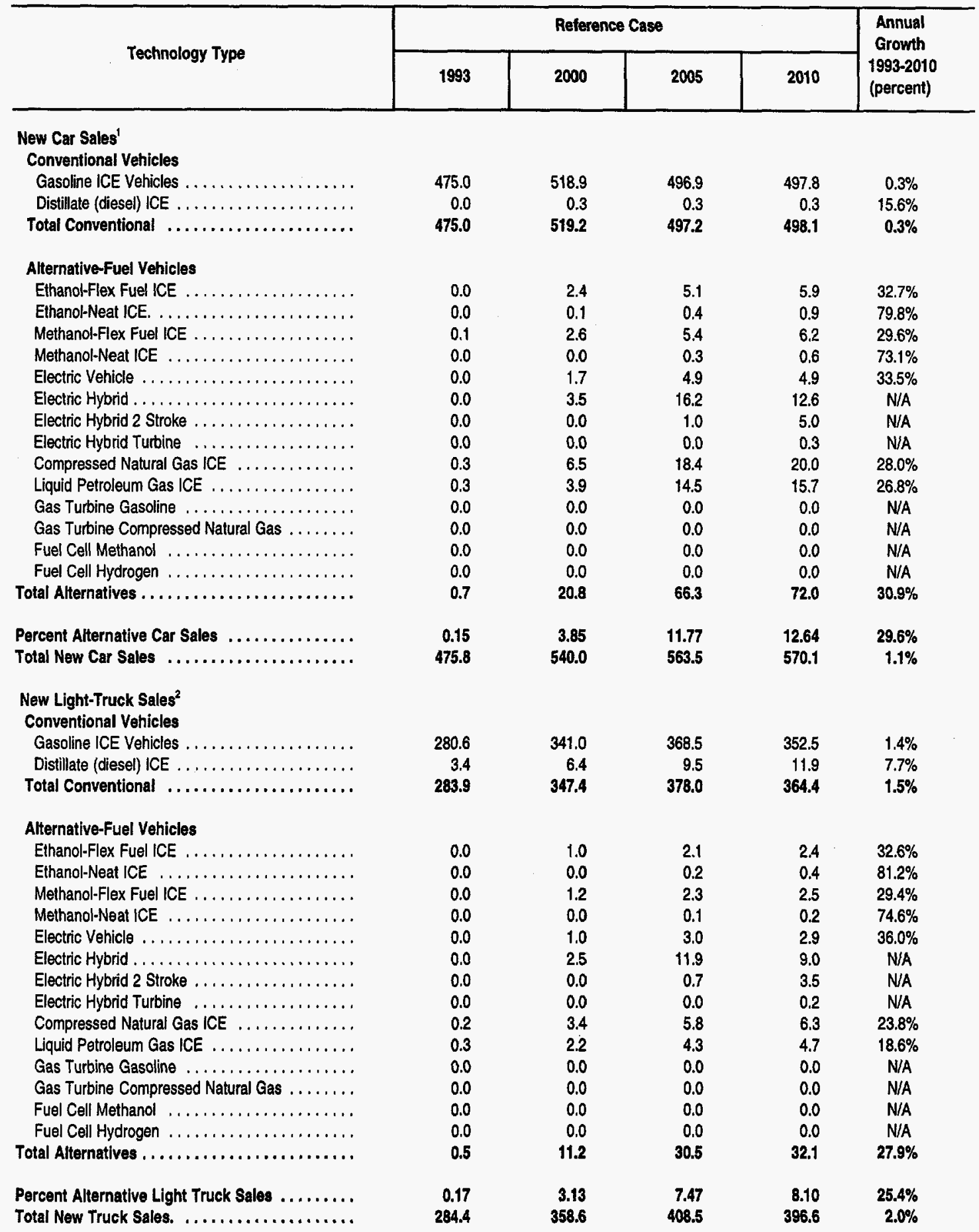


Table 35. Light-Duty Vehicle Sales by Technology Type New England Census Division (Continued)

(Thousands)

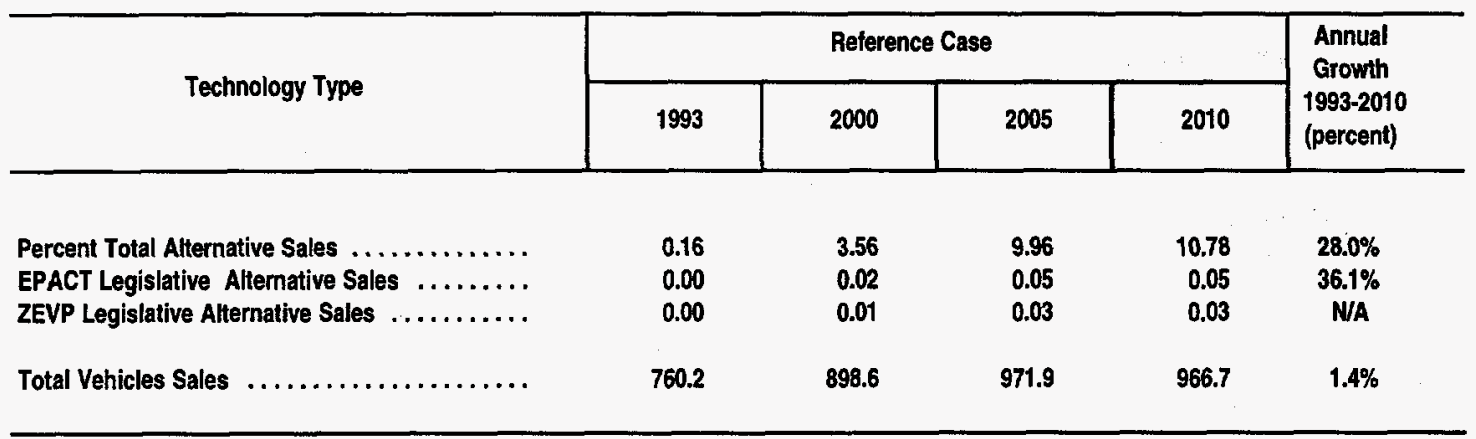

'Includes personal, and fleet light-duty cars.

${ }^{2}$ Includes personal, fleet, and freight light-duty trucks.

ICE = Internal combustion engine.

EPACT = Energy Policy Act of 1992.

ZEVP = Zero emission vehicles from the low emission vehicle program.

$\mathrm{N} / \mathrm{A}=$ Not applicable.

Sources: 1993 derived using: California Air Resources Board, "Proposed Regulations for Low-Emission Vehicles and Clean Fuels, Staff Report"; United States Department of Energy, Office of Domestic and International Energy Policy, "Assessment of Costs and Benefits of Flexible and Alternative Fuel Use in the U.S. Transportation Sector, Technical Report Ten: Analysis of Alternative Fuel Fleet Requirements," (Washington, D.C., May 1992); Bunch, David S., Mark Bradley, Thomas F. Glob, Ryuichi Kitamura, Gareth P. Occhiuzzo, "Demand for Clean-Fuel Personal Vehicles in California: A Discrete-Choice Stated Preference Survey," (December 1991); and Energy Information Administration (EIA), AEO95 National Energy Modeling System run AEO95B.D1103942. Projections: EIA, AEO95 National Energy Modeling System run AEO95B.D1103942. 
Table 36. Light-Duty Vehicle Sales by Technology Type Middle Atlantic Census Division (Thousands)

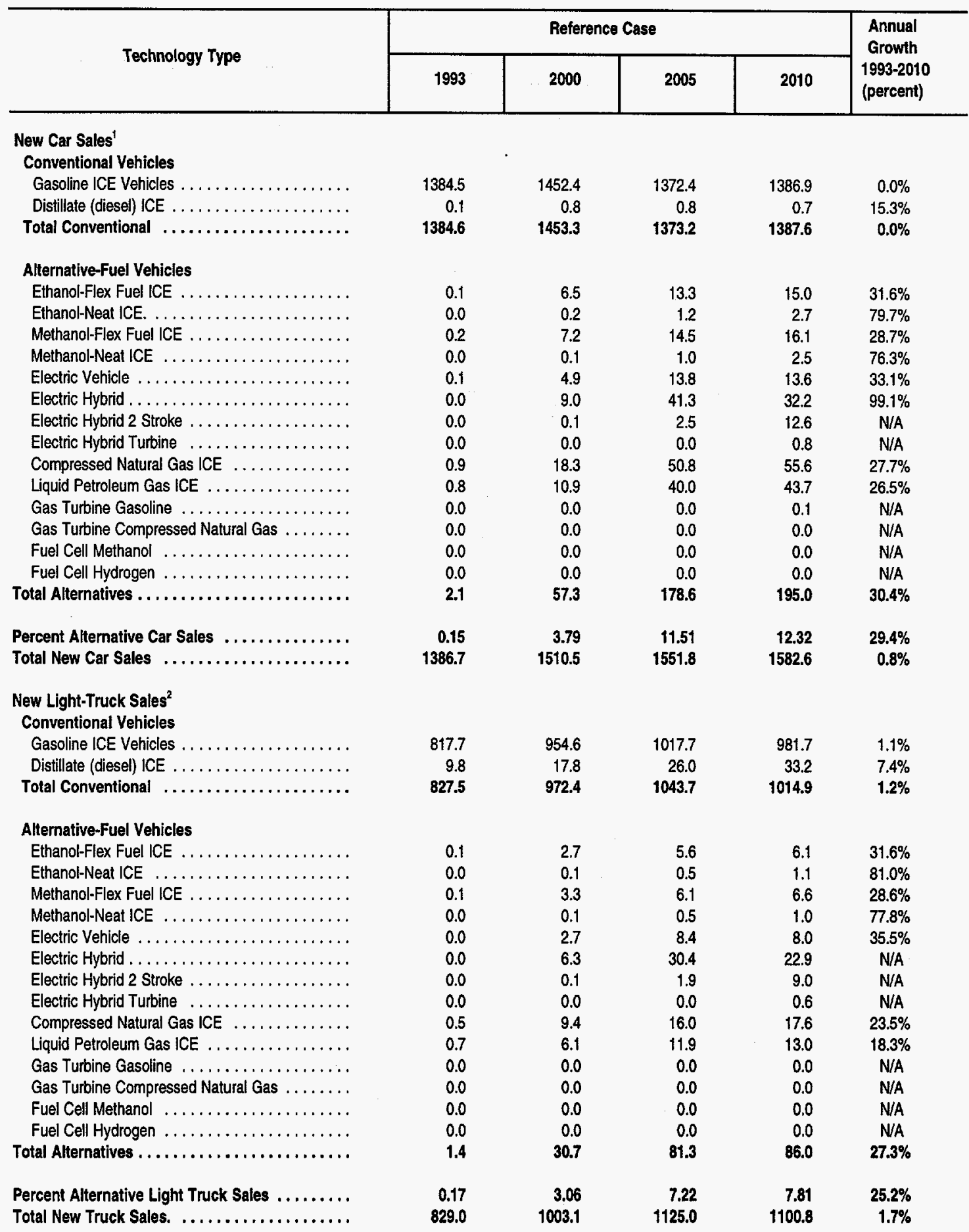


Table 36. Light-Duty Vehicle Sales by Technology Type Middle Atlantic Census Division (Continued)

(Thousands)

\begin{tabular}{|c|c|c|c|c|c|}
\hline \multirow{2}{*}{ Technology Type } & \multicolumn{4}{|c|}{ Reterence Case } & \multirow{2}{*}{$\begin{array}{l}\text { Annual } \\
\text { Growth } \\
\text { 1993-2010 } \\
\text { (percent) }\end{array}$} \\
\hline & 1993 & 2000 & 2005 & 2010 & \\
\hline Percent Total Altemative Sales .............. & 0.16 & 3.50 & 9.71 & 10.47 & $27.8 \%$ \\
\hline Total Vehicles Sales $\ldots . \ldots \ldots \ldots \ldots \ldots \ldots$ & 2215.7 & 2513.6 & 2676.8 & 2683.5 & $1.1 \%$ \\
\hline
\end{tabular}

'Includes personal, and fleet light-duty cars.

${ }^{2}$ Includes personal, fleet, and freight light-duty trucks.

ICE = Internal combustion engine.

EPACT = Energy Policy Act of 1992

ZEVP = Zero emission vehicles from the low emission vehicle program.

N/A = Not applicable.

Sources: 1993 derived using: California Air Resources Board, "Proposed Regulations for Low-Emission Vehicles and Clean Fuels, Staft Report"; United States Department of Energy, Office of Domestic and International Energy Policy, "Assessment of Costs and Benefits of Flexible and Altemative Fuel Use in the U.S. Transportation Sector, Technical Report Ten: Analysis of Alternative Fuel Fleet Requirements," (Washington, D.C., May 1992); Bunch, David S., Mark Bradley, Thomas F. Glob; Ryuichi Kitamura, Gareth P. Occhiuzzo, "Demand for Clean-Fuel Personal Vehicles in California: A Discrete-Choice Stated Preference Survey," (December 1991); and Energy Information Administration (EIA), AEO95 National Energy Modeling System run AEO95B.D1103942. Projections: EIA, AEO95 National Energy Modeling System run AEOS5B.D1103942. 
Table 37. Light-Duty Vehicle Sales by Technology Type

East North Central Census Division

(Thousands)

\begin{tabular}{|c|c|c|c|c|c|}
\hline \multirow{2}{*}{ Technology Type } & \multicolumn{4}{|c|}{ Reference Case } & \multirow{2}{*}{$\begin{array}{l}\text { Annue } \\
\text { Growt } \\
1993-20 \\
\text { (percer }\end{array}$} \\
\hline & 1993 & 2000 & 2005 & 2010 & \\
\hline \multicolumn{6}{|l|}{ New Car Sales ${ }^{1}$} \\
\hline Gasoline ICE Vehicles ................. & 1468.2 & 1505.3 & 1455.0 & 1460.8 & $0.0 \%$ \\
\hline Distillate (diesel) ICE $\ldots \ldots \ldots \ldots \ldots \ldots \ldots$ & 0.1 & 0.9 & 0.8 & 0.7 & $15.0 \%$ \\
\hline Total Conventional $\ldots \ldots \ldots \ldots \ldots \ldots \ldots$ & 1468.3 & 1506.2 & 1455.8 & 1461.5 & $0.0 \%$ \\
\hline \multicolumn{6}{|l|}{ Alternative-Fuel Vehicles } \\
\hline Ethanol-Flex Fuel ICE $\ldots \ldots \ldots \ldots \ldots \ldots$ & 0.1 & 6.7 & 13.7 & 15.6 & $31.5 \%$ \\
\hline Ethanol-Neat ICE. . ................... & 0.0 & 0.2 & 1.2 & 2.7 & $79.2 \%$ \\
\hline Methanol-Flex Fuel ICE $\ldots \ldots \ldots \ldots \ldots \ldots$ & 0.2 & 7.0 & 14.1 & 15.9 & $28.2 \%$ \\
\hline Methanol-Neat ICE $\ldots \ldots \ldots \ldots \ldots \ldots \ldots \ldots$ & 0.0 & 0.1 & 0.7 & 1.5 & $71.6 \%$ \\
\hline Electric Vehicle $\ldots \ldots \ldots \ldots \ldots \ldots \ldots \ldots$ & 0.1 & 4.2 & 6.4 & 7.0 & $27.5 \%$ \\
\hline Electric Hybrid . . . . . . . . & 0.0 & 0.8 & 2.3 & 2.6 & $71.0 \%$ \\
\hline Electric Hybrid 2 Stroke $\ldots \ldots \ldots \ldots \ldots \ldots \ldots$ & 0.0 & 0.0 & 0.1 & 1.0 & N/A \\
\hline Electric Hybrid Turbine $\ldots \ldots \ldots \ldots \ldots \ldots$ & 0.0 & 0.0 & 0.0 & 0.1 & N/A \\
\hline Compressed Natural Gas ICE $\ldots \ldots \ldots \ldots \ldots$ & 0.9 & 18.9 & 52.0 & 56.6 & $27.4 \%$ \\
\hline Liquid Petroleum Gas ICE ............... & 0.9 & 11.3 & 41.1 & 44.7 & $26.2 \%$ \\
\hline Gas Turbine Gasoline $\ldots \ldots \ldots \ldots \ldots \ldots$ & 0.0 & 0.0 & 0.0 & 0.1 & N/A \\
\hline Gas Turbine Compressed Natural Gas ........ & 0.0 & 0.0 & 0.0 & 0.0 & N/A \\
\hline Fuel Cell Methanol $\ldots \ldots \ldots \ldots \ldots \ldots \ldots$ & 0.0 & 0.0 & 0.0 & 0.0 & N/A \\
\hline Fuel Cell Hydrogen . . . . . . . . . . . . . . & 0.0 & 0.0 & 0.0 & 0.0 & N/A \\
\hline Total Alternatives . . . . . . . . . . . . . . . . . & 2.3 & 49.1 & 131.6 & 147.8 & $27.8 \%$ \\
\hline Percent Alternative Car Sales $\ldots \ldots \ldots \ldots \ldots \ldots$ & 0.15 & 3.16 & 8.29 & 9.18 & $27.1 \%$ \\
\hline Total New Car Sales..$\ldots \ldots \ldots \ldots \ldots \ldots \ldots$ & 1470.6 & 1555.3 & 1587.4 & 1609.3 & $0.5 \%$ \\
\hline \multicolumn{6}{|l|}{$\begin{array}{l}\text { New Light-Truck Sales } \\
\text { Conventional Vehicles }\end{array}$} \\
\hline Gasoline ICE Vehicles & 867.2 & 990.0 & 1079.1 & 1035.2 & $1.0 \%$ \\
\hline Distillate (diesel) ICE . & 10.4 & 18.3 & 26.6 & 33.7 & $7.2 \%$ \\
\hline Total Conventional $\ldots \ldots \ldots \ldots \ldots \ldots \ldots$ & 877.6 & 1008.3 & 1105.7 & 1068.9 & $1.2 \%$ \\
\hline \multicolumn{6}{|l|}{ Alternative-Fuel Vehicles } \\
\hline Ethanol-Flex Fuel ICE $\ldots \ldots \ldots \ldots \ldots \ldots \ldots$ & 0.1 & 2.8 & 5.7 & 6.3 & $31.4 \%$ \\
\hline Ethanol-Neat ICE $\ldots \ldots \ldots \ldots \ldots \ldots \ldots \ldots$ & 0.0 & 0.1 & 0.5 & 1.1 & $80.5 \%$ \\
\hline Methanol-Flex Fuel ICE $\ldots \ldots \ldots \ldots \ldots \ldots \ldots$ & 0.1 & 3.2 & 5.9 & 6.5 & $28.1 \%$ \\
\hline Methanol-Neat ICE $\ldots \ldots \ldots \ldots \ldots \ldots \ldots$, & 0.0 & 0.0 & 0.3 & 0.6 & $73.1 \%$ \\
\hline Electric Vehicle $\ldots \ldots \ldots \ldots \ldots \ldots \ldots \ldots$ & 0.0 & 2.2 & 2.9 & 3.1 & $27.7 \%$ \\
\hline Electric Hybrid ...................... & 0.0 & 0.3 & 1.0 & 1.1 & $72.4 \%$ \\
\hline Electric Hybrid 2 Stroke $\ldots \ldots \ldots \ldots \ldots \ldots \ldots$ & 0.0 & 0.0 & 0.1 & 0.4 & N/A \\
\hline Electric Hybrid Turbine $\quad \ldots \ldots \ldots \ldots \ldots \ldots$ & 0.0 & 0.0 & 0.0 & 0.0 & N/A \\
\hline Compressed Natural Gas ICE $\ldots \ldots \ldots \ldots \ldots$ & 0.5 & 9.7 & 16.4 & 17.9 & $23.2 \%$ \\
\hline Liquid Petroleum Gas ICE . . . . . . . . . . . . . & 0.8 & 6.3 & 12.3 & 13.3 & $18.1 \%$ \\
\hline Gas Turbine Gasoline $\ldots \ldots \ldots \ldots \ldots \ldots \ldots$ & 0.0 & 0.0 & 0.0 & 0.0 & N/A \\
\hline Gas Turbine Compressed Natural Gas ........ & 0.0 & 0.0 & 0.0 & 0.0 & NA \\
\hline Fuel Cell Methanol $\ldots \ldots \ldots \ldots \ldots \ldots \ldots$ & 0.0 & 0.0 & 0.0 & 0.0 & N/A \\
\hline Fuel Cell Hydrogen $\ldots \ldots \ldots \ldots \ldots \ldots \ldots$ & 0.0 & 0.0 & 0.0 & 0.0 & N/A \\
\hline Total Alternatives ..................... & 1.5 & 24.5 & 45.0 & 50.5 & $22.9 \%$ \\
\hline Percent Alternative Light Truck Sales ......... & 0.17 & 2.38 & 3.91 & 4.51 & $21.2 \%$ \\
\hline Total New Truek Sales. .................. & 879.1 & 1032.9 & 1150.7 & 1119.4 & $1.4 \%$ \\
\hline
\end{tabular}


Table 37. Light-Duty Vehicle Sales by Technology Type East North Central Census Division (Continued) (Thousands)

\begin{tabular}{|c|c|c|c|c|c|}
\hline \multirow{2}{*}{ Technology Type } & \multicolumn{4}{|c|}{ Reference Case } & \multirow{2}{*}{$\begin{array}{l}\text { Annual } \\
\text { Growth } \\
\text { 1993-2010 } \\
\text { (percent) }\end{array}$} \\
\hline & 1993 & 2000 & 2005 & 2010 & \\
\hline Percent Total Alternative Sales & 0.16 & 2.85 & 6.45 & 7.27 & $25.1 \%$ \\
\hline EPACT Legislative Alternative Sales ......... & 0.00 & 0.05 & 0.14 & 0.15 & $35.4 \%$ \\
\hline ZEVP Legislative Alternative Sales .......... & 0.00 & 0.00 & 0.00 & 0.00 & N/A \\
\hline Total Vehicles Sales $\ldots \ldots \ldots \ldots \ldots \ldots \ldots \ldots$ & 2349.7 & 2588.2 & 2738.1 & 2728.7 & $0.9 \%$ \\
\hline
\end{tabular}

'Includes personal, and fleet light-duty cars.

Includes personal, fleet, and freight light-duty trucks.

ICE = Internal combustion engine.

EPACT = Energy Policy Act of 1992.

ZEVP $=$ Zero emission vehicles from the low emission vehicle program.

N/A = Not applicable.

Sources: 1993 derived using: California Air Resources Board, "Proposed Regulations for Low-Emission Vehicles and Clean Fuels, Staff Report"; United States Department of Energy, Otfice of Domestic and Intemational Energy Policy, "Assessment of Costs and Benefits of Flexible and Alternative Fuel Use in the U.S. Transportation Sector, Technical Report Ten: Analysis of Alternative Fuel Fleet Requirements," (Washington, D.C., May 1992); Bunch, David S., Mark Bradley, Thomas F. Glob, Ryuichi Kitamura, Gareth P. Occhiuzzo, "Demand for Clean-Fuel Personal Vehicles in California: A Discrete-Choice Stated Preference Survey," (December 1991); and Energy information Administration (EIA), AEO95 National Energy Modeling System run AEO95B.D1103942. Projections: EIA, AEO95 National Energy Modeling System run AEO958.D1103942. 
Table 38. Light-Duty Vehicle Sales by Technology Type West North Central Census Division

(Thousands)

\begin{tabular}{|c|c|c|c|c|c|}
\hline \multirow{2}{*}{ Technology Type } & \multicolumn{4}{|c|}{ Reterence Case } & \multirow{2}{*}{$\begin{array}{l}\text { Annua } \\
\text { Growt } \\
1993-20 \\
\text { (percer }\end{array}$} \\
\hline & 1993 & 2000 & 2005 & 2010 & \\
\hline \multicolumn{6}{|l|}{ New Car Sales' } \\
\hline Gasoline ICE Vehicles $\ldots \ldots \ldots \ldots \ldots \ldots$ & 586.5 & 626.9 & 606.5 & 608.9 & $0.2 \%$ \\
\hline Distillate (diesel) ICE $\ldots \ldots \ldots \ldots \ldots \ldots \ldots$ & 0.0 & 0.4 & 0.3 & 0.3 & $15.3 \%$ \\
\hline Total Conventional $\ldots \ldots \ldots \ldots \ldots \ldots \ldots$ & 586.5 & 627.2 & 606.8 & 609.2 & $0.2 \%$ \\
\hline \multicolumn{6}{|l|}{ Alternative-Fuel Vehicles } \\
\hline Ethanol-Flex Fuel ICE .. & 0.1 & 2.7 & 5.2 & 5.6 & $30.7 \%$ \\
\hline Ethanol-Neat ICE. ..... & 0.0 & 0.1 & 0.9 & 2.3 & $84.2 \%$ \\
\hline Methanol-Flex Fuel ICE $\ldots \ldots \ldots \ldots \ldots \ldots$ & 0.1 & 2.9 & 5.5 & 5.9 & $27.6 \%$ \\
\hline Methanol-Neat ICE $\ldots \ldots \ldots \ldots \ldots \ldots \ldots$ & 0.0 & 0.0 & 0.3 & 0.5 & $70.2 \%$ \\
\hline Electric Vehicle $\ldots \ldots \ldots \ldots \ldots \ldots \ldots \ldots$ & 0.0 & 1.7 & 2.7 & 2.9 & $27.7 \%$ \\
\hline Electric Hybrid $\ldots \ldots \ldots \ldots \ldots \ldots \ldots \ldots$ & 0.0 & 0.3 & 0.9 & 0.9 & $69.7 \%$ \\
\hline Electric Hybrid 2 Stroke.$\ldots \ldots \ldots \ldots \ldots \ldots$ & 0.0 & 0.0 & 0.1 & 0.4 & N/A \\
\hline Electric Hybrid Turbine $\ldots \ldots \ldots \ldots \ldots \ldots$ & 0.0 & 0.0 & 0.0 & 0.0 & N/A \\
\hline Compressed Natural Gas ICE $\ldots \ldots \ldots \ldots \ldots$ & 0.4 & 7.9 & 21.7 & 23.9 & $27.8 \%$ \\
\hline Liquid Petroleum Gas ICE $\ldots \ldots \ldots \ldots \ldots \ldots$ & 0.3 & 4.7 & 17.2 & 19.0 & $26.6 \%$ \\
\hline Gas Turbine Gasoline $\ldots \ldots \ldots \ldots \ldots \ldots$ & 0.0 & 0.0 & 0.0 & 0.0 & N/A \\
\hline Gas Turbine Compressed Natural Gas ........ & 0.0 & 0.0 & 0.0 & 0.0 & N/A \\
\hline Fuel Cell Methanol $\ldots \ldots \ldots \ldots \ldots \ldots$ & 0.0 & 0.0 & 0.0 & 0.0 & N/A \\
\hline Fuel Cell Hydrogen $\ldots \ldots \ldots \ldots \ldots \ldots \ldots$ & 0.0 & 0.0 & 0.0 & 0.0 & N/A \\
\hline Total Alternatives $\ldots \ldots \ldots \ldots \ldots \ldots \ldots \ldots \ldots$ & 0.9 & 20.4 & 54.4 & 61.3 & $28.1 \%$ \\
\hline Percent Alternative Car Sales $\ldots \ldots \ldots \ldots \ldots$. & 0.15 & 3.15 & 8.23 & 9.14 & $27.1 \%$ \\
\hline Total New Car Sales $\ldots \ldots \ldots \ldots \ldots \ldots \ldots \ldots$ & 587.4 & 647.6 & 661.2 & 670.5 & $0.8 \%$ \\
\hline \multirow{2}{*}{\multicolumn{6}{|c|}{$\begin{array}{l}\text { New Light-Truck Sales }{ }^{2} \\
\text { Conventional Vehicles }\end{array}$}} \\
\hline & & & & & \\
\hline Gasoline ICE Vehicles & 346.4 & 412.3 & 449.7 & 431.4 & $1.3 \%$ \\
\hline Distillate (diesel) ICE $\ldots \ldots \ldots \ldots \ldots \ldots \ldots$ & 4.2 & 7.6 & 11.1 & 14.1 & $7.4 \%$ \\
\hline Total Conventional $\ldots \ldots \ldots \ldots \ldots \ldots \ldots$ & 350.6 & 419.9 & 460.8 & 445.5 & $1.4 \%$ \\
\hline \multicolumn{6}{|l|}{ Alternative-Fuel Vehicles } \\
\hline Ethanol-Flex Fuel ICE ... & 0.0 & 1.1 & 2.2 & 2.3 & $30.6 \%$ \\
\hline Ethanol-Neat ICE $\ldots .$. & 0.0 & 0.0 & 0.4 & 0.9 & $85.6 \%$ \\
\hline Methanol-Flex Fuel ICE $\ldots \ldots \ldots \ldots \ldots \ldots \ldots$ & 0.0 & 1.3 & 2.3 & 2.4 & $27.5 \%$ \\
\hline Methanol-Neat ICE $\ldots \ldots \ldots \ldots \ldots \ldots \ldots \ldots$ & 0.0 & 0.0 & 0.1 & 0.2 & $71.7 \%$ \\
\hline Electric Vehicle $\ldots \ldots \ldots \ldots \ldots \ldots \ldots \ldots$ & 0.0 & 0.9 & 1.2 & 1.3 & $27.9 \%$ \\
\hline Electric Hybrid $\ldots \ldots \ldots \ldots \ldots \ldots \ldots \ldots$ & 0.0 & 0.1 & 0.4 & 0.4 & $71.2 \%$ \\
\hline Electric Hybrid 2 Stroke $\ldots \ldots \ldots \ldots \ldots \ldots$ & 0.0 & 0.0 & 0.0 & 0.1 & N/A \\
\hline Electric Hybrid Turbine $\ldots \ldots \ldots \ldots \ldots \ldots \ldots$ & 0.0 & 0.0 & 0.0 & 0.0 & $N / A$ \\
\hline Compressed Natural Gas ICE $\ldots \ldots \ldots \ldots \ldots$ & 0.2 & 4.0 & 6.9 & 7.6 & $23.6 \%$ \\
\hline Liquid Petroleum Gas ICE $\ldots \ldots \ldots \ldots \ldots \ldots$ & 0.3 & 2.6 & 5.2 & 5.7 & $18.6 \%$ \\
\hline Gas Turbine Gasoline $\ldots \ldots \ldots \ldots \ldots \ldots \ldots$ & 0.0 & 0.0 & 0.0 & 0.0 & N/A \\
\hline Gas Turbine Compressed Natural Gas ......... & 0.0 & 0.0 & 0.0 & 0.0 & N/A \\
\hline Fuel Cell Methanol $\ldots \ldots \ldots \ldots \ldots \ldots \ldots$ & 0.0 & 0.0 & 0.0 & 0.0 & N/A \\
\hline Fuel Cell Hydrogen $\ldots \ldots \ldots \ldots \ldots \ldots \ldots$ & 0.0 & 0.0 & 0.0 & 0.0 & N/A \\
\hline Total Alternatives $\ldots \ldots \ldots \ldots \ldots \ldots \ldots \ldots \ldots$ & 0.6 & 10.2 & 18.6 & 20.9 & $23.2 \%$ \\
\hline Percent Alternative Light Truck Sales ......... & 0.17 & 2.37 & 3.88 & 4.48 & $21.1 \%$ \\
\hline Total New Truck Sales. $\ldots \ldots \ldots \ldots \ldots \ldots \ldots$ & 351.2 & 430.1 & 479.3 & 466.4 & $1.7 \%$ \\
\hline
\end{tabular}


Table 38. Light-Duty Vehicle Sales by Technology Type

West North Central Census Division (Continued)

(Thousands)

\begin{tabular}{|c|c|c|c|c|c|}
\hline \multirow{2}{*}{ Technology Type } & \multicolumn{4}{|c|}{ Reference Case } & \multirow{2}{*}{$\begin{array}{c}\text { Annual } \\
\text { Growth } \\
1993-2010 \\
\text { (percent) }\end{array}$} \\
\hline & 1993 & 2000 & 2005 & 2010 & \\
\hline Percent Total Alternative Sales ............. & 0.16 & 2.84 & 6.40 & 7.23 & $25.1 \%$ \\
\hline EPACT Legislative Alternative Sales ......... & 0.00 & 0.02 & 0.06 & 0.06 & $35.7 \%$ \\
\hline ZEVP Legislative Allernative Sales .......... & 0.00 & 0.00 & 0.00 & 0.00 & N/A \\
\hline Total Vehicles Sales $\ldots \ldots \ldots \ldots \ldots \ldots \ldots$ & 938.6 & 1077.7 & 1140.5 & 1136.9 & $1.1 \%$ \\
\hline
\end{tabular}

Includes personal, and fleet light-duty cars.

${ }^{2}$ Includes personal, fleet, and freight light-duty trucks.

ICE = Internal combustion engine.

EPACT = Energy Policy Act of 1992.

ZEVP = Zero emission vehicles from the low emission vehicle program.

N/A $=$ Not applicable.

Sources: 1993 derived using: California Air Resources Board, "Proposed Regulations for Low-Emission Vehicles and Clean Fuels, Staff Report"; United States Department of Energy, Office of Domestic and International Energy Policy, "Assessment of Costs and Benefits of Flexible and Alternative Fuel Use in the U.S. Transportation Sector, Technical Report Ten: Analysis of Alternative Fuel Fleet Requirements," (Washington, D.C., May 1992); Bunch, David S., Mark Bradley, Thomas F. Glob, Ryuichi Kitamura, Gareth P. Occhiuzzo, "Demand for Clean-Fuel Personal Vehicles in California: A Discrete-Choice Stated Preference Survey," (December 1991); and Energy Information Administration (EIA), AEO95 National Energy Modeling System run AEO95B.D1103942. Projections: EIA, AEO95 National Energy Modeling System run AEO95B.D1103942. 
Table 39. Light-Duty Vehicle Sales by Technology Type South Atlantic Census Division (Thousands)

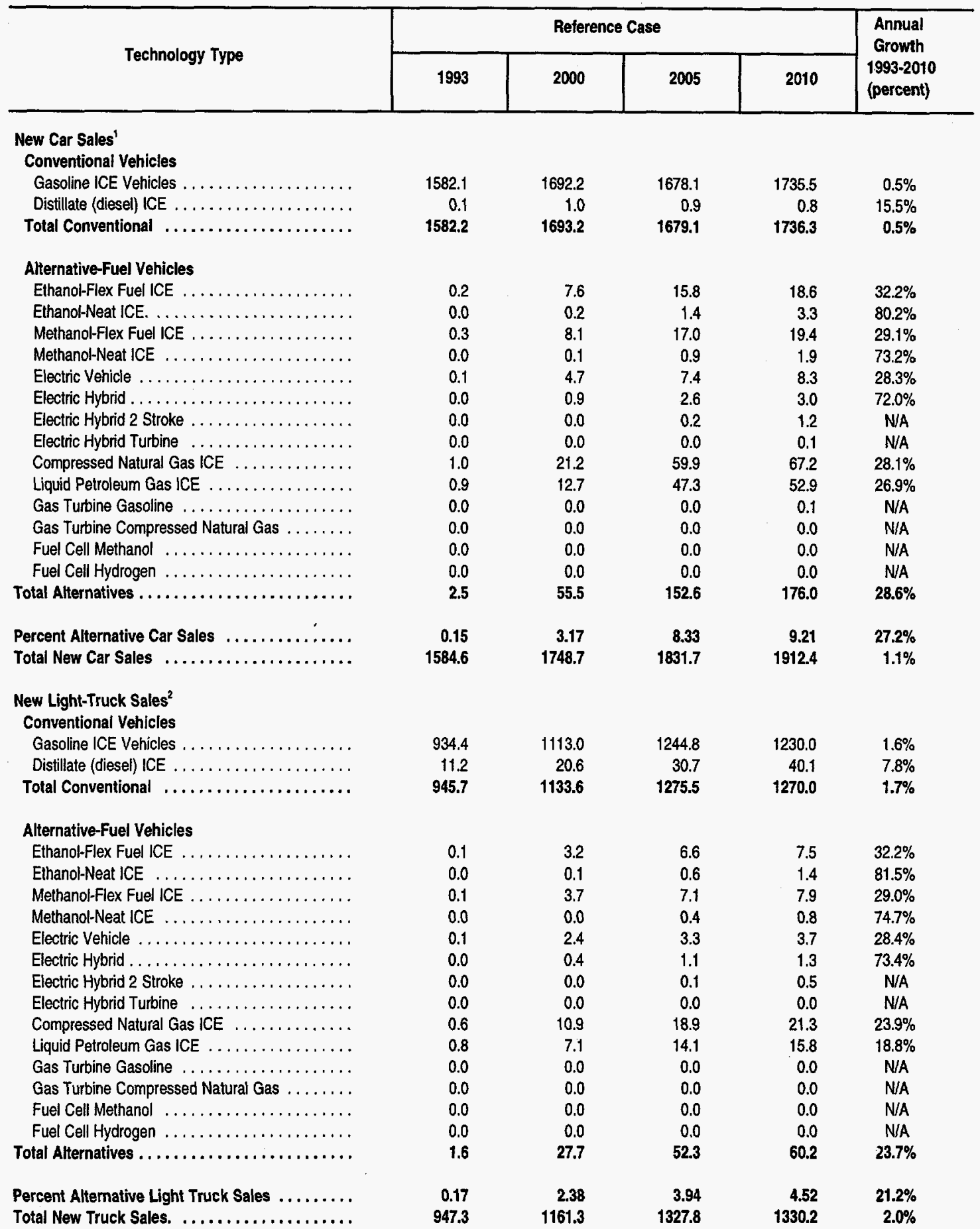


Table 39. Light-Duty Vehicle Sales by Technology Type South Atlantic Census Division (Continued) (Thousands)

\begin{tabular}{|c|c|c|c|c|c|}
\hline \multirow{2}{*}{ Technology Type } & \multicolumn{4}{|c|}{ Reference Case } & \multirow{2}{*}{$\begin{array}{c}\text { Annual } \\
\text { Growth } \\
1993-2010 \\
\text { (percent) }\end{array}$} \\
\hline & 1993 & 2000 & 2005 & 2010 & \\
\hline Percent Total Alternative Sales . . . . . . . . . . . & 0.16 & 2.86 & 6.48 & 7.28 & $25.1 \%$ \\
\hline ZEVP Legislative Alternative Sales . . . . . . . . & 0.00 & 0.00 & 0.00 & 0.00 & N/A \\
\hline Total Vehicles Sales . . . . . . . . . . . . . . . . . & 2531.9 & 2909.9 & 3159.5 & 3242.5 & $1.5 \%$ \\
\hline
\end{tabular}

'Includes personal, and fleet light-duty cars.

IIncludes personal, fleet, and freight light-duty trucks.

ICE = Internal combustion engine.

EPACT = Energy Policy Act of 1992.

ZEVP = Zero emission vehicles from the low emission vehicle program.

N/A = Not applicable.

Sources: 1993: Califomia Air Resources Board, "Proposed Regulations for Low-Emission Vehicles and Clean Fuels, Staff Report"; United States Department of Energy, Office of Domestic and Intemational Energy Policy, "Assessment of Costs and Benefits of Flexible and Alternative Fuel Use in the U.S. Transportation Sector, Technical Report Ten: Analysis of Alternative Fuel Fleet Requirements," (Washington, D.C., May 1992); Bunch, David S., Mark Bradley, Thomas F. Glob, Ryuichi Kitamura, Gareth P. Occhiuzzo, "Demand for Clean-Fuel Personal Vehicles in Califomia: A Discrete-Choice Stated Preference Survey," (December 1991); and Energy Information Administration (EIA), AEO95 National Energy Modeling System run AEO95B.D1103942. Projections: EIA, AEO95 National Energy Modeling System run AEO95B.D1103942. 
Table 40. Light-Duty Vehicle Sales by Technology Type East South Central Census Division (Thousands)

\begin{tabular}{|c|c|c|c|c|c|}
\hline \multirow{2}{*}{ Technology Type } & \multicolumn{4}{|c|}{ Reference Case } & \multirow{2}{*}{$\begin{array}{l}\text { Annu } \\
\text { Growt } \\
\text { 1993-2 } \\
\text { (perce }\end{array}$} \\
\hline & 1993 & 2000 & 2005 & 2010 & \\
\hline \multicolumn{6}{|l|}{ New Car Sales ${ }^{1}$} \\
\hline Gasoline ICE Vehicles & 480.8 & 516.0 & 501.2 & 503.4 & $0.3 \%$ \\
\hline Distillate (diesel) ICE $\ldots \ldots \ldots \ldots \ldots \ldots \ldots$ & 0.0 & 0.3 & 0.3 & 0.3 & $15.4 \%$ \\
\hline Total Conventional $\quad \ldots \ldots \ldots \ldots \ldots \ldots \ldots$ & 480.8 & 516.3 & 501.5 & 503.6 & $0.3 \%$ \\
\hline \multicolumn{6}{|l|}{ Afternative-Fuel Vehicles } \\
\hline Ethanol-Flex Fuel ICE ... & 0.0 & 2.3 & 4.7 & 5.3 & $31.8 \%$ \\
\hline Ethanol-Neat ICE. ..... & 0.0 & 0.1 & 0.4 & 0.9 & $79.7 \%$ \\
\hline Methanol-Flex Fuel ICE . & 0.1 & 2.5 & 5.0 & 5.6 & $28.7 \%$ \\
\hline Methanol-Neat ICE $\ldots \ldots \ldots \ldots \ldots \ldots \ldots$ & 0.0 & 0.0 & 0.3 & 0.6 & $72.8 \%$ \\
\hline Electric Vehicle...$\ldots \ldots \ldots \ldots \ldots \ldots \ldots$ & 0.0 & 1.4 & 2.2 & 2.4 & $28.0 \%$ \\
\hline Electric Hybrid $\ldots \ldots \ldots \ldots \ldots \ldots \ldots \ldots \ldots$ & 0.0 & 0.3 & 0.8 & 0.9 & $71.7 \%$ \\
\hline Electric Hybrid 2 Stroke $\ldots \ldots \ldots \ldots \ldots \ldots$. & 0.0 & 0.0 & 0.1 & 0.4 & N/A \\
\hline Electric Hybrid Turbine $\ldots .$. & 0.0 & 0.0 & 0.0 & 0.0 & N/A \\
\hline Compressed Natural Gas ICE & 0.3 & 6.5 & 17.9 & 19.5 & $27.8 \%$ \\
\hline Liquid Petroleum Gas ICE ... & 0.3 & 3.9 & 14.2 & 15.4 & $26.6 \%$ \\
\hline Gas Turbine Gasoline $\ldots \ldots \ldots \ldots \ldots \ldots$ & 0.0 & 0.0 & 0.0 & 0.0 & N/A \\
\hline Gas Turbine Compressed Natural Gas ........ & 0.0 & 0.0 & 0.0 & 0.0 & N/A \\
\hline Fuel Cell Methanol $\ldots \ldots \ldots \ldots \ldots \ldots \ldots$ & 0.0 & 0.0 & 0.0 & 0.0 & N/A \\
\hline Fuel Cell Hydrogen $\ldots \ldots \ldots \ldots \ldots \ldots \ldots$ & 0.0 & 0.0 & 0.0 & 0.0 & N/A \\
\hline Total Alternatives $\ldots \ldots \ldots \ldots \ldots \ldots \ldots \ldots$ & 0.7 & 16.9 & 45.6 & 51.1 & $28.2 \%$ \\
\hline Percent Alternative Car Sales...$\ldots \ldots \ldots \ldots$ & 0.15 & 3.17 & 8.33 & 9.22 & $27.2 \%$ \\
\hline Total New Car Sales..$\ldots \ldots \ldots \ldots \ldots \ldots \ldots$ & 481.5 & 533.3 & 547.0 & 554.8 & $0.8 \%$ \\
\hline \multicolumn{6}{|l|}{$\begin{array}{l}\text { New Light-Truck Sales } \\
\text { Conventional Vehicles }\end{array}$} \\
\hline Gasoline ICE Vehicles & 284.0 & 339.4 & 371.8 & 356.8 & $1.4 \%$ \\
\hline Distillate (diesel) ICE .. & 3.4 & 6.3 & 9.2 & 11.6 & $7.5 \%$ \\
\hline Total Conventional $\ldots \ldots \ldots \ldots \ldots \ldots \ldots$ & 287.4 & 345.7 & 381.0 & 368.4 & $1.5 \%$ \\
\hline \multicolumn{6}{|l|}{ Alternative-Fuel Vehicles } \\
\hline Ethanol-Flex Fuel ICE $\ldots \ldots \ldots \ldots \ldots \ldots$ & 0.0 & 1.0 & 2.0 & 2.2 & $31.8 \%$ \\
\hline Ethanol-Neat ICE $\ldots \ldots \ldots \ldots \ldots \ldots \ldots \ldots$ & 0.0 & 0.0 & 0.2 & 0.4 & $81.1 \%$ \\
\hline Methanol-Flex Fuel ICE $\ldots \ldots \ldots \ldots \ldots \ldots$ & 0.0 & 1.1 & 2.1 & 2.3 & $28.6 \%$ \\
\hline Methanol-Neat ICE $\ldots \ldots \ldots \ldots \ldots \ldots \ldots$ & 0.0 & 0.0 & 0.1 & 0.2 & $74.2 \%$ \\
\hline Electric Vehicle...$\ldots \ldots \ldots \ldots \ldots \ldots$ & 0.0 & 0.7 & 1.0 & 1.1 & $28.1 \%$ \\
\hline Electric Hybrid $\ldots \ldots \ldots \ldots \ldots \ldots \ldots$ & 0.0 & 0.1 & 0.3 & 0.4 & $73.2 \%$ \\
\hline Electric Hybrid 2 Stroke $\ldots \ldots \ldots \ldots \ldots \ldots$ & 0.0 & 0.0 & 0.0 & 0.2 & N/A \\
\hline Electric Hybrid Turbine $\ldots \ldots \ldots \ldots \ldots \ldots$ & 0.0 & 0.0 & 0.0 & 0.0 & N/A \\
\hline Compressed Natural Gas ICE $\ldots \ldots \ldots \ldots \ldots$ & 0.2 & 3.3 & 5.6 & 6.2 & $23.6 \%$ \\
\hline Liquid Petroleum Gas ICE . .............. & 0.3 & 2.2 & 4.2 & 4.6 & $18.5 \%$ \\
\hline Gas Turbine Gasoline $\ldots \ldots \ldots \ldots \ldots \ldots \ldots$ & 0.0 & 0.0 & 0.0 & 0.0 & N/A \\
\hline Gas Turbine Compressed Nalural Gas ........ & 0.0 & 0.0 & 0.0 & 0.0 & N/A \\
\hline Fuel Cell Methanol $\ldots \ldots \ldots \ldots \ldots \ldots \ldots$ & 0.0 & 0.0 & 0.0 & 0.0 & N/A \\
\hline Fuel Cell Hydrogen $\ldots \ldots \ldots \ldots \ldots \ldots \ldots$ & 0.0 & 0.0 & 0.0 & 0.0 & NA \\
\hline Total Alternatives $\ldots \ldots \ldots \ldots \ldots \ldots \ldots \ldots$ & 0.5 & 8.4 & 15.6 & 17.5 & $23.3 \%$ \\
\hline Percent Alternative Light Truck Sales ......... & 0.17 & 2.38 & 3.94 & 4.53 & $21.2 \%$ \\
\hline Total New Truck Sales. $\ldots \ldots \ldots \ldots \ldots \ldots \ldots$ & 287.9 & 354.1 & 396.6 & 385.9 & \\
\hline
\end{tabular}


Table 40. Light-Duty Vehicle Sales by Technology Type East South Central Census Division (Continued) (Thousands)

\begin{tabular}{|c|c|c|c|c|c|}
\hline Technology Type & 1993 & 2000 & 2005 & 2010 & $\begin{array}{l}\text { Annual } \\
\text { Growth } \\
1993-2010 \\
\text { (percent) }\end{array}$ \\
\hline ZEVP Legislative Altemative Sales .......... & 0.00 & 0.00 & 0.00 & 0.00 & NA \\
\hline Total Vehicles Sales . . . . . . . . . . . . . . . . . & 769.4 & 887.4 & 943.6 & 940.7 & $1.2 \%$ \\
\hline
\end{tabular}

'Includes personal, and fleet light-duty cars.

${ }^{2}$ Includes personal, fleet, and freight light-duty trucks.

ICE = Internal combustion engine.

EPACT = Energy Policy Act of 1992.

ZEVP = Zero emission vehicles from the low emission vehicle program.

N/A = Not applicable.

Sources: 1993 derived using: California Air Resources Board, "Proposed Regulations for Low-Emission Vehicles and Clean Fuels, Staft Report"; United States Department of Energy, Office of Domestic and International Energy Policy, "Assessment of Costs and Benefits of Flexible and Alternative Fuel Use in the U.S. Transportation Sector, Technical Report Ten: Analysis of Alternative Fuel Fleet Requirements,

" (Washington, D.C. May 1992); Bunch, David S. Mark Bradley, Thomas F. Glob, Ryuichi Kitarnura, Gareth P. Occhiuzzo, "Demand for Clean-Fuel Personal Vehicles in California: A Discrete-Choice Stated Preference Survey," (December 1991); and Energy Information Administration (ElA), AEO95 National Energy Modeling System run AEO95B.D1103942. Projections: EIA, AEO95 National Energy Modeling System run AEO95B.D1103942. 
Table 41. Light-Duty Vehicle Sales by Technology Type West South Central Census Division (Thousands)

\begin{tabular}{|c|c|c|c|c|c|}
\hline \multirow{2}{*}{ Technology Type } & \multicolumn{4}{|c|}{ Reference Case } & \multirow{2}{*}{$\begin{array}{l}\text { Annual } \\
\text { Growth } \\
1993-20 \\
\text { (percent }\end{array}$} \\
\hline & 1993 & 2000 & 2005 & 2010 & \\
\hline \multicolumn{6}{|l|}{ New Car Sales' } \\
\hline Gasoline ICE Vehicles & 872.7 & 937.2 & 916.0 & 929.4 & $0.4 \%$ \\
\hline Distillate (diesel) ICE $\ldots \ldots \ldots \ldots \ldots \ldots \ldots$ & 0.0 & 0.6 & 0.5 & 0.5 & $15.6 \%$ \\
\hline Total Conventional $\ldots \ldots \ldots \ldots \ldots \ldots \ldots$ & 872.8 & 937.7 & 916.6 & 929.8 & $0.4 \%$ \\
\hline \multicolumn{6}{|l|}{ Alternative-Fuel Vehicles } \\
\hline Ethanol-Fiex Fuel ICE $\ldots \ldots \ldots \ldots \ldots \ldots$ & 0.1 & 4.0 & 7.9 & 8.8 & $31.1 \%$ \\
\hline Ethanol-Neat ICE. . .................. & 0.0 & 0.1 & 0.7 & 1.6 & $79.1 \%$ \\
\hline Methanol-Flex Fuel ICE $\ldots \ldots \ldots \ldots \ldots \ldots$ & 0.1 & 4.5 & 8.8 & 9.6 & $28.3 \%$ \\
\hline Methanol-Neat ICE $\ldots \ldots \ldots \ldots \ldots \ldots \ldots$ & 0.0 & 0.1 & 0.4 & 0.8 & $70.9 \%$ \\
\hline Electric Vehicle ............. & 0.1 & 2.6 & 4.1 & 4.4 & $28.0 \%$ \\
\hline Electric Hybrid $\ldots \ldots \ldots \ldots \ldots \ldots \ldots \ldots$ & 0.0 & 0.5 & 1.4 & 1.5 & $71.0 \%$ \\
\hline Electric Hybrid 2 Stroke . ............... & 0.0 & 0.0 & 0.1 & 0.6 & $N / A$ \\
\hline Electric Hybrid Turbine . & 0.0 & 0.0 & 0.0 & 0.0 & N/A \\
\hline Compressed Natural Gas ICE $\ldots \ldots \ldots \ldots \ldots$ & 0.5 & 11.8 & 32.9 & 36.7 & $28.0 \%$ \\
\hline Liquid Petroleum Gas ICE $\ldots \ldots \ldots \ldots \ldots \ldots$ & 0.5 & 7.2 & 26.8 & 31.1 & $27.3 \%$ \\
\hline Gas Turbine Gasoline $\ldots \ldots \ldots \ldots \ldots \ldots \ldots$ & 0.0 & 0.0 & 0.0 & 0.1 & N/A \\
\hline Gas Turbine Compressed Natural Gas ........ & 0.0 & 0.0 & 0.0 & 0.0 & N/A \\
\hline Fuel Cell Methanol $\ldots \ldots \ldots \ldots \ldots \ldots \ldots$ & 0.0 & 0.0 & 0.0 & 0.0 & N/A \\
\hline Fuel Cell Hydrogen $\ldots \ldots \ldots \ldots \ldots \ldots \ldots$ & 0.0 & 0.0 & 0.0 & 0.0 & NA \\
\hline Total Alternatives $\ldots \ldots \ldots \ldots \ldots \ldots \ldots \ldots$ & 1.4 & 30.8 & 83.3 & 95.3 & $28.4 \%$ \\
\hline Percent Alternative Car Sales...$\ldots \ldots \ldots \ldots$ & 0.15 & 3.18 & 8.33 & 9.29 & $27.2 \%$ \\
\hline Total New Car Sales $\ldots \ldots \ldots \ldots \ldots \ldots \ldots \ldots$ & 874.1 & 968.5 & 999.9 & 1025.1 & $0.9 \%$ \\
\hline \multicolumn{6}{|l|}{$\begin{array}{l}\text { New Light-Truck Sales } \\
\text { Conventional Vehicles }\end{array}$} \\
\hline Gasoline ICE Vehicles . & 515.5 & 616.4 & 679.5 & 659.0 & $1.5 \%$ \\
\hline Distillate (diesel) ICE .. & 6.2 & 11.4 & 16.8 & 21.5 & $7.6 \%$ \\
\hline Total Conventional $\ldots \ldots \ldots \ldots \ldots \ldots \ldots$ & 521.7 & 627.8 & 696.3 & 680.4 & $1.6 \%$ \\
\hline \multicolumn{6}{|l|}{ Alternative-Fuel Vehicles } \\
\hline Ethanol-Flex Fuel ICE $\ldots \ldots \ldots \ldots \ldots \ldots$ & 0.0 & 1.7 & 3.3 & 3.5 & $31.0 \%$ \\
\hline Ethanol-Neat ICE $\ldots \ldots \ldots \ldots \ldots \ldots \ldots$ & 0.0 & 0.0 & 0.3 & 0.7 & $80.4 \%$ \\
\hline Methanol-Flex Fuel ICE $\ldots \ldots \ldots \ldots \ldots \ldots$ & 0.1 & 2.0 & 3.7 & 3.9 & $28.2 \%$ \\
\hline Methanol-Neat ICE,$\ldots \ldots \ldots \ldots \ldots \ldots \ldots$ & 0.0 & 0.0 & 0.2 & 0.3 & $72.3 \%$ \\
\hline Electric Vehicle $\ldots \ldots \ldots \ldots \ldots \ldots \ldots$ & 0.0 & 1.3 & 1.8 & 2.0 & $28.2 \%$ \\
\hline Electric Hybrid $\ldots \ldots \ldots \ldots \ldots \ldots \ldots \ldots$ & 0.0 & 0.2 & 0.6 & 0.6 & $72.5 \%$ \\
\hline Electric Hybrid 2 Stroke $\ldots \ldots \ldots \ldots \ldots \ldots \ldots$ & 0.0 & 0.0 & 0.0 & 0.3 & N/A \\
\hline Electric Hybrid Turbine $\ldots \ldots \ldots \ldots \ldots \ldots$ & 0.0 & 0.0 & 0.0 & 0.0 & N/A \\
\hline Compressed Natural Gas ICE $\ldots \ldots \ldots \ldots \ldots$ & 0.3 & 6.0 & 10.4 & 11.7 & $23.9 \%$ \\
\hline Liquid Petroleum Gas ICE $\ldots \ldots \ldots \ldots \ldots \ldots$ & 0.5 & 4.0 & 8.2 & 9.6 & $19.4 \%$ \\
\hline Gas Turbine Gasoline $\ldots \ldots \ldots \ldots \ldots \ldots \ldots$ & 0.0 & 0.0 & 0.0 & 0.0 & $N / A$ \\
\hline Gas Turbine Compressed Natural Gas ........ & 0.0 & 0.0 & 0.0 & 0.0 & N/A \\
\hline Fuel Cell Methanol $\ldots \ldots \ldots \ldots \ldots \ldots \ldots$ & 0.0 & 0.0 & 0.0 & 0.0 & N/A \\
\hline Fuel Cell Hydrogen $\ldots \ldots \ldots \ldots \ldots \ldots \ldots$ & 0.0 & 0.0 & 0.0 & 0.0 & N/A \\
\hline Total Alternatives . . . . . . . . . . . . . . . . . & 0.9 & 15.3 & 28.5 & 32.6 & $23.5 \%$ \\
\hline Percent Alternative Light Truck Sales .......... & 0.17 & 2.39 & 3.94 & 4.57 & $21.3 \%$ \\
\hline Total New Truck Sales. . . . . . . . . . . . . . . . & 522.6 & 643.2 & 724.9 & 713.0 & $1.8 \%$ \\
\hline
\end{tabular}


Table 41. Light-Duty Vehicle Sales by Technology Type West South Central Census Division (Continued)

(Thousands)

\begin{tabular}{|c|c|c|c|c|c|}
\hline \multirow{2}{*}{ Technology Type } & \multicolumn{4}{|c|}{ Reference Case } & \multirow{2}{*}{$\begin{array}{c}\text { Annual } \\
\text { Growth } \\
\text { 1993-2010 } \\
\text { (percent) }\end{array}$} \\
\hline & 1993 & 2000 & 2005 & 2010 & \\
\hline Percent Total Alternative Sales $\ldots \ldots \ldots \ldots \ldots$. & 0.16 & 2.86 & 6.49 & 7.35 & $25.2 \%$ \\
\hline EPACT Legislative Alternative Sales ......... & 0.00 & 0.03 & 0.09 & 0.09 & $36.0 \%$ \\
\hline ZEVP Legislative Alternative Sales...$\ldots \ldots \ldots$ & 0.00 & 0.00 & 0.00 & 0.00 & N/A \\
\hline Total Vehicles Sales $\ldots \ldots \ldots \ldots \ldots \ldots \ldots \ldots$ & 1396.7 & 1611.7 & 1724.8 & 1738.1 & $1.3 \%$ \\
\hline
\end{tabular}

'Includes personal, and fleet light-duty cars.

${ }^{2}$ Includes personal, fleet, and freight light-duty trucks.

ICE = Internal combustion engine.

EPACT = Energy Policy Act of 1992.

ZEVP = Zero emission vehicles from the low emission vehicle program.

N/A $=$ Not applicable.

Sources: 1993 derived using: California Air Resources Board, "Proposed Regulations for Low-Emission Vehicles and Clean Fuels, Staft Report"; United States Department of Energy, Office of Domestic and International Energy Policy, "Assessment of Costs and Benefits of Flexible and Alternative Fuel Use in the U.S. Transportation Sector, Technical Report Ten: Analysis of Attemative Fuel Fieet Requirements, "(Washington, D.C., May 1992); Bunch, David S., Mark Bradley, Thomas F. Glob, Ryuichi Kitamura, Gareth P. Occhiuzzo, "Demand for Clean-Fuel Personal Vehicles in Califomia: A Discrete-Choice Stated Preference Survey," (December 1991); and Energy information Administration (EIA), AEO95 National Energy Modeling System run AEO95B.D1103942. Projections: EIA, AEO95 National Energy Modeling System run AEO95B.D1 103942. 
Table 42. Light-Duty Vehicle Sales by Technology Type Mountain Census Division

(Thousands)

\begin{tabular}{|c|c|c|c|c|c|}
\hline \multirow{2}{*}{ Technology Type } & \multicolumn{4}{|c|}{ Reference Case } & \multirow{2}{*}{$\begin{array}{l}\text { Annual } \\
\text { Growth } \\
\text { 1993-20 } \\
\text { (percent }\end{array}$} \\
\hline & 1993 & 2000 & 2005 & 2010 & \\
\hline \multicolumn{6}{|l|}{ New Car Sales' } \\
\hline \multicolumn{6}{|l|}{ Conventional Vehicles } \\
\hline Gasoline ICE Vehicles & 435.2 & 496.4 & 492.0 & 505.7 & $0.9 \%$ \\
\hline Distillate (diesel) ICE . . . . . . . . . . . . . . & 0.0 & 0.3 & 0.3 & 0.3 & $16.0 \%$ \\
\hline Total Conventional $\ldots \ldots \ldots \ldots \ldots \ldots \ldots$ & 435.2 & 496.7 & 492.3 & 505.9 & $0.9 \%$ \\
\hline \multicolumn{6}{|l|}{ Alternative-Fuel Vehicles } \\
\hline Ethanol-Flex Fuel ICE $\ldots \ldots \ldots \ldots \ldots \ldots$ & 0.0 & 2.2 & 4.3 & 4.7 & $31.7 \%$ \\
\hline Ethanol-Neat ICE. ..... & 0.0 & 0.1 & 0.5 & 1.2 & $82.1 \%$ \\
\hline Methanol-Flex Fuel ICE ..... & 0.1 & 2.4 & 4.7 & 5.1 & $28.8 \%$ \\
\hline Methanol-Neat ICE ........ & 0.0 & 0.0 & 0.3 & 0.7 & $76.7 \%$ \\
\hline Electric Vehicle ...... & 0.0 & 1.4 & 2.1 & 2.4 & $28.5 \%$ \\
\hline Electric Hybrid $\ldots \ldots \ldots \ldots \ldots \ldots \ldots \ldots$ & 0.0 & 0.3 & 0.7 & 0.7 & $70.3 \%$ \\
\hline Electric Hybrid 2 Stroke $\ldots \ldots \ldots \ldots \ldots \ldots$ & 0.0 & 0.0 & 0.0 & 0.3 & $\mathrm{~N} / \mathrm{A}$ \\
\hline Electric Hybrid Turbine $\quad \ldots \ldots \ldots \ldots \ldots \ldots$ & 0.0 & 0.0 & 0.0 & 0.0 & N/A \\
\hline Compressed Natural Gas ICE $\ldots \ldots \ldots \ldots \ldots$ & 0.3 & 6.2 & 17.6 & 19.8 & $28.6 \%$ \\
\hline Liquid Petroleum Gas ICE ............... & 0.3 & 3.8 & 14.1 & 15.9 & $27.5 \%$ \\
\hline Gas Turbine Gasoline $\ldots \ldots \ldots \ldots \ldots \ldots$ & 0.0 & 0.0 & 0.0 & 0.0 & N/A \\
\hline Gas Turbine Compressed Natural Gas ........ & 0.0 & 0.0 & 0.0 & 0.0 & N/A \\
\hline Fuel Cell Methanol $\ldots \ldots \ldots \ldots \ldots \ldots$ & 0.0 & 0.0 & 0.0 & 0.0 & N/A \\
\hline Fuel Cell Hydrogen $\ldots \ldots \ldots \ldots \ldots \ldots \ldots$ & 0.0 & 0.0 & 0.0 & 0.0 & N/A \\
\hline Total Alternatives $\ldots \ldots \ldots \ldots \ldots \ldots \ldots \ldots$ & 0.7 & 16.3 & 44.4 & 50.9 & $29.0 \%$ \\
\hline Percent Alternative Car Sales .............. & 0.15 & 3.17 & 8.28 & 9.13 & $27.1 \%$ \\
\hline Total New Car Sales $\ldots \ldots \ldots \ldots \ldots \ldots \ldots$ & 435.9 & 513.0 & 536.8 & 556.8 & $1.5 \%$ \\
\hline \multicolumn{6}{|l|}{ New Light-Truck Sales ${ }^{2}$} \\
\hline \multicolumn{6}{|l|}{ Conventional Vehicles } \\
\hline$\ldots \ldots \ldots \ldots \ldots, \ldots$ & 257.0 & 326.5 & 364.9 & 358.3 & $2.0 \%$ \\
\hline Distillate (diesel) ICE . . . . . . . . . . . . . . & 3.1 & 6.0 & 9.0 & 11.7 & $8.1 \%$ \\
\hline Total Conventional .................... & 260.1 & 332.6 & 373.9 & 369.9 & $2.1 \%$ \\
\hline \multicolumn{6}{|l|}{ Alternative-Fuel Vehicles } \\
\hline Ethanol-Flex Fuel ICE .. & 0.0 & 0.9 & 1.8 & 1.9 & $31.5 \%$ \\
\hline Ethanol-Neat ICE $\ldots \ldots \ldots \ldots \ldots \ldots \ldots$ & 0.0 & 0.0 & 0.2 & 0.5 & $83.4 \%$ \\
\hline Methanol-Flex Fuel ICE $\ldots \ldots \ldots \ldots \ldots \ldots$ & 0.0 & 1.1 & 2.0 & 2.1 & $28.6 \%$ \\
\hline Methanol-Neat ICE $\ldots \ldots \ldots \ldots \ldots \ldots \ldots$ & 0.0 & 0.0 & 0.1 & 0.3 & $78.2 \%$ \\
\hline Electric Vehicle ....................... & 0.0 & 0.7 & 1.0 & 1.0 & $28.7 \%$ \\
\hline Electric Hybrid $\ldots \ldots \ldots \ldots \ldots \ldots \ldots \ldots$ & 0.0 & 0.1 & 0.3 & 0.3 & $71.8 \%$ \\
\hline Electric Hybrid 2 Stroke $\ldots \ldots \ldots \ldots \ldots \ldots$ & 0.0 & 0.0 & 0.0 & 0.1 & N/A \\
\hline Electric Hybrid Turbine $\ldots \ldots \ldots \ldots \ldots \ldots \ldots$ & 0.0 & 0.0 & 0.0 & 0.0 & N/A \\
\hline Compressed Natural Gas ICE $\ldots \ldots \ldots \ldots \ldots$. & 0.2 & 3.2 & 5.6 & 6.3 & $24.4 \%$ \\
\hline Liquid Petroleum Gas ICE $\ldots \ldots \ldots \ldots \ldots \ldots$ & 0.2 & 2.1 & 4.2 & 4.8 & $19.4 \%$ \\
\hline Gas Turbine Gasoline $\ldots \ldots \ldots \ldots \ldots \ldots$ & 0.0 & 0.0 & 0.0 & 0.0 & N/A \\
\hline Gas Turbine Compressed Natural Gas ......... & 0.0 & 0.0 & 0.0 & 0.0 & $N / A$ \\
\hline Fuel Cell Methanol $\ldots \ldots \ldots \ldots \ldots \ldots$ & 0.0 & 0.0 & 0.0 & 0.0 & N/A \\
\hline Fuel Cell Hydrogen $\ldots \ldots \ldots \ldots \ldots \ldots \ldots$ & 0.0 & 0.0 & 0.0 & 0.0 & NA \\
\hline Total Alternatives $\ldots \ldots \ldots \ldots \ldots \ldots \ldots \ldots \ldots$ & 0.4 & 8.1 & 15.2 & 17.3 & $24.0 \%$ \\
\hline Percent Alternative Light Truck Sales ......... & 0.17 & 2.38 & 3.91 & 4.48 & $21.1 \%$ \\
\hline Total New Truck Sales. ................... & 260.6 & 340.7 & 389.1 & 387.3 & $2.4 \%$ \\
\hline
\end{tabular}


Table 42. Light-Duty Vehicle Sales by Technology Type Mountain Census Division (Continued)

(Thousands)

\begin{tabular}{|c|c|c|c|c|c|}
\hline & 1993 & 2000 & 2005 & 2010 & $\begin{array}{c}\text { Annual } \\
\text { Growth } \\
1993-2010 \\
\text { (percent) }\end{array}$ \\
\hline ZEVP Legislative Alternative Sales $\ldots \ldots \ldots \ldots$ & 0.00 & 0.00 & 0.00 & 0.00 & NA \\
\hline Total Vehicles Sales ................... & 696.4 & 853.7 & 925.9 & 944.0 & $1.8 \%$ \\
\hline
\end{tabular}

'Includes personal, and fleet light-duty cars.

'Includes personal, fleet, and freight light-duty trucks.

ICE = Internal combustion engine.

EPACT = Energy Policy Act of 1992.

ZEVP = Zero emission vehicles from the low emission vehicle program.

N/A $=$ Not applicable.

Sources: 1993 derived using: California Air Resources Board, "Proposed Regulations for Low-Emission Vehicles and Clean Fuels, Staff Report"; United States Department of Energy, Office of Domestic and International Energy Policy, "Assessment of Costs and Benefits of Flexible and Alternative Fuel Use in the U.S. Transportation Sector, Technical Report Ten: Analysis of Alternative Fuel Fleet Requirements, "(Washington, D.C., May 1992); Bunch, David S., Mark Bradley, Thomas F. Glob, Ryuichi Kitamura, Gareth P. Occhiuzzo, "Demand for Clean-Fuel Personal Vehicles in California: A Discrete-Choice Stated Preference Survey," (December 1991); and Energy Information Administration (EIA), AEO95 National Energy Modeling System run AEO95B.D1103942. Projections: EIA, AEO95 National Energy Modeling System run AEO95B.D1103942. 
Table 43. Light-Duty Vehicle Sales by Technology Type Pacific Census Division

(Thousands)

\begin{tabular}{|c|c|c|c|c|c|}
\hline \multirow{2}{*}{ Technology Type } & \multicolumn{4}{|c|}{ Reference Case } & \multirow{2}{*}{$\begin{array}{l}\text { Annual } \\
\text { Growth } \\
1993-20 \\
\text { (percen }\end{array}$} \\
\hline & 1993 & 2000 & 2005 & 2010 & \\
\hline \multicolumn{6}{|l|}{ New Car Sales' } \\
\hline \multicolumn{6}{|l|}{ Conventional Vehicles } \\
\hline Gasoline ICE Vehicles .. & 1403.9 & 1489.4 & 1367.0 & 1391.6 & $-0.1 \%$ \\
\hline Distillate (diesel) ICE .... & 0.1 & 0.9 & 0.8 & 0.7 & $15.4 \%$ \\
\hline Total Conventional $. . . \ldots \ldots \ldots \ldots \ldots . . . .$. & 1404.0 & 1490.3 & 1367.8 & 1392.3 & $0.0 \%$ \\
\hline \multicolumn{6}{|l|}{ Alternative-Fuel Vehicles } \\
\hline Ethanol-Flex Fuel ICE .. & 0.1 & 6.5 & 12.5 & 13.3 & $30.6 \%$ \\
\hline Ethanol-Neat ICE. $\ldots \ldots \ldots \ldots \ldots \ldots \ldots$ & 0.0 & 0.2 & 1.5 & 3.7 & $80.8 \%$ \\
\hline Methanol-Flex Fuel ICE $\ldots \ldots \ldots \ldots \ldots \ldots$. & 0.2 & 7.4 & 14.0 & 15.0 & $28.1 \%$ \\
\hline Methanol-Neat ICE .... & 0.0 & 0.2 & 1.4 & 3.5 & $79.6 \%$ \\
\hline Electric Vehicle ... & 0.1 & 6.5 & 25.7 & 24.2 & $37.6 \%$ \\
\hline Electric Hybrid ......... & 0.0 & 20.6 & 95.7 & 74.6 & N/A \\
\hline Electric Hybrid 2 Stroke . ............... & 0.0 & 0.2 & 5.9 & 29.3 & $\mathrm{~N} / \mathrm{A}$ \\
\hline Electric Hybrid Turbine $\ldots \ldots \ldots \ldots \ldots \ldots$. & 0.0 & 0.0 & 0.1 & 2.1 & N/A \\
\hline Compressed Natural Gas ICE $\ldots \ldots \ldots \ldots \ldots$ & 0.9 & 19.0 & 53.2 & 59.1 & $28.0 \%$ \\
\hline Liquid Petroleum Gas ICE .............. & 0.8 & 11.5 & 42.9 & 48.5 & $27.1 \%$ \\
\hline Gas Turbine Gasoline .................. & 0.0 & 0.0 & 0.0 & 0.1 & $\mathrm{~N} / \mathrm{A}$ \\
\hline Gas Turbine Compressed Natural Gas ........ & 0.0 & 0.0 & 0.0 & 0.0 & N/A \\
\hline Fuel Cell Methanol $\ldots \ldots \ldots \ldots \ldots \ldots$ & 0.0 & 0.0 & 0.0 & 0.0 & N/A \\
\hline Fuel Cell Hydrogen $\ldots \ldots \ldots \ldots \ldots \ldots$ & 0.0 & 0.0 & 0.0 & 0.0 & N/A \\
\hline Total Alternatives . . . . . . . . . . . . . . . . . & 2.2 & 72.1 & 253.0 & 273.4 & $32.9 \%$ \\
\hline Percent Alternative Car Sales .............. & 0.15 & 4.61 & 15.61 & 16.41 & $31.6 \%$ \\
\hline Total New Car Sales $. . . \ldots \ldots \ldots \ldots \ldots . . .$. & 1406.2 & 1562.4 & 1620.7 & 1665.7 & $1.0 \%$ \\
\hline \multicolumn{6}{|l|}{$\begin{array}{l}\text { New Light-Truck Sales }{ }^{2} \\
\text { Conventional Vehicles }\end{array}$} \\
\hline Gasoline ICE Vehicles $\ldots \ldots \ldots \ldots \ldots \ldots \ldots$ & 829.2 & 978.3 & 1013.8 & 984.9 & $1.0 \%$ \\
\hline Distillate (diesel) ICE $\ldots \ldots \ldots \ldots \ldots \ldots \ldots$ & 10.0 & 18.4 & 27.2 & 34.9 & $7.7 \%$ \\
\hline Total Conventional $\ldots \ldots \ldots \ldots \ldots \ldots \ldots$ & 839.2 & 996.7 & 1041.0 & 1019.8 & $1.2 \%$ \\
\hline \multicolumn{6}{|l|}{ Alternative-Fuel Vehicles } \\
\hline Ethanol-Fiex Fuel ICE ... & 0.1 & 2.7 & 5.2 & 5.4 & $30.5 \%$ \\
\hline Ethanol-Neat ICE $\ldots \ldots \ldots \ldots \ldots \ldots \ldots$ & 0.0 & 0.1 & 0.7 & 1.5 & $82.2 \%$ \\
\hline Methanol-Flex Fuel ICE. & 0.1 & 3.3 & 5.9 & 6.1 & $28.0 \%$ \\
\hline Methanol-Neat ICE $\ldots \ldots \ldots \ldots \ldots \ldots \ldots$ & 0.0 & 0.1 & 0.6 & 1.5 & $81.0 \%$ \\
\hline Electric Vehicle ........................ & 0.0 & 3.8 & 17.1 & 15.5 & $40.8 \%$ \\
\hline Electric Hybrid $\ldots \ldots \ldots \ldots \ldots \ldots \ldots \ldots \ldots$ & 0.0 & 14.6 & 70.4 & 53.1 & N/A \\
\hline Electric Hybrid 2 Stroke . . . . . . . . . . . . . & 0.0 & 0.1 & 4.3 & 20.8 & N/A \\
\hline Electric Hybrid Turbine $\ldots \ldots \ldots \ldots \ldots \ldots$ & 0.0 & 0.0 & 0.1 & 1.5 & $\mathrm{~N} / \mathrm{A}$ \\
\hline Compressed Natural Gas ICE $\ldots \ldots \ldots \ldots \ldots$. & 0.5 & 9.7 & 16.8 & 18.8 & $23.9 \%$ \\
\hline Liquid Petroleum Gas ICE ................ & 0.8 & 6.4 & 12.9 & 14.7 & $19.1 \%$ \\
\hline Gas Turbine Gasoline $\ldots \ldots \ldots \ldots \ldots \ldots \ldots$ & 0.0 & 0.0 & 0.0 & 0.0 & N/A \\
\hline Gas Turbine Compressed Natural Gas ........ & 0.0 & 0.0 & 0.0 & 0.0 & N/A \\
\hline Fuel Cell Methanol $\ldots \ldots \ldots \ldots \ldots \ldots \ldots$ & 0.0 & 0.0 & 0.0 & 0.0 & N/A \\
\hline Fuel Cell Hydrogen $\ldots \ldots \ldots \ldots \ldots \ldots \ldots$ & 0.0 & 0.0 & 0.0 & 0.0 & N/A \\
\hline 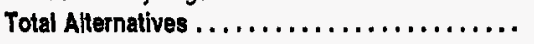 & 1.4 & 40.9 & 133.9 & 138.9 & $30.8 \%$ \\
\hline Percent Alternative Light Truck Sales ......... & 0.17 & 3.94 & 11.40 & 11.98 & $28.4 \%$ \\
\hline Total New Truck Sales. ................... & 840.6 & 1037.5 & 1174.9 & 1158.6 & $1.9 \%$ \\
\hline
\end{tabular}


Table 43. Light-Duty Vehicle Sales by Technology Type

Pacific Census Division (Continued)

(Thousands)

\begin{tabular}{|c|c|c|c|c|c|}
\hline \multirow{2}{*}{ Technology Type } & \multicolumn{4}{|c|}{ Reference Case } & \multirow{2}{*}{$\begin{array}{l}\text { Annual } \\
\text { Growth } \\
\text { 1993-2010 } \\
\text { (percent) }\end{array}$} \\
\hline & 1993 & 2000 & 2005 & 2010 & \\
\hline Percent Total Alternative Sales $\ldots \ldots \ldots \ldots \ldots$. & 0.16 & 4.34 & 13.84 & 14.60 & $30.4 \%$ \\
\hline EPACT Legislative Alternative Sales ......... & 0.00 & 0.05 & 0.14 & 0.15 & $36.0 \%$ \\
\hline ZEVP Legislative Alternative Sales .......... & 0.00 & 0.04 & 0.20 & 0.21 & N/A \\
\hline Total Vehicles Sales $\ldots \ldots \ldots \ldots \ldots \ldots \ldots \ldots$ & 2246.8 & 2599.9 & 2795.7 & 2824.4 & $1.4 \%$ \\
\hline
\end{tabular}

'Includes personal, and fleet light-duty cars.

${ }^{2}$ Includes personal, fleet, and freight light-duty trucks.

ICE = Internal combustion engine.

EPACT $=$ Energy Policy Act of 1992

ZEVP $=$ Zero emission vehicles from the low emission vehicle program.

N/A = Not applicable.

Sources: 1993 derived using: California Air Resources Board, "Proposed Regulations for Low-Emission Vehicles and Clean Fuels, Staff Report"; United States Department of Energy, Office of Domestic and International Energy Policy, "Assessment of Costs and Benefits of Flexible and Alternative Fuel Use in the U.S. Transportation Sector, Technical Report Ten: Analysis of Alternative Fuel Fleet Requirements," (Washington, D.C. May 1992); Bunch, David S., Mark Bradley, Thomas F. Glob, Ryuichi Kilamura, Gareth P. Occhiuzzo, "Demand for Clean-Fuel Personal Vehicles in Califomia: A Discrete-Choice Stated Preference Survey," (December 1991); and Energy Information Administration (EIA), AEO95 National Energy Modeling System run AEO95B.D1103942. Projections: EIA, AEO95 National Energy Modeling System run AEO95B.D1103942. 
Table 44. Light-Duty Vehicle Sales by Technology Type United States

(Thousands)

\begin{tabular}{|c|c|c|c|c|c|}
\hline \multirow{2}{*}{ Technology Type } & \multicolumn{4}{|c|}{ Reference Case } & \multirow{2}{*}{$\begin{array}{l}\text { Annual } \\
\text { Growth } \\
1993-20 \\
\text { (percent }\end{array}$} \\
\hline & 1993 & 2000 & 2005 & 2010 & \\
\hline \multicolumn{6}{|l|}{ New Car Sales' } \\
\hline \multicolumn{6}{|l|}{ Conventional Vehicles } \\
\hline Gasoline ICE Vehicles & 8688.9 & 9234.7 & 8885.1 & 9019.9 & $0.2 \%$ \\
\hline Distillate (diesel) ICE $\ldots \ldots \ldots \ldots \ldots \ldots \ldots$ & 0.4 & 5.4 & 5.1 & 4.5 & $15.4 \%$ \\
\hline Total Conventional,$\ldots \ldots \ldots \ldots \ldots \ldots \ldots$ & 8689.3 & 9240.1 & 8890.2 & 9024.5 & $0.2 \%$ \\
\hline \multicolumn{6}{|l|}{ Alternative-Fuel Vehicles } \\
\hline Ethanol-Flex Fuel ICE ... & 0.9 & 41.0 & 82.5 & 92.8 & $31.5 \%$ \\
\hline Ethanol-Neat ICE. ... & 0.0 & 1.2 & 8.4 & 19.4 & $80.5 \%$ \\
\hline Methanol-Flex Fuel ICE . & 1.4 & 44.4 & 89.1 & 98.8 & $28.6 \%$ \\
\hline Methanol-Neat ICE .... & 0.0 & 0.8 & 5.6 & 12.6 & $74.8 \%$ \\
\hline Electric Vehicle $\ldots \ldots \ldots \ldots \ldots \ldots \ldots \ldots$ & 0.7 & 29.3 & 69.3 & 70.0 & $31.6 \%$ \\
\hline Electric Hybrid $\ldots \ldots \ldots \ldots, \ldots, \ldots, \ldots$ & 0.0 & 36.1 & 161.9 & 129.0 & $93.9 \%$ \\
\hline Electric Hybrid 2 Stroke $\ldots \ldots \ldots \ldots \ldots \ldots$ & 0.0 & 0.4 & 9.9 & 50.8 & $\mathrm{~N} / \mathrm{A}$ \\
\hline Electric Hybrid Turbine $\ldots .$. & 0.0 & 0.0 & 0.2 & 3.5 & N/A \\
\hline Compressed Natural Gas ICE $\ldots \ldots \ldots \ldots \ldots$. & 5.5 & 116.2 & 324.5 & 358.5 & $27.9 \%$ \\
\hline Liquid Petroleum Gas ICE ............... & 5.1 & 69.8 & 258.2 & 286.8 & $26.8 \%$ \\
\hline Gas Turbine Gasoline $\ldots \ldots \ldots \ldots \ldots \ldots$ & 0.0 & 0.0 & 0.0 & 0.5 & N/A \\
\hline Gas Turbine Compressed Natural Gas ........ & 0.0 & 0.0 & 0.0 & 0.1 & N/A \\
\hline Fuel Cell Methanol $\ldots \ldots \ldots \ldots \ldots \ldots \ldots$ & 0.0 & 0.0 & 0.0 & 0.0 & N/A \\
\hline Fuel Cell Hydrogen . & 0.0 & 0.0 & 0.0 & 0.0 & N/A \\
\hline Total Alternatives $\ldots \ldots \ldots \ldots \ldots \ldots \ldots \ldots \ldots$ & 13.5 & 339.2 & 1009.7 & 1122.8 & $29.7 \%$ \\
\hline Percent Alternative Car Sales...$\ldots \ldots \ldots \ldots$. & 0.15 & 3.54 & 10.20 & 11.06 & $28.6 \%$ \\
\hline Total New Car Sales $\ldots \ldots \ldots \ldots \ldots \ldots \ldots$ & 8702.8 & 9579.3 & 9899.9 & 10147.3 & $0.9 \%$ \\
\hline \multicolumn{6}{|l|}{$\begin{array}{l}\text { New Light-Truck Sales }{ }^{2} \\
\text { Conventional Vehicles }\end{array}$} \\
\hline Gasoline ICE Vehicles . & 5132.0 & 6071.6 & 6589.8 & 6389.7 & $1.3 \%$ \\
\hline Distillate (diesel) ICE $\ldots \ldots \ldots \ldots \ldots \ldots \ldots$ & 61.6 & 112.7 & 166.1 & 212.6 & $7.6 \%$ \\
\hline Total Conventional $\ldots \ldots \ldots \ldots \ldots \ldots \ldots$ & 5193.6 & 6184.3 & 6755.9 & 6602.3 & $1.4 \%$ \\
\hline \multicolumn{6}{|l|}{ Alternative-Fuel Vehicles } \\
\hline Ethanol-Flex Fuel ICE .. & 0.4 & 17.1 & 34.6 & 37.5 & $31.4 \%$ \\
\hline Ethanol-Neat ICE $\ldots \ldots \ldots \ldots \ldots \ldots \ldots \ldots$ & 0.0 & 0.5 & 3.6 & 8.0 & $81.8 \%$ \\
\hline Methanol-Flex Fuel ICE $\ldots \ldots \ldots \ldots \ldots \ldots \ldots$ & 0.6 & 20.2 & 37.4 & 40.3 & $28.4 \%$ \\
\hline Methanol-Neat ICE $\ldots \ldots \ldots \ldots \ldots \ldots \ldots \ldots$ & 0.0 & 0.3 & 2.4 & 5.2 & $76.2 \%$ \\
\hline Electric Vehicle $\ldots \ldots \ldots \ldots \ldots \ldots \ldots \ldots$ & 0.3 & 15.7 & 39.5 & 38.4 & $33.4 \%$ \\
\hline Electric Hybrid .......................... & 0.0 & 24.6 & 116.4 & 89.0 & N/A \\
\hline Electric Hybrid 2 Stroke $\ldots \ldots \ldots \ldots \ldots \ldots$ & 0.0 & 0.2 & 7.1 & 34.9 & N/A \\
\hline Electric Hybrid Turbine $\ldots \ldots \ldots \ldots \ldots \ldots$ & 0.0 & 0.0 & 0.1 & 2.5 & N/A \\
\hline Compressed Natural Gas ICE $\ldots \ldots \ldots \ldots \ldots$ & 3.1 & 59.6 & 102.4 & 113.6 & $23.7 \%$ \\
\hline Liquid Petroleum Gas ICE $\ldots \ldots \ldots \ldots \ldots \ldots$ & 4.7 & 38.8 & 77.3 & 86.2 & $18.7 \%$ \\
\hline Gas Turbine Gasoline $\ldots \ldots \ldots \ldots \ldots \ldots \ldots$ & 0.0 & 0.0 & 0.0 & 0.2 & NAA \\
\hline Gas Turbine Compressed Natural Gas ........ & 0.0 & 0.0 & 0.0 & 0.0 & NA \\
\hline Fuel Cell Methand $\ldots \ldots \ldots \ldots \ldots \ldots \ldots$ & 0.0 & 0.0 & 0.0 & 0.0 & N/A \\
\hline Fusl Cell Hydrogen $\ldots \ldots \ldots \ldots \ldots \ldots$. . . . . . & 0.0 & 0.0 & 0.0 & 0.0 & $N / A$ \\
\hline Total Allernatives $\ldots \ldots \ldots \ldots \ldots \ldots \ldots \ldots$ & 8.9 & 177.1 & 420.9 & 455.9 & $26.0 \%$ \\
\hline $\begin{array}{l}\text { Percent Atternative Light Truck Sales } \ldots \ldots \ldots \ldots \\
\text { Total New Truck Sales. } \ldots \ldots \ldots \ldots \ldots \ldots \ldots \text {. }\end{array}$ & $\begin{array}{r}0.17 \\
52025\end{array}$ & 2.78 & $\begin{array}{r}5.87 \\
71768\end{array}$ & $\begin{array}{r}6.46 \\
7058.2\end{array}$ & $\begin{array}{r}23.8 \% \\
1.8 \%\end{array}$ \\
\hline & 5202.5 & 6861.4 & 7176.8 & 7058.2 & \\
\hline
\end{tabular}


Table 44. Light-Duty Vehicle Sales by Technology Type

United States (Continued)

(Thousands)

\begin{tabular}{|c|c|c|c|c|c|}
\hline \multirow{2}{*}{ Technology Type } & \multicolumn{4}{|c|}{ Reference Case } & \multirow{2}{*}{$\begin{array}{c}\text { Annual } \\
\text { Growth } \\
\text { 1993-2010 } \\
\text { (percent) }\end{array}$} \\
\hline & 1993 & 2000 & 2005 & 2010 & \\
\hline Percent Total Alternative Sales . . . . . . . . . . & 0.16 & 3.24 & 8.38 & 9.18 & $26.8 \%$ \\
\hline EPACT Legislative Alternative Sales ......... & 0.00 & 0.33 & 0.86 & 0.92 & $35.9 \%$ \\
\hline ZEVP Legislative Alternative Sales...$\ldots \ldots \ldots$ & 0.00 & 0.06 & 0.33 & 0.33 & N/A \\
\hline Total Vehicles Sales $\ldots \ldots \ldots \ldots \ldots \ldots \ldots \ldots$ & 13905.3 & 15940.7 & 17076.7 & 17205.5 & $1.3 \%$ \\
\hline
\end{tabular}

'Includes personal, and fleet light-duty cars.

'Includes personal, fleet, and freight light-duty trucks.

ICE = Internal combustion engine.

EPACT = Energy Policy Act of 1992.

ZEVP = Zero emission vehicles from the low emission vehicle program.

$\mathrm{N} / \mathrm{A}=$ Not applicable.

Sources: 1993 derived using: California Air Resources Board, "Proposed Regulations for Low-Emission Vehicles and Clean Fuels, Staff Report"; United States Department of Energy, Office of Domestic and International Energy Policy, "Assessment of Costs and Benefits of Flexible and Alternative Fuel Use in the U.S. Transportation Sector, Technical Report Ten: Analysis of Alternative Fuel Fleet Requirements," (Washington, D.C. May 1992); Bunch, David S., Mark Bradley, Thomas F. Glob, Ryuichi Kitarnura, Gareth P. Occhiuzzo, "Demand for Clean-Fuel Personal Vehicles in California: A Discrete-Choice Stated Preference Survey," (December 1991); and Energy Information Administration (EIA), AEO95 National Energy Modeling System run AEO95B.D1103942. Projections: EIA, AEO95 National Energy Modeling System run AEO95B.D1103942. 
Table 45. Light-Duty Vehicle Stock by Technology Type (Millions)

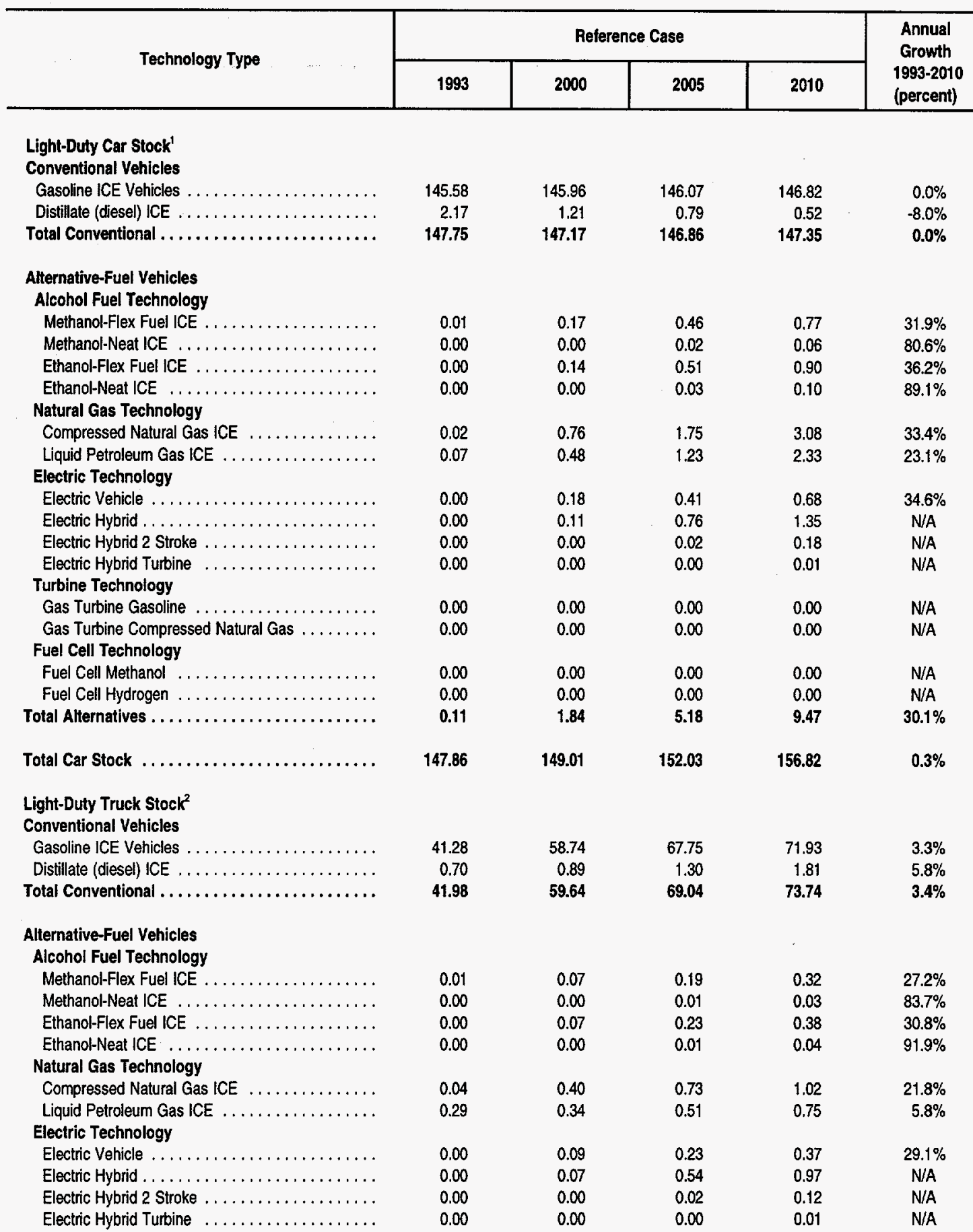


Table 45. Light-Duty Vehicle Stock by Technology Type (Continued) (Millions)

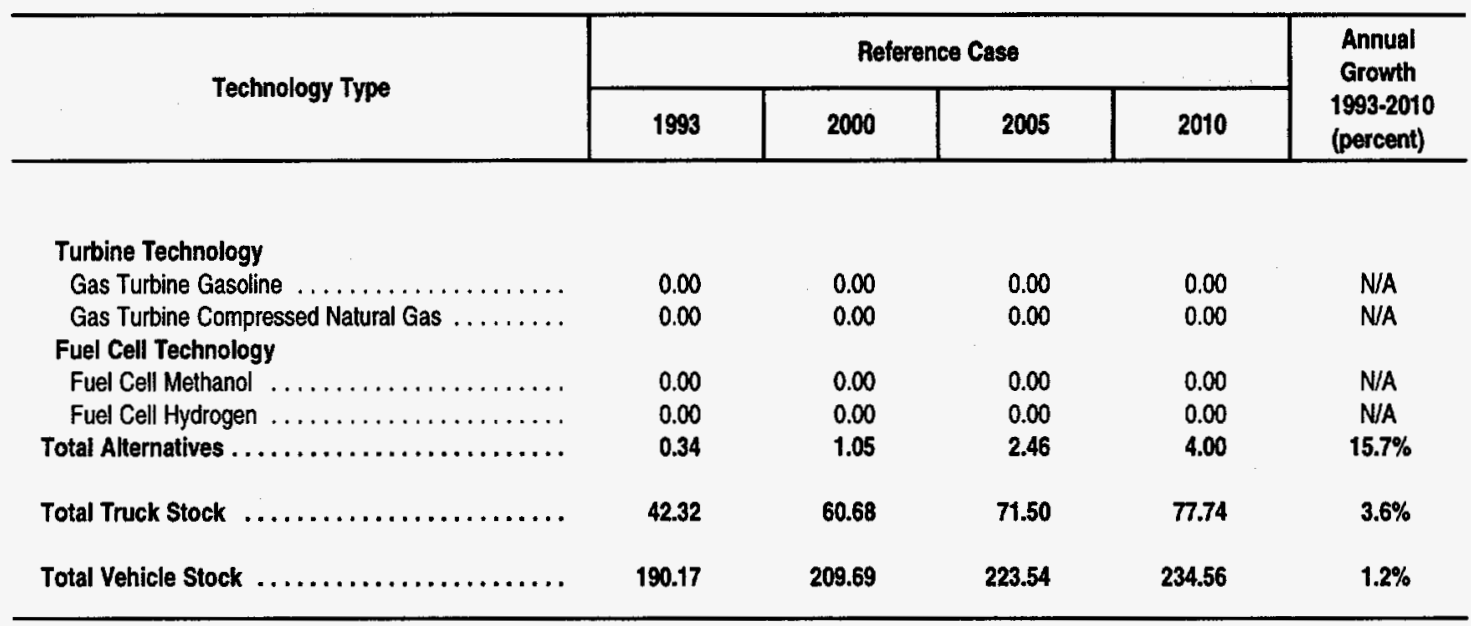

${ }^{\dagger}$ Includes personal and fleet vehicles.

${ }^{2}$ Includes personal vehicles, fleet vehicles, and freight light trucks.

ICE = Internal combustion engine.

N/A = Not applicable.

Sources: 1993 derived using: Energy information Administration (ElA), Household Vehicles Energy Consumption 1991, DOE/ElA-0464(91) (Washington, D.C., December 1993); and EIA, AEO95 National Energy Modeling System run AEO95B.D1103942. Projections: EIA, AEO95 National Energy Modeling System run AEO95B.D1103942. 
Table 46. Light-Duty Vehicle MPG by Technology Type

(MPG Gasoline Equivalents)

\begin{tabular}{|c|c|c|c|c|c|}
\hline \multirow{2}{*}{ Technology Types } & \multicolumn{4}{|c|}{ Reference Case } & \multirow{2}{*}{$\begin{array}{c}\text { Annual } \\
\text { Growth } \\
1993-2010 \\
\text { (percent) }\end{array}$} \\
\hline & 1993 & 2000 & 2005 & 2010 & \\
\hline \multicolumn{6}{|l|}{ Automobiles' } \\
\hline \multicolumn{6}{|l|}{ Conventional Vehicles } \\
\hline Gasoline ICE Vehicles .................... & 27.81 & 28.81 & 29.65 & 32.47 & $0.9 \%$ \\
\hline 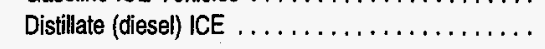 & 30.53 & 31,31 & 32.44 & 35.95 & $1.0 \%$ \\
\hline \multicolumn{6}{|l|}{ Alternative-Fuel Vehicles } \\
\hline Methanol-Flex Fuel ICE .. & 29.09 & 30.33 & 31.60 & 34.81 & $1.1 \%$ \\
\hline Methanol-Neat ICE $\ldots \ldots \ldots \ldots \ldots$. & 30.23 & 31.85 & 32.72 & 35.91 & $1.0 \%$ \\
\hline Ethanol-Flex Fuel ICE $\ldots \ldots \ldots \ldots \ldots \ldots$ & 28.80 & 29.97 & 31.20 & 34.32 & $1.0 \%$ \\
\hline Ethanol-Neat ICE $\ldots \ldots \ldots \ldots \ldots \ldots \ldots$ & 31.98 & 33.17 & 34.30 & 37.57 & $1.0 \%$ \\
\hline \multicolumn{6}{|l|}{ Natural Gas Technology } \\
\hline Compressed Natural Gas ICE $\ldots . \ldots \ldots \ldots \ldots$ & 26.56 & 27.79 & 28.37 & 31.02 & $0.9 \%$ \\
\hline Liquid Petroleum Gas ICE ................ & 36.15 & 37.79 & 38.58 & 42.16 & $0.9 \%$ \\
\hline \multicolumn{6}{|l|}{ Electric Technology } \\
\hline Electric Vehicle .... & 42.85 & 44.38 & 46.06 & 50.63 & $1.0 \%$ \\
\hline Electric Hybrid . ........ & 40.33 & 41.83 & 43.39 & 47.59 & $1.0 \%$ \\
\hline Electric Hybrid 2 Stroke . & 40.33 & 41.74 & 43.50 & 47.75 & $1.0 \%$ \\
\hline Electric Hybrid Turbine & 40.33 & 41.74 & 43.42 & 47.48 & $1.0 \%$ \\
\hline \multicolumn{6}{|l|}{ Turbine Technology } \\
\hline Gas Turbine Gasoline $\ldots \ldots \ldots \ldots \ldots \ldots$ & 37.45 & 38.76 & 40.32 & 44.09 & $1.0 \%$ \\
\hline Gas Turbine Compressed Natural Gas ......... & 37.45 & 38.76 & 40.32 & 44.09 & $1.0 \%$ \\
\hline \multicolumn{6}{|l|}{ Fuel Cell Technology } \\
\hline Fuel Cell Methanol .. & 46.09 & 47.70 & 49.62 & 54.27 & $1.0 \%$ \\
\hline Fuel Cell Hydrogen & 46.09 & 47,70 & 49.62 & 54.27 & $1.0 \%$ \\
\hline Average New Car MPG $\ldots \ldots \ldots \ldots \ldots \ldots \ldots$ & 27.81 & 28.88 & 29.96 & 32,83 & $1.0 \%$ \\
\hline \multicolumn{6}{|l|}{ Light-Duty Trucks² } \\
\hline \multicolumn{6}{|l|}{ Conventional Vehicles } \\
\hline Gasoline ICE Vehicles & 20.34 & 21.44 & 22.38 & 23.40 & $0.8 \%$ \\
\hline Distillate (diesel) ICE ....... & 17.40 & 18.77 & 19.39 & 19.90 & $0.8 \%$ \\
\hline \multicolumn{6}{|l|}{ Alternative-Fuel Vehicles } \\
\hline \multicolumn{6}{|l|}{ Alcohol Fuel Technology } \\
\hline Methanol-Flex Fuel ICE . & 21.19 & 23.56 & 24.59 & 25.83 & $1.2 \%$ \\
\hline Methanol-Neat ICE ... & 22.48 & 23.47 & 24.60 & 25.74 & $0.8 \%$ \\
\hline Ethanol-Flex Fuel ICE ... & 20.98 & 23.21 & 24.21 & 25.39 & $1.1 \%$ \\
\hline Ethanol-Neat ICE $\ldots \ldots \ldots \ldots \ldots \ldots \ldots \ldots$ & 24.11 & 25.46 & 26.55 & 27.78 & $0.8 \%$ \\
\hline \multicolumn{6}{|l|}{ Natural Gas Technology } \\
\hline Compressed Natural Gas ICE $\ldots . \ldots$. & 19.31 & 20.48 & 21.35 & 22.34 & $0.9 \%$ \\
\hline Liquid Petroleum Gas ICE . . . . . . . . & 26.52 & 28.02 & 29.23 & 30.58 & $0.8 \%$ \\
\hline \multicolumn{6}{|l|}{ Electric Technology } \\
\hline Electric Vehicle $\ldots \ldots \ldots \ldots \ldots \ldots \ldots \ldots$ & 30.62 & 32.44 & 33.87 & 35.45 & $0.9 \%$ \\
\hline Electric Hybrid $\ldots \ldots \ldots \ldots \ldots \ldots \ldots$ & 29.38 & 31.01 & 32.23 & 33.61 & $0.8 \%$ \\
\hline Electric Hybrid 2 Stroke $\ldots \ldots \ldots, \ldots, \ldots \ldots$ & 29.38 & 30.92 & 32.34 & 33.75 & $0.8 \%$ \\
\hline Electric Hybrid Turbine $\ldots \ldots \ldots \ldots \ldots \ldots$ & 29.38 & 30.92 & 32.24 & 33.74 & $0.8 \%$ \\
\hline \multicolumn{6}{|l|}{ Turbine Technology } \\
\hline Gas Turbine Gasoline & 27.28 & 28.71 & 29.93 & 31.33 & $0.8 \%$ \\
\hline Gas Turbine Compressed Natural Gas ......... & 27.28 & 28.71 & 29.93 & 31.33 & $0.8 \%$ \\
\hline \multicolumn{6}{|l|}{ Fuel Cell Technology } \\
\hline Fuel Cell Methanol . . & 33.57 & 35.34 & 36.84 & 38.56 & $0.8 \%$ \\
\hline Fuel Cell Hydrogen $\ldots \ldots \ldots \ldots \ldots \ldots \ldots$ & 33.57 & 35.34 & 36.84 & 38.56 & $0.8 \%$ \\
\hline Average New Truck MPG. .... & 20.34 & 21.52 & 22.74 & 23.80 & $0.9 \%$ \\
\hline
\end{tabular}


Table 46. Light-Duty Vehicle MPG by Technology Type (Continued) (MPG Gasoline Equivalents)

\begin{tabular}{|c|c|c|c|c|c|}
\hline \multirow{2}{*}{ Technology Types } & \multicolumn{4}{|c|}{ Reference Case } & \multirow{2}{*}{$\begin{array}{l}\text { Annual } \\
\text { Growth } \\
1993-2010 \\
\text { (percent) }\end{array}$} \\
\hline & 1993 & 2000 & 2005 & 2010 & \\
\hline Fleet Average Stock Car $\mathrm{MPG}^{3} \ldots \ldots \ldots \ldots \ldots$ & 20.68 & 22.26 & 23.25 & 24.43 & $1.0 \%$ \\
\hline Fleet Average Stock Vehicle $M_{P G}{ }^{3} \ldots \ldots \ldots \ldots$ & 19.30 & 20.33 & 20.96 & 21.82 & $0.7 \%$ \\
\hline
\end{tabular}

'Fuel efficiencies are EPA rated. Includes personal and fleet vehicles.

${ }^{2}$ Fuel efficiencies are EPA rated. Includes personal vehicles, fleet vehicles, and freight light trucks.

${ }^{3}$ Stock values are on road efficiencies. Includes personal vehicles, fleet vehicles, and freight light trucks.

$M P G=$ Miles per Gallon.

ICE = Internal combustion engine.

Sources: 1993 derived using: Decision Analysis Corporation of Virginia and Science Applications International Corporation, Afternative Fuel Vehicle Module Database Updates, Draft Report, Subtask 9-2, prepared for Energy Information Administration (ElA), September 15, 1994; EA Engineering, Science, and Technology, Inc., AFV Differential Costs and Performance Attributes, prepared for Oak Ridge National Laboratory, November 1993; Fulton, Lew, "AFV and EPACT: A Case Study in Technology Policy," Dissertation Draft, June 1994; Department of Energy, Office of Transportation Technologies and Energy Efficiency and Renewable Energy, Federal Altemative Fuel Program Light Duty Vehicle Operations: Second Annual Report to Congress for Fiscal Year 1992, (Washington, D.C., July 1993); Department of Energy, Office of Transportation Technologies and Energy Efficiency and Renewable Energy, Alternative Fuel Vehicle Model, 1994; and EIA, AEO95 National Energy Modeling System run AEO95B.D1103942. Projections: ElA, AEO95 National Energy Modeling System run AEO95B.D1103942. 
Table 47. Light-Duty Vehicle VMT by Technology Type (Billion Miles, Unless Otherwise Noted)

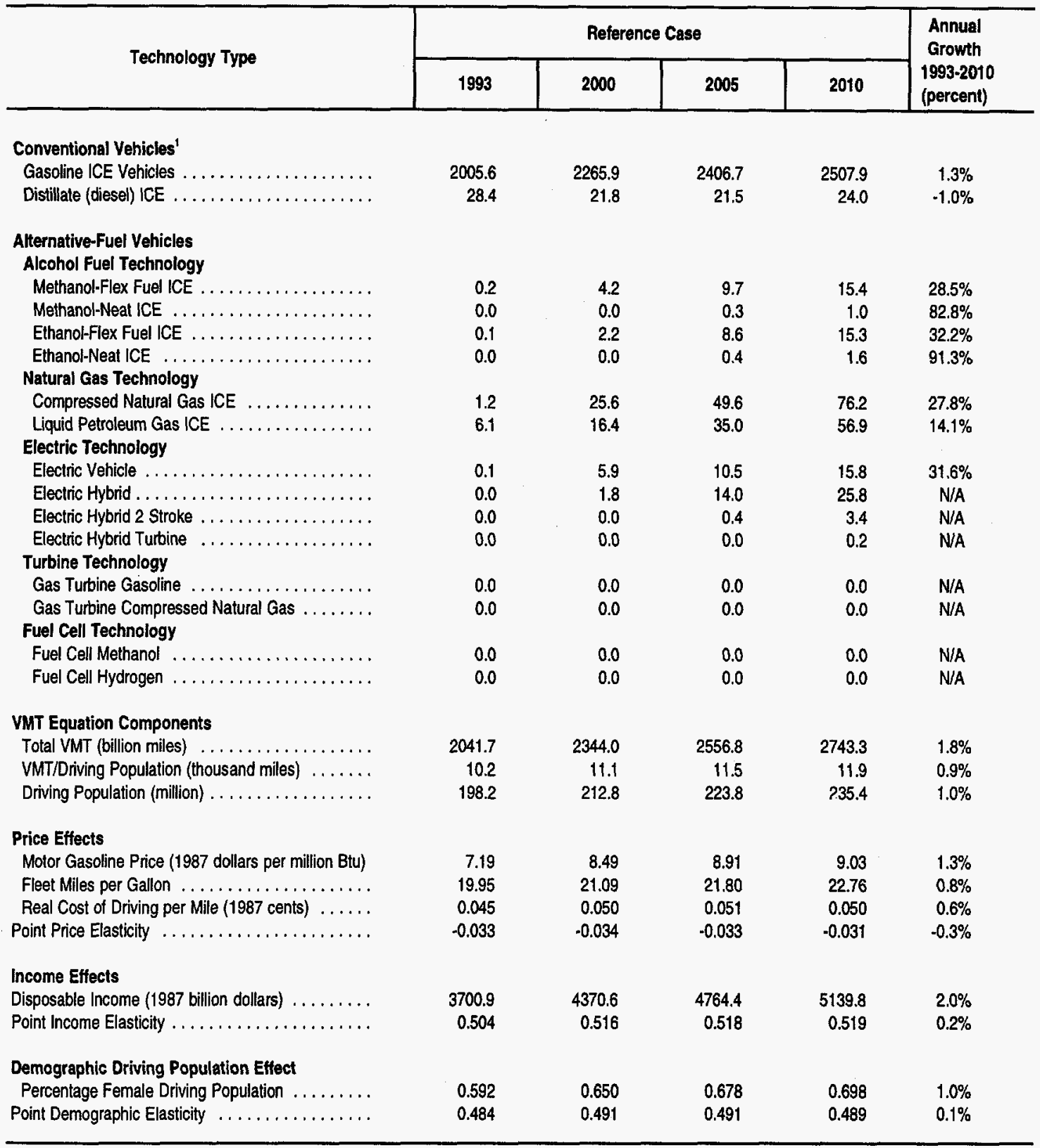

'Includes personal vehicles, fleet vehicles, and freight light trucks. Includes both cars and light trucks.

VMT = Vehicle miles traveled.

ICE = Internal combustion engine.

N/A $=$ Not applicable

Sources: 1993 derived using: Federal Highway Administration, Highway Statistics 1992, (1993); Oak Ridge National Laboratory, Transportation Energy Data Book: 12, 13, and 14, (May 1994); and Energy Information Administration (EIA), AEO95 National Energy Modeling System run AEO95B.D1103942. Projections: EIA, AEO95 National Energy Modeling System run AEO95B.D1103942. 
Table 48. Transportation Fleet Car and Truck Fuel Consumption by Type and Technology

(Trillion Btu)

\begin{tabular}{|c|c|c|c|c|c|}
\hline \multirow{2}{*}{ Technology Type } & \multicolumn{4}{|c|}{ Reference Case } & \multirow{2}{*}{$\begin{array}{c}\text { Annual } \\
\text { Growth } \\
1993-2010 \\
\text { (percent) }\end{array}$} \\
\hline & 1993 & 2000 & 2005 & 2010 & \\
\hline \multicolumn{6}{|l|}{ Cars' $^{1}$} \\
\hline Gasoline Conventional. & 1147.29 & 1031.98 & 917.18 & 839.62 & $-1.8 \%$ \\
\hline$\ldots \ldots \ldots \ldots \ldots \ldots \ldots$ & 0.00 & 0.00 & 0.00 & 0.00 & NA \\
\hline$\ldots \ldots \ldots \ldots \ldots \ldots \ldots \ldots$ & 0.13 & 2.33 & 3.92 & 4.76 & $23.7 \%$ \\
\hline Flex $\ldots \ldots \ldots \ldots \ldots \ldots \ldots \ldots \ldots \ldots \ldots$ & 0.13 & 2.33 & 3.92 & 4.76 & $23.7 \%$ \\
\hline Neat $\ldots \ldots \ldots \ldots \ldots \ldots \ldots \ldots \ldots \ldots \ldots \ldots$ & 0.00 & 0.00 & 0.00 & 0.00 & N/A \\
\hline Ethanol $\ldots \ldots \ldots \ldots \ldots \ldots \ldots \ldots \ldots \ldots \ldots$ & 0.07 & 0.11 & 0.97 & 1.30 & $18.7 \%$ \\
\hline Flex $\ldots \ldots \ldots \ldots \ldots \ldots \ldots \ldots \ldots \ldots \ldots \ldots$ & 0.07 & 0.11 & 0.97 & 1.30 & $18.7 \%$ \\
\hline Neat $\ldots \ldots \ldots \ldots \ldots \ldots \ldots \ldots \ldots \ldots \ldots$ & 0.00 & 0.00 & 0.00 & 0.00 & N/A \\
\hline Electric $\ldots \ldots \ldots \ldots \ldots \ldots \ldots \ldots \ldots \ldots \ldots \ldots \ldots$ & 0.19 & 12.57 & 15.09 & 17.46 & $30.5 \%$ \\
\hline Dedicated...$\ldots \ldots \ldots \ldots \ldots \ldots \ldots \ldots$ & 0.19 & 12.57 & 15.09 & 17.46 & $30.5 \%$ \\
\hline Hybrid $\ldots \ldots \ldots \ldots \ldots \ldots \ldots \ldots \ldots \ldots \ldots \ldots$ & 0.00 & 0.00 & 0.00 & 0.00 & N/A \\
\hline Hybrid with Small ICE,$\ldots \ldots \ldots \ldots \ldots \ldots$ & 0.00 & 0.00 & 0.00 & 0.00 & N/A \\
\hline Hybrid with Gas Turbine $\ldots \ldots \ldots \ldots \ldots \ldots$ & 0.00 & 0.00 & 0.00 & 0.00 & N/A \\
\hline Compressed Nalural Gas.$\ldots \ldots \ldots \ldots \ldots \ldots$ & 2.64 & 86.65 & 159.92 & 216.74 & $29.6 \%$ \\
\hline Liquid Petroleum Gas .................. & 3.51 & 36.28 & 84.59 & . 119.64 & $23.1 \%$ \\
\hline Gas Turbine Gasoline $\ldots \ldots \ldots \ldots \ldots \ldots \ldots$ & 0.00 & 0.00 & 0.00 & 0.00 & N/A \\
\hline Gas Turbine Compressed Natural Gas ......... & 0.00 & 0.00 & 0.00 & 0.00 & N/A \\
\hline Fuel Cell Methanol $\ldots \ldots \ldots \ldots \ldots \ldots \ldots$ & 0.00 & 0.00 & 0.00 & 0.00 & $N / A$ \\
\hline Fuel Cell Hydrogen $\ldots \ldots \ldots \ldots \ldots \ldots \ldots$ & 0.00 & 0.00 & 0.00 & 0.00 & N/A \\
\hline Total Fleet Cars $\ldots \ldots \ldots \ldots \ldots \ldots \ldots \ldots \ldots \ldots$ & 1153.84 & 1169.92 & 1181.67 & 1199.52 & $0.2 \%$ \\
\hline \multicolumn{6}{|l|}{ Light Trucks' } \\
\hline Gasoline Conventional .. & 579.73 & 676.31 & 688.80 & 636.57 & $0.6 \%$ \\
\hline Distillate $\ldots \ldots \ldots \ldots \ldots \ldots \ldots \ldots \ldots \ldots$ & 0.00 & 0.00 & 0.00 & 0.00 & N/A \\
\hline 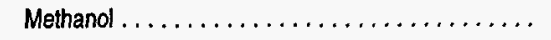 & 0.09 & 1.53 & 2.20 & 2.55 & $21.5 \%$ \\
\hline Flex $\ldots \ldots \ldots \ldots \ldots \ldots \ldots \ldots \ldots \ldots \ldots \ldots$ & 0.09 & 1.53 & 2.20 & 2.55 & $21.5 \%$ \\
\hline Neat $\ldots \ldots \ldots \ldots \ldots \ldots \ldots \ldots \ldots \ldots \ldots$ & 0.00 & 0.00 & 0.00 & 0.00 & $N / A$ \\
\hline Ethanol $\ldots \ldots \ldots \ldots \ldots \ldots \ldots \ldots \ldots \ldots$ & 0.03 & 0.15 & 0.55 & 0.73 & $20.8 \%$ \\
\hline$\ldots \ldots \ldots \ldots, \ldots, \ldots, \ldots$, & 0.03 & 0.15 & 0.55 & 0.73 & $20.8 \%$ \\
\hline Neat $\ldots \ldots \ldots \ldots \ldots \ldots \ldots \ldots \ldots \ldots \ldots$ & 0.00 & 0.00 & 0.00 & 0.00 & N/A \\
\hline Electric $\ldots \ldots \ldots \ldots \ldots \ldots \ldots \ldots \ldots \ldots$ & 0.20 & 7.63 & 8.48 & 9.14 & $25.1 \%$ \\
\hline Dedicated $\ldots \ldots \ldots \ldots \ldots \ldots \ldots \ldots \ldots$ & 0.20 & 7.63 & 8.48 & 9.14 & $25.1 \%$ \\
\hline Hybrid $\ldots \ldots \ldots \ldots \ldots \ldots \ldots \ldots \ldots \ldots$ & 0.00 & 0.00 & 0.00 & 0.00 & N/A \\
\hline Hybrid with Small ICE $\ldots \ldots \ldots \ldots \ldots \ldots \ldots$ & 0.00 & 0.00 & 0.00 & 0.00 & N/A \\
\hline Hybrid with Gas Turbine $\ldots \ldots \ldots \ldots \ldots \ldots$ & 0.00 & 0.00 & 0.00 & 0.00 & $\mathrm{~N} / \mathrm{A}$ \\
\hline Compressed Natural Gas ................. & 4.00 & 56.18 & 75.53 & 93.72 & $20.4 \%$ \\
\hline Liquid Petroleum Gas $\ldots \ldots \ldots \ldots \ldots \ldots \ldots$ & 18.83 & 24.77 & 37.88 & 49.56 & $5.9 \%$ \\
\hline Gas Turbine Gasoline $\ldots \ldots \ldots \ldots \ldots \ldots \ldots$ & 0.00 & 0.00 & 0.00 & 0.00 & N/A \\
\hline Gas Turbine Compressed Natural Gas $\ldots \ldots \ldots \ldots$ & 0.00 & 0.00 & 0.00 & 0.00 & N/A \\
\hline Fuel Cell Methanol $\ldots \ldots \ldots \ldots \ldots \ldots \ldots$ & 0.00 & 0.00 & 0.00 & 0.00 & NA \\
\hline Fuel Cell Hydrogen $\ldots \ldots \ldots \ldots \ldots \ldots \ldots$ & 0.00 & 0.00 & 0.00 & 0.00 & N/A \\
\hline Total Fleet Light Trucks $\ldots \ldots \ldots \ldots \ldots \ldots \ldots$ & 602.88 & 766.57 & 813.42 & 792.29 & $1.6 \%$ \\
\hline Total Fleet Vehicles $\ldots \ldots \ldots \ldots \ldots \ldots \ldots \ldots$ & 1756.72 & 1936.49 & 1995.09 & 1991.81 & $0.7 \%$ \\
\hline
\end{tabular}

'Includes all fleets of 10 or more.

ICE = Internal combustion engine.

Btu $=$ British thermal unit.

N/A = Not applicable.

Sources: 1993 derived using: Oak Ridge National Laboratory, "Fleet Vehicles in the United States: Composition, Operating Characteristics, and Fueling Practices," prepared for the Department of Energy, Office of Transportation Technologies, and Office of Policy, Planning, and Analysis, March 1992; Bobit Publishing Company, Fleet Fact Book, Redondo Beach, California, various issues; United States Department of Energy, Office of Domestic and International Energy Policy, "Assessment of Costs and Benefits of Flexible and Alternative Fuel Use in the U.S. Transportation Sector, Technical Report Ten: Analysis of Alternative Fuel Fleet Requirements," (Washington, D.C., May 1992); and Energy Information Administration (EIA), AEO95 National Energy Modeling System run AEO95B.D1103942. Projections: EIA, AEO95 National Energy Modeling System run AE095B.D1103942. 
Table 49. Transportation Fleet Car and Truck Sales by Type and Technology (Thousands)

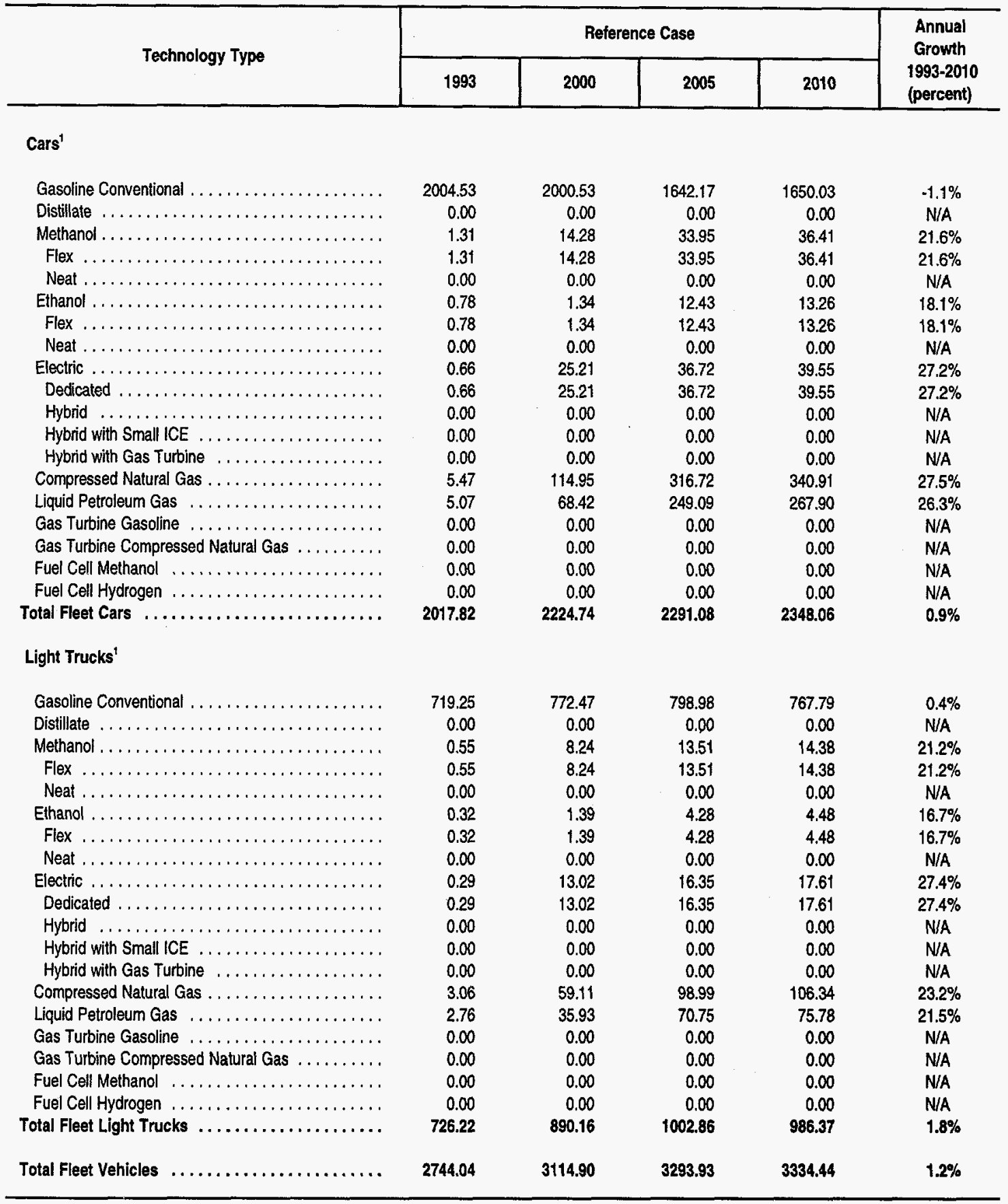

'Includes all fleets of 10 or more.

ICE = Internal combustion engine.

N/A = Not Applicable.

Sources: 1993 derived using: Oak Ridge National Laboratory, "Fleet Vehicles in the United States: Composition, Operating Characteristics, and Fueling Practices," prepared for the Department of Energy, Office of Transportation Technologies, and Office of Policy, Planning, and Analysis, March 1992; Bobit Publishing Company, Fleet Fact Book, Redondo Beach, Califomia, various issues; United States Department of Energy, Office of Domestic and International Energy Policy, "Assessment of Costs and Benefits of Flexible and Alternative Fuel Use in the U.S. Transportation Sector, Technical Report Ten: Analysis of Alternative Fuel Fleet Requirements," (Washington, D.C., May 1992); and Energy Information Administration (EIA), AEO95 National Energy Modeling System run AEO95B.D1103942. Projectlons: EIA, AEO95 National Energy Modeling System run AEO95B.D1103942. 
Table 50. Transportation Fleet Car and Truck Stock by Type and Technology (Thousands)

\begin{tabular}{|c|c|c|c|c|c|}
\hline \multirow{2}{*}{ Technology Type } & \multicolumn{4}{|c|}{ Reference Case } & \multirow{2}{*}{$\begin{array}{c}\text { Annual } \\
\text { Growth } \\
1993-2010 \\
\text { (percent) }\end{array}$} \\
\hline & 1993 & 2000 & 2005 & 2010 & \\
\hline \multicolumn{6}{|l|}{ Cars' } \\
\hline Gasoline Conventional $\ldots \ldots \ldots \ldots \ldots \ldots \ldots$ & 8126.65 & 7718.35 & 7121.83 & 7038.36 & $-0.8 \%$ \\
\hline Distillate $\ldots \ldots \ldots \ldots \ldots \ldots \ldots \ldots \ldots \ldots \ldots$ & 0.00 & 0.00 & 0.00 & 0.00 & N/A \\
\hline 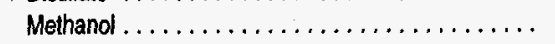 & 3.91 & 75.96 & 132.94 & 174.72 & $25.1 \%$ \\
\hline Flex $\ldots \ldots \ldots \ldots \ldots \ldots \ldots \ldots \ldots \ldots \ldots \ldots \ldots$ & 3.91 & 75.96 & 132.94 & 174.72 & $25.1 \%$ \\
\hline 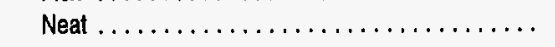 & 0.00 & 0.00 & 0.00 & 0.00 & NA \\
\hline Ethanol . & 2.25 & 3.75 & 34.64 & 50.27 & $20.0 \%$ \\
\hline$\ldots \ldots \ldots \ldots$ & 2.25 & 3.75 & 34.64 & 50.27 & $20.0 \%$ \\
\hline 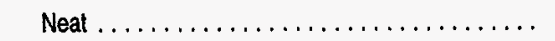 & 0.00 & 0.00 & 0.00 & 0.00 & $N / A$ \\
\hline Electric $\ldots \ldots \ldots \ldots \ldots \ldots \ldots \ldots \ldots \ldots$ & 2.04 & 142.59 & 179.03 & 223.38 & $31.8 \%$ \\
\hline Dedicated..$\ldots \ldots \ldots \ldots \ldots \ldots \ldots \ldots$ & 2.04 & 142.59 & 179.03 & 223.38 & $31.8 \%$ \\
\hline Hybrid $\ldots \ldots \ldots \ldots \ldots \ldots \ldots \ldots \ldots \ldots$ & 0.00 & 0.00 & 0.00 & 0.00 & N/A \\
\hline Hybrid with Smail ICE $\ldots \ldots \ldots \ldots \ldots \ldots \ldots$ & 0.00 & 0.00 & 0.00 & 0.00 & N/A \\
\hline Hybrid with Gas Turbine $\ldots \ldots \ldots \ldots \ldots \ldots$ & 0.00 & 0.00 & 0.00 & 0.00 & $\mathrm{~N} / \mathrm{A}$ \\
\hline Compressed Natural Gas...$\ldots \ldots \ldots \ldots \ldots$ & 17.56 & 616.55 & 1179.85 & 1714.82 & $30.9 \%$ \\
\hline Liquid Petroleum Gas ................... & 31.62 & 351.19 & 849.15 & 1288.20 & $24.4 \%$ \\
\hline Gas Turbine Gasoline $\ldots \ldots \ldots \ldots \ldots \ldots \ldots$ & 0.00 & 0.00 & 0.00 & 0.00 & N/A \\
\hline Gas Turbine Compressed Natural Gas ......... & 0.00 & 0.00 & 0.00 & 0.00 & N/A \\
\hline Fuel Cell Methanol $\ldots \ldots \ldots \ldots \ldots \ldots \ldots$ & 0.00 & 0.00 & 0.00 & 0.00 & N/A \\
\hline Fuel Cell Hydrogen $\ldots \ldots \ldots \ldots \ldots \ldots \ldots$ & 0.00 & 0.00 & 0.00 & 0.00 & N/A \\
\hline Total Fieet Cars $\ldots \ldots \ldots \ldots \ldots \ldots \ldots \ldots \ldots$ & 8184.02 & 8908.38 & 9497.44 & 10489.75 & $1.5 \%$ \\
\hline \multicolumn{6}{|l|}{ Light Trucks' } \\
\hline Gasoline Conventional . . & 3063.89 & 3712.59 & 3979.33 & 3906.92 & $1.4 \%$ \\
\hline Distillate $\ldots \ldots \ldots \ldots \ldots \ldots \ldots \ldots \ldots \ldots \ldots \ldots \ldots \ldots$ & 0.00 & 0.00 & 0.00 & 0.00 & N/A \\
\hline Methanal $\ldots \ldots \ldots \ldots \ldots \ldots \ldots \ldots \ldots \ldots$ & 2.16 & 36.31 & 55.51 & 68.77 & $22.6 \%$ \\
\hline Flex $\ldots \ldots \ldots \ldots \ldots \ldots \ldots \ldots \ldots \ldots$ & 2.16 & 36.31 & 55.51 & 68.77 & $22.6 \%$ \\
\hline Neat $\ldots \ldots \ldots \ldots \ldots \ldots \ldots \ldots \ldots \ldots \ldots$ & 0.00 & 0.00 & 0.00 & 0.00 & N/A \\
\hline Ethanol $\ldots \ldots \ldots \ldots \ldots \ldots \ldots \ldots \ldots \ldots$ & 0.72 & 4.03 & 14.97 & 21.18 & $22.0 \%$ \\
\hline Flex $\ldots \ldots \ldots \ldots \ldots \ldots \ldots \ldots \ldots \ldots \ldots \ldots \ldots$ & 0.72 & 4.03 & 14.97 & 21.18 & $22.0 \%$ \\
\hline Neat $\ldots \ldots \ldots \ldots \ldots \ldots \ldots \ldots \ldots \ldots \ldots \ldots$ & 0.00 & 0.00 & 0.00 & 0.00 & N/A \\
\hline Electric $\ldots \ldots \ldots \ldots \ldots \ldots \ldots \ldots \ldots$ & 1.63 & 62.62 & 73.72 & 84.77 & $26.2 \%$ \\
\hline Dedicated $\ldots \ldots \ldots \ldots \ldots \ldots \ldots \ldots \ldots$ & 1.63 & 62.62 & 73.72 & 84.77 & $26.2 \%$ \\
\hline Hybrid $\ldots \ldots \ldots \ldots \ldots \ldots \ldots \ldots \ldots$ & 0.00 & 0.00 & 0.00 & 0.00 & N/A \\
\hline Hybrid with Small ICE $\ldots \ldots \ldots \ldots \ldots \ldots$ & 0.00 & 0.00 & 0.00 & 0.00 & N/A \\
\hline Hybrid with Gas Turbine ................. & 0.00 & 0.00 & 0.00 & 0.00 & $\mathrm{~N} / \mathrm{A}$ \\
\hline Compressed Natural Gas ................. & 20.10 & 290.66 & 414.23 & 545.99 & $21.4 \%$ \\
\hline 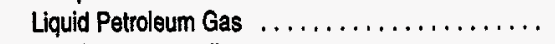 & 130.69 & 175.08 & 284.39 & 394.96 & $6.7 \%$ \\
\hline Gas Turbine Gasoline $\ldots \ldots \ldots \ldots \ldots \ldots \ldots$ & 0.00 & 0.00 & 0.00 & 0.00 & N/A \\
\hline Gas Turbine Compressed Natural Gas .......... & 0.00 & 0.00 & 0.00 & 0.00 & N/A \\
\hline Fuel Cell Methanol $\ldots \ldots \ldots \ldots \ldots \ldots \ldots$ & 0.00 & 0.00 & 0.00 & 0.00 & N/A \\
\hline Fuel Cell Hydrogen $\ldots \ldots \ldots \ldots \ldots \ldots \ldots \ldots$ & 0.00 & 0.00 & 0.00 & 0.00 & N/A \\
\hline Total Fleot Light Trucks .................. & 3219.21 & 4281.29 & 4822.15 & 5022.59 & $2.7 \%$ \\
\hline Total Fleet Vehicles $\ldots \ldots \ldots \ldots \ldots \ldots \ldots \ldots \ldots$ & 11403.22 & 13189.67 & 14319.59 & 15512.33 & $1.8 \%$ \\
\hline
\end{tabular}

'Includes all fleets of 10 or more.

ICE = Internal combustion engine

N/A $=$ Not applicable.

Sources: 1993 derived using: Oak Ridge National Laboratory, "Fleet Vehicles in the United States: Composition, Operating Characteristics, and Fueling Practices," prepared for the Department of Energy, Office of Transportation Technologies, and Office of Policy, Planning, and Analysis, March 1992; Bobit Publishing Company, Fleet Fact Book, Redondo Beach, Calitomia, various issues; United States Depantment of Energy, Office of Domestic and Intemational Energy Policy, "Assessment of Costs and Benefits of Flexible and Alternative Fuel Use in the U.S. Transportation Sector, Technical Repon Ten: Analysis of Alternative Fuel Fleet Requirements," (Washington, D.C., May 1992); and Energy Information Administration (EIA), AEO95 National Energy Modeling System run AEO95B.D1103942. Projectlons: EIA, AEO95 National Energy Modeling System run AE095B.D1103942. 
Table 51. Transportation Fleet Car and Truck VMT by Type and Technology (Billion Miles per Year)

\begin{tabular}{|c|c|c|c|c|c|}
\hline \multirow{2}{*}{ Technology Type } & \multicolumn{4}{|c|}{ Reference Case } & \multirow{2}{*}{$\begin{array}{l}\text { Annual } \\
\text { Growth } \\
1993-2010 \\
\text { (percent) }\end{array}$} \\
\hline & 1993 & 2000 & 2005 & 2010 & \\
\hline \multicolumn{6}{|l|}{ Cars $^{1}$} \\
\hline Gasoline Conventional $\ldots \ldots \ldots \ldots \ldots \ldots$ & 209.75 & 196.35 & 179.37 & 173.30 & $-1.1 \%$ \\
\hline Distillate $\ldots \ldots \ldots \ldots \ldots \ldots \ldots \ldots \ldots$ & 0.00 & 0.00 & 0.00 & 0.00 & NA \\
\hline Methanol $\ldots \ldots \ldots \ldots \ldots \ldots \ldots \ldots \ldots$ & 0.10 & 1.93 & 3.35 & 4.30 & $24.7 \%$ \\
\hline Flex $\ldots \ldots \ldots \ldots \ldots \ldots \ldots \ldots \ldots$ & 0.10 & 1.93 & 3.35 & 4.30 & $24.7 \%$ \\
\hline Neat,$\ldots \ldots \ldots \ldots \ldots \ldots \ldots \ldots \ldots$ & 0.00 & 0.00 & 0.00 & 0.00 & N/A \\
\hline Ethand $\ldots \ldots \ldots \ldots \ldots \ldots \ldots \ldots \ldots$ & 0.06 & 0.10 & 0.87 & 1.24 & $19.7 \%$ \\
\hline Flex $\ldots \ldots \ldots \ldots \ldots \ldots \ldots \ldots \ldots$ & 0.06 & 0.10 & 0.87 & 1.24 & $19.7 \%$ \\
\hline Neat $\ldots \ldots \ldots \ldots \ldots \ldots \ldots \ldots \ldots$ & 0.00 & 0.00 & 0.00 & 0.00 & N/A \\
\hline Electric $\ldots \ldots \ldots \ldots \ldots \ldots \ldots \ldots \ldots$ & 0.05 & 3.63 & 4.51 & 5.50 & $31.5 \%$ \\
\hline Dedicated $\ldots \ldots \ldots \ldots \ldots \ldots \ldots \ldots \ldots$ & 0.05 & 3.63 & 4.51 & 5.50 & $31.5 \%$ \\
\hline Hybrid $\ldots \ldots \ldots \ldots \ldots \ldots \ldots \ldots \ldots$ & 0.00 & 0.00 & 0.00 & 0.00 & N/A \\
\hline Hybrid with Small ICE $\ldots \ldots \ldots \ldots \ldots \ldots \ldots$ & 0.00 & 0.00 & 0.00 & 0.00 & N/A \\
\hline Hybrid with Gas Turbine $\ldots \ldots \ldots \ldots \ldots$ & 0.00 & 0.00 & 0.00 & 0.00 & N/A \\
\hline Compressed Natural Gas . . . . . . . . . . . & 0.45 & 15.68 & 29.72 & 42.22 & $30.6 \%$ \\
\hline Liquid Petroleum Gas $\ldots \ldots \ldots \ldots \ldots \ldots \ldots$ & 0.82 & 8.93 & 21.39 & 31.72 & $24.0 \%$ \\
\hline Gas Turtine Gasoline $\ldots \ldots \ldots \ldots \ldots \ldots \ldots$ & 0.00 & 0.00 & 0.00 & 0.00 & N/A \\
\hline Gas Turbine Compressed Natural Gas $\ldots . \ldots \ldots$ & 0.00 & 0.00 & 0.00 & 0.00 & N/A \\
\hline Fuel Cell Methanol $\ldots \ldots \ldots \ldots \ldots \ldots \ldots \ldots$ & 0.00 & 0.00 & 0.00 & 0.00 & N/A \\
\hline Fuel Cell Hydrogen $\ldots \ldots \ldots \ldots \ldots \ldots \ldots \ldots$ & 0.00 & 0.00 & 0.00 & 0.00 & N/A \\
\hline Total Fleet Cars . . . . . . . . . . . . . . . . . & 211.23 & 226.62 & 239.21 & 258.28 & $1.2 \%$ \\
\hline \multicolumn{6}{|l|}{ Light Trucks } \\
\hline Gasoline Conventional . . . . . . . . . . . . & 79.08 & 94.44 & 100.23 & 96.20 & $1.2 \%$ \\
\hline Distillate $\ldots \ldots \ldots \ldots \ldots \ldots \ldots \ldots \ldots$ & 0.00 & 0.00 & 0.00 & 0.00 & NA \\
\hline Methanol $\ldots \ldots \ldots \ldots \ldots \ldots \ldots \ldots$ & 0.06 & 0.92 & 1.40 & 1.69 & $22.2 \%$ \\
\hline Fiex $\ldots \ldots \ldots \ldots \ldots \ldots \ldots \ldots \ldots$ & 0.06 & 0.92 & 1.40 & 1.69 & $22.2 \%$ \\
\hline Neat $\ldots \ldots \ldots \ldots \ldots \ldots \ldots \ldots \ldots \ldots$ & 0.00 & 0.00 & 0.00 & 0.00 & N/A \\
\hline 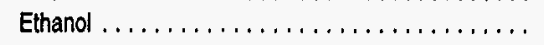 & 0.02 & 0.10 & 0.38 & 0.52 & $21.6 \%$ \\
\hline Flex $\ldots \ldots \ldots \ldots \ldots \ldots \ldots \ldots \ldots \ldots$ & 0.02 & 0.10 & 0.38 & 0.52 & $21.6 \%$ \\
\hline Neat $\ldots \ldots \ldots \ldots \ldots \ldots \ldots \ldots \ldots$ & 0.00 & 0.00 & 0.00 & 0.00 & N/A \\
\hline Electric $\ldots \ldots \ldots \ldots \ldots \ldots \ldots \ldots \ldots$ & 0.04 & 1.59 & 1.86 & 2.09 & $25.8 \%$ \\
\hline Dedicated . . . . . . . . . . . . . . . . . & 0.04 & 1.59 & 1.86 & 2.09 & $25.8 \%$ \\
\hline Hybrid $\ldots \ldots \ldots \ldots \ldots \ldots \ldots \ldots$ & 0.00 & 0.00 & 0.00 & 0.00 & N/A \\
\hline Hybrid with Small ICE $\ldots \ldots \ldots \ldots \ldots \ldots \ldots$ & 0.00 & 0.00 & 0.00 & .0 .00 & N/A \\
\hline Hybrid with Gas Turbine $\ldots \ldots \ldots \ldots \ldots \ldots$ & 0.00 & 0.00 & 0.00 & 0.00 & N/A \\
\hline Compressed Natural Gas . . . . . . . . . . . . . . & 0.52 & 7.39 & 10.43 & 13.44 & $21.1 \%$ \\
\hline Liquid Petroleum Gas . . . . . . . . . . . . . . . & 3.37 & 4.45 & 7.16 & 9.72 & $6.4 \%$ \\
\hline Gas Turbine Gasoline $\ldots \ldots \ldots \ldots \ldots \ldots$ & 0.00 & 0.00 & 0.00 & 0.00 & N/A \\
\hline Gas Turbine Compressed Natural Gas . . . . . . . . & 0.00 & 0.00 & 0.00 & 0.00 & N/A \\
\hline Fuel Cell Methanol $\ldots \ldots \ldots \ldots \ldots \ldots$ & 0.00 & 0.00 & 0.00 & 0.00 & N/A \\
\hline Fuel Cell Hydrogen $\ldots \ldots \ldots \ldots \ldots \ldots \ldots \ldots$ & 0.00 & 0.00 & 0.00 & 0.00 & N/A \\
\hline Total Fleet Light Truck . . . . . . . . . . . . . . . . & 83.09 & 108.91 & 121.45 & 123.67 & $2.4 \%$ \\
\hline Total Fleet Vehicles . . . . . . . . . . . . . . . . . & 294.32 & 335.53 & 360.66 & 381.94 & $1.5 \%$ \\
\hline
\end{tabular}

'Includes all fleets of 10 or more.

ICE = Internal combustion engine.

N/A = Not applicable.

Sources: 1993 derived using: Oak Ridge National Laboratory, "Fleet Vehicles in the United States: Composition, Operating Characteristics, and Fueling Practices," prepared for the Department of Energy, Office of Transportation Technologies, and Otfice of Policy, Planning, and Analysis, March 1992; Bobit Publishing Company, Fleet Fact Book, Redondo Beach, California, various issues; United States Department of Energy, Office of Domestic and International Energy Policy, "Assessment of Costs and Benefits of Flexible and Alternative Fuel Use in the U.S. Transportation Sector, Technical Report Ten: Analysis of Alternative Fuel Fleet Requirements," (Washington, D.C., May 1992); and Energy information Administration (EIA), AEO95 National Energy Modeling System run AEO95B.D1103942. Projectlons: EIA, AEO95 National Energy Modeling System run AEO95B.D1103942. 


\begin{tabular}{|c|c|c|c|c|c|}
\hline \multirow{2}{*}{ Indicators } & \multicolumn{4}{|c|}{ Reference Case } & \multirow{2}{*}{$\begin{array}{l}\text { Annual } \\
\text { Growth } \\
1993-2010 \\
\text { (percent) }\end{array}$} \\
\hline & 1993 & 2000 & 2005 & 2010 & \\
\hline \multicolumn{6}{|l|}{ Travel Demand (billion of miles) } \\
\hline Revenue Passenger Miles Domestic . . .......... & 361.3 & 499.8 & 561.0 & 616.0 & $3.2 \%$ \\
\hline 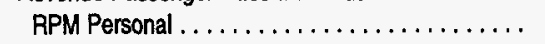 & 187.9 & 277.0 & 307.3 & 335.4 & $3.5 \%$ \\
\hline RPM Business $\ldots . \ldots \ldots \ldots \ldots \ldots$ & 173.4 & 222.8 & 253.7 & 280.6 & $2.9 \%$ \\
\hline Load Factor Domestic ${ }^{1} \ldots \ldots \ldots \ldots \ldots$ & 0.6 & 0.6 & 0.6 & 0.6 & N/A \\
\hline Revenue Passenger Miles International ......... & 143.5 & 234.3 & 270.2 & 304.7 & $4.5 \%$ \\
\hline Load Factor International' & 0.7 & 0.7 & 0.7 & 0.7 & N/A \\
\hline Revenue Ton Miles Freight (billion ) ........... & 12.2 & 19.8 & 26.4 & 32.0 & $5.8 \%$ \\
\hline GDP (billion 1987 dollars) . ................ & 5135.6 & 6126.2 & 6851.6 & 7485.3 & $2.2 \%$ \\
\hline Exports (billion 1987 dollars) . . ............ & 598.1 & 937.8 & 1296.6 & 1625.3 & $6.1 \%$ \\
\hline Ticket Price (yield, 1987 cents per passenger mile) . & 12.6 & 13.8 & 14.3 & 14.6 & $0.8 \%$ \\
\hline \multicolumn{6}{|l|}{ Operating Cost } \\
\hline (1987 dollars per available seat-mile) . . . . . . . & 0.1 & 0.1 & 0.1 & 0.1 & N/A \\
\hline Fuel Cost (1991 dollars per thousand Biu) ...... & 3.4 & 4.7 & 5.2 & 5.5 & $2.8 \%$ \\
\hline Seat Miles Demanded (billion) . ............. & 792.1 & 1163.9 & 1352.4 & 1520.2 & $3.9 \%$ \\
\hline \multicolumn{6}{|l|}{ Aircraft Sales } \\
\hline Narrow Body Aircraft . & 191.3 & 224.0 & 211.4 & 206.3 & $0.4 \%$ \\
\hline Wide Body Aircraft . . . . . . . . . . . . . . . . . & 37.6 & 73.6 & 83.4 & 86.5 & $5.0 \%$ \\
\hline \multicolumn{6}{|l|}{ Aircraft Stock } \\
\hline Narrow Body Aircraft & 3677.0 & 4537.0 & 5013.5 & 5359.5 & $2.2 \%$ \\
\hline 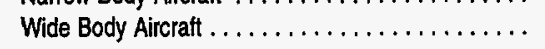 & 761.3 & 1176.0 & 1434.0 & 1684.1 & $4.8 \%$ \\
\hline \multicolumn{6}{|l|}{ Aircraft New Efficiency (seat miles per gallon) } \\
\hline Narrow Body Aircraft ................... & 47.7 & 50.1 & 51.8 & 53.4 & $0.7 \%$ \\
\hline Wide Body Aircraft ........... & 57.7 & 59.8 & 61.2 & 62.9 & $0.5 \%$ \\
\hline Average Aircratt Etficiency ................ & 49.1 & 52.2 & 54.1 & 55.9 & $0.8 \%$ \\
\hline \multicolumn{6}{|l|}{ Aircraft Stock Etficiency (seat miles per gallon) } \\
\hline Narrow Body Aircraft...$\ldots \ldots \ldots \ldots \ldots \ldots$ & 45.5 & 47.8 & 49.4 & 50.9 & $0.7 \%$ \\
\hline Wide Body Aircraft ..................... & 55.1 & 57.2 & 58.5 & 59.7 & $0.5 \%$ \\
\hline Average Aircratt Stock Efficiency ............. & 49.5 & 52.1 & 53.7 & 55.4 & $0.7 \%$ \\
\hline \multicolumn{6}{|l|}{ Seat Miles Demanded (billion) } \\
\hline 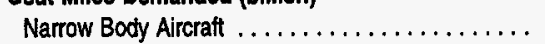 & 426.6 & 584.2 & 645.6 & 690.1 & $2.9 \%$ \\
\hline 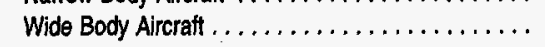 & 365.5 & 579.6 & 706.8 & 830.1 & $4.9 \%$ \\
\hline \multicolumn{6}{|l|}{ Fuel Consumption (trililion Btu) } \\
\hline \multicolumn{6}{|l|}{ Commercial } \\
\hline Jet Fuel $\ldots \ldots \ldots \ldots \ldots \ldots \ldots \ldots \ldots$ & 2296.7 & 3169.0 & 3566.7 & 3891.7 & $3.2 \%$ \\
\hline Aviation Gasoline $\ldots . . \ldots \ldots \ldots \ldots . . . . .$. & 47.2 & 46.3 & 46.0 & 45.9 & $-0.2 \%$ \\
\hline Military & & & & & \\
\hline Jet Fuel $\ldots \ldots \ldots \ldots \ldots \ldots \ldots \ldots \ldots \ldots$ & 743.6 & 559.3 & 555.5 & 563.3 & $-1.6 \%$ \\
\hline
\end{tabular}

'Fraction of seats filled.

RPM = Revenue passenger miles.

GDP $=$ Gross domestic product.

Btu $=$ British thermal unit.

N/A = Not applicable.

Sources: 1993 derived using: Federal Aviation Administration (FAA), FAA Aviation Forecasts, Fiscal Years 1991-2002, FAA-APO 91-1, and previous editions; United States Department of Transportation (DOT), Research and Special Programs Administration (RSPA), Fuel Cost and Consumption Tables, annual summaries, 1979-1990; DOT, RSPA, Air Carrier Financial Statistics Quarterly, December 1990/1989, and prior issues; DOT, RSPA, Air Carrier Traffic Statistics Monthly, December 1990/1989, and prior issues; Greene, D.L., "Energy Efficiency Improvement Potential of Commercial Aircraft to 2010," ORNL-6622, 6/1990; Rathi, A. B. Peterson, and D. Greene, Air Transport Energy Use Model, Oak Ridge National Laboratory, April 1991, Draft; and Energy Information Administration (EIA), AEO95 National Energy Modeling Systern run AEO95B.D1103942. Projectlons: EIA AEO95 National Energy Modeling System run AEO95B.D1103942. 
Table 53. Freight Transportation Energy Use

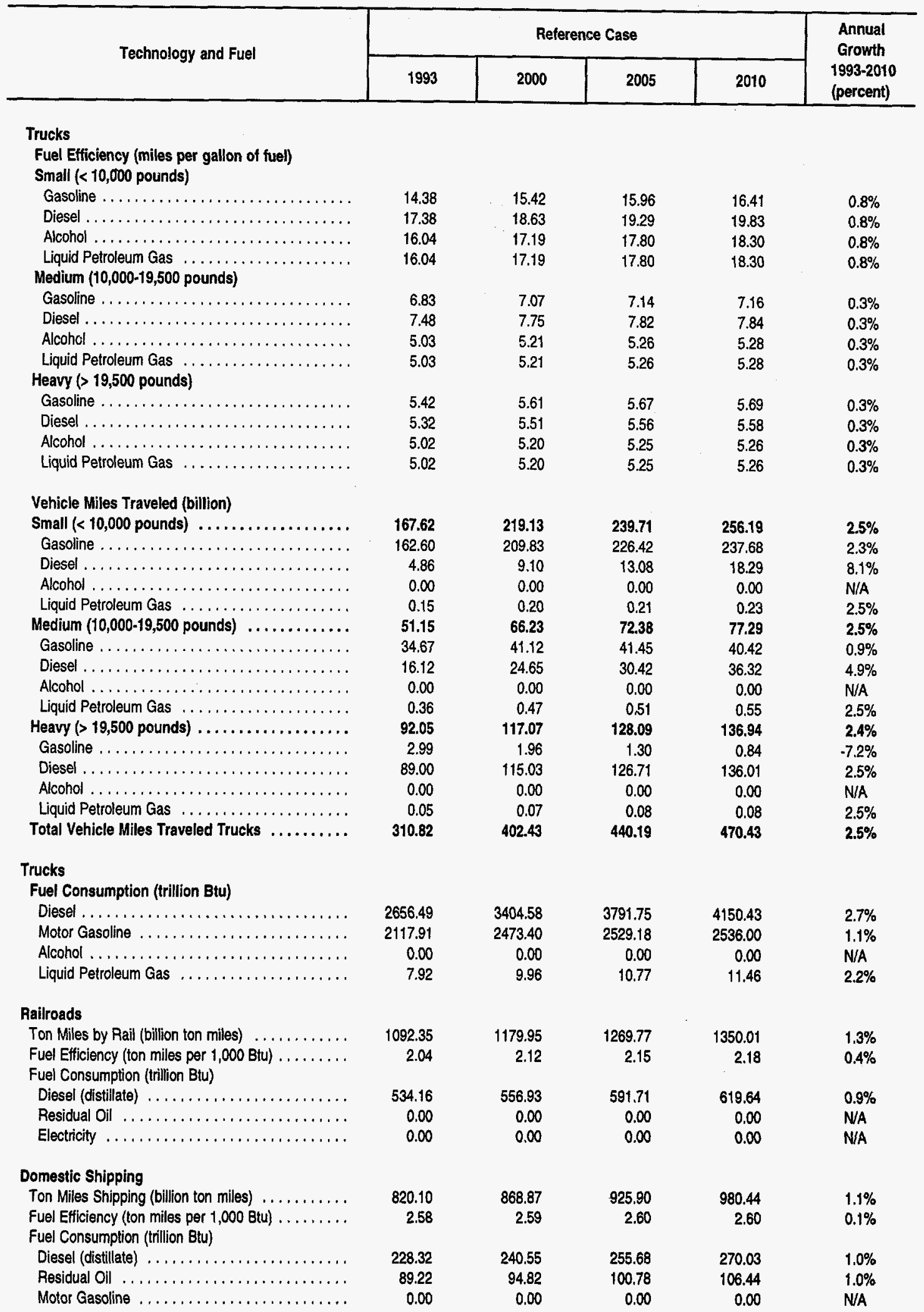


Table 53. Freight Transportation Energy Use (Continued)

\begin{tabular}{|c|c|c|c|c|c|}
\hline \multirow{2}{*}{ Technology and Fuel } & \multicolumn{4}{|c|}{ Reference Case } & \multirow{2}{*}{$\begin{array}{c}\text { Annual } \\
\text { Growth } \\
1993-2010 \\
\text { (percent) }\end{array}$} \\
\hline & 1993 & 2000 & 2005 & 2010 & \\
\hline \multicolumn{6}{|l|}{ International Shipping } \\
\hline Gross Trade (billion 1987 dollars) & 1272.53 & 1962.75 & 2602.61 & 3202.79 & $5.6 \%$ \\
\hline Exports (billion 1987 dollars) . . . . & 598.06 & 937.79 & 1296.64 & 1625.28 & $6.1 \%$ \\
\hline Imports (billion 1987 dollars) $\ldots \ldots \ldots \ldots$ & 674.48 & 1024.96 & 1305.97 & 1577.50 & $5.1 \%$ \\
\hline \multicolumn{6}{|l|}{ Fuel Consumption(trillion Btu) } \\
\hline Diesel (distillate) $\ldots \ldots \ldots \ldots \ldots \ldots \ldots \ldots$ & 75.46 & 91.49 & 105.57 & 117.23 & $2.6 \%$ \\
\hline Residual OIl $\ldots \ldots \ldots \ldots \ldots \ldots \ldots \ldots$ & 990.23 & 1210.92 & 1397.18 & 1551.60 & $2.7 \%$ \\
\hline
\end{tabular}

Btu $=$ British thermal unit.

N/A = Not applicable.

Sources: 1993 derived using: Oak Ridge National Laboratory, Transportation Energy Data Book: 12, 13, and 14, (May 1994); Argonne National Laboratory, FRATE Model, 1990; United States Department of Transportation, 1989 Carload Waybill Statistics Traffic and Revenue by Commodity Classes, September 1991 and prior issues; Reebie Associates, TRANSEARCH Database, (Greenwich, Connecticut, 1989); Army Corps of Engineers, Waterborne Commerce of the United States, (New Orleans), 1991 and prior issues; and Energy Information Administration (ElA), AEO95 National Energy Modeling System run AEO95B.D1103942. Projections: EIA, AEO95 National Energy Modeling System run AEO95B.D1103942. 
Table 54. Electric Power Data and Projections for the EMM Region East Central Area Reliability Coordination Agreement (ECAR)

\begin{tabular}{l|l|l|l|l|l}
\hline \multirow{2}{*}{ Electricity Supply and Demand } & \multicolumn{4}{|c|}{ Reference Case } & \multicolumn{2}{c}{$\begin{array}{c}\text { Annual } \\
\text { Growth } \\
1993-2010 \\
\text { (percent) }\end{array}$} \\
\cline { 2 - 5 } & 1993 & 2000 & 2005 & 2010 & \\
\hline
\end{tabular}

\section{Electricity Generating Capacity' \\ (gigawatts)}

Utilities

Coal Steam $\ldots \ldots \ldots \ldots \ldots \ldots \ldots \ldots \ldots$

Other Fossil Steam ${ }^{2} \ldots \ldots \ldots \ldots \ldots \ldots \ldots \ldots \ldots$

Combined Cycle .......................

Combustion Turbine/Diesel ................

Nuclear Power .......................

Pumped Storage/Other ${ }^{3} \ldots \ldots \ldots \ldots \ldots \ldots \ldots \ldots$

Renewable $e^{4} \ldots \ldots \ldots \ldots \ldots \ldots \ldots \ldots$

Total Utilities Capability .

\section{itions ${ }^{s}$}

Cumulative Planned Additions ${ }^{5}$

Coal Steam .........................

Other Fossil Steam ${ }^{2} \ldots \ldots \ldots \ldots \ldots \ldots \ldots \ldots$

Combined Cycle ......................

Combustion Turbine/Diesel ................

Nuclear Power ......................

Pumped Storage/Other ${ }^{3} \ldots \ldots \ldots \ldots \ldots \ldots \ldots \ldots$

Renewable ${ }^{4} \ldots \ldots \ldots \ldots \ldots \ldots \ldots \ldots$

Total (planned)

84.02
3.79
0.39
4.19
7.65
3.26
1.29
104.61

80.78
3.13
0.39
6.20
7.58
3.26
1.36
102.72

80.42
2.34
0.51
7.70
7.58
3.27
1.36
103.18

$\begin{array}{rr}80.12 & -0.3 \% \\ 2.31 & -2.9 \% \\ 0.63 & 2.8 \% \\ 9.92 & 5.2 \% \\ 6.83 & -0.7 \% \\ 3.27 & 0.0 \% \\ 1.36 & 0.3 \% \\ 104.43 & 0.0 \%\end{array}$

Cumulative Unplanned Additions ${ }^{\mathbf{5}}$

Coal Steam

Other Fossil Steam ${ }^{2}$

0.00

0.00

0.00

0.00

0.00

0.00

0.00

0.00

$$
\begin{aligned}
& 0.26 \\
& 0.00 \\
& 0.00 \\
& 2.01 \\
& 0.00 \\
& 0.00 \\
& 0.08 \\
& 2.35
\end{aligned}
$$

Combined Cycle ...........

Combustion Turbine/Diesel

Nuclear Power .................

Pumped Storage/Other ${ }^{3}$...................

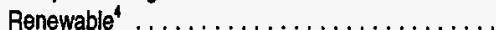

Total (unplanned) ......................

Cumulative Total Utility Additions

\subsection{0}

0.00

0.00

0.00

0.00

0.00

0.00

0.00

0.00

Cumulative Utility Retirements

0.78

0.00

0.00

0.00

0.00

0.00

0.00

(1)

$\begin{array}{lll}0.26 & 0.26 & \text { N/A } \\ 0.00 & 0.00 & \text { N/A } \\ 0.12 & 0.12 & \text { N/A } \\ 3.29 & 3.29 & \text { N/A } \\ 0.00 & 0.00 & \text { N/A } \\ 0.00 & 0.00 & \text { N/A } \\ 0.08 & 0.08 & \text { N/A } \\ 3.75 & 3.75 & \text { N/A }\end{array}$

Nonutilities Capacity (excludes cogenerators) $)^{6,7}$

Coal Steam ........................

Other Fossil Steam ${ }^{2} \ldots \ldots \ldots \ldots \ldots \ldots \ldots$

Combined Cycle .........................

Combustion Turbine/Diesel ...............

Nuclear Power .........................

Pumped Storage/Other ${ }^{8} \ldots \ldots \ldots \ldots \ldots \ldots \ldots$,

Renewable $e^{4}$

Total Nonutilities Capability

$\begin{array}{ll}0.18 & 0.46 \\ 0.00 & 0.00 \\ 0.00 & 0.00 \\ 0.04 & 0.05 \\ 0.00 & 0.00 \\ 0.00 & 0.00 \\ 0.52 & 2.06 \\ 0.74 & 2.57\end{array}$

$\begin{array}{lll}0.00 & 0.00 & \text { N/A } \\ 0.00 & 0.00 & \text { N/A } \\ 0.00 & 0.12 & \text { N/A } \\ 0.31 & 2.53 & \text { N/A } \\ 0.00 & 0.00 & \text { N/A } \\ 0.00 & 0.00 & \text { N/A } \\ 0.00 & 0.00 & \text { N/A } \\ 0.31 & 2.65 & \text { N/A } \\ 4.06 & 6.39 & \text { N/A } \\ 6.27 & 7.35 & 14.1 \%\end{array}$

\section{Cogenerators?}

Capacity

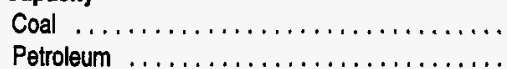

Natural Gas .........................

Renewables $\ldots \ldots \ldots \ldots \ldots \ldots \ldots \ldots \ldots$.

Other ................................

Total

i...........

Electricity Demand
(billion kilowatthours)

Residential ..........................

Commercial/other . . . . . . . . . . . . . . . . .

Industrial $\ldots \ldots \ldots \ldots \ldots \ldots \ldots \ldots \ldots$

Transportation ..........................

Total Sales ....

$\begin{array}{ll}0.84 & 0.98 \\ 0.04 & 0.07 \\ 2.58 & 2.95 \\ 0.34 & 0.36 \\ 0.00 & 0.00 \\ 3.79 & 4.35\end{array}$

0.46
0.00
0.04
1.01
0.00
0.00
2.17
3.67

$\begin{array}{rrrrr}141.13 & 148.08 & 151.12 & 157.37 & 0.6 \% \\ 119.15 & 129.42 & 133.01 & 137.24 & 0.8 \% \\ 180.19 & 196.56 & 214.22 & 226.16 & 1.3 \% \\ 2.65 & 3.76 & 5.57 & 7.53 & 6.3 \% \\ \mathbf{4 4 3 . 1 2} & \mathbf{4 7 7 . 8 2} & \mathbf{5 0 3 . 9 3} & \mathbf{5 2 8 . 3 0} & 1.0 \%\end{array}$


Table 54. Electric Power Data and Projections for the EMM Region East Central Area Reliability Coordination Agreement (ECAR) (Continued)

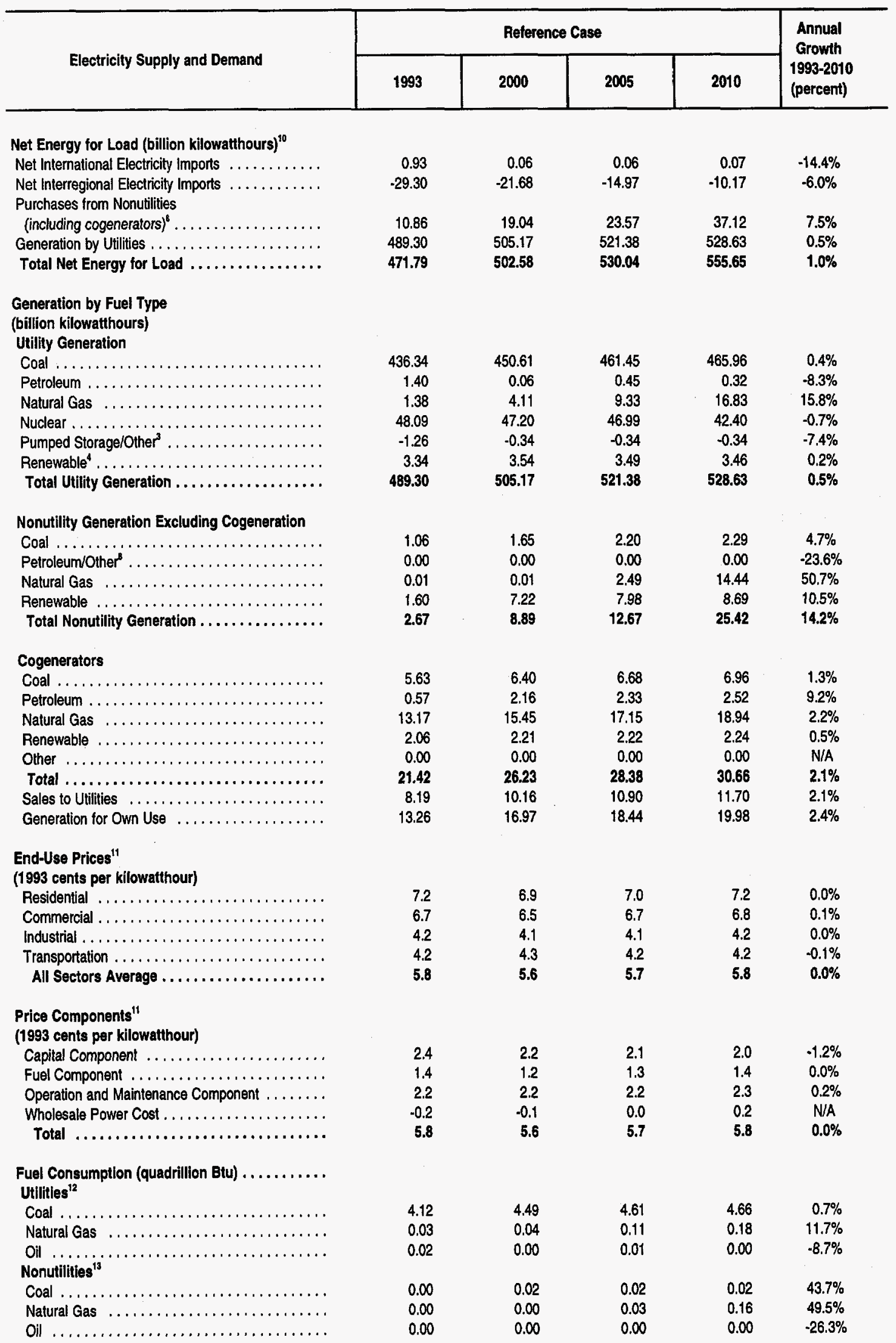


Table 54. Electric Power Data and Projections for the EMM Region East Central Area Reliability Coordination Agreement (ECAR) (Continued)

\begin{tabular}{|c|c|c|c|c|c|}
\hline \multirow{2}{*}{ Electricity Supply and Demand } & \multicolumn{4}{|c|}{ Reference Case } & \multirow{2}{*}{$\begin{array}{c}\text { Annual } \\
\text { Growth } \\
\text { 1993-2010 } \\
\text { (percent) }\end{array}$} \\
\hline & 1993 & 2000 & 2005 & 2010 & \\
\hline \multicolumn{6}{|l|}{ Emissions (million metric tons) ${ }^{14}$} \\
\hline Total Carbon $\ldots . . . \ldots \ldots$ & 109.09 & 114.17 & 118.81 & 122.95 & $0.7 \%$ \\
\hline Carbon Dioxide .... & 399.97 & 418.62 & 435.64 & 450.82 & $0.7 \%$ \\
\hline Sulfur Dioxide $\ldots \ldots \ldots \ldots \ldots \ldots \ldots \ldots$ & 5.68 & 3.43 & 2.88 & 2.86 & $-4.0 \%$ \\
\hline
\end{tabular}

'Net summer capability is the steady hourly output that generating equipment is expected to supply to system load (exclusive of auxiliary power), as demonstrated by tests during summer peak demand.

inciudes oil-, gas-, and dual-fired capability.

${ }^{3}$ Other includes methane, propane gas, and blast furnace gas.

Includes conventional hydroelectric, geothermal, wood, wood waste, municipal solid waste, other biomass, solar, and wind power.

${ }^{5}$ Cumulative additions after December 31, 1992.

'Electrcity was produced solely for sale to an electric utility or another end-user, and there is no business activity at the site (standard industrial classification 49 ).

"Nameplate capacity is reported for nonutilities on Form EIA-867, "Annual Nonutility Power Producer Report." Nameplate capacity is designated by the manufacturer. The nameplate capacity has been converted to net summer capacity based on historic relationships.

${ }^{8}$ Other includes hydrogen, sulfur, batteries, chemicals, fish oil, and spent sulfite liquor.

Includes generators and cogenerators at facilities whose primary function is not electricity production (standard industrial classification other than 49).

${ }^{10}$ Generation to meet system load by source.

"Prices represent average revenue per kilowatthour.

12 In the end-use energy consumptions tables, projected fuel consumption in the utility sector includes fuel used by independent power producers. In this table, fuel used by independent power producers is included in the nonutility category.

${ }^{13}$ Includes fuel consumption by small power producers, independent power producers, and exempt wholesale generators, which produce electricity for sales to utilities.

${ }^{14}$ Estimated emissions from utilities and independent power producers.

$E M M=$ Electricity market module.

N/A = Not applicable.

Note: Totals may not equal sum of components due to independent rounding.

Sources: 1993 (except for prices): Energy Information Administration (EIA), Annual Energy Review 1993, DOE/EIA-0384(93) (Washington, D.C., July 1994). Prices and all projections: EIA, AEO95 National Energy Modeling System run AEO95B.D1103942. 
Table 55. Electric Power Data and Projections for the EMM Region Electric Reliability Council of Texas (ERCOT)

\begin{tabular}{l|c|c|c|c|c|c|}
\hline \multirow{2}{*}{ Electricity Supply and Demand } & \multicolumn{4}{|c|}{ Reterence Case } & $\begin{array}{c}\text { Annual } \\
\text { Growth } \\
1993-2010 \\
\text { (percent) }\end{array}$ \\
\cline { 2 - 6 } & 1993 & 2000 & 2005 & 2010 \\
\hline
\end{tabular}

Electricity Generating Capacity

(gigawatts)

Utilities

Coal Steam $\ldots \ldots \ldots \ldots \ldots \ldots \ldots \ldots \ldots$

Other Fossil Steam ${ }^{2} \ldots \ldots \ldots \ldots \ldots \ldots \ldots \ldots \ldots$

Combined Cycle . . . . . . . . . . . . . . . .

Combustion Turbine/Diesel $\ldots \ldots \ldots \ldots \ldots \ldots$

Nuclear Power $\ldots \ldots \ldots \ldots \ldots \ldots \ldots \ldots \ldots \ldots$

Pumped Storage/Other ${ }^{3} \ldots \ldots \ldots \ldots \ldots \ldots \ldots$

Renewable ${ }^{4} \ldots \ldots \ldots \ldots \ldots \ldots \ldots \ldots \ldots \ldots \ldots$

Total Utilities Capability $\ldots \ldots \ldots \ldots \ldots \ldots$

$\begin{array}{rrrrr}14.95 & 15.76 & 18.65 & 19.45 & 1.6 \% \\ 29.83 & 28.75 & 28.60 & 27.94 & -0.4 \% \\ 0.74 & 1.93 & 3.87 & 4.28 & 10.9 \% \\ 2.28 & 3.08 & 3.08 & 3.18 & 2.0 \% \\ 4.78 & 4.78 & 4.78 & 4.78 & \text { NAA } \\ 0.00 & 0.00 & 0.00 & 0.00 & \text { N/A } \\ 0.57 & 0.58 & 0.58 & 0.58 & 0.1 \% \\ 53.15 & 54.88 & 59.57 & 60.21 & 0.7 \%\end{array}$

Cumulative Planned Additions ${ }^{5}$

Coal Steam $\ldots \ldots \ldots \ldots \ldots \ldots \ldots \ldots \ldots$

Other Fossil Steam ${ }^{2} \ldots \ldots \ldots \ldots \ldots \ldots \ldots$

Combined Cycle . . . . . . . . . . . . . . .

Combustion Turbine/Diesel . . . . . . . . . . .

Nuclear Power . ...................

Pumped Storage/Other ${ }^{3} \ldots \ldots \ldots \ldots \ldots \ldots \ldots$

Renewable ${ }^{4} \ldots \ldots \ldots \ldots \ldots \ldots \ldots \ldots \ldots$

Total (planned) . . . . . . . . . . . . .

Cumulative Unplanned Additions ${ }^{5}$

Coal Steam . . . . . . . . . . . . . . .

Other Fossil Steam ${ }^{2} \ldots \ldots \ldots \ldots \ldots \ldots \ldots \ldots$

Combined Cycle . . . . . . . . . . . . . . .

Combustion Turbine/Diesel $\ldots \ldots \ldots \ldots \ldots \ldots$

Nuclear Power . . . . . . . . . . . . . . . . . .

Pumped Storage/Other ${ }^{3} \ldots \ldots \ldots \ldots \ldots \ldots$

Renewable ${ }^{4} \ldots \ldots \ldots \ldots \ldots \ldots \ldots \ldots$

Total (unplanned) . . . . . . . . . . . . .

Cumulative Total Utility Additions . . . . . . .

Cumulative Utility Relirements $\ldots \ldots \ldots \ldots \ldots \quad 0.06$

0.00

0.00

0.00

0.00

1.15

0.00

0.00

1.15

$\begin{array}{lrr}3.70 & 4.49 & \text { N/A } \\ 0.00 & 0.00 & \text { N/A } \\ 3.14 & 3.54 & \text { N/A } \\ 0.82 & 0.93 & \text { N/A } \\ 1.15 & 1.15 & \text { N/A } \\ 0.00 & 0.00 & \text { N/A } \\ 0.00 & 0.00 & \text { N/A } \\ 8.80 & 10.12 & 13.6 \%\end{array}$

$\begin{array}{ll}0.00 & \text { N/A } \\ 0.00 & \text { N/A } \\ 0.00 & \text { N/A } \\ 0.00 & \text { N/A } \\ 0.00 & \text { N/A } \\ 0.00 & \text { N/A } \\ 0.01 & \text { N/A } \\ 0.01 & \text { N/A } \\ 10.13 & 13.7 \% \\ & \\ 2.22 & 24.1 \%\end{array}$

Nonutilities Capacity (excludes cogenerators) ${ }^{6,7}$

Coal Steam . . . . . . . . . . . . . . .

Other Fossil Steam ${ }^{2} \ldots \ldots \ldots \ldots \ldots \ldots \ldots \ldots$

Combined Cycle . ...................

Combustion Turbine/Diesel . . . . . . . . . . . . . .

Nuclear Power . . . . . . . . . . . . . . . . . . .

Pumped Storage/Other ${ }^{8} \ldots \ldots \ldots \ldots \ldots \ldots \ldots$

Renewablet ${ }^{4}$.

Total Nonutilities Capability

Cogenerators

\section{Capacity}

Coal

Petroleum $\ldots \ldots \ldots \ldots \ldots \ldots \ldots \ldots$

Natural Gas . . . . . . . . . . . . . . . .

Renewables . . . . . . . . . . . . . . . . . .

Other .......................

Total $\ldots \ldots \ldots \ldots \ldots \ldots \ldots \ldots \ldots \ldots \ldots \ldots$

Electricity Demand

(billion kilowatthours)

Residential . . . . . . . . . . . . . . . . . .

Commercial/other . . . . . . . . . . . . .

Industrial $\ldots \ldots \ldots \ldots \ldots \ldots \ldots \ldots \ldots \ldots$

Transportation $\ldots \ldots \ldots \ldots \ldots \ldots \ldots \ldots \ldots$

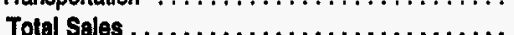


Table 55. Electric Power Data and Projections for the EMM Region Electric Reliability Council of Texas (ERCOT) (Continued)

\begin{tabular}{|c|c|c|c|c|c|}
\hline \multirow{2}{*}{ Electricity Supply and Demand } & \multicolumn{4}{|c|}{ Reference Case } & \multirow{2}{*}{$\begin{array}{c}\text { Annual } \\
\text { Growth } \\
1993-2010 \\
\text { (percent) }\end{array}$} \\
\hline & 1993 & 2000 & 2005 & 2010 & \\
\hline \multicolumn{6}{|l|}{ Net Energy for Load (billion kilowatthours) ${ }^{10}$} \\
\hline Net International Electricity Imports $\ldots \ldots \ldots \ldots$ & -0.01 & -0.30 & -0.45 & -0.67 & $30.0 \%$ \\
\hline Net Interregional Electricity Imports $\ldots \ldots \ldots \ldots$ & -0.57 & -0.67 & -2.16 & -2.16 & $8.1 \%$ \\
\hline $\begin{array}{l}\text { Purchases from Nonutilities } \\
\text { (including cogenerators) }{ }^{6} \ldots \ldots \ldots \ldots \ldots \ldots\end{array}$ & 25.13 & 33.26 & 3545 & & \\
\hline Generation by Utilities $\ldots \ldots \ldots \ldots \ldots \ldots \ldots$ & 200.10 & $\begin{array}{r}00.20 \\
206.57\end{array}$ & 218.37 & $\begin{array}{r}38.05 \\
230.88\end{array}$ & $\begin{array}{l}2.5 \% \\
0.8 \%\end{array}$ \\
\hline Total Net Energy for Load . . . . . . . . . . . & 224.65 & 238.85 & 251.21 & 266.10 & $1.0 \%$ \\
\hline \multirow{2}{*}{\multicolumn{6}{|c|}{$\begin{array}{l}\text { Generation by Fuel Type } \\
\text { (billion kilowatthours) } \\
\text { Utility Generation }\end{array}$}} \\
\hline & & & & & \\
\hline Coal $\ldots \ldots \ldots \ldots \ldots \ldots \ldots \ldots \ldots$ & 100.50 & 93.07 & 111.17 & 116.05 & $0.8 \%$ \\
\hline Petroleum $\ldots \ldots \ldots \ldots \ldots \ldots \ldots \ldots \ldots$ & 0.44 & 0.26 & 0.22 & 0.23 & $-3.7 \%$ \\
\hline Natural Gas $\ldots \ldots \ldots \ldots \ldots \ldots \ldots \ldots$ & 85.03 & 83.57 & 77.31 & 84.93 & $0.0 \%$ \\
\hline Nuclear $\ldots \ldots \ldots \ldots \ldots \ldots \ldots \ldots \ldots \ldots \ldots$ & 12.41 & 28.12 & 28.12 & 28.12 & $4.9 \%$ \\
\hline Pumped Storage/Other $\ldots \ldots \ldots \ldots \ldots \ldots$ & 0.00 & 0.00 & 0.00 & 0.00 & N/A \\
\hline Renewablet $\ldots \ldots \ldots \ldots \ldots \ldots \ldots \ldots$ & 1.72 & 1.54 & 1.54 & 1.54 & $.0 .7 \%$ \\
\hline Total Utility Generation . . . . . . . . . . . . . . . . & 200.10 & 206.57 & 218.37 & 230.88 & $0.8 \%$ \\
\hline \multicolumn{6}{|l|}{ Nonutility Generation Excluding Cogeneration } \\
\hline Coal $\ldots \ldots \ldots \ldots \ldots \ldots \ldots \ldots \ldots$ & 0.00 & 0.00 & 0.00 & 0.00 & N/A \\
\hline Petroleum/Other $\ldots \ldots \ldots \ldots \ldots \ldots \ldots$ & 0.00 & 0.00 & 0.00 & 0.00 & N/A \\
\hline Natural Gas $\ldots \ldots \ldots \ldots \ldots \ldots \ldots \ldots$ & 0.52 & 2.78 & 2.73 & 2.78 & $10.3 \%$ \\
\hline Renewable $\ldots \ldots \ldots \ldots \ldots \ldots \ldots \ldots \ldots$ & 0.03 & 0.00 & 0.00 & 0.15 & $10.1 \%$ \\
\hline Total Nonutility Generation . . . . . . . . . . . . & 0.55 & 2.78 & 2.74 & 2.93 & $10.3 \%$ \\
\hline \multicolumn{6}{|l|}{ Cogenerators } \\
\hline Coal $\ldots \ldots \ldots \ldots \ldots \ldots \ldots \ldots \ldots$ & 3.16 & 3.59 & 3.74 & 3.90 & $1.3 \%$ \\
\hline Petroleum $\ldots \ldots \ldots \ldots \ldots \ldots \ldots \ldots$ & 1.81 & 6.90 & 7.44 & 8.02 & $9.2 \%$ \\
\hline Natural Gas $\ldots \ldots \ldots \ldots \ldots \ldots \ldots \ldots$ & 49.30 & 57.83 & 64.17 & 70.89 & $2.2 \%$ \\
\hline Renewable $\ldots \ldots \ldots \ldots \ldots \ldots \ldots \ldots \ldots$ & 1.07 & 1.15 & 1.16 & 1.17 & $0.5 \%$ \\
\hline Other $\ldots \ldots \ldots \ldots \ldots \ldots \ldots \ldots \ldots$ & 0.22 & 0.32 & 0.34 & 0.36 & $3.0 \%$ \\
\hline Total $\ldots \ldots \ldots \ldots \ldots \ldots \ldots \ldots \ldots \ldots$ & 55.55 & 69.79 & 76.86 & 84.35 & $2.5 \%$ \\
\hline Sales to Utilities $\ldots \ldots \ldots \ldots \ldots \ldots \ldots \ldots$ & 24.57 & 30.48 & 32.72 & 35.12 & $2.1 \%$ \\
\hline Generation for Own Use $\ldots \ldots \ldots \ldots \ldots \ldots$ & 30.98 & 39.65 & 43.08 & 46.67 & $2.4 \%$ \\
\hline \multicolumn{6}{|l|}{$\begin{array}{l}\text { End-Use Prices" } \\
\text { (1993 cents per kilowatthour) }\end{array}$} \\
\hline Residential $\ldots \ldots \ldots \ldots \ldots \ldots \ldots \ldots$ & 7.6 & 7.6 & 8.0 & 7.8 & $0.1 \%$ \\
\hline Commercial . . . . . . . . . . . . . . . . & 6.9 & 7.2 & 7.6 & 7.9 & $0.8 \%$ \\
\hline Industrial $\ldots \ldots \ldots \ldots \ldots \ldots \ldots \ldots \ldots \ldots$ & 4.5 & 4.7 & 4.9 & 5.0 & $0.7 \%$ \\
\hline Transportation . . . . . . . . . . . . . . . . . & 3.8 & 3.9 & 4.1 & 4.0 & $0.3 \%$ \\
\hline All Sectors Average . . . . . . . . . . . . . . . & 6.2 & 6.4 & 6.7 & 6.7 & $0.5 \%$ \\
\hline \multicolumn{6}{|l|}{ Price Components ${ }^{11}$} \\
\hline \multicolumn{6}{|l|}{ (1993 cents per kilowatthour) } \\
\hline Capital Component $\ldots \ldots \ldots \ldots \ldots \ldots \ldots$ & 2.3 & 2.3 & 2.4 & 2.2 & $-0.3 \%$ \\
\hline Fuel Component $\ldots \ldots \ldots \ldots \ldots \ldots \ldots \ldots$ & 1.6 & 1.7 & 1.8 & 2.0 & $1.5 \%$ \\
\hline Operation and Maintenance Component . . . . . . . & 2.1 & 2.1 & 2.2 & 2.2 & $0.2 \%$ \\
\hline Wholesale Power Cost . . . . . . . . . . . . . . . & 0.2 & 0.3 & 0.3 & 0.3 & $2.0 \%$ \\
\hline Total $\ldots \ldots \ldots \ldots \ldots \ldots \ldots \ldots$ & 6.2 & 6.4 & 6.7 & 6.7 & $0.5 \%$ \\
\hline \multicolumn{6}{|l|}{$\begin{array}{l}\text { Fuel Consumption (quadrillion Btu) } \ldots \ldots \ldots \ldots \text {. } \\
\text { Utilities }^{12}\end{array}$} \\
\hline Coal $\ldots \ldots \ldots \ldots \ldots \ldots \ldots \ldots \ldots \ldots$ & 1.19 & 0.99 & 1.17 & 1.22 & $0.2 \%$ \\
\hline Natural Gas $\ldots \ldots \ldots \ldots \ldots \ldots \ldots \ldots$ & 0.89 & 0.85 & 0.78 & 0.86 & $-0.2 \%$ \\
\hline 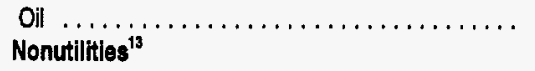 & 0.01 & 0.00 & 0.00 & 0.00 & $-4.4 \%$ \\
\hline Coal $\ldots \ldots \ldots \ldots \ldots \ldots \ldots \ldots \ldots \ldots$ & 0.00 & 0.00 & 0.00 & 0.00 & $N / A$ \\
\hline Natural Gas $\ldots \ldots \ldots \ldots \ldots \ldots \ldots \ldots \ldots$ & 0.00 & 0.03 & 0.03 & 0.03 & $10.8 \%$ \\
\hline Oil $\ldots \ldots \ldots \ldots \ldots \ldots \ldots \ldots \ldots \ldots$ & 0.00 & 0.00 & 0.00 & 0.00 & N/A \\
\hline
\end{tabular}


Table 55. Electric Power Data and Projections for the EMM Region Electric Reliability Council of Texas (ERCOT) (Continued)

\begin{tabular}{|c|c|c|c|c|c|}
\hline Electricity Supply and Demand & 1993 & 2000 & 2005 & 2010 & $\begin{array}{l}\text { Annual } \\
\text { Growth } \\
\text { 1993-2010 } \\
\text { (percent) }\end{array}$ \\
\hline \multicolumn{6}{|l|}{ Emissions (million metric tons) ${ }^{14}$} \\
\hline Sulfur Dioxide $\ldots \ldots \ldots \ldots \ldots \ldots \ldots \ldots$ & 0.47 & 0.37 & 0.35 & 0.35 & $-1.7 \%$ \\
\hline
\end{tabular}

'Net summer capability is the steady hourly output that generating equipment is expected to supply to system load (exclusive of auxiliary power), as demonstrated by tests during summer peak demand.

Includes oil-, gas-, and dual-fired capability.

${ }^{3}$ Other includes methane, propane gas, and blast furnace gas.

Includes conventional hydroelectric, geothermal, wood, wood waste, municipal solid waste, other biomass, solar, and wind power.

${ }^{5}$ Cumulative additions after December $31,1992$.

"Electrcity was produced solely for sale to an electric utility or another end-user, and there is no business activity at the site (standard industrial classification 49 ).

${ }^{7}$ Nameplate capacity is reported for nonutilities on Form EIA-867, "Annual Nonutility Power Producer Report." Nameplate capacity is designated by the manufacturer. The nameplate capacity has been converted to net summer capacity based on historic relationships.

"Other includes hydrogen, sulfur, batteries, chemicals, fish oil, and spent sulfite liquor.

Includes generators and cogenerators at facilities whose primary function is not electricity production (standard industrial classification other than 49).

${ }^{10}$ Generation to meet system load by source.

"'Prices represent average revenue per kilowatthour.

${ }^{12}$ In the end-use energy consumptions tables, projected fuel consumption in the utility sector includes fuel used by independent power producers. In this table, fuel used by independent power producers is included in the nonutility categon.

${ }^{13}$ Includes fuel consumption by small power producers, independent power producers, and exempt wholesale generators, which produce electricity for sales to utilities.

${ }^{14}$ Estimated emissions from utilities and independent power producers.

$E M M=$ Electricity market module.

N/A = Not applicable.

Note: Totals may not equal sum of components due to independent rounding.

Sources: 1993 (except for prices): Energy Information Administration (ElA), Annual Energy Review 1993, DOE/EIA-0384(93) (Washington, D.C., July 1994). Prices and all projections: EIA, AEO95 National Energy Modeling System run AEO95B.D1103942. 
Table 56. Electric Power Data and Projections for the EMM Region Mid-Atlantic Area Council (MAAC)

\begin{tabular}{l|c|c|c|c|c}
\hline \multirow{2}{*}{ Electricity Supply and Demand } & \multicolumn{4}{|c|}{ Reference Case } & \multicolumn{1}{c}{$\begin{array}{c}\text { Annual } \\
\text { Growth } \\
1993-2010 \\
\text { (percent) }\end{array}$} \\
\cline { 2 - 6 } & 1993 & 2000 & 2005 & 2010 \\
\hline
\end{tabular}

Electricity Generating Capacity

(gigawatts)

Utilities

Coal Steam ...................... $\quad 18.79$

Other Fossil Steam ${ }^{2}$

Combined Cycle ..........

Combustion Turbine/Diesel . . . . . . . . . . . . .

Nuclear Power ......................

Pumped Storage/Other ${ }^{3}$

Renewable ${ }^{4}$

.

Total Utilities Capability

\subsection{67}

8.56

12.58

1.34

1.05

52.86

18.59
8.13
2.46
8.97
12.58
1.34
1.05
53.12

18.52
7.53
3.26
9.31
12.58
1.34
1.05
53.60

Cumulative Planned Additions ${ }^{5}$

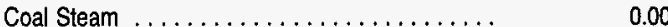

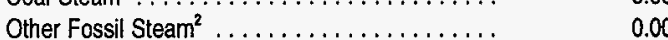

Combined Cycle ..................... $\quad 0.00$

Combustion Turbine/Diesel ................

Nuclear Power . .....................

Pumped Storage/Other ${ }^{3}, \ldots \ldots \ldots \ldots \ldots \ldots$

Renewable $\ldots \ldots \ldots \ldots \ldots \ldots \ldots \ldots \ldots$

Total (planned)

0.30

0.30

Cumulative Unplanned Additions ${ }^{5}$

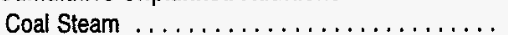

Other Fossil Steam ${ }^{2} \ldots \ldots \ldots \ldots \ldots \ldots \ldots \ldots \ldots$

Combined Cycle .......................

Combustion Turbine/Diesel . . . . . . . . ......

Nuclear Power ......................

Pumped Storage/Other ${ }^{3} \ldots \ldots \ldots \ldots \ldots \ldots \ldots \ldots$

Renewable ${ }^{4} \ldots \ldots \ldots \ldots \ldots \ldots \ldots \ldots$

Total (unplanned) $\ldots \ldots \ldots \ldots \ldots \ldots \ldots$

Cumulative Total Utility Additions .........

2.75

Cumulative Utility Retirements

0.00

0.66

0.30

Nonutilities Capacity (excludes cogenerators) ${ }^{6,7}$

Coal Steam ......................

Other Fossil Steam ${ }^{2} \ldots \ldots \ldots \ldots \ldots \ldots \ldots \ldots$

Combined Cycle . . ....................

Combustion Turbine/Diesel . . . . . . . . . . . . .

Nuclear Power . . .....................

Pumped Storage/Other ${ }^{\mathrm{s}} \ldots \ldots \ldots \ldots \ldots \ldots \ldots$

Renewable ${ }^{4} \ldots \ldots \ldots \ldots \ldots \ldots \ldots \ldots$

Total Nonutilities Capability

0.00
0.00

\section{Cogenerators ${ }^{9}$}

\section{Capacity}

Coal $\ldots \ldots \ldots \ldots \ldots \ldots \ldots \ldots \ldots \ldots$

Petroleum $\ldots \ldots \ldots \ldots \ldots \ldots \ldots \ldots \ldots$

Natural Gas . . . . . . . . . . . . . . .

Renewables ....................

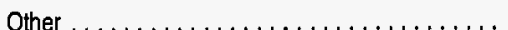

Total $\ldots \ldots \ldots \ldots \ldots \ldots \ldots \ldots \ldots$

$\begin{array}{ccc}0.83 & 1.63 & 11.9 \% \\ 0.05 & 0.05 & \text { N/A } \\ 0.62 & 0.68 & \text { N/A } \\ 0.03 & 0.14 & 9.5 \% \\ 0.00 & 0.00 & \text { N/A } \\ 0.00 & 0.00 & \text { N/A } \\ 1.12 & 1.60 & 6.8 \% \\ 2.65 & 4.11 & 9.7 \%\end{array}$

Electricity Demand

(billion kilowatthours)

Residential . ....................

Commercial/Other $\ldots \ldots \ldots \ldots \ldots \ldots \ldots \ldots \ldots$

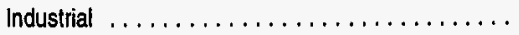

Transportation $\ldots \ldots \ldots \ldots \ldots \ldots \ldots \ldots \ldots \ldots \ldots$

$$
\begin{array}{r}
81.47 \\
80.72 \\
67.58 \\
2.32
\end{array}
$$

218.61 
Table 56. Electric Power Data and Projections for the EMM Region Mid-Atlantic Area Council (MAAC) (Continued)

\begin{tabular}{|c|c|c|c|c|c|}
\hline \multirow{2}{*}{ Electricity Supply and Demand } & \multicolumn{4}{|c|}{ Reference Case } & \multirow{2}{*}{$\begin{array}{l}\text { Annual } \\
\text { Growth } \\
\text { 1993-2010 } \\
\text { (percent) }\end{array}$} \\
\hline & 1993 & 2000 & 2005 & 2010 & \\
\hline \multicolumn{6}{|l|}{ Net Energy for Load (billion kilowatthours) ${ }^{10}$} \\
\hline Net International Electricity Imports $\ldots \ldots \ldots \ldots$ & 0.00 & 0.00 & 0.00 & 0.00 & $N / A$ \\
\hline Net Interregional Electricity Imports . . . . . . . . . & 13.41 & 9.42 & 6.53 & 7.03 & $-3.7 \%$ \\
\hline \multicolumn{6}{|l|}{ Purchases from Nonutilities } \\
\hline (including cogenerators) ${ }^{6} \ldots \ldots \ldots \ldots \ldots$ & 23.04 & 34.55 & 38.90 & 48.76 & $4.5 \%$ \\
\hline Generation by Utilities $\ldots \ldots \ldots \ldots \ldots \ldots \ldots$ & 210.50 & 209.61 & 218.26 & 218.75 & $0.2 \%$ \\
\hline Total Net Energy for Load . . . . . . . . . . . . & 246.95 & 253.57 & 263.68 & 274.54 & $0.6 \%$ \\
\hline \multicolumn{6}{|l|}{$\begin{array}{l}\text { Generation by Fuel Type } \\
\text { (billion kilowatthours) } \\
\text { Utility Generation }\end{array}$} \\
\hline $\begin{array}{l}\text { Utility Generation } \\
\text { Coal } \ldots \ldots \ldots \ldots \ldots \ldots \ldots \ldots \ldots \ldots\end{array}$ & \multicolumn{5}{|c|}{ Utility Generation } \\
\hline Petroleum $\ldots \ldots \ldots \ldots \ldots \ldots \ldots \ldots \ldots \ldots \ldots$ & 11.80 & 5.40 & 8.32 & $\begin{array}{r}113.00 \\
10.15\end{array}$ & $\begin{array}{r}0.6 \% \\
-0.9 \%\end{array}$ \\
\hline Natural Gas $\ldots \ldots \ldots \ldots \ldots \ldots \ldots$ & 5.46 & 12.82 & 17.92 & 23.19 & $8.9 \%$ \\
\hline Nuclear $\ldots \ldots \ldots \ldots \ldots \ldots \ldots \ldots \ldots \ldots$ & 87.01 & 82.49 & 82.49 & 68.13 & $-1.4 \%$ \\
\hline Pumped Storage/Other ${ }^{3} \ldots \ldots \ldots \ldots \ldots \ldots$ & -0.81 & -0.14 & -0.13 & -0.11 & $-11.3 \%$ \\
\hline Renewable $\ldots \ldots \ldots \ldots \ldots \ldots \ldots \ldots$ & 3.67 & 3.11 & 3.11 & 3.51 & $-0.3 \%$ \\
\hline Total Utility Generation ............... & 210.50 & 209.61 & 218.26 & 218.75 & $0.2 \%$ \\
\hline \multicolumn{6}{|l|}{ Nonutility Generation Excluding Cogeneration } \\
\hline Coal $\ldots \ldots \ldots \ldots \ldots \ldots \ldots \ldots \ldots$ & 1.13 & 4.20 & 4.85 & 9.61 & $13.4 \%$ \\
\hline Petroleum/Other ${ }^{8} \ldots \ldots \ldots \ldots \ldots \ldots \ldots$ & 0.19 & 0.11 & 0.20 & 0.20 & $0.1 \%$ \\
\hline Natural Gas $\ldots \ldots \ldots \ldots \ldots \ldots \ldots \ldots$ & 1.31 & 3.01 & 3.36 & 4.29 & $7.2 \%$ \\
\hline Renewable $\ldots \ldots \ldots \ldots \ldots \ldots \ldots \ldots$ & 3.26 & 5.94 & 7.65 & 10.14 & $6.9 \%$ \\
\hline Total Nonutility Generation . . . . . . . . . . . . . & 5.89 & 13.27 & 16.06 & 24.24 & $8.7 \%$ \\
\hline \multicolumn{6}{|l|}{ Cogenerators } \\
\hline Coal $\ldots \ldots \ldots \ldots \ldots \ldots \ldots \ldots \ldots$ & 7.36 & 8.38 & 8.73 & 9.10 & $1.3 \%$ \\
\hline Petroleum $\ldots \ldots \ldots \ldots \ldots \ldots \ldots \ldots \ldots$ & 0.74 & 2.82 & 3.04 & 3.28 & $9.2 \%$ \\
\hline Natural Gas $\ldots \ldots \ldots \ldots \ldots \ldots \ldots$ & 16.21 & 19.02 & 21.10 & 23.31 & $2.2 \%$ \\
\hline Renewable $\ldots \ldots \ldots \ldots \ldots \ldots \ldots \ldots$ & 0.66 & 0.71 & 0.72 & 0.72 & $0.5 \%$ \\
\hline Other $\ldots \ldots \ldots \ldots \ldots \ldots \ldots \ldots \ldots$ & 0.25 & 0.37 & 0.39 & 0.41 & $3.0 \%$ \\
\hline Total $\ldots \ldots \ldots \ldots \ldots \ldots \ldots \ldots \ldots$ & 25.22 & 31.29 & 33.98 & 36.83 & $2.3 \%$ \\
\hline Sales to Utilities $\ldots \ldots \ldots \ldots \ldots \ldots \ldots$ & 17.15 & 21.28 & 22.84 & 24.52 & $2.1 \%$ \\
\hline Generation for Own Use $\ldots \ldots \ldots \ldots \ldots \ldots$ & 7.38 & 9.44 & 10.26 & 11.11 & $2.4 \%$ \\
\hline End-Use Prices ${ }^{11}$ & & & & & \\
\hline (1993 cents per kilowatthour) & & & & & \\
\hline Residential $\ldots \ldots \ldots \ldots \ldots \ldots \ldots \ldots$ & 9.6 & 9.6 & 9.9 & 10.3 & $0.4 \%$ \\
\hline Commercial $\ldots \ldots \ldots \ldots \ldots \ldots \ldots \ldots \ldots$ & 7.9 & 7.7 & 7.8 & 8.1 & $0.2 \%$ \\
\hline Industrial $\ldots \ldots \ldots \ldots \ldots \ldots \ldots \ldots \ldots$ & 6.1 & 5.9 & 6.0 & 6.2 & $0.1 \%$ \\
\hline Transportation $\ldots \ldots \ldots \ldots \ldots \ldots \ldots$ & 5.7 & 5.9 & 6.0 & 6.0 & $0.3 \%$ \\
\hline All Sectors Average . . . . . . . . . . . . . . . & 7.9 & 7.8 & 8.0 & 8.3 & $0.3 \%$ \\
\hline \multicolumn{6}{|l|}{$\begin{array}{l}\text { Price Components" } \\
\text { ( } 1993 \text { cents per kilowatthour) }\end{array}$} \\
\hline Capital Component $\ldots \ldots \ldots \ldots \ldots \ldots \ldots$ & 3.2 & 3.1 & 3.1 & 3.1 & $-0.2 \%$ \\
\hline Fuel Component $\ldots \ldots \ldots \ldots \ldots \ldots \ldots \ldots$ & 1.1 & 1.1 & 1.2 & 1.4 & $1.3 \%$ \\
\hline Operation and Maintenance Component . . . . . . . & 3.3 & 3.4 & 3.4 & 3.3 & $0.0 \%$ \\
\hline Wholesale Power Cost . . . . . . . . . . . . & 0.3 & 0.2 & 0.3 & 0.5 & $3.5 \%$ \\
\hline Total $\ldots \ldots \ldots \ldots \ldots \ldots \ldots \ldots \ldots$ & 7.9 & 7.8 & 8.0 & 8.3 & $0.3 \%$ \\
\hline \multicolumn{6}{|l|}{$\begin{array}{l}\text { Fuel Consumption (quadrillion Btu) } \ldots \ldots \ldots \ldots \\
\text { Utilities }^{12}\end{array}$} \\
\hline Coal $\ldots \ldots \ldots \ldots \ldots \ldots \ldots \ldots \ldots \ldots$ & 0.88 & 1.04 & 1.05 & 1.12 & $1.5 \%$ \\
\hline Natural Gas $\ldots \ldots \ldots \ldots \ldots \ldots \ldots \ldots$ & 0.06 & 0.14 & 0.20 & 0.25 & $8.6 \%$ \\
\hline Oil $\ldots \ldots \ldots \ldots \ldots \ldots \ldots \ldots \ldots \ldots$ & 0.14 & 0.06 & 0.09 & 0.12 & $-1.0 \%$ \\
\hline \multicolumn{6}{|l|}{ Nonutilities $^{13}$} \\
\hline Coal $\ldots \ldots \ldots \ldots \ldots \ldots \ldots \ldots \ldots \ldots$ & 0.01 & 0.04 & 0.05 & 0.09 & $16.3 \%$ \\
\hline Natural Gas $\ldots \ldots \ldots \ldots \ldots \ldots \ldots \ldots$ & 0.00 & 0.03 & 0.03 & 0.04 & $18.0 \%$ \\
\hline Oil $\ldots \ldots \ldots \ldots \ldots \ldots \ldots \ldots \ldots \ldots \ldots \ldots \ldots$ & 0.01 & 0.00 & 0.00 & 0.00 & $-7.3 \%$ \\
\hline
\end{tabular}


Table 56. Electric Power Data and Projections for the EMM Region

Mid-Atlantic Area Council (MAAC) (Continued)

\begin{tabular}{|c|c|c|c|c|c|}
\hline \multirow{2}{*}{ Electricity Supply and Demand } & \multicolumn{4}{|c|}{ Reference Case } & \multirow{2}{*}{$\begin{array}{c}\text { Annual } \\
\text { Growth } \\
\text { 1993-2010 } \\
\text { (percent) }\end{array}$} \\
\hline & 1993 & 2000 & 2005 & 2010 & \\
\hline \multicolumn{6}{|l|}{ Emissions (million metric tons) 14} \\
\hline Total Carbon $\ldots . . . \ldots \ldots \ldots$ & 29.47 & 31.09 & 32.90 & 37.20 & $1.4 \%$ \\
\hline Carbon Dioxide & 108.04 & 114.00 & 120.63 & 136.41 & $1.4 \%$ \\
\hline Sulfur Dioxido . . & 1.55 & 0.80 & 0.79 & 0.83 & $-3.6 \%$ \\
\hline
\end{tabular}

${ }^{2} \mathrm{Net}$ summer capability is the steady hourly ouput that generating equipment is expected to supply to system load (exclusive of auxiliary power), as demonstrated by tests during summer peak demand.

${ }^{2}$ Includes oil-, gas-, and dual-fired capability.

${ }^{3}$ Other includes methane, propane gas, and blast furnace gas.

Includes conventional hydroelectric, geothermal, wood, wood waste, municipal solid waste, other biomass, solar, and wind power.

${ }^{5}$ Cumulative additions after December 31, 1992.

"Electrcity was produced solely for sale to an electric utility or another end-user, and there is no business activity at the site (standard industriat classification 49).

"Nameplate capacity is reported for nonutilities on Form ElA-867, "Annual Nonutility Power Producer Report." Nameplate capacity is designated

by the manufacturer. The nameplate capacity has been converted to net summer capacity based on historic relationships.

'Other includes hydrogen, sulfur, batteries, chemicals, fish oil, and spent sulfite liquor.

Includes generators and cogenerators at facilities whose primary function is not electricity production (standard industrial classification other than 49).

${ }^{10} \mathrm{Generation}$ to meet system load by source.

"Prices represent average revenue per kilowatthour.

${ }^{12}$ In the end-use energy consumptions tables, projected fuel consumption in the utility sector includes fuel used by independent power producers. In this table, fuel used by independent power producers is included in the nonutility category.

${ }^{13}$ Includes fuel consumption by small power producers, independent power producers, and exempt wholesale generators, which produce electricity for sales to utilities.

${ }^{14}$ Estimated emissions from utilities and independent power producers.

$E M M=$ Electricity market module.

N/A = Not applicable.

Note: Totals may not equal sum of components due to independent rounding.

Sources: 1993 (except for prices): Energy Information Administration (EIA), Annual Energy Review 1993, DOE/EIA-0384(93) (Washington,

D.C., July 1994). Prices and all projections: EIA, AEO95 National Energy Modeling System run AEO95B.D1103942. 
Table 57. Electric Power Data and Projections for the EMM Region

Mid-America Interconnected Network (MAIN)

\begin{tabular}{l|l|l|l|l|l|}
\hline \multirow{2}{*}{ Electricity Supply and Demand } & \multicolumn{4}{|c|}{ Reference Case } \\
\cline { 2 - 5 } & 1993 & 2000 & 2005 & $\begin{array}{l}\text { Annul } \\
1993-2010 \\
\text { (percent) }\end{array}$ \\
\hline
\end{tabular}

Electricity Generating Capacity

(gigawatts)

Utilities

Coal Steam..$\ldots \ldots \ldots \ldots \ldots \ldots \ldots \ldots$.

Other Fossil Steam ${ }^{2} \ldots \ldots \ldots \ldots \ldots \ldots \ldots$

Combined Cycle .....................

Combustion Turbine/Diesel $\ldots \ldots \ldots \ldots \ldots \ldots$

Nuclear Power .......................

Pumped Storage/Other ${ }^{3}, \ldots \ldots \ldots \ldots \ldots \ldots$.

Renewable ${ }^{4} \ldots \ldots \ldots \ldots \ldots \ldots \ldots \ldots$.

Total Utilities Capability

27.96

Cumulative Planned Additions ${ }^{5}$

Coal Steam .......................

Other Fossil Steam ${ }^{2} \ldots \ldots \ldots \ldots \ldots \ldots \ldots$

Combined Cycle ......................

Combustion Turbine/Diesel .................

Nuclear Power .......................

Pumped Storage/Other ${ }^{3}$..................

Renewable ${ }^{4} \ldots \ldots \ldots \ldots \ldots \ldots \ldots \ldots$

Total (planned)

Cumulative Unplanned Additions ${ }^{5}$

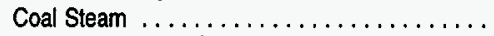

Other Fossil Steam ${ }^{2} \ldots \ldots \ldots \ldots \ldots \ldots \ldots$

Combined Cycle .....................

Combustion Turbine/Diesel ................

Nuclear Power .....................

Pumped Storage/Other ${ }^{3} \ldots \ldots \ldots \ldots \ldots \ldots .$.

Renewable ${ }^{4} \ldots \ldots \ldots \ldots \ldots \ldots \ldots \ldots \ldots$

Total (unplanned)

Cumulative Total Utility Additions

Cumulative Utility Retirements

...........

Nonutilities Capacity (excludes cogenerators) ${ }^{6,7}$

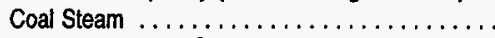

Other Fossil Steam ${ }^{2} \ldots \ldots \ldots \ldots \ldots \ldots \ldots \ldots$

Combined Cycle . ......................

Combustion Turbine/Diesel ................

Nuclear Power ........................

Pumped Storage/Other ${ }^{8} \ldots \ldots \ldots \ldots \ldots \ldots \ldots$.

Renewable ${ }^{4} \ldots \ldots \ldots \ldots \ldots \ldots \ldots \ldots \ldots$

Total Nonutilities Capability

Cogenerators ${ }^{9}$

Capacity

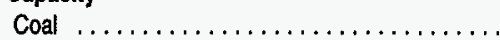

Petroleum $\ldots \ldots \ldots \ldots \ldots \ldots \ldots \ldots \ldots$

Natural Gas $\ldots \ldots \ldots \ldots \ldots \ldots \ldots \ldots$

Renewables..$\ldots \ldots \ldots \ldots \ldots \ldots \ldots \ldots$.

Other . ............................

Total $\ldots \ldots \ldots \ldots \ldots \ldots \ldots \ldots \ldots \ldots$.

Electricity Demand

(billion kilowatthours)

Residential ..........................

Commercial/Other $\ldots \ldots \ldots \ldots \ldots \ldots \ldots \ldots \ldots$

Industrial $\ldots \ldots \ldots \ldots \ldots \ldots \ldots \ldots \ldots \ldots$

Transportation..$\ldots \ldots \ldots \ldots \ldots \ldots \ldots \ldots$.

Total Sales .
3.53

0.00

3.10

14.85

0.35

0.63

50.41

26.88
2.91
0.00
6.53
14.85
0.35
0.63
52.15

26.48
2.91
0.00
8.33
14.85
0.35
0.64
53.56

25.96

2.88

0.08

9.14

13.58

0.35

0.64

52.63

$-0.4 \%$

$-1.2 \%$

N/A

$6.6 \%$

$-0.5 \%$

N/A

$0.1 \%$

$0.3 \%$

$\begin{array}{ll}0.00 & 0.11 \\ 0.00 & 0.00 \\ 0.00 & 0.00 \\ 0.00 & 3.38 \\ 0.00 & 0.00 \\ 0.00 & 0.00 \\ 0.00 & 0.00 \\ 0.00 & 3.50\end{array}$

0.11
0.00
0.00
5.12
0.00
0.00
0.02
5.24

0.11

0.00

0.00

5.18

0.00

0.00

0.02

5.31

N/A

N/A

N/A

N/A

N/A

N/A

N/A

NA

0.00

0.00

0.00

0.00

0.00

0.00

0.00

0.00

0.00

0.08

0.00

0.00

0.00

0.05

0.00

0.00

0.00

0.05

0.00

0.00

0.00

0.11

0.00

0.00

0.00

0.11

0.00

0.00

0.08

0.87

0.00

0.00

0.00

0.94

3.55

5.36

6.25

4.11

$25.9 \%$

0.00

0.00

0.00

0.01

0.00

0.00

0.08

0.09

1.90

2.29

0.00

0.00

0.00

0.27

0.00

0.00

0.13

0.40

0.00

0.00

0.01

0.45

0.00

0.00

0.15

0.61

0.00

0.00

0.34

3.23

0.00

0.00

0.17

3.74

N/A

N/A

N/A

N/A

N/A

N/A

N/A

N/A

N/A

0.60

0.70

0.73

0.03

0.76

0.04

0.34

0.23

0.00

1.37

$1.4 \%$

$4.2 \%$

$2.0 \%$

$0.5 \%$

N/A

0.00

$1.4 \%$ 
Table 57. Electric Power Data and Projections for the EMM Region Mid-America Interconnected Network (MAIN) (Continued)

\begin{tabular}{l|l|l|l|l|l}
\hline \multirow{2}{*}{ Electricity Supply and Demand } & \multicolumn{4}{|c|}{ Reference Case } & $\begin{array}{l}\text { Annual } \\
\text { Growth } \\
1993-2010 \\
\text { (percent) }\end{array}$ \\
\cline { 2 - 6 } & 1993 & 2000 & 2005 & 2010 & \multicolumn{3}{|c|}{} \\
\hline
\end{tabular}

Net Energy for Load (billion kilowatthours) ${ }^{10}$

Net International Electricity Imports $\ldots \ldots \ldots \ldots$.

Net Interregional Electricity Imports $\ldots \ldots \ldots \ldots$.

Purchases from Nonutilities

(including cogenerators) ${ }^{6} \ldots \ldots \ldots \ldots \ldots \ldots$

Generation by Utilities $\ldots \ldots \ldots \ldots \ldots \ldots \ldots$

Total Net Energy for Load ..............

$-10.51$

0.52

216.53

206.53

Generation by Fuel Type

(billion kilowatthours)

Utility Generation

Coal ............................

Petroleum .........................

Natural Gas $\ldots \ldots \ldots \ldots \ldots \ldots \ldots \ldots$

Nuclear ............................

Pumped Storage/Other ${ }^{3} \ldots \ldots \ldots \ldots \ldots \ldots$.

Renewable ${ }^{4} \ldots \ldots \ldots \ldots \ldots \ldots \ldots \ldots \ldots$.

Total Utility Generation . . . . . . . . . . . .

Nonutility Generation Excluding Cogeneration

Coal ............................

Petroleum/Other ${ }^{8}$......................

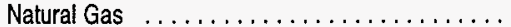

Renewable .......................

Total Nonutility Generation . . . . . . . . . . . .

Cogenerators

Coal ...........................

Pefroleum . .........................

Natural Gas $\ldots \ldots \ldots \ldots \ldots \ldots \ldots \ldots$.

Renewable $\ldots \ldots \ldots \ldots \ldots \ldots \ldots \ldots \ldots$.

Other $\ldots \ldots \ldots \ldots \ldots \ldots \ldots \ldots \ldots \ldots \ldots$

Total $\ldots \ldots \ldots \ldots \ldots \ldots \ldots \ldots \ldots \ldots \ldots \ldots \ldots \ldots$

Sales to Utilities

Generation for Own Use

$\begin{array}{rr}113.95 & 134.99 \\ 0.91 & 0.03 \\ 1.65 & 0.23 \\ 96.18 & 94.88 \\ -0.07 & -0.04 \\ 3.91 & 2.86 \\ 216.53 & 232.95\end{array}$

145.44

0.64

1.58

94.88

$-0.04$

2.86

245.37

0.00

0.00

0.01

0.45

0.46

3.19

0.13

1.41

0.89

0.04

5.66

0.06

5.79

End-Use Prices"

(1993 cents per kilowatthour)

Residential .........................

Commercial . .......................

Industrial ..........................

Transportation .

All Sectors Average

Price Components"

(1993 cents per kilowatthour)

Capital Component ....................

Fuel Component..$\ldots \ldots \ldots \ldots \ldots \ldots \ldots$.

Operation and Maintenance Component .........

Wholesale Power Cost . . . . . . . . . . . . . . . .

Total $\ldots \ldots \ldots \ldots \ldots \ldots \ldots \ldots \ldots \ldots \ldots \ldots$

Fuel Consumption (quadrillion Btu)

Utilities $^{12}$

Coal ......

Natural Gas

Oil

Nonutilities

Coal .........

Natural Gas

Oil

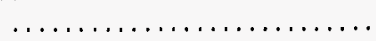

0.00
0.00
0.02
0.84
0.85

0.00

0.00

0.67

0.95

1.62

3.79

0.52

1.84

0.96

0.07

7.17

0.07

8.05

7.41

\section{0}

\section{4}

150.11

0.12

3.36

90.42

$-0.03$

286

246.84

$1.6 \%$

$-11.3 \%$

$4.3 \%$

$-0.4 \%$

$-4.6 \%$

$-1.8 \%$

$0.8 \%$

$\begin{array}{lr}0.00 & \text { N/A } \\ 0.00 & -2.1 \% \\ 7.28 & 45.5 \% \\ 1.15 & 5.7 \% \\ \mathbf{8 . 4 3} & \mathbf{1 8 . 7 \%}\end{array}$

3.95

0.56

2.03

0.97

0.07

7.57

0.08

8.72

$1.3 \%$

$9.2 \%$

$2.2 \%$

$0.5 \%$

$3.0 \%$

$1.7 \%$

$2.1 \%$

$2.4 \%$ 
Table 57. Electric Power Data and Projections for the EMM Region Mid-America Interconnected Network (MAIN) (Continued)

\begin{tabular}{|c|c|c|c|c|c|}
\hline \multirow{2}{*}{ Electricity Supply and Demand } & \multicolumn{4}{|c|}{ Reference Case } & \multirow{2}{*}{$\begin{array}{c}\text { Annual } \\
\text { Growth } \\
\text { 1993-2010 } \\
\text { (percent) }\end{array}$} \\
\hline & 1993 & 2000 & 2005 & 2010 & \\
\hline \multicolumn{6}{|l|}{ Emissions (million metric tons) ${ }^{14}$} \\
\hline Total Carbon $\ldots \ldots \ldots \ldots \ldots \ldots \ldots \ldots$ & 33.25 & 36.78 & 40.82 & 43.11 & $1.5 \%$ \\
\hline Carbon Dioxide $\ldots \ldots \ldots \ldots \ldots \ldots \ldots \ldots$ & 121.90 & 134.85 & 149.69 & 158.06 & $1.5 \%$ \\
\hline Sulfur Dioxide $\ldots \ldots \ldots \ldots \ldots \ldots \ldots \ldots$ & 1.45 & 0.79 & 0.76 & 0.64 & $-4.7 \%$ \\
\hline
\end{tabular}

1 Net summer capability is the steady hourly output that generating equipment is expected to supply to system load (exclusive of auxiliary power), as demonstrated by tests during summer peak demand.

${ }^{2}$ Includes oil-, gas-, and dual-fired capability.

${ }^{3}$ Other includes methane, propane gas, and blast furnace gas.

"Includes conventional hydroelectric, geothermal, wood, wood waste, municipal solid waste, other biomass, solar, and wind power.

${ }^{5}$ Cumulative additions after December $31,1992$.

"Electrcity was produced solely for sale to an electric utility or another end-user, and there is no business activity at the site (standard industrial classification 49).

"Nameplate capacity is reported for nonutilities on Form ElA-867, "Annual Nonutility Power Producer Report." Nameplate capacity is designated by the manufacturer. The nameplate capacity has been converted to net summer capacity based on historic relationships.

"Other includes hydrogen, sulfur, batteries, chemicals, fish oil, and spent sulfite liquor.

includes generators and cogenerators at facilities whose primary function is not electricity production (standard industrial classification other than 49).

${ }^{10}$ Generation to meet system load by source.

"Prices represent average revenue per kilowatthour.

${ }^{12}$ In the end-use energy consumptions tables, projected fuel consumption in the utility sector includes fuel used by independent power producers.

In this table, fuel used by independent power producers is included in the nonutility category.

${ }^{13}$ Includes fuel consumption by small power producers, independent power producers, and exempt wholesale generators, which produce electricity for sales to utilities.

${ }^{14}$ Estimated emissions from utilities and independent power producers.

EMM = Electricity market module.

N/A $=$ Not applicable.

Note: Totals may not equal sum of components due to independent rounding.

Sources: 1993 (except for prices): Energy Information Administration (EIA), Annual Energy Review 1993, DOE/EIA-0384(93) (Washington, D.C., July 1994). Prices and all projections: EIA, AEO95 National Energy Modeling System run AEO95B.D1103942. 
Table 58. Electric Power Data and Projections for the EMM Region Mid-Continent Area Power Pool (MAPP)

\begin{tabular}{|l|l|l|l|l|l|}
\hline \multirow{2}{*}{ Electricity Supply and Demand } & \multicolumn{4}{|c|}{ Reference Case } & \multicolumn{2}{c|}{$\begin{array}{l}\text { Annual } \\
\text { Growth } \\
1993-2010 \\
\text { (percent) }\end{array}$} \\
\cline { 2 - 5 } & 1993 & 2000 & 2005 & 2010 & \multicolumn{4}{|c|}{} \\
\hline
\end{tabular}

Electricity Generating Capacity'

(gigawatts)

Utilities

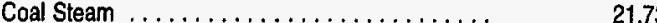

Other Fossil Steam ${ }^{2} \ldots \ldots \ldots \ldots \ldots \ldots \ldots \ldots, \quad 0.61$

Combined Cycle .......................... 0

Combustion Turbine/Diesel ................ $\quad 4.45$

Nuclear Power ........................

Pumped Storage/Other ${ }^{3} \ldots \ldots \ldots \ldots \ldots \ldots . . .60$

Renewable ${ }^{4} . \ldots \ldots \ldots \ldots \ldots \ldots \ldots \ldots, \quad 3.49$

Total Utilities Capability ............... $\quad 34.07$

Cumulative Planned Additions ${ }^{5}$

Coal Steam .........................

Other Fossil Steam ${ }^{2} \ldots \ldots \ldots \ldots \ldots \ldots \ldots$

Combined Cycle ......................

Combustion Turbine/Diesel ................

Nuclear Power .......................

Pumped Storage/Other" ${ }^{3} . \ldots \ldots \ldots \ldots \ldots \ldots$

Renewable ${ }^{4}$......

Total (planned)

$\ldots \ldots \ldots \ldots \ldots \ldots \ldots \ldots \ldots \ldots \ldots \ldots \ldots \ldots \ldots$

Cumulative Unplanned Additions ${ }^{5}$

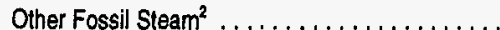

Combined Cycle ......................

Combustion Turbine/Diessl,$\ldots \ldots \ldots \ldots \ldots \ldots$

Nuclear Power ........................

Pumped Storage/Other ${ }^{3}$..................

Renewable ${ }^{4} \ldots \ldots \ldots \ldots \ldots \ldots \ldots . . . . .$.

Total (unplanned)

....................

Cumulative Total Utility Additions

Cumulative Utility Retirements

s..........

Nonutilities Capacity (excludes cogenerators) ${ }^{6,7}$

Coal Steam ........................

Other Fossil Steam ${ }^{2} \ldots \ldots \ldots \ldots \ldots \ldots \ldots . . . . .$.

Combined Cycle .......................

Combustion Turbine/Diesel ................

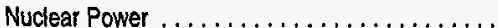

Pumped Storage/Others . .................

Renewable ${ }^{4} \ldots \ldots \ldots \ldots \ldots \ldots \ldots \ldots \ldots$

Total Nonutilities Capability .............

Cogenerators ${ }^{9}$

\section{Capacity}

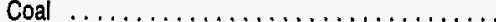

Petroleum $\ldots \ldots \ldots, \ldots, \ldots, \ldots, \ldots, \ldots$

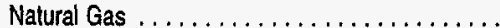

Renewables $\ldots \ldots \ldots, \ldots \ldots \ldots, \ldots \ldots$.

Other ..............................

Total

Electricity Demand

(billion kilowatthours)

Residential ..........................

Commercial/Other . . . . . . . . . . . . . . . . . . .

Industrial ...........................

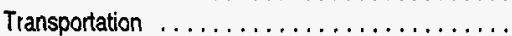

Total Sales

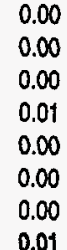

0.00

0.00

0.03

0.62

0.00

0.00

0.00

0.64

0.00

0.00

0.00

0.00

0.00

0.00

0.00

0.00

0.01

0.35

0.00

0.00

0.00

0.10

0.00

0.00

0.06

0.16

0.55

0.10

0.06

0.13

0.00

0.84

$\begin{array}{rr}43.76 & 46.00 \\ 35.54 & 37.51 \\ 42.17 & 45.75 \\ 0.77 & 1.09 \\ 122.24 & 130.35\end{array}$

0.64

1.45

0.00

0.00

0.00

0.10

0.00

0.00

0.34

0.45

0.64
0.18
0.07
0.14
0.00
1.03

20.86

0.37

0.12

5.04

3.71

0.00

3.49

33.59

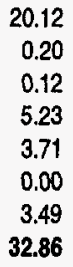

19.64

0.18

0.12

5.68

3.17

0.00

3.49

32.27

$-0.6 \%$

$-6.9 \%$

$1.4 \%$

$1.4 \%$

$-0.9 \%$

N/A

N/A

$-0.3 \%$

$\begin{array}{llc}0.00 & 0.00 & \text { N/A } \\ 0.00 & 0.00 & \text { N/A } \\ 0.03 & 0.03 & \text { N/A } \\ 0.80 & 0.80 & 30.4 \% \\ 0.00 & 0.00 & \text { N/A } \\ 0.00 & 0.00 & \text { N/A } \\ 0.00 & 0.00 & \text { N/A } \\ 0.83 & 0.83 & 30.6 \%\end{array}$

$\begin{array}{ll}0.00 & 0.00 \\ 0.00 & 0.00 \\ 0.00 & 0.00 \\ 0.00 & 0.00 \\ 0.00 & 0.00 \\ 0.00 & 0.00 \\ 0.00 & 0.00 \\ 0.00 & 0.00\end{array}$

0.00

N/A

N/A

N/A

N/A

N/A

N/A

N/A

NA

0.83

$34.0 \%$

2.37

$14.3 \%$

$\begin{array}{llr}0.00 & 0.00 & \text { N/A } \\ 0.00 & 0.00 & \text { N/A } \\ 0.00 & 0.00 & \text { N/A } \\ 0.10 & 0.10 & \text { N/A } \\ 0.00 & 0.00 & \text { N/A } \\ 0.00 & 0.00 & \text { N/A } \\ 0.64 & 0.67 & 15.1 \% \\ 0.74 & 0.78 & 9.6 \%\end{array}$

0.67

0.19

0.07

0.14

0.00

1.08

0.70

0.21

0.08

0.14

0.00

1.13

$1.4 \%$

$4.2 \%$

$2.0 \%$

$0.5 \%$

N/A

$1.7 \%$ 
Table 58. Electric Power Data and Projections for the EMM Region Mid-Continent Area Power Pool (MAPP) (Continued)

\begin{tabular}{|c|c|c|c|c|c|}
\hline \multirow{2}{*}{ Electricity Supply and Demand } & \multicolumn{4}{|c|}{ Reference Case } & \multirow{2}{*}{$\begin{array}{c}\text { Annual } \\
\text { Growth } \\
\text { 1993-2010 } \\
\text { (percent) }\end{array}$} \\
\hline & 1993 & 2000 & 2005 & 2010 & \\
\hline \multicolumn{6}{|l|}{ Net Energy for Load (billion kilowatthours) ${ }^{10}$} \\
\hline Net International Electricity Imports . .......... & 7.81 & 7.88 & 8.00 & 8.31 & $0.4 \%$ \\
\hline Net Interregional Electricity Imports . .......... & -4.63 & -2.80 & -1.66 & -1.66 & $-5.9 \%$ \\
\hline \multicolumn{6}{|l|}{ Purchases from Nonutilities } \\
\hline (including cogenerators) $)^{6} \ldots \ldots \ldots \ldots \ldots \ldots$ & 0.56 & 1.66 & 2.96 & 3.31 & $11.0 \%$ \\
\hline Generation by Utilities.$\ldots \ldots \ldots \ldots \ldots \ldots$ & 146.38 & 134.29 & 137.64 & 142.69 & $-0.2 \%$ \\
\hline Total Net Energy for Load ............... & 150.12 & 141.03 & 146.93 & 152.65 & $0.1 \%$ \\
\hline \multicolumn{6}{|l|}{$\begin{array}{l}\text { Generation by Fuel Type } \\
\text { (billion kilowatthours) }\end{array}$} \\
\hline \multicolumn{6}{|l|}{ Utility Generation } \\
\hline Coal $\ldots \ldots \ldots \ldots$ & 112.17 & 98.42 & 101.46 & 105.32 & $-0.4 \%$ \\
\hline$\ldots \ldots \ldots \ldots \ldots$ & 0.78 & 0.00 & 0.00 & 0.00 & $-29.5 \%$ \\
\hline Natural Gas $\ldots . . .$. & 0.77 & 0.00 & 0.30 & 2.28 & $6.6 \%$ \\
\hline Nuclear..$\ldots \ldots \ldots \ldots \ldots \ldots \ldots \ldots \ldots \ldots$ & 24.06 & 25.52 & 25.52 & 24.73 & $0.2 \%$ \\
\hline Pumped Storage/Other ${ }^{3} \ldots \ldots \ldots \ldots \ldots \ldots$ & 0.00 & 0.00 & 0.00 & 0.00 & N/A \\
\hline Renewable ${ }^{4} \ldots \ldots \ldots \ldots \ldots \ldots \ldots \ldots$ & 8.60 & 10.35 & 10.35 & 10.36 & $1.1 \%$ \\
\hline Total Utility Generation ................. & 146.38 & 134.29 & 137.64 & 142.69 & $-0.2 \%$ \\
\hline \multicolumn{6}{|l|}{ Nonutility Generation Excluding Cogeneration } \\
\hline Coal $\ldots \ldots \ldots \ldots \ldots \ldots \ldots \ldots \ldots \ldots \ldots \ldots \ldots$ & 0.00 & 0.00 & 0.00 & 0.00 & N/A \\
\hline Petroleum/Other ${ }^{8} \ldots \ldots \ldots \ldots \ldots \ldots \ldots$ & 0.00 & 0.00 & 0.00 & 0.00 & $-6.8 \%$ \\
\hline Natural Gas $\ldots \ldots \ldots \ldots \ldots \ldots \ldots \ldots$ & 0.01 & 0.00 & 0.00 & 0.05 & $14.1 \%$ \\
\hline Renewable $\ldots \ldots \ldots \ldots \ldots \ldots \ldots \ldots$ & 0.33 & 1.38 & 2.66 & 2.94 & $13.6 \%$ \\
\hline Total Nonutility Generation ............... & 0.34 & 1.38 & 2.66 & 2.99 & $13.6 \%$ \\
\hline \multicolumn{6}{|l|}{ Cogenerators } \\
\hline 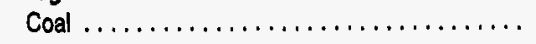 & 2.55 & 2.90 & 3.02 & 3.15 & $1.3 \%$ \\
\hline Petroleum $\ldots \ldots \ldots \ldots \ldots \ldots \ldots \ldots$ & 0.05 & 0.18 & 0.19 & 0.20 & $9.2 \%$ \\
\hline Natural Gas $\ldots \ldots \ldots \ldots \ldots \ldots \ldots \ldots$ & 0.39 & 0.46 & 0.51 & 0.56 & $2.2 \%$ \\
\hline Renewable..$\ldots \ldots \ldots \ldots \ldots \ldots \ldots$ & 0.70 & 0.75 & 0.76 & 0.76 & $0.5 \%$ \\
\hline Other $\ldots \ldots \ldots \ldots \ldots \ldots \ldots \ldots \ldots \ldots \ldots$ & 0.00 & 0.00 & 0.00 & 0.00 & N/A \\
\hline Total $\ldots \ldots \ldots \ldots \ldots \ldots \ldots \ldots \ldots \ldots \ldots \ldots \ldots \ldots \ldots \ldots$ & 3.68 & 4.28 & 4.48 & 4.68 & $1.4 \%$ \\
\hline Sales to Utilities $\ldots \ldots \ldots \ldots \ldots \ldots \ldots$ & 0.22 & 0.28 & 0.30 & 0.32 & $2.1 \%$ \\
\hline Generalion for Own Use $\ldots \ldots \ldots \ldots \ldots \ldots$ & 3.55 & 4.55 & 4.94 & 5.35 & $2.4 \%$ \\
\hline \multicolumn{6}{|l|}{$\begin{array}{l}\text { End-Use Prices" } \\
\text { (1993 cents per kilowatthour) }\end{array}$} \\
\hline Residential..$\ldots \ldots \ldots \ldots \ldots \ldots \ldots \ldots$ & 6.9 & 7.1 & 6.9 & 7.3 & $0.3 \%$ \\
\hline Commercial $\ldots \ldots \ldots \ldots \ldots \ldots \ldots \ldots \ldots$ & 6.0 & 6.0 & 5.9 & 6.2 & $0.3 \%$ \\
\hline 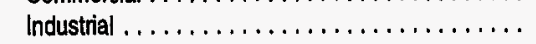 & 4.0 & 4.0 & 3.9 & 4.1 & $0.1 \%$ \\
\hline 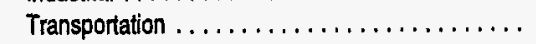 & 4.5 & 4.5 & 4.4 & 4.5 & $0.0 \%$ \\
\hline All Sectors Average ................. & 5.6 & 5.7 & 5.5 & 5.8 & $0.2 \%$ \\
\hline \multicolumn{6}{|l|}{$\begin{array}{l}\text { Price Components" } \\
\text { (1993 cents per kllowatthour) }\end{array}$} \\
\hline 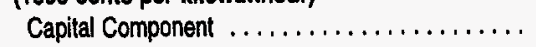 & 2.2 & 2.1 & 1.9 & 1.9 & $-0.6 \%$ \\
\hline 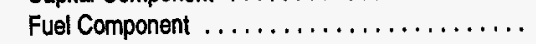 & 0.8 & 0.9 & 0.9 & 1.0 & $1.6 \%$ \\
\hline Operation and Maintenance Component ........ & 2.5 & 2.5 & 2.4 & 2.5 & $-0.1 \%$ \\
\hline Wholesale Power Cost ................... & 0.1 & 0.3 & 0.3 & 0.3 & $5.6 \%$ \\
\hline Total $\ldots \ldots \ldots \ldots \ldots \ldots \ldots \ldots \ldots \ldots \ldots \ldots$ & 5.6 & 5.7 & 5.5 & 5.8 & $0.2 \%$ \\
\hline \multicolumn{6}{|l|}{$\begin{array}{l}\text { Fuel Consumption (quadrillion Btu) } \ldots \ldots \ldots \ldots \ldots \\
\text { Utilities }^{12}\end{array}$} \\
\hline Coal $\ldots \ldots \ldots \ldots \ldots \ldots \ldots \ldots \ldots \ldots \ldots \ldots \ldots \ldots \ldots$ & 1.40 & 1.06 & 1.09 & 1.13 & $-1.3 \%$ \\
\hline Natural Gas $\ldots \ldots \ldots \ldots \ldots \ldots \ldots \ldots$ & 0.01 & 0.00 & 0.00 & 0.02 & $5.0 \%$ \\
\hline 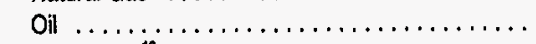 & 0.01 & 0.00 & 0.00 & 0.00 & $-29.2 \%$ \\
\hline \multicolumn{6}{|l|}{ Nonutilities $^{13}$} \\
\hline 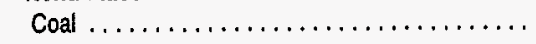 & 0.00 & 0.00 & 0.00 & 0.00 & N/A \\
\hline Natural Gas $\ldots \ldots \ldots \ldots \ldots \ldots \ldots \ldots$ & 0.00 & 0.00 & 0.00 & 0.00 & $6.6 \%$ \\
\hline \multirow[t]{2}{*}{ 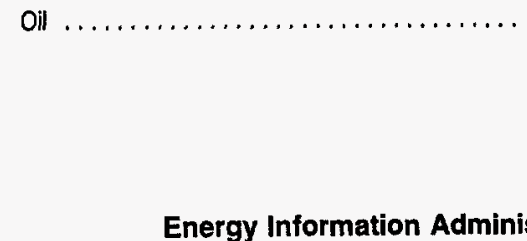 } & 0.00 & 0.00 & 0.00 & 0.00 & $-8.7 \%$ \\
\hline & on/ Supp & nt to the & ual Ener & utlook 1995 & 205 \\
\hline
\end{tabular}


Table 58. Electric Power Data and Projections for the EMM Region Mid-Continent Area Power Pool (MAPP) (Continued)

\begin{tabular}{|c|c|c|c|c|c|}
\hline \multirow{2}{*}{ Electricity Supply and Demand } & \multicolumn{4}{|c|}{ Reference Case } & \multirow{2}{*}{$\begin{array}{c}\text { Annual } \\
\text { Growth } \\
\text { 1993-2010 } \\
\text { (percent) }\end{array}$} \\
\hline & 1993 & 2000 & 2005 & 2010 & \\
\hline \multicolumn{6}{|l|}{ Emissions (million metric tons) ${ }^{14}$} \\
\hline Total Carbon $\ldots \ldots \ldots \ldots \ldots \ldots \ldots \ldots$ & 26.20 & 27.51 & 28.36 & 29.72 & $0.7 \%$ \\
\hline Carbon Dioxide $\ldots \ldots \ldots \ldots \ldots \ldots \ldots$ & 96.07 & 100.88 & 104.00 & 108.98 & $0.7 \%$ \\
\hline Sulfur Dioxide $\ldots \ldots \ldots \ldots \ldots \ldots \ldots \ldots$ & 0.49 & 0.32 & 0.30 & 0.32 & $-2.5 \%$ \\
\hline
\end{tabular}

'Net summer capability is the steady hourly output that generating equipment is expected to supply to system load (exclusive of auxiliary power), as demonstrated by tests during summer peak demand.

Includes oil-, gas-, and dual-fired capability.

3Other includes methane, propane gas, and blast fumace gas.

"Includes conventional hydroelectric, geothermal, wood, wood waste, municipal solid waste, other biomass, solar, and wind power.

${ }^{5}$ Cumulative additions after December 31, 1992.

${ }^{6}$ Electrcity was produced solely for sale to an electric utility or another end-user, and there is no business activity at the site (standard industrial classification 49).

"Nameplate capacity is reported for nonutilities on Form EIA-867, "Annual Nonutility Power Producer Report." Nameplate capacity is designated by the manufacturer. The nameplate capacity has been converted to net summer capacity based on historic relationships.

Other includes hydrogen, sulfur, batteries, chemicals, fish oil, and spent sulfite liquor.

Includes generators and cogenerators at facilities whose primary function is not electricity production (standard industrial classification other than 49).

${ }^{10}$ Generation to meet system load by source.

"Prices represent average revenue per kilowatthour.

${ }^{12}$ In the end-use energy consumptions tables, projected fuel consumption in the utility sector includes fuel used by independent power producers. In this table, fuel used by independent power producers is included in the nonutility category.

${ }^{13}$ includes fuel consumption by small power producers, independent power producers, and exempt wholesale generators, which produce electricity for sales to utilities.

${ }^{14}$ Estimated emissions from utilities and independent power producers.

$E M M=$ Electricity market module.

N/A $=$ Not applicable.

Note: Totals may not equal sum of components due to independent rounding.

Sources: 1993 (except for prices): Energy Information Administration (EIA), Annual Energy Review 1993, DOE/EIA-0384(93) (Washington, D.C., July 1994). Prices and all projections: EIA, AEO95 National Energy Modeling System run AEO95B.D1103942. 
Table 59. Electric Power Data and Projections for the EMM Region Northeast Power Coordinating Council/New York (NPCC/NY)

\begin{tabular}{l|l|l|l|l|l}
\hline \multirow{2}{*}{ Electricity Supply and Demand } & \multicolumn{4}{|c|}{ Reference Case } & $\begin{array}{l}\text { Annual } \\
\text { Growth } \\
1993-2010 \\
\text { (percent) }\end{array}$ \\
\cline { 2 - 6 } & 1993 & 2000 & 2005 & 2010 & \multicolumn{4}{|c|}{} \\
\cline { 2 - 6 }
\end{tabular}

Electricity Generating Capacity'
(gigawatts)

Colsteam

Other Fossil Steam ${ }^{2} \ldots \ldots \ldots \ldots \ldots \ldots \ldots \ldots$

Combined Cycle .....................

Combustion Turbine/Diesel .................

Nuclear Power ........................

Pumped Siorage/Other ${ }^{3}$...................

Renewable ${ }^{4} \ldots \ldots \ldots \ldots \ldots \ldots \ldots \ldots$

Total Utilities Capability

Cumulative Planned Additions ${ }^{5}$

Coal Steam ........................

Other Fossil Steam ${ }^{2} \ldots \ldots \ldots \ldots \ldots \ldots \ldots$

Combined Cycle .......................

Combustion Turbine/Diesel . . . .............

Nuclear Power ........................

Pumped Storage/Other ${ }^{3}$...................

Renewable ${ }^{4} \ldots \ldots \ldots \ldots \ldots \ldots \ldots \ldots$

Total (planned)

Cumulative Unplanned Additions ${ }^{5}$

Coal Steam ........................

Other Fossil Steam ${ }^{2} \ldots \ldots \ldots \ldots \ldots \ldots \ldots$

Combined Cycle ......................

Combustion Turbine/Diesel ................

Nuclear Power .........................

Pumped Storage/Other ${ }^{3} \ldots \ldots \ldots \ldots \ldots \ldots \ldots$

Renewable ${ }^{4} \ldots \ldots \ldots \ldots \ldots \ldots \ldots \ldots \ldots$

Total (unplanned) $\ldots \ldots \ldots \ldots \ldots \ldots \ldots$

Cumulative Total Utility Additions

Cumulative Utility Retirements

Nonutilities Capacity (excludes cogenerators) ) $^{6,7}$

Coal Steam .........................

Other Fossil Steam ${ }^{2} \ldots \ldots \ldots \ldots \ldots \ldots \ldots \ldots$

Combined Cycle ......................

Combustion Turbine/Diesel . . . . . . . . . . . ...

Nuclear Power .........................

Pumped Storage/Other ${ }^{8} \ldots \ldots \ldots \ldots \ldots \ldots .$.

Renewable ${ }^{4} \ldots \ldots \ldots \ldots \ldots \ldots \ldots \ldots \ldots$.

Total Nonutillies Capabilly $. . . \ldots \ldots \ldots . .$.

\section{Cogenerators}

Capacity

Coal $\ldots \ldots \ldots \ldots \ldots \ldots \ldots \ldots \ldots \ldots$

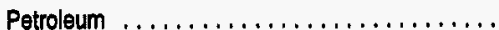

Natural Gas $\ldots \ldots \ldots \ldots \ldots, \ldots, \ldots, \ldots$

Renewables ........................

Other .......

Total

y Demand

(billion kilowatthours)

Residential ...

Commercial/Other .......................

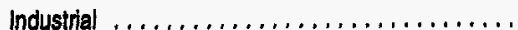

Transportation $\ldots \ldots \ldots \ldots \ldots \ldots \ldots \ldots \ldots$.

Total Sales .

3.88
13.34
0.00
3.82
4.83
1.28
3.81
30.96

3.07

12.32

0.33

3.82

4.83

1.28

4.04

29.68

0.00

0.00

0.00

0.00

0.00

0.00

0.00

0.00

0.00

0.00

0.00

0.00

0.00

0.00

0.00

0.00

0.00

0.45

0.00

0.00

0.16

0.01

0.00

0.00

0.11

0.28

12.25

0.45

3.82

4.83

1.28

4.41

29.95

$\begin{array}{rc}3.02 & -1.5 \% \\ 12.22 & -0.5 \% \\ 0.49 & \mathrm{~N} / \mathrm{A} \\ 3.82 & 0.0 \% \\ 3.76 & -1.5 \% \\ 1.28 & \mathrm{~N} / \mathrm{A} \\ 4.80 & 1.4 \% \\ 29.38 & -0.3 \%\end{array}$

0.00

0.00

0.16

0.01

0.00

0.00

0.11

0.28

$\begin{array}{ll}0.00 & \text { N/A } \\ 0.00 & \text { N/A } \\ 0.16 & \text { N/A } \\ 0.01 & \text { N/A } \\ 0.00 & \text { N/A } \\ 0.00 & \text { N/A } \\ 0.11 & \text { N/A } \\ 0.28 & \text { N/A }\end{array}$

0.00

0.00

0.17

0.02

0.00

0.00

0.00

0.18

0.47

0.00

0.00

0.29

0.02

0.00

0.00

0.00

0.31

0.59

2.32

2.55

0.11

0.00

0.32

0.02

0.00

0.00

0.23

0.69

0.97

3.66

0.08

0.00

0.01

0.00

0.00

0.00

0.60

0.70

0.08
0.00
0.21
0.07
0.00
0.00
0.77
1.13

0.08

0.00

0.30

0.07

0.00

0.00

0.88

1.34

$\begin{array}{cc}0.08 & \text { N/A } \\ 0.00 & \text { N/A } \\ 0.30 & 21.4 \% \\ 0.07 & \text { N/A } \\ 0.00 & \text { N/A } \\ 0.00 & \text { N/A } \\ 1.40 & 5.1 \% \\ 1.85 & 5.9 \%\end{array}$

0.28

0.26

1.18

0.10

0.00

1.82

0.32
0.46
1.36
0.11
0.00
2.24

0.33

0.49

1.50

0.11

0.00

2.44

0.35

0.52

1.66

0.11

0.00

2.64

$1.4 \%$

$4.2 \%$

$2.0 \%$

$0.5 \%$

N/A

$2.2 \%$

$\begin{array}{rr}44.52 & 46.05 \\ 50.56 & 50.53 \\ 38.52 & 41.79 \\ 1.10 & 1.57 \\ 134.69 & 139.95\end{array}$

46.74
48.82
44.95
2.38
142.90

48.62

47.62

46.36

$0.5 \%$

$.0 .4 \%$

$1.1 \%$

$6.6 \%$

3.27
145.86

$0.5 \%$ 
Table 59. Electric Power Data and Projections for the EMM Region Northeast Power Coordinating Council/New York (NPCC/NY) (Continued)

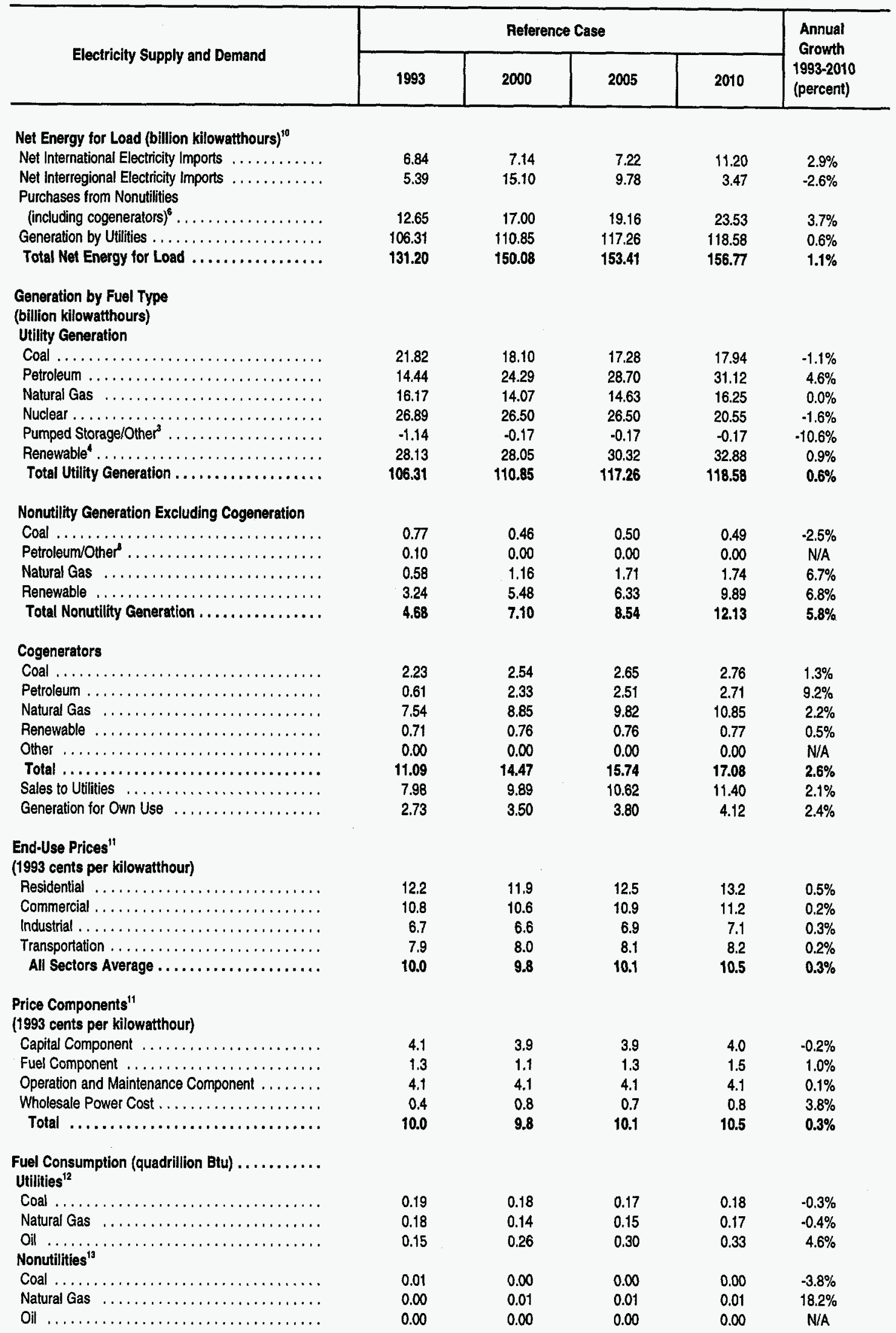


Table 59. Electric Power Data and Projections for the EMM Region Northeast Power Coordinating Council/New York (NPCC/NY) (Continued)

\begin{tabular}{|c|c|c|c|c|c|}
\hline \multirow{2}{*}{ Electricity Supply and Demand } & \multicolumn{4}{|c|}{ Reference Case } & \multirow{2}{*}{$\begin{array}{l}\text { Annual } \\
\text { Growth } \\
1993-2010 \\
\text { (percent) }\end{array}$} \\
\hline & 1993 & 2000 & 2005 & 2010 & \\
\hline \multicolumn{6}{|l|}{ Emissions (million metric tons) ${ }^{14}$} \\
\hline Total Carbon $\ldots \ldots \ldots \ldots \ldots$ & 15.94 & 12.00 & 12.90 & 13.83 & $-0.8 \%$ \\
\hline Carbon Dioxide . & 58.46 & 44.00 & 47.31 & 50.72 & $-0.8 \%$ \\
\hline Sulfur Dioxide $\ldots \ldots \ldots \ldots \ldots \ldots \ldots \ldots$ & 0.55 & 0.24 & 0.21 & 0.23 & $-5.1 \%$ \\
\hline
\end{tabular}

'Net summer capability is the steady hourly output that generating equipment is expected to supply to system load (exclusive of auxiliary power), as demonstrated by tests during summer peak demand.

${ }^{2}$ Includes oil-, gas-, and dual-fired capability.

${ }^{3}$ Other includes methane, propane gas, and blast furnace gas.

Ancludes conventional hydroelectric, geothermal, wood, wood waste, municipal solid waste, other biomass, solar, and wind power.

${ }^{5}$ Cumulative additions after December $31,1992$.

${ }^{8}$ Electrcity was produced solely for sale to an electric utility or another end-user, and there is no business activity at the site (standard industrial classification 49).

7Nameplate capacity is reported for nonutilities on Form ElA-867, "Annual Nonutility Power Producer Report." Nameplate capacity is designated

by the manufacturer. The nameplate capacity has been converted to net summer capacity based on historic relationships.

${ }^{8}$ Other includes hydrogen, sulfur, batteries, chemicals, fish oil, and spent sulfite liquor.

'Includes generators and cogenerators at facilities whose primary function is not electricity production (standard industrial classification other than 49).

${ }^{10}$ Generation to meet system load by source.

"Prices represent average revenue per kilowatthour.

${ }^{12}$ In the end-use energy consumptions tables, projected fuel consumption in the utility sector includes fuel used by independent power producers. In this table, fuel used by independent power producers is included in the nonutility category.

${ }^{13}$ Includes fuel consumption by small power producers, independent power producers, and exempt wholesale generators, which produce electricity for sales to utilities.

${ }^{14}$ Estimated emissions from utilities and independent power producers.

EMM = Electricity market module

N/A = Not applicable.

Note: Totals may not equal sum of components due to independent rounding.

Sources: 1993 (except for prices): Energy Information Administration (EIA), Annual Energy Review 1993, DOE/EIA-0384(93) (Washington, D.C., July 1994). Prices and all projections: EIA, AEO95 National Energy Modeling System run AEO95B.D1103942. 
Table 60. Electric Power Data and Projections for the EMM Region Northeast Power Coordinating Council/New England (NPCC/NE)

\begin{tabular}{l|c|c|c|c|c}
\hline \multirow{2}{*}{ Electricity Supply and Demand } & \multicolumn{4}{|c|}{ Reference Case } & $\begin{array}{l}\text { Annual } \\
\text { Growth } \\
1993-2010 \\
\text { (percent) }\end{array}$ \\
\cline { 2 - 6 } & 1993 & 2000 & 2005 & 2010 \\
\hline
\end{tabular}

Electricity Generating Capacity

(gigawatts)

Utilities

Coal Steam $\ldots \ldots \ldots \ldots \ldots \ldots \ldots \ldots \ldots, \quad 2.64$

Other Fossil Steam ${ }^{2} \ldots \ldots \ldots \ldots \ldots \ldots$

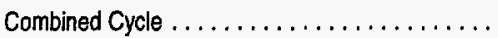

Combustion Turbine/Diesel ...............

Nuclear Power $\ldots \ldots \ldots \ldots \ldots \ldots \ldots \ldots$.

Pumped Storage/Other ${ }^{3} \ldots \ldots \ldots \ldots \ldots \ldots \ldots$

Renewable ${ }^{4} \ldots \ldots \ldots \ldots \ldots \ldots \ldots \ldots$

Total Utilities Capability

Cumulative Planned Additions ${ }^{5}$

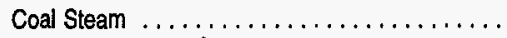

Other Fossil Steam ${ }^{2} \ldots \ldots \ldots \ldots \ldots \ldots \ldots$

Combined Cycle .......................

Combustion Turbine/Diesel $\ldots \ldots \ldots \ldots \ldots \ldots$

Nuclear Power .......................

Pumped Storage/Other ${ }^{3} \ldots \ldots \ldots \ldots \ldots \ldots$.

Renewable ${ }^{4} \ldots \ldots \ldots \ldots \ldots \ldots \ldots \ldots \ldots$

Total (planned) .....................

21.90

Cumulative Unplanned Additions ${ }^{5}$

Coal Steam ........................

Other Fossil Steam ${ }^{2} \ldots \ldots \ldots \ldots \ldots \ldots \ldots$

Combined Cycle ......................

Combustion Turbine/Diesel . . . . . . . . . . . .

Nuclear Power .........................

Pumped Storage/Other ${ }^{3} \ldots \ldots \ldots \ldots \ldots \ldots$

Renewable ${ }^{4} \ldots \ldots \ldots \ldots \ldots \ldots \ldots \ldots$.

Total (unplanned)

0.00

0.00

0.00

$0.00 \quad \quad N / A$

0.00

0.00

0.00

0.00

0.00

0.00

0.00

0.00

0.00

0.36

0.00

0.00

0.06

0.41

\subsection{0}

0.00

0.36

0.00

0.00

0.06

0.41

$\begin{array}{ll}0.00 & \text { N/A } \\ 0.00 & \text { N/A } \\ 0.36 & \text { N/A } \\ 0.00 & \text { N/A } \\ 0.00 & \text { N/A } \\ 0.06 & \text { N/A } \\ 0.41 & \text { N/A }\end{array}$

Cumulative Total Utility Additions

0.00

0.00

0.00

0.00

0.00

0.00

0.00

0.00

0.00

0.00

0.00

0.00

0.00

0.00

Cumulative Utility Retirements

$10.0 \%$

Nonutilities Capacity (excludes cogenerators) ${ }^{6,7}$

Coal Steam ......................

Other Fossil Steam ${ }^{2} \ldots \ldots \ldots \ldots \ldots \ldots \ldots$

Combined Cycle ........................

Combustion Turbine/Diesel ...............

Nuclear Power .......................

Pumped Storage/Other ${ }^{8} \ldots \ldots \ldots \ldots \ldots \ldots \ldots$

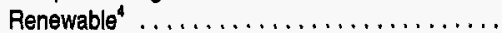

Total Nonutilities Capability $. . . \ldots \ldots \ldots . .$.

Cogenerators ${ }^{9}$

Capacity

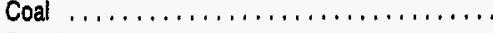

Petroleum $. . ., \ldots, \ldots, \ldots, \ldots, \ldots, \ldots$

Natural Gas $\ldots \ldots \ldots \ldots \ldots \ldots \ldots \ldots \ldots$

Renewables $\ldots \ldots \ldots \ldots \ldots \ldots \ldots \ldots \ldots$

Other ................................

Total

\section{Electrieity Demand}

(bllllon kilowatthours)

Residential . . . . . . . . . . . . . . . .

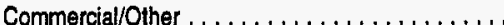

Industrial $\ldots \ldots \ldots \ldots \ldots \ldots \ldots \ldots \ldots \ldots$

Transportation $\ldots \ldots \ldots \ldots \ldots \ldots \ldots \ldots \ldots \ldots$

Total Sales

$\begin{array}{rrrrr}41.55 & 44.11 & 46.07 & 48.71 & 0.9 \% \\ 40.50 & 41.27 & 40.87 & 40.42 & 0.0 \% \\ 26.58 & 28.94 & 31.19 & 32.21 & 1.1 \% \\ 0.90 & 1.32 & 2.04 & 2.79 & 6.8 \% \\ 109.54 & 115.68 & 120.17 & 124.13 & 0.7 \%\end{array}$


Table 60. Electric Power Data and Projections for the EMM Region Northeast Power Coordinating Council/New England (NPCC/NE) (Continued)

\begin{tabular}{|c|c|c|c|c|c|}
\hline \multirow{2}{*}{ Electricity Supply and Demand } & \multicolumn{4}{|c|}{ Reference Case } & \multirow{2}{*}{$\begin{array}{l}\text { Annual } \\
\text { Growth } \\
\text { 1993-2010 } \\
\text { (percent) }\end{array}$} \\
\hline & 1993 & 2000 & 2005 & 2010 & \\
\hline \multicolumn{6}{|l|}{ Net Energy for Load (billion kilowatthours) } \\
\hline Net International Electricily Imports ........... & 9.91 & 15.10 & 7.90 & 11.17 & $0.7 \%$ \\
\hline Net Interregional Electricity Imports $\ldots \ldots \ldots \ldots$ & 3.25 & 0.96 & 0.97 & 0.97 & $-6.8 \%$ \\
\hline \multicolumn{6}{|l|}{ Purchases from Nonutilities } \\
\hline (including cogenerators) $^{6} \ldots \ldots \ldots \ldots \ldots \ldots$ & 22.59 & 26.42 & 28.65 & 36.91 & $2.9 \%$ \\
\hline Generation by Utilities . ................. & 83.90 & 82.51 & 92.44 & 85.27 & $0.1 \%$ \\
\hline Total Net Energy for Load ................ & 119.65 & 124.99 & 129.96 & 134.32 & $0.7 \%$ \\
\hline \multicolumn{6}{|l|}{$\begin{array}{l}\text { Generation by Fuel Type } \\
\text { (billion kilowatthours) } \\
\text { Utility Generation }\end{array}$} \\
\hline Coal ................ & 14.99 & 14.16 & 13.58 & 14.03 & $-0.4 \%$ \\
\hline Petroleum ............ & 17.38 & 17.13 & 26.95 & 23.96 & $1.9 \%$ \\
\hline Natural Gas $\ldots \ldots \ldots \ldots \ldots \ldots \ldots \ldots$ & 3.00 & 4.55 & 5.25 & 9.78 & $7.2 \%$ \\
\hline Nuclear $\ldots \ldots \ldots \ldots \ldots \ldots \ldots \ldots \ldots$ & 44.30 & 40.80 & 40.80 & 30.62 & $-2.1 \%$ \\
\hline Pumped Storage/Other ${ }^{3} \ldots \ldots \ldots \ldots \ldots \ldots$ & -0.68 & -0.21 & -0.22 & -0.21 & $-6.8 \%$ \\
\hline Renewable ${ }^{4} \ldots \ldots \ldots \ldots \ldots \ldots \ldots \ldots$ & 4.92 & 6.08 & 6.08 & 7.08 & $2.2 \%$ \\
\hline Total Utility Generation..$\ldots \ldots \ldots \ldots \ldots$ & 83.90 & 82.51 & 92.44 & 85.27 & $0.1 \%$ \\
\hline \multicolumn{6}{|l|}{ Nonutility Generation Excluding Cogeneration } \\
\hline 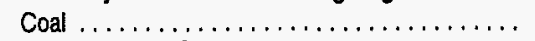 & 0.00 & 1.95 & 1.95 & 2.31 & N/A \\
\hline Petroleum/Other $\ldots \ldots \ldots \ldots \ldots \ldots \ldots$ & 0.08 & 0.00 & 0.00 & 0.00 & N/A \\
\hline Natural Gas $\ldots \ldots \ldots \ldots \ldots \ldots \ldots$ & 7.01 & 5.82 & 6.04 & 8.16 & $0.9 \%$ \\
\hline Renewable $\ldots \ldots \ldots \ldots \ldots \ldots \ldots \ldots$ & 7.28 & 8.46 & 9.71 & 14.70 & $4.2 \%$ \\
\hline Total Nonutility Generation .............. & 14.37 & 16.23 & 17.70 & 25.16 & $3.3 \%$ \\
\hline \multicolumn{6}{|l|}{ Cogenerators } \\
\hline Coal $\ldots \ldots \ldots \ldots \ldots \ldots \ldots \ldots \ldots \ldots \ldots \ldots$ & 2.69 & 3.07 & 3.20 & 3.33 & $1.3 \%$ \\
\hline Petroleum $\ldots \ldots \ldots \ldots \ldots \ldots \ldots \ldots \ldots$ & 1.57 & 5.98 & 6.45 & 6.96 & $9.2 \%$ \\
\hline Natural Gas $\ldots \ldots \ldots \ldots \ldots \ldots \ldots \ldots$ & 5.07 & 5.95 & 6.60 & 7.30 & $2.2 \%$ \\
\hline Renewable $\ldots \ldots \ldots \ldots \ldots \ldots \ldots \ldots$ & 4.17 & 4.47 & 4.50 & 4.53 & $0.5 \%$ \\
\hline Other $\ldots \ldots \ldots \ldots \ldots \ldots \ldots \ldots \ldots \ldots \ldots \ldots \ldots$ & 0.00 & 0.00 & 0.00 & 0.00 & N/A \\
\hline Total $\ldots \ldots \ldots \ldots \ldots \ldots \ldots \ldots \ldots \ldots \ldots$ & 13.50 & 19.47 & 20.76 & 22.12 & $2.9 \%$ \\
\hline Sales to Utilities $\ldots \ldots \ldots \ldots \ldots \ldots \ldots \ldots$ & 8.22 & 10.20 & 10.95 & 11.75 & $2.1 \%$ \\
\hline Generation for Own Use $\ldots \ldots \ldots \ldots \ldots \ldots$ & 4.93 & 6.31 & 6.86 & 7.43 & $2.4 \%$ \\
\hline \multicolumn{6}{|l|}{$\begin{array}{l}\text { End-Use Prices" } \\
\text { (1993 cents per kilowatthour) }\end{array}$} \\
\hline Residential ........................... & 11.9 & 11.4 & 11.8 & 12.4 & $0.3 \%$ \\
\hline Commercial ....................... & 10.2 & 10.0 & 10.1 & 10.7 & $0.3 \%$ \\
\hline Industrial $\ldots \ldots \ldots \ldots \ldots \ldots \ldots \ldots \ldots$ & 8.6 & 8.2 & 8.3 & 8.7 & $0.1 \%$ \\
\hline Transportation $\ldots \ldots \ldots \ldots \ldots \ldots \ldots \ldots$ & 7.8 & 7.9 & 8.1 & 8.3 & $0.4 \%$ \\
\hline All Sectors Average..$\ldots \ldots \ldots \ldots \ldots \ldots$ & 10.3 & 10.0 & 10.2 & 10.8 & $0.3 \%$ \\
\hline \multicolumn{6}{|l|}{$\begin{array}{l}\text { Price Components" } \\
\text { (1993 cents per kilowatthour) }\end{array}$} \\
\hline Capital Component ..................... & 2.8 & 2.6 & 2.6 & 2.8 & $0.0 \%$ \\
\hline Fuel Component $\ldots \ldots \ldots \ldots \ldots \ldots \ldots$ & 1.1 & 0.9 & 1.2 & 1.3 & $1.2 \%$ \\
\hline Operation and Maintenance Component ........ & 5.8 & 5.8 & 5.9 & 5.8 & $0.0 \%$ \\
\hline Wholesale Power Cost . ................. & 0.6 & 0.8 & 0.5 & 0.9 & $1.8 \%$ \\
\hline Total $\ldots \ldots \ldots \ldots \ldots \ldots \ldots \ldots \ldots \ldots \ldots \ldots \ldots$ & 10.3 & 10.0 & 10.2 & 10.8 & $0.3 \%$ \\
\hline \multicolumn{6}{|l|}{$\begin{array}{l}\text { Fuel Consumption (quadrillion Btu) ............ } \\
\text { Utilities }\end{array}$} \\
\hline Coal $\ldots \ldots \ldots \ldots \ldots \ldots \ldots \ldots \ldots \ldots \ldots \ldots \ldots \ldots \ldots \ldots \ldots$ & 0.12 & 0.14 & 0.13 & 0.14 & $0.6 \%$ \\
\hline Natural Gas $\ldots \ldots \ldots \ldots \ldots \ldots \ldots \ldots \ldots$ & 0.03 & 0.04 & 0.05 & 0.08 & $6.0 \%$ \\
\hline 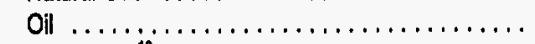 & 0.18 & 0.17 & 0.28 & 0.24 & $1.7 \%$ \\
\hline \multicolumn{6}{|l|}{ 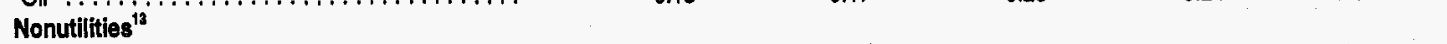 } \\
\hline 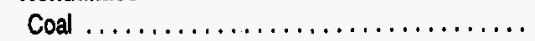 & 0.00 & 0.02 & 0.02 & 0.02 & N/A \\
\hline Natural Gas $\ldots \ldots \ldots \ldots \ldots \ldots \ldots \ldots$ & 0.05 & 0.05 & 0.06 & 0.07 & $2.0 \%$ \\
\hline \multirow[t]{2}{*}{ 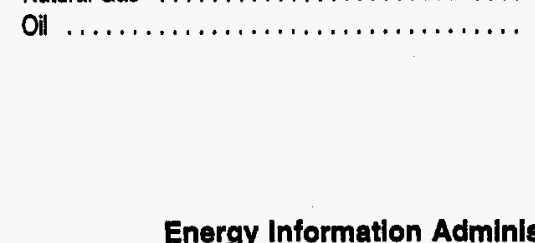 } & 0.00 & 0.00 & 0.00 & 0.00 & N/A \\
\hline & on/ Supp & ment to the & ual Ener & utlook 1995 & 211 \\
\hline
\end{tabular}


Table 60. Electric Power Data and Projections for the EMM Region Northeast Power Coordinating Council/New England (NPCC/NE) (Continued)

\begin{tabular}{|c|c|c|c|c|c|}
\hline \multirow{2}{*}{ Electricity Supply and Demand } & \multicolumn{4}{|c|}{ Reference Case } & \multirow{2}{*}{$\begin{array}{c}\text { Annual } \\
\text { Growth } \\
1993-2010 \\
\text { (percent) }\end{array}$} \\
\hline & 1993 & 2000 & 2005 & 2010 & \\
\hline \multicolumn{6}{|l|}{ Emissions (million metric tons) ${ }^{14}$} \\
\hline Total Carbon $\ldots \ldots \ldots \ldots$ & 9.23 & 9.01 & 11.07 & 11.29 & $1.2 \%$ \\
\hline Carbon Dioxide $\ldots$ & 33.83 & 33.04 & 40.59 & 41.38 & $1.2 \%$ \\
\hline Sulfur Dioxide,$\ldots \ldots \ldots \ldots \ldots \ldots \ldots \ldots \ldots$ & 0.30 & 0.14 & 0.19 & 0.17 & $-3.3 \%$ \\
\hline
\end{tabular}

'Net summer capability is the steady hourly output that generating equipment is expected to supply to system load (exclusive of auxiliary power), as demonstrated by tests during summer peak demand.

Includes oil-, gas-, and dual-fired capability.

${ }^{3}$ Other includes methane, propane gas, and blast furnace gas.

IIncludes conventional hydroelectric, geothermal, wood, wood waste, municipal solid waste, other biomass, solar, and wind power.

5Cumulative additions after December 31, 1992.

"Electrcity was produced solely for sale to an electric utility or another end-user, and there is no business activity at the site (standard industrial classification 49).

'Nameplate capacity is reported for nonutilities on Form ElA-867, "Annual Nonutility Power Producer Report." Nameplate capacity is designated by the manufacturer. The nameplate capacity has been converted to net summer capacity based on historic relationships.

"Other includes hydrogen, sulfur, batteries, chemicals, fish oil, and spent sulfite liquor.

'Includes generators and cogenerators at facilities whose primary function is not electricity production (standard industrial classification other than 49).

${ }^{10} \mathrm{Generation}$ to meet system load by source.

"Prices represent average revenue per kilowatthour.

12 In the end-use energy consumptions tables, projected fuel consumption in the utility sector includes fuel used by independent power producers.

In this table, fuel used by independent power producers is included in the nonutility category.

${ }^{13}$ Includes fuel consumption by small power producers, independent power producers, and exempt wholesale generators, which produce electricity for sales to utilities.

${ }^{14}$ Estimated emissions from utilities and independent power producers.

EMM = Electricity market module.

N/A = Not applicable.

Note: Totals may not equal sum of components due to independent rounding.

Sources: 1993 (except for prices): Energy Information Administration (EIA), Annual Energy Review 1993, DOE/EIA-0384(93) (Washington,

D.C., July 1994). Prices and all projections: EIA, AEO95 National Energy Modeling System run AEO95B.01103942. 
Table 61. Electric Power Data and Projections for the EMM Region

Southeastern Electric Reliability Council/FIorida (SERC/STV)

\begin{tabular}{l|l|l|l|l|l}
\hline \multirow{2}{*}{ Electricity Supply and Demand } & \multicolumn{4}{|c|}{ Reference Case } & $\begin{array}{l}\text { Annual } \\
\text { Growth } \\
1993-2010 \\
\text { (percent) }\end{array}$ \\
\cline { 2 - 6 } & 1993 & 2000 & 2005 & 2010 & \multicolumn{4}{|c|}{} \\
\hline
\end{tabular}

Electricity Generating Capacity
(gigawatts)

Utilities

Coal Steam $\ldots \ldots \ldots \ldots \ldots \ldots \ldots \ldots \ldots . . . \ldots \ldots$

Other Fossil Steam ${ }^{2} \ldots \ldots \ldots \ldots \ldots \ldots \ldots \ldots \ldots$

Combined Cycle ....................

13.36

Combustion Turbine/Diesel ...............

2.26

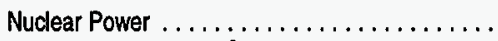

Pumped Storage/Other ${ }^{3}$. . . . . . . . . . . . .

Renewable $\ldots . \ldots \ldots \ldots \ldots \ldots \ldots \ldots \ldots$.

Total Utilities Capability ...............

Cumulative Planned Additions ${ }^{5}$

Coal Steam $\ldots \ldots \ldots \ldots \ldots \ldots \ldots \ldots$.

Other Fossil Steam ${ }^{2} \ldots \ldots \ldots \ldots \ldots \ldots \ldots \ldots$

Combined Cycle .......................

Combustion Turbine/Diesel ................

Nuclear Power .........................

Pumped Storage/Other ${ }^{3}$................

Renewable ${ }^{4} \ldots \ldots \ldots \ldots \ldots \ldots \ldots \ldots \ldots \ldots$

Tolal (planned) $\ldots \ldots \ldots \ldots \ldots \ldots \ldots \ldots$

Cumulative Unplanned Additions ${ }^{5}$

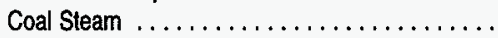

Other Fossil Steam ${ }^{2} \ldots \ldots \ldots \ldots \ldots \ldots \ldots$

Combined Cycle .......................

Combustion Turbine/Diesel ...............

Nuclear Power ......................

Pumped Storage/Other ${ }^{3} \ldots \ldots \ldots \ldots \ldots \ldots \ldots$

Renewable ${ }^{4} \ldots \ldots \ldots \ldots \ldots \ldots$

Total (unplanned) $\ldots \ldots \ldots \ldots \ldots \ldots \ldots$

Cumulative Total Utility Additions ..........

Cumulative Utility Retirements

9.91
12.99
4.58
5.57
3.83
0.00
0.05
36.92

9.91
12.66
4.75
5.56
3.83
0.00
0.05
36.75

$\begin{array}{rc}10.05 & 0.6 \% \\ 11.86 & -0.7 \% \\ 4.83 & 4.6 \% \\ 5.85 & 0.6 \% \\ 2.49 & -2.5 \% \\ 0.00 & \text { N/A } \\ 0.05 & \text { N/A } \\ 35.13 & 0.2 \%\end{array}$

\subsection{9}

0.00

2.93

0.38

0.00

0.00

0.00

4.10

$\begin{array}{llc}0.79 & 0.79 & \text { N/A } \\ 0.00 & 0.00 & \text { N/A } \\ 3.10 & 3.10 & 10.0 \% \\ 0.43 & 0.43 & 15.0 \% \\ 0.00 & 0.00 & \text { N/A } \\ 0.00 & 0.00 & \text { N/A } \\ 0.00 & 0.00 & \text { N/A } \\ 4.33 & 4.33 & 11.8 \%\end{array}$

Nonutilities Capacity (excludes cogenerators) ${ }^{6,7}$

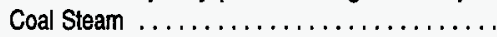

Other Fossil Steam ${ }^{2} \ldots \ldots \ldots \ldots \ldots \ldots \ldots$

Combined Cycle ........................

Combustion Turbine/Diesel . . . . . . . . . . . .

Nuclear Power ......................

Pumped Storage/Other ${ }^{8} \ldots \ldots \ldots \ldots \ldots \ldots \ldots$

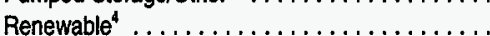

Total Nonutilities Capability

.

Cogenerators $^{9}$

\section{Capacity}

Coal $\ldots \ldots \ldots \ldots \ldots \ldots \ldots \ldots \ldots \ldots \ldots \ldots \ldots \ldots \ldots$

Petroleum $\ldots \ldots \ldots \ldots \ldots \ldots \ldots \ldots \ldots \ldots \ldots \ldots$

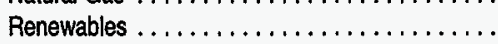

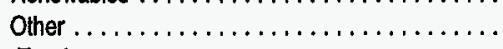

Total

0.13
0.04
0.23
0.91
0.02
1.34

\begin{tabular}{ll|}
0.14 & $1.4 \%$ \\
0.05 & $4.2 \%$ \\
0.26 & $2.0 \%$ \\
0.91 & $0.5 \%$ \\
0.02 & N $/ A$ \\
1.38 & $1.0 \%$
\end{tabular}

Electricity Demand

(billion kilowatthours)

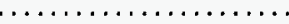

Commercial/Other ......................

Industrial .............................

Transportation $\ldots \ldots \ldots \ldots \ldots \ldots \ldots \ldots \ldots$

Total Sales .

59.26
45.78
40.24
0.80
146.07

64.95
51.91
44.76
1.18
162.81

68.73
55.97
49.16
1.79
175.65


Table 61. Electric Power Data and Projections for the EMM Region Southeastern Electric Reliability Council/Florida (SERC/STV) (Continued)

\begin{tabular}{|c|c|c|c|c|c|}
\hline \multirow{2}{*}{ Electricity Supply and Demand } & \multicolumn{4}{|c|}{ Reference Case } & \multirow{2}{*}{$\begin{array}{l}\text { Annual } \\
\text { Growth } \\
\text { 1993-201 } \\
\text { (percent) }\end{array}$} \\
\hline & 1993 & 2000 & 2005 & 2010 & \\
\hline \multicolumn{6}{|l|}{ Net Energy for Load (billion kilowatthours) } \\
\hline Net international Electricity Imports . . . . . . . . & 0.00 & 0.00 & 0.00 & 0.00 & N/A \\
\hline Net Interregional Electricity Imports & 25.12 & 23.82 & 18.27 & 16.86 & $-2.3 \%$ \\
\hline \multicolumn{6}{|l|}{ Purchases from Nonutilities } \\
\hline (including cogenerators) ${ }^{6}$ & 6.12 & 6.71 & 7.76 & 12.91 & $4.5 \%$ \\
\hline Generation by Utilities $\ldots \ldots \ldots \ldots \ldots \ldots \ldots$ & 135.08 & 143.70 & 161.94 & 173.35 & $1.5 \%$ \\
\hline Total Net Energy for Load ............... & 166.32 & 174.22 & 187.97 & 203.12 & $1.2 \%$ \\
\hline \multicolumn{6}{|l|}{$\begin{array}{l}\text { Generation by Fuel Type } \\
\text { (billion kilowatthours) }\end{array}$} \\
\hline \multicolumn{6}{|l|}{ Utility Generation } \\
\hline Coal $\ldots . . . \ldots$ & 57.02 & 57.63 & 59.30 & 60.13 & $0.3 \%$ \\
\hline Petroleum ...... & 34.27 & 27.01 & 37.67 & 45.17 & $1.6 \%$ \\
\hline Natural Gas & 17.70 & 33.31 & 39.22 & 49.77 & $6.3 \%$ \\
\hline Nuclear ............ & 25.89 & 25.65 & 25.65 & 18.19 & $-2.1 \%$ \\
\hline Pumped Storage/Other ${ }^{3}$. & 0.00 & 0.00 & 0.00 & 0.00 & N/A \\
\hline Renewable ${ }^{4} \ldots \ldots \ldots \ldots \ldots \ldots \ldots \ldots$ & 0.21 & 0.09 & 0.09 & 0.09 & $-4.7 \%$ \\
\hline Total Utility Generation . . . . . . . . . . . . . & 135.08 & 143.70 & 161.94 & 173.35 & $1.5 \%$ \\
\hline \multicolumn{6}{|l|}{ Nonutility Generation Excluding Cogeneration } \\
\hline Coal $\ldots \ldots \ldots \ldots \ldots \ldots \ldots \ldots \ldots \ldots$ & 0.10 & 0.00 & 0.00 & 1.27 & $15.9 \%$ \\
\hline Petroleum/Others & 0.01 & 0.00 & 0.00 & 0.00 & N/A \\
\hline Natural Gas $\ldots \ldots \ldots \ldots \ldots \ldots \ldots \ldots$ & 1.66 & 1.63 & 1.79 & 4.56 & $6.1 \%$ \\
\hline Renewable $\ldots \ldots \ldots \ldots \ldots \ldots \ldots \ldots \ldots$ & 3.21 & 3.67 & 4.47 & 5.46 & $3.2 \%$ \\
\hline Total Nonutility Generation .............. & 4.99 & 5.30 & 6.26 & 11.29 & $4.9 \%$ \\
\hline \multicolumn{6}{|l|}{ Cogenerators } \\
\hline Coal $\ldots \ldots \ldots \ldots \ldots \ldots \ldots \ldots \ldots \ldots \ldots \ldots \ldots$ & 1.30 & 1.47 & 1.54 & 1.60 & $1.3 \%$ \\
\hline Petroleum $\ldots \ldots \ldots \ldots \ldots \ldots \ldots \ldots$ & 0.58 & 2.21 & 2.39 & 2.57 & $9.2 \%$ \\
\hline Natural Gas $\ldots \ldots \ldots \ldots \ldots \ldots \ldots \ldots$ & 1.45 & 1.70 & 1.88 & 2.08 & $2.2 \%$ \\
\hline Renewable $\ldots \ldots \ldots \ldots \ldots \ldots \ldots \ldots$ & 2.39 & 2.57 & 2.58 & 2.60 & $0.5 \%$ \\
\hline Other $\ldots \ldots \ldots \ldots \ldots \ldots \ldots \ldots \ldots$ & 1.52 & 2.27 & 2.39 & 2.51 & $3.0 \%$ \\
\hline Total $\ldots \ldots \ldots \ldots \ldots \ldots \ldots \ldots \ldots \ldots$ & 7.24 & 10.22 & 10.78 & 11.37 & $2.7 \%$ \\
\hline Sales to Utilities $\ldots \ldots \ldots \ldots \ldots \ldots \ldots$ & 1.13 & 1.41 & 1.51 & 1.62 & $2.1 \%$ \\
\hline Generation for Own Use $\ldots \ldots \ldots \ldots \ldots \ldots$ & 6.72 & 8.60 & 9.34 & 10.12 & $2.4 \%$ \\
\hline \multicolumn{6}{|l|}{$\begin{array}{l}\text { End-Use Prices" } \\
\text { (1993 cents per kilowatthour) }\end{array}$} \\
\hline Residential $\ldots \ldots \ldots \ldots \ldots \ldots \ldots \ldots \ldots$ & 8.2 & 8.6 & 9.0 & 9.6 & $0.9 \%$ \\
\hline Commercial $\ldots \ldots \ldots \ldots \ldots \ldots \ldots \ldots \ldots$ & 6.7 & 7.0 & 7.5 & 8.1 & $1.1 \%$ \\
\hline Industrial $\ldots \ldots \ldots \ldots \ldots \ldots \ldots \ldots \ldots$ & 6.5 & 6.9 & 7.3 & 7.8 & $1.1 \%$ \\
\hline Transportation ....................... & 4.5 & 4.9 & 5.0 & 5.0 & $0.7 \%$ \\
\hline All Sectors Average ................... & 7.2 & 7.6 & 8.0 & 8.6 & $1.1 \%$ \\
\hline \multicolumn{6}{|l|}{ Price Components" } \\
\hline \multicolumn{6}{|l|}{ (1993 cents per kilowatthour) } \\
\hline Capital Component ......... & 2.2 & 2.4 & 2.3 & 2.3 & $0.4 \%$ \\
\hline Fuel Component $\ldots \ldots \ldots \ldots \ldots \ldots \ldots$ & 1.4 & 1.7 & 2.2 & 2.6 & $3.7 \%$ \\
\hline Operation and Maintenance Component ......... & 3.0 & 3.0 & 3.0 & 3.0 & $0.1 \%$ \\
\hline Wholesale Power Cost . . . . . . . . . . . . . . . . . & 0.6 & 0.6 & 0.5 & 0.6 & $0.0 \%$ \\
\hline Total $\ldots \ldots \ldots \ldots \ldots \ldots \ldots \ldots \ldots \ldots \ldots$ & 7.2 & 7.6 & 8.0 & 8.6 & $1.1 \%$ \\
\hline \multicolumn{6}{|l|}{$\begin{array}{l}\text { Fuel Consumption (quadrillion Btu) ............ } \\
\text { Utilities }^{12}\end{array}$} \\
\hline 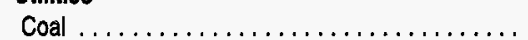 & 0.49 & 0.57 & 0.60 & 0.61 & $1.2 \%$ \\
\hline Natural Gas $\ldots \ldots \ldots \ldots \ldots \ldots \ldots \ldots \ldots$. & 0.18 & 0.32 & 0.39 & 0.52 & $6.5 \%$ \\
\hline Oil ...................................... & 0.34 & 0.28 & 0.39 & 0.47 & $1.9 \%$ \\
\hline Coal $\ldots \ldots \ldots \ldots \ldots \ldots \ldots \ldots \ldots \ldots$ & 0.00 & 0.00 & 0.00 & 0.01 & N/A \\
\hline Natural Gas & 0.00 & 0.02 & 0.02 & 0.04 & $15.0 \%$ \\
\hline 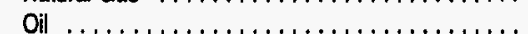 & 0.00 & 0.00 & 0.00 & 0.00 & NA \\
\hline
\end{tabular}


Table 61. Electric Power Data and Projections for the EMM Region Southeastern Electric Reliability Council/FIorida (SERC/STV) (Continued)

\begin{tabular}{|c|c|c|c|c|c|}
\hline \multirow{2}{*}{ Electricity Supply and Demand } & \multicolumn{4}{|c|}{ Reference Case } & \multirow{2}{*}{$\begin{array}{c}\text { Annual } \\
\text { Growth } \\
1993-2010 \\
\text { (percent) }\end{array}$} \\
\hline & 1993 & 2000 & 2005 & 2010 & \\
\hline \multicolumn{6}{|l|}{ Emissions (million metric tons) } \\
\hline Total Carbon $\ldots \ldots \ldots \ldots$ & 21.91 & 24.94 & 28.97 & 33.48 & $2.5 \%$ \\
\hline Carbon Dioxide ... & 80.34 & 91.46 & 106.23 & 122.75 & $2.5 \%$ \\
\hline Sulfur Dioxide ..... . & 0.51 & 0.29 & 0.34 & 0.36 & $-2.0 \%$ \\
\hline
\end{tabular}

${ }^{1}$ Net summer capability is the steady hourly output that generating equipment is expected to supply to system load (exclusive of auxiliary power), as demonstrated by tests during summer peak demand.

${ }^{2}$ Includes oil-, gas-, and dual-fired capability.

${ }^{3}$ Other includes methane, propane gas, and blast furnace gas.

Includes conventional hydroelectric, geothermal, wood, wood waste, municipal solid waste, other biomass, solar, and wind power.

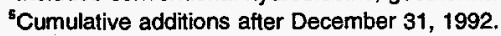

'Electrcity was produced solely for sale to an electric utility or another end-user, and there is no business activity at the site (standard industrial classification 49)

"Nameplate capacity is reported for nonutilities on Form EIA-867, "Annual Nonutility Power Producer Report." Nameplate capacity is designated by the manufacturer. The nameplate capacity has been converted to net summer capacity based on historic relationships.

'Other includes hydrogen, sulfur, batteries, chemicals, fish oil, and spent sulfite liquor.

Includes generators and cogenerators at facilities whose primary function is not electricity production (standard industrial classification other than 49).

${ }^{10}$ Generation to meet system load by source.

"Prices represent average revenue per kilowatthour.

${ }^{12}$ In the end-use energy consumptions tables, projected fuel consumption in the utility sector includes fuel used by independent power producers. In this table, fuel used by independent power producers is included in the nonutility category.

${ }^{13}$ Includes fuel consumption by small power producers, independent power producers, and exempt wholesale generators, which produce electricity for sales to utilities.

${ }^{14}$ Estimated emissions from utilities and independent power producers.

EMM = Electricity market module.

N/A $=$ Not applicable.

Note: Totals may not equal sum of components due to independent rounding.

Sources: 1993 (except for prices): Energy Information Administration (EIA), Annual Energy Review 1993, DOE/EIA-0384(93) (Washington D.C., July 1994). Prices and all projections: EIA, AEO95 National Energy Modeling System run AEO95B.D1103942. 
Table 62. Electric Power Data and Projections for the EMM Region Southeastern Electric Reliability Council/excluding Florida (SERC/STV)

\begin{tabular}{|l|l|l|l|l|l}
\hline \multirow{2}{*}{ Electricity Supply and Demand } & \multicolumn{4}{|c|}{ Reference Case } & \multicolumn{2}{c|}{$\begin{array}{c}\text { Annual } \\
\text { Growth } \\
1993-2010 \\
\text { (percent) }\end{array}$} \\
\cline { 2 - 5 } & 1993 & 2000 & 2005 & 2010 & \multicolumn{1}{|c|}{} \\
\hline
\end{tabular}

Electricity Generating Capacity' (gigawatts)

Utilities

Coal Steam $\ldots \ldots \ldots \ldots \ldots \ldots \ldots \ldots \ldots$

Other Fossil Steam ${ }^{2} \ldots \ldots \ldots \ldots \ldots \ldots \ldots$

Combined Cycle .....................

Combustion Turbine/Diesel . . . . . . . . . . . .

Nuclear Power ......................

Pumped Storage/Other ${ }^{3}, \ldots \ldots \ldots \ldots \ldots \ldots$.

Renewable ${ }^{4} \ldots \ldots \ldots \ldots \ldots \ldots \ldots \ldots \ldots$

Total Utilities Capability

61.69

3.17

0.90

6.65

26.37

5.94

11.25

115.97

Cumulative Planned Additions ${ }^{5}$

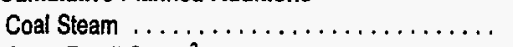

Other Fossil Steam ${ }^{2} \ldots \ldots \ldots \ldots \ldots \ldots \ldots$

Combined Cycle .....................

Combustion Turbine/Diesel ...............

Nuclear Power .........................

Pumped Storage/Other ${ }^{3}$. . . . . . . . . . . . . .

Renewable

Total (planned)

........................

Cumulative Unplanned Additions ${ }^{5}$

Coal Steam ........................

Other Fossil Steam ${ }^{2}$. . . . . . . . . . . . . . . .

Combined Cycle ....................

Combustion Turbine/Diesel . . . . . . . . . . . . . .

Nuclear Power .......................

Pumped Storage/Other ${ }^{3}, \ldots \ldots \ldots \ldots \ldots \ldots$.

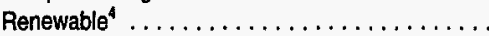

Total (unplanned) $\ldots \ldots \ldots \ldots \ldots \ldots \ldots .$.

Cumulative Total Utility Additions

Cumulative Utility Retirements

...........

Nonutilities Capacity (excludes cogenerators) ${ }^{6,7}$

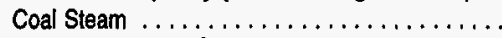

Other Fossil Steam ${ }^{2} \ldots \ldots \ldots \ldots \ldots \ldots \ldots \ldots$

Combined Cycle ......................

Combustion Turbine/Diesel . . . . . . . . . . . . .

Nuclear Power ........................

Pumped Storage/Other ${ }^{8} \ldots \ldots \ldots \ldots \ldots \ldots \ldots$,

Renewable $\ldots \ldots \ldots \ldots \ldots \ldots \ldots \ldots$

Total Nonutilities Capability

\section{Cogenerators $^{9}$}

\section{Capacity}

Coal .......

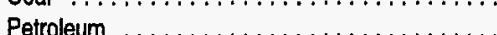

Natural Gas . . . . . . . . . . . . . . . . .

Renewables ........................

Other.

Total

0.00
0.00
0.00
0.08
0.00
0.30
0.00
0.38

62.11
2.66
1.05
12.68
28.71
6.79
11.25
125.25

61.23
2.42
1.95
13.14
28.71
6.79
11.25
125.49

$\begin{array}{rr}61.05 & -0.1 \% \\ 2.33 & -1.8 \% \\ 3.19 & 7.7 \% \\ 14.70 & 4.8 \% \\ 28.03 & 0.4 \% \\ 6.79 & 0.8 \% \\ 11.25 & \text { N/A } \\ 127.33 & 0.6 \%\end{array}$

\subsection{6}

0.00

0.15

6.16

2.34

1.15

0.00

11.65

\subsection{6}

$$
\begin{aligned}
& 0.00 \\
& 1.05 \\
& 7.77
\end{aligned}
$$$$
7.77
$$$$
2.34
$$

1.15

0.00

14.17

$\begin{array}{rc}1.86 & \text { N/A } \\ 0.00 & \text { N/A } \\ 1.05 & \text { N/A } \\ 7.77 & 30.9 \% \\ 2.34 & \text { N/A } \\ 1.15 & 8.2 \% \\ 0.00 & \text { N/A } \\ 14.17 & 23.7 \%\end{array}$

\subsection{0}

0.00

0.00

0.00

0.00

0.00

0.00

0.00

0.38

0.22

\subsection{0}

0.00

0.00

0.00

0.00

0.00

0.00

0.00

11.65

2.21

\subsection{0}

\subsection{0}

$$
\begin{aligned}
& 0.00 \\
& 0.00
\end{aligned}
$$$$
0.00
$$$$
0.00
$$$$
0.00
$$$$
0.00
$$$$
14.17
$$$$
4.48
$$

$0.97 \quad$ N/A

1.23 N/A

$1.62 \mathrm{~N} / \mathrm{A}$

$0.00 \quad \mathrm{~N} / \mathrm{A}$

$0.00 \quad \mathrm{~N} / \mathrm{A}$

$\begin{array}{ll}0.00 & \text { N/A } \\ 3.82 & \text { N/A }\end{array}$

$17.99 \quad 25.5 \%$

$6.47 \quad 22.2 \%$

$\begin{array}{llllc}0.00 & 0.00 & 0.00 & 1.00 & \text { N/A } \\ 0.00 & 0.00 & 0.00 & 0.00 & \text { N/A } \\ 0.86 & 0.86 & 0.86 & 2.75 & 7.1 \% \\ 0.27 & 0.58 & 0.58 & 1.66 & 11.3 \% \\ 0.00 & 0.00 & 0.00 & 0.00 & \text { N/A } \\ 0.00 & 0.00 & 0.00 & 0.00 & \text { N/A } \\ 0.30 & 0.31 & 0.31 & 0.32 & 0.5 \% \\ 1.42 & 1.75 & 1.75 & 5.73 & 8.5 \%\end{array}$

Electricity Demand

(billion kilowatthours)

Residential .........................

Commercial/Other . . . . . . . . . . . . . . . . .

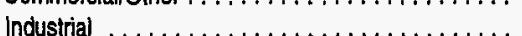

Transportation $\ldots \ldots \ldots \ldots \ldots \ldots \ldots \ldots \ldots \ldots$

Total Sales.

$\begin{array}{ll}2.49 & 1.4 \% \\ 0.78 & 4.2 \% \\ 1.16 & 2.0 \% \\ 2.36 & 0.5 \% \\ 0.00 & \mathrm{~N} / \mathrm{A} \\ 6.80 & 1.4 \%\end{array}$

$\begin{array}{rrrr}202.32 & 212.13 & 226.62 & 1.1 \% \\ 140.64 & 150.10 & 162.11 & 1.5 \% \\ 192.25 & 210.92 & 225.01 & 1.6 \% \\ 3.57 & 5.36 & 7.36 & 6.7 \% \\ \mathbf{5 3 8 . 7 8} & \mathbf{5 7 8 . 5 1} & \mathbf{6 2 1 . 1 1} & \mathbf{1 . 4 \%}\end{array}$


Table 62. Electric Power Data and Projections for the EMM Region

Southeastern Electric Reliability Council/excluding Florida (SERC/STV) (Continued)

\begin{tabular}{|c|c|c|c|c|c|}
\hline \multirow{2}{*}{ Electricity Supply and Demand } & \multicolumn{4}{|c|}{ Reference Case } & \multirow{2}{*}{$\begin{array}{l}\text { Annual } \\
\text { Growth } \\
1993-2010 \\
\text { (percent) }\end{array}$} \\
\hline & 1993 & 2000 & 2005 & 2010 & \\
\hline \multicolumn{6}{|l|}{ Net Energy for Load (billion kilowatthours) } \\
\hline Net International Electricity Imports $\ldots \ldots \ldots \ldots$. & 0.00 & 0.00 & 0.00 & 0.00 & NA \\
\hline Net Interregional Electricity Imports $\ldots \ldots \ldots \ldots$. & -25.19 & -35.35 & -21.33 & -16.86 & $-2.3 \%$ \\
\hline \multicolumn{6}{|l|}{ Purchases from Nonutilities } \\
\hline (including cogenerators) ${ }^{6}$ & 12.13 & 16.36 & 18.97 & 40.22 & $7.3 \%$ \\
\hline Generation by Utilities.$\ldots \ldots \ldots \ldots \ldots \ldots \ldots$ & 530.43 & 591.99 & 617.58 & 637.14 & $1.1 \%$ \\
\hline Total Net Energy for Load ................. & 517.37 & 573.00 & 615.22 & 660.49 & $1.4 \%$ \\
\hline \multirow{2}{*}{\multicolumn{6}{|c|}{$\begin{array}{l}\text { Generation by Fuel Type } \\
\text { (billion kilowatthours) } \\
\text { Utility Generation }\end{array}$}} \\
\hline & & & & & \\
\hline Coal $\ldots \ldots \ldots \ldots \ldots \ldots \ldots \ldots \ldots \ldots \ldots$ & 341.19 & 359.80 & 364.93 & 366.41 & $0.4 \%$ \\
\hline Petroleum.$\ldots \ldots \ldots \ldots \ldots \ldots \ldots \ldots \ldots$ & 3.02 & 1.67 & 2.73 & 3.77 & $1.3 \%$ \\
\hline Natural Gas $\ldots \ldots \ldots \ldots \ldots \ldots \ldots \ldots$ & 4.64 & 8.55 & 27.16 & 45.18 & $14.3 \%$ \\
\hline Nuclear $\ldots \ldots \ldots \ldots \ldots \ldots \ldots \ldots \ldots \ldots$ & 148.90 & 184.70 & 185.45 & 184.43 & $1.3 \%$ \\
\hline Pumped Storage/Other ${ }^{3} \ldots \ldots \ldots \ldots \ldots \ldots$ & -0.94 & -0.73 & -0.68 & -0.64 & $-2.3 \%$ \\
\hline Renewable ${ }^{4} \ldots \ldots \ldots \ldots \ldots \ldots \ldots \ldots$ & 33.62 & 37.99 & 37.99 & 37.99 & $0.7 \%$ \\
\hline Total Utility Generation..$\ldots \ldots \ldots \ldots \ldots$ & 530.43 & 591.99 & 617.58 & 637.14 & $1.1 \%$ \\
\hline \multicolumn{6}{|l|}{ Nonutility Generation Excluding Cogeneration } \\
\hline Coal $\ldots \ldots \ldots \ldots \ldots \ldots \ldots \ldots \ldots \ldots \ldots \ldots \ldots \ldots \ldots \ldots \ldots \ldots$ & 0.00 & 0.00 & 0.00 & 5.94 & N/A \\
\hline Petroleum/Other ${ }^{8} \ldots \ldots \ldots \ldots \ldots \ldots \ldots$ & 0.04 & 0.00 & 0.00 & 0.00 & $-14.6 \%$ \\
\hline Natural Gas $\ldots \ldots \ldots \ldots \ldots \ldots \ldots \ldots \ldots$ & 2.07 & 3.81 & 5.61 & 20.07 & $14.3 \%$ \\
\hline Renewable $\ldots \ldots \ldots \ldots \ldots \ldots \ldots \ldots$ & 1.18 & 1.60 & 1.60 & 1.58 & $1.7 \%$ \\
\hline Total Nonutility Generation ............... & 3.30 & 5.41 & 7.21 & 27.59 & $13.3 \%$ \\
\hline \multicolumn{6}{|l|}{ Cogenerators } \\
\hline Coal $\ldots \ldots \ldots \ldots \ldots \ldots \ldots \ldots \ldots \ldots \ldots \ldots \ldots \ldots \ldots \ldots \ldots$ & 13.39 & 15.23 & 15.88 & 16.56 & $1.3 \%$ \\
\hline Petroleum $\ldots \ldots \ldots \ldots \ldots \ldots \ldots \ldots \ldots$ & 1.58 & 6.05 & 6.52 & 7.04 & $9.2 \%$ \\
\hline Natural Gas $\ldots \ldots \ldots \ldots \ldots \ldots \ldots \ldots$ & 3.60 & 4.22 & 4.68 & 5.17 & $2.2 \%$ \\
\hline Renewable $\ldots \ldots \ldots \ldots \ldots \ldots \ldots \ldots \ldots$ & 12.36 & 13.26 & 13.35 & 13.44 & $0.5 \%$ \\
\hline Other,$\ldots \ldots \ldots \ldots \ldots \ldots \ldots \ldots \ldots \ldots \ldots \ldots \ldots$ & 0.27 & 0.39 & 0.42 & 0.44 & $3.0 \%$ \\
\hline Total $\ldots \ldots \ldots \ldots \ldots \ldots \ldots \ldots \ldots \ldots \ldots$ & 31.19 & 39.16 & 40.86 & 42.65 & $1.9 \%$ \\
\hline Sales to Utilities $\ldots \ldots \ldots \ldots \ldots \ldots \ldots \ldots$ & 8.83 & 10.96 & 11.76 & 12.62 & $2.1 \%$ \\
\hline Generation for Own Use $\ldots \ldots \ldots \ldots \ldots \ldots$ & 22.73 & 29.09 & 31.61 & 34.24 & $2.4 \%$ \\
\hline \multicolumn{6}{|l|}{$\begin{array}{l}\text { End-Use Prices" } \\
\text { (1993 cents per kilowatthour) }\end{array}$} \\
\hline Residential $\ldots . . . \ldots \ldots \ldots \ldots \ldots \ldots \ldots$ & 7.4 & 7.1 & 7.1 & 7.4 & $0.0 \%$ \\
\hline Commercial $\ldots \ldots \ldots \ldots \ldots \ldots \ldots \ldots \ldots$ & 6.4 & 6.3 & 6.3 & 6.3 & $-0.1 \%$ \\
\hline Industrial $\ldots \ldots \ldots \ldots \ldots \ldots \ldots \ldots \ldots \ldots \ldots$ & 4.3 & 4.2 & 4.2 & 4.2 & $-0.2 \%$ \\
\hline Transportation $\ldots \ldots \ldots \ldots \ldots \ldots \ldots \ldots$ & 4.1 & 4.4 & 4.3 & 4.2 & $0.1 \%$ \\
\hline All Sectors Average $\ldots \ldots \ldots \ldots \ldots \ldots \ldots$ & 6.0 & 5.8 & 5.8 & 5.9 & $0.0 \%$ \\
\hline \multicolumn{6}{|l|}{$\begin{array}{l}\text { Price Components" } \\
\text { (1993 cents per kilowatthour) }\end{array}$} \\
\hline Capital Component ..................... & 2.7 & 2.6 & 2.4 & 2.3 & $-0.9 \%$ \\
\hline Fuel Component $\ldots \ldots \ldots \ldots \ldots \ldots \ldots \ldots$ & 1.2 & 1.2 & 1.3 & 1.4 & $0.8 \%$ \\
\hline Operation and Maintenance Component ........ & 2.1 & 2.2 & 2.1 & 2.1 & $0.0 \%$ \\
\hline Wholesale Power Cost .................. & -0.1 & -0.1 & -0.1 & 0.1 & $\mathrm{~N} / \mathrm{A}$ \\
\hline Total $\ldots \ldots \ldots \ldots \ldots \ldots \ldots \ldots \ldots \ldots \ldots$ & 6.0 & 5.8 & 5.8 & 5.9 & $0.0 \%$ \\
\hline \multicolumn{6}{|l|}{$\begin{array}{l}\text { Fuel Consumption (quadrillion Btu) } \ldots \ldots \ldots \ldots \ldots \\
\text { Utillities }^{12}\end{array}$} \\
\hline Coal $\ldots \ldots \ldots \ldots \ldots \ldots \ldots \ldots \ldots \ldots \ldots \ldots \ldots \ldots$ & 2.96 & 3.57 & 3.62 & 3.63 & $1.2 \%$ \\
\hline Natural Gas $\ldots \ldots \ldots \ldots \ldots \ldots \ldots \ldots \ldots$ & 0.06 & 0.08 & 0.29 & 0.48 & $13.1 \%$ \\
\hline 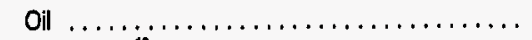 & 0.03 & 0.02 & 0.03 & 0.04 & $1.5 \%$ \\
\hline \multicolumn{6}{|l|}{ Nonutilities $^{13}$} \\
\hline Coal $\ldots \ldots \ldots \ldots \ldots \ldots \ldots \ldots \ldots \ldots \ldots \ldots \ldots \ldots$ & 0.00 & 0.00 & 0.00 & 0.06 & N/A \\
\hline Natural Gas $\ldots \ldots \ldots \ldots \ldots \ldots \ldots \ldots$ & 0.02 & 0.04 & 0.06 & 0.18 & $14.5 \%$ \\
\hline \multirow[t]{2}{*}{ 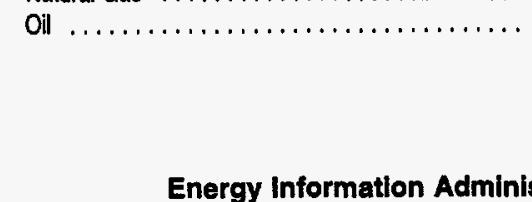 } & 0.00 & 0.00 & 0.00 & 0.00 & $-14.3 \%$ \\
\hline & on/ Supp & nt to the & ual Ener & utlook 1995 & 217 \\
\hline
\end{tabular}


Table 62. Electric Power Data and Projections for the EMM Region

Southeastern Electric Reliability Council/excluding Florida (SERC/STV) (Continued)

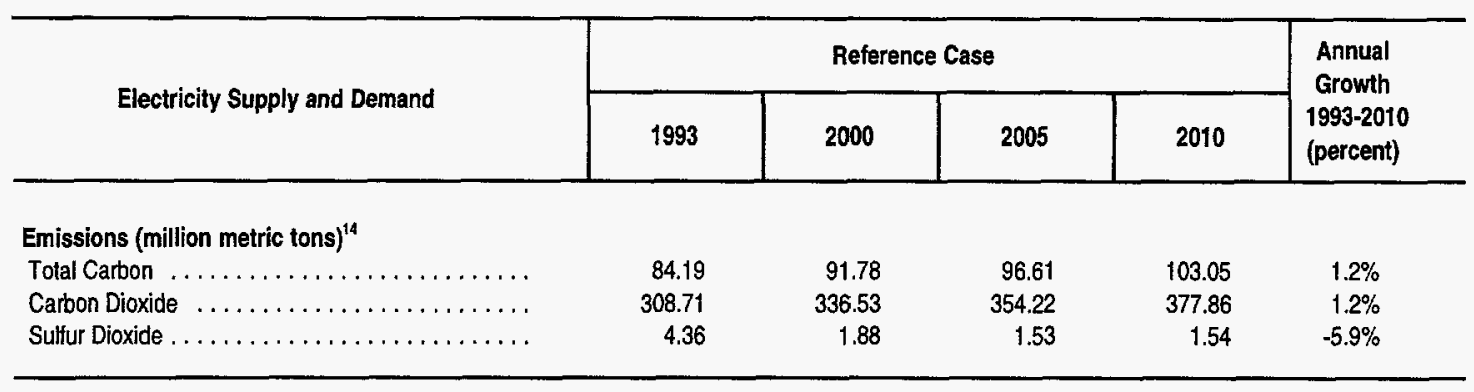

'Net summer capability is the steady hourly output that generating equipment is expected to supply to system load (exclusive of auxiliary power), as demonstrated by tests during summer peak demand.

${ }^{2}$ Includes oil-, gas-, and dual-fired capability.

${ }^{3}$ Other includes methane, propane gas, and blast furnace gas.

${ }^{4}$ Includes conventional hydroelectric, geothermal, wood, wood waste, municipal solid waste, other biomass, solar, and wind power.

${ }^{5}$ Cumulative additions after December 31, 1992.

'Electrcity was produced solely for sale to an electric utility or another end-user, and there is no business activity at the site (standard industrial classification 49).

${ }^{7}$ Nameplate capacity is reported for nonutilities on Form EIA-867, "Annual Nonutility Power Producer Report." Nameplate capacity is designated by the manufacturer. The nameplate capacity has been converted to net summer capacity based on historic relationships.

'Other includes hydrogen, sulfur, batteries, chemicals, fish oil, and spent sulfite liquor.

Includes generators and cogenerators at facilities whose primary function is not electricity production (standard industrial classification other than 49).

${ }^{10}$ Generation to meet system load by source.

"Prices represent average revenue per kilowatthour.

${ }^{12}$ In the end-use energy consumptions tables, projected fuel consumption in the utility sector includes fuel used by independent power producers. In this table, fuel used by independent power producers is included in the nonutility category.

${ }^{13}$ Includes fuel consumption by small power producers, independent power producers, and exempt wholesale generators, which produce electricity for sales to utilities.

${ }^{14}$ Estimated emissions from utilities and independent power producers.

EMM = Electricity market module.

N/A = Not applicable.

Note: Totals may not equal sum of components due to independent rounding.

Sources: 1993 (except for prices): Energy Information Administration (EIA), Annual Energy Review 1993, DOE/EIA-0384(93) (Washington, D.C., July 1994). Prices and all projections: EIA, AEO95 National Energy Modeling System run AEO95B.D1103942. 
Table 63. Electric Power Data and Projections for the EMM Region Southwest Power Pool (SPP)

\begin{tabular}{l|l|l|l|l|l|}
\hline \multirow{2}{*}{ Electricity Supply and Demand } & \multicolumn{3}{|c|}{ Reference Case } & $\begin{array}{c}\text { Annual } \\
\text { Growth } \\
1993-2010 \\
\text { (percent) }\end{array}$ \\
\cline { 2 - 6 } & 1993 & 2000 & 2005 & 2010 \\
\hline
\end{tabular}

Electricity Generating Capacity
(gigawatts)

Utilities

Coal Steam

Other Fossil Steam ${ }^{2} \ldots \ldots \ldots \ldots \ldots \ldots \ldots \ldots$

Combined Cycle $\ldots \ldots \ldots \ldots \ldots \ldots \ldots \ldots \ldots$

Combustion Turbine/Diesel $\ldots \ldots \ldots \ldots \ldots \ldots$

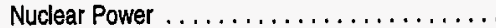

Pumped Storage/Other ${ }^{3} \ldots \ldots \ldots \ldots \ldots \ldots$

Renewable ${ }^{4} \ldots \ldots \ldots \ldots \ldots \ldots \ldots \ldots$

Total Utilities Capability $\ldots \ldots \ldots \ldots \ldots \ldots$.

27.09

30.41

1.19

4.27

4.83

0.50

2.46

70.76

Cumulative Planned Additions ${ }^{5}$

Coal Steam .....................

Other Fossil Steam ${ }^{2} \ldots \ldots \ldots \ldots \ldots \ldots \ldots \ldots$

Combined Cycle . ... . . . . . . . . . . . . . . . .

Combustion Turbine/Diesel . . . . . . . . . .

Nuclear Power . . . . . . . . . . . . . . . . . . . .

Pumped Storage/Other ${ }^{3} \ldots \ldots \ldots \ldots \ldots \ldots \ldots$

Renewable ${ }^{4}$.

Total (planned) . . . . . . . . . . . . . . . .

Cumulative Unplanned Additions

Coal Steam . ....................

Other Fossil Steam ${ }^{2} \ldots \ldots \ldots \ldots \ldots \ldots \ldots$

Combined Cycle . . . . . . . . . . . . . . .

Combustion Turbine/Diesel . . . . . . . . . . .

Nuclear Power . . . . . . . . . . . . . . . .

Pumped Storage/Other ${ }^{3} \ldots \ldots \ldots \ldots \ldots \ldots \ldots$

Renewable ${ }^{4} \ldots .$.

Total (unplanned)

$\ldots \ldots \ldots \ldots \ldots \ldots \ldots$

Cumulative Total Utility Additions .........

Cumulative Utility Retirements

............

Nonutilities Capacity (excludes cogenerators) (,7 $^{6}$

Coal Steam . . . . . . . . . . . . . . . .

Other Fossil Steam ${ }^{2} \ldots \ldots \ldots \ldots \ldots \ldots \ldots \ldots$

Combined Cycle . . . . . . . . . . . . . . .

Combustion Turbine/Diesel ................

Nuclear Power . ...................

Pumped Storage/Other ${ }^{8} \ldots \ldots \ldots \ldots \ldots \ldots \ldots$.

Renewable ${ }^{4}$

Total Nonutilities Capability

Cogenerators ${ }^{\circ}$

Capacity

Coal $\ldots \ldots \ldots \ldots \ldots \ldots \ldots \ldots \ldots \ldots \ldots$

Petroleum $\ldots \ldots \ldots \ldots \ldots \ldots \ldots \ldots \ldots$

Natural Gas . . . . . . . . . . . . . . . . . .

Renewables .....................

Other $\ldots \ldots \ldots \ldots \ldots \ldots \ldots \ldots \ldots \ldots$

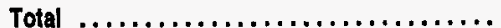

Electricity Demand

(billion kilowatthours)

Residential . . . . . . . . . . . . . . . . . . .

Commercial/Other . . . . . . . . . . . . . . .

Industrial $\ldots \ldots \ldots \ldots \ldots \ldots \ldots \ldots \ldots \ldots$

Transportation

Total Sales
0.00

0.00

0.00

0.01

0.00

0.00

0.00

0.01

0.00

0.00

0.00

0.00

0.00

0.00

0.00

0.00

0.01

0.91

0.00

0.04

0.00

0.09

0.00

0.00

0.22

0.35

0.41

0.12

2.23

0.86

0.00

3.62

86.42

69.34

88.15

1.30

245.20

27.20
28.10
1.50
4.87
4.83
0.50
2.54
69.54

28.49

25.59

1.94

4.98

4.83

0.50

2.54

68.88

0.36

0.00

0.37

0.60

0.00

0.00

0.08

1.41

1.54

0.00

0.82

1.00

0.00

0.00

0.08

3.43

$$
0.00
$$

0.00

0.00

0.00

0.00

0.00

0.00

0.00

1.41

3.54

0.00

0.00

0.00

0.00

0.00

0.00

0.00

0.00

3.43

6.22

0.00

0.04

0.00

0.09

0.00

0.00

0.24

0.37

0.48

0.21

2.55

0.92

0.00

4.16

0.50

0.23

2.83

0.93

0.00

4.48

0.52

91.53
75.41
97.71
1.85
266.50

93.89
77.47
105.86
2.71
279.92

99.01

80.58

112.09

3.66

295.33 
Table 63. Electric Power Data and Projections for the EMM Region Southwest Power Pool (SPP) (Continued)

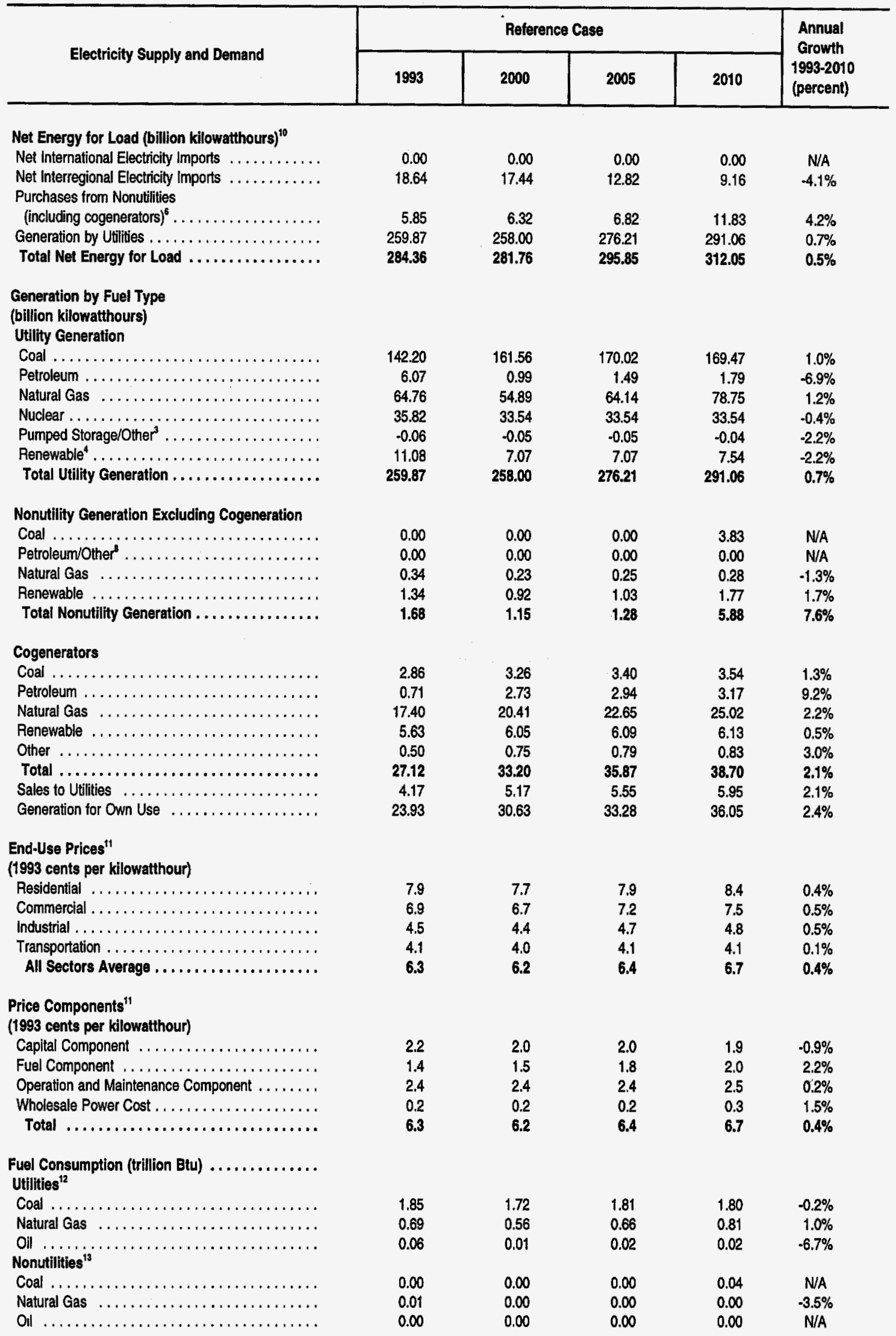


Table 63. Electric Power Data and Projections for the EMM Region Southwest Power Pool (SPP) (Continued)

\begin{tabular}{|c|c|c|c|c|c|}
\hline \multirow{2}{*}{ Electricity Supply and Demand } & \multicolumn{4}{|c|}{ Reference Case } & \multirow{2}{*}{$\begin{array}{l}\text { Annual } \\
\text { Growth } \\
\text { 1993-2010 } \\
\text { (percent) }\end{array}$} \\
\hline & 1993 & 2000 & 2005 & 2010 & \\
\hline \multicolumn{6}{|l|}{ Emissions (million metric tons) ${ }^{14}$} \\
\hline Total Carbon...$\ldots \ldots \ldots \ldots \ldots \ldots \ldots$ & 50.55 & 52.70 & 56.53 & 59.56 & $1.0 \%$ \\
\hline Carbon Dioxide $\ldots \ldots \ldots \ldots \ldots \ldots \ldots$ & 185.35 & 193.23 & 207.27 & 218.38 & $1.0 \%$ \\
\hline Sultur Dioxide $\ldots \ldots \ldots \ldots \ldots \ldots \ldots \ldots$ & 1.10 & 0.72 & 0.58 & 0.54 & $-4.1 \%$ \\
\hline
\end{tabular}

Net summer capability is the steady hourly output that generating equipment is expected to supply to system load (exclusive of auxiliary power), as demonstrated by tests during summer peak demand.

'2includes oil-, gas-, and dual-fired capability.

${ }^{3}$ Other includes methane, propane gas, and blast furnace gas.

Includes conventional hydroelectric, geothermal, wood, wood waste, municipal solid waste, other biomass, solar, and wind power.

${ }^{5}$ Cumulative additions after December 31, 1992.

"Electrcity was produced solely for sale to an electric utility or another end-user, and there is no business activity at the site (standard industrial classification 49).

${ }^{7}$ Nameplate capacity is reported for nonutilities on Form EIA-867, "Annual Nonutility Power Producer Report." Nameplate capacity is designated by the manufacturer. The nameplate capacity has been converted to net summer capacity based on historic relationships.

Other includes hydrogen, sulfur, batteries, chemicals, fish oil, and spent sulfite liquor.

Includes generators and cogenerators at facilities whose primary function is not electricity production (standard industrial classification other than 49).

${ }^{10}$ Generation to meet system load by source.

"Prices represent average revenue per kilowatthour.

${ }^{12}$ In the end-use energy consumptions tables, projected fuel consumption in the utility sector includes fuel used by independent power producers. In this table, fuel used by independent power producers is included in the nonutility category.

${ }^{13}$ Includes fuel consumption by small power producers, independent power producers, and exempt wholesale generators, which produce electricity for sales to utilities.

${ }^{14}$ Estimated emissions from utilities and independent power producers.

$E M M=$ Electricity market module.

N/A $=$ Not applicable.

Note: Totals may not equal sum of components due to independent rounding.

Sources: 1993 (except for prices): Energy Information Administration (EIA), Annual Energy Review 1993, DOE/EIA-0384(93) (Washington,

D.C., July 1994). Prices and all projections: EIA, AEO95 National Energy Modeling System run AEO95B.D1103942. 
Table 64. Electric Power Data and Projections for the EMM Region Western Systems Coordinating Council/Northwest Power Pool Area (WSCC/NWP)

\begin{tabular}{l|l|l|l|l|l}
\hline \multirow{2}{*}{ Electricity Supply and Demand } & \multicolumn{4}{|c|}{ Reference Case } & \multicolumn{2}{c|}{$\begin{array}{c}\text { Annual } \\
\text { Growth } \\
1993-2010 \\
\text { (percent) }\end{array}$} \\
\cline { 2 - 6 } & 1993 & 2000 & 2005 & 2010 & \multicolumn{1}{|c|}{} \\
\hline
\end{tabular}

\section{(gigawatts) \\ Utilities}

Electricity Generating Capacity'

Coal Steam $\ldots \ldots \ldots \ldots \ldots \ldots \ldots \ldots \ldots$

Other Fossil Steam ${ }^{2} \ldots \ldots \ldots \ldots \ldots \ldots \ldots$

Combined Cycle ......................

Combustion Turbine/Diesel ................

Nuclear Power .......................

Pumped Storage/Other ${ }^{3} \ldots \ldots \ldots \ldots \ldots \ldots$

Renewable ${ }^{4} \ldots \ldots \ldots \ldots \ldots \ldots \ldots \ldots \ldots$

Total Utilities Capability $\ldots \ldots \ldots \ldots \ldots \ldots$.

Cumulative Planned Additions $\mathbf{s}^{\mathbf{5}}$

Coal Steam $\ldots \ldots \ldots \ldots \ldots \ldots \ldots \ldots$

Other Fossil Steam ${ }^{2} \ldots \ldots \ldots \ldots \ldots \ldots \ldots$

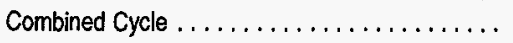

Combustion Turbine/Diesel ................

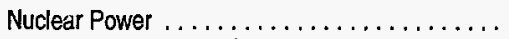

Pumped Storage/Other ${ }^{3}$. . . . . . . . . . . . . .

Renewable ${ }^{4}$

Total (planned) $\ldots \ldots \ldots \ldots \ldots \ldots \ldots \ldots$

$\begin{array}{rrrrr}10.87 & 10.79 & 11.19 & 12.34 & 0.8 \% \\ 0.79 & 0.57 & 0.47 & 0.42 & -3.7 \% \\ 0.49 & 1.52 & 2.33 & 2.79 & 10.7 \% \\ 0.98 & 1.93 & 1.93 & 1.93 & 4.1 \% \\ 1.10 & 1.10 & 1.10 & 1.10 & \text { N/A } \\ 0.31 & 0.31 & 0.31 & 0.31 & \text { N/A } \\ 34.27 & 34.88 & 34.88 & 34.95 & 0.1 \% \\ 48.81 & 51.11 & 52.22 & 53.84 & 0.6 \%\end{array}$

Cumulative Unplanned Additions $\mathbf{s}^{5}$

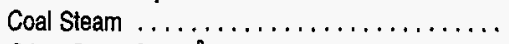

Other Fossil Steam ${ }^{2} \ldots \ldots \ldots \ldots \ldots \ldots \ldots$

Combined Cycle .......................

Combustion Turbine/Diesel ................

Nuclear Power .......................

Pumped Storage/Other ${ }^{3} \ldots \ldots \ldots \ldots \ldots \ldots$

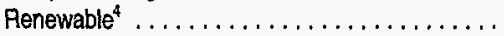

Total (unplanned)

Cumulative Total Utility Additions

Nonutilities Capacity (excludes cogenerators)

Coal Steam ........................

Other Fossil Steam ${ }^{2} \ldots \ldots \ldots \ldots \ldots \ldots \ldots$

Combined Cycle ......................

Combustion Turbine/Diesel ...............

Nuclear Power .......................

Pumped Storage/Other ${ }^{s}$. . . . . . . . . . . . . .

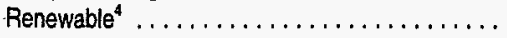

Total Nonutilities Capability

Cogenerators ${ }^{9}$

Capacity

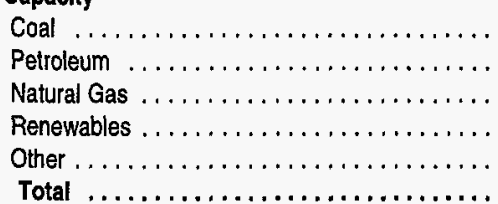

Electricity Demand

(billion kilowatthours)

Residential . . .

Commerciallother .....................

Industrial $\ldots \ldots \ldots \ldots \ldots \ldots \ldots \ldots \ldots \ldots$

Transportation $\ldots \ldots \ldots \ldots \ldots \ldots \ldots \ldots \ldots \ldots$

Total Sales

$\begin{array}{rrrrr}67.44 & 72.27 & 75.03 & 79.55 & 1.0 \% \\ 72.64 & 81.47 & 86.43 & 93.36 & 1.5 \% \\ 66.18 & 72.05 & 78.15 & 83.17 & 1.4 \% \\ 1.46 & 2.13 & 3.19 & 4.37 & 6.7 \% \\ 207.71 & 227.93 & 242.80 & 260.46 & 1.3 \%\end{array}$


Table 64. Electric Power Data and Projections for the EMM Region Western Systems Coordinating Council/Northwest Power Pool Area (WSCC/NWP) (Continued)

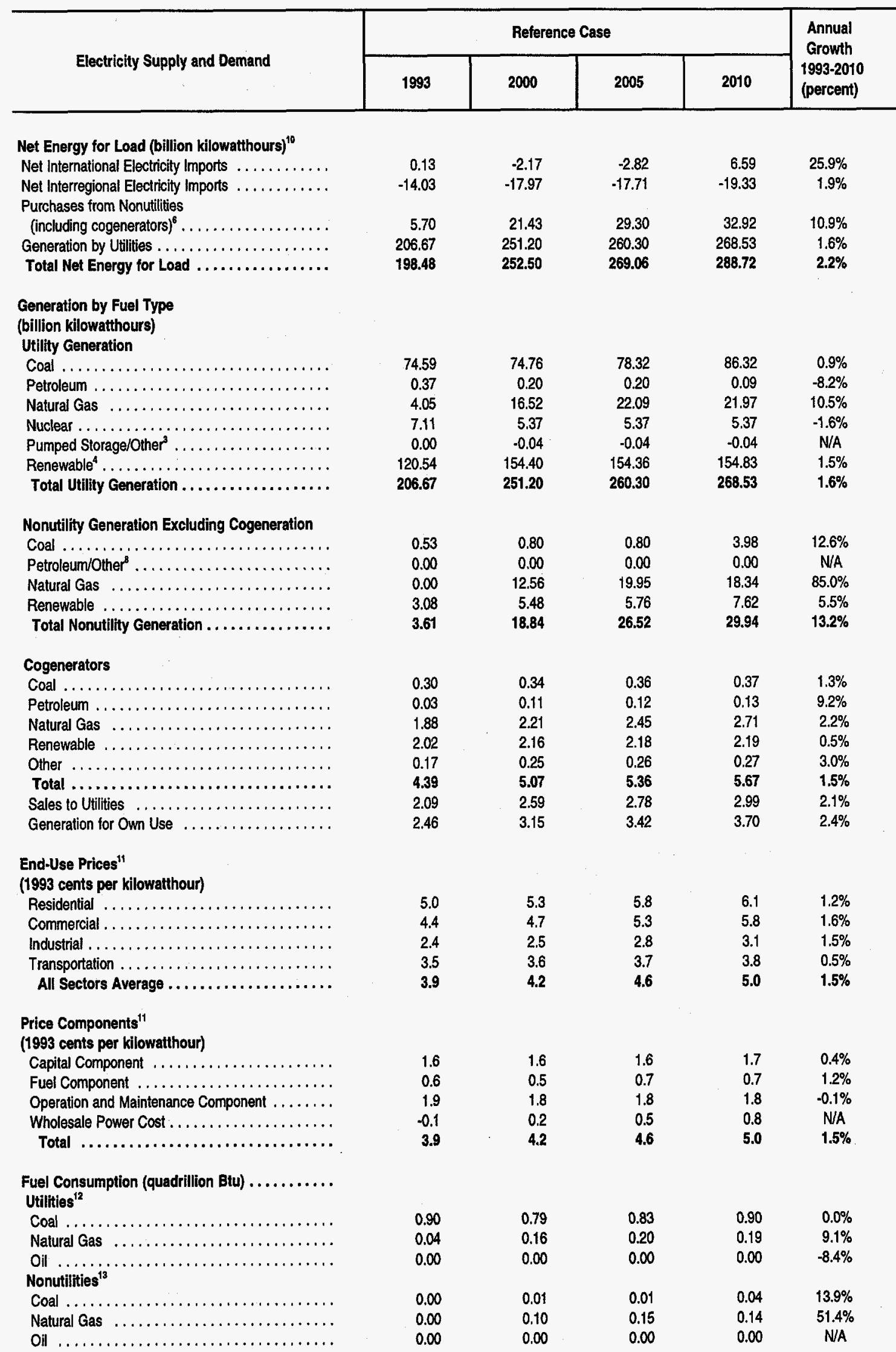




\section{Table 64. Electric Power Data and Projections for the EMM Region Western Systems Coordinating Council/Northwest Power Pool Area (WSCC/NWP) (Continued)}

\begin{tabular}{|c|c|c|c|c|c|}
\hline \multirow{2}{*}{ Electricity Supply and Demand } & \multicolumn{4}{|c|}{ Reference Case } & \multirow{2}{*}{$\begin{array}{c}\text { Annual } \\
\text { Growth } \\
1993-2010 \\
\text { (percent) }\end{array}$} \\
\hline & 1993 & 2000 & 2005 & 2010 & \\
\hline \multicolumn{6}{|l|}{ Emissions (million metric tons) } \\
\hline Total Carbon $\ldots \ldots \ldots \ldots$ & 23.05 & 24.19 & 26.55 & 29.06 & $1.4 \%$ \\
\hline Carbon Dioxide & 84.53 & 88.71 & 97.35 & 106.54 & $1.4 \%$ \\
\hline Sulfur Dioxide .. & 0.30 & 0.15 & 0.14 & 0.16 & $-3.5 \%$ \\
\hline
\end{tabular}

${ }^{1}$ Net summer capability is the steady hourly output that generating equipment is expected to supply to system load (exclusive of auxiliary power), as demonstrated by tests during summer peak demand.

Includes oil-, gas-, and dual-fired capability.

${ }^{3}$ Other includes methane, propane gas, and blast furnace gas.

"Includes conventional hydroelectric, geothermal, wood, wood waste, municipal solid waste, other biomass, solar, and wind power.

${ }^{5}$ Cumulative additions after December $31,1992$.

'Electrcity was produced solely for sale to an electric utility or another end-user, and there is no business activity at the site (standard industrial classification 49).

'Nameplate capacity is reported for nonutilities on Form EIA-867, "Annual Nonutility Power Producer Report." Nameplate capacity is designated

by the manufacturer. The nameplate capacity has been converted to net summer capacity based on historic relationships.

'Other includes hydrogen, sulfur, batteries, chemicals, fish oil, and spent sulfite liquor.

'Includes generators and cogenerators at facilities whose primary function is not electricity production (standard industrial classification other than 49).

${ }^{10}$ Generation to meet system load by source.

"Prices represent average revenue per kilowatthour.

${ }^{12}$ In the end-use energy consumptions tables, projected fuel consumption in the utility sector includes fuel used by independent power producers. In this table, fuel used by independent power producers is included in the nonutility category.

${ }^{13}$ Includes fuel consumption by small power producers, independent power producers, and exempt wholesale generators, which produce electricity for sales to utilities.

${ }^{14}$ Estimated emissions from utilities and independent power producers.

$E M M=$ Electricity market module.

N/A = Not applicable.

Note: Totals may not equal sum of components due to independent rounding.

Sources: 1993 (except for prices): Energy Information Administration (ElA), Annual Energy Review 1993, DOE/E|A-0384(93) (Washington, D.C., July 1994). Prices and all projections: EIA, AEO95 National Energy Modeling System run AEO95B.D1103942. 
Table 65. Electric Power and Projections for the EMM Region Western Systems Coordinating Council/Rocky Mountain Power Area and Arizona (WSCC/RA)

\begin{tabular}{|l|c|c|c|c|c|}
\hline \multirow{2}{*}{ Electricity Supply and Demand } & \multicolumn{4}{|c|}{ Reference Case } & \multicolumn{2}{c}{$\begin{array}{l}\text { Annual } \\
\text { Growth } \\
1993-2010 \\
\text { (percent) }\end{array}$} \\
\cline { 2 - 5 } & 1993 & 2000 & 2005 & 2010 & \\
\hline
\end{tabular}

Electricity Generating Capacity

(gigawatts)

Utilities

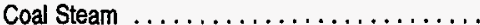

Other Fossil Steam ${ }^{2} \ldots \ldots \ldots \ldots \ldots \ldots \ldots \ldots \ldots$

Combined Cycle ......................

Combustion Turbine'Diesel ................

Nuclear Power .......................

Pumped Storage/Other ${ }^{3}$..................

Renewable ${ }^{4} \ldots \ldots \ldots \ldots \ldots \ldots \ldots \ldots \ldots$

Total Utilities Capability

13.68

2.77

0.95

1.91

1.71

0.68

3.99

25.68

Cumulative Planned Additions ${ }^{5}$

Coal Steam .......................

Other Fossil Steam ${ }^{2} \ldots \ldots \ldots \ldots \ldots \ldots \ldots . . . . .$.

Combined Cycle ......................

Combustion Turbine/Diesel ...............

Nuclear Power ........................

Pumped Storage/Other ${ }^{3}$..................

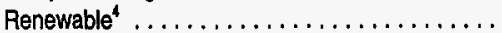

Total (planned)

Cumulative Unplanned Additions $^{5}$

Coal Steam ........................

Other Fossil Steam ${ }^{2}$. . . . . . . . . . . . . . . . .

Combined Cycle ......................

Combustion Turbine/Diesel .................

Nuclear Power .........................

Pumped Storage/Other ${ }^{3} \ldots \ldots \ldots \ldots \ldots \ldots \ldots$

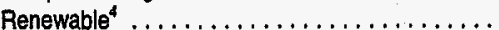

Total (unplanned)

Cumulative Total Utility Addítions

Cumulative Utility Retirements

.............

Nonutilities Capacity (excludes cogenerators) ${ }^{6,3}$

Coal Steam ........................

Other Fossil Steam ${ }^{2} \ldots \ldots \ldots \ldots \ldots \ldots \ldots . .$.

Combined Cycle ......................

Combustion Turbine/Diesel . . . . . . . . . . . . . . .

Nuclear Power .........................

Pumped Storage/Other ${ }^{8} \ldots \ldots \ldots \ldots \ldots \ldots \ldots$

Renewable ${ }^{4} \ldots \ldots \ldots \ldots \ldots \ldots \ldots \ldots$.

Total Nonutilitles Capability

Cogenerators ${ }^{9}$

\section{Capacity}

Coal ......

n.

Natural Gas .......................

Renewables .........................

Other.

Total

Electricity Demand

(billion kilowatthours)

Residential ........................

Commercial/Other .....................

Industrial $\ldots \ldots \ldots \ldots \ldots \ldots \ldots \ldots \ldots, \ldots$

Transportation $\ldots \ldots \ldots \ldots \ldots \ldots \ldots \ldots \ldots$

Total Sales . . . .

0,00

0.00

0.03

0.13

0.00

0.00

0.00

0.01

0.00

0.00

0.35

0.36

0.08

0.09

0.00

0.00

0.54

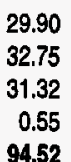

14.49
2.28
1.48
2.54
1.71
0.72
4.06
27.28

14.43
1.95
1.86
2.77
1.71
0.72
4.07
27.51

15.16

1.65

2.09

2.79

171

0.72

4.68

28.81

$0.6 \%$

$-3.0 \%$

$4.7 \%$

$2.3 \%$

N/A

$0.3 \%$

$0.9 \%$

$0.7 \%$

$\begin{array}{ll}0.00 & 0.99 \\ 0.00 & 0.00 \\ 0.00 & 0.03 \\ 0.00 & 0.25 \\ 0.00 & 0.00 \\ 0.00 & 0.04 \\ 0.03 & 0.07 \\ 0.03 & 1.38\end{array}$

$\begin{array}{lll}0.99 & 1.20 & \text { N/A } \\ 0.00 & 0.00 & \text { N/A } \\ 0.21 & 0.39 & \text { N/A } \\ 0.38 & 0.38 & \text { N/A } \\ 0.00 & 0.00 & \text { N/A } \\ 0.04 & 0.04 & \text { N/A } \\ 0.07 & 0.07 & 4.8 \% \\ 1.69 & 2.08 & 28.1 \%\end{array}$

0.00

0.00

0.50

0.05

0.00

0.00

0.04

0.58

1.96

0.80

0.02

0.00

0.70

0.15

0.00

0.00

0.05

0.92

2.61

1.22

$\begin{array}{ll}0.66 & \text { N/A } \\ 0.00 & \text { N/A } \\ 0.74 & \text { N/A } \\ 0.16 & \text { N/A } \\ 0.00 & \text { N/A } \\ 0.00 & \text { N/A } \\ 0.66 & \text { N/A } \\ 2.22 & \text { N/A } \\ & \\ 4.30 & 33.7 \% \\ 1.61 & 16.0 \%\end{array}$

0.00
0.00
0.30
0.20
0.00
0.00
0.56
1.06

0.02

0.00

0.90

0.23

0.00

0.00

0.56

1.71

$\begin{array}{lc}0.15 & \text { N/A } \\ 0.00 & \text { N/A } \\ 0.96 & \text { N/A } \\ 0.35 & 26.0 \% \\ 0.00 & \text { N/A } \\ 0.00 & \text { N/A } \\ 1.31 & 8.0 \% \\ 2.77 & 12.7 \%\end{array}$

0.09

0.16

0.42

0.00

0.00

0.10
0.17
0.47
0.00
0.00
0.74

0.10

0.18

0.52

0.00

0.00

0.80

$1.4 \%$

$4.2 \%$

$2.0 \%$

N/A

N/A

$\mathrm{N} / \mathrm{A}$
$2.4 \%$

33.10
35.88
34.06
0.80
103.84

34.90
36.51
36.93
1.18
109.51

37.65

37.41

39.29

$1.4 \%$

$0.8 \%$

$1.3 \%$

$\begin{array}{rr}1.61 & 6.5 \% \\ 115.97 & 1.2 \%\end{array}$ 
Table 65. Electric Power and Projections for the EMM Region Western Systems Coordinating Council/Rocky Mountain Power Area and Arizona (WSCC/RA) (Continued)

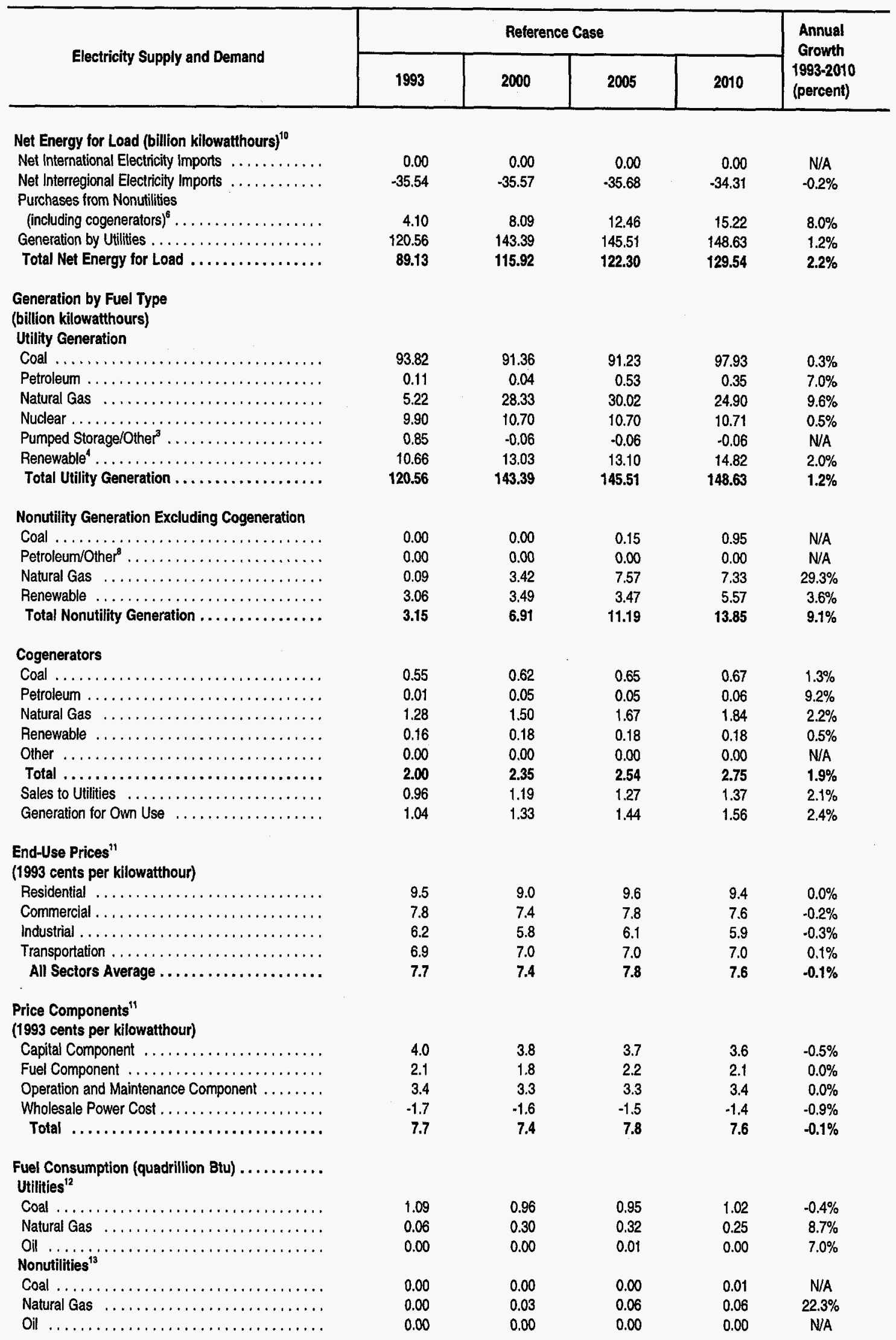


Table 65. Electric Power and Projections for the EMM Region

Western Systems Coordinating Council/Rocky Mountain Power Area and Arizona (WSCC/RA) (Continued)

\begin{tabular}{|c|c|c|c|c|c|}
\hline \multirow{2}{*}{ Electricity Supply and Demand } & \multicolumn{4}{|c|}{ Reference Case } & \multirow{2}{*}{$\begin{array}{l}\text { Annual } \\
\text { Growth } \\
\text { 1993-2010 } \\
\text { (percent) }\end{array}$} \\
\hline & 1993 & 2000 & 2005 & 2010 & \\
\hline \multicolumn{6}{|l|}{ Emissions (million metric tons) } \\
\hline Total Carbon $\ldots \ldots \ldots \ldots$ & 28.43 & 29.24 & 29.97 & 30.78 & $0.5 \%$ \\
\hline Carbon Dioxide & 104.26 & 107.20 & 109.90 & 112.85 & $0.5 \%$ \\
\hline Sulfur Dioxide ... & 0.54 & 0.20 & 0.20 & 0.20 & $-5.7 \%$ \\
\hline
\end{tabular}

'Net summer capability is the steady hourly output that generating equipment is expected to supply to system load (exclusive of auxiliary power), as demonstrated by tests during summer peak demand.

Includes oil-, gas-, and dual-fired capability.

${ }^{3}$ Other includes methane, propane gas, and blast furnace gas.

"Includes conventional hydroelectric, geothermal, wood, wood waste, municipal solid waste, other biomass, solar, and wind power.

${ }^{5}$ Cumulative additions after December 31, 1992.

'Electrcity was produced solely for sale to an electric utility or another end-user, and there is no business activity at the site (standard industrial classification 49 ).

"Nameplate capacity is reported for nonutilities on Form EłA-867, "Annual Nonutility Power Producer Report." Nameplate capacity is designated by the manufacturer. The nameplate capacity has been converted to net summer capacity based on historic relationships.

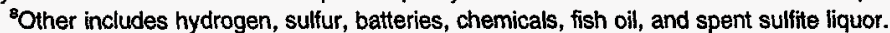

'Includes generators and cogenerators at facilities whose primary function is not electricity production (standard industrial classification other than 49).

${ }^{10}$ Generation to meet system load by source.

${ }^{11}$ Prices represent average revenue per kllowatthour.

${ }^{12}$ In the end-use energy consumptions tables, projected fuel consumption in the utility sector includes fuel used by independent power producers. In this table, fuel used by independent power producers is included in the nonutility category.

${ }^{13}$ Includes fuel consumption by small power producers, independent power producers, and exempt wholesale generators, which produce electricity for sales to utilities.

${ }^{14}$ Estimated emissions from utilities and independent power producers.

EMM = Electricity market module.

N/A $=$ Not applicable.

Note: Totals may not equal sum of components due to independent rounding.

Sources: 1993 (except for prices): Energy Information Administration (EIA), Annual Energy Review 1993, DOE/EIA-0384(93) (Washington, D.C., July 1994). Prices and all projections: EIA, AEO95 National Energy Modeling System run AEO95B.D1103942. 
Table 66. Electric Power and Projections for the EMM Region Western Systems Coordinating Council/California-Southern Nevada Power (WSCC/CNV)

\begin{tabular}{l|l|l|l|l|l}
\hline \multirow{2}{*}{ Electricity Supply and Demand } & \multicolumn{4}{|c|}{ Relerence Case } & \multicolumn{2}{c}{$\begin{array}{c}\text { Annual } \\
\text { Growth } \\
1993-2010 \\
\text { (percent) }\end{array}$} \\
\cline { 2 - 5 } & 1993 & 2000 & 2005 & 2010 & \multicolumn{3}{|c|}{} \\
\hline
\end{tabular}

\begin{tabular}{|c|c|c|c|c|c|}
\hline \multicolumn{6}{|l|}{$\begin{array}{l}\text { Electricity Generating Capacity' } \\
\text { (gigawatts) } \\
\text { Utilities }\end{array}$} \\
\hline Coal Steam $\ldots \ldots \ldots \ldots \ldots$ & 4.24 & 4.29 & 6.46 & 9.29 & $4.7 \%$ \\
\hline Other Fossil Steam ${ }^{2}$ & 21.48 & 20.53 & 20.06 & 19.66 & $-0.5 \%$ \\
\hline Combined Cycle $\ldots \ldots \ldots \ldots \ldots \ldots \ldots$ & 1.54 & 1.85 & 1.85 & 1.85 & $1.1 \%$ \\
\hline Combustion Turbine/Diesel $\ldots \ldots \ldots \ldots \ldots \ldots$ & 2.38 & 2.95 & 3.41 & 3.41 & $2.1 \%$ \\
\hline Nuclear Power.$\ldots \ldots \ldots \ldots \ldots \ldots \ldots$ & 6.41 & 6.41 & 6.41 & 4.25 & $-2.4 \%$ \\
\hline Pumped Storage/Other ${ }^{3} \ldots \ldots \ldots \ldots \ldots \ldots$ & 3.73 & 3.83 & 3.83 & 3.83 & $0.2 \%$ \\
\hline Renewable ${ }^{4} \ldots \ldots \ldots \ldots \ldots \ldots \ldots \ldots$ & 12.35 & 12.52 & 12.90 & 13.92 & $0.7 \%$ \\
\hline Total Utilities Capability $\ldots \ldots \ldots \ldots \ldots \ldots$ & 52.13 & 52.38 & 54.92 & 56.21 & $0.4 \%$ \\
\hline \multicolumn{6}{|l|}{ Cumulative Planned Additions $s^{5}$} \\
\hline Coal Steam $\ldots \ldots \ldots \ldots \ldots$ & 0.00 & 0.05 & 1.92 & 2.67 & N/A \\
\hline Other Fossil Steam ${ }^{2} \ldots \ldots \ldots \ldots \ldots \ldots$ & 0.00 & 0.00 & 0.00 & 0.00 & NA \\
\hline Combined Cycle $\ldots \ldots \ldots \ldots \ldots \ldots \ldots$ & 0.00 & 0.30 & 0.30 & 0.30 & N/A \\
\hline Combustion Turbine/Diesel . .............. & 0.00 & 0.63 & 1.10 & 1.10 & N/A \\
\hline Nuclear Power ..................... & 0.00 & 0.00 & 0.00 & 0.00 & N/A \\
\hline Pumped Storage/Other ${ }^{3} \ldots \ldots \ldots \ldots \ldots \ldots$ & 0.00 & 0.10 & 0.10 & 0.10 & N/A \\
\hline Renewable ${ }^{4} \ldots \ldots \ldots \ldots \ldots \ldots \ldots \ldots$ & 0.16 & 0.26 & 0.26 & 0.26 & $3.0 \%$ \\
\hline Total (planned) $\ldots \ldots \ldots \ldots \ldots \ldots \ldots \ldots$ & 0.16 & 1.34 & 3.68 & 4.43 & $21.7 \%$ \\
\hline \multicolumn{6}{|l|}{ Cumulative Unplanned Additions ${ }^{5}$} \\
\hline Coal Steam $\ldots \ldots \ldots \ldots \ldots \ldots \ldots \ldots \ldots$ & 0.00 & 0.00 & 0.30 & 2.37 & N/A \\
\hline Other Fossil Steam ${ }^{2} \ldots \ldots \ldots \ldots \ldots \ldots$ & 0.00 & 0.00 & 0.00 & 0.00 & N/A \\
\hline 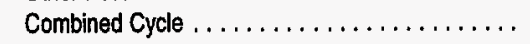 & 0.00 & 0.00 & 0.00 & 0.00 & N/A \\
\hline Combustion Turbine/Diesel . . ............. & 0.00 & 0.00 & 0.01 & 0.01 & $\mathrm{~N} / \mathrm{A}$ \\
\hline Nuclear Power.$\ldots \ldots \ldots \ldots \ldots \ldots \ldots$ & 0.00 & 0.00 & 0.00 & 0.00 & N/A \\
\hline Pumped Storage/Other ${ }^{3}$ & 0.00 & 0.00 & 0.00 & 0.00 & N/A \\
\hline Renewable ${ }^{4} \ldots \ldots \ldots \ldots \ldots \ldots \ldots \ldots$ & 0.00 & 0.05 & 0.43 & 1.45 & N/A \\
\hline Total (unplanned) $\ldots \ldots \ldots \ldots \ldots \ldots$ & 0.00 & 0.05 & 0.74 & 3.84 & N/A \\
\hline Cumulative Total Utility Additions ........... & 0.16 & 1.39 & 4.42 & 8.27 & $26.3 \%$ \\
\hline Cumulative Utility Retirements $\ldots \ldots \ldots \ldots \ldots$ & 1.52 & 2.54 & 3.03 & 5.58 & $7.9 \%$ \\
\hline \multicolumn{6}{|l|}{ Nonutilities Capacity (excludes cogenerators) ${ }^{6,7}$} \\
\hline 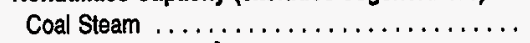 & 0.02 & 0.02 & 0.27 & 1.99 & $31.6 \%$ \\
\hline Other Fossil Steam ${ }^{2}$. & 0.12 & 0.16 & 0.16 & 0.16 & $1.5 \%$ \\
\hline Combined Cycle ..................... & 0.12 & 0.12 & 0.12 & 0.12 & N/A \\
\hline Combustion Turbine/Diesel $\ldots \ldots \ldots \ldots \ldots \ldots$ & 0.66 & 0.66 & 0.67 & 0.67 & $0.1 \%$ \\
\hline Nuclear Power...$\ldots \ldots \ldots \ldots \ldots \ldots$. & 0.00 & 0.00 & 0.00 & 0.00 & N/A \\
\hline Pumped Storage/Other" $\ldots \ldots \ldots \ldots \ldots \ldots \ldots$ & 0.00 & 0.00 & 0.00 & 0.00 & N/A \\
\hline Renewable ${ }^{4} \ldots \ldots \ldots \ldots \ldots \ldots \ldots$ & 4.08 & 5.23 & 6.16 & 8.61 & $4.5 \%$ \\
\hline Total Nonutilities Capability...$\ldots \ldots \ldots \ldots$ & 5.00 & 6.19 & 7.39 & 11.55 & $5.0 \%$ \\
\hline \multicolumn{6}{|l|}{$\begin{array}{l}\text { Cogenerators } \\
\text { Capacity }\end{array}$} \\
\hline Coal $\ldots \ldots \ldots$ & 0.39 & 0.46 & 0.48 & 0.50 & $1.4 \%$ \\
\hline$\ldots \ldots \ldots \ldots \ldots$ & 0.13 & 0.22 & 0.24 & 0.26 & $4.2 \%$ \\
\hline Natural Gas ........ & 3.85 & 4.41 & 4.89 & 5.40 & $2.0 \%$ \\
\hline 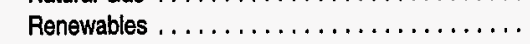 & 0.31 & 0.33 & 0.33 & 0.33 & $0.5 \%$ \\
\hline Other $\ldots \ldots \ldots \ldots \ldots \ldots \ldots \ldots \ldots \ldots \ldots \ldots$ & 0.00 & 0.00 & 0.00 & 0.00 & N/A \\
\hline Total $\ldots \ldots \ldots \ldots \ldots \ldots \ldots \ldots \ldots \ldots \ldots \ldots \ldots \ldots \ldots$ & 4.68 & 5.42 & 5.94 & 6.49 & $1.9 \%$ \\
\hline \multicolumn{6}{|l|}{$\begin{array}{l}\text { Electricity Demand } \\
\text { (billion kilowatthours) }\end{array}$} \\
\hline 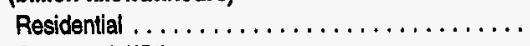 & 74.52 & 78.70 & 81.09 & 85.27 & $0.8 \%$ \\
\hline 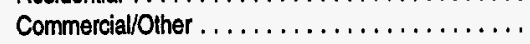 & 79.16 & 89.64 & 96.72 & 106.58 & $1.8 \%$ \\
\hline Industrial $\ldots \ldots \ldots \ldots \ldots \ldots \ldots \ldots$ & 71.01 & 77.41 & 83.96 & 89.35 & $1.4 \%$ \\
\hline Transportation ....... & 1.70 & 2.49 & 3.75 & 5.14 & $6.7 \%$ \\
\hline Total Sales $\ldots \ldots \ldots \ldots \ldots \ldots \ldots \ldots \ldots \ldots$ & 226.39 & 248.24 & 265.53 & 286.34 & $1.4 \%$ \\
\hline
\end{tabular}


Table 66. Electric Power and Projections for the EMM Region

Western Systems Coordinating Council/California-Southern Nevada Power (WSCC/CNV) (Continued)

\begin{tabular}{|c|c|c|c|c|c|}
\hline \multirow{2}{*}{ Electricity Supply and Demand } & \multicolumn{4}{|c|}{ Reference Case } & \multirow{2}{*}{$\begin{array}{l}\text { Annual } \\
\text { Growth } \\
1993-2010 \\
\text { (percent) }\end{array}$} \\
\hline & 1993 & 2000 & 2005 & 2010 & \\
\hline \multicolumn{6}{|l|}{ Net Energy for Load (billion kilowatthours) ${ }^{10}$} \\
\hline Net International Electricity Imports $\ldots \ldots \ldots \ldots$. & 2.81 & 6.88 & 12.69 & 19.78 & $12.2 \%$ \\
\hline Net Interregional Electricity Imports . . ......... & 52.79 & 56.88 & 56.75 & 56.82 & $0.4 \%$ \\
\hline \multicolumn{6}{|l|}{ Purchases from Nonutilities } \\
\hline (including cogenerators) ${ }^{6} \ldots$ & 52.26 & 54.16 & 60.58 & 84.42 & $2.9 \%$ \\
\hline 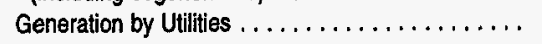 & 166.23 & 151.79 & 158.50 & 150.19 & $-0.6 \%$ \\
\hline Total Net Energy for Load . ............. & 274.09 & 269.71 & 288.52 & 311.21 & $0.7 \%$ \\
\hline \multicolumn{6}{|l|}{$\begin{array}{l}\text { Generation by Fuel Type } \\
\text { (billion kilowatthours) } \\
\text { Utility Generation }\end{array}$} \\
\hline 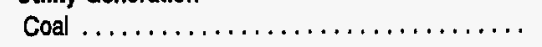 & 26.87 & 28.19 & 40.23 & 61.73 & $5.0 \%$ \\
\hline 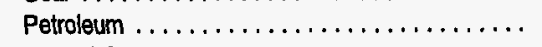 & 2.03 & 2.99 & 2.88 & 0.65 & $-6.5 \%$ \\
\hline 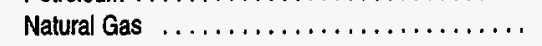 & 46.58 & 40.07 & 33.24 & 9.56 & $-8.9 \%$ \\
\hline Nuclear .............. & 43.73 & 46.63 & 46.63 & 38.83 & $-0.7 \%$ \\
\hline Pumped Storage/Other ${ }^{3} . . . \ldots \ldots \ldots \ldots . . .$. & 1.65 & -0.50 & -0.50 & -0.50 & N/A \\
\hline Renewable ${ }^{4} \ldots \ldots \ldots \ldots \ldots \ldots \ldots$ & 45.36 & 34.41 & 36.01 & 39.92 & $-0.7 \%$ \\
\hline Total Utility Generation ................ & 166.23 & 151.79 & 158.50 & 150.19 & $-0.6 \%$ \\
\hline \multicolumn{6}{|l|}{ Nonutility Generation Excluding Cogeneration } \\
\hline Coal $\ldots \ldots \ldots \ldots \ldots \ldots \ldots \ldots \ldots \ldots \ldots \ldots \ldots \ldots \ldots \ldots \ldots$ & 0.11 & 0.13 & 1.81 & 13.33 & $32.3 \%$ \\
\hline Petroleum/Other $\ldots \ldots \ldots \ldots \ldots \ldots \ldots \ldots$ & 0.85 & 0.00 & 0.00 & 0.00 & N/A \\
\hline Natural Gas $\ldots \ldots \ldots \ldots \ldots \ldots \ldots \ldots$ & 7.67 & 1.24 & 0.92 & 0.64 & $-13.6 \%$ \\
\hline 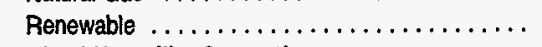 & 16.52 & 19.16 & 21.76 & 31.70 & $3.9 \%$ \\
\hline Total Nonutility Generation ............... & 25.16 & 20.53 & 24.49 & 45.67 & $3.6 \%$ \\
\hline \multicolumn{6}{|l|}{ Cogenerators } \\
\hline 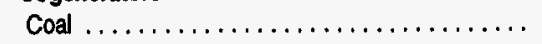 & 3.22 & 3.66 & 3.81 & 3.98 & $1.3 \%$ \\
\hline Petroleum ......................... & 1.05 & 4.00 & 4.31 & 4.65 & $9.2 \%$ \\
\hline Natural Gas $\ldots \ldots \ldots \ldots \ldots \ldots \ldots \ldots \ldots$ & 30.93 & 36.29 & 40.27 & 44.48 & $2.2 \%$ \\
\hline Renewable ....................... & 2.05 & 2.20 & 2.22 & 2.23 & $0.5 \%$ \\
\hline Other $\ldots \ldots \ldots \ldots \ldots \ldots \ldots \ldots \ldots \ldots \ldots$ & 0.02 & 0.03 & 0.03 & 0.03 & $3.0 \%$ \\
\hline Total $\ldots \ldots \ldots \ldots \ldots \ldots \ldots \ldots \ldots \ldots \ldots \ldots \ldots \ldots \ldots$ & 37.26 & 46.17 & 50.64 & 55.37 & $2.4 \%$ \\
\hline Sales to Utilities...$\ldots \ldots \ldots \ldots \ldots \ldots$ & 27.11 & 33.62 & 36.09 & 38.74 & $2.1 \%$ \\
\hline Generation for Own Use $\ldots \ldots \ldots \ldots \ldots \ldots$ & 9.12 & 11.68 & 12.69 & 13.74 & $2.4 \%$ \\
\hline \multicolumn{6}{|l|}{$\begin{array}{l}\text { End-Use Prices" } \\
\text { (1993 cents per kilowatthour) }\end{array}$} \\
\hline Residential $\ldots \ldots \ldots \ldots \ldots \ldots \ldots \ldots \ldots$ & 10.7 & 11.0 & 11.6 & 12.4 & $0.9 \%$ \\
\hline Commercial ......................... & 10.0 & 10.2 & 10.9 & 11.7 & $0.9 \%$ \\
\hline 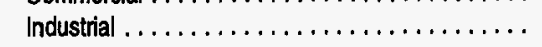 & 7.6 & 7.6 & 8.1 & 8.6 & $0.8 \%$ \\
\hline Transportation...$\ldots \ldots \ldots \ldots \ldots \ldots$ & 6.5 & 7.0 & 7.3 & 7.7 & $1.0 \%$ \\
\hline All Sectors Average . .................... & 9.4 & 9.6 & 10.2 & 10.9 & $0.9 \%$ \\
\hline \multicolumn{6}{|l|}{$\begin{array}{l}\text { Price Components" } \\
\text { (1993 cents per kilowatthour) }\end{array}$} \\
\hline 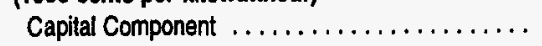 & 2.7 & 3.0 & 3.1 & 3.6 & $1.6 \%$ \\
\hline 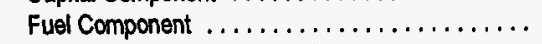 & 0.8 & 0.7 & 0.8 & 0.5 & $-2.2 \%$ \\
\hline Operation and Maintenance Component ........ & 4.3 & 4.3 & 4.3 & 4.3 & $0.0 \%$ \\
\hline Wholesale Power Cost ................. & 1.5 & 1.6 & 1.9 & 2.5 & $2.8 \%$ \\
\hline Total $\ldots \ldots \ldots \ldots \ldots \ldots \ldots \ldots \ldots \ldots \ldots \ldots \ldots \ldots$ & 9.4 & 9.6 & 10.2 & 10.9 & $0.9 \%$ \\
\hline \multicolumn{6}{|l|}{$\begin{array}{l}\text { Fuel Consumption (quadrillion Btu) } \ldots \ldots \ldots \ldots \text {. } \\
\text { Utilities }^{12}\end{array}$} \\
\hline Coal $\ldots \ldots \ldots \ldots \ldots \ldots \ldots \ldots \ldots \ldots \ldots \ldots$ & 0.27 & 0.31 & 0.44 & 0.65 & $5.3 \%$ \\
\hline 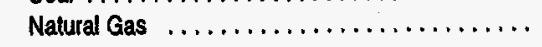 & 0.48 & 0.41 & 0.33 & 0.09 & $-9.2 \%$ \\
\hline 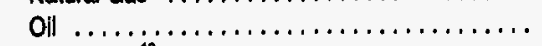 & 0.02 & 0.03 & 0.03 & 0.01 & $-6.8 \%$ \\
\hline \multicolumn{6}{|l|}{ Nonutilities ${ }^{43}$} \\
\hline 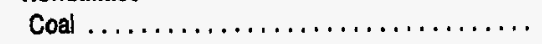 & 0.00 & 0.00 & 0.02 & 0.13 & $29.4 \%$ \\
\hline 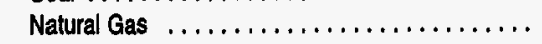 & 0.15 & 0.01 & 0.01 & 0.01 & $-17.4 \%$ \\
\hline \multirow[t]{2}{*}{ 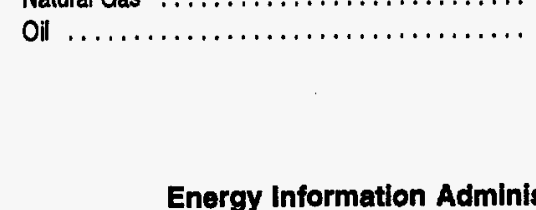 } & 0.01 & 0.00 & 0.00 & 0.00 & N/A \\
\hline & on/ SupF & nt to the & ual Ene & utlook 1995 & 229 \\
\hline
\end{tabular}


Table 66. Electric Power and Projections for the EMM Region Western Systems Coordinating Council/California-Southern Nevada Power (WSCC/CNV) (Continued)

\begin{tabular}{|c|c|c|c|c|c|}
\hline \multirow{2}{*}{ Electricity Supply and Demand } & \multicolumn{4}{|c|}{ Reference Case } & \multirow{2}{*}{$\begin{array}{l}\text { Annual } \\
\text { Growth } \\
1993-2010 \\
\text { (percent) }\end{array}$} \\
\hline & 1993 & 2000 & 2005 & 2010 & \\
\hline \multicolumn{6}{|l|}{ Emissions (million metric tons) ${ }^{14}$} \\
\hline Total Carbon ................ & 14.03 & 14.61 & 17.01 & 21.26 & $2.5 \%$ \\
\hline Carbon Dioxide $\ldots$ & 51.45 & 53.56 & 62.35 & 77.96 & $2.5 \%$ \\
\hline Sulfur Dioxide .... . & 0.12 & 0.07 & 0.08 & 0.10 & $-0.8 \%$ \\
\hline
\end{tabular}

'Net summer capability is the steady hourly output that generating equipment is expected to supply to system load (exclusive of auxiliary power), as demonstrated by tests during summer peak demand.

Includes oil-, gas-, and dual-fired capability.

${ }^{3}$ Other includes methane, propane gas, and blast furnace gas.

4Includes conventional hydroelectric, geothermal, wood, wood waste, municipal solid waste, other biomass, solar, and wind power.

${ }^{5}$ Cumulative additions after December 31, 1992.

"Electrcity was produced solely for sale to an electric utility or another end-user, and there is no business activity at the site (standard industrial classification 49).

7Nameplate capacity is reported for nonutilities on Form ElA-867, "Annual Nonutility Power Producer Report." Nameplate capacity is designated by the manufacturer. The nameplate capacity has been converted to net summer capacity based on historic relationships.

${ }^{8}$ Other includes hydrogen, sulfur, batteries, chemicals, fish oil, and spent sulfite liquor.

Includes generators and cogenerators at facilities whose primary function is not electricity production (standard industrial classification other than 49).

${ }^{10} \mathrm{Generation}$ to meet system load by source.

${ }^{11}$ Prices represent average revenue per kilowatthour.

${ }^{12}$ In the end-use energy consumptions tables, projected fuel consumption in the utility sector includes fuel used by independent power producers. In this table, fuel used by independent power producers is included in the nonutility category.

${ }^{13}$ Includes fuel consumption by small power producers, independent power producers, and exempt wholesale generators, which produce electricity for sales to utilities.

${ }^{14}$ Estimated emissions from utilities and independent power producers.

EMM = Electricity market module.

N/A = Not applicable.

Note: Totals may not equal sum of components due to independent rounding

Sources: 1993 (except for prices): Energy Information Administration (EIA), Annual Energy Review 1993, DOE/EIA-0384(93) (Washington, D.C., July 1994). Prices and all projections: EIA, AEO95 National Energy Modeling System run AEO95B.D1103942. 
Table 67. Electric Power and Projections for the United States

\begin{tabular}{l|l|l|l|l|l}
\hline \multirow{2}{*}{ Electricity Supply and Demand } & \multicolumn{4}{|c|}{ Reference Case } & $\begin{array}{l}\text { Annual } \\
\text { Growth } \\
1993-2010 \\
\text { (percent) }\end{array}$ \\
\cline { 2 - 6 } & 1993 & 2000 & 2005 & 2010 \\
\hline
\end{tabular}

Electricity Generating Capacity'
(gigawatts)

Utilities

Coal Steam ........

Other Fossil Steam

$\begin{array}{rrrrr}300.66 & 297.10 & 301.09 & 306.36 & 0.1 \% \\ 141.27 & 130.39 & 124.33 & 120.41 & -0.9 \% \\ 9.71 & 17.68 & 23.39 & 27.20 & 6.2 \% \\ 49.21 & 65.87 & 70.96 & 77.76 & 2.7 \% \\ 99.04 & 101.31 & 101.31 & 88.74 & -0.6 \% \\ 19.05 & 20.05 & 20.05 & 20.05 & 0.3 \% \\ 76.78 & 78.10 & 78.87 & 81.58 & 0.4 \% \\ 695.70 & 710.48 & 719.96 & 722.06 & 0.2 \%\end{array}$

Combined Cycle ......................

Combustion Turbine/Diesel ................

Nuclear Power .......................

Pumped Storage/Other ${ }^{3}$.................

Renewable ${ }^{4}$.

Total Utilities Capability $\ldots \ldots \ldots \ldots \ldots \ldots$

695.70

Cumulative Planned Additions $\mathbf{s}^{5}$

Coal Steam .......................

Other Fossil Steam ${ }^{2} \ldots \ldots \ldots \ldots \ldots \ldots \ldots$

Combined Cycle ......................

Combustion Turbine/Diesel ................

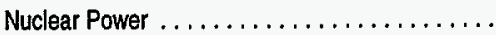

Pumped Storage/Other ${ }^{3} \ldots \ldots \ldots \ldots \ldots \ldots$.

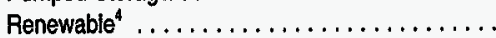

Total (planned) $\ldots \ldots \ldots \ldots \ldots \ldots \ldots \ldots$

Cumulative Unplanned Additions ${ }^{5}$

Coal Steam ........................

Other Fossil Steam ${ }^{2} \ldots \ldots \ldots \ldots \ldots \ldots \ldots$.

Combined Cycle .........................

Combustion Turbine/Diesel ...............

Nuclear Power . .......................

Pumped Storage/Other ${ }^{3} \ldots \ldots \ldots \ldots \ldots \ldots$

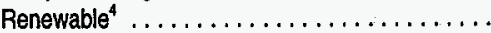

Total (unplanned) $\ldots \ldots \ldots \ldots \ldots \ldots \ldots$

Cumulative Total Utility Additions

$\begin{array}{rrr}11.98 & 13.74 & \text { N/A } \\ 0.00 & 0.00 & \text { N/A } \\ 11.79 & 12.38 & \text { N/A } \\ 22.41 & 22.77 & \text { N/A } \\ 3.49 & 3.49 & \text { N/A } \\ 1.29 & 1.29 & \text { N/A } \\ 1.15 & 1.15 & \text { N/A } \\ 52.11 & 54.82 & \text { N/A }\end{array}$

Cumulative Utility Retirements

Nonutilities Capacity (excludes cogenerators) (.7 $^{6,7}$

Coal Steam ........................

Other Fossil Steam ${ }^{2} \ldots \ldots \ldots \ldots \ldots \ldots \ldots \ldots$

Combined Cycle .....................

Combustion Turbine/Diesel ................

Nuclear Power ......................

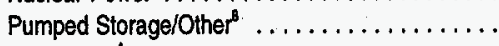

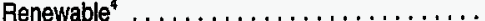

Total Nonutilities Capability

1.82
0.25
5.29
2.80
0.00
0.00
13.45
23.61

\section{Cogenerators ${ }^{9}$}

\section{Capacity}

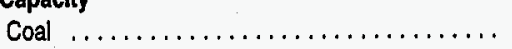

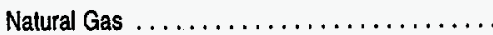

Renewables ........................

Other

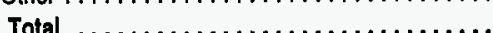

$\begin{array}{rl}8.72 & 1.4 \% \\ 6.81 & 4.2 \% \\ 29.52 & 2.0 \% \\ 7.51 & 0.5 \% \\ 0.03 & \mathrm{~N} / \mathrm{A} \\ \mathbf{5 2 . 5 9} & 1.9 \%\end{array}$

Electricity Demand

(billion kilowatthours)

Residential ............

$\begin{array}{rrrrr}988.77 & 1051.97 & 1086.84 & 1147.37 & 0.9 \% \\ 862.73 & 938.93 & 972.34 & 1018.66 & 1.0 \% \\ 978.08 & 1073.93 & 1168.25 & 1235.65 & 1.4 \% \\ 17.56 & 25.31 & 37.85 & 51.59 & 6.5 \% \\ \mathbf{2 8 4 7 . 1 2} & \mathbf{3 0 9 0 . 1 4} & 3265.28 & \mathbf{3 4 5 3 . 2 6} & 1.1 \%\end{array}$


Table 67. Electric Power and Projections for the United States (Continued)

\begin{tabular}{|c|c|c|c|c|c|}
\hline \multirow{2}{*}{ Electricity Supply and Demand } & \multicolumn{4}{|c|}{ Reference Case } & \multirow{2}{*}{$\begin{array}{c}\text { Annual } \\
\text { Growth } \\
1993-2010 \\
\text { (percent) }\end{array}$} \\
\hline & 1993 & 2000 & 2005 & 2010 & \\
\hline \multicolumn{6}{|l|}{ Net Energy for Load (billion kilowatthours) ${ }^{10}$} \\
\hline Net International Electricity Imports $\ldots \ldots \ldots \ldots$ & 28.43 & 34.59 & 32.59 & 56.45 & $4.1 \%$ \\
\hline $\begin{array}{l}\text { Net Interregional Electricity Imports } \ldots \ldots \ldots \ldots \ldots \\
\text { Purchases from Nonutilities }\end{array}$ & -1.17 & -1.50 & -1.19 & -0.99 & $-1.0 \%$ \\
\hline (including cogenerators) ${ }^{6} \ldots \ldots \ldots \ldots \ldots \ldots$ & 184.02 & 246.45 & 286.84 & 394.32 & $4.6 \%$ \\
\hline Generation by Utilities $\ldots \ldots \ldots \ldots \ldots \ldots \ldots$ & 2882.52 & 3022.00 & 3170.74 & 3240.52 & $0.7 \%$ \\
\hline Total Net Energy for Load . . . . . . . . . . . . . . . & 3093.80 & 3301.54 & 3488.98 & 3690.30 & $1.0 \%$ \\
\hline \multicolumn{6}{|l|}{$\begin{array}{l}\text { Generation by Fuel Type } \\
\text { (billion kilowatthours) } \\
\text { Utility Generation }\end{array}$} \\
\hline Coal $\ldots \ldots \ldots \ldots \ldots \ldots \ldots \ldots \ldots$ & 1639.15 & 1688.57 & 1760.95 & 1825.28 & $0.6 \%$ \\
\hline Petroleum $\ldots \ldots \ldots \ldots \ldots \ldots \ldots \ldots \ldots$ & 99.54 & 80.11 & 110.81 & 117.71 & $1.0 \%$ \\
\hline Natural Gas $\ldots \ldots \ldots \ldots \ldots \ldots \ldots \ldots$ & 258.91 & 301.01 & 342.19 & 386.77 & $2.4 \%$ \\
\hline Nuclear $\ldots \ldots \ldots \ldots \ldots \ldots \ldots \ldots \ldots \ldots \ldots$ & 610.29 & 652.09 & 652.63 & 596.02 & $-0.1 \%$ \\
\hline Pumped Storage/Other ${ }^{3} \ldots \ldots \ldots \ldots \ldots \ldots$ & -2.46 & -2.29 & -2.22 & -2.14 & $-0.8 \%$ \\
\hline Renewable ${ }^{4} \ldots \ldots \ldots \ldots \ldots \ldots \ldots \ldots \ldots$ & 277.09 & 302.51 & 306.38 & 316.88 & $0.8 \%$ \\
\hline Total Utility Generation . . . . . . . . . . . . . . & 2882.52 & 3022.00 & 3170.74 & 3240.52 & $0.7 \%$ \\
\hline \multicolumn{6}{|l|}{ Nonutility Generation Excluding Cogeneration } \\
\hline Coal $\ldots \ldots \ldots \ldots \ldots \ldots \ldots \ldots \ldots$ & 5.23 & 9.20 & 12.25 & 44.01 & $13.4 \%$ \\
\hline Petroleum/Other ${ }^{8} \ldots \ldots \ldots \ldots \ldots \ldots \ldots \ldots$ & 1.29 & 0.11 & 0.20 & 0.20 & $-10.4 \%$ \\
\hline Natural Gas $\ldots \ldots \ldots \ldots \ldots \ldots \ldots \ldots$ & 21.30 & 35.70 & 53.10 & 89.96 & $8.8 \%$ \\
\hline Renewable $\ldots \ldots \ldots \ldots \ldots \ldots \ldots \ldots \ldots$ & 45.12 & 63.64 & 73.38 & 101.36 & $4.9 \%$ \\
\hline Total Nonutility Generation . . . . . . . . . . . . . & 72.93 & 108.65 & 138.94 & 235.53 & $7.1 \%$ \\
\hline \multicolumn{6}{|l|}{ Cogenerators } \\
\hline Coal $\ldots \ldots \ldots \ldots \ldots \ldots \ldots \ldots \ldots$ & 48.72 & 55.43 & 57.79 & 60.25 & $1.3 \%$ \\
\hline Petroleum $\ldots \ldots \ldots \ldots \ldots \ldots \ldots \ldots$ & 9.98 & 38.08 & 41.08 & 44.31 & $9.2 \%$ \\
\hline Natural Gas $\ldots \ldots \ldots \ldots \ldots \ldots \ldots \ldots \ldots$ & 150.52 & 176.58 & 195.95 & 216.47 & $2.2 \%$ \\
\hline Renewable $\ldots \ldots \ldots \ldots \ldots \ldots \ldots \ldots \ldots$ & 35.48 & 38.08 & 38.34 & 38.61 & $0.5 \%$ \\
\hline Other $\ldots \ldots \ldots \ldots \ldots \ldots \ldots \ldots \ldots$ & 2.98 & 4.44 & 4.67 & 4.91 & $3.0 \%$ \\
\hline Total $\ldots \ldots \ldots \ldots \ldots \ldots \ldots \ldots \ldots \ldots$ & 247.69 & 312.62 & 337.84 & 364.55 & $2.3 \%$ \\
\hline Sales to Utilities $\ldots \ldots \ldots \ldots \ldots \ldots \ldots \ldots$ & 111.09 & 137.80 & 147.91 & 158.79 & $2.1 \%$ \\
\hline Generation for Own Use $\ldots \ldots \ldots \ldots \ldots \ldots$ & 136.59 & 174.81 & 189.94 & 205.76 & $2.4 \%$ \\
\hline \multicolumn{6}{|l|}{$\begin{array}{l}\text { End-Use Prices" } \\
\text { (1993 cents per kilowatthour) }\end{array}$} \\
\hline Residential $\ldots \ldots \ldots \ldots \ldots \ldots \ldots \ldots \ldots$ & 8.3 & 8.2 & 8.4 & 8.8 & $0.3 \%$ \\
\hline Commercial $\ldots \ldots \ldots \ldots \ldots \ldots \ldots \ldots \ldots$ & 7.4 & 7.3 & 7.6 & 7.9 & $0.4 \%$ \\
\hline Industrial $\ldots \ldots \ldots \ldots \ldots \ldots \ldots \ldots \ldots \ldots$ & 5.0 & 4.9 & 5.0 & 5.2 & $0.3 \%$ \\
\hline Transportation $\ldots \ldots \ldots \ldots \ldots \ldots \ldots \ldots$ & 5.1 & 5.2 & 5.3 & 5.4 & $0.3 \%$ \\
\hline All Sectors Average . . . . . . . . . . . . . . . & 6.8 & 6.7 & 6.9 & 7.2 & $0.3 \%$ \\
\hline \multicolumn{6}{|l|}{$\begin{array}{l}\text { Price Components }{ }^{11} \\
\text { (1993 cents per kilowatthour) }\end{array}$} \\
\hline Capital Component $\ldots \ldots \ldots \ldots \ldots \ldots \ldots$ & 2.8 & 2.6 & 2.5 & 2.5 & $-0.5 \%$ \\
\hline Fuel Component $\ldots \ldots \ldots \ldots \ldots \ldots \ldots \ldots$ & 1.2 & 1.2 & 1.4 & 1.4 & $1.1 \%$ \\
\hline Operation and Maintenance Component ........ & 2.7 & 2.7 & 2.8 & 2.7 & $0.0 \%$ \\
\hline Wholesale Power Cost . . . . . . . . . . . . . . & 0.1 & 0.2 & 0.3 & 0.5 & $7.0 \%$ \\
\hline Total $\ldots \ldots \ldots \ldots \ldots \ldots \ldots \ldots \ldots \ldots$ & 6.8 & 6.7 & 6.9 & 7.2 & $0.3 \%$ \\
\hline \multicolumn{6}{|l|}{$\begin{array}{l}\text { Fuel Consumption (quadrillion Btu) } \ldots \ldots \ldots \ldots \\
\text { Utilities }^{12}\end{array}$} \\
\hline Coal $\ldots \ldots \ldots \ldots \ldots \ldots \ldots \ldots \ldots$ & 16.79 & 17.26 & 18.06 & 18.69 & $0.6 \%$ \\
\hline Natural Gas $\ldots \ldots \ldots \ldots \ldots \ldots \ldots \ldots$ & 2.76 & 3.06 & 3.50 & 3.96 & $2.1 \%$ \\
\hline Oil $\ldots \ldots \ldots \ldots \ldots \ldots \ldots \ldots \ldots \ldots \ldots \ldots$ & 1.06 & 0.83 & 1.16 & 1.24 & $0.9 \%$ \\
\hline Coal $\ldots \ldots \ldots \ldots \ldots \ldots \ldots \ldots \ldots \ldots$ & 0.02 & 0.09 & 0.12 & 0.43 & $18.9 \%$ \\
\hline Natural Gas $\ldots \ldots \ldots \ldots \ldots \ldots \ldots \ldots$ & 0.24 & 0.31 & 0.46 & 0.82 & $7.5 \%$ \\
\hline Oil $\ldots \ldots \ldots \ldots \ldots \ldots \ldots \ldots \ldots \ldots$ & 0.02 & 0.00 & 0.00 & 0.00 & $-12.3 \%$ \\
\hline
\end{tabular}


Table 67. Electric Power and Projections for the United States (Continued)

\begin{tabular}{|c|c|c|c|c|c|}
\hline \multirow{2}{*}{ Electricity Supply and Demand } & \multicolumn{4}{|c|}{ Reference Case } & \multirow{2}{*}{$\begin{array}{c}\text { Annual } \\
\text { Growth } \\
1993-2010 \\
\text { (percent) }\end{array}$} \\
\hline & 1993 & 2000 & 2005 & 2010 & \\
\hline \multicolumn{6}{|l|}{ Emissions (million metric tons) ${ }^{14}$} \\
\hline Total Carbon $\ldots \ldots \ldots \ldots \ldots \ldots \ldots \ldots$ & 482.29 & 506.49 & 542.70 & 580.01 & $1.1 \%$ \\
\hline Carbon Dioxide $\ldots \ldots \ldots \ldots \ldots \ldots \ldots \ldots$ & 1768.38 & 1857.13 & 1989.88 & 2126.68 & $1.1 \%$ \\
\hline Sulfur Dioxide $\ldots \ldots \ldots \ldots \ldots \ldots \ldots \ldots \ldots$ & 17.44 & 9.40 & 8.35 & 8.31 & $-4.3 \%$ \\
\hline
\end{tabular}

'Net summer capability is the steady hourly output that generating equipment is expected to supply to system load (exclusive of auxiliary power), as demonstrated by tests during summer peak demand.

${ }^{2}$ Includes oil-, gas-, and dual-fired capability.

'Other includes methane, propane gas, and blast fumace gas.

"Includes conventional hydroelectric, geothermal, wood, wood waste, municipal solid waste, other biomass, solar, and wind power.

${ }^{5}$ Cumulative additions after December 31, 1992.

'Electrcity was produced solely for sale to an electric utility or another end-user, and there is no business activity at the site (standard industrial classification 49).

${ }^{7}$ Nameplate capacity is reported for nonutilities on Form ElA-867, "Annual Nonutility Power Producer Report." Nameplate capacity is designated

by the manufacturer. The nameplate capacity has been converted to net summer capacity based on historic relationships.

OOther includes hydrogen, sulfur, batteries, chemicals, fish oil, and spent sulfite liquor.

Includes generators and cogenerators at facilities whose primary function is not electricity production (standard industrial classification other than 49).

${ }^{10}$ Generation to meet system load by source.

${ }^{11}$ Prices represent average revenue per kilowatthour.

${ }^{12}$ In the end-use energy consumptions tables, projected fuel consumption in the utility sector includes fuel used by independent power producers. In this table, fuel used by independent power producers is included in the nonutility category.

${ }^{13}$ Includes fuel consumption by small power producers, independent power producers, and exempt wholesale generators, which produce electricity for sales to utilities.

${ }^{14}$ Estimated emissions from utilities and independent power producers.

$E M M=$ Electricity market module.

$\mathrm{N} / \mathrm{A}=$ Not applicable.

Note: Totals may not equal sum of components due to independent rounding.

Sources: 1993 (except for prices): Energy Information Administration (EIA), Annual Energy Review 1993, DOE/EIA-0384(93) (Washington,

D.C., July 1994). Prices and all projections: EIA, AEO95 National Energy Modeling System run AEO95B.D1103942. 
Table 68. Electric Generation by Electricity Market Module Region and Source (Billion Kilowatthours)

\begin{tabular}{|c|c|c|c|c|c|}
\hline \multirow{2}{*}{ Region and Source } & \multicolumn{4}{|c|}{ Reference Case } & \multirow{2}{*}{$\begin{array}{c}\text { Annual } \\
\text { Growth } \\
\text { 1993-2010 } \\
\text { (percent) }\end{array}$} \\
\hline & 1993 & 2000 & 2005 & 2010 & \\
\hline \multicolumn{6}{|l|}{$\begin{array}{l}\text { East Central Area Reliability } \\
\text { Coordination Agreement (ECAR) }\end{array}$} \\
\hline 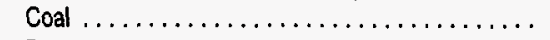 & 437.40 & 452.26 & 463.65 & 468.25 & $0.4 \%$ \\
\hline Petroleum $\ldots \ldots \ldots \ldots \ldots \ldots \ldots \ldots$ & 1.40 & 0.06 & 0.45 & 0.32 & $-8.3 \%$ \\
\hline Natural Gas $\ldots \ldots \ldots \ldots \ldots \ldots \ldots$ & 1.40 & 4.11 & 11.82 & 31.27 & $20.1 \%$ \\
\hline Nuclear $\ldots \ldots \ldots \ldots \ldots \ldots \ldots \ldots \ldots$ & 48.09 & 47.20 & 46.99 & 42.40 & $-0.7 \%$ \\
\hline Pumped Storage/Other' ${ }^{1} \ldots \ldots \ldots \ldots \ldots \ldots$ & -1.26 & -0.34 & -0.34 & -0.34 & $-7.4 \%$ \\
\hline Renewables $^{2} \ldots \ldots \ldots \ldots \ldots \ldots \ldots \ldots$ & 4.94 & 10.76 & 11.47 & 12.15 & $5.4 \%$ \\
\hline Total $\ldots \ldots \ldots \ldots \ldots \ldots \ldots \ldots \ldots$ & 491.98 & 514.05 & 534.05 & 554.05 & $0.7 \%$ \\
\hline \multicolumn{6}{|l|}{ Electric Reliability Council of Texas (ERCOT) } \\
\hline Coal $\ldots \ldots \ldots \ldots \ldots \ldots \ldots \ldots \ldots \ldots \ldots$ & 100.50 & 93.07 & 111.17 & 116.05 & $0.8 \%$ \\
\hline Petroleum $\ldots \ldots \ldots \ldots \ldots \ldots \ldots \ldots$ & 0.44 & 0.26 & 0.22 & 0.23 & $-3.8 \%$ \\
\hline Natural Gas $\ldots \ldots \ldots \ldots \ldots \ldots \ldots \ldots$ & 85.55 & 86.35 & 80.05 & 87.71 & $0.1 \%$ \\
\hline Nuclear $\ldots \ldots \ldots \ldots \ldots \ldots \ldots \ldots \ldots$ & 12.41 & 28.12 & 28.12 & 28.12 & $4.9 \%$ \\
\hline Pumped Storage/Other ${ }^{1} \ldots \ldots \ldots \ldots \ldots \ldots \ldots$ & 0.00 & 0.00 & 0.00 & 0.00 & NA \\
\hline Renewables $^{2} \ldots \ldots \ldots \ldots \ldots \ldots \ldots$ & 1.75 & 1.54 & 1.55 & 1.69 & $-0.2 \%$ \\
\hline Total $\ldots \ldots \ldots \ldots \ldots \ldots \ldots \ldots \ldots \ldots$ & 200.66 & 209.35 & 221.10 & 233.81 & $0.9 \%$ \\
\hline \multicolumn{6}{|l|}{ Mid-Atlantic Area Council (MAAC) } \\
\hline Coal $\ldots \ldots \ldots \ldots \ldots \ldots \ldots \ldots \ldots \ldots$ & 104.50 & 110.13 & 111.40 & 123.49 & $1.0 \%$ \\
\hline Petroleum $\ldots \ldots \ldots \ldots \ldots \ldots \ldots \ldots$ & 11.99 & 5.52 & 8.52 & 10.35 & $-0.9 \%$ \\
\hline Natural Gas $\ldots \ldots \ldots \ldots \ldots \ldots \ldots \ldots$ & 6.77 & 15.84 & 21.28 & 27.49 & $8.6 \%$ \\
\hline Nuclear $\ldots \ldots \ldots \ldots \ldots \ldots \ldots \ldots \ldots$ & 87.01 & 82.49 & 82.49 & 68.13 & $-1.4 \%$ \\
\hline Pumped Storage/Other' ${ }^{1} \ldots \ldots \ldots \ldots \ldots \ldots \ldots$ & -0.81 & -0.14 & -0.13 & -0.11 & $-11.3 \%$ \\
\hline Renewables ${ }^{2} \ldots \ldots \ldots \ldots \ldots \ldots \ldots$ & 6.92 & 9.05 & 10.76 & 13.65 & $4.1 \%$ \\
\hline Total $\ldots \ldots \ldots \ldots \ldots \ldots \ldots \ldots \ldots \ldots \ldots$ & 216.39 & 222.88 & 234.32 & 242.99 & $0.7 \%$ \\
\hline \multicolumn{6}{|l|}{ Mid-America Interconnected Network (MAIN) } \\
\hline Coal $\ldots \ldots \ldots \ldots \ldots \ldots \ldots \ldots \ldots \ldots \ldots \ldots$ & 113.95 & 134.99 & 145.44 & 150.11 & $1.6 \%$ \\
\hline Petroleum. $\ldots \ldots \ldots \ldots \ldots \ldots \ldots \ldots \ldots$ & 0.91 & 0.03 & 0.64 & 0.12 & $-11.3 \%$ \\
\hline Natural Gas $\ldots \ldots \ldots \ldots \ldots \ldots \ldots \ldots$ & 1.66 & 0.25 & 2.25 & 10.64 & $11.6 \%$ \\
\hline Nuclear $\ldots \ldots \ldots \ldots \ldots \ldots \ldots \ldots \ldots \ldots$ & 96.18 & 94.88 & 94.88 & 90.42 & $-0.4 \%$ \\
\hline Pumped Storage/Other' . . . . . . . . . . . . . . & -0.07 & -0.04 & -0.04 & -0.03 & $-4.6 \%$ \\
\hline Renewables $^{2} \ldots \ldots \ldots \ldots \ldots \ldots \ldots \ldots$ & 4.36 & 3.69 & 3.81 & 4.01 & $-0.5 \%$ \\
\hline Total $\ldots \ldots \ldots \ldots \ldots \ldots \ldots \ldots$ & 216.99 & 233.81 & 246.99 & 255.27 & $1.0 \%$ \\
\hline \multicolumn{6}{|l|}{ Mid-Continent Area Power Pool (MAPP) } \\
\hline Coal $\ldots \ldots \ldots \ldots \ldots \ldots \ldots \ldots \ldots$ & 112.17 & 98.42 & 101.46 & 105.32 & $-0.4 \%$ \\
\hline Petroleum $\ldots \ldots \ldots \ldots \ldots \ldots \ldots \ldots \ldots$ & 0.78 & 0.00 & 0.00 & 0.00 & $-29.0 \%$ \\
\hline Natural Gas $\ldots \ldots \ldots \ldots \ldots \ldots \ldots \ldots$ & 0.77 & 0.00 & 0.30 & 2.33 & $6.7 \%$ \\
\hline Nuclear $\ldots \ldots \ldots \ldots \ldots \ldots \ldots \ldots \ldots \ldots$ & 24.06 & 25.52 & 25.52 & 24.73 & $0.2 \%$ \\
\hline Pumped Storage/Other' $\ldots \ldots \ldots \ldots \ldots \ldots \ldots$ & 0.00 & 0.00 & 0.00 & 0.00 & N/A \\
\hline Renewables $^{2} \ldots \ldots \ldots \ldots \ldots \ldots \ldots \ldots$ & 8.94 & 11.73 & 13.01 & 13.29 & $2.4 \%$ \\
\hline Total $\ldots \ldots \ldots \ldots \ldots \ldots \ldots \ldots \ldots$ & 146.72 & 135.67 & 140.30 & 145.68 & $0.0 \%$ \\
\hline \multicolumn{6}{|l|}{$\begin{array}{l}\text { Northeast Power Coordinating } \\
\text { Council/New York (NPCC/NY) }\end{array}$} \\
\hline 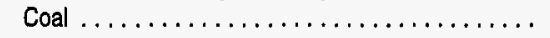 & 22.59 & 18.56 & 17.78 & 18.43 & $-1.2 \%$ \\
\hline Petroleum $\ldots \ldots \ldots \ldots \ldots \ldots \ldots \ldots \ldots$ & 14.53 & 24.29 & 28.70 & 31.12 & $4.6 \%$ \\
\hline Natural Gas $\ldots \ldots \ldots \ldots \ldots \ldots \ldots \ldots$ & 16.74 & 15.23 & 16.34 & 18.00 & $0.4 \%$ \\
\hline Nuclear $\ldots \ldots \ldots \ldots \ldots \ldots \ldots \ldots \ldots$ & 26.89 & 26.50 & 26.50 & 20.55 & $-1.6 \%$ \\
\hline Pumped Storage/Other ${ }^{1} \ldots \ldots \ldots \ldots \ldots \ldots \ldots$ & -1.14 & -0.17 & -0.17 & -0.17 & $-10.6 \%$ \\
\hline Renewables ${ }^{2} \ldots \ldots \ldots \ldots \ldots \ldots \ldots \ldots$ & 31.37 & 33.53 & 36.65 & 42.77 & $1.8 \%$ \\
\hline Total $\ldots \ldots \ldots \ldots \ldots \ldots \ldots \ldots \ldots$ & 110.99 & 117.95 & 125.80 & 130.71 & $1.0 \%$ \\
\hline
\end{tabular}


Table 68. Electric Generation by Electricity Market Module Region and Source (Continued).

(Billion Kilowatthours)

\begin{tabular}{|c|c|c|c|c|c|}
\hline \multirow{2}{*}{ Region and Source } & \multicolumn{4}{|c|}{ Reference Case } & \multirow{2}{*}{$\begin{array}{c}\text { Annual } \\
\text { Growth } \\
1993-2010 \\
\text { (percent) }\end{array}$} \\
\hline & 1993 & 2000 & 2005 & 2010 & \\
\hline \multicolumn{6}{|l|}{$\begin{array}{l}\text { Northeast Power Coordinating } \\
\text { CouncilNew England (NPCC/NE) }\end{array}$} \\
\hline Coal $\ldots \ldots \ldots \ldots \ldots$ & 14.99 & 16.11 & 15.53 & 16.33 & $0.5 \%$ \\
\hline Petroleum ................. & 17.45 & 17.13 & 26.95 & 23.96 & $1.9 \%$ \\
\hline Natural Gas ..... & 10.02 & 10.37 & 11.28 & 17.94 & $3.5 \%$ \\
\hline Nuclear $\ldots \ldots \ldots \ldots \ldots \ldots \ldots \ldots \ldots$ & 44,30 & 40.80 & 40.80 & 30.62 & $-2.1 \%$ \\
\hline Pumped Storage/Other ${ }^{1} \ldots \ldots \ldots \ldots \ldots \ldots$ & -0.68 & -0.21 & -0.22 & -0.21 & $-6.8 \%$ \\
\hline Renewables $^{2} \ldots \ldots \ldots \ldots \ldots \ldots \ldots$ & 12.20 & 14.53 & 15.79 & 21.78 & $3.5 \%$ \\
\hline Total $\ldots \ldots \ldots \ldots \ldots \ldots \ldots \ldots \ldots \ldots \ldots \ldots \ldots$ & 98.27 & 98.74 & 110.14 & 110.43 & $0.7 \%$ \\
\hline \multicolumn{6}{|l|}{$\begin{array}{l}\text { Southeastern Electric Reliability } \\
\text { CouncilfFlorida (SERC/STV) }\end{array}$} \\
\hline Coal $\ldots \ldots \ldots \ldots \ldots \ldots$ & 57.12 & 57.63 & 59.30 & 61.40 & $0.4 \%$ \\
\hline Petroleum...$\ldots \ldots \ldots \ldots$ & 34.28 & 27.01 & 37.67 & 45.17 & $1.6 \%$ \\
\hline Natural Gas $\ldots \ldots \ldots \ldots \ldots \ldots \ldots \ldots$ & 19.36 & 34.94 & 41.01 & 54.33 & $6.3 \%$ \\
\hline Nuclear...$\ldots \ldots \ldots \ldots \ldots \ldots \ldots \ldots$ & 25.89 & 25.65 & 25.65 & 18.19 & $-2.1 \%$ \\
\hline Pumped Storage/Other' & 0.00 & 0.00 & 0.00 & 0.00 & N/A \\
\hline Renewables ${ }^{2} \ldots \ldots \ldots \ldots$. & 3.42 & 3.77 & 4.56 & 5.56 & $2.9 \%$ \\
\hline Total $\ldots \ldots \ldots \ldots \ldots \ldots \ldots \ldots \ldots \ldots \ldots \ldots \ldots \ldots \ldots \ldots$ & 140.06 & 149.00 & 168.19 & 184.64 & $1.6 \%$ \\
\hline \multicolumn{6}{|l|}{$\begin{array}{l}\text { Southeastern Electric Reliability } \\
\text { Councillexcluding Florida (SERC/STV) }\end{array}$} \\
\hline Coal $\ldots \ldots \ldots \ldots \ldots \ldots \ldots$ & 341.19 & 359.80 & 364.93 & 372.35 & $0.5 \%$ \\
\hline Petroleum ......................... & 3.06 & 1.67 & 2.74 & 3.77 & $1.2 \%$ \\
\hline Natural Gas $\ldots \ldots \ldots \ldots \ldots \ldots \ldots \ldots$ & 6.72 & 12.36 & 32.77 & 65.25 & $14.3 \%$ \\
\hline Nuclear $\ldots \ldots \ldots \ldots$. & 148.90 & 184.70 & 185.45 & 184.43 & $1.3 \%$ \\
\hline Pumped Storage/Other' & -0.94 & -0.73 & -0.68 & -0.64 & $-2.3 \%$ \\
\hline Renewables $^{2} \ldots \ldots \ldots \ldots \ldots \ldots \ldots$ & 34.80 & 39.59 & 39.59 & 39.57 & $0.8 \%$ \\
\hline Total $\ldots \ldots \ldots \ldots \ldots \ldots \ldots \ldots \ldots \ldots \ldots \ldots \ldots$ & 533.73 & 597.39 & 624.79 & 664.73 & $1.3 \%$ \\
\hline \multicolumn{6}{|l|}{ Southwest Power Pool (SPP) } \\
\hline Coal $\ldots \ldots \ldots \ldots \ldots \ldots$ & 142.20 & 161.56 & 170.02 & 173.30 & $1.2 \%$ \\
\hline Petroleum. $\ldots \ldots \ldots \ldots \ldots \ldots \ldots \ldots \ldots$ & 6.07 & 0.99 & 1.49 & 1.79 & $-6.9 \%$ \\
\hline Natural Gas $\ldots \ldots \ldots \ldots \ldots \ldots \ldots \ldots$ & 65.10 & 55.12 & 64.39 & 79.03 & $1.1 \%$ \\
\hline Nuclear $\ldots \ldots \ldots \ldots \ldots \ldots \ldots \ldots \ldots$ & 35.82 & 33.54 & 33.54 & 33.54 & $-0.4 \%$ \\
\hline Pumped Storage/Other' & -0.06 & -0.05 & -0.05 & -0.04 & $-2.2 \%$ \\
\hline Renewables $^{2} \ldots \ldots \ldots \ldots \ldots \ldots \ldots \ldots$ & 12.42 & 7.99 & 8.10 & 9.32 & $-1.7 \%$ \\
\hline Total $\ldots \ldots \ldots \ldots \ldots \ldots \ldots \ldots \ldots \ldots \ldots \ldots \ldots \ldots$ & 261.55 & 259.15 & 277.49 & 296.94 & $0.7 \%$ \\
\hline \multicolumn{6}{|l|}{$\begin{array}{l}\text { Western Systems Coordinating CounciV } \\
\text { Northwest Power Pool Area (WSCCNWP) }\end{array}$} \\
\hline 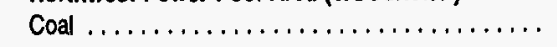 & 75.11 & 75.56 & 79.12 & 90,30 & $1.1 \%$ \\
\hline Pelroleum .......................... & 0.37 & 0.20 & 0.20 & 0.09 & $-8.2 \%$ \\
\hline Natural Gas $\ldots \ldots \ldots \ldots \ldots \ldots \ldots \ldots \ldots$ & 4.05 & 29.08 & 42.04 & 40.31 & $14.5 \%$ \\
\hline Nuclear $\ldots \ldots \ldots \ldots \ldots \ldots \ldots \ldots \ldots \ldots$ & 7.11 & 5.37 & 5.37 & 5.37 & $-1.6 \%$ \\
\hline Pumped Storage/Other' ................... & 0.00 & -0.04 & -0.04 & -0.04 & $\mathrm{~N} / \mathrm{A}$ \\
\hline Renewables ${ }^{2} \ldots \ldots \ldots \ldots \ldots \ldots \ldots \ldots$ & 123.62 & 159.88 & 160.13 & 162.44 & $1.6 \%$ \\
\hline Total $\ldots \ldots \ldots \ldots \ldots \ldots \ldots \ldots \ldots \ldots \ldots \ldots \ldots \ldots \ldots$ & 210.28 & 270.05 & 286.82 & 298.47 & $2.1 \%$ \\
\hline \multicolumn{6}{|l|}{$\begin{array}{l}\text { Western Systems Coordinating Council Rocky } \\
\text { Mountain Power Area and Arizona (WSCC/RA) }\end{array}$} \\
\hline Coal $\ldots \ldots \ldots \ldots \ldots \ldots \ldots \ldots \ldots \ldots \ldots \ldots \ldots \ldots \ldots$ & 93.82 & 91.36 & 91.38 & 98.88 & $0.3 \%$ \\
\hline 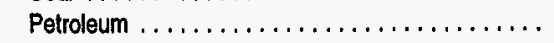 & 0.11 & 0.04 & 0.53 & 0.35 & $7.0 \%$ \\
\hline Natural Gas $\ldots \ldots \ldots \ldots \ldots \ldots \ldots \ldots$ & 5.31 & 31.75 & 37.59 & 32.23 & $11.2 \%$ \\
\hline Nuclear $\ldots \ldots \ldots \ldots \ldots \ldots \ldots \ldots \ldots \ldots$ & 9.90 & 10.70 & 10.70 & 10.71 & $0.5 \%$ \\
\hline Pumped Storage/Other ${ }^{1} \ldots \ldots \ldots \ldots \ldots \ldots$ & 0.85 & -0.06 & -0.06 & $-0,06$ & N/A \\
\hline Renewables ${ }^{2} \ldots \ldots \ldots \ldots \ldots \ldots \ldots \ldots$ & 13.71 & 16.51 & 16.57 & 20.39 & $2.4 \%$ \\
\hline Total $\ldots \ldots \ldots \ldots \ldots \ldots \ldots \ldots \ldots \ldots \ldots \ldots \ldots \ldots \ldots$ & 123.71 & 150.30 & 156.71 & 162.49 & $1.6 \%$ \\
\hline
\end{tabular}


Table 68. Electric Generation by Electricity Market Module Region and Source (Continued)

(Billion Kilowatthours)

\begin{tabular}{|c|c|c|c|c|c|}
\hline \multirow{2}{*}{ Region and Source } & \multicolumn{4}{|c|}{ Reference Case } & \multirow{2}{*}{$\begin{array}{c}\text { Annual } \\
\text { Growth } \\
1993-2010 \\
\text { (percent) }\end{array}$} \\
\hline & 1993 & 2000 & 2005 & 2010 & \\
\hline \multicolumn{6}{|l|}{$\begin{array}{l}\text { Western Systems Coordinating Council } \\
\text { California-Southern Nevada Power (WSCC/CNV) }\end{array}$} \\
\hline Coal $\ldots \ldots \ldots \ldots \ldots \ldots \ldots \ldots \ldots \ldots \ldots \ldots$ & 26.99 & 28.32 & 42.04 & 75.07 & $6.2 \%$ \\
\hline Petroleum $\ldots \ldots \ldots \ldots \ldots \ldots \ldots \ldots \ldots$ & 2.88 & 2.99 & 2.88 & 0.65 & $.8 .4 \%$ \\
\hline Natural Gas ....... & 54.25 & 41.31 & 34.16 & 10.20 & $-9.4 \%$ \\
\hline Nuclear ............ & 43.73 & 46.63 & 46.63 & 38.83 & $-0.7 \%$ \\
\hline Pumped Storage/Other' & 1.65 & -0.50 & -0.50 & -0.50 & N/A \\
\hline Renewables ${ }^{2} \ldots \ldots \ldots \ldots \ldots \ldots \ldots \ldots \ldots$ & 61.88 & 53.57 & 57.78 & 71.62 & $0.9 \%$ \\
\hline Total $\ldots \ldots \ldots \ldots \ldots \ldots \ldots \ldots \ldots \ldots \ldots, \ldots$ & 191.39 & 172.32 & 182.99 & 195.86 & $0.1 \%$ \\
\hline
\end{tabular}

'Other includes methane, propane and blast furnace gas for utilities; and hydrogen, sulfur, batteries, chemicals, fish oil, and spent sulfite liquor for nonutilities.

${ }^{2}$ Renewables includes conventional hydroelectric, geothermal, wood, wood waste, municipal solid waste, other biomass, solar, and wind power.

N/A $=$ Not applicable

Notes: Totals may not equal sum of components due to independent rounding. Values represent generation for utilities and nonutilities (excluding cogenerators) and is net summer capability. Net summer capability is the steady hourly output that generating equipment is expected to supply to system load as demonstrated by tests during summer peak load.

Sources: 1993 utility generation: Energy Information Administration (ElA), Form ElA-759, "Monthly Power Plant Report." 1993 nonutility generation: EIA, Form EIA-867, "Annual Nonutility Power Producer Report." Projections: EIA, AEO95 National Energy Modeling System run AEO95B.D1103942. 
Table 69. Electricity Generating Capacity by Electricity Market Module Region and Source

(Thousand Megawatts)

\begin{tabular}{|c|c|c|c|c|c|}
\hline \multirow{2}{*}{ Region and Source } & \multicolumn{4}{|c|}{ Reference Case } & \multirow{2}{*}{$\begin{array}{c}\text { Annual } \\
\text { Growth } \\
1993-2010 \\
\text { (percent) }\end{array}$} \\
\hline & 1993 & 2000 & 2005 & 2010 & \\
\hline \multicolumn{6}{|l|}{$\begin{array}{l}\text { East Central Area Reliability } \\
\text { Coordination Agreement (ECAR) }\end{array}$} \\
\hline Coal Steam $\ldots \ldots \ldots \ldots \ldots \ldots \ldots \ldots \ldots$ & 84.20 & 81.24 & 80.88 & 80.57 & $-0.3 \%$ \\
\hline Other Fossil Steam ${ }^{1}, \ldots \ldots \ldots \ldots \ldots \ldots \ldots$ & 3.79 & 3.13 & 2.34 & 2.31 & $-2.9 \%$ \\
\hline Combined Cycle $\ldots \ldots \ldots \ldots \ldots \ldots \ldots \ldots$ & 0.39 & 0.39 & 0.55 & 0.93 & $5.2 \%$ \\
\hline Combustion Turbine/Diesel $\ldots \ldots \ldots \ldots \ldots$ & 4.23 & 6.25 & 8.71 & 15.26 & $7.8 \%$ \\
\hline Nuclear Power $\ldots \ldots \ldots \ldots \ldots \ldots \ldots \ldots$ & 7.65 & 7.58 & 7.58 & 6.83 & $-0.7 \%$ \\
\hline Pumped Storage/Other ${ }^{2} \ldots \ldots \ldots \ldots \ldots \ldots$ & 3.26 & 3.26 & 3.27 & 3.27 & $0.0 \%$ \\
\hline Renewable Sources ${ }^{3} \ldots \ldots \ldots \ldots \ldots \ldots$ & 1.81 & 3.43 & 3.53 & 3.63 & $4.2 \%$ \\
\hline Total $\ldots \ldots \ldots \ldots \ldots \ldots \ldots \ldots \ldots \ldots$ & 105.35 & 105.29 & 106.85 & 112.79 & $0.4 \%$ \\
\hline \multicolumn{6}{|l|}{ Electric Reliability Council of Texas (ERCOT) } \\
\hline 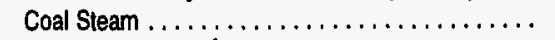 & 14.95 & 15.76 & 18.65 & 19.45 & $1.6 \%$ \\
\hline Other Fossil Steam ${ }^{i} \ldots \ldots \ldots \ldots \ldots \ldots \ldots$ & 29.83 & 28.75 & 28.60 & 27.94 & $-0.4 \%$ \\
\hline Combined Cycle $\ldots \ldots \ldots \ldots \ldots \ldots \ldots \ldots$ & 0.81 & 2.37 & 4.31 & 4.71 & $10.9 \%$ \\
\hline Combustion Turbine/Diesel $\ldots \ldots \ldots \ldots \ldots \ldots$ & 2.28 & 3.09 & 3.09 & 3.19 & $2.0 \%$ \\
\hline Nuclear Power $\ldots \ldots \ldots \ldots \ldots \ldots \ldots \ldots$ & 4.78 & 4.78 & 4.78 & 4.78 & N/A \\
\hline Pumped Storage/Other ${ }^{2} \ldots \ldots \ldots \ldots \ldots \ldots$ & 0.00 & 0.00 & 0.00 & 0.00 & N/A \\
\hline Renewable Sources ${ }^{3} \ldots \ldots \ldots \ldots \ldots \ldots \ldots$ & 0.57 & 0.58 & 0.58 & 0.63 & $0.6 \%$ \\
\hline Total $\ldots \ldots \ldots \ldots \ldots \ldots \ldots \ldots \ldots \ldots \ldots \ldots \ldots \ldots$ & 53.22 & 55.32 & 60.01 & 60.70 & $0.8 \%$ \\
\hline \multicolumn{6}{|l|}{ Mid-Atlantic Area Council (MAAC) } \\
\hline Coal Steam $\ldots \ldots \ldots \ldots \ldots \ldots \ldots \ldots$ & 19.03 & 19.43 & 19.36 & 21.16 & $0.6 \%$ \\
\hline Other Fossil Steam' . .................. & 9.92 & 8.18 & 7.58 & 7.53 & $-1.6 \%$ \\
\hline Combined Cycle $\ldots \ldots \ldots \ldots \ldots \ldots \ldots \ldots$ & 0.67 & 3.08 & 3.88 & 4.17 & $11.4 \%$ \\
\hline Combustion Turbine/Diesel $\ldots \ldots \ldots \ldots \ldots \ldots$ & 8.60 & 9.00 & 9.34 & 9.85 & $0.8 \%$ \\
\hline Nuclear Power $\ldots \ldots \ldots \ldots \ldots \ldots \ldots \ldots$ & 12.58 & 12.58 & 12.58 & 9.88 & $-1.4 \%$ \\
\hline Pumped Storage/Other ${ }^{2} \ldots \ldots \ldots \ldots \ldots \ldots$ & 1.34 & 1.34 & 1.34 & 1.34 & N/A \\
\hline Renewable Sources ${ }^{3} \ldots \ldots \ldots \ldots \ldots \ldots$ & 1.58 & 1.94 & 2.17 & 2.74 & $3.3 \%$ \\
\hline Tolal $\ldots \ldots \ldots \ldots \ldots \ldots \ldots \ldots \ldots \ldots$ & 53.71 & 55.54 & 56.25 & 56.66 & $0.3 \%$ \\
\hline \multicolumn{6}{|l|}{ Mid-America Interconnected Network (MAIN) } \\
\hline 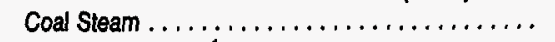 & 27.96 & 26.88 & 26.48 & 25.96 & $-0.4 \%$ \\
\hline Other Fossil Steam ${ }^{1} \ldots \ldots \ldots \ldots \ldots \ldots \ldots$ & 3.53 & 2.91 & 2.91 & 2.88 & $-1.2 \%$ \\
\hline Combined Cycle $\ldots \ldots \ldots \ldots \ldots \ldots \ldots \ldots$ & 0.00 & 0.00 & 0.01 & 0.41 & N/A \\
\hline Combustion Turbine/Diesel $\ldots \ldots \ldots \ldots \ldots \ldots$ & 3.11 & 6.81 & 8.78 & 12.37 & $8.5 \%$ \\
\hline Nuclear Power $\ldots \ldots \ldots \ldots \ldots \ldots \ldots \ldots$ & 14.85 & 14.85 & 14.85 & 13.58 & $-0.5 \%$ \\
\hline Pumped Storage/Other ${ }^{2} \ldots \ldots \ldots \ldots \ldots \ldots \ldots$ & 0.35 & 0.35 & 0.35 & 0.35 & $N / A$ \\
\hline Renewable Sources ${ }^{3} \ldots \ldots \ldots \ldots \ldots \ldots \ldots$ & 0.70 & 0.76 & 0.79 & 0.81 & $0.9 \%$ \\
\hline Total $\ldots \ldots \ldots \ldots \ldots \ldots \ldots \ldots \ldots \ldots \ldots$ & 50.50 & 52.55 & 54.17 & 56.37 & $0.6 \%$ \\
\hline \multicolumn{6}{|l|}{ Mid-Continent Area Power Pool (MAPP) } \\
\hline Coal Steam $\ldots \ldots \ldots \ldots \ldots \ldots \ldots \ldots \ldots$ & 21.73 & 20.86 & 20.12 & 19.64 & $-0.6 \%$ \\
\hline Other Fossil Steam' $\ldots \ldots \ldots \ldots \ldots \ldots \ldots \ldots$ & 0.61 & 0.37 & 0.20 & 0.18 & $-6.9 \%$ \\
\hline Combined Cycle $\ldots \ldots \ldots \ldots \ldots \ldots \ldots \ldots$ & 0.09 & 0.12 & 0.12 & 0.12 & $1.4 \%$ \\
\hline Combustion Turbine/Diesel $\ldots \ldots \ldots \ldots \ldots \ldots$ & 4.55 & 5.15 & 5.33 & 5.78 & $1.4 \%$ \\
\hline Nuclear Power $\ldots \ldots \ldots \ldots \ldots \ldots \ldots \ldots \ldots$ & 3.71 & 3.71 & 3.71 & 3.17 & $-0.9 \%$ \\
\hline Pumped Storage/Other ${ }^{2} \ldots \ldots \ldots \ldots \ldots \ldots$ & 0.00 & 0.00 & 0.00 & 0.00 & N/A \\
\hline Renewable Sources ${ }^{3} \ldots \ldots \ldots \ldots \ldots . . . . .$. & 3.55 & 3.83 & 4.13 & 4.16 & $0.9 \%$ \\
\hline Total $\ldots \ldots \ldots \ldots \ldots \ldots \ldots \ldots \ldots \ldots$ & 34.24 & 34.04 & 33.60 & 33.05 & $-0.2 \%$ \\
\hline \multicolumn{6}{|l|}{$\begin{array}{l}\text { Northeast Power Coordinating } \\
\text { CouncilNew York (NPCCNY) }\end{array}$} \\
\hline Coal Steam $\ldots \ldots \ldots \ldots \ldots \ldots \ldots \ldots$ & 3.96 & 3.15 & 2.99 & 3.11 & $-1.4 \%$ \\
\hline Other Fossil Steam ${ }^{1} \ldots \ldots \ldots \ldots \ldots \ldots \ldots$ & 13.34 & 12.32 & 12.25 & 12.22 & $-0.5 \%$ \\
\hline Combined Cycle $\ldots \ldots \ldots \ldots \ldots \ldots \ldots, \ldots \ldots$ & 0.01 & 0.54 & 0.75 & 0.79 & $28.6 \%$ \\
\hline Combustion Turbine/Diesel $\ldots \ldots \ldots \ldots \ldots \ldots$ & 3.82 & 3.89 & 3.89 & 3.89 & $0.1 \%$ \\
\hline Nuclear Power $\ldots \ldots \ldots \ldots \ldots \ldots \ldots \ldots \ldots$ & 4.83 & 4.83 & 4.83 & 3.76 & $-1.5 \%$ \\
\hline Pumped Storage/Ott $v^{2} \ldots \ldots \ldots \ldots \ldots \ldots \ldots$ & 1.28 & 1.28 & 1.28 & 1.28 & N/A \\
\hline Renewable Sources ${ }^{3} \ldots \ldots \ldots \ldots \ldots \ldots$ & 4.41 & 4.81 & 5.29 & 6.20 & $2.0 \%$ \\
\hline Total $\ldots \ldots \ldots \ldots \ldots \ldots \ldots \ldots \ldots$ & 31.65 & 30.81 & 31.29 & 31.23 & $-0.1 \%$ \\
\hline
\end{tabular}


Table 69. Electricity Generating Capacity by Electricity Market Module Region and Source (Continued)

(Thousand Megawatts)

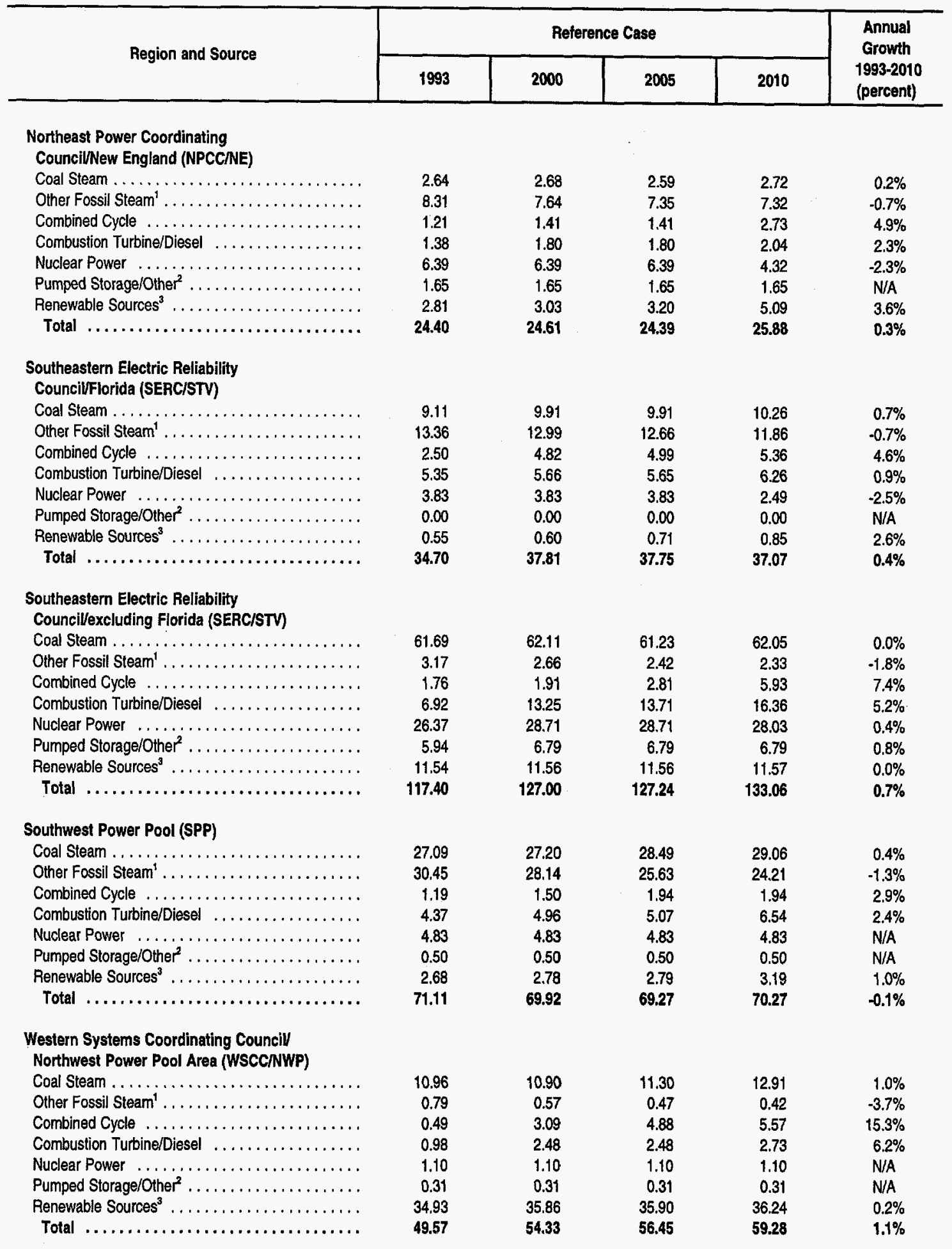


Table 69. Electricity Generating Capacity by Electricity Market Module Region and Source (Continued)

(Thousand Megawatts)

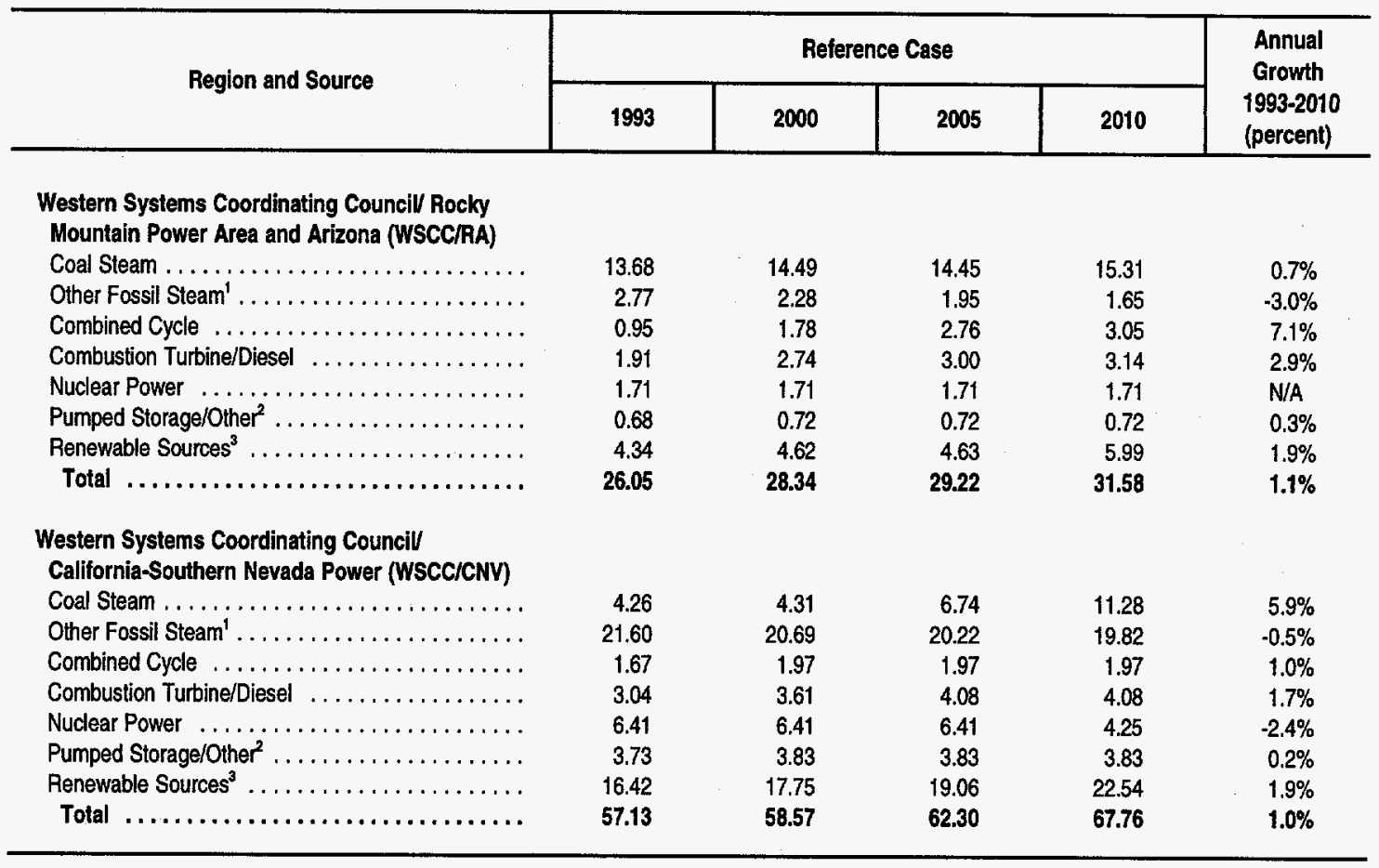

'Includes oil-, gas-, and dual-fired capacity.

${ }^{2}$ Other includes methane, propane, blast furnace gas, hydrogen, sulfur, batteries, chemicals, fish oil, and spent sulfite liquor.

${ }^{3}$ Penewable sources include conventional hydroelectric, geothermal, wood, wood waste, municipal solid waste, other biomass, solar, and wind power.

N/A $=$ Not applicable.

Notes: Totals may not equal sum of components due to independent rounding. Values represent capacity for utilities and nonutilities (excluding cogenerators) and is net summer capability. Net summer capability is the steady hourly output that generating equipment is expected to supply to system load as demonstrated by tests during summer peak load.

Sources: 1993 utility: Energy Information Administration (EIA), Form EIA-860, "Annual Electric Generator Report." 1993 nonutility: EIA, Form EIA-867, "Annual Nonutility Power Producer Report." Projections: EIA, AEO95 National Energy Modeling System run AEO95B.D1103942. 
Table 70. Domestic Refinery Distillation Base Capacity, Expansion, and Utilization (Millions of Barrels per Day)

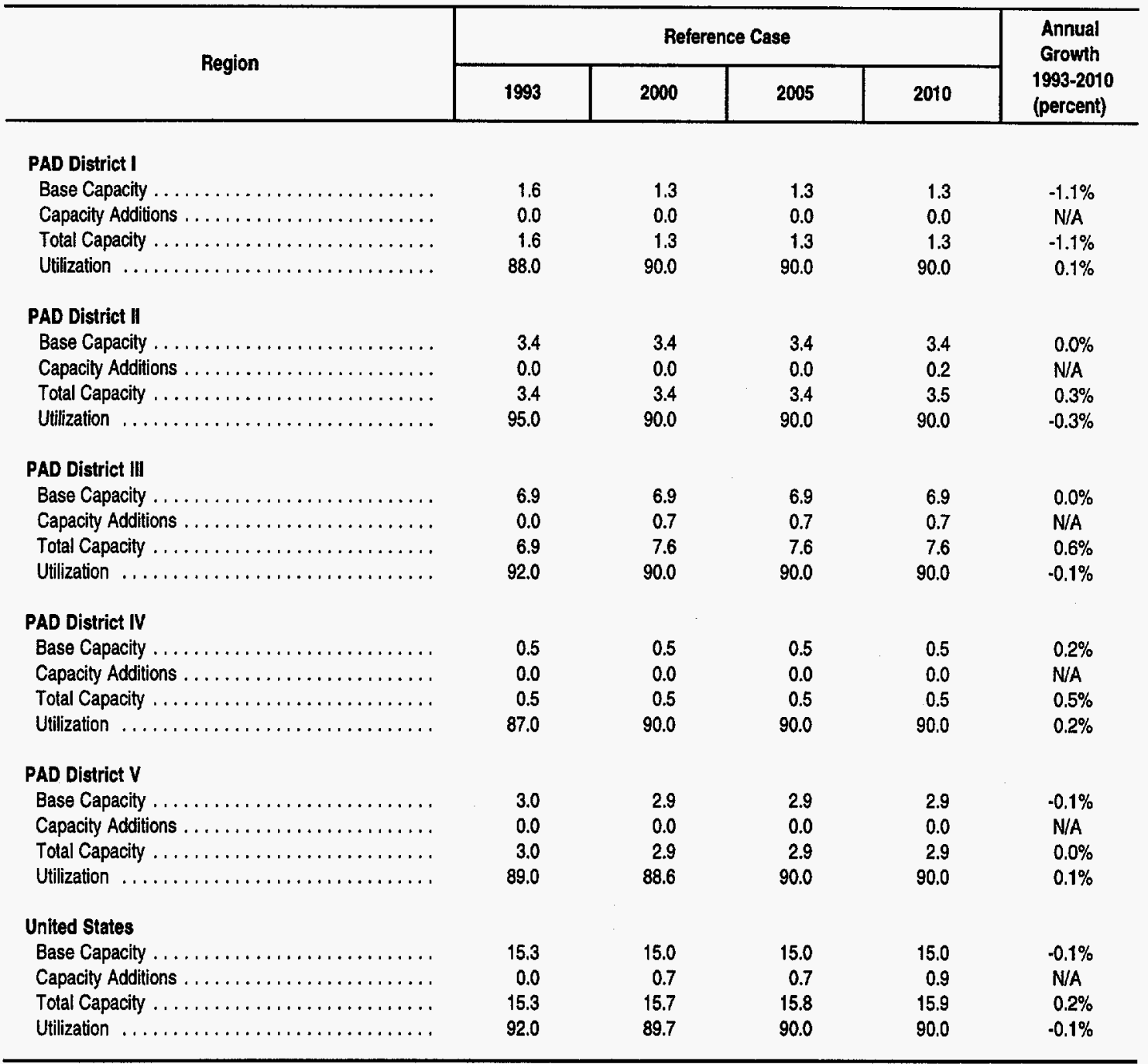

$\mathrm{PAD}=$ Petroleum Administration for Defense

N/A $=$ Not applicable.

Source: 1993: Energy Information Administration (EIA), Petroleum Supply Annual 1993, DOE/EIA-0340(93) (Washington, D.C., May 1994). Projections: EIA, AEO95 National Energy Modeling System run AE095B.D1103942. 
Table 71. Lower 48 Crude Oil Production and Wellhead Prices by Supply Region

\begin{tabular}{|c|c|c|c|c|c|}
\hline \multirow{2}{*}{ Region } & \multicolumn{4}{|c|}{ Reference Case } & \multirow{2}{*}{$\begin{array}{l}\text { Annual } \\
\text { Growth } \\
1993-2010 \\
\text { (percent) }\end{array}$} \\
\hline & 1998 & 2000 & 2005 & 2010 & \\
\hline \multicolumn{6}{|l|}{$\begin{array}{l}\text { Production } \\
\text { (million barrels per day) }\end{array}$} \\
\hline Lower 48 Total ........................ & 5.26 & 4.19 & 4.33 & 4.62 & $-0.8 \%$ \\
\hline \multicolumn{6}{|l|}{ Lower 48 Onshore } \\
\hline Northeast ....... & 0.14 & 0.06 & 0.04 & 0.04 & $-7.7 \%$ \\
\hline$\ldots \ldots, \ldots, \ldots, \ldots$, & 0.98 & 0.61 & 0.62 & 0.69 & $-2.0 \%$ \\
\hline Midcontinent .... & 0.47 & 0.39 & 0.41 & 0.43 & $-0.5 \%$ \\
\hline Southwest $\ldots \ldots \ldots \ldots \ldots \ldots \ldots \ldots \ldots$ & 1.31 & 1.24 & 1.27 & 1.30 & $0.0 \%$ \\
\hline Rocky Mountain $\ldots \ldots \ldots \ldots \ldots \ldots \ldots$ & 0.53 & 0.52 & 0.60 & 0.66 & $1.3 \%$ \\
\hline 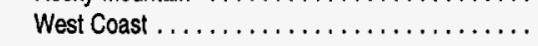 & 0.75 & 0.71 & 0.76 & 0.84 & $0.7 \%$ \\
\hline \multicolumn{6}{|l|}{ Lower 48 Offshore } \\
\hline Guff $\ldots \ldots \ldots \ldots$ & 0.89 & 0.48 & 0.45 & 0.49 & $-3.4 \%$ \\
\hline$\ldots \ldots \ldots \ldots \ldots$ & 0.20 & 0.18 & 0.17 & 0.17 & $-0.8 \%$ \\
\hline Atlantic $\ldots \ldots \ldots \ldots \ldots \ldots \ldots \ldots \ldots \ldots \ldots \ldots$ & 0.00 & 0.00 & 0.00 & 0.00 & $\mathrm{~N} / \mathrm{A}$ \\
\hline \multicolumn{6}{|l|}{ Wellhead Prices (1993 dollars per barrel) } \\
\hline Lower 48 Average $\ldots \ldots \ldots \ldots \ldots \ldots \ldots \ldots$ & 15.36 & 18.47 & 20.58 & 22.92 & $2.4 \%$ \\
\hline \multicolumn{6}{|l|}{ Lower 48 Onshore } \\
\hline Northeast $\ldots . .$. & 16.74 & 19.54 & 21.81 & 24.28 & $2.2 \%$ \\
\hline Gulf Coast $\ldots \ldots \ldots \ldots \ldots \ldots \ldots \ldots \ldots \ldots$ & 16.13 & 19.71 & 22.00 & 24.49 & $2.5 \%$ \\
\hline Midcontinent $\ldots \ldots \ldots \ldots \ldots \ldots \ldots \ldots \ldots$ & 16.26 & 19.34 & 21.63 & 24.12 & $2.3 \%$ \\
\hline Southwest $\ldots \ldots \ldots \ldots \ldots \ldots \ldots \ldots \ldots$ & 16.17 & 19.29 & 21.55 & 24.02 & $2.4 \%$ \\
\hline Rocky Mountain $\ldots \ldots \ldots \ldots \ldots \ldots \ldots \ldots$ & 15.39 & 18.27 & 20.47 & 22.88 & $2.4 \%$ \\
\hline West Coast $\ldots \ldots \ldots \ldots \ldots \ldots \ldots \ldots \ldots \ldots \ldots$ & 12.07 & 15.26 & 17.03 & 18.97 & $2.7 \%$ \\
\hline \multicolumn{6}{|l|}{ Lower 48 Offshore } \\
\hline Gulf $\ldots \ldots \ldots \ldots$ & 16.17 & 20.54 & 22.83 & 25.32 & $2.7 \%$ \\
\hline Pacific $\ldots \ldots \ldots \ldots \ldots \ldots \ldots \ldots, \ldots$ & 11.59 & 13.90 & 15.63 & 17.54 & $2.5 \%$ \\
\hline Atlantic $\ldots \ldots \ldots \ldots \ldots \ldots \ldots \ldots \ldots \ldots$ & 16.17 & 20.54 & 22.83 & 25.32 & $2.7 \%$ \\
\hline
\end{tabular}

'Includes lease condensate.

N/A = Not applicable.

Notes: Supply regions are defined in Appendix A. Totals may not equal sum of components due to independent rounding.

Sources: 1993 lower 48 total, Gulf, Pacific, Atlantic production: Energy Information Administration (EIA). Petroleum Supply Annual 1993. DOE/EIA-0340(93)/1 (Washington, D.C., June 1994). Other 1993: EIA, Office of Integrated Analysis and Forecasting. Figures for 1993 data may differ from published data due to internal conversion factors within the AEO95 National Energy Modeling System. Projections: EIA, AEO95 National Energy Modeling System run AEO95B.D1103942. 
Table 72. Lower 48 Natural Gas Production and Wellhead Prices by Supply Region

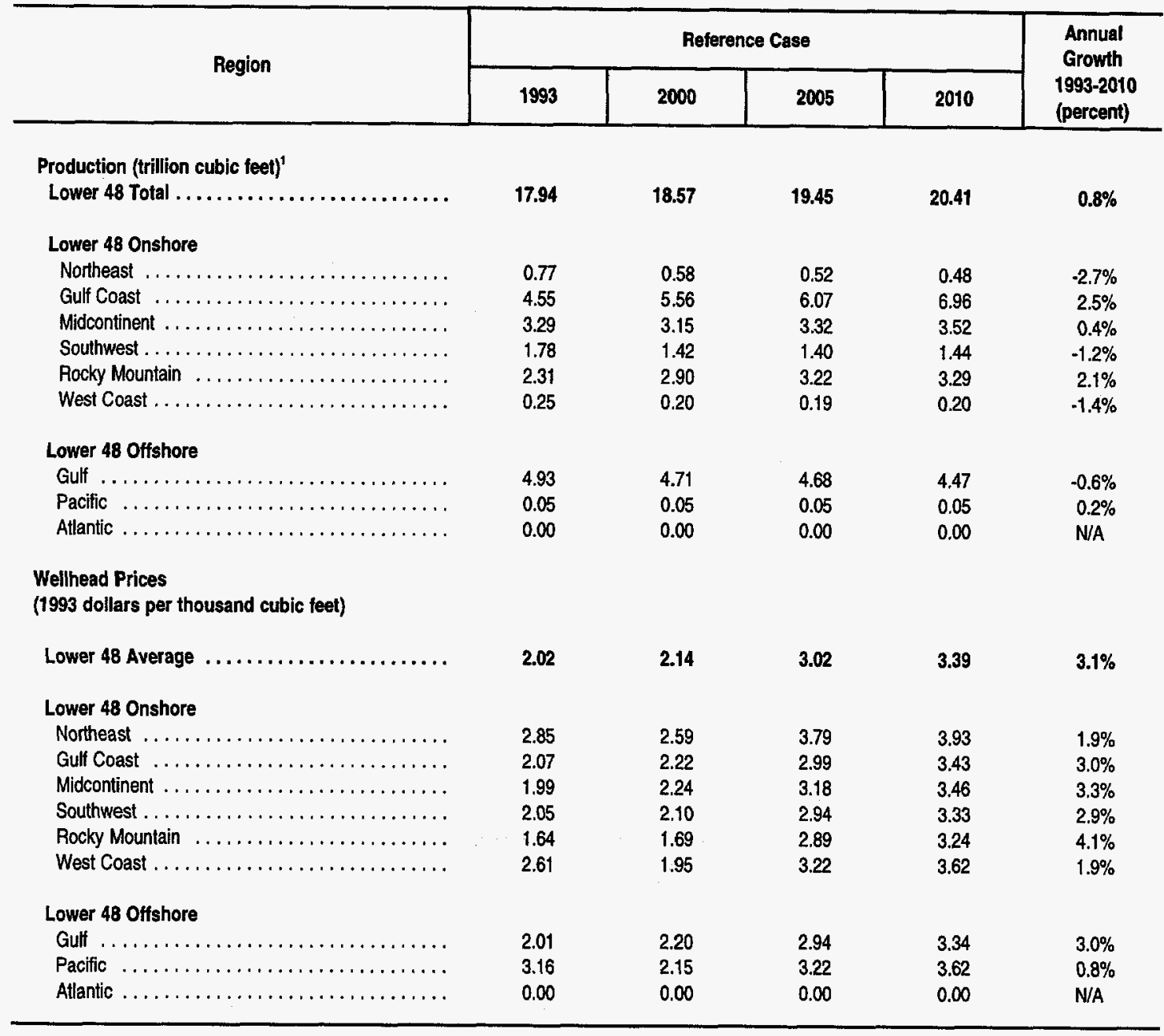

'Marketed production (wet) minus extraction losses.

N/A = Not applicable.

Notes: Supply regions are defined in Appendix A. Totals may not equal the sum of the components due to independent rounding.

Source: 1993: Energy Information Administration (EIA), Office of Integrated Analysis and Forecasting. Projections: EIA, AEO95 National Energy Modeling System run AEO95B.D1103942. 
Table 73. Oil and Gas Reserves

\begin{tabular}{|c|c|c|c|c|c|}
\hline \multirow{2}{*}{ Categories } & \multicolumn{4}{|c|}{ Reference Case } & \multirow{2}{*}{$\begin{array}{l}\text { Annual } \\
\text { Growth } \\
\text { 1993-2010 } \\
\text { (percent) }\end{array}$} \\
\hline & 1993 & 2000 & 2005 & 2010 & \\
\hline \multicolumn{6}{|l|}{ Crude Oil } \\
\hline \multicolumn{6}{|l|}{ Reserves (billion barrels) } \\
\hline U.S. Total,$\ldots \ldots \ldots \ldots$ & 23.30 & 17.59 & 16.12 & 16.97 & $-1.8 \%$ \\
\hline Lower 48 Onshore ....... & 14.79 & $\$ 1.72$ & 11.72 & 12,09 & $-1.2 \%$ \\
\hline Conventionai $\ldots \ldots \ldots \ldots \ldots \ldots \ldots \ldots$ & 11.93 & 8.66 & 8.09 & 7.71 & $-2.5 \%$ \\
\hline Enhanced Oil Recovery,$\ldots \ldots \ldots \ldots \ldots \ldots$. & 2.86 & 3.07 & 3.62 & 4.38 & $2.5 \%$ \\
\hline Lower 48 Offshore ....... & 2.98 & 1.68 & 1.48 & 1.44 & $-4.2 \%$ \\
\hline Alaska $\ldots \ldots \ldots \ldots \ldots \ldots \ldots \ldots \ldots \ldots \ldots$ & 5.53 & 4.20 & 2.93 & 3.44 & $-2.8 \%$ \\
\hline \multirow{2}{*}{\multicolumn{6}{|c|}{$\begin{array}{l}\text { Dry Natural Gas } \\
\text { Reserves (trillion cubic feet) }\end{array}$}} \\
\hline & & & & & \\
\hline U.S. Total $\ldots \ldots \ldots \ldots \ldots \ldots \ldots \ldots \ldots$ & 167.8 & 145.7 & 147.5 & 152.5 & $-0.6 \%$ \\
\hline Lower 48 Onshore $\ldots \ldots \ldots \ldots \ldots \ldots \ldots \ldots$ & 128.7 & 113.9 & 116.7 & 120.7 & $-0.4 \%$ \\
\hline Associated-Dissolved ${ }^{2}, \ldots \ldots \ldots \ldots \ldots \ldots$ & 18.1 & 12.7 & 13.7 & 14.8 & $-1.2 \%$ \\
\hline Non-Associated ..... . & 110.6 & 101.2 & 103.0 & 105.9 & $-0.3 \%$ \\
\hline Conventional . & 80.9 & 72.5 & 73.8 & 75.8 & $-0.4 \%$ \\
\hline Unconventional. & 29.7 & 28.7 & 29.2 & 30.1 & $0.1 \%$ \\
\hline Tight Sands $\ldots \ldots \ldots \ldots \ldots \ldots \ldots \ldots$ & 15.8 & 13.1 & 14.6 & 16.7 & $0.3 \%$ \\
\hline Coal Bed Methane $\ldots \ldots \ldots \ldots \ldots \ldots \ldots$ & 11.4 & 13.6 & 12.6 & 11.3 & $0.0 \%$ \\
\hline Devonian Shale $\ldots \ldots \ldots \ldots \ldots \ldots \ldots$ & 2.5 & 2.0 & 1.9 & 2.0 & $-1.1 \%$ \\
\hline Lower 48 Offshore.$\ldots \ldots \ldots \ldots \ldots \ldots \ldots$ & 29.3 & 21.5 & 20.2 & 20.5 & $-2.1 \%$ \\
\hline Associated-Dissolved ${ }^{2}$ & 6.9 & 4.1 & 4.1 & 4.4 & $-2.6 \%$ \\
\hline Non-Associaled $\ldots \ldots \ldots \ldots \ldots \ldots \ldots \ldots$ & 22.4 & 17.3 & 16.1 & 16.1 & $-1.9 \%$ \\
\hline Alaska $\ldots \ldots \ldots \ldots \ldots \ldots \ldots \ldots \ldots$ & 9.7 & 10.2 & 10.6 & 11.2 & $0.8 \%$ \\
\hline
\end{tabular}

Includes lease condensate.

${ }^{2}$ Gas which occurs in crude oil reservoirs either as free gas (associated) or as gas in solution with crude oil (dissolved).

Note: Totals may not equal sums due to independent rounding.

Source: 1993: Energy Information Administration (EIA), Office of Integrated Analysis and Forecasting. Projections: EIA, AEO95 National Energy Modeling System run AEO95B.D1103942. 
Table 74. Natural Gas Imports and Exports

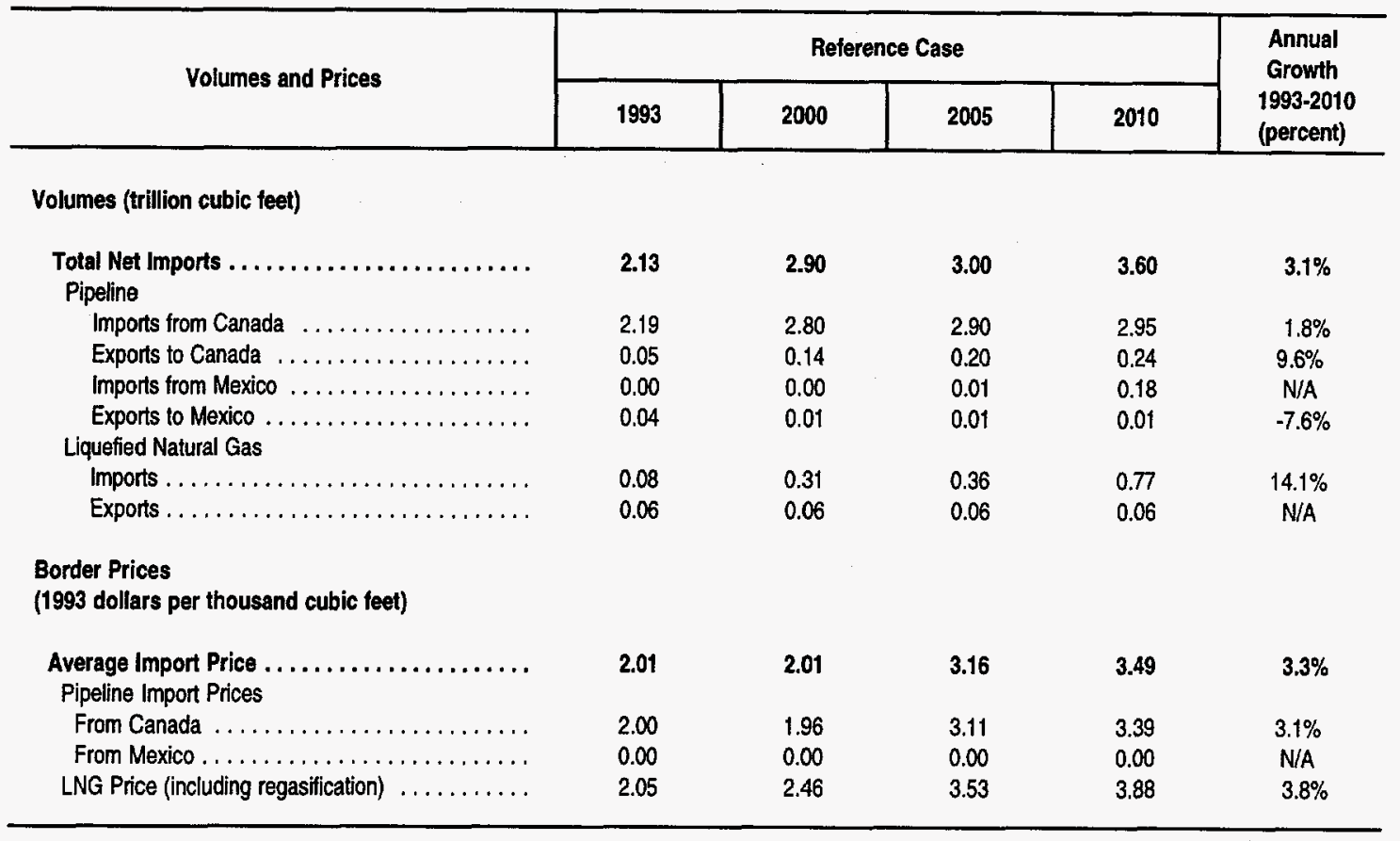

N/A = Not applicable.

$\mathrm{LNG}=$ Liquefied natural gas.

Note: Totals may not equal sum of components due to independent rounding.

Sources: 1993 import and export volumes: U.S. Department of Energy, Office of Fuels Programs, and Office of Fossil Energy, Natural Gas Imports and Exports, Fourth Quarter Report 1993, DOE/FE-0298. 1993 pipeline import price from Canada and LNG price: Energy Information Administration (EIA), Natural Gas Monthly, DOE/EIA-0130(94/6) (Washington, D.C., July 1993). Other 1993: EIA, Office of Integrated Analysis and Forecasting. Figures for 1993 may differ from the published data due to internal conversion factors within the AEO95 National Energy Modeling System. Projections: EIA, AEO95 National Energy Modeling System run AEO95B.D1103942. 
Table 75. Natural Gas Consumption by End-Use Sector and Census Division (Quadrillion Btu per Year)

\begin{tabular}{|c|c|c|c|c|c|}
\hline \multirow{2}{*}{ Sector and Region } & \multicolumn{4}{|c|}{ Reference Case } & \multirow{2}{*}{$\begin{array}{c}\text { Annual } \\
\text { Growth } \\
\text { 1993-2010 } \\
\text { (percent) }\end{array}$} \\
\hline & 1998 & 2000 & 2005 & 2010 & \\
\hline \multicolumn{6}{|l|}{ Residential } \\
\hline New England,$\ldots \ldots \ldots \ldots \ldots \ldots \ldots \ldots$ & 0.21 & 0.22 & 0.22 & 0.23 & $0.6 \%$ \\
\hline Middle Atlantic ......................... & 0.92 & 0.90 & 0.87 & 0.86 & $-0.4 \%$ \\
\hline$\ldots \ldots \ldots \ldots \ldots \ldots \ldots$ & 1.58 & 1.57 & 1.51 & 1.49 & $-0.3 \%$ \\
\hline 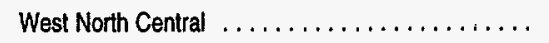 & 0.47 & 0.47 & 0.45 & 0.44 & $-0.3 \%$ \\
\hline South Atlantic $\ldots \ldots \ldots \ldots \ldots \ldots \ldots \ldots$ & 0.42 & 0.45 & 0.46 & 0.48 & $0.7 \%$ \\
\hline East South Central $\ldots \ldots \ldots \ldots \ldots \ldots \ldots$ & 0.21 & 0.22 & 0.22 & 0.22 & $0.2 \%$ \\
\hline West South Central $\ldots \ldots \ldots \ldots \ldots \ldots \ldots \ldots$ & 0.41 & 0.42 & 0.41 & 0.41 & $-0.1 \%$ \\
\hline Mountain $\ldots \ldots \ldots \ldots \ldots \ldots \ldots \ldots \ldots$ & 0.28 & 0.29 & 0.28 & 0.29 & $0.1 \%$ \\
\hline Pacific $\ldots \ldots \ldots \ldots \ldots \ldots \ldots \ldots \ldots \ldots$ & 0.61 & 0.63 & 0.62 & 0.62 & $0.1 \%$ \\
\hline Total $\ldots \ldots \ldots \ldots \ldots \ldots \ldots \ldots \ldots \ldots \ldots \ldots$ & 5.11 & 5.17 & 5.04 & 5.04 & $-0.1 \%$ \\
\hline \multicolumn{6}{|l|}{ Commercial } \\
\hline$\ldots \ldots \ldots \ldots \ldots \ldots \ldots$ & 0.12 & 0.11 & 0.11 & 0.12 & $-0.1 \%$ \\
\hline Middle Atlantic ........................ & 0.52 & 0.51 & 0.49 & 0.48 & $.0 .5 \%$ \\
\hline East North Central . .................... & 0.72 & 0.74 & 0.73 & 0.72 & $0.0 \%$ \\
\hline West North Central $\ldots \ldots \ldots \ldots \ldots \ldots \ldots$ & 0.31 & 0.31 & 0.30 & 0.29 & $-0.3 \%$ \\
\hline South Atlantic $\ldots \ldots \ldots \ldots \ldots \ldots \ldots \ldots$ & 0.31 & 0.33 & 0.35 & 0.38 & $1.2 \%$ \\
\hline East South Central $\ldots \ldots \ldots \ldots \ldots \ldots \ldots$ & 0.14 & 0.13 & 0.14 & 0.14 & $0.2 \%$ \\
\hline 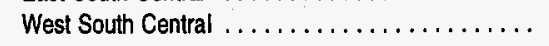 & 0.30 & 0.31 & 0.33 & 0,35 & $1.0 \%$ \\
\hline Mountain $\ldots \ldots \ldots \ldots \ldots \ldots \ldots \ldots \ldots$ & 0.20 & 0.20 & 0.19 & 0.19 & $-0.3 \%$ \\
\hline Pacific $\ldots \ldots \ldots \ldots \ldots \ldots \ldots \ldots \ldots \ldots \ldots \ldots \ldots \ldots \ldots$ & 0.38 & 0.39 & 0.39 & 0.41 & $0.4 \%$ \\
\hline Total $\ldots \ldots \ldots \ldots \ldots \ldots \ldots \ldots \ldots \ldots \ldots \ldots \ldots$ & 2.98 & 3.04 & 3.04 & 3.06 & $0.2 \%$ \\
\hline \multicolumn{6}{|l|}{ Industrial' } \\
\hline New England $\ldots \ldots \ldots \ldots \ldots \ldots \ldots$ & 0.13 & 0.14 & 0.15 & 0.17 & $1.6 \%$ \\
\hline Middle Allantic . ...................... & 0.59 & 0.69 & 0.74 & 0.79 & $1.7 \%$ \\
\hline East North Central $\ldots \ldots \ldots \ldots \ldots \ldots \ldots$ & 1.35 & 1.55 & 1.61 & 1.68 & $1.3 \%$ \\
\hline West North Ceniral $\ldots \ldots \ldots \ldots \ldots \ldots \ldots$ & 0.43 & 0.47 & 0.48 & 0.50 & $0.8 \%$ \\
\hline South Atlantic ......................... & 0.65 & 0.66 & 0.70 & 0.74 & $0.7 \%$ \\
\hline East South Central $\ldots \ldots \ldots \ldots \ldots \ldots \ldots \ldots$ & 0.51 & 0.49 & 0.50 & 0.53 & $0.2 \%$ \\
\hline West South Central $\ldots \ldots \ldots \ldots \ldots \ldots \ldots \ldots$ & 3.19 & 3.74 & 3.85 & 4.04 & $1.4 \%$ \\
\hline Mountain $\ldots \ldots \ldots \ldots \ldots \ldots \ldots \ldots \ldots \ldots \ldots$ & 0.26 & 0.26 & 0.27 & 0.29 & $0.6 \%$ \\
\hline Pacific $\ldots \ldots \ldots \ldots \ldots \ldots \ldots \ldots \ldots \ldots \ldots \ldots$ & 0.72 & 0.95 & 0.99 & 1.07 & $2.3 \%$ \\
\hline Total $\ldots \ldots \ldots \ldots \ldots \ldots \ldots \ldots \ldots \ldots \ldots \ldots$ & 7.85 & 8.95 & 9.29 & 9.79 & $1.3 \%$ \\
\hline \multicolumn{6}{|l|}{ Electric Generators ${ }^{2}$} \\
\hline New England $\ldots \ldots \ldots \ldots \ldots \ldots \ldots$ & 0.08 & 0.10 & 0.11 & 0.15 & $3.8 \%$ \\
\hline Middle Allantic $\ldots \ldots \ldots \ldots \ldots \ldots \ldots \ldots \ldots$ & 0.23 & 0.26 & 0.29 & 0.36 & $2.8 \%$ \\
\hline East North Central $\ldots \ldots \ldots \ldots \ldots \ldots \ldots$ & 0.05 & 0.03 & 0.14 & 0.43 & $13.7 \%$ \\
\hline West North Central $\ldots \ldots \ldots \ldots \ldots \ldots \ldots \ldots$ & 0.04 & 0.08 & 0.05 & 0.09 & $5.1 \%$ \\
\hline South Atlantic $\ldots \ldots \ldots \ldots \ldots \ldots \ldots \ldots$ & 0.25 & 0.53 & 0.81 & 1.27 & $10.1 \%$ \\
\hline East South Central $\ldots \ldots \ldots \ldots \ldots \ldots \ldots$ & 0.05 & 0.08 & 0.09 & 0.12 & $5.6 \%$ \\
\hline West South Central $\ldots \ldots \ldots \ldots \ldots \ldots \ldots \ldots$ & 1.54 & 1.30 & 1.44 & 1.63 & $0.3 \%$ \\
\hline Mountain $\ldots \ldots \ldots \ldots \ldots \ldots \ldots \ldots \ldots$ & 0.08 & 0.43 & 0.41 & 0.31 & $8.1 \%$ \\
\hline Pacific $\ldots \ldots \ldots \ldots \ldots \ldots \ldots \ldots \ldots \ldots \ldots \ldots \ldots \ldots$ & 0.68 & 0.62 & 0.67 & 0.45 & $-2.4 \%$ \\
\hline Total $\ldots \ldots \ldots \ldots \ldots \ldots \ldots \ldots \ldots \ldots \ldots \ldots$ & 3.00 & 3.42 & 4.01 & 4.82 & $2.8 \%$ \\
\hline \multicolumn{6}{|l|}{ Transportation ${ }^{3}$} \\
\hline New England $\ldots \ldots \ldots \ldots \ldots \ldots \ldots \ldots$ & 0.00 & 0.01 & 0.02 & 0.02 & $26.5 \%$ \\
\hline Middle Atlantic $\ldots . . . \ldots \ldots \ldots \ldots \ldots \ldots$ & 0.00 & 0.03 & 0.05 & 0.07 & $26.1 \%$ \\
\hline East North Central . .................... & 0.00 & 0.03 & 0.05 & 0.07 & $25.8 \%$ \\
\hline West North Central $\ldots \ldots \ldots \ldots \ldots \ldots \ldots \ldots$ & 0.00 & 0.01 & 0.02 & 0.03 & $26.1 \%$ \\
\hline South Atlantic $\ldots \ldots \ldots \ldots \ldots \ldots \ldots \ldots \ldots$ & 0.00 & 0.03 & 0.05 & 0.08 & $26.5 \%$ \\
\hline East South Central $\ldots \ldots \ldots \ldots \ldots \ldots \ldots$ & 0.00 & 0.01 & 0.02 & 0.02 & $26.2 \%$ \\
\hline West South Central ..................... & 0.00 & 0.02 & 0.03 & 0.04 & $26.3 \%$ \\
\hline Mountain.$\ldots \ldots \ldots \ldots \ldots \ldots \ldots \ldots \ldots \ldots$ & 0.00 & 0.01 & 0.02 & 0.02 & $27.0 \%$ \\
\hline Pacific $\ldots \ldots \ldots \ldots \ldots \ldots \ldots \ldots \ldots \ldots \ldots \ldots \ldots \ldots \ldots$ & 0.00 & 0.03 & 0.05 & 0.07 & $26.4 \%$ \\
\hline Tolal $\ldots \ldots \ldots \ldots \ldots \ldots \ldots \ldots \ldots \ldots \ldots$ & 0.01 & 0.16 & 0.29 & 0.43 & $26.3 \%$ \\
\hline
\end{tabular}


Table 75. Natural Gas Consumption by End-Use Sector and Census Division (Continued) (Quadrillion Btu per Year)

\begin{tabular}{|c|c|c|c|c|c|}
\hline \multirow{2}{*}{ Sector and Region } & \multicolumn{4}{|c|}{ Reference Case } & \multirow{2}{*}{$\begin{array}{c}\text { Annual } \\
\text { Growth } \\
\text { 1993-2010 } \\
\text { (percent) }\end{array}$} \\
\hline & 1993 & 2000 & 2005 & 2010 & \\
\hline \multicolumn{6}{|l|}{ All Sectors ${ }^{4}$} \\
\hline New England $\ldots \ldots \ldots \ldots \ldots \ldots \ldots \ldots$ & 0.54 & 0.58 & 0.62 & 0.69 & $1.5 \%$ \\
\hline Middle Allantic $\ldots \ldots \ldots \ldots \ldots \ldots \ldots \ldots \ldots$ & 2.26 & 2.38 & 2.44 & 2.56 & $0.7 \%$ \\
\hline East North Central $\ldots \ldots \ldots \ldots \ldots \ldots \ldots \ldots$ & 3.70 & 3.92 & 4.03 & 4.38 & $1.0 \%$ \\
\hline West North Central $\ldots \ldots \ldots \ldots \ldots \ldots \ldots \ldots$ & 1.25 & 1.34 & 1.30 & 1.35 & $0.5 \%$ \\
\hline South Atlantic $\ldots \ldots \ldots \ldots \ldots \ldots \ldots \ldots \ldots$ & 1.63 & 2.00 & 2.38 & 2.94 & $3.5 \%$ \\
\hline East South Central $\ldots \ldots \ldots \ldots \ldots \ldots \ldots$ & 0.90 & 0.93 & 0.96 & 1.03 & $0.8 \%$ \\
\hline West South Central $\ldots \ldots \ldots \ldots \ldots \ldots \ldots$ & 5.45 & 5.79 & 6.05 & 6.47 & $1.0 \%$ \\
\hline Mountain $\ldots \ldots \ldots \ldots \ldots \ldots \ldots \ldots$ & 0.82 & 1.19 & 1.17 & 1.10 & $1.7 \%$ \\
\hline Pacific $\ldots \ldots \ldots \ldots \ldots \ldots \ldots \ldots \ldots$ & 2.40 & 2.61 & 2.71 & 2.62 & $0.5 \%$ \\
\hline 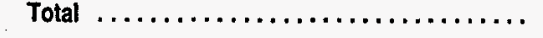 & 18.95 & 20.74 & 21.66 & 23.15 & $1.2 \%$ \\
\hline
\end{tabular}

'Excludes lease and plant fuel, and includes consumption by cogenerators.

${ }^{2}$ Includes all electric power generators except cogenerators, which produce electricity as a by-product of other processes.

${ }^{3}$ Compressed natural gas used as a vehicle fuel.

Excludes lease and plant fuel and natural gas used for pipeline compressor station fuel.

Btu $=$ British thermal unit

N/A $=$ Not applicable.

Notes: Totals may not equal sum of components due to independent rounding. Figures for 1993 may differ from published data due to internal conversion factors in the AEO95 National Energy Modeling System.

Sources: 1993 transportation sector compressed natural gas consumption: Energy Information Administration (EIA), AEO95 National Energy Modeling System run AEO95B.D1103942. Other 1993 values: EIA, Natural Gas Monthly, DOE/EIA-0130(94/6) (Washington, D.C., June 1994) with adjustments to end-use sector consumption levels for consumption of natural gas by electric wholesale generators based on ElA, AEO95 National Energy Modeling System run AEO95B.D1103942. Projections: EIA, AEO95 National Energy Modeling System run AEO95B.D1103942. 
Table 76. Natural Gas Delivered Prices by End-Use Sector and Census Division (1993 Dollars per Million Btu)

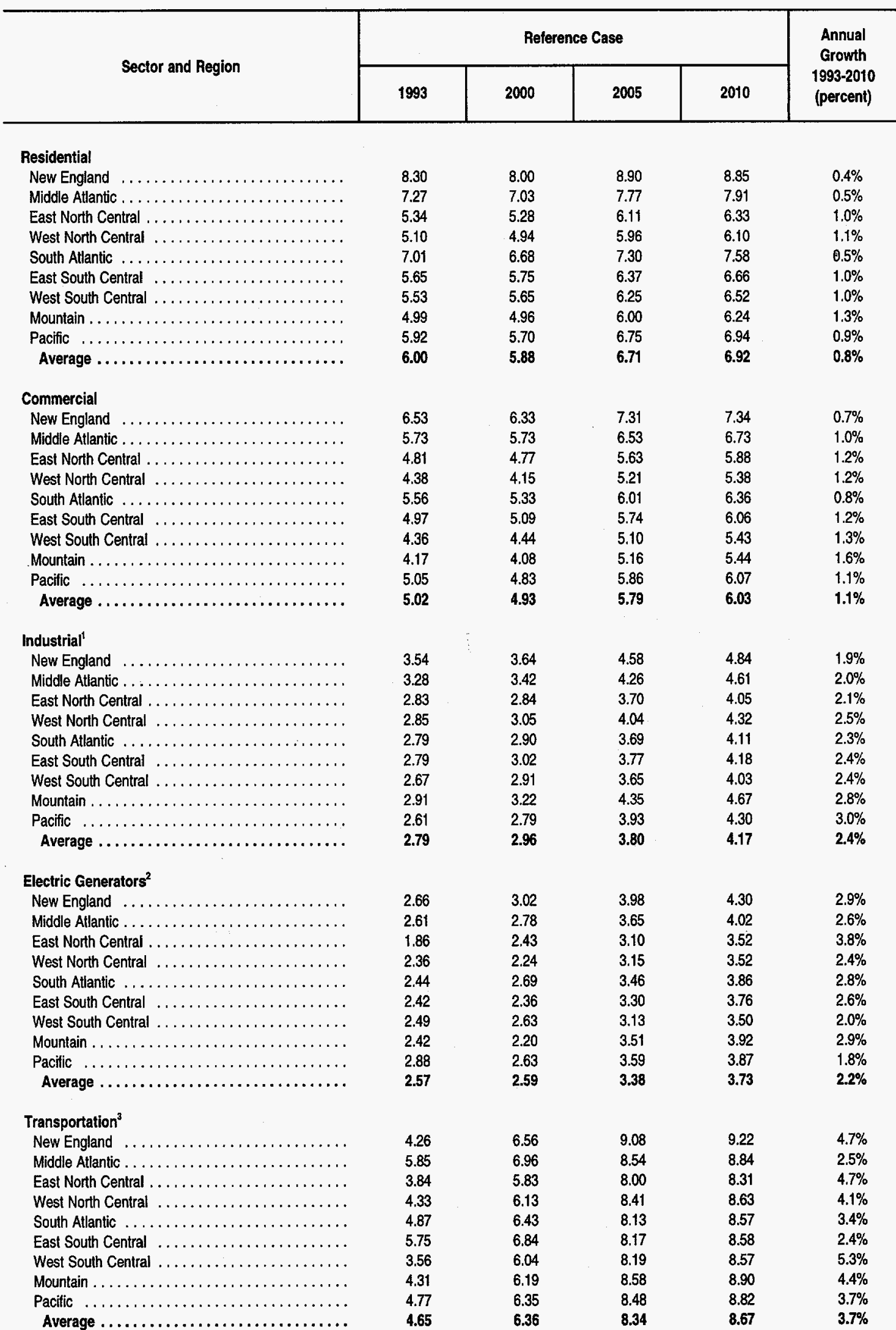


Table 76. Natural Gas Delivered Prices by End-Use Sector and Census Division (Continued) (1993 Dollars per Million Btu)

\begin{tabular}{|c|c|c|c|c|c|}
\hline Sector and Region & \multicolumn{4}{|c|}{ Reterence Case } & $\begin{array}{c}\text { Annual } \\
\text { Growth } \\
\text { 1993-20t0 } \\
\text { (percent) }\end{array}$ \\
\hline \multicolumn{6}{|l|}{ All Sectors ${ }^{4}$} \\
\hline New England $\ldots \ldots \ldots \ldots \ldots \ldots \ldots$ & 5.92 & 5.75 & 6.68 & 6.64 & $0.7 \%$ \\
\hline Middle Atlantic . . . . . . . . . . . . . . . . . & 5.40 & 5.24 & 5.98 & 6.14 & $0.8 \%$ \\
\hline East North Central . . . . . . . . . . . . . . & 4.27 & 4.20 & 4.98 & 5.14 & $1.1 \%$ \\
\hline West North Central $\ldots \ldots \ldots \ldots \ldots \ldots \ldots$ & 4.06 & 3.95 & 5.01 & 5.17 & $1.4 \%$ \\
\hline South Atlantic $\ldots \ldots \ldots \ldots \ldots \ldots \ldots \ldots$ & 4.36 & 4.15 & 4.76 & 4.98 & $0.8 \%$ \\
\hline East South Central $\ldots \ldots \ldots \ldots \ldots \ldots \ldots$ & 3.77 & 3.93 & 4.67 & 5.01 & $1.7 \%$ \\
\hline West South Central ................... & 2.93 & 3.14 & 3.80 & 4.16 & $2.1 \%$ \\
\hline Mountain $\ldots \ldots \ldots \ldots \ldots \ldots \ldots \ldots \ldots$ & 3.87 & 3.44 & 4.64 & 5.09 & $1.6 \%$ \\
\hline Pacific $\ldots \ldots \ldots \ldots \ldots \ldots \ldots \ldots \ldots$ & 3.91 & 3.79 & 4.84 & 5.25 & $1.7 \%$ \\
\hline Average $\ldots \ldots \ldots \ldots \ldots \ldots \ldots \ldots \ldots \ldots$ & 3.97 & 3.94 & 4.74 & 5.01 & $1.4 \%$ \\
\hline
\end{tabular}

'Excludes lease and plant fuel and includes consumption by cogenerators.

Includes all electric power generators except cogenerators, which produce electricity as a by-product of other processes.

${ }^{3}$ Compressed natural gas used as a vehicle fuel.

"Weighted average price. Weights used are the sector consumption values.

Btu = British thermal unit.

N/A = Not applicable.

Notes: Totals may not equal sum of components due to independent rounding. Figures for 1993 may differ from published data due to internal conversion factors in the AEO95 National Energy Modeling System.

Sources: 1993 residential and commercial sector values: Energy Information Administration (EIA), Natura/ Gas Monthly, DOE/EIA-0130(94/6) (Washington, D.C., June 1994). Other 1993 values and projections: EIA, AEO95 National Energy Modeling System run AEO958.D1 103942. 
Table 77. Natural Gas Pipeline Capacity by Census Division (Design Capacity in Billions of Cubic Feet per Year)

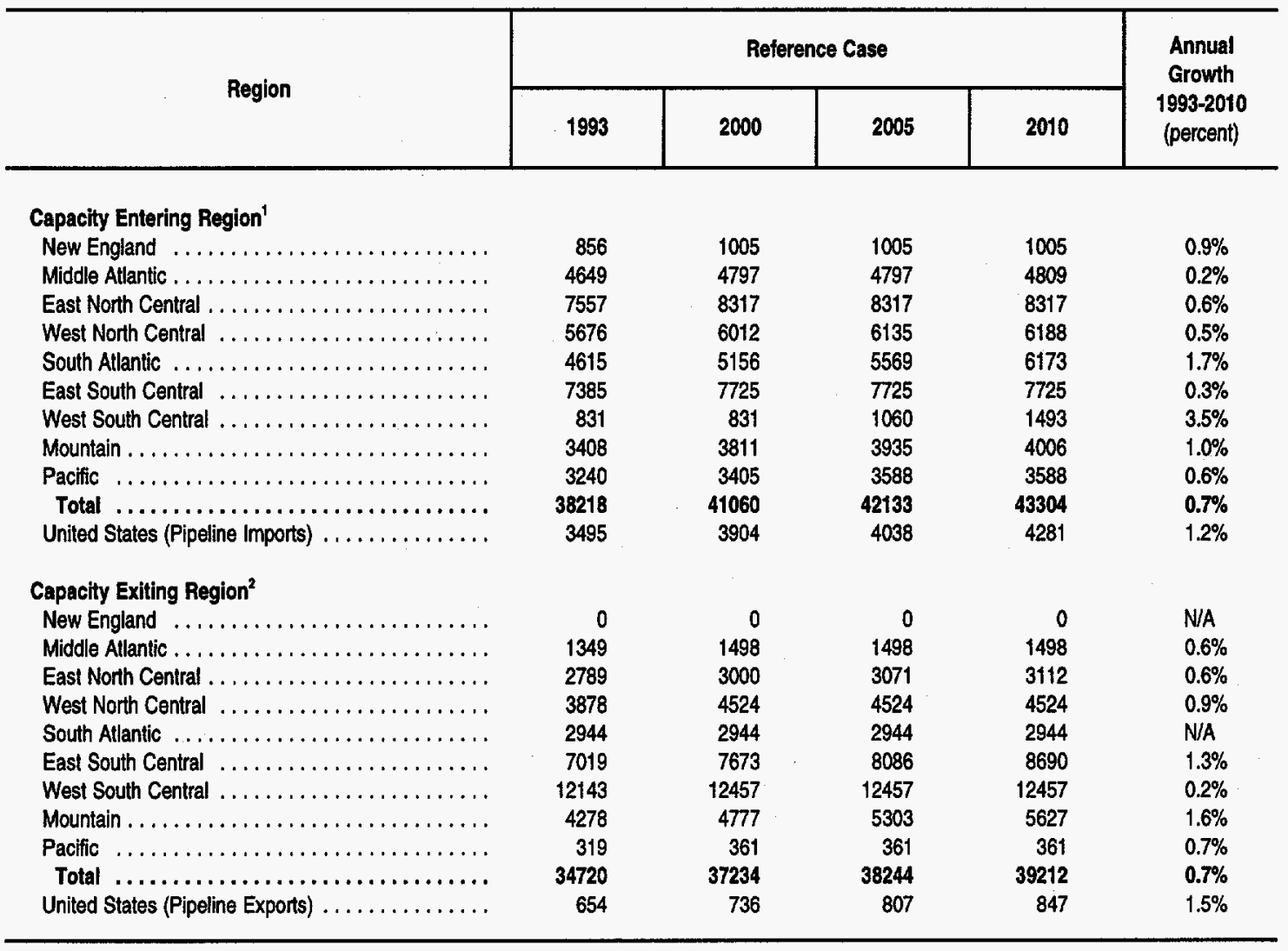

'Includes only the sum of capacity levels for the States bounding the respective regions and excludes pipeline import capacity. ${ }^{2}$ Includes only the sum of capacily levels for the States bounding the respective regions and excludes pipeline export capacity. N/A = Not applicable.

Note: Totals may not equal sum of components due to independent rounding.

Source: Energy Information Administration, AEO95 National Energy Modeling System run AEO95B.D1103942. 
Table 78. Natural Gas Pipeline Capacity Utilization' by Census Division (Percent)

\begin{tabular}{|c|c|c|c|c|c|}
\hline \multirow{2}{*}{ Region } & \multicolumn{4}{|c|}{ Reference Case } & \multirow{2}{*}{$\begin{array}{c}\text { Annual } \\
\text { Growth } \\
\text { 1993-2010 } \\
\text { (percent) }\end{array}$} \\
\hline & 1993 & 2000 & 2005 & 2010 & \\
\hline \multicolumn{6}{|l|}{ Capacity Entering Region } \\
\hline New England $\ldots \ldots \ldots$ & 0.50 & 0.48 & 0.46 & 0.54 & $0.5 \%$ \\
\hline Middle Allantic $\ldots \ldots \ldots \ldots \ldots \ldots \ldots \ldots \ldots$ & 0.55 & 0.58 & 0.59 & 0.63 & $0.9 \%$ \\
\hline East North Central $\ldots \ldots \ldots \ldots \ldots \ldots \ldots \ldots$ & 0.65 & 0.64 & 0.68 & 0.69 & $0.3 \%$ \\
\hline West North Central $\ldots \ldots \ldots \ldots \ldots \ldots \ldots \ldots$ & 0.47 & 0.39 & 0.39 & 0.38 & $-1.3 \%$ \\
\hline South Atlantic $, \ldots \ldots \ldots \ldots, \ldots \ldots \ldots \ldots$ & 0.67 & 0.67 & 0.74 & 0.69 & $0.2 \%$ \\
\hline East South Central $\ldots \ldots \ldots \ldots \ldots \ldots \ldots$ & 0.79 & 0.85 & 0.80 & 0.75 & $-0.3 \%$ \\
\hline West South Central . .................. & 0.48 & 0.46 & 0.49 & 0.62 & $1.5 \%$ \\
\hline Mountain $\ldots \ldots \ldots \ldots \ldots \ldots \ldots \ldots \ldots$ & 0.35 & 0.41 & 0.42 & 0.42 & $1.1 \%$ \\
\hline Pacific $\ldots \ldots \ldots \ldots \ldots \ldots \ldots \ldots \ldots \ldots \ldots \ldots \ldots$ & 0.57 & 0.64 & 0.65 & 0.62 & $0.5 \%$ \\
\hline Average $^{2} \ldots \ldots \ldots \ldots \ldots \ldots \ldots \ldots$ & 0.60 & 0.61 & 0.62 & 0.61 & $0.1 \%$ \\
\hline United States (Pipeline Imports) ............. & 0.78 & 0.84 & 0.84 & 0.84 & $0.5 \%$ \\
\hline \multicolumn{6}{|l|}{ Capacity Exiting Region } \\
\hline New England $\ldots \ldots \ldots$ & 0.00 & 0.00 & 0.00 & 0.00 & N/A \\
\hline Middle Atlantic $\ldots \ldots \ldots \ldots \ldots \ldots \ldots \ldots$ & 0.37 & 0.37 & 0.36 & 0.41 & $0.6 \%$ \\
\hline East North Central $\ldots \ldots \ldots \ldots \ldots \ldots \ldots \ldots$ & 0.56 & 0.54 & 0.59 & 0.47 & $-1.0 \%$ \\
\hline West North Central $\ldots \ldots \ldots \ldots \ldots \ldots \ldots \ldots$ & 0.58 & 0.46 & 0.54 & 0.54 & $-0.4 \%$ \\
\hline South Atlantic $\ldots \ldots \ldots \ldots \ldots \ldots \ldots \ldots \ldots$ & 0.55 & 0.55 & 0.66 & 0.74 & $1.7 \%$ \\
\hline East South Central $\ldots \ldots \ldots \ldots \ldots \ldots \ldots$ & 0.74 & 0.83 & 0.82 & 0.82 & $0.6 \%$ \\
\hline West South Central . .................. & 0.57 & 0.55 & 0.52 & 0.48 & $-1.1 \%$ \\
\hline Mountain $\ldots \ldots \ldots \ldots \ldots \ldots \ldots \ldots \ldots$ & 0.64 & 0.70 & 0.70 & 0.69 & $0.4 \%$ \\
\hline Pacific,$\ldots \ldots \ldots \ldots \ldots \ldots \ldots \ldots \ldots \ldots$ & 0.03 & 0.02 & 0.02 & 0.02 & $-0.7 \%$ \\
\hline Average $^{2} \ldots \ldots \ldots \ldots \ldots \ldots \ldots \ldots \ldots \ldots$ & 0.59 & 0.59 & 0.60 & 0.59 & $0.1 \%$ \\
\hline United States (Pipeline Exports) . . . . . . . . . . & 0.86 & 0.85 & 0.85 & 0.85 & $0.0 \%$ \\
\hline
\end{tabular}

'Capacity utilization is defined as the annual throughput volume divided by the design capacity (Table 77). On bi-directional arcs, the annual volume only reflects the volume moving in the dominate direction of the flow. Capacity utilization may be somev'hat understated for pipeline corridors where flow changes directions to accommodate seasonal changes in supply, demand and storage patterns.

${ }^{2}$ Weighted average utilization. Weights used are the regional pipeline capacity levels provided in Table 77.

N/A = Not applicable.

Note: Totals may not equal sum of components due to independent rounding.

Source: Energy Information Administration, AEO95 National Energy Modeling System run AEO95B.D1103942. 
Table 79. Domestic Coal Supply, Disposition, and Prices New England Census Division

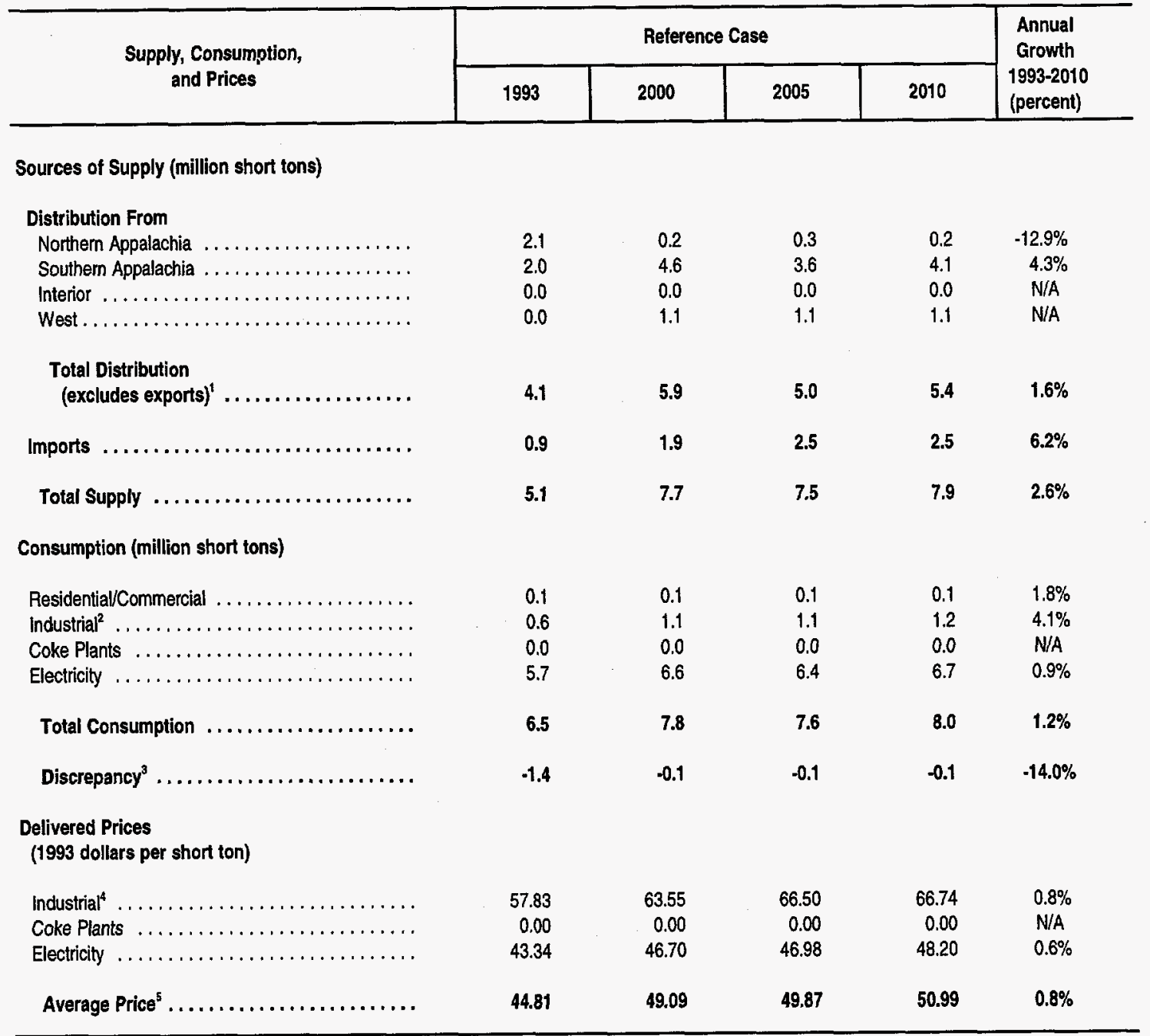

'Excludes distributions less than $\mathbf{5 0 0}$ tons and to unknown destinations.

${ }^{2}$ Historical data is the sum of steam and coking coal consumption.

${ }^{3}$ includes stock changes.

"Historical data is the average for steam and coking coal consumption

${ }^{5}$ Weighted average excludes residential/commercial prices.

N/A = Not applicable.

Note: Total may not equal sum of components due to independent rounding.

Sources: 1993: Distribution: Unpublished Energy information Administration (EIA) Form EIA-6 data for 1993. Imports: U.S. Bureau of the Census, Form IM-145. Stock changes, consumption and prices: ElA, Quarterly Coal Report, October-December 1993, DOE/EIA-0121(93/4Q) (Washington, D.C., May 1994). Withheld values have been estimated from EIA, State Energy Data Report 1992, Consumption Estimates, DOE/EIA$0214(92)$ and EIA, State Energy Price and Expenditure Report 1992, DOE/EIA-0376(92) (Washington, D.C., December 1994). Projections: EIA, AEO95 National Energy Modeling System run AEO95B.D1103942. 
Table 80. Domestic Coal Supply, Disposition, and Prices Middle Atlantic Census Division

\begin{tabular}{|c|c|c|c|c|c|}
\hline \multirow{2}{*}{$\begin{array}{l}\text { Supply, Consumption, } \\
\text { and Prices }\end{array}$} & \multicolumn{4}{|c|}{ Reference Case } & \multirow{2}{*}{$\begin{array}{c}\text { Annual } \\
\text { Growth } \\
\text { 1993-2010 } \\
\text { (percent) }\end{array}$} \\
\hline & 1993 & 2000 & 2005 & 2010 & \\
\hline \multicolumn{6}{|l|}{ Sources of Supply (million short tons) } \\
\hline \multicolumn{6}{|l|}{ Distribution From } \\
\hline Northem Appalachia $\ldots \ldots \ldots \ldots$ & 51.2 & 44.7 & 50.5 & 56.4 & $0.6 \%$ \\
\hline Southem Appalachia $\ldots \ldots \ldots \ldots \ldots \ldots \ldots$ & 13.2 & 21.5 & 14.4 & 12.5 & $-0.3 \%$ \\
\hline Interior $\ldots \ldots \ldots \ldots \ldots \ldots \ldots \ldots \ldots \ldots \ldots$ & 0.0 & 0.0 & 0.0 & 0.0 & N/A \\
\hline West.............................. & 0.0 & 3.1 & 3.1 & 3.5 & N/A \\
\hline Total Distribution & & & & & \\
\hline (excludes exports) ${ }^{1} \ldots \ldots \ldots \ldots \ldots \ldots$ & 64.4 & 69.2 & 68.0 & 72.4 & $0.7 \%$ \\
\hline Imports $\ldots \ldots \ldots \ldots \ldots \ldots \ldots \ldots \ldots \ldots \ldots \ldots$ & 0.1 & 0.7 & 0.7 & 0.7 & $12.0 \%$ \\
\hline Total Supply $\ldots \ldots \ldots \ldots \ldots \ldots \ldots \ldots$ & 64.6 & 69.8 & 68.7 & 73.1 & $0.7 \%$ \\
\hline \multicolumn{6}{|l|}{ Consumption (million short tons) } \\
\hline Residential/Commercial . & 1.5 & 2.1 & 2.0 & 2.0 & $1.8 \%$ \\
\hline Industrial $^{2} \ldots \ldots \ldots \ldots \ldots \ldots$ & 5.9 & 7.8 & 8.2 & 8.7 & $2.3 \%$ \\
\hline Coke Plants $\ldots \ldots \ldots \ldots \ldots \ldots \ldots \ldots$ & 12.2 & 8.8 & 7.7 & 6.7 & $-3.4 \%$ \\
\hline Electricity $\ldots \ldots \ldots \ldots \ldots \ldots \ldots \ldots \ldots$ & 51.1 & 51.4 & 50.9 & 55.6 & $0.5 \%$ \\
\hline Total Consumption $\ldots \ldots \ldots \ldots \ldots \ldots \ldots$ & 70.7 & 70.0 & 68.8 & 73.1 & $0.2 \%$ \\
\hline Discrepancy ${ }^{3} \ldots \ldots \ldots \ldots \ldots \ldots \ldots \ldots \ldots \ldots$ & -6.1 & -0.2 & -0.1 & 0.0 & N/A \\
\hline \multicolumn{6}{|l|}{$\begin{array}{l}\text { Delivered Prices } \\
\text { (1993 dollars per short ton) }\end{array}$} \\
\hline Industrial $^{4} \ldots$ & 36.53 & 33.52 & 33.47 & 34.61 & $-0.3 \%$ \\
\hline Coke Plants $\ldots \ldots \ldots \ldots \ldots \ldots \ldots \ldots$ & 43.40 & 43.59 & 45.12 & 45.60 & $0.3 \%$ \\
\hline Electricity $\ldots \ldots \ldots \ldots \ldots \ldots \ldots \ldots \ldots$ & 36.66 & 34.28 & 34,37 & 36.13 & $-0.1 \%$ \\
\hline Average Price ${ }^{5} \ldots \ldots \ldots \ldots \ldots \ldots \ldots$ & 37.84 & 35.39 & 35.50 & 36.84 & $-0.2 \%$ \\
\hline
\end{tabular}

'Excludes distributions less than 500 tons and to unknown destinations.

2Historical data is the sum of steam and coking coal consumption.

${ }^{3}$ Includes stock changes.

Historical data is the average for steam and coking coal consumption

"Weighted average excludes residentialcommercial prices.

$\mathrm{N} / \mathrm{A}=$ Not applicable.

Note: Total may not equal sum of components due to independent rounding

Sources: 1993: Distribution: Unpublished Energy Information Administration (EIA) Form EIA-6 data for 1993. Imports: U.S. Bureau of the Census, Form IM-145. Stock changes, consumption and prices: EIA, Quarterly Coal Report, October-December 1993, DOE/EIA-0121(93/4Q) (Washington, D.C., May 1994). Withheld values have been estimated from ElA, State Energy Data Report 1992, Consumption Estimates, DOE/EIA0214(92) and EIA, State Energy Price and Expenditure Report 1992, DOE/EIA-0376(92) (Washington, D.C., December 1994). Projections: EIA, AEO95 National Energy Modeling System run AEO95B.D1 103942. 
Table 81. Domestic Coal Supply, Disposition, and Prices East North Central Census Division

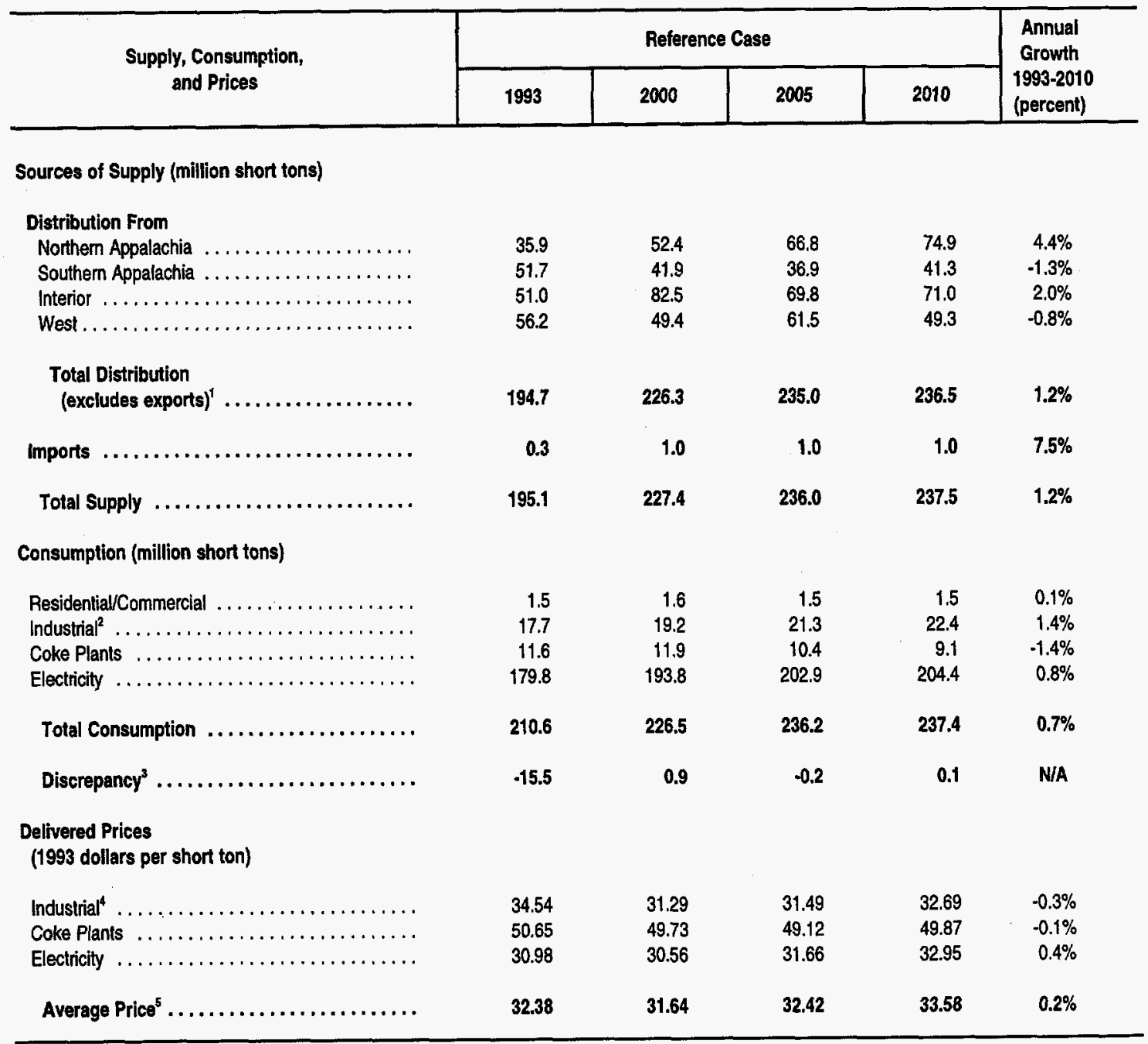

'Excludes distributions less than $\mathbf{5 0 0}$ tons and to unknown destinations.

${ }^{2}$ Historical data is the sum of steam and coking coal consumption.

Includes stock changes.

"Historical data is the average for steam and coking coal consumption

Weighted average excludes residentiaVcommercial prices.

N/A = Not applicable.

Note: Total may not equal sum of components due to independent rounding.

Sources: 1993: Distribution: Unpublished Energy Information Administration (EIA) Form EIA-6 data for 1993. Imports: U.S. Bureau of the Census, Form IM-145. Stock changes, consumption and prices: EIA, Quarterly Coal Report, October-December 1993, DOE/EIA-0121(93/4Q) (Washington, D.C. May 1994). Withheld values have been estimated from EIA, State Energy Data Report 1992, Consumption Estimates, DOE/EIA0214(92) and EIA, State Energy Price and Expenditure Report 1992, DOE/EIA-0376(92) (Washington, D.C., December 1994). Projections: EIA, AEO95 National Energy Modeling System run AEO95B.D1 103942. 
Table 82. Domestic Coal Supply, Disposition, and Prices West North Central Census Division

\begin{tabular}{|c|c|c|c|c|c|}
\hline \multirow{2}{*}{$\begin{array}{l}\text { Supply, Consumption, } \\
\text { and Prices }\end{array}$} & \multicolumn{4}{|c|}{ Reference Case } & \multirow{2}{*}{$\begin{array}{l}\text { Annual } \\
\text { Growth } \\
\text { 1993-2010 } \\
\text { (percent) }\end{array}$} \\
\hline & 1993 & 2000 & 2005 & 2010 & \\
\hline \multicolumn{6}{|l|}{ Sources of Supply (million short tons) } \\
\hline \multicolumn{6}{|l|}{ Distribution From } \\
\hline Northern Appalachia $\ldots \ldots \ldots \ldots \ldots \ldots \ldots$ & 0.4 & 0.0 & 0.0 & 1.5 & $8.0 \%$ \\
\hline Southern Appalachia $\ldots \ldots \ldots \ldots \ldots \ldots \ldots$ & 0.7 & 0.0 & 0.0 & 0.0 & N/A \\
\hline Interior $\ldots \ldots \ldots \ldots \ldots \ldots \ldots \ldots \ldots$ & 10.6 & 18.5 & 10.4 & 8.2 & $-1.5 \%$ \\
\hline 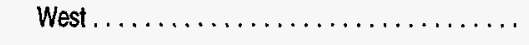 & 104.1 & 104.2 & 117.7 & 122.8 & $1.0 \%$ \\
\hline Total Distribution & & & & & \\
\hline (excludes exports),$\ldots \ldots \ldots \ldots \ldots \ldots$ & 115.7 & 122.7 & 128.1 & 132.4 & $0.8 \%$ \\
\hline Imports $\ldots \ldots \ldots \ldots \ldots \ldots \ldots \ldots \ldots \ldots \ldots \ldots \ldots$ & 0.0 & 0.0 & 0.0 & 0.0 & N/A \\
\hline Total Supply $\ldots \ldots \ldots \ldots \ldots \ldots \ldots \ldots$ & 116.3 & 122.7 & 128.1 & 132.4 & $0.8 \%$ \\
\hline \multicolumn{6}{|l|}{ Consumption (million short tons) } \\
\hline Residential/Commercial & 0.6 & 0.5 & 0.5 & 0.5 & $-1.0 \%$ \\
\hline Industrial $^{2} \ldots \ldots \ldots \ldots$ & 12.8 & 14.5 & 16.0 & 16.6 & $1.5 \%$ \\
\hline Coke Plants $\ldots \ldots \ldots \ldots \ldots \ldots \ldots \ldots \ldots$ & 0.0 & 0.0 & 0.0 & $0.0^{\circ}$ & N/A \\
\hline Electricity $\ldots \ldots \ldots \ldots \ldots \ldots \ldots \ldots$ & 107.6 & 107.5 & 111.7 & 115.3 & $0.4 \%$ \\
\hline Total Consumption $\ldots \ldots \ldots \ldots \ldots \ldots \ldots$ & 120.9 & 122.5 & 128.1 & 132.4 & $0.5 \%$ \\
\hline Discrepancy $^{3} \ldots \ldots \ldots \ldots \ldots \ldots \ldots \ldots$ & -4.6 & 0.2 & 0.0 & 0.0 & N/A \\
\hline \multicolumn{6}{|l|}{$\begin{array}{l}\text { Delivered Prices } \\
\text { (1993 dollars per short ton) }\end{array}$} \\
\hline Industrial $^{4} \ldots$ & 18.00 & 18.91 & 18.16 & 20.65 & $0.8 \%$ \\
\hline Coke Plants $\ldots \ldots \ldots \ldots \ldots \ldots \ldots \ldots \ldots$ & 0.00 & 0.00 & 0.00 & 0.00 & N/A \\
\hline Electricity $\ldots \ldots \ldots \ldots \ldots \ldots \ldots \ldots \ldots$ & 16.88 & 21.13 & 22.00 & 23.94 & $2.1 \%$ \\
\hline Average Price ${ }^{5} \ldots \ldots \ldots \ldots \ldots \ldots \ldots \ldots$ & 17.00 & 20.87 & 21.52 & 23.52 & $1.9 \%$ \\
\hline
\end{tabular}

'Excludes distributions less than $\mathbf{5 0 0}$ tons and to unknown destinations.

${ }^{2}$ Historical data is the sum of steam and coking coal consumption.

"includes stock changes.

"Historical data is the average for steam and coking coal consumption

"Weighted average excludes residential/commercial prices.

$\mathrm{N} / \mathrm{A}=$ Not applicable.

Note: Total may not equal sum of components due to independent rounding.

Sources: 1993: Distribution: Unpublished Energy Information Administration (EIA) Form EIA-6 data for 1993. Imports: U.S. Bureau of the Census, Form IM-145. Stock changes, consumption and prices: EIA, Quarterly Coal Report, October-December 1993, DOE/EIA-0121(93/4Q) (Washington, D.C., May 1994). Withheld values have been estimated from EIA, State Energy Data Report 1992, Consumption Estimates, DOE/EIA0214(92) and EIA, State Energy Price and Expenditure Report 1992, DOE/EIA-0376(92) (Washington, D.C., December 1994). Projections: ElA, AEO95 National Energy Modeling System run AEO95B.D1103942. 
Table 83. Domestic Coal Supply, Disposition, and Prices South Atlantic Census Division

\begin{tabular}{|c|c|c|c|c|c|}
\hline \multirow{2}{*}{$\begin{array}{l}\text { Supply, Consumption, } \\
\text { and Prices }\end{array}$} & \multicolumn{4}{|c|}{ Reference Case } & \multirow{2}{*}{$\begin{array}{c}\text { Annual } \\
\text { Growth } \\
1993-2010 \\
\text { (percent) }\end{array}$} \\
\hline & 1993 & 2000 & 2005 & 2010 & \\
\hline \multicolumn{6}{|l|}{ Sources of Supply (million short tons) } \\
\hline \multicolumn{6}{|l|}{ Distribution From } \\
\hline Northem Appalachia & 26.1 & 24.8 & 25.1 & 25.6 & $-0.1 \%$ \\
\hline Southern Appalachia . & 103.0 & 120.0 & 121.0 & 121.8 & $1.0 \%$ \\
\hline 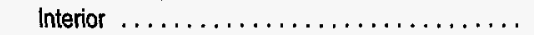 & 11.4 & 0.0 & 0.0 & 0.0 & $-50.9 \%$ \\
\hline 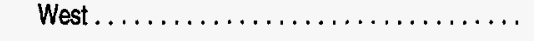 & 1.0 & 20.8 & 24.8 & 31.0 & $22.4 \%$ \\
\hline $\begin{array}{l}\text { Total Distribution } \\
\text { (excludes exports) }{ }^{1} \ldots \ldots \ldots \ldots \ldots \ldots \ldots\end{array}$ & 141.5 & 165.5 & 170.9 & 178.5 & $1.4 \%$ \\
\hline Imports $\ldots \ldots \ldots \ldots \ldots \ldots \ldots \ldots \ldots \ldots \ldots \ldots$ & 2.5 & 6.0 & 6.1 & 6.2 & $5.5 \%$ \\
\hline Total Supply $\ldots \ldots \ldots \ldots \ldots \ldots \ldots \ldots \ldots$ & 144.0 & 171.5 & 177.0 & 184.7 & $1.5 \%$ \\
\hline \multicolumn{6}{|l|}{ Consumption (million short tons) } \\
\hline Residential/Commercial .... & 0.9 & 0.7 & 0.7 & 0.6 & $-1.9 \%$ \\
\hline |ndustrial $^{2} \ldots \ldots \ldots \ldots \ldots \ldots \ldots \ldots \ldots$ & 14.0 & 17.9 & 18.9 & 20.0 & $2.1 \%$ \\
\hline Coke Plants $\ldots \ldots \ldots \ldots \ldots \ldots \ldots \ldots \ldots$ & 2.7 & 2.5 & 2.2 & 1.9 & $-1.9 \%$ \\
\hline Electricity $\ldots \ldots \ldots \ldots \ldots \ldots \ldots \ldots \ldots$ & 132.9 & 150.5 & 154.9 & 161.8 & $1.2 \%$ \\
\hline Total Consumption $\ldots \ldots \ldots \ldots \ldots \ldots \ldots$ & 150.4 & 171.6 & 176.7 & 184.4 & $1.2 \%$ \\
\hline Discrepancy $^{3}, \ldots \ldots \ldots \ldots \ldots \ldots \ldots \ldots$ & -6.4 & -0.2 & 0.4 & 0.3 & N/A \\
\hline \multicolumn{6}{|l|}{$\begin{array}{l}\text { Delivered Prices } \\
\text { (1993 dollars per short ton) }\end{array}$} \\
\hline Industrial $^{4} \ldots \ldots \ldots \ldots \ldots \ldots \ldots \ldots \ldots$ & 41.77 & 39.13 & 40.99 & 41.38 & $-0.1 \%$ \\
\hline Coke Plants $\ldots \ldots \ldots \ldots \ldots \ldots \ldots \ldots \ldots$ & 41.91 & 36.49 & 38.23 & 38.54 & $-0.5 \%$ \\
\hline Electricity $\ldots \ldots \ldots \ldots \ldots \ldots \ldots \ldots$ & 40.80 & 39.87 & 42.46 & 42.06 & $0.2 \%$ \\
\hline Average Price ${ }^{5}, \ldots \ldots \ldots \ldots \ldots \ldots \ldots \ldots$ & 40.91 & 39.75 & 42.25 & 41.95 & $0.1 \%$ \\
\hline
\end{tabular}

'Excludes distributions less than 500 tons and to unknown destinations.

${ }^{2}$ Historical data is the sum of steam and coking coal consumption.

Includes stock changes.

"Historical data is the average for steam and coking coal consumption

Weighted average excludes residential/commercial prices.

N/A = Not applicable.

Note: Total may not equal sum of components due to independent rounding.

Sources: 1993: Distribution: Unpublished Energy Information Administration (EIA) Form ElA-6 data for 1993. Imports: U.S. Bureau of the Census, Form IM-145. Stock changes, consumption and prices: EIA, Quarterly Coal Report, October-December 1993, DOE/EIA-0121(93/4Q) (Washington, D.C., May 1994). Withheld values have been estimated from EIA, State Energy Data Report 1992, Consumption Estimates, DOE/EIA0214(92) and EIA, State Energy Price and Expenditure Report 1992, DOE/EIA-0376(92) (Washington, D.C., December 1994). Projections: EIA, AEO95 National Energy Modeling System run AEO95B.D1103942. 
Table 84. Domestic Coal Supply, Disposition, and Prices East South Central Census Division

\begin{tabular}{|c|c|c|c|c|c|}
\hline \multirow{2}{*}{$\begin{array}{l}\text { Supply, Consumption, } \\
\text { and Prices }\end{array}$} & \multicolumn{4}{|c|}{ Reference Case } & \multirow{2}{*}{$\begin{array}{c}\text { Annual } \\
\text { Growth } \\
1993-2010 \\
\text { (percent) }\end{array}$} \\
\hline & 1993 & 2000 & 2005 & 2010 & \\
\hline \multicolumn{6}{|l|}{ Sources of Supply (million short tons) } \\
\hline \multicolumn{6}{|l|}{ Distribution From } \\
\hline Northern Appalachia & 1.8 & 25.6 & 22.6 & 31.0 & $18.2 \%$ \\
\hline Southern Appalachia $\ldots \ldots \ldots \ldots \ldots \ldots$ & 60.1 & 65.2 & 68.0 & 59.2 & $-0.1 \%$ \\
\hline Interior $\ldots \ldots \ldots \ldots \ldots \ldots \ldots \ldots$ & 33.8 & 0.3 & 0.2 & 0.2 & $-25.8 \%$ \\
\hline West $\ldots \ldots \ldots \ldots \ldots \ldots \ldots \ldots \ldots \ldots \ldots \ldots \ldots \ldots \ldots$ & 1.2 & 0.0 & 0.0 & 0.0 & $-43.3 \%$ \\
\hline $\begin{array}{l}\text { Total Distribution } \\
\text { (excludes exports) }{ }^{1} \ldots \ldots \ldots \ldots \ldots \ldots \ldots\end{array}$ & 97.0 & 91.1 & 90.9 & 90.4 & $-0.4 \%$ \\
\hline Imports $\ldots \ldots \ldots \ldots \ldots \ldots \ldots \ldots \ldots \ldots \ldots \ldots$ & 0.9 & 0.3 & 0.3 & 0.3 & $-6.7 \%$ \\
\hline Total Supply . ..................... & 97.9 & 91.4 & 91.2 & 90.7 & $-0.5 \%$ \\
\hline \multicolumn{6}{|l|}{ Consumption (million short tons) } \\
\hline Residential/Commercial. & 0.4 & 0.5 & 0.5 & 0.5 & $0.7 \%$ \\
\hline industrial $^{2} \ldots \ldots \ldots \ldots \ldots \ldots \ldots \ldots \ldots$ & 9.2 & 10.0 & 10.9 & 11.5 & $1.3 \%$ \\
\hline Coke Plants $\ldots \ldots \ldots \ldots \ldots \ldots \ldots \ldots$ & 4.4 & 4.3 & 3.8 & 3.3 & $-1.6 \%$ \\
\hline 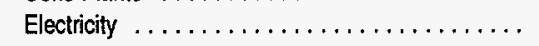 & 90.4 & 76.6 & 76.0 & 75.4 & $-1.1 \%$ \\
\hline Total Consumption $\ldots \ldots \ldots \ldots \ldots \ldots \ldots$ & 104.4 & 91.4 & 91.2 & 90.7 & $-0.8 \%$ \\
\hline Discrepancy ${ }^{3} \ldots \ldots \ldots \ldots \ldots \ldots \ldots$ & -6.5 & 0.0 & 0.0 & 0.0 & $-32.6 \%$ \\
\hline \multicolumn{6}{|l|}{$\begin{array}{l}\text { Delivered Prices } \\
\text { (1993 dollars per short ton) }\end{array}$} \\
\hline Industrial ${ }^{4} .$. & 35.10 & 37.64 & 39.00 & 39.77 & $0.7 \%$ \\
\hline$\ldots \ldots \ldots \ldots \ldots \ldots \ldots$ & 46.10 & 43.45 & 45.09 & 45.68 & $-0.1 \%$ \\
\hline Electricity $\ldots \ldots \ldots \ldots \ldots \ldots \ldots \ldots \ldots$ & 33.30 & 31.50 & 31.93 & 33.03 & $0.0 \%$ \\
\hline Average Price ${ }^{5} \ldots \ldots \ldots \ldots \ldots \ldots \ldots \ldots$ & 33.99 & 32.75 & 33.33 & 34.36 & $0.1 \%$ \\
\hline
\end{tabular}

'Excludes distributions less than $\mathbf{5 0 0}$ tons and to unknown destinations.

${ }^{2}$ Historical data is the sum of steam and coking coal consumption.

${ }^{3}$ Includes stock changes.

${ }^{4}$ Historical data is the average for steam and coking coal consumption

${ }^{5}$ Weighted average excludes residential/commercial prices.

N/A = Not applicable.

Note: Total may not equal sum of components due to independent rounding.

Sources: 1993: Distribution: Unpublished Energy Information Administration (ElA) Form ElA-6 data for 1993. Imports: U.S. Bureau of the Census, Form IM-145. Stock changes, consumption and prices: EIA, Quarterly Coal Report, October-December 1993, DOE/EIA-0121(93/4Q) (Washington, D.C., May 1994). Withheld values have been estimated from EIA, State Energy Data Report 1992, Consumption Estimates, DOE/EIA0214(92) and EIA, State Energy Price and Expenditure Report 1992, DOE/EIA-0376(92) (Washington, D.C., December 1994). Projections: EIA, AEO95 National Energy Modeling System run AEO95B.D1103942. 
Table 85. Domestic Coal Supply, Disposition, and Prices West South Central Census Division

\begin{tabular}{|c|c|c|c|c|c|}
\hline \multirow{2}{*}{$\begin{array}{l}\text { Supply, Consumption, } \\
\text { and Prices }\end{array}$} & \multicolumn{4}{|c|}{ Reference Case } & \multirow{2}{*}{$\begin{array}{l}\text { Annual } \\
\text { Growth } \\
1993-2010 \\
\text { (percent) }\end{array}$} \\
\hline & 1993 & 2000 & 2005 & 2010 & \\
\hline \multicolumn{6}{|l|}{ Sources of Supply (million short tons) } \\
\hline Northern Appalachia $\ldots \ldots \ldots \ldots \ldots \ldots \ldots$ & 0.2 & 0.0 & 0.0 & 0.0 & N/A \\
\hline Southern Appalachia . . . . . . . . . . . . . . & 0.2 & 5.7 & 9.2 & 11.0 & $26.6 \%$ \\
\hline Interior $\ldots \ldots \ldots \ldots \ldots \ldots \ldots \ldots \ldots \ldots$ & 59.7 & 59.9 & 65.1 & 65.5 & $0.5 \%$ \\
\hline West $\ldots \ldots \ldots \ldots \ldots \ldots \ldots \ldots \ldots \ldots$ & 76.6 & 67.3 & 69.7 & 71.0 & $-0.4 \%$ \\
\hline $\begin{array}{l}\text { Total Distribution } \\
\text { (excludes exports)' } \ldots \ldots \ldots \ldots \ldots \ldots \ldots\end{array}$ & 135.0 & 132.9 & 144.0 & 147.4 & $0.5 \%$ \\
\hline Total Supply $\ldots . \ldots \ldots \ldots \ldots \ldots \ldots$ & 137.4 & 135.5 & 146.8 & 150.7 & $0.5 \%$ \\
\hline \multicolumn{6}{|l|}{ Consumption (million short tons) } \\
\hline Residential/Commercial . . . . . . . . . . . . . . & 0.0 & 0.0 & 0.0 & 0.0 & N/A \\
\hline Industrial $^{2} \ldots \ldots \ldots \ldots \ldots \ldots \ldots \ldots$ & 6.8 & 6.7 & 7.1 & 7.5 & $0.6 \%$ \\
\hline Coke Plants $\ldots \ldots \ldots \ldots \ldots \ldots \ldots \ldots$ & 0.0 & 0.0 & 0.0 & 0.0 & N/A \\
\hline Electricity $\ldots \ldots \ldots \ldots \ldots \ldots \ldots \ldots$ & 134.0 & 130.2 & 141.5 & 145.3 & $0.5 \%$ \\
\hline Total Consumption $\ldots \ldots \ldots \ldots \ldots \ldots$ & 140.8 & 137.0 & 148.6 & 152.7 & $0.5 \%$ \\
\hline Coke Plants $\ldots \ldots \ldots \ldots \ldots \ldots \ldots \ldots$ & 0.00 & 0.00 & 0.00 & 0.00 & N/A \\
\hline Electricity $\ldots \ldots \ldots \ldots \ldots \ldots \ldots \ldots \ldots$ & 22.14 & 22.89 & 25.05 & 26.26 & $1.0 \%$ \\
\hline Average Price ${ }^{5} \ldots \ldots \ldots \ldots \ldots \ldots \ldots \ldots$ & 22.10 & 22.62 & 24.73 & 25.94 & $0.9 \%$ \\
\hline
\end{tabular}

${ }^{1}$ Excludes distributions less than $\mathbf{5 0 0}$ tons and to unknown destinations.

${ }^{2}$ Historical data is the sum of steam and coking coal consumption.

includes stock changes.

${ }^{4} H$ istorical data is the average for steam and coking coal consumption

${ }^{5}$ Weighted average excludes residential/commercial prices.

N/A $=$ Not applicable.

Note: Total may not equal sum of components due to independent rounding.

Sources: 1993: Distribution: Unpublished Energy Information Administration (EIA) Form ElA-6 data for 1993. Imports: U.S. Bureau of the Census, Form IM-145. Stock changes, consumption and prices: EIA, Quarterly Coal Report, October-December 1993, DOE/EIA-0121(93/4Q) (Washington, D.C., May 1994). Withheld values have been estimated from EIA, State Energy Data Report 1992, Consumption Estimates, DOE/EIA0214(92) and EIA, State Energy Price and Expenditure Report 1992, DOE/EIA-0376(92) (Washington, D.C., December 1994). Projections: EIA, AEO95 National Energy Modeling System run AEO95B.D1103942. 
Table 86. Domestic Coal Supply, Disposition, and Prices Mountain Census Division

\begin{tabular}{|c|c|c|c|c|c|}
\hline \multirow{2}{*}{$\begin{array}{l}\text { Supply, Consumption, } \\
\text { and Prices }\end{array}$} & \multicolumn{4}{|c|}{ Reference Case } & \multirow{2}{*}{$\begin{array}{c}\text { Annual } \\
\text { Growth } \\
1993-2010 \\
\text { (percent) }\end{array}$} \\
\hline & 1993 & 2000 & 2005 & 2010 & \\
\hline \multicolumn{6}{|l|}{ Sources of Supply (million short tons) } \\
\hline \multicolumn{6}{|l|}{ Distribution From } \\
\hline Northem Appalachia $\ldots \ldots \ldots \ldots \ldots$ & 0.2 & 0.9 & 0.8 & 0.6 & $6.9 \%$ \\
\hline Southern Appalachia $\ldots \ldots \ldots \ldots \ldots$ & 0.2 & 0.2 & 0.1 & 0.2 & $1.1 \%$ \\
\hline Interior $\ldots \ldots \ldots \ldots$. & 0.0 & 0.0 & 1.6 & 12.4 & N/A \\
\hline West $\ldots \ldots \ldots \ldots \ldots \ldots \ldots \ldots \ldots$ & 108.5 & 113.7 & 119.9 & 134.3 & $1.3 \%$ \\
\hline $\begin{array}{l}\text { Total Distribution } \\
\text { (excludes exports) }{ }^{1} \ldots \ldots \ldots \ldots \ldots \ldots\end{array}$ & 108.9 & 114.8 & 122.4 & 147.5 & $1.8 \%$ \\
\hline Imports $\ldots \ldots \ldots \ldots \ldots \ldots \ldots \ldots \ldots \ldots \ldots$ & 0.0 & 0.0 & 0.0 & 0.0 & N/A \\
\hline Total Supply $\ldots \ldots \ldots \ldots \ldots \ldots \ldots \ldots$ & 108.9 & 114.8 & 122.4 & 147.5 & $1.8 \%$ \\
\hline \multicolumn{6}{|l|}{ Consumption (million short tons) } \\
\hline Residential/Commercial & 0.4 & 0.5 & 0.5 & 0.5 & $1.6 \%$ \\
\hline Industrial| ${ }^{2} \ldots \ldots \ldots \ldots$ & 5.1 & 5.7 & 6.0 & 6.0 & $1.0 \%$ \\
\hline Coke Plants & 1.1 & 1.1 & 1.0 & 0.9 & $-1.4 \%$ \\
\hline Electricity $\ldots \ldots \ldots \ldots \ldots \ldots \ldots \ldots \ldots$ & 104.1 & 107.0 & 114.9 & 140.1 & $1.8 \%$ \\
\hline Total Consumption..$\ldots \ldots \ldots \ldots \ldots \ldots$ & 110.7 & 114.4 & 122.4 & 147.6 & $1.7 \%$ \\
\hline Discrepancy ${ }^{3} \ldots \ldots \ldots \ldots \ldots \ldots \ldots \ldots \ldots$ & -1.8 & 0.4 & 0.1 & 0.0 & $-24.4 \%$ \\
\hline \multicolumn{6}{|l|}{$\begin{array}{l}\text { Delivered Prices } \\
\text { (1993 dollars per short ton) }\end{array}$} \\
\hline Industrial $^{4} \ldots$ & 28.51 & 26.17 & 27.58 & 29.77 & $0.3 \%$ \\
\hline Coke Plants $\ldots \ldots \ldots \ldots \ldots \ldots \ldots \ldots \ldots$ & 48.21 & 55.84 & 57.24 & 58.42 & $1.1 \%$ \\
\hline Electricity $\ldots \ldots \ldots \ldots \ldots \ldots \ldots \ldots \ldots$ & 22.11 & 21.63 & 23.33 & 25.34 & $0.8 \%$ \\
\hline Average Price ${ }^{5} \ldots \ldots \ldots \ldots \ldots \ldots \ldots \ldots$ & 22.68 & 22.19 & 23.81 & 25.71 & $0.7 \%$ \\
\hline
\end{tabular}

'Excludes distributions less than 500 tons and to unknown destinations.

${ }^{2} \mathrm{Historical}$ data is the sum of steam and coking coal consumption.

Includes stock changes.

"Historical data is the average for steam and coking coal consumption

Weighted average excludes residential/commercial prices.

$\mathrm{N} / \mathrm{A}=$ Not applicable.

Note: Total may not equal sum of components due to independent rounding.

Sources: 1993: Distribution: Unpublished Energy Information Administration (EIA) Form EIA-6 data for 1993. Imports: U.S. Bureau of the Census, Form IM-145. Stock changes, consumption and prices: EIA, Quarterly Coal Report, October-December 1993, DOE/EIA-0121(93/4Q) (Washington, D.C., May 1994). Withheld values have been estimated from EIA, State Energy Data Report 1992, Consumption Estimates, DOE/EIA0214(92) and EIA, State Energy Price and Expenditure Report 1992, DOE/EIA-0376(92) (Washington, D.C., December 1994). Projections: EIA, AEO95 National Energy Modeling System run AEO95B.D1103942 . 
Table 87. Domestic Coal Supply, Disposition, and Prices Pacific Cenșus Division

\begin{tabular}{|c|c|c|c|c|c|}
\hline \multirow{2}{*}{$\begin{array}{l}\text { Supply, Consumption, } \\
\text { and Prices }\end{array}$} & \multicolumn{4}{|c|}{ Reference Case } & \multirow{2}{*}{$\begin{array}{c}\text { Annual } \\
\text { Growth } \\
\text { 1993-20t0 } \\
\text { (percent) }\end{array}$} \\
\hline & 1993 & 2000 & 2005 & 2010 & \\
\hline \multicolumn{6}{|l|}{ Sources of Supply (million short tons) } \\
\hline \multicolumn{6}{|l|}{ Distribution From } \\
\hline Northern Appalachia & 0.0 & 0.0 & 0.0 & 0.0 & N/A \\
\hline Southern Appalachia & 0.0 & 0.0 & 0.0 & 0.0 & N/A \\
\hline Interior ........... & 0.0 & 0.0 & 0.0 & 0.0 & N/A \\
\hline West $\ldots \ldots \ldots \ldots \ldots \ldots \ldots \ldots \ldots \ldots$ & 10.8 & 11.6 & 11.7 & 11.7 & $0.5 \%$ \\
\hline $\begin{array}{l}\text { Total Distribution } \\
\text { (excludes exports) }{ }^{1} \ldots \ldots \ldots \ldots \ldots \ldots \ldots\end{array}$ & 10.8 & 11.6 & 11.7 & 11.7 & $0.5 \%$ \\
\hline Imports..$\ldots \ldots \ldots \ldots \ldots \ldots \ldots \ldots \ldots \ldots \ldots \ldots$ & 0.7 & 0.9 & 1.0 & 1.0 & $2.1 \%$ \\
\hline Total Supply $\ldots \ldots \ldots \ldots \ldots \ldots \ldots \ldots$ & 11.5 & 12.5 & 12.7 & 12.7 & $0.6 \%$ \\
\hline \multicolumn{6}{|l|}{ Consumption (million short tons) } \\
\hline Residential/Commercial $\ldots \ldots \ldots \ldots \ldots \ldots \ldots$ & 0.8 & 0.6 & 0.6 & 0.6 & $-2.1 \%$ \\
\hline Industrial $^{2} \ldots \ldots \ldots \ldots$ & 2.7 & 3.4 & 3.6 & 3.7 & $1.8 \%$ \\
\hline Coke Plants & 0.0 & 0.0 & 0.0 & 0.0 & N/A \\
\hline Electricity $\ldots \ldots \ldots \ldots \ldots \ldots \ldots \ldots$ & 7.9 & 7.8 & 8.0 & 7.9 & $0.0 \%$ \\
\hline Total Consumption...$\ldots \ldots \ldots \ldots \ldots$ & 11.4 & 11.8 & 12.1 & 12.2 & $0.4 \%$ \\
\hline Discrepancy $^{3} \ldots \ldots \ldots \ldots \ldots \ldots \ldots \ldots$ & 0.1 & 0.7 & 0.6 & 0.5 & $10.4 \%$ \\
\hline \multicolumn{6}{|l|}{$\begin{array}{l}\text { Delivered Prices } \\
\text { (1993 dollars per short ton) }\end{array}$} \\
\hline Industrial ${ }^{4} \ldots$ & 43.83 & 44.39 & 45.14 & 46.91 & $0.4 \%$ \\
\hline Coke Plants & 0.00 & 0.00 & 0.00 & 0.00 & N/A \\
\hline Electricity .. & 21.55 & 26.87 & 24.79 & 25.62 & $1.0 \%$ \\
\hline Average Price $^{5} \ldots \ldots \ldots \ldots \ldots \ldots \ldots \ldots$ & 27.18 & 32.24 & 31.05 & 32.36 & $1.0 \%$ \\
\hline
\end{tabular}

'Excludes distributions less than 500 tons and to unknown destinations.

${ }^{2}$ Historical data is the sum of steam and coking coal consumption.

Includes stock changes.

"Historical data is the average for steam and coking coal consumption

${ }^{5}$ Weighted average excludes residential/commercial prices.

N/A = Not applicable.

Note: Total may not equal sum of components due to independent rounding.

Sources: 1993: Distribution: Unpublished Energy Information Administration (EIA) Form EIA-6 data for 1993. Imports: U.S. Bureau of the Census, Form IM-145. Stock changes, consumption and prices: EIA, Quarterly Coal Report, October-December 1993, DOE/EIA-0121(93/4Q) (Washington, D.C., May 1994). Withheld values have been estimated from EIA, State Energy Data Report 1992, Consumption Estimates, DOE/EIA0214(92) and EIA, State Energy Price and Expenditure Report 1992, DOE/EIA-0376(92) (Washington, D.C., December 1994). Projections: EIA, AEO95 National Energy Modeling System run AEO95B.D1103942. 
Table 88. Domestic Coal Supply, Disposition, and Prices

United States

\begin{tabular}{|c|c|c|c|c|c|}
\hline \multirow{2}{*}{$\begin{array}{l}\text { Supply, Consumption, } \\
\text { and Prices }\end{array}$} & \multicolumn{4}{|c|}{ Reference Case } & \multirow{2}{*}{$\begin{array}{c}\text { Annual } \\
\text { Growth } \\
1993-2010 \\
\text { (percent) }\end{array}$} \\
\hline & 1993 & 2000 & 2005 & 2010 & \\
\hline \multicolumn{6}{|l|}{ Sources of Supply (million short tons) } \\
\hline \multicolumn{6}{|l|}{ Distribution From } \\
\hline Northern Appalachia $\ldots \ldots \ldots \ldots \ldots \ldots$ & 119.6 & 148.5 & 166.2 & 190.3 & $2.8 \%$ \\
\hline Southem Appalachia $\ldots \ldots \ldots \ldots \ldots \ldots \ldots$ & 233.3 & 259.2 & 253.2 & 250.0 & $0.4 \%$ \\
\hline Interior $\ldots \ldots \ldots \ldots \ldots \ldots \ldots \ldots \ldots \ldots$ & 166.8 & 161.3 & 147.1 & 157.3 & $-0.3 \%$ \\
\hline West .......................... & 358.4 & 371.2 & 409.5 & 424.6 & $1.0 \%$ \\
\hline $\begin{array}{l}\text { Total Distribution } \\
\text { (excludes exports) }{ }^{1} \ldots \ldots \ldots \ldots \ldots \ldots \ldots\end{array}$ & 878.1 & 940.1 & 976.0 & 1022.3 & $0.9 \%$ \\
\hline Imports...$\ldots \ldots \ldots \ldots \ldots \ldots \ldots \ldots \ldots \ldots \ldots$ & 7.3 & 13.2 & 14.5 & 15.0 & $4.3 \%$ \\
\hline Total Supply $\ldots \ldots \ldots \ldots \ldots \ldots \ldots \ldots \ldots$ & 885.4 & 953.3 & 990.5 & 1037.3 & $0.9 \%$ \\
\hline \multicolumn{6}{|l|}{ Consumption (million short tons) } \\
\hline Residential/Commercial . & 6.2 & 6.6 & 6.4 & 6.4 & $0.2 \%$ \\
\hline Industrial ${ }^{2} \ldots \ldots \ldots \ldots$ & 74.8 & 86.4 & 92.9 & 97.5 & $1.6 \%$ \\
\hline Coke Plants $\ldots \ldots \ldots \ldots \ldots \ldots \ldots \ldots$ & 31.3 & 28.7 & 25.1 & 22.0 & $-2.1 \%$ \\
\hline 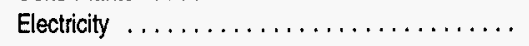 & 813.5 & 832.0 & 867.6 & 912.7 & $0.7 \%$ \\
\hline Total Consumption $\ldots \ldots \ldots \ldots \ldots \ldots \ldots$ & 925.8 & 953.7 & 992.1 & 1038.6 & $0.7 \%$ \\
\hline Discrepancy ${ }^{3} \ldots \ldots \ldots \ldots \ldots \ldots \ldots \ldots$ & -40.4 & .0 .4 & -1.6 & -1.3 & $-18.3 \%$ \\
\hline \multicolumn{6}{|l|}{$\begin{array}{l}\text { Delivered Prices } \\
\text { (1993 dollars per short ton) }\end{array}$} \\
\hline Industrial $^{4} \ldots$ & 32.23 & 31.32 & 31.90 & 33.25 & $0.2 \%$ \\
\hline Coke Plants $\ldots \ldots \ldots \ldots \ldots \ldots \ldots \ldots$ & 47.44 & 45.96 & 46.64 & 47.26 & $0.0 \%$ \\
\hline 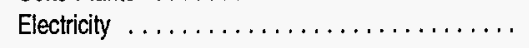 & 28.60 & 29.06 & 30.38 & 31.43 & $0.6 \%$ \\
\hline Average Price ${ }^{5} \ldots \ldots \ldots \ldots \ldots \ldots \ldots \ldots$ & 29.54 & 29.78 & 30.94 & 31.94 & $0.5 \%$ \\
\hline
\end{tabular}

'Excludes distributions less than 500 short tons and to unknown destinations.

${ }^{2}$ Historical data is the sum of steam and coking coal consumption.

${ }^{3}$ Includes stock changes.

${ }^{4}$ Historical data is the average for steam and coking coal consumption

sWeighted average excludes residential/commercial prices.

N/A = Not applicable.

Note: Total may not equal sum of components due to independent rounding.

Sources: 1993: Distribution: Unpublished Energy Information Administration (EIA), Form EIA-6 data for 1993. Imports: U.S. Bureau of the Census, Form IM-145. Stock changes, consumption and prices: ElA, Quarterly Coal Report, October-December 1993, DOE/EIA-0121(93/4Q) (Washington, D.C., May 1994). Projections: ElA, AEO95 National Energy Modeling System run AEO95B.D1103942. 
Table 89. Coal Production and Minemouth Prices by Region

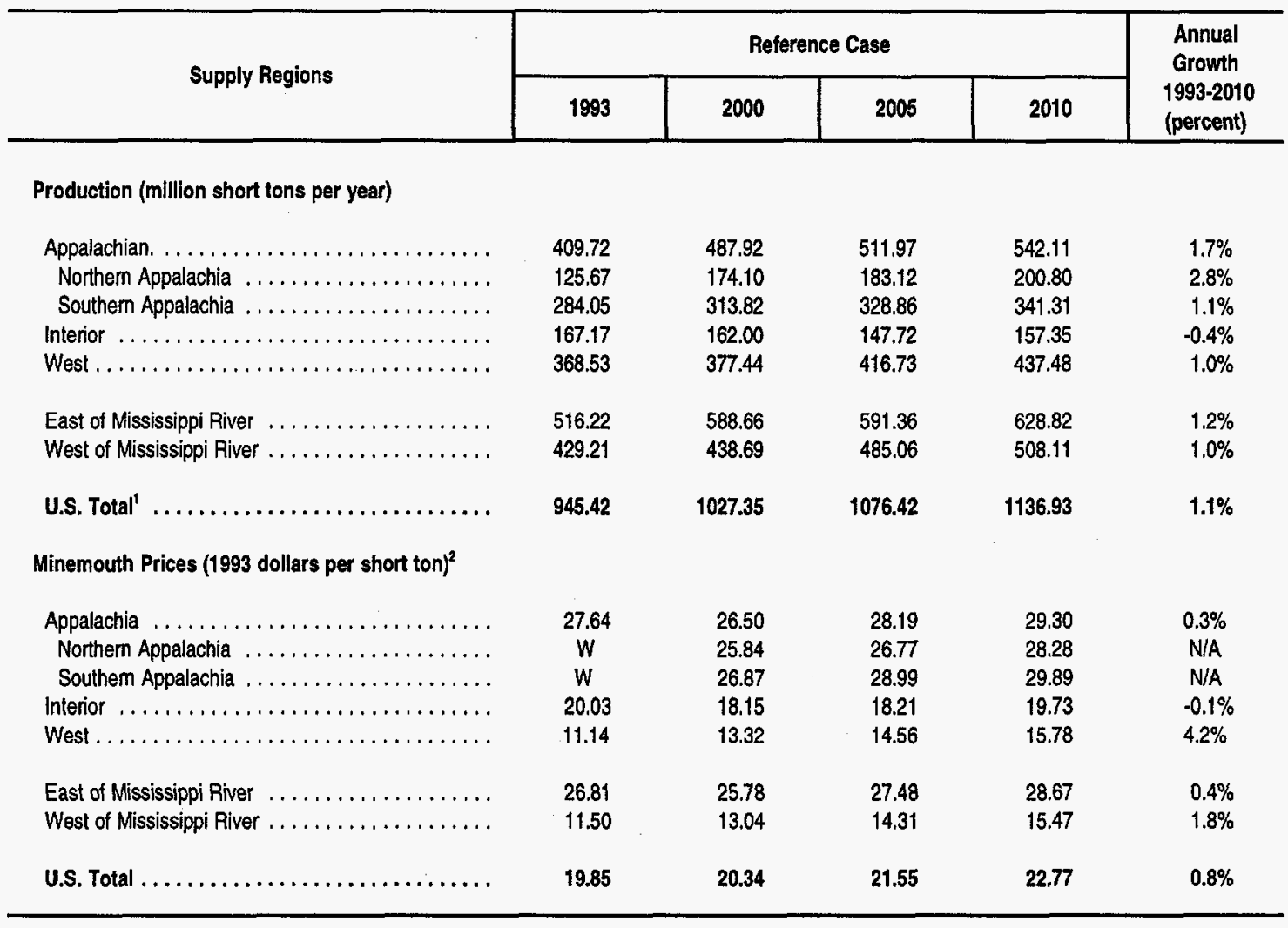

'Excludes distributions less than 500 tons and to unknown destinations; includes exports.

${ }^{2}$ Historical minemouth prices withheld due to withheld State and counly data.

Northern Appalachia: PA, MD, OH, Northern WV.

Southern Appalachia: VA, TN, AL, GA, Southern WV, East $K Y$.

Interior: $\mathrm{MI}, \mathrm{IL}, \mathrm{IN}, \mathrm{IA}, \mathrm{MO}, \mathrm{KS}, \mathrm{AR}, \mathrm{OK}, \mathrm{LA}, \mathrm{TX}$, WEST KY.

West: ND, SD, MT, WY, CO, UT, AZ, NM, WA, OR, AK, CA.

$W=$ Withheld to prevent disclosure of proprietary data.

N/A $=$ Not applicable

Note: Totals may not equal sum of components due to independent rounding.

Source: Energy Information Administration (EIA), Coal Industry Annual 1993, DOE/EIA-0584(93) (Washington, D.C., December 1994). Projections: EIA, AEO95 National Energy Modeling System run AEO95B.D1103942. 
Table 90. Coal Production by Region and Type (Million Short Tons per Year)

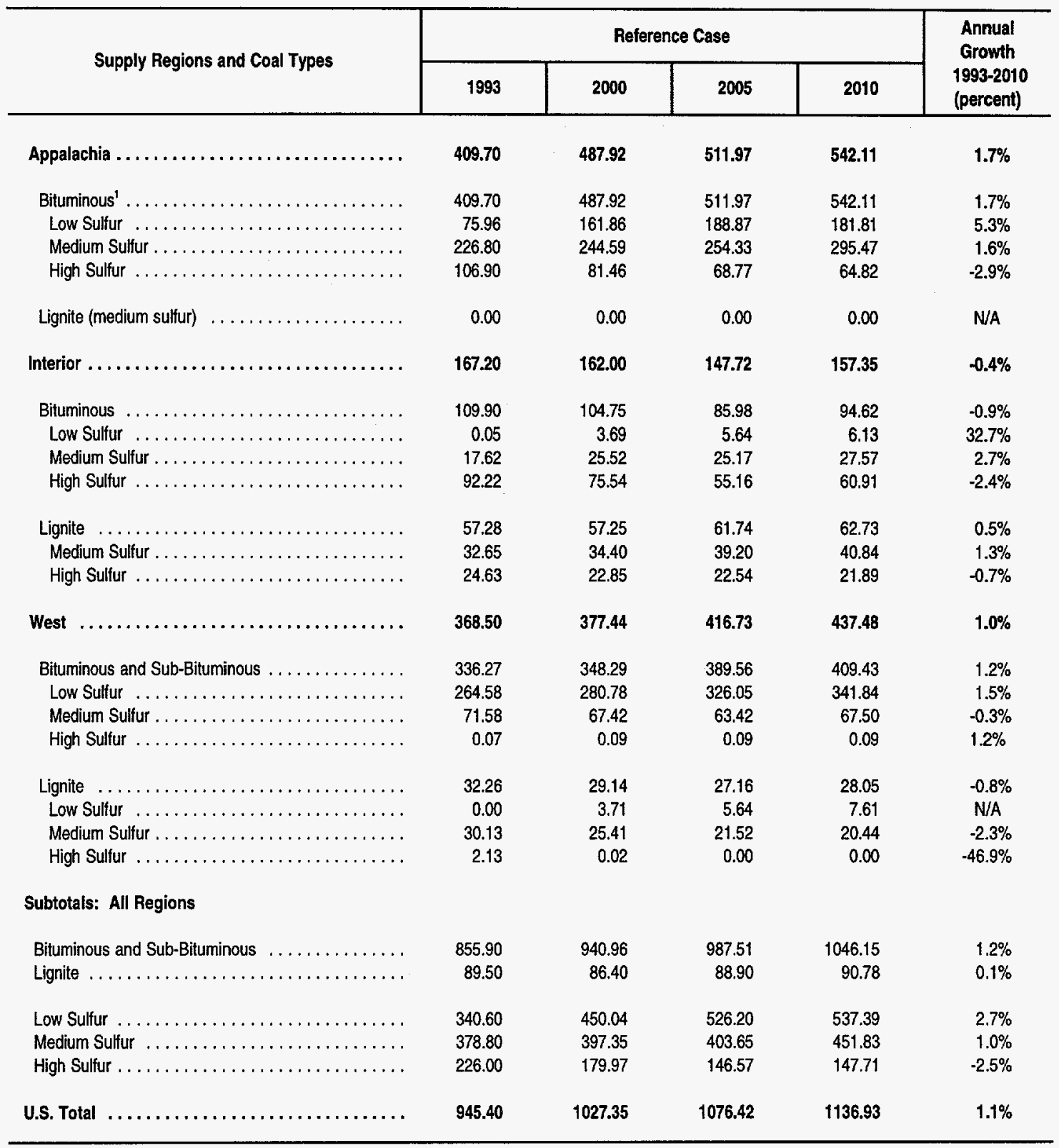

'Includes Pennsylvania anthracite.

Appalachia: PA, OH, MD, WV, VA, TN, AL, GA, EAST KY.

Interior: MI, IL, IN, IA, MO, KS, AR, OK, LA, TX, WEST KY.

West: ND, SD, MT, WY, CO, UT, AZ, NM, WA, OR, AK, CA.

Sulfur Definitions:

Low Sulfur: $\quad 0-0.60$ pounds of sulfur per million Btu.

Medium Sulfur: $0.61-1.67$ pounds of sulfur per million Btu.

High Sulfur: Over 1.67 pounds of sulfur per million Btu.

$\mathrm{Btu}=$ British thermal unit.

N/A = Not applicable.

Note: Totals may not equal sum of components due to independent rounding.

Sources: 1993: Energy Information Administration (EIA), Coal Industry Annual 1993, DOE/ElA-0584(93) (Washington, D.C., December 1994). Sulfur content estimated for all sectors from Federal Energy Regulatory Commission, Form FERC-423, Forms EIA-3A and EIA-5A. Projections: EIA, AEO95 National Energy Modeling System run AEO95B.D1103942. 
Table 91. World Steam Coal Flows By Importing Regions and Exporting Countries (Million Short Tons)

\begin{tabular}{|c|c|c|c|c|c|}
\hline \multirow{2}{*}{ Import and Export Regions } & \multicolumn{4}{|c|}{ Relerence Case } & \multirow{2}{*}{$\begin{array}{l}\text { Annual } \\
\text { Grouth } \\
1993-2010 \\
\text { (percent) }\end{array}$} \\
\hline & 1993 & 2000 & 2005 & 2010 & \\
\hline \multicolumn{6}{|l|}{ Steam Coal Exports to Europe } \\
\hline Australia $\ldots \ldots \ldots \ldots \ldots \ldots \ldots \ldots \ldots$ & 9.8 & 0.0 & 0.0 & 12.9 & $1.6 \%$ \\
\hline United States $\ldots \ldots \ldots \ldots \ldots \ldots \ldots \ldots$ & 13.7 & 34.2 & 39.3 & 44.3 & $7.1 \%$ \\
\hline South Africa $\ldots \ldots \ldots \ldots \ldots \ldots \ldots$ & 33.4 & 39.4 & 30.5 & 29.2 & $-0.8 \%$ \\
\hline Former U.S.S.R $\ldots \ldots \ldots \ldots \ldots \ldots \ldots \ldots$ & 13.9 & 7.6 & 8.2 & 8.8 & $-2.6 \%$ \\
\hline Poland $\ldots \ldots \ldots \ldots \ldots \ldots \ldots \ldots$ & 15.8 & 12.9 & 14.9 & 14.9 & $-0.3 \%$ \\
\hline Canada $\ldots \ldots \ldots \ldots \ldots \ldots \ldots \ldots \ldots$ & 0.9 & 4.6 & 7.0 & 7.0 & $12.6 \%$ \\
\hline China $\ldots \ldots \ldots \ldots \ldots \ldots \ldots \ldots \ldots$ & 1.3 & 0.0 & 0.0 & 0.0 & NA \\
\hline South America $\ldots \ldots \ldots \ldots \ldots \ldots \ldots$ & 13.1 & 25.3 & 43.0 & 52.5 & $8.5 \%$ \\
\hline Other $\ldots \ldots \ldots \ldots \ldots \ldots \ldots \ldots \ldots \ldots \ldots \ldots \ldots \ldots \ldots$ & 8.9 & 4.2 & 8.3 & 11.3 & $1.4 \%$ \\
\hline Total $\ldots \ldots \ldots \ldots \ldots \ldots \ldots \ldots \ldots$ & 110.9 & 128.2 & 151.2 & 180.9 & $2.9 \%$ \\
\hline \multicolumn{6}{|l|}{ Steam Coal Exports to Asia } \\
\hline Australia $\ldots \ldots \ldots \ldots \ldots \ldots \ldots \ldots \ldots$ & 50.6 & 88.6 & 117.9 & 146.7 & $6.5 \%$ \\
\hline United States $\ldots \ldots \ldots \ldots \ldots \ldots \ldots \ldots \ldots$ & 7.6 & 4.3 & 5.4 & 8.9 & $0.9 \%$ \\
\hline South Alrica $\ldots \ldots \ldots \ldots \ldots \ldots \ldots$ & 16.9 & 21.5 & 36.4 & 52.2 & $6.9 \%$ \\
\hline Former U.S.S.R $\ldots \ldots \ldots \ldots \ldots \ldots \ldots \ldots$ & 2.2 & 6.1 & 6.1 & 6.1 & $6.1 \%$ \\
\hline Poland $\ldots \ldots \ldots \ldots \ldots \ldots \ldots \ldots \ldots$ & 0.0 & 0.0 & 0.0 & 0.0 & N/A \\
\hline Canada $\ldots \ldots \ldots \ldots \ldots \ldots \ldots \ldots \ldots$ & 3.2 & 2.6 & 5.7 & 7.6 & $5.2 \%$ \\
\hline China $\ldots \ldots \ldots \ldots \ldots \ldots \ldots \ldots \ldots \ldots$ & 15.4 & 20.4 & 23.9 & 27.5 & $3.5 \%$ \\
\hline South America $\ldots \ldots \ldots \ldots \ldots \ldots \ldots \ldots$ & 0.4 & 0.0 & 0.0 & 0.4 & $0.1 \%$ \\
\hline Other $\ldots \ldots \ldots \ldots \ldots \ldots \ldots \ldots \ldots \ldots \ldots$ & 15.8 & 29.2 & 33.0 & 33.7 & $4.6 \%$ \\
\hline Total $\ldots \ldots \ldots \ldots \ldots \ldots \ldots \ldots \ldots$ & 112.1 & 172.5 & 228.5 & 283.1 & $5.6 \%$ \\
\hline \multicolumn{6}{|l|}{ Steam Coal Exports to Others } \\
\hline Australia $\ldots \ldots \ldots \ldots \ldots \ldots \ldots \ldots \ldots$ & 1.1 & 0.2 & 0.2 & 0.2 & $-9.9 \%$ \\
\hline United States $\ldots \ldots \ldots \ldots \ldots \ldots \ldots \ldots \ldots$ & 5.1 & 6.7 & 6.9 & 8.1 & $2.8 \%$ \\
\hline South Africa $\ldots \ldots \ldots \ldots \ldots \ldots \ldots \ldots$ & 2.2 & 4.0 & 5.1 & 6.7 & $6.7 \%$ \\
\hline Former U.S.S.R $\ldots \ldots \ldots \ldots \ldots \ldots \ldots \ldots$ & 0.0 & 0.0 & 0.0 & 0.0 & N/A \\
\hline Poland $\ldots \ldots \ldots \ldots \ldots \ldots \ldots \ldots \ldots$ & 0.0 & 0.0 & 0.0 & 0.0 & N/A \\
\hline 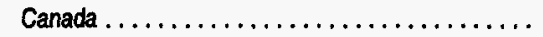 & 1.3 & 1.1 & 1.1 & 1.1 & $-0.7 \%$ \\
\hline China $\ldots \ldots \ldots \ldots \ldots \ldots \ldots \ldots \ldots \ldots$ & 0.3 & 0.0 & 0.0 & 0.0 & N/A \\
\hline South America $\ldots \ldots \ldots \ldots \ldots \ldots \ldots \ldots$ & 5.6 & 17.8 & 19.3 & 21.9 & $8.3 \%$ \\
\hline Other $\ldots \ldots \ldots \ldots \ldots \ldots \ldots \ldots \ldots \ldots$ & 1.1 & 0.0 & 0.0 & 0.2 & $-9.1 \%$ \\
\hline Total $\ldots \ldots \ldots \ldots \ldots \ldots \ldots \ldots$ & 16.6 & 29.7 & 32.5 & 38.2 & $5.0 \%$ \\
\hline \multicolumn{6}{|l|}{ Total Steam Coal Exports } \\
\hline Australia $\ldots \ldots \ldots \ldots \ldots \ldots \ldots \ldots$ & 61.5 & 88.8 & 118.1 & 159.8 & $5.8 \%$ \\
\hline United States $\ldots \ldots \ldots \ldots \ldots \ldots \ldots \ldots \ldots$ & 26.4 & 45.2 & 51.6 & 61.3 & $5.1 \%$ \\
\hline South Africa $\ldots \ldots \ldots \ldots \ldots \ldots \ldots \ldots$ & 52.4 & 64.9 & 72.0 & 88.1 & $3.1 \%$ \\
\hline Former U.S.S.R $\ldots \ldots \ldots \ldots \ldots \ldots \ldots \ldots$ & 16.2 & 13.7 & 14.3 & 14.9 & $-0.5 \%$ \\
\hline Poland $\ldots \ldots \ldots \ldots \ldots \ldots \ldots \ldots \ldots$ & 15.8 & 12.9 & 14.9 & 14.9 & $-0.3 \%$ \\
\hline Canada $\ldots \ldots \ldots \ldots \ldots \ldots \ldots \ldots \ldots$ & 5.4 & 8.3 & 13.9 & 15.7 & $6.5 \%$ \\
\hline China $\ldots \ldots \ldots \ldots \ldots \ldots \ldots \ldots \ldots$ & 17.1 & 20.4 & 23.9 & 27.5 & $2.9 \%$ \\
\hline South America $\ldots \ldots \ldots \ldots \ldots \ldots \ldots$ & 19.1 & 43.1 & 62,3 & 74.8 & $8.4 \%$ \\
\hline Other $\ldots \ldots \ldots \ldots \ldots \ldots \ldots \ldots \ldots \ldots$ & 25.8 & 33.4 & 41.3 & 45.2 & $3.4 \%$ \\
\hline Total $\ldots \ldots \ldots \ldots \ldots \ldots \ldots \ldots \ldots \ldots$ & 239.6 & 330.5 & 412.2 & 502.2 & $4.4 \%$ \\
\hline
\end{tabular}

N/A = Not applicable.

Note: Totals may not equal sum of components due to independent rounding.

Source: 1993: Intemational Energy Agency, Coal Information 1993, (Paris, France, 1994). Projections: Energy Information Administration, AEO95 National Energy Modeling System run AEO95B.D1103942. 
Table 92. World Metallurgical Coal Flows By Importing Regions and Exporting Countries Regions (Million Short Tons)

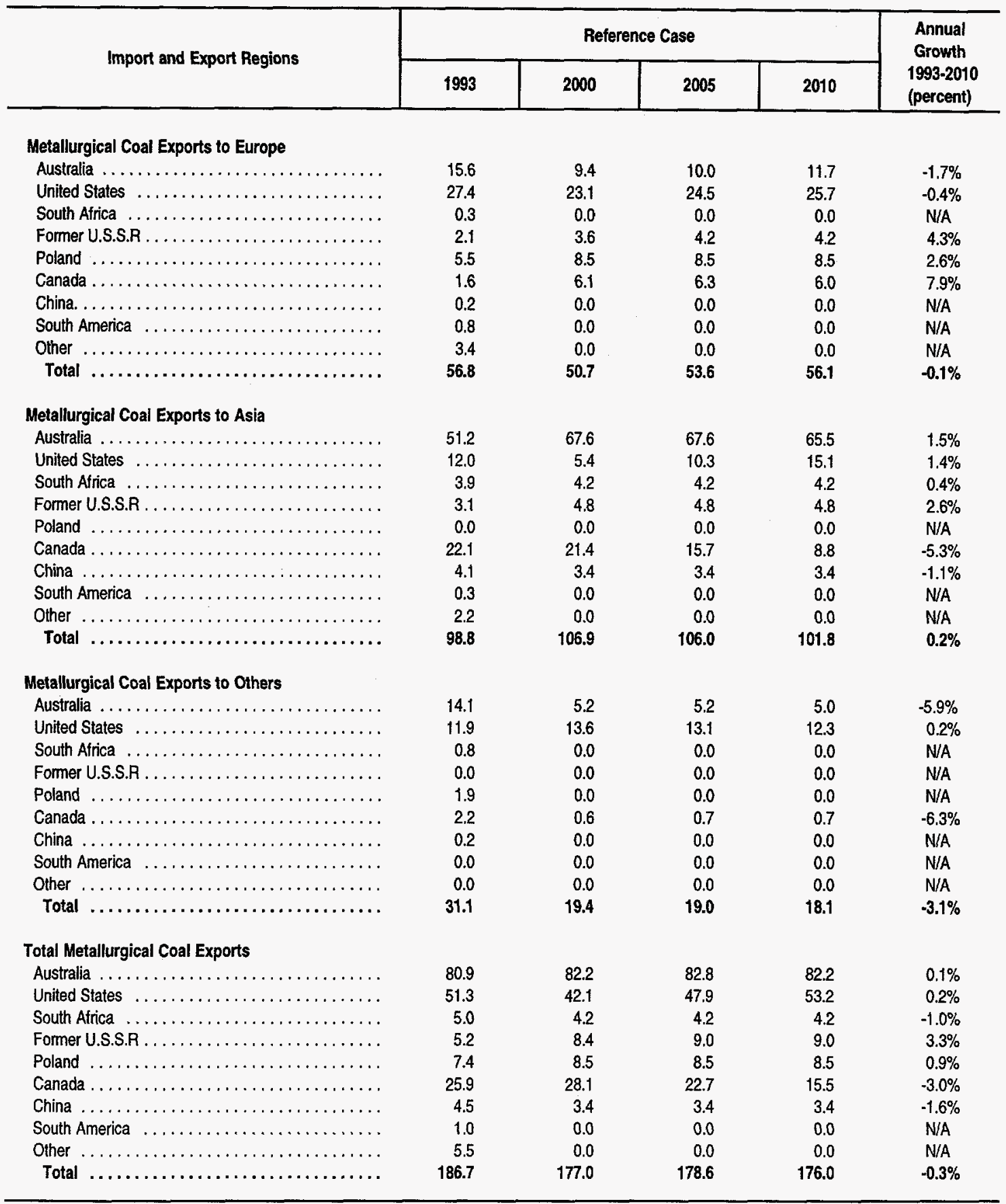

N/A $=$ Not applicable

Note: Totals may not equal sum of components due to independent rounding.

Source: 1993: Intermational Energy Agency, Coal Information 1993, (Paris, France, 1994). Projections: Energy Information Administration, AEO95 National Energy Modeling System run AEO95B.D1103942. 
Table 93. World Total Coal Flows By Importing Regions and Exporting Countries (Million Short Tons)

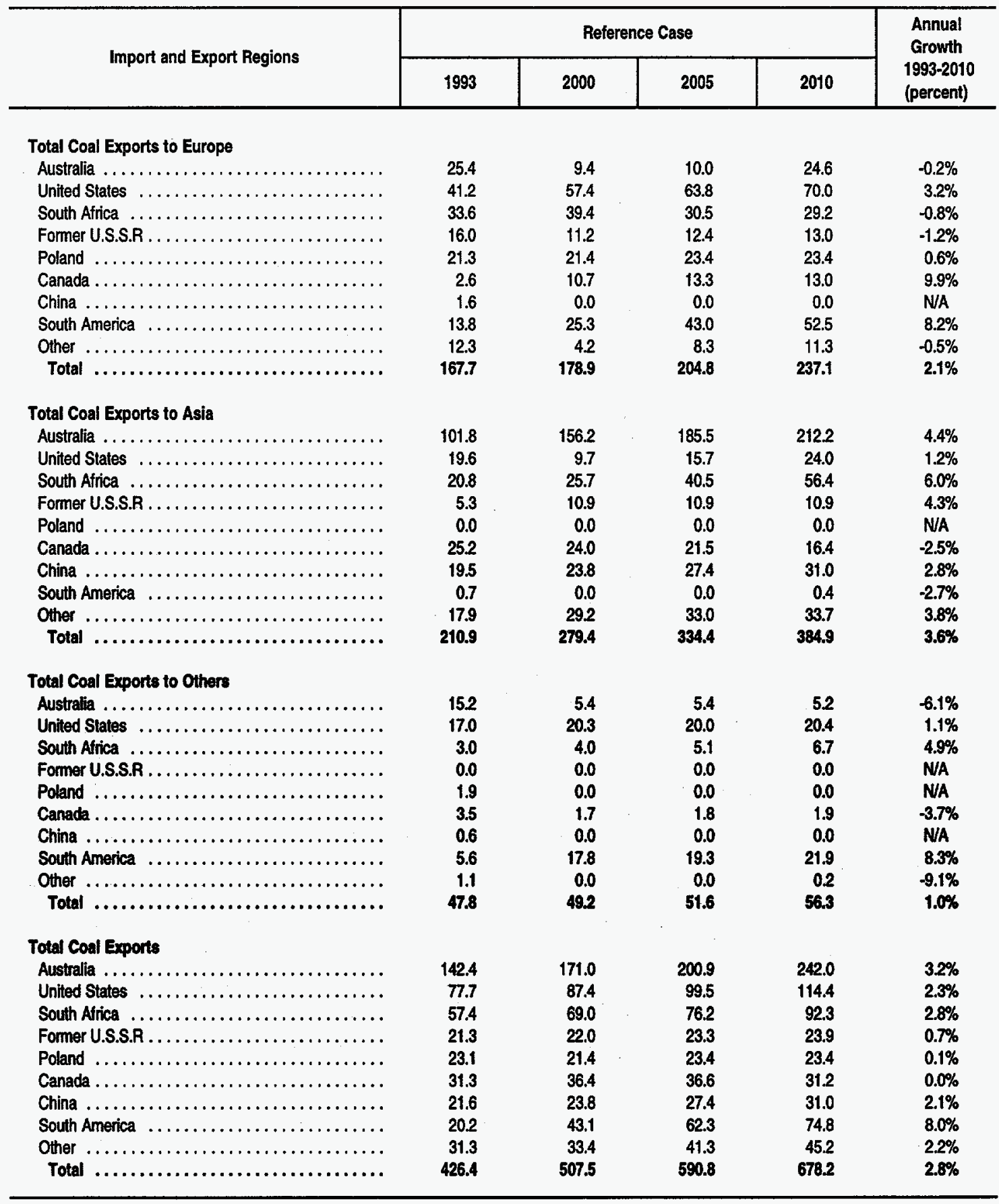

NA $=$ Not applicable.

Note: Totals may not equal sum of components due to independent rounding.

Source: 1993: Intemational Energy Agency, Coal Information 1993, (Paris, France, 1994). Projections: Energy Information Administration, AEO95 National Energy Modeling System run AEO95B.D1 103942. 
Table 94. Indicators of Macroeconomic Activity

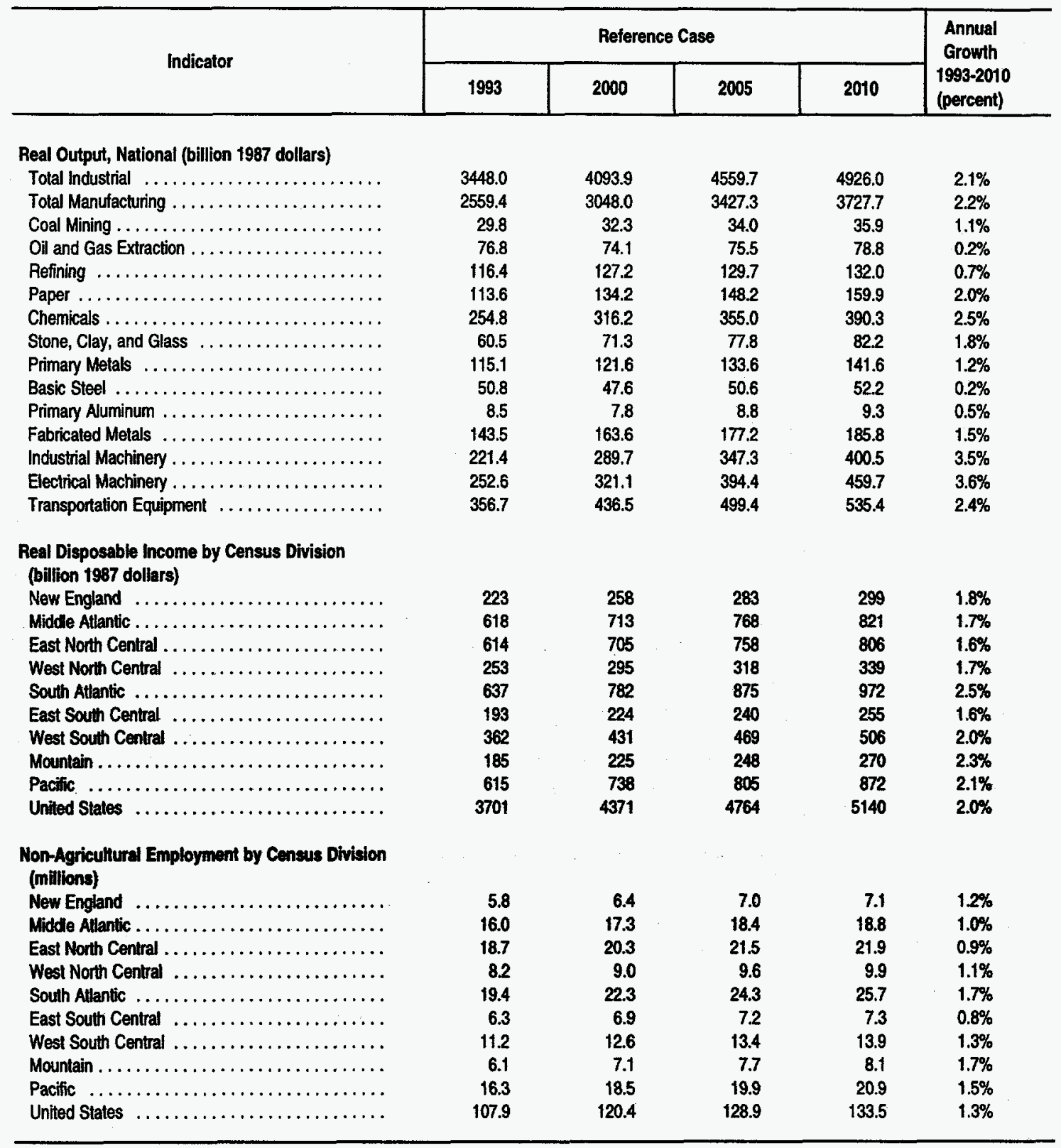

Note: Totals may not equal sum of components due to independent rounding.

Source: 1993: Data Resources Incorporated (DRI), DRI Trend0294. Projections: Energy Information Administration, AEO95 National Energy Modeling System run AEO95B.D1103942. 
Table 95. Imported Petroleum by Source (Million Barrels per Day)

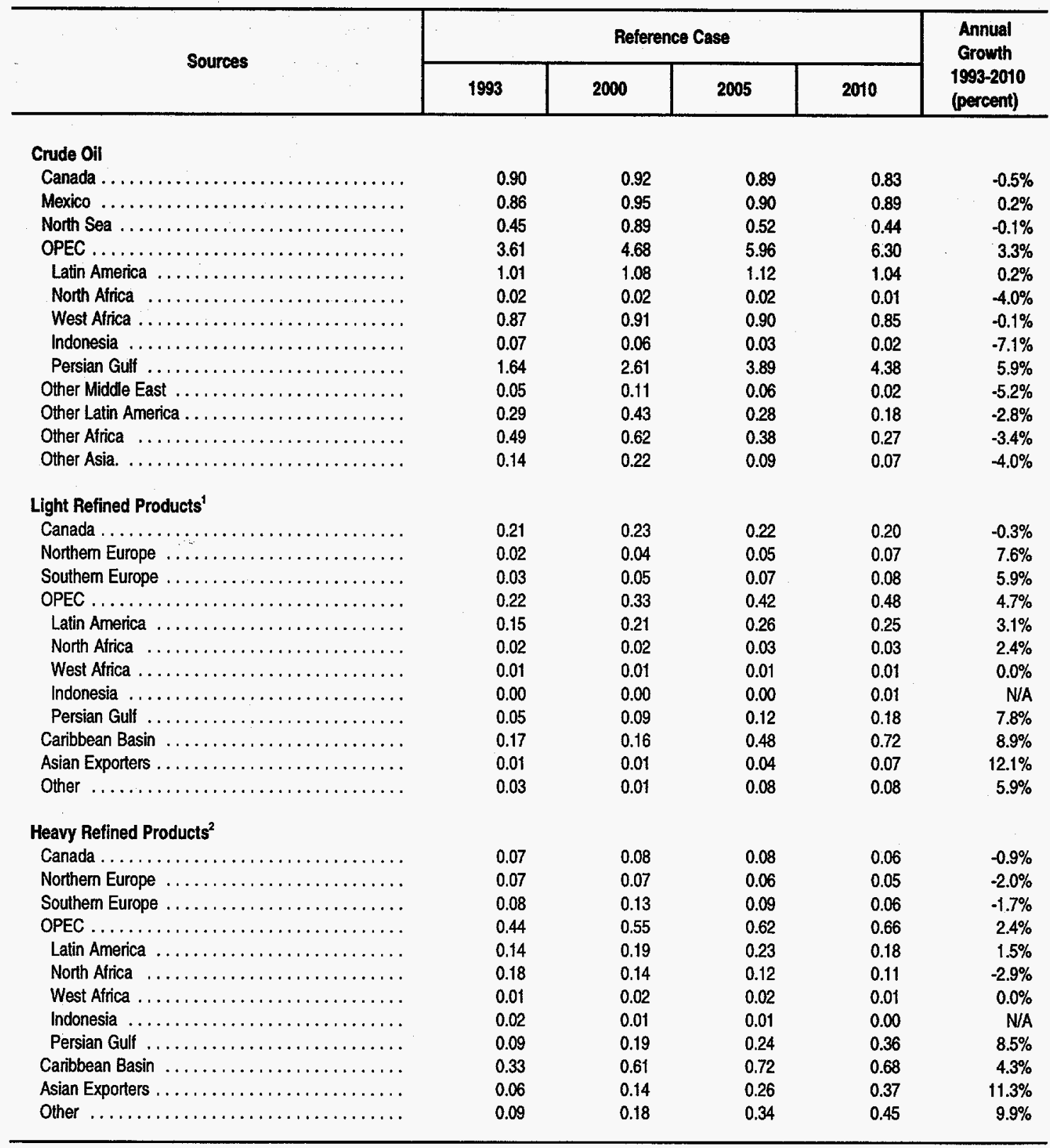

1'Includes gasoline, distillate, jet fuel, and liquified petroleum gases.

${ }^{2}$ includes residual fuel oil and other refined products.

OPEC = Organization of Petroleum Exporting Countries - Algeria, Gabon, Indonesia, Iran, Iraq, Kuwait, Libya, Nigeria, Qatar, Saudi Arabia, the United Arab Emirates, and Venezuela.

Caribbean Basin = Bahama Islands, Columbia, Ecuador, Guatemala, Jamaica, Mexico, Netherlands Antilles, Panama, Puerto Rico, Trinidad and Tobago, and the Virgin islands.

N/A = Not applicable.

Source: Energy Information Administration, AEO95 National Energy Modeling System run AEO95B.D1103942. 



\section{Appendix A}

\section{Maps}

Figure A1. U.S. Census Divisions

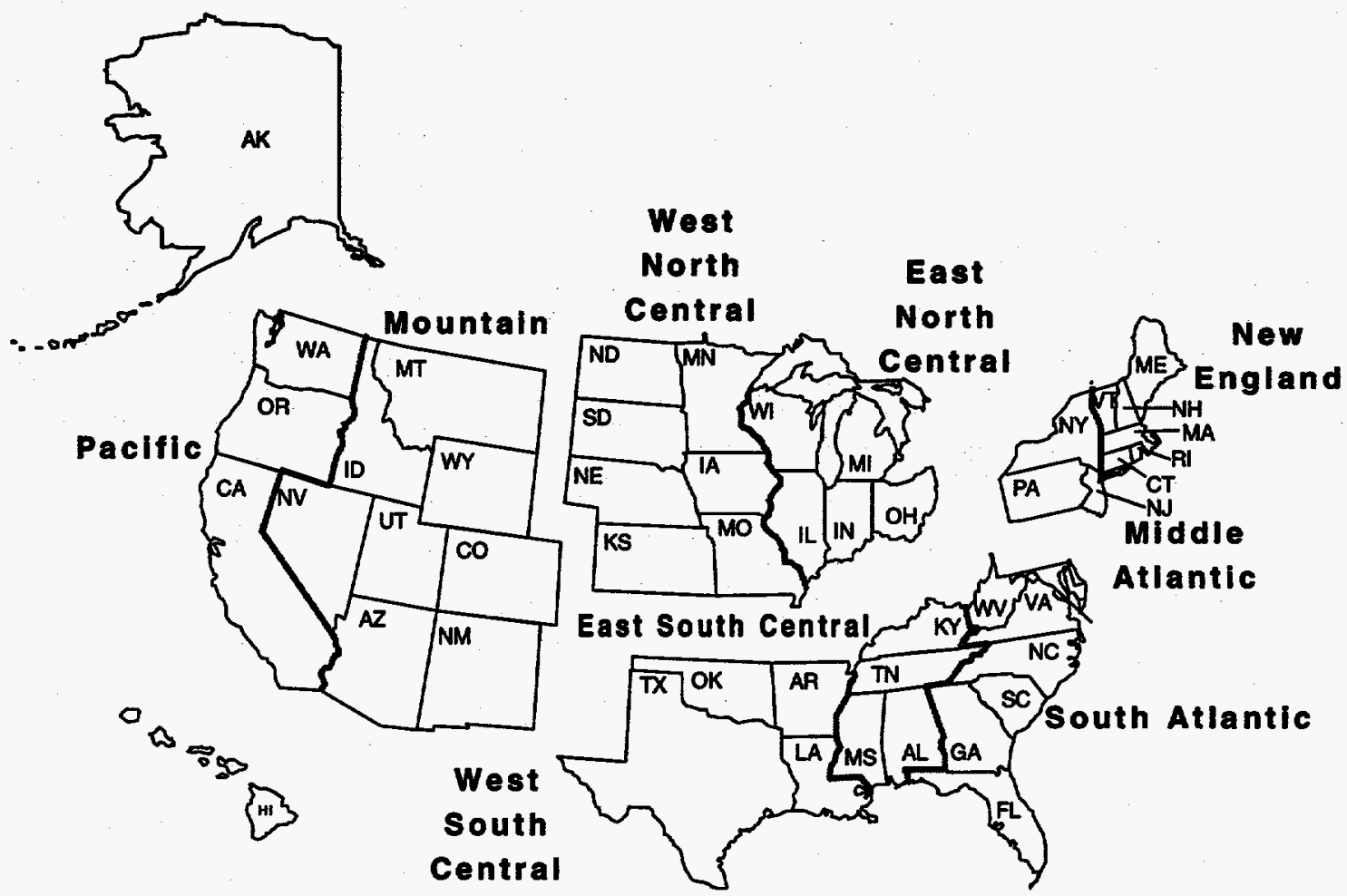

\begin{tabular}{|c|c|c|c|c|}
\hline$\frac{\text { Division } 1}{\text { New England }}$ & $\frac{\text { Division } 3}{\text { East North Central }}$ & $\frac{\text { Division } 5}{\text { South Atlantic }}$ & $\frac{\text { Division } 7}{\text { West South Central }}$ & $\frac{\text { Division } 9}{\text { Pacific }}$ \\
\hline $\begin{array}{l}\text { Connecticut } \\
\text { Maine } \\
\text { Massachusetts } \\
\text { New Hampshire } \\
\text { Rhode Island } \\
\text { Vermont } \\
\text { Division } 2 \\
\text { Middle Atlantic } \\
\text { New Jersey } \\
\text { New York } \\
\text { Pennsylvania }\end{array}$ & $\begin{array}{l}\text { Illinois } \\
\text { Indiana } \\
\text { Michigan } \\
\text { Ohio } \\
\text { Wisconsin } \\
\text { Division 4 } \\
\text { West North Central } \\
\text { lowa } \\
\text { Kansas } \\
\text { Minnesota } \\
\text { Missouri } \\
\text { Nebraska } \\
\text { North Dakota } \\
\text { South Dakota }\end{array}$ & $\begin{array}{l}\text { Delaware } \\
\text { District of Columbia } \\
\text { Florida } \\
\text { Georgia } \\
\text { Maryland } \\
\text { North Carolina } \\
\text { South Carolina } \\
\text { Virginia } \\
\text { West Virginia } \\
\text { Division } 6 \\
\text { East South Central } \\
\text { Alabama } \\
\text { Kentucky } \\
\text { Mississippi } \\
\text { Tennessee }\end{array}$ & $\begin{array}{l}\text { Arkansas } \\
\text { Louisiana } \\
\text { Oklahoma } \\
\text { Texas } \\
\text { Division } 8 \\
\text { Mountain } \\
\text { Arizona } \\
\text { Colorado } \\
\text { Idaho } \\
\text { Montana } \\
\text { Nevada } \\
\text { New Mexico } \\
\text { Utah } \\
\text { Wyoming }\end{array}$ & $\begin{array}{l}\text { Alaska } \\
\text { California } \\
\text { Hawaii } \\
\text { Oregon } \\
\text { Washington }\end{array}$ \\
\hline
\end{tabular}

Source: Energy Information Administration, Office of Integrated Analysis and Forecasting. 
Figure A2. Electricity Market Module (EMM) Regions

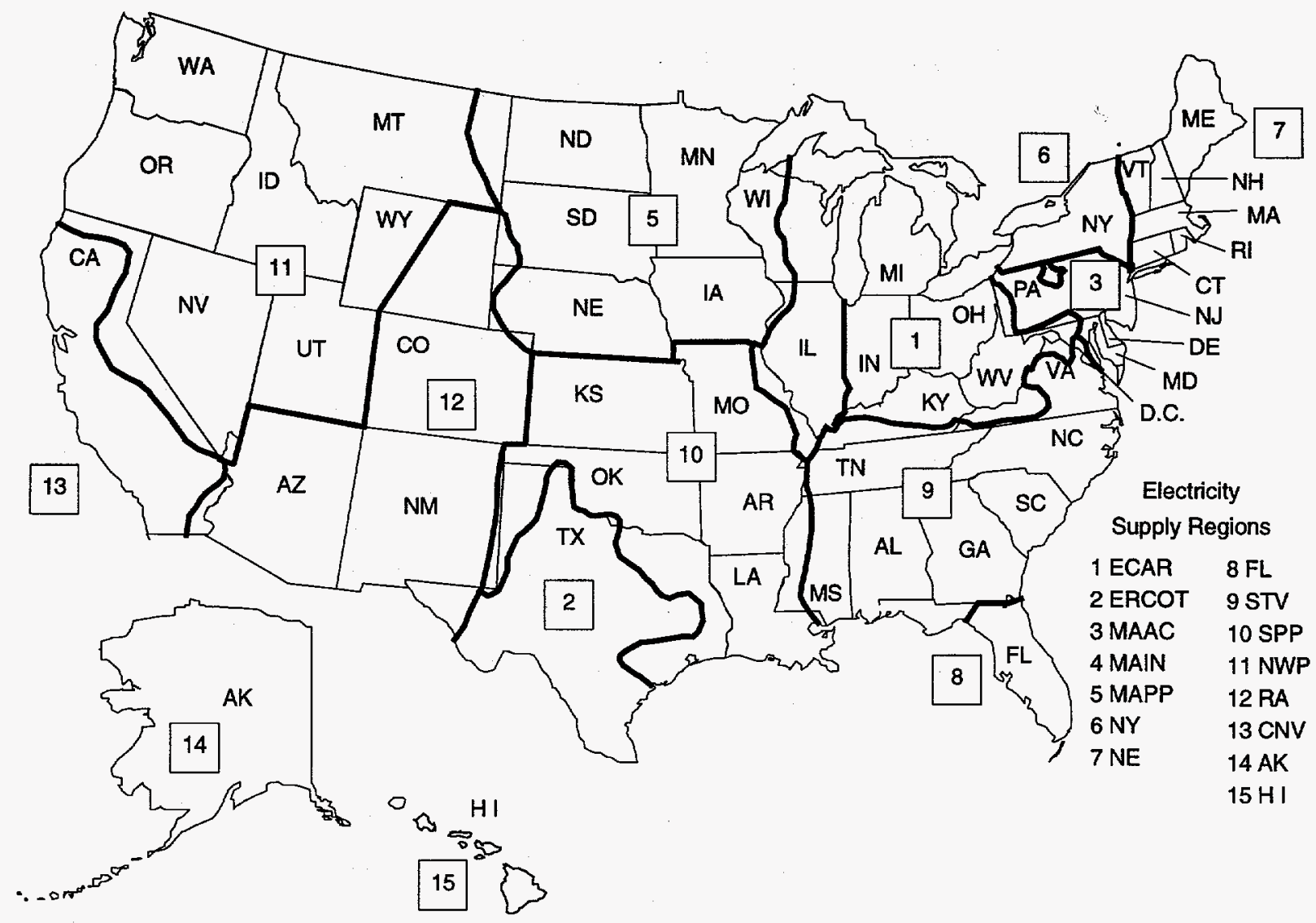

\footnotetext{
1. ECAR = East Central Area Reliability Coordination Agreement

2. ERCOT = Electric Reliability Council of Texas

3. MACC $=$ Mid-Atlantic Area Council

4. MAIN = Mid-America Interconnected Network

5. MAPP $=$ Mid-Continent Area Power Pool

6. NY = Northeast Power Coordinating CounciV New York

7. NE = Northeast Power Coordinating CounciV New England

8. FL = Southeastern Electric Reliability Council Fiorida

9. STV = Southeastern Electric Reliability Council/ excluding Florida

10. SPP $=$ Southwest Power Pool

11. NWP = Western Systems Coordinating Council/ Northwest Power Pool Area

12. RA = Western Systems Coordinating Council Rocky Mountain Power Area and Arizona

13. CNV = Western Systems Coordinating Council California-Southern Nevada Power

14. AK = Alaska

15. HI = Hawaii
}

Source: Energy Information Administration, Office of Integrated Analysis and Forecasting. 
Figure A3. Petroleum Administration for Defense Districts

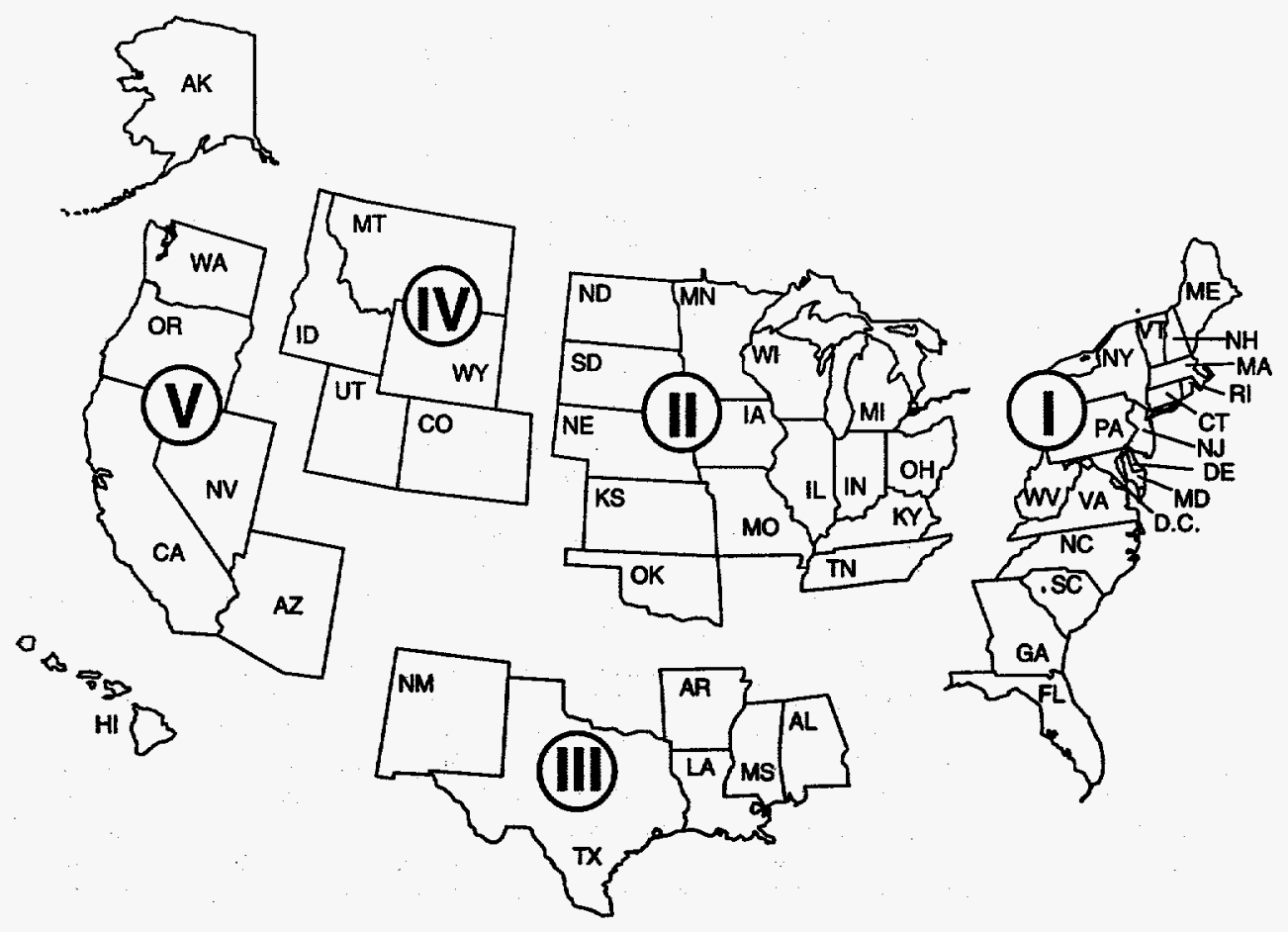

Source: Energy Information Administration, Otfice of Integrated Analysis and Forecasting. 
Figure A4. Oil and Gas Supply Module Regions
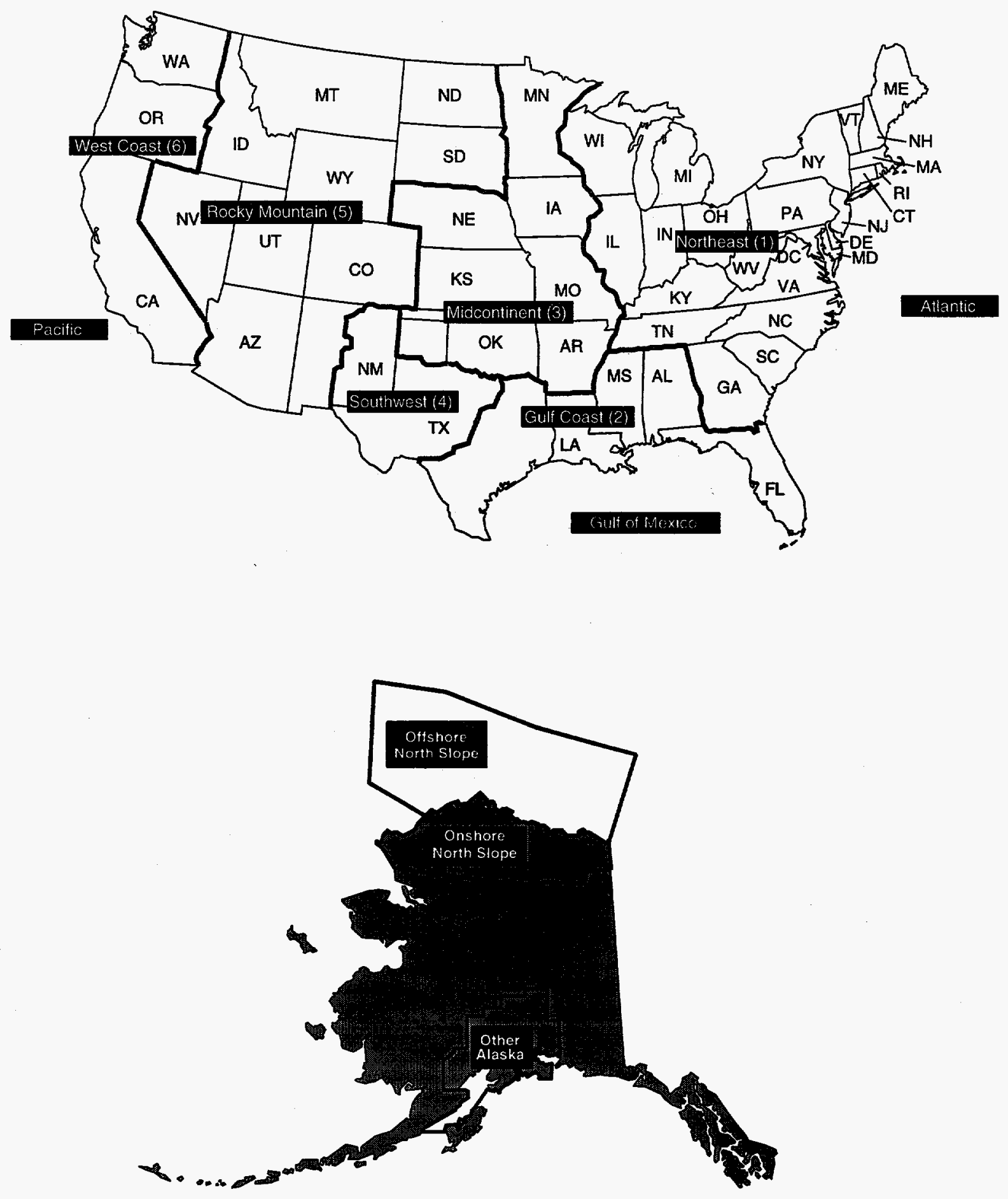

Source: Energy Information Administration, Office of Integrated Analysis and Forecasting. 
Figure A5. Natural Gas Transmission and Distribution Module Regions

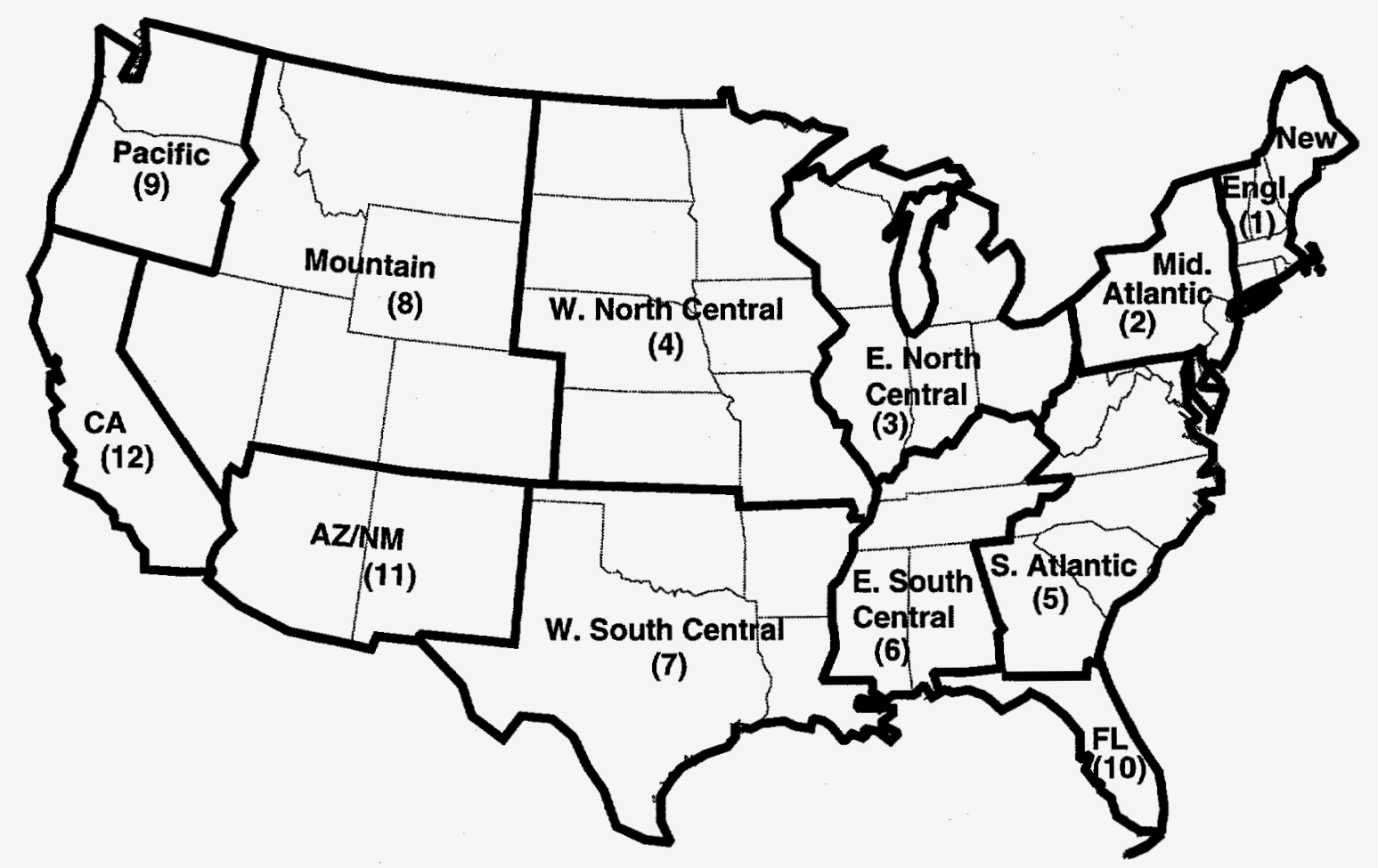

Source: Energy Information Administration, Office of Integrated Analysis and Forecasting. 
Figure A6. Coal Market Module Supply Regions

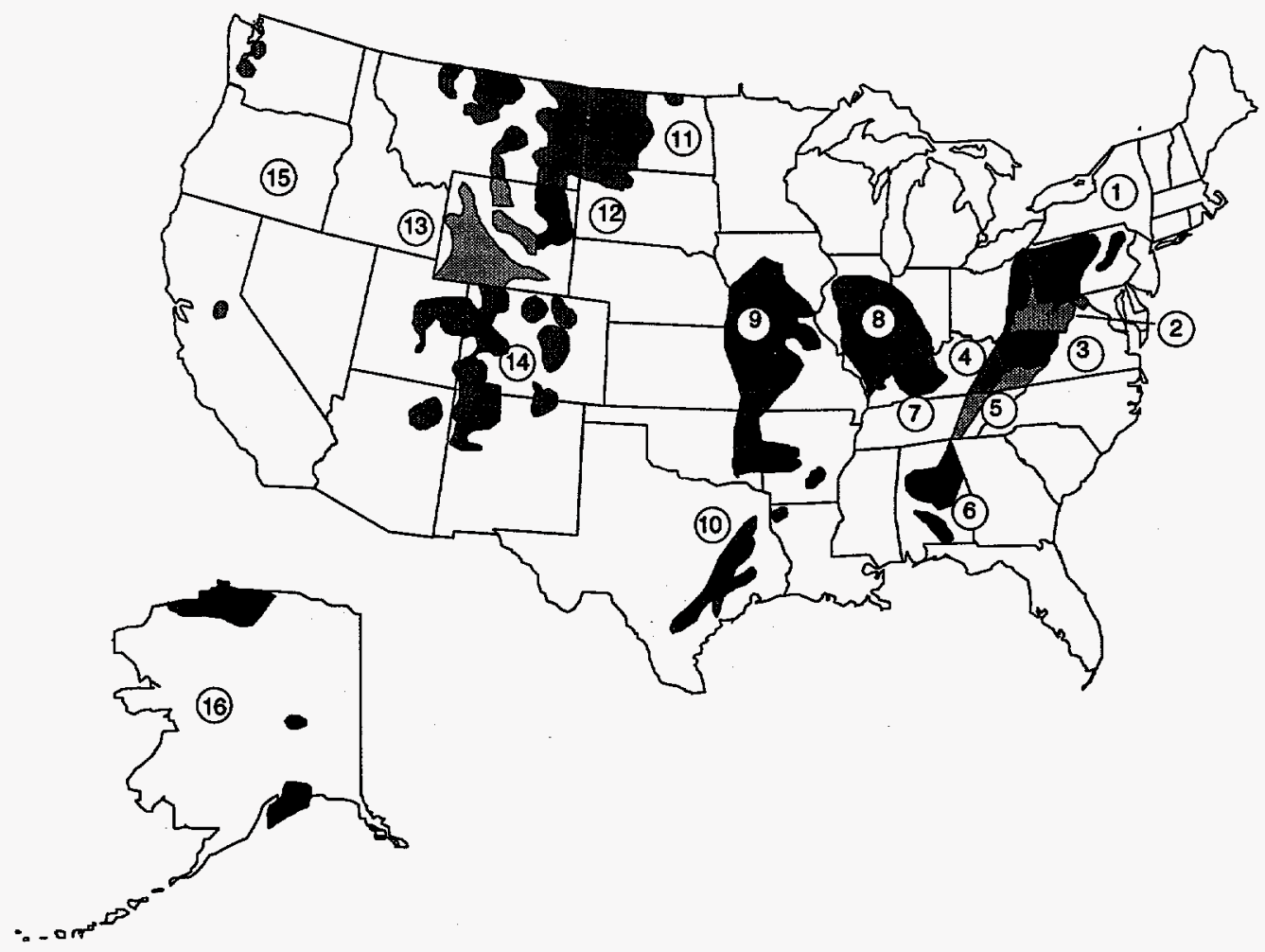

Region

Definition

\begin{tabular}{|c|c|c|}
\hline Northern Appalachia & $\begin{array}{l}1 \\
2\end{array}$ & $\begin{array}{l}\text { Pennsylvania, Maryland, and Ohio } \\
\text { West Virginia (north) }\end{array}$ \\
\hline \multirow[t]{4}{*}{ Southern Appalachia } & 3 & West Virginia (south) \\
\hline & 4 & Kentucky (east) \\
\hline & 5 & Virginia and Tennessee \\
\hline & 6 & Alabama \\
\hline \multirow[t]{4}{*}{ Interior } & 7 & Kentucky (west) \\
\hline & 8 & Illinois and Indiana \\
\hline & 9 & Arkansas, lowa, Kansas, Missouri, and Oklahoma \\
\hline & 10 & Texas and Louisiana \\
\hline \multirow[t]{2}{*}{ North Great Plains } & $\begin{array}{l}11 \\
12\end{array}$ & $\begin{array}{l}\text { North Dakota, South Dakota, and Montana } \\
\text { Wyoming (east) }\end{array}$ \\
\hline & 13 & Wyoming (west) \\
\hline Other West & 14 & Arizona, New Mexico, Colorado, and Utah \\
\hline & 15 & Washington, Oregon, and California \\
\hline Alaska & 16 & Alaska \\
\hline
\end{tabular}

Source: Energy Information Administration, Office of Integrated Analysis and Forecasting. 


\section{Appendix B}

\section{Documentation Reports}

The National Energy Modeling System is documented in a series of model documentation reports, available by contacting the National Energy Information Center (202/586-8800).

Energy Information Administration, The National Energy Modeling System: An Overview, DOE/EIA-0581 (Washington, DC, May 1994).

Energy Information Administration, National Energy Modeling System Integrating Module Documentation Report, DOE/EIA-M057 (Washington, DC, December 1993).

Energy Information Administration, Model Documentation Report: Macroeconomic Activity Module (MAM) of the National Energy Modeling System, DOE/EIAM065 (Washington, DC, February 1994).

Energy Information Administration, Documentation of the DRI Model of the U.S. Economy, DOE/EIA-M061 (Washington, DC, December 1993).

Energy Information Administration, NEMS International Energy Module, Model Documentation Report, DOE/EIA-M071 (Washington, DC, April 1994)

Energy Information Administration, EIA Model Documentation: World Oil Refining Logistics Demand Model, "World" Reference Manual, DOE/EIA-M058 (Washington, DC, March 1994).

Energy Information Administration, Model Documentation Report: Residential Sector Demand Module of the National Energy Modeling System, DOE/EIA-M067 (Washington, DC, March 1994).

Energy Information Administration, Model Documentation Report: Commercial Sector Demand Module of the National Energy Modeling System, DOE/EIA-M066 (Washington, DC, March 1994).

Energy Information Administration, Model Documentation Report: Industrial Sector Demand Module of the National Energy Modeling System, DOE/EIA-M064 (Washington, DC, January 1994).

Energy Information Administration, Model Documentation Report: Transportation Sector Model of the National Energy Modeling System, DOE/EIA-M070 (Washington, DC, March 1994).
Energy Information Administration, Model Documentation Report: Electricity Market Module, Load and Demand-Side Management Submodule. Volume 1. Model Description, DOE/EIA-M068-A/1 (Washington, DC, March 1994).

Energy Information Administration, Model Documentation Report: Electricity Market Module, Load and Demand-Side Management Submodule. Volume 2. Model Code Listing, DOE/EIA-M068-A/2 (Washington, DC, March 1994).

Energy Information Administration, Model Documentation Report: Electricity Market Module, Electricity Capacity Planning Submodule, DOE/EIA-M068-B (Washington, DC, March 1994).

Energy Information Administration, Model Documentation Report: Electricity Market Module, Electricity Finance and Pricing Submodule, DOE/EIA-M068-C (Washington, DC, March 1994).

Energy Information Administration, Model Documentation Report: Electricity Market Module, Electricity Fuel Dispatch Submodule, DOE/EIA-M068-D (Washington, DC, March 1994).

Energy Information Administration, Documentation of the Oil and Gas Supply Module (OGSM), DOE/EIAM063 (Washington, DC, March 1994).

Energy Information Administration, Model Documentation: Natural Gas Transmission and Distribution Model of the National Energy Modeling System, DOE/EIA-M062 (Washington, DC, February 1994).

Energy Information Administration, EIA Model Documentation: Petroleum Model of the National Energy Modeling System, DOE/EIA-M059 (Washington, DC, February 1994).

Energy Information Administration, Model Documentation: Coal Market Module of the National Energy Modeling System, DOE/EIA-M060 (Washington, DC, March 1994).

Energy Information Administration, Model Documentation Report: Model Documentation Renewable Fuels Module of the National Energy Modeling System, DOE/EIA-M069 (Washington, DC, April 1994). 


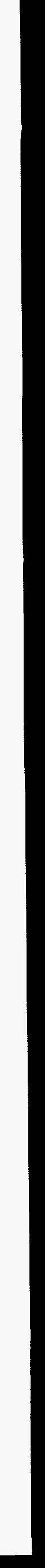




\section{Appendix C \\ Results from Side Cases}

Table C1. Key Results for Residential Sector Efficiency Cases

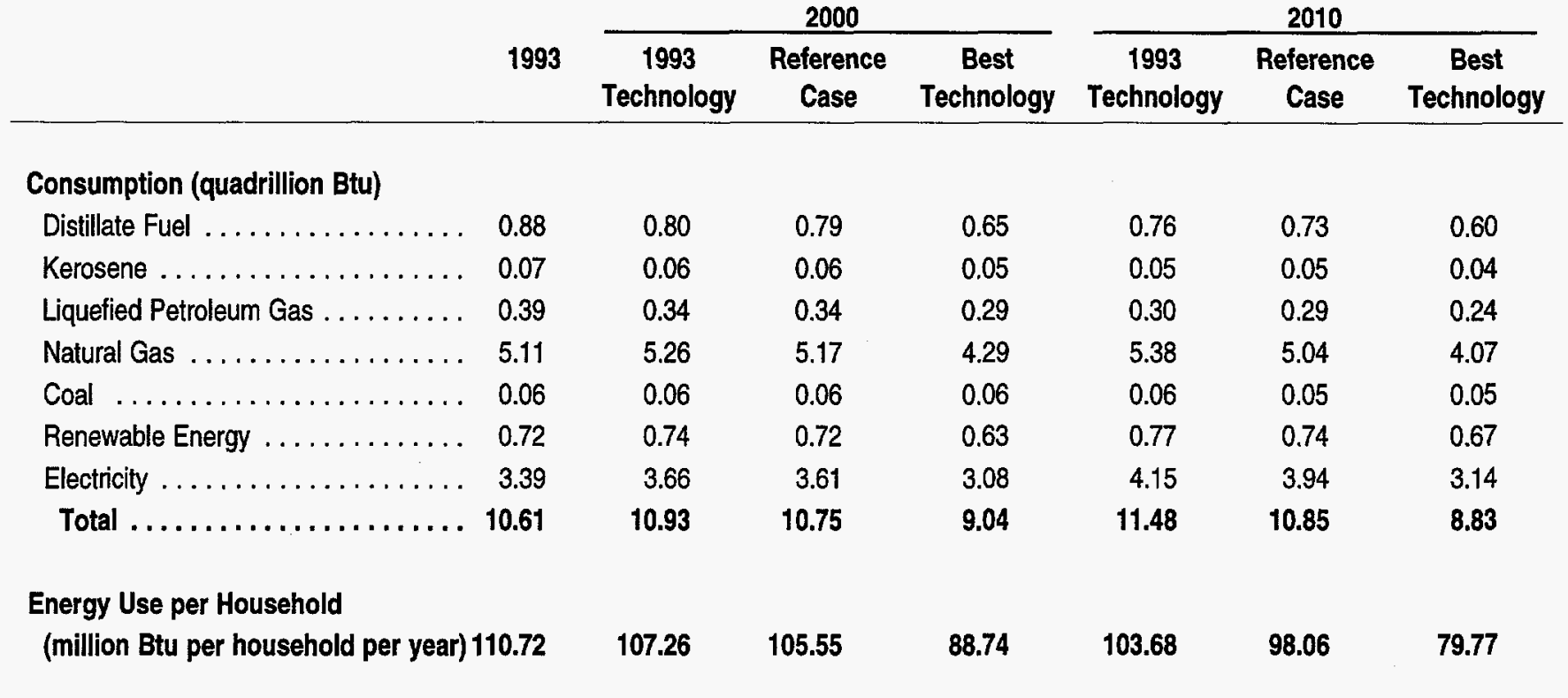

Btu = British thermal units.

Note: Side cases were run without the fully integrated modeling system, so not all feedbacks are captured.

Sources: 1993: AEO95 Forecasting System run AEO95B.D1103942. Projections: AEO95 Forecasting System runs, FROZEN.D1107941, AE095B.D1103942, and TECH95.D1107941.

Table C2. Key Results for Commercial Sector Efficiency Cases

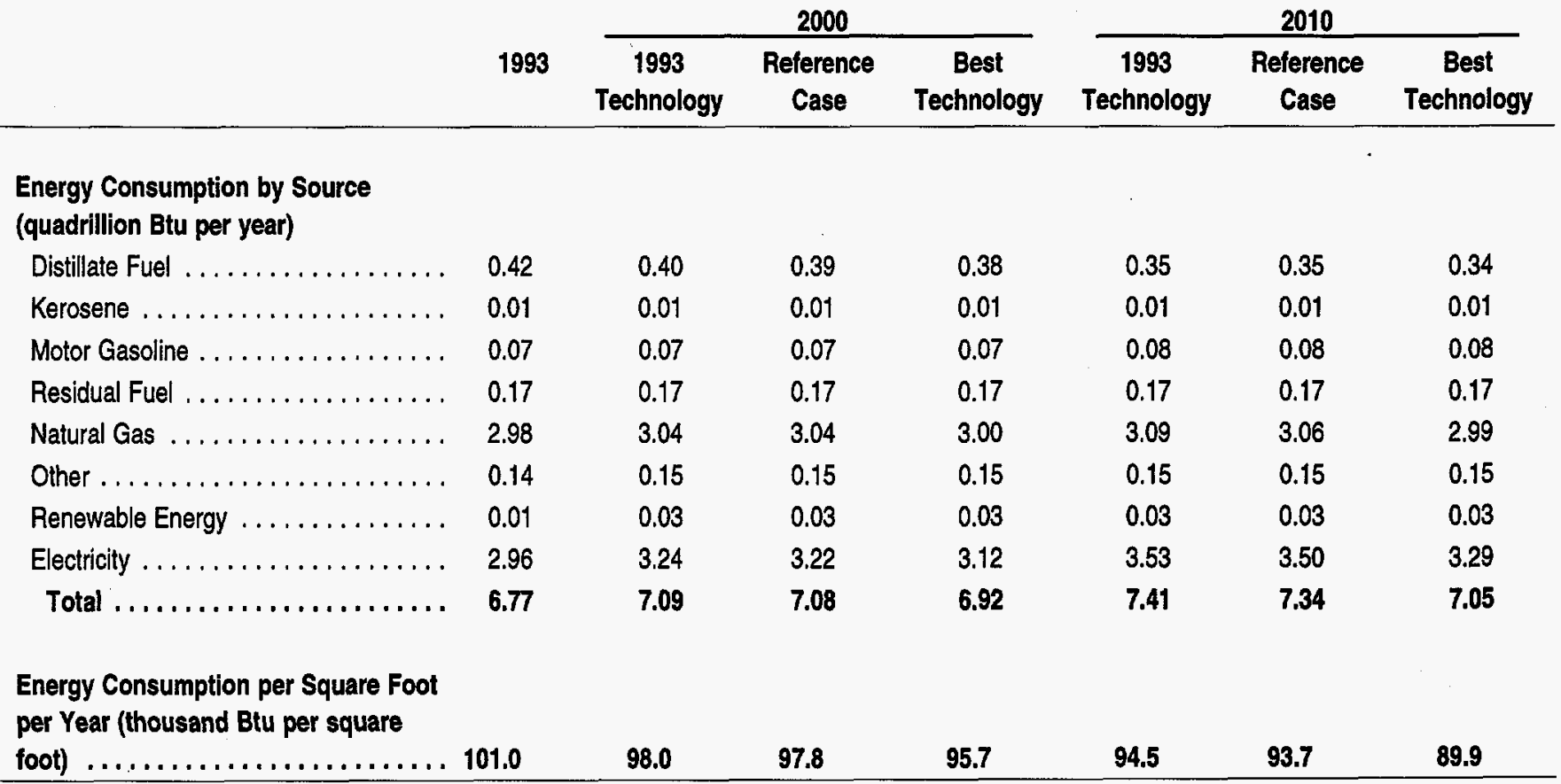

Btu $=$ British thermal units.

Note: Side cases were run without the fully integrated modeling system, so not all potential feedbacks are captured.

Sources: 1993: AEO95 Forecasting System run AEO95B.D1103942. Projections: AEO95 Forecasting System runs, COMFZN.D1201941, AEO95B.D1103942, and COMBST.D1201941. 
2000

1993

\begin{tabular}{ccc}
\hline 1993 & Reference & High \\
Technology & Case & Efficiency
\end{tabular}

\begin{tabular}{ccc}
\multicolumn{3}{c}{2010} \\
\hline 1993 & Reference & High \\
Technology & Case & Efficiency
\end{tabular}

\begin{tabular}{|c|c|c|c|c|c|c|}
\hline $\begin{array}{l}\text { Energy Consumption } \\
\text { (quadrillion Btu per year) }\end{array}$ & & & & & & \\
\hline Purchased Electricity & 3.35 & 3.74 & 3.68 & 3.48 & 4.36 & 4.24 \\
\hline Natural Gas ....... & 9.09 & 10.47 & 10.32 & 9.78 & 11.61 & 11.28 \\
\hline Coal $\ldots \ldots \ldots \ldots \ldots \ldots$ & 2.52 & 2.86 & 2.66 & 2.55 & 3.06 & 2.74 \\
\hline Residual Fuel $\ldots \ldots \ldots \ldots \ldots \ldots$ & 0.38 & 0.52 & 0.49 & 0.75 & 0.59 & 0.56 \\
\hline Distillate $\ldots \ldots \ldots \ldots \ldots \ldots \ldots$ & 1.12 & 1.25 & 1.24 & 1.80 & 1.40 & 1.39 \\
\hline Liquefied Petroleum Gas .......... & 1.82 & 2.04 & 2.04 & 1.66 & 2.40 & 2.40 \\
\hline Petroleum Feedstocks $\ldots \ldots \ldots \ldots$ & 1.17 & 1.31 & 1.31 & 1.06 & 1.52 & 1.52 \\
\hline Other Petroleum ........ & 3.97 & 4.07 & 4.07 & 3.75 & 4.33 & 4.31 \\
\hline Renewables $\ldots \ldots \ldots \ldots \ldots \ldots$ & 2.12 & 2.45 & 2.45 & 2.41 & 2.84 & 2.84 \\
\hline Total $\ldots \ldots \ldots \ldots \ldots \ldots \ldots \ldots$ & 25.55 & 28.70 & 28.25 & 26.18 & 32.12 & 31.28 \\
\hline $\begin{array}{l}\text { Energy Use per Dollar of Output } \\
\text { (thousand Btu per } 1987 \text { dollar) ..... }\end{array}$ & 7.41 & 7.01 & 6.90 & 6.40 & 6.52 & 6.35 \\
\hline
\end{tabular}

Table C4. Key Results for Transportation Sector Efficiency Cases

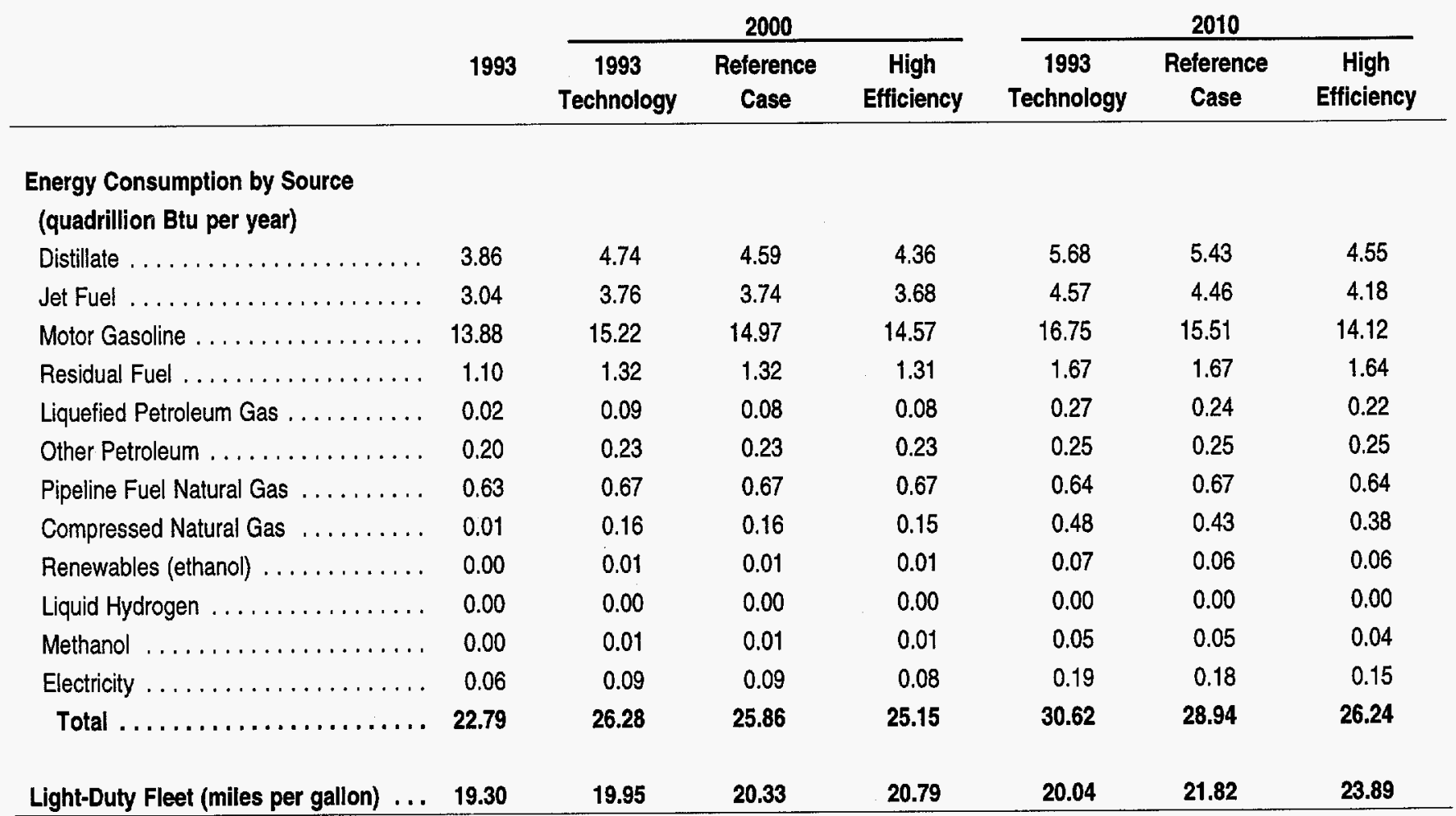

Btu $=$ British thermal units.

Note: Side cases were run without the fully integrated modeling system, so not all potential feedbacks were captured.

Sources: 1993: AEO95 Forecasting System run AEO94B.D1103942. Projections: AEO95 Forecasting System runs, FROZEN.D1018941, AEO95B.D1103942, and HIEFF.D1018941. 
Table C5. Key Results for Nuclear Retirement Cases

(Thousand Megawatts, Unless Otherwise Noted)

2000

1993

\begin{tabular}{ccc}
\hline Low & Reference & High \\
Nuclear & Case & Nuclear
\end{tabular}

\begin{tabular}{ccc}
\multicolumn{3}{c}{2010} \\
\hline Low & $\begin{array}{c}\text { Reference } \\
\text { Nuclear }\end{array}$ & $\begin{array}{c}\text { High } \\
\text { Nuclear }\end{array}$
\end{tabular}

Electric Utilities

\section{Capacity}

Coal Steam

Other Fossil Fuel ........... 141.3

Combined Cycle . . . . . . . . . . . . 9.7

Combustion Turbine/Diesel . . . . . . 49.2

Nuclear Power . . . . . . . . . . . . . . 99.0

Pumped Storage $\ldots \ldots \ldots \ldots \ldots \ldots \quad 19.1$

Renewable Sources . . . . . . . . 76.8

Total

Cumulative Planned Additions . 695.7

2.40

Cumulative Unplanned Additions

Coal Steam ............... 0.00

Other Fossil Fuel $\ldots \ldots \ldots \ldots \ldots \ldots, 0.00$

Combined Cycle . . . . . . . . . . . . $\quad 0.00$

Combustion Turbine/Diesel . . . . . . $\quad 0.00$

Nuclear Power . . . . . . . . . . . . . $\quad 0.00$

Pumped Storage $\ldots \ldots \ldots \ldots \ldots . \quad 0.00$

Renewable Sources ........... 0.00

Total

0.00

Cumulative Total Additions

2.40

Cumulative Retirements

8.71

Nonutilities (excluding cogenerators)

$\begin{array}{rr}297.1 & 297.1 \\ 130.4 & 130.4 \\ 17.7 & 17.7 \\ 65.8 & 65.9 \\ 101.3 & 101.3 \\ 20.0 & 20.0 \\ 78.1 & 78.1 \\ 710.4 & 710.5\end{array}$

\section{Capacity}

Coal Steam

Other Fossil Fuel . . . . . . . . . . . 0.21

Combined Cycle .............. 2.03

Combustion Turbine/Diesel ....... 1.33

Nuclear Power . . . . . . . . . . . . . $\quad 0.00$

Pumped Storage . . . . . . . . . . . 0.00

Renewable Sources ............ 9.11

Total ................... 13.30

\section{Cogenerators}

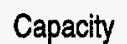

Cumulative Additions
38.25

7.80
34.97

0.00

0.00

1.46

0.69

0.00

0.00

0.14

2.29

37.26

29.26

34.97

\subsection{2}

0.00

1.42

0.74

0.00

0.00

0.13

2.32

37.29

29.26

1.81

0.25

5.33

2.61

0.00

0.00

13.45

23.44

45.54

25.23

1.82

0.25

5.29

2.80

0.00

0.00

13.45

23.61

45.54

25.40

297.
130.
17.7
65
101.
20.
78.
710

34.97

0.00

0.00

1.46

0.74

0.00

0.00

0.14

2.34

37.31

29.20

1.81

0.25

5.33

2.81

0.00

0.00

13.45

23.65
45.54

25.44

313.8
120.4
30.7
82.5
62.5
20.0
81.9
711.9

306.4

120.4

303.9

120.4

27.2

25.7

77.8

75.5

88.7

101.3

20.0

20.0

81.6

80.7

722.1

727.5

54.82

54.82

54.82

14.14

6.68

4.21

0.00

0.00

0.00

9.33

5.79

4.29

12.83

8.05

5.78

0.00

0.00

0.00

0.00

3.40

0.00

2.20

39.69

23.59

16.47

$94.51 \quad 78.41$

71.30

85.82

59.57

46.99

$\begin{array}{rrr}11.65 & 7.11 & 5.88 \\ 0.25 & 0.25 & 0.25 \\ 13.17 & 10.48 & 9.92 \\ 17.23 & 13.72 & 13.17 \\ 0.00 & 0.00 & 0.00 \\ 0.00 & 0.00 & 0.00 \\ 22.78 & 22.07 & 19.53 \\ 65.07 & 53.62 & 48.74\end{array}$


Table C5. Key Results for Nuclear Retirement Cases (Continued)

(Thousand Megawatts, Unless Otherwise Noted)

2000

1993

\begin{tabular}{ccc}
\multicolumn{3}{c}{2000} \\
\hline Low & Reference & High \\
Nuclear & Case & Nuclear
\end{tabular}

2010

\begin{tabular}{ccc}
\hline Low & Reference & High \\
Nuclear & Case & Nuclear
\end{tabular}

\section{Carbon Emissions for Electric}

Generators by Source

(million metric tons per year)

\begin{tabular}{|c|c|c|c|c|c|c|c|}
\hline$\ldots \ldots \ldots \ldots \ldots \ldots$ & 22.9 & 19.7 & 19.9 & 19.8 & 32.9 & 28.8 & 27.2 \\
\hline Natural Gas & 41.7 & 49.5 & 49.2 & 49.0 & 77.3 & 69.4 & 67.3 \\
\hline Steam Coal ...... & 427.1 & 440.5 & 440.5 & 440.9 & 508.7 & 485.5 & 478.4 \\
\hline Renewable Energy $\ldots \ldots \ldots \ldots$ & 0.0 & 0.0 & 0.0 & 0.0 & 0.0 & 0.0 & 0.0 \\
\hline Total $\ldots \ldots \ldots \ldots \ldots \ldots \ldots \ldots$ & 491.7 & 509.7 & 509.6 & 509.7 & 618.9 & 583.7 & 572.9 \\
\hline
\end{tabular}

Electric Generation by Fuel Type

(billion kilowatthours)

Electric Utilities

\begin{tabular}{|c|c|c|c|c|c|c|}
\hline$\ldots \ldots \ldots \ldots \ldots \ldots \ldots \ldots$ & 1639 & 1688 & 1689 & 1690 & 1886 & 1825 \\
\hline Petroleum $\ldots \ldots \ldots \ldots \ldots \ldots$ & 100 & 79 & 80 & 80 & 137 & 118 \\
\hline Natural Gas ...... & 259 & 302 & 301 & 300 & 421 & 387 \\
\hline Nuclear Power ... & 610 & 652 & 652 & 652 & 414 & 596 \\
\hline Pumped Storage $\ldots .$. & -2 & -2 & -2 & -2 & -2 & -2 \\
\hline Renewable Sources $\ldots . \ldots \ldots \ldots$ & 277 & 303 & 303 & 303 & 317 & 317 \\
\hline Total $\ldots \ldots \ldots \ldots \ldots \ldots \ldots \ldots$ & 2883 & 3022 & 3022 & 3022 & 3172 & 3241 \\
\hline
\end{tabular}

Nonutilities

(excluding cogenerators)

Coal $\ldots \ldots \ldots \ldots \ldots \ldots \ldots \ldots \ldots$

Petroleum $\ldots \ldots \ldots \ldots \ldots \ldots \ldots, \quad 1$

Natural Gas .................. 21

Renewable Sources . . . . . . . . . 45

Total .................... 73

Cogenerators

5

9

9

73

44

36

364

\section{Energy Consumption for Electric \\ Generators by Source \\ (quadrillion Btu per year)}

Distillate Fuel . . . . . . . . . . . . . 0.01

$\begin{array}{rrr}0.01 & 0.01 & 0.01 \\ 1.07 & 0.92 & 0.93 \\ 3.00 & 3.44 & 3.42 \\ 16.78 & 17.36 & 17.36 \\ 6.52 & 6.96 & 6.96 \\ 3.92 & 4.60 & 4.60 \\ 31.30 & 33.28 & 33.27\end{array}$

0.01

0.01

0.06

0.05

0.05

Residual Fuel . .

3.42

0.92

1.50

1.31

1.24

Natural Gas

17.36

5.37

4.82

4.67

Steam Coal

6.96

17.37

20.03

19.13

18.85

Renewable Energy/Other

4.60
33.27

6.97

4.42

6.36

7.03

4.60

5.77

5.65

5.53

Total

31.30

32.27

37.15

37.32

37.37 
Table C5. Key Results for Nuclear Retirement Cases (Continued)

(Thousand Megawatts, Unless Otherwise Noted)

\begin{tabular}{|c|c|c|c|c|c|c|c|}
\hline & \multirow[b]{2}{*}{1993} & \multicolumn{3}{|c|}{2000} & \multicolumn{3}{|c|}{2010} \\
\hline & & $\begin{array}{l}\text { Low } \\
\text { Nuclear }\end{array}$ & $\begin{array}{l}\text { Reference } \\
\text { Case }\end{array}$ & $\begin{array}{c}\text { High } \\
\text { Nuclear }\end{array}$ & $\begin{array}{l}\text { Low } \\
\text { Nuclear }\end{array}$ & $\begin{array}{l}\text { Reference } \\
\text { Case }\end{array}$ & $\begin{array}{l}\text { High } \\
\text { Nuclear }\end{array}$ \\
\hline \multicolumn{8}{|l|}{ Electric Generators Delivered Prices } \\
\hline Coal (1993 dollars per short ton) . . . . & 28.60 & 29.17 & 29.06 & 29.17 & 32.69 & 31.43 & 31.25 \\
\hline \multicolumn{8}{|l|}{ Natural Gas (1993 dollars per } \\
\hline thousand cubic feet) $\ldots \ldots \ldots \ldots$ & 2.63 & 2.67 & 2.65 & 2.65 & 3.97 & 3.82 & 3.70 \\
\hline
\end{tabular}

Blu $=$ British thermal units.

Note: Side cases were run without the fully integrated modeling system, so not all potential feedbacks are captured.

Sources: 1993: AEO95 Forecasting System run AEO95B.D1103942. Projections: AEO95 Forecasting System runs, LONUKE.D1116941, AEO95B.D1103942, and HINUKE.D1116941.

Table C6. Key Results for High Electricity Demand Case

(Thousand Megawatts)

\begin{tabular}{|c|c|c|c|c|}
\hline \multirow[b]{2}{*}{1993} & \multicolumn{2}{|c|}{2000} & \multicolumn{2}{|c|}{2010} \\
\hline & $\begin{array}{l}\text { Reference } \\
\text { Case }\end{array}$ & $\begin{array}{c}\text { High } \\
\text { Demand }\end{array}$ & $\begin{array}{l}\text { Reference } \\
\text { Case }\end{array}$ & $\begin{array}{l}\text { High } \\
\text { Demand }\end{array}$ \\
\hline
\end{tabular}

Electric Utilities

Capability

Coal Steam ....................

Other Fossil Steam . . . . . . . . . 141

297.1

306.4

327.2

Combined Cycle .................

130.4

130.4

120.4

120.4

Combustion Turbine/Diesel . . . . . 49.2

17.7

18.1

27.2

37.3

Nuclear Power ............. 99.0

65.9

68.9

77.8

101.0

Pumped Storage . . . . . . . . . . . . 19.1

101,3

101.3

88.7

88.7

Renewable Sources . . . . . . . 76.8

20.0

20.0

20.0

20.0

78.1

78.4

81.6

84.5

Total . . . . . . . . . . . . . . . . 695.7

710.5

714.2

722.1

779.2

Cumulative Planned Additions . . . . $\quad 2.40$

34.97

34.97

54.82

54.82

Cumulative Unplanned Additions

Coal Steam . . . . . . . . . . . . . . . 0.00

Other Fossil Steam . . . . . . . . . . . 0.00

0.02

0.00

6.68

27.53

Combined Cycle ............ 0.00

0.00

0.00

0.00

0.00

1.42

1.83

5.79

15.93

Combustion Turbine/Diesel ..... 0.00

0.74

3.76

8.05

31.29

Nuclear Power ............. 0.00

0.00

0.00

0.00

0.00

Pumped Storage ............ 0.00

0.00

0.00

0.00

0.00

Renewable Sources .......... 0.00

Total

0.00

23.59

80.70

Cumulative Total Additions

2,40

37.29

41.01

78.41

135.50

Cumulative Retirements

8.71

29.26

29.26

59.57

59.57 
Table C6. Key Results for High Electricity Demand Case (Continued) (Thousand Megawatts)

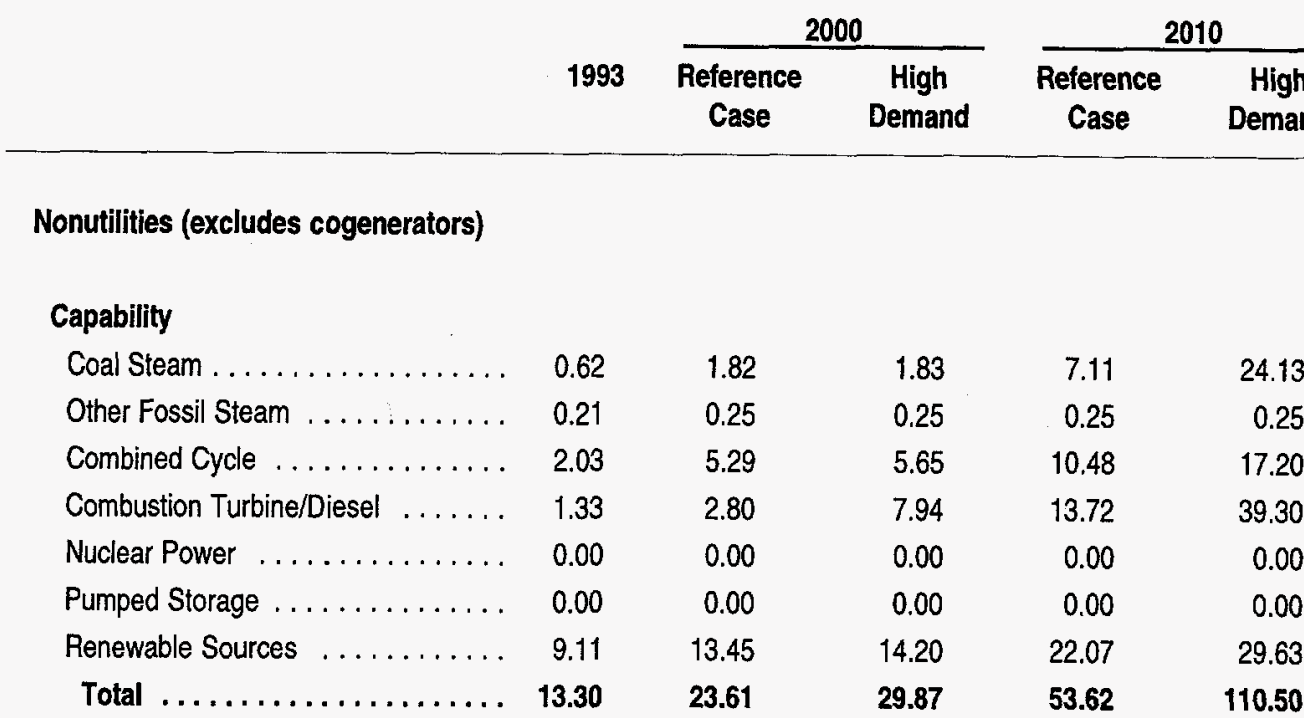

\section{Cogenerators}

\begin{tabular}{|c|c|c|c|c|c|}
\hline \multicolumn{6}{|l|}{ Capability } \\
\hline Coal $\ldots$ & 6.90 & 8.03 & 8.03 & 8.72 & 8.72 \\
\hline Petroleum ..... & 3.36 & 5.96 & 5.96 & 6.81 & 6.81 \\
\hline Natural Gas & 21.06 & 24.12 & 24.02 & 29.52 & 29.62 \\
\hline Renewables & 6.92 & 7.41 & 7.41 & 7.51 & 7.51 \\
\hline Other $\ldots \ldots \ldots \ldots \ldots \ldots \ldots$ & 0.00 & 0.03 & 0.03 & 0.03 & 0.03 \\
\hline Total $\ldots \ldots \ldots \ldots \ldots \ldots \ldots$ & 38.25 & 45.54 & 45.44 & 52.59 & 52.69 \\
\hline Cumulative Additions $\ldots \ldots \ldots \ldots$. & 7.80 & 25.40 & 31.56 & 62.46 & 119.40 \\
\hline \multicolumn{6}{|l|}{$\begin{array}{l}\text { Carbon Emissions for Electric } \\
\text { Generators by Source } \\
\text { (million metric tons per year) }\end{array}$} \\
\hline Petroleum $\ldots . . .$. & 22.9 & 19.9 & 35.2 & 28.8 & 38.8 \\
\hline Natural Gas ....... & 41.7 & 49.2 & 69.9 & 69.4 & 93.8 \\
\hline Steam Coal..... & 427.1 & 440.5 & 458.4 & 485.5 & 547.2 \\
\hline Renewable Energy & 0.0 & 0.0 & 0.0 & 0.0 & 0.0 \\
\hline Total ..................... & 491.7 & 509.6 & 563.5 & 583.7 & 679.8 \\
\hline
\end{tabular}

Electric Generation by Fuel Type

(billion kilowatthours)

Electric Utilities

Petroleum ................... 100

\begin{tabular}{|c|c|}
\hline 1.82 & 1.83 \\
\hline 0.25 & 0.25 \\
\hline 5.29 & 5.65 \\
\hline 2.80 & 7.94 \\
\hline 0.00 & 0.00 \\
\hline 0.00 & 0.00 \\
\hline 13.45 & 14.20 \\
\hline 23.61 & 29.87 \\
\hline 8.03 & 8.03 \\
\hline 5.96 & 5.96 \\
\hline 24.12 & 24.02 \\
\hline 7.41 & 7.41 \\
\hline 0.03 & 0.03 \\
\hline 45.54 & 45.44 \\
\hline 25.40 & 31.56 \\
\hline 19.9 & 35.2 \\
\hline 49.2 & 69.9 \\
\hline 440.5 & 458.4 \\
\hline 0.0 & 0.0 \\
\hline 509.6 & 563.5 \\
\hline
\end{tabular}

Natural Gas . . . . . . . . . . . . . . . . 259

$\begin{array}{llll}1689 & 1748 & 1825 & 1969\end{array}$

$\begin{array}{llll}80 & 147 & 118 & 163\end{array}$

Nuclear Power ................. 610

Pumped Storage $\ldots \ldots \ldots \ldots \ldots \ldots$. 2

Renewable Sources . . . . . . . . . 277

$\begin{array}{llll}301 & 410 & 387 & 503\end{array}$

$652 \quad 652 \quad 596 \quad 596$

$-2 \quad-2$

$-2 \quad-2$

$\begin{array}{llll}303 & 304 & 317 & 325\end{array}$

Total

$.2883 \quad 3022$

3258

3241

3554 
Table C6. Key Results for High Electricity Demand Case (Continued) (Thousand Megawatts)

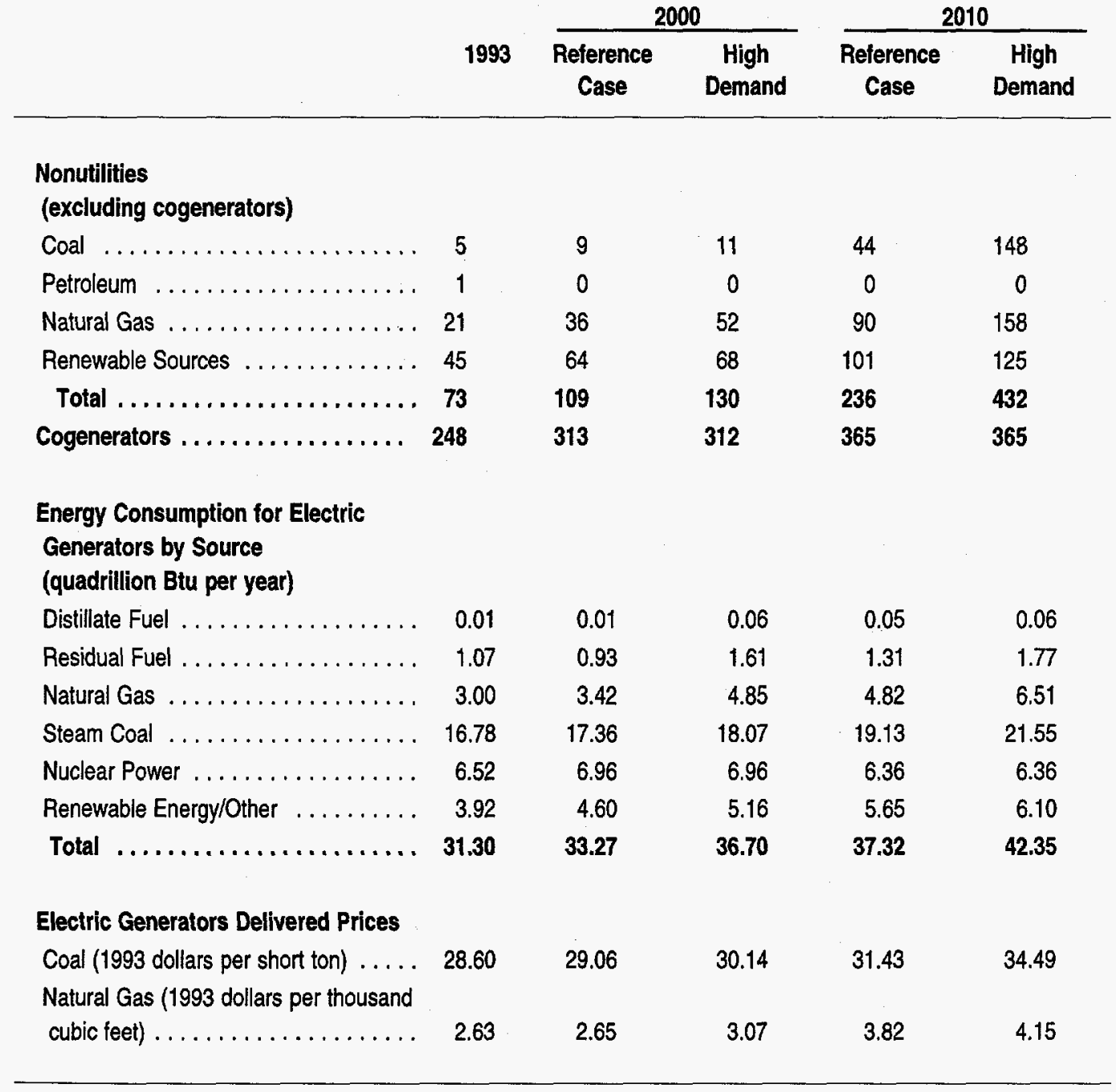

Btu $=$ British thermal units.

Note: Side cases were run without the fully integrated modeling system, so not all polential feedbacks are captured. Sources: 1993: AEO95 Forecasting System run AEO95B.D1103942. Projections: AEO95 Forecasting System runs, AEO95B.D1103942, and NEWDEM.D1213942. 
Table C7. Variations from the Reference Case Projections for Key Results from the Oil and Gas Technology Cases (percent)

\begin{tabular}{ccccc}
\multicolumn{2}{c}{2000} & & \multicolumn{2}{c}{2010} \\
\cline { 1 - 1 } \cline { 5 - 6 } Low & $\begin{array}{c}\text { High } \\
\text { Technology }\end{array}$ & Technology & Technology & $\begin{array}{c}\text { High } \\
\text { Technology }\end{array}$
\end{tabular}

\section{Lower 48 Crude Oil}

Successful New Wells ........... $\quad-6.9 \%$

$-5.3 \%$

Reserve Additions

$-1.6 \%$

$7.2 \%$
$5.5 \%$
$1.7 \%$

$-13.4 \%$

$14.5 \%$

Production

$\ldots \ldots \ldots \ldots$

$1.7 \%$

$-10.6 \%$

$11.6 \%$

\section{Lower 48 Natural Gas}

Successful New Wells ............ $\quad-6.9 \%$

Reserve Additions

$-2.4 \%$

$7.3 \%$

Production

$\cdots \cdots \cdots \cdots \cdots \cdots$

$2.5 \%$

$-11.5 \%$

$12.0 \%$

Note: Side cases were run without the fully integrated modeling system, so not all potential feedbacks are captured. Sources: AEO95 Forecasting System runs, LOTECH.D1110942, TBASE.D1110942, and HITECH.D1110942.

Table C8. Key Results for Natural Gas Pipeline Refurbishment Case (Billion Current Year Dollars, Unless Otherwise Noted)

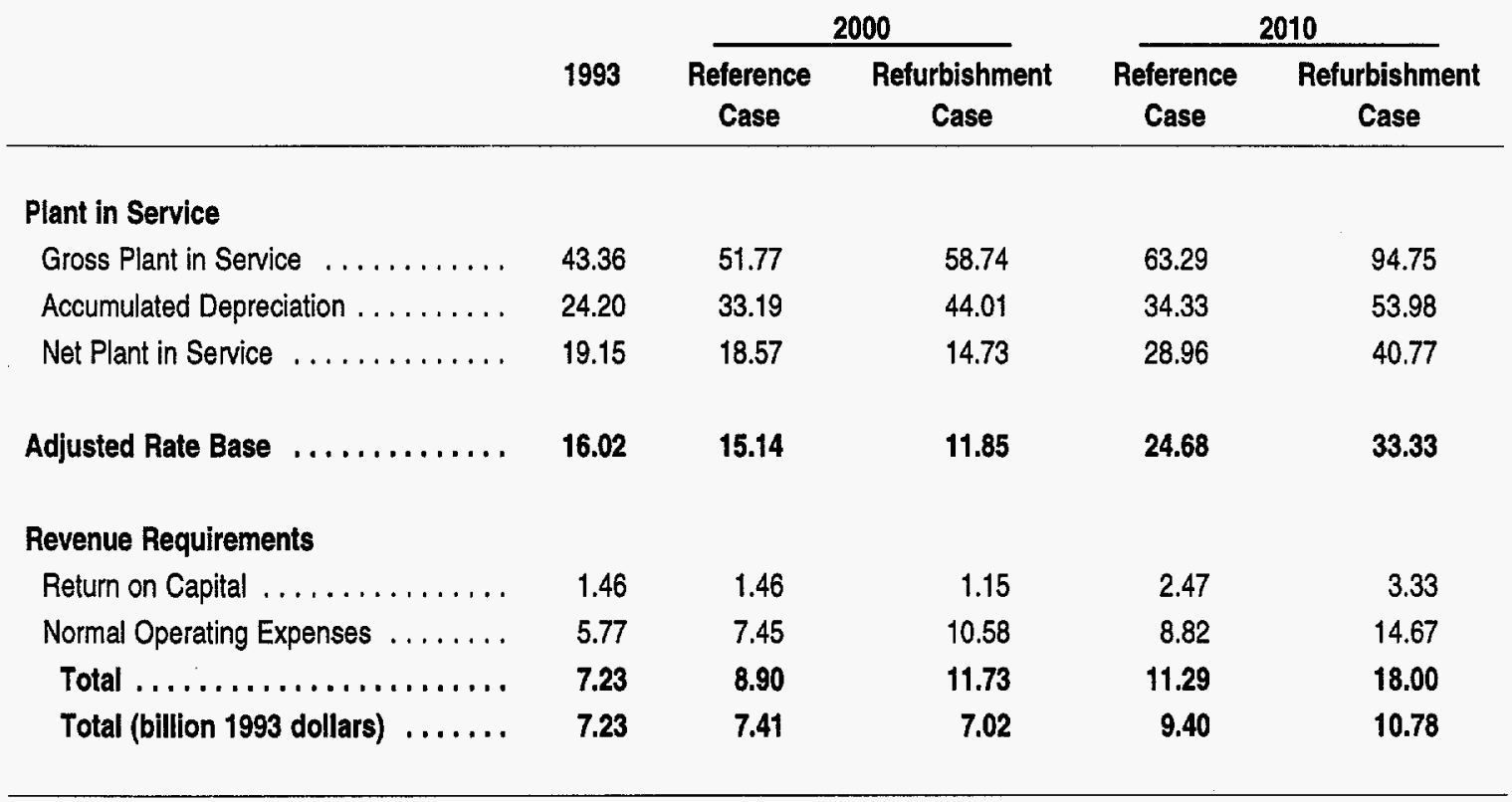

Note: Side cases were run without the fully integrated modeling system, so not all potential feedbacks are captured. Sources: 1993: AEO95 Forecasting System run AEO95B.D1103942. Projections: AEO95 Forecasting System runs, AEO95B.D1103942, and NGALO.D1114943. 
Table C9. Key Results for Coal Productivity Cases

\begin{tabular}{|c|c|c|c|c|c|c|c|}
\hline & \multirow[b]{2}{*}{1993} & \multicolumn{3}{|c|}{2000} & \multicolumn{3}{|c|}{2010} \\
\hline & & $\begin{array}{c}\text { Low } \\
\text { Productivity }\end{array}$ & $\begin{array}{l}\text { Reference } \\
\text { Case }\end{array}$ & $\begin{array}{c}\text { High } \\
\text { Productivity }\end{array}$ & $\begin{array}{c}\text { Low } \\
\text { Productivity }\end{array}$ & $\begin{array}{l}\text { Reference } \\
\text { Case }\end{array}$ & $\begin{array}{c}\text { High } \\
\text { Productivity }\end{array}$ \\
\hline \multicolumn{8}{|l|}{ Minemouth Price } \\
\hline (1993 dollars per short ton) & 19.85 & 21.17 & 20.34 & 19.70 & 24.14 & 22.77 & 21.91 \\
\hline \multicolumn{8}{|l|}{ Labor Productivity } \\
\hline (short tons per miner per hour) $\ldots \ldots$ & 4.70 & 6.05 & 6.73 & 7.48 & 7.05 & 9.04 & 11.54 \\
\hline \multicolumn{8}{|l|}{ Labor Productivity } \\
\hline (average annual growth, from 1993) .. & $N / A$ & $3.7 \%$ & $5.3 \%$ & $6.9 \%$ & $2.4 \%$ & $3.9 \%$ & $5.4 \%$ \\
\hline
\end{tabular}

N/A $=$ Not Applicable.

Note: Side cases were run without the fully integrated modeling system, so not all potential feedbacks are captured.

Sources: 1993: AEO95 Forecasting System run AEO95B.D1103942. Projections: AEO95 Forecasting System runs, LPRD.D1109941, AEO95B.D1103942, and HPRD.D1109942. 


\section{Call \\ for}

your
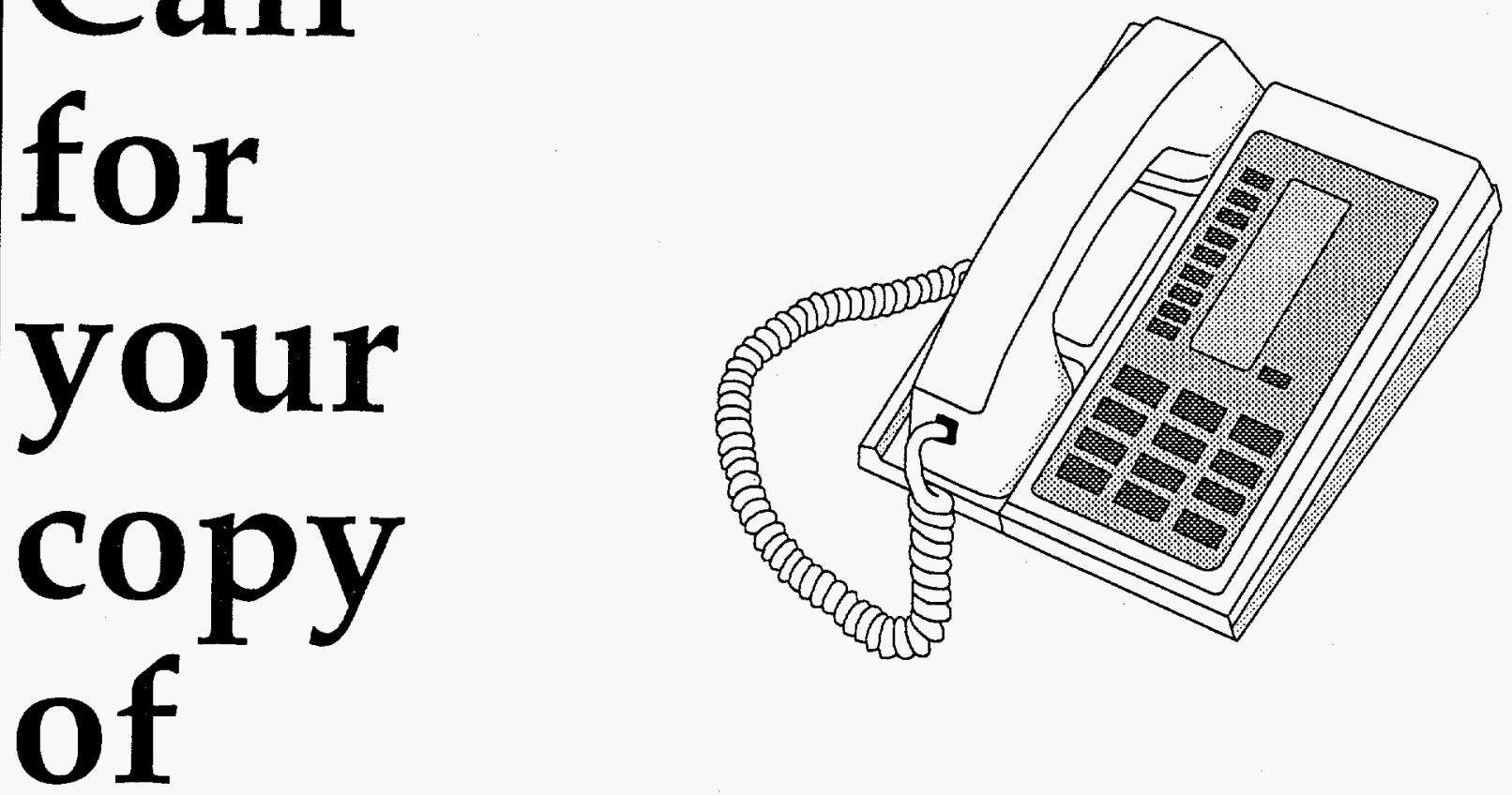

eia new releases

A concise and timely review of new statistical publications and energy news

Offered from the National Energy Information Center

For a complimentary copy of this bimonthly bulletin, or a complimentary subscription, call (202)586-8800. 


\section{Annual Energy Outlook 1995 Diskettes}

These diskettes contain the forecast tables for Appendices A, B, and C in the Annual Energy Outlook 1995 (AEO95) in worksheet (WK1) format, so they can be viewed using most spreadsheet packages. They come on 3.5 inch disks and will be available early in January 1995.

\section{Supplement to the Annual Energy Outlook 1995 Diskettes}

These diskettes contain the Detailed Tables in Part II of the Supplement to the Annual Energy Outlook 1995 (AEO95 Supplement) in worksheet (WK1) format, so they can be viewed using most spreadsheet packages. They come on 3.5 inch disks and will be available early in February 1995.

\section{PC Version of the National Energy Modeling System}

The National Energy Modeling System, used for the forecasts in the AEO95, will be available for execution on a personal computer. The system allows execution of the individual NEMS modules on a stand-alone basis. The AEO95 version is scheduled for release in April 1995.

To receive any of the items above please either:

a. ) send a letter with your business address, phone number, and which of the above items you would like to:

\section{U.S. Department of Energy}

Attn: Joe Baumgartner

Energy Information Administration, El- 811

1000 Independence Avenue, S.W.

Washington, D.C., 20585

b. ) fax your business address, phone number, and which items you wish to receive Joe Baumgartner at (202) 586-3045.

c. ) send an Internet E-mail message to jbaumgar@eia.doe.gov and include your business address, a phone number, and which items you would like to receive.

1. Which do you wish to receive?

Annual Energy Outlook 1995 Appendix Tables in worksheet format.

Supplement to the Annual Energy Outlook 1995, Part II Detailed Tables in worksheet format.

Information on the PC version of the National Energy Modeling System

2. Address to be sent:

Name

Organization

Address

Internet E-Mail address (if applicable)

Fax

Phone 